\title{
University of the Northern Plains: a History of the University of North Dakota, 1883-1958
}

Louis G. Geiger

University of North Dakota

How does access to this work benefit you? Let us know!

Follow this and additional works at: https://commons.und.edu/und-books

Part of the Higher Education Commons

\section{Recommended Citation}

Geiger, Louis G., "University of the Northern Plains: a History of the University of North Dakota, 1883-1958" (1958). UND Publications. 4.

https://commons.und.edu/und-books/4

This Book is brought to you for free and open access by the Elwyn B. Robinson Department of Special Collections at UND Scholarly Commons. It has been accepted for inclusion in UND Publications by an authorized administrator of UND Scholarly Commons. For more information, please contact und.commons@library.und.edu. 


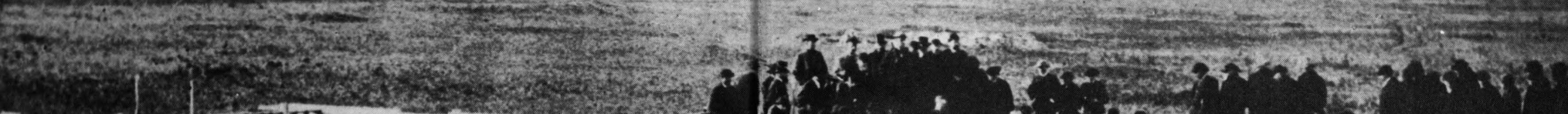

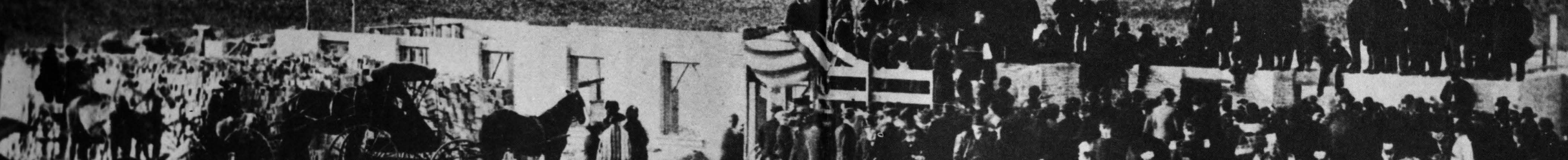

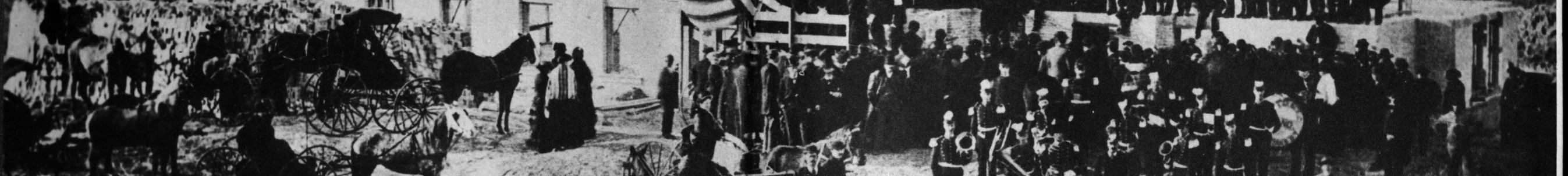

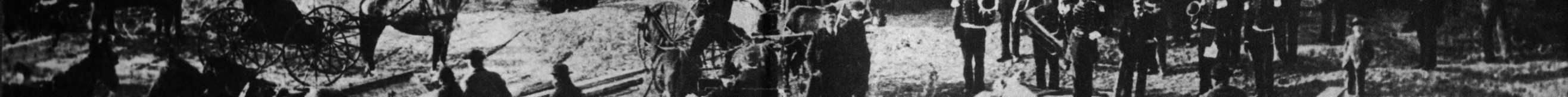

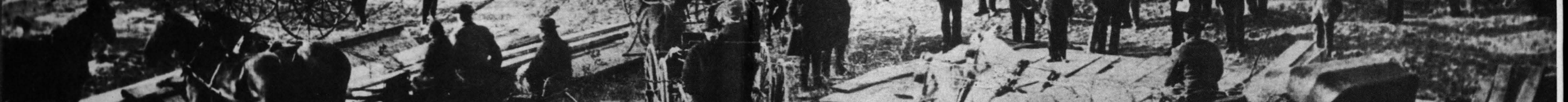

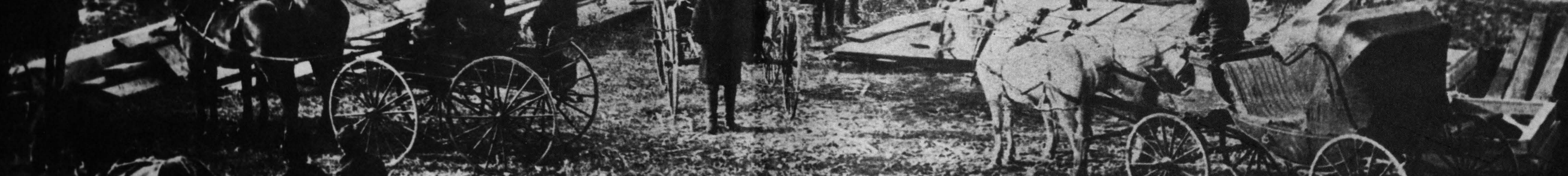

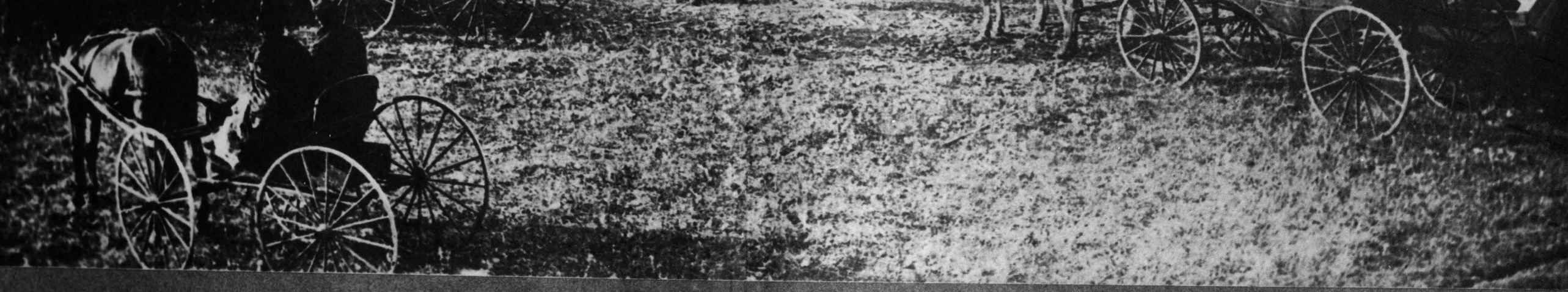

Laying of the Corner Stone of the 2(riversity of Torth Dafiota OCTOBER 2, 1883. 


\section{University of the Northern Plains}

Published on the Occasion of the Seventy-fifth AnNiversary of the

UnIVERSITY OF NoRTh Dakota 


\section{University of the Northern Plains}

\section{A History of the University of North Dakota 1883-1958}

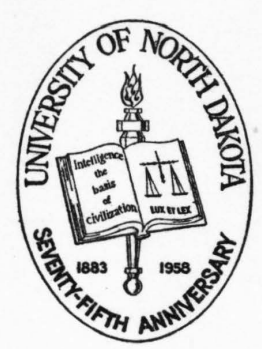

By LOUIS G. GEIGER

The University of North Dakota Press Grand Forks 1958 
COPYRIGHT, 1958, BY

The UnIVERSity OF NORTH DAKota Press

Library of Congress Catalog Card Number 58-9644
DEDICATED

TO

THOSE WHO STAYED IN 1895 


\section{Foreword}

\section{T}

1 HE 75TH ANNIVERSARY of the founding of the University is an appropriate time to review its history and to have this permanent record of the fascinating story of events that antedate and parallel the development of the State of North Dakota. Here are encountered many of the subtle tensions in North Dakota history and some of the most perplexing problems our state has had to face. Here is a human drama determined by circumstances of time and place as well as by the hopes and aspirations of a pioneering people.

Despite the demands of a hard reality on those pioneers, the University represented a spiritual movement of unique hopefulness which ignored the practical in favor of a more classical curriculum. Through all the political turmoil of securing statehood and developing a new state, the University has held its standards inviolate and has stood firmly for values which must at all cost be preserved. The period covered by this history has deep significance for all of North Dakota, no less than for our graduates. The University's impressive progress toward the "proud eminence in the nation" predicted for it in 1883 has been due to the loyal devotion, hard 
work, and personal sacrifice of many-founders, alumni, faculty, and friends.

Dr. Louis G. Geiger, encouraged and helped by his wife, Helen, has written a sound and truthful account of the times and circumstances in which it all took place. He has made no attempt to conceal the tensions, the conflicts, or the real issues for which men fought. Nor has he glossed over the failures of those in responsible position. His account will stir many memories. It will stimulate a new pride in the hearts of all those who have had a part in the story of the University of the Northern Plains. To all of them this history will express our grateful tribute.

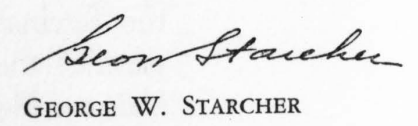

GEORGE W. STARCHER

\section{PRESIDENT}

UNIVERSITY OF NORTH DAKOTA

\section{Introduction}

\section{$\mathrm{W}$} nearly three years ago, my first impulse was to plead a prior commitment to another half-completed project. I decided to turn aside from it, however, upon reflection that in nearly ten years of association with this institution I had learned little about its past, that no one else who arrived after World War II appeared to have learned any more than I, and that one of the University's most conspicuous lacks was a historical tradition which could serve as a point of orientation as well as a source of pride and legend.

The author at least has found this study enormously instructive. It has been a pleasure to discover that governing Boards have been more consistently and intelligently devoted to the cause of higher education than professors have at times been willing to admit. Interference by politically appointed Boards-which all of them were in North Dakota until 1938-has been the exception rather than the rule. The real source of some of the major difficulties of higher education in North Dakota has been the local and regional rivalry which has thwarted time and again all efforts to work out a genuine state system.

It is with no intention of minimizing the vital necessity of independence for the scholar and teacher in the academic situation that I confess to a considerable revision of my conception of the role of the administrator. It would be better to refer to him as a leader, for it is the capacity for leadership rather than for adminis- 
trative mechanics which distinguishes the great from the ordinary in the world of presidents and deans. There is possibly no more difficult executive post than the presidency of a state university. Subject to the public, the legislature, and the governing board, and armed only lightly with powers over their "employees"-which faculties rightly insist they are not-presidents, and likewise deans, must nevertheless provide the leadership and direction which faculties or boards rarely provide themselves, particularly in youthful regions like North Dakota, where an academic tradition is still in the process of being formed and understood. Those leaders who would be great, or even successful, must be guided by high personal and public ideals and a mature educational philosophy, and these they must be able to articulate convincingly.

Finally, I have been impressed by the influence that institutions like the University of North Dakota have in the regions they serve, and by their importance to the development of the nation in the last seventy-five years. Educational history in general has been seriously neglected by professional historians, and histories of institutions are all too often considered the province of the well-meaning alumnus or the retired professor with nothing else to do. It was most encouraging therefore when a little more than a year ago a committee of distinguished historians called upon their colleagues to turn their attention to the study of American education and at the same time announced that the Fund for the Advancement of Education had made grants available to underwrite acceptable studies.

I have tried to keep several threads in mind in the preparation of this volume: the effect of the general trends in higher education upon this particular institution, the aims and ideals of the University and of those who support it, the University's role in the educational system of North Dakota, the influence of the University upon the life and development of the state, the impact of North Dakota political and economic conditions upon the University, and the life of the University itself. Moreover, I have tried to write for several audiences and purposes: to inform faculty, students, and alumni, and to entertain them a little if I could, to provide the historical background which must be a part of any intelligent planning for the future, and to make some small contribution to the general history of American life and culture.

I am indebted to so many people for assistance that any list of acknowledgements will inevitably contain some omissions. The Board of Higher Education and former Commissioner Albert F. Arnason generously opened their records to me. President George W. Starcher and Dean Robert B. Witmer reduced my teaching hours in the regular term and relieved me entirely in the summer. Miss Ruby McKenzie, registrar of the University, Mr. Edward Olson, business manager, and Mr. J. Lloyd Stone, director of alumni relations, their secretaries, and various members of the faculty have been generous of their time and trusting with their records. The deans have been most willing to supply facts and figures regarding their respective colleges. I owe more than I can acknowledge here to the assistance and tolerance of the University librarian, Dr. Jon. R. Ashton, and the library staff. Mr. Russell Reid and Miss Margaret Rose of the North Dakota State Historical Society, and Mr. H. Dean Stallings, librarian of the North Dakota Agricultural College, provided every assistance I requested. Professor William C. Hunter, formerly of the Agricultural College faculty, permitted me to make full use of his manuscript history of that institution. Professor Edwin B. Stevens, formerly of the faculty of the University of Washington, allowed me the same privilege with his manuscript biography of Thomas Franklin Kane. Mr. Douglas Williams, graduate assistant in the University department of speech, lent ime the notes for his M.A. thesis on the development of the University radio station (KFJM).

A number of the faculty, alumni, and friends have read parts of the manuscript. Among the former have been Professors George A. Abbott, William E. Koenker, Elwyn B. Robinson, and George C. Wheeler, President Starcher, and Mr. D. J. Robertson, administrative assistant to President John C. West and dean of students in the postwar years and now dean of the University College. The list of alumni and friends includes President Elmer Ellis of the University of Missouri, Mrs. Margaret Libby Barr, Mrs. William G. Bek, Mrs. Katherine B. Tiffany, Miss Edna Twamley, and Mrs. Robert B. Witmer. Mrs. Orin G. Libby and Mrs. Bek per- 
mitted me to use parts of their husbands' correspondence relating to University matters. I have had the pleasure and advantage of conversations and correspondence with a number of older alumni. Miss M. Beatrice Johnstone, Dr. Johanna Kildahl, Mr. Albert Stenmo, Mrs. Tiffany, and Miss Twamley, all of whose memories reach back to the 1890 's, have been particularly helpful.

Mr. Stanley O. Johnson of the University department of art designed the jacket and cover; Mr. Harvey Jacobson of the University news bureau arranged the illustrations. The stenographic bureau typed the manuscript. Miss Nancy Hall Kane, assistant editor of the American Historical Review, prepared it for the printer, read proof, made the index, and offered suggestions for improvement. Mr. Joe W. Hughes, manager of the University Press, and his staff have taken great pains with the book's production, and they have been endlessly patient with an author who would be revising his copy even yet if he could. I wish also to acknowledge the contribution of the student assistants provided by the University at various times: Miss Mary Helen Hillman, Mr. Richard Jobes, Mr. Bruce Listoe, and Mr. Keith McKean.

My obligation to my wife, Helen, formerly a member of the University English faculty, can be only partially repaid in such merit as others see in this volume. She has criticized, suggested, edited, read proof, done research, endured irascibility (but not meekly), managed a household, and done without vacations. She deserves no less than a co-authorship.

\section{Grand Forks, North Dakota}

March 21, 1958

\section{Contents}

Foreword . . . . . . . . . . . . . . . vii

Introduction . . . . . . . . . . . . . . . ix

“GRAND FORKS UNIVERSITY,” 1883-1899

I The Founders and the Founding . . . . . . . . 3

II The First Year . . . . . . . . . . . . . . . 28

III The University Takes Root . . . . . . . . 50

IV The 1890's-Years of Crisis . . . . . . . . . 91

\section{THE STATE UNIVERSITY, 1899-1945}

V The Making of a University . . . . . . . . . . 137

VI An Era of Progress-and Poverty . . . . . . . . 190

VII Student Life in Transition . . . . . . . . 237

VIII Stresses and Strains . . . . . . . . . . . 275

IX The Golden Twenties . . . . . . . . . . . . 319

X The Depression and World War II . . . . . . . 366

THE NEW UNIVERSITY, 1945-1958

XI A New Day . . . . . . . . . . . . . 407 Illustrations: following pages 160 and 320

(CONTINUEd ON Next PAge) 


\section{APPENDIXES}

Bibliographical Note . . . . . . . . . 457

An Act Establishing a Territorial University

at Grand Forks, Dakota . . . . . . . . . 461

Article VIII of the Constitution of the

State of North Dakota (Education) . . . . . 466

Constitutional Amendment Establishing a

State Board of Higher Education . . . . . . 467

The AAUP "Code of Criteria" . . . . . . . . . 471

Contributors to the University Maintenance Fund . . 472

$$
\text { INDEX . . } 479
$$

The contrast between these earliest universities and those of today is of course broad and striking . . . . And yet, great as these differences are, the fact remains that the university of the twentieth century is the lineal descendant of mediaeval Paris and Bologna. They are the rock whence we were hewn; the hole of the pit whence we were digged. The fundamental organization is the same, the historic continuity is unbroken. They created the university tradition of the modern world, that common tradition which belongs to all our institutions of higher learning, the newest as well as the oldest, and which all college and university men should know and cherish.

Charles Homer Haskins 


\section{PART ONE}

"GRAND FORKS UNIVERSITY"

$1883-1899$ 


\section{The Founders and the Founding}

$\mathrm{O}$

N OCTOBER 2, 1883, a group of dignitaries of Dakota Territory gathered on the windy, chilly prairie more than a mile west of the boom town of Grand Forks to lay the cornerstone of the first building of the University of North Dakota. Observing that the event had been celebrated with "great éclat," the Grand Forks Herald recorded further that one of the "brightest, crispest, freshest, most palpably wholesome days of the most glorious autumn that even Dakota ever saw crowned the object of the day's proceedings with an approving and sunlit smile." The language reflects not only the literary fashion of the day but also the high optimism generated by the great North Dakota land boom that was then at its peak. Only a year before large tracts of Indian lands in central Dakota had been added to the public domain; until 1882 the western limit of land available for pre-emption or entry in that area was about seventy miles west of Grand Forks. In the summer of 1883 immigrants and speculators were arriving by the hundreds each day; railroad construction was proceeding feverishly; and homestead shacks, jerry-built false-front stores and saloons, ambitious courthouses, and city halls were rising everywhere on the empty Dakota prairies. A part of the process had been the Territorial Assembly's acts, approved on February 27 by Governor Nehemiah G. Ordway, 
establishing a university at Grand Forks and authorizing a $\$ 30,000$ bond issue for construction of a building, provided that the city donated a ten-acre site and $\$ 10,000$ for an observatory. The conditions had been met, and in the intervening months a Board of Regents had been appointed, ground broken, final contracts let, and the first professor chosen.

The Board of Regents, with the help of the Acacia Lodge of the Masonic Order of Grand Forks, had planned the program and had made preliminary arrangements for the founding ceremonies, frcluding an arrangement for reduced railroad fares for visitors from anywhere in the Territory or in western Minnesota and a special train to carry them from Grand Forks to the University site; tickets for the latter were placed on sale in the three local drug stores at 25 cents each. At noon on the appointed day the train from Fargo brought in the leading performers of the occasion, among them the gigantic Governor Ordway, a popular figure in Grand Forks; David L. Kiehle, the superintendent of public instruction in Minnesota, who was to give the main address; his counterpart in Dakota Territory, General W. H. H. Beadle, and O. S. Gifford, Grand Master of the Masonic Order of Dakota, who was to lay the stone. Gifford was accompanied by a number of his lodge brethren. An hour later the four uniformed fire companies entertained the spectators with a drill exhibition, and after a tedious wait broken by impromptu "feats of dexterity" by Judge Cutts, one of the firemen, and quick trips by some "to see a man" in a nearby saloon, the scheduled procession took form. First in line was Captain U. O. Krause, the Grand Marshal, then the brightly uniformed seventeenpiece Cadet Band and its drum major, W. H. Brown. Governor Ordway and Dr. C. E. Teel and James Twamley, local members of the University Board of Regents, were next, followed by Mayor Masons, the fireck and the Grand Forks City Council, some sixty Masons, the fire companies, "citizens in carriages," and, bringing up the rear, a straggling group of "citizens on foot." After a turn through the business section, the parade disbanded at the Third Street crossing of the St. Paul, Minneapolis, and Manitoba railroad to board the waiting special train. As it "sped away" a group of carriages filled with "citizens and their ladies" followed by way of the "famous Broadway" (now University Avenue), which had been freshly graded for the occasion. ${ }^{1}$

The next scene in the ceremonies, described by a contemporary reporter as a "novel and attractive one," was at the partially completed basement and foundation for the University's first building, situated near the winding English Coulee, a minor depression in the otherwise table-flat prairie. The outskirts of Grand Forks were more than a mile distant; the only other visible habitations were scattered claim shacks, the John Carroll farm, and the building contractor's bunkhouse. The nearest trees were the giant cottonwoods fringing the Red River, nearly three miles to the east. In every direction, as far as the eye could see, stretched the yellow stubble of harvested wheat fields under the fleecy clouds of the limitless western sky.

A platform had been erected at the southeast corner of the excavation, and "the stone lay ready to receive into its granite bosom the relics which might be forthcoming." Here were seated the governor and the rest of the dignitaries; the firemen and Masons, infiltrated by a number of small boys, were gathered close around; and a scattering of spectators in carriages and buggies informally collected on the outer fringes completed the audience. Mrs. Carroll, the keeper of the workmen's boarding house, took in $\$ 300$ selling coffee and sandwiches. Local reporters called it a large crowd, but a photograph of the gathering reveals less the crowd they professed to see than the vast emptiness of the Dakota prairie.

The ceremonies began with music by the Cadet Band, a prayer, and some introductory remarks by General Beadle. Governor Ordway followed with an account of the events leading to the establishment of the University. According to him its existence stemmed from a meeting of territorial leaders he had called in 1882, following Congress' refusal to divide Dakota Territory or to confer statehood upon it, and from his support of one university in each section, each with a normal department, in preference to the rash of normal schools which had been threatened. Ordway observed that the

${ }^{1}$ Fred Twamley, the fifteen-year-old son of James Twamley, a member of the first Board of Regents, recorded in his diary: "School closed this afternoon on account of the laying of the cornerstone for the University. Bob, the Cooley boys, Strickenberg, Mr. and Mrs. Goff here to supper. Weather fair." 
Dakota University building at Vermillion was already under cover. He praised the pioneer spirit which had prompted the people of Dakota to make provision for educating their children on their own soil, and he looked forward to the not too distant day when "the people of this valley would rise up and call those who had laid the foundation of this institution today, blessed."

Grand Master Gifford followed with a short speech and called for the contributions to the cornerstone: copies of the current issues of the Grand Forks newspapers, the Herald and the Plaindealer, a silver dollar engraved with the name of the contractor, P. B. Broughton, a list of the Masonic officers and the visiting members present, a United States Treasury stamp, a copy of Governor Ordway's 1883 message to the territorial legislature in which he had urged the establishment of a university in the north, a copy of The Common Schools of Dakota, a pamphlet by E. A. Healy, one of the Regents, an envelope addressed to the Reverend F. W. Iddings, secretary of the Board of Regents, in which had been enclosed the first draft of funds for construction of the building, and miscellaneous coins, post cards, and the like.

The laying of the stone was followed by the main address by David L. Kiehle, a long and flowery discourse on "Intelligence, the Basis of Christian Civilization." Taking his cue from Jefferson and from that calmer era before the revelations of the nuclear physicists, Kiehle declared his belief that education could solve most of men's problems, that educated intelligence was the basis of industry, the essential element in civil government, the requisite to adequate expression of benevolence and philanthropy, and the source of all moral reform. As a natural consequence, he averred, higher education-that is, intellectual training rather than learning-was as legitimate a function of government as elementary and secondary education. "Government," he said, "has always been the friend of higher education, from the days of the Pharaohs . . . to the modern universities," and he challenged his hearers to demonstrate how a republican form of government could dispense with a high and broad culture for its people. Kiehle concluded:

Permit me to name the conditions, which, I am well-persuaded, have not been lost sight of in laying the foundation of this promising institution.
First, it must have pure and intelligent administration; one that will not allow its plan and aim to be disturbed by diverting influence, personal, political, or sectarian.

Second, its curriculum should be broad and generous, in that it shall provide the culture that will promote scholarship in every department that affects human happiness. It should provide generously for the study of natural science, the mental, moral, and social nature of man.

That which deserves the rank of university must recognize man in his widest relations as a social and religious being, and cultivate an intelligence which shall fit him for his highest good here, and, at least, be in harmony with his great future lying just beyond the horizon of mortal vision.

The last of the ceremonies was the presentation of a goldheaded cane to J. L. Bjorquist, the construction foreman, by his workmen. The audience went its way. Governor Ordway, however, remained another day to meet with the Regents to discuss plans for completing and equipping the building in time to open in the fall of 1884.

The University of North Dakota had been officially launched. The events of October 2 gave the University the distinction of being the first public territorial institution established in the northern half of Dakota. As such it marked the progress of the great "Dakota Boom," which reached its peak in 1884, the year the University opened its doors. Less than a quarter century before, the United States Census (1860) had counted only 4,837 persons, nearly half of them Indians, in all the Territory, which then included Montana and Wyoming as well as North and South Dakota. The first permanent public school building had been erected in 1864 at Vermillion. As recently as 1870 there had been only 2,405 people in what is now North Dakota. But population growth had been rapid following the resumption of railroad construction after 1878. In 1883 the Northern Pacific drove its golden spike at Helena, Montana, and the St. Paul, Minneapolis, and Manitoba, which had entered Dakota at Grand Forks only three years before, had reached the western boundary of Grand Forks County. Attracted by the systematic propaganda of the railroad immigration departments, and by the blandishments of promoters like George $\mathrm{H}$. Walsh, who was to play the largest single role in founding the University, settlers came in droves.

In the year ending June 30,1883 , claims were filed upon 
$7,500,000$ acres in Dakota Territory, or about two fifths of the total acreage claimed in the whole United States that year. Half of Dakota-42,000,000 acres-was claimed in the decade of 1879-1889. The population of North Dakota rose from 36,909 in 1880 , to $75,000-80,000$ in 1883 , to 151,000 in 1885 , largely concentrated in the eastern quarter of the area; in 1885 the first two tiers of eastern counties had a population of 116,000 ; there were 14,000 in the four counties of the Bismarck area.

Most of the settlers came from the neighboring states of Minnesota and Wisconsin, but New York State ranked a strong third, just ahead of Iowa, as a source of immigrants. The census of 1890 also revealed a high percentage of foreign-born $-81,000$, or nearly 45 per cent of the total population of 183,000 . About one third of these were Norwegian, the next largest group was German $(9,500)$, and the third, Canadian $(7,800)$. The Scandinavian element in the North Dakota population was already well marked by 1883 , and gave the state the distinctive ethnic pattern which it retains to this day as reflected in the names of the University students. It should be noted in passing, however, that it was the American-born and the Canadians who were the first to support the University by sending their sons and daughters.

The great attraction of North Dakota, the northern edge of the "farmers' last frontier," was the soil. There was practically nothing else; no forests existed except a few cottonwoods and willows along water courses, and mineral deposits were either undiscovered or difficult to develop. But the soil of the eastern side of the state, particularly the Red River Valley, the old bed of prehistoric Lake Agassiz, was fabulously fertile and quickly accessible to the pioneer farmer who, finding no trees in his way, could break a claim and harvest a crop of hard spring wheat in one season. The comparative ease of pioneer agriculture made for rapid settlement once it began, but it also invited a speculative type of one-crop farming. The individual farmer, either the homesteader or the purchaser of railroad land, was all too often operating on a shoestring, betting everything he owned or could borrow on making a wheat crop where the temperature and rainfall always hovered at the safety margin.

On the other hand, there were chances for quick money. The fertile land ready for the plow attracted large operators in unusual numbers for a pioneering farming region. Such were the bonanza farmers. By 1890 there were over three hundred farms of more than a thousand acres in the Red River Valley. Employing gangs of laborers, using dozens of machines, and harvesting crops measured in the thousands of bushels, these farms were not typical, but they illustrate the unique character of Dakota agriculture. Moreover, they provided the glamour which, exploited in the eastern states, attracted the speculative immigrant with some money.

Grand Forks, situated in the northern part of the Red River Valley in one of its particularly fertile areas, was one of the most active of the boom towns when the University was founded. It had had a remarkable growth since its first more or less formal settlement in 1871. For the first half dozen years or so of the seventies, the years of the great panic, its growth was steady, although slow. The town had a Hudson's Bay Company store; it was a thriving station for the Red River steamboat line, established by Captain Alexander Griggs, one of the founders of Grand Forks, an associate of James J. Hill and a brother-in-law of George Walsh. The town was also a stop on the stage line from Wahpeton to Pembina and Winnipeg. The first telegraph line came in 1871. Schools and churches had made their beginnings by 1875 , the year that Walsh founded the first newspaper, the Plaindealer. There were seven hundred people in the town when its first government was organized in 1878, with Walsh as president of the council. In 1879 George Winship founded a second newspaper, the Herald. By 1883 the population was up to about three thousand and by 1890 to nearly five thousand.

These were flush times indeed. The raw village which only three or four years before had witnessed the periodic trek of Red Lake Indians with wives, horses, and dogs en route to visit and trade with their friends the Sioux, had by 1882 a $\$ 20,000$ courthouse, a $\$ 30,000$ school, two flour mills, four hotels with accommodations for two hundred guests, two daily newspapers, a Norwegian weekly, a telephone exchange with fifty subscribers at $\$ 5$ per month, a brewery, two brickyards, twenty saloons, and six churches. The Herald reported fifty buildings erected that year, $\$ 20,000$ spent on 
board sidewalks and the first systematic grading of the streets, $\$ 15,000$ on a water works (to pump unfiltered water from the Red Lake River into mains serving the business section), an $\$ 8,000$ city hall, a fire engine house, and sixty-four new businesses. It was estimated that a half million dollars had been spent on construction in 1882. The crack of the stage driver's whip was last heard that year, and the steamboats' days were numbered after the railroad reached the town.

Life in such an atmosphere furnished its excitements and its contrasts. The newspapers regularly reported events from the rough side of - the community: a hair pulling brawl over distribution of fees at the establishment of "Big Kate," the best knowr madam in town, an after-midnight wedding at one of the "houses" witnessed by a large gathering of the "fast and fancy" set, the suicide of the "frail but beautiful" Mrs. Burdick, a "private courtesan," a lynching off the Red River bridge, the discovery on a doorstep of the dead body of a "victim of dissipation," and the drunkenly hilarious drenching of a half-breed's hair and beard with kerosene and setting it ablaze in a saloon. Such incidents were to be expected in a frontier community in which transient men made up a large proportion of the population (of the 1,706 people counted in 1880 fewer than 200 remained in 1885).

Yet Grand Forks also possessed a solid core of permanent citizens. The six churches were full. More than three hundred children were reported enrolled in the city schools in February, 1882, fiftysix of them on the high school level. The Masonic Lodge came in 1880 , a chamber of commerce was formed in 1881, and a racing association laid out a track in 1882. Meanwhile, a social elite-qualifications for membership being education, American birth, pure white blood, early arrival, or wealth-was clearly discernible, and the process of making it permanent and formal had begun. An Old Settlers' Association was formed in 1879, its membership limited to those who had arrived before 1876 . The Pioneer Club, also founded in 1879 , was restricted to a hundred members possessing the proper qualifications of money or manners. Its members, among them the George and Thomas Walshes and other families associated with the University's founding, entertained each other at the clubrooms or at their homes "in the suburbs." They were also the town's civic and cultural leaders. Most of these people were small scale nouveau riche who had made good in the boom, but included also was an unusually large number of welleducated and gently reared men and women, among them three of the first Board of Regents of the University, Twamley, Collins, and Teel.

James Twamley, who with Frank Viets operated a large general store on the site now occupied by R. B. Griffith Company, was born in Ireland of English parentage; educated in the New York City public schools and City College, he had engaged in a variety of business enterprises in New York, Chicago, and St. Paul before migrating to Grand Forks in 1876. Dr. William T. Collins, born in Massachusetts, was a graduate of Georgetown University medical school (1865) who had practiced in Minnesota before coming to Grand Forks in 1878. Dr. Charles E. Teel, who arrived a year later, likewise abandoned a successful practice in Minnesota. A native of Quebec, he was a graduate of the University of Vermont medical school (1865).

The opportunities afforded by the high rate of land transfer in a new country attracted a number of able and well-trained lawyers, one of whom, James M. Cochrane, accumulated a large library which served as the main collection of the University law school for a number of years and also furnished the nucleus for the library of the medical school when it was first organized. Educated easterners and some foreigners of means were lured out to Dakota for a variety of reasons, among them the realization that this was America's last frontier, the last chance to wrest a new land from a stern nature and savage Indians, to test a new environment, or to build a new social order unencumbered by tradition. A young Yale instructor of Greek, Webster Merrifield, coming by rail to Fargo and walking the rest of the way, summered in or near Grand Forks in 1879; he was looking after his family's investments in Red River lands and seeking relief from hay fever. The year the University was founded Andrew and R. B. Mellon of Pittsburgh established a bank at Bismarck, and Theodore Roosevelt, seeking profit as well as outdoor life and adventure, began his ranching 
operations in the Bad Lands. His neighbors were the well-to-do French adventurers, the Marquis de Mores and his wife.

The booming new region of the Dakotas was a kaleidoscope of the history of American development. All the experience of the preceding three hundred years was compressed into a decade. Simultaneously the region was subject to all the currents in the new industrial and urban America that was emerging after the Civil War. Its educational system, for example, was to be established at the very time the whole American educational pattern was being revolutionized. With the changes, education became a near religion and the stage was set for that steady rise in enrollments which has produced the fantastic school population of the 1950's. All levels of education were affected. The primary system was systematized and graded, the principle of free public education was extended to the secondary schools, and teaching methods and curriculum were subjected to a critical re-examination. Higher education had actually declined in general popularity on the eve of the Civil War because the traditional curriculum, providing neither culture nor useful knowledge as it had come to be taught, failed to meet the needs of a dynamic society. The revival dates from the elevation to collegiate status of the agricultural and mechanic arts, the systematizing and deepening of the preparation for most of the traditional professions, and the creation of curricula for a number of new ones. And it was in the 1870's and 1880's, the years of the Dakota boom, that the American university achieved its unique form by the addition of the German graduate school to the college system that had existed since colonial days.

The revival of interest was accompanied not only by rising enrollment but by a revival of public support. Organized church groups took a renewed interest in founding colleges, and for the first time they became a favorite object of philanthropy. The owners of huge fortunes accumulated in the Civil War and the postwar expansion became convinced that they could spend their money to no better effect than on education-to prepare young Americans for useful employment in an increasingly complicated economic system and to impart such principles of religion or economics as would render them socially stable defenders of the system that had produced the fortunes which educated them. Finally, and of particular significance to Dakota, the period of 1870 to 1890 was one of vigorous development and interest in state universities and land grant colleges emphasizing technical education in agriculture and the mechanic arts.

One can almost ignore the element of philanthropy or organized church effort in considering the history of higher educational institutions in North Dakota. Although numerous efforts were made to launch "church colleges," none received any really substantial support, and only one has managed to survive as an independent institution. North Dakota's churches were themselves infant institutions in no condition to collect large quantities of funds, and her rich were either too few or too new to part with their money. Philanthropists outside the state tended to put their money where the need was obvious and massive, or where it would show. The only alternative that remained was the publicly financed institution.

The Morrill Act of 1862 provided the incentive of gifts from the federal domain to endow such colleges as met its requirements. Unfortunately, it also invited haste and shortsighted rivalry among struggling communities, a fact which militated against a wellplanned or coordinated system of higher education or the wise placing of colleges. In North Dakota, the establishment of major colleges before the population pattern had set and in the circumstances of a speculative boom with its sectional rivalries resulted in placing the two major state colleges and normal school in a radius of seventy-five miles along the eastern boundary. The law's requirements as to curriculum were no hindrance in Dakota, where the educational outlook conformed to Morrill's philosophy of practical, nonornamental mass education. Even the requirement of military training could be viewed as a wholly practical one in Dakota, where the Indian problem was still immediate when the University was established. The Battle of the Little Big Horn was still a living memory; the Ghost Dancer uprising and the Battle of Wounded Knee were a half dozen years in the future. The practical aspects of education were the most important ones, at least as far as the great public of homesteaders and farmers was concerned- 
if they ever thought about higher education at all. Yet the old classical education had its share of adherents in the 1880's, even in an area as rough and ready as North Dakota. And it was they who had the largest influence on the University in its early years. Those who had attended colleges in the east, and even the newly well-to-do who had not, preferred to give their sons and daughters the traditional educational ornaments and discipline rather than practical training in agriculture, mechanic arts, or Indian fighting.

There was an element of the incongruous in the movement to establish colleges in Dakota Territory or areas like it. In the early 1880 's the elementary school system was barely developed in Dakota, and secondary schools existed hardly at all. The first high school, at Yankton, the territorial capital, had been organized as recently as 1875 . Five years later, still the only four-year school in the huge territory, it had an enrollment of forty-nine and a faculty of three; eleven graduated in the class of 1880 . By 1883 three high schools, all ungraded, were in session in North Dakota, at Grand Forks, Fargo, and Bismarck. Only Fargo offered a four-year course, and Grand Forks did not graduate its first class until 1887. Yet the very lack of a school system provided an argument for the founding of colleges and normal schools, the former to train secondary and the latter elementary teachers. An important factor in the successful passage of the University bill in 1883 was the provision for a normal department. In this connection it may be noted that the University's first significant public service to North Dakota was the training of teachers for the public schools, and that it was the president and faculty of the University who organized the secondary school system and undertook to standardize it.

Although the Dakota territorial legislature had passed a bill in its first session, 1862, to establish a university at Vermillion, no appropriation accompanied the measure, and it was not actually until statehood seemed imminent in the beginning of the 1880's that the legislature gave its first really serious consideration to college founding. The 1881 legislature voted to establish three normals, but with the provision that the measures would not be implemented unless statehood was achieved. The fact that all of the prospective institutions were to be in what is now South Dakota aroused jealous apprehension in the rapidly growing northern part of the territory. Such ambitious towns as Grand Forks, Fargo, Bismarck, and Jamestown anticipated that if the trend were not halted every other public institution-penal, eleemosynary, as well as educational-would go to the south. It was almost inevitable that an involved and corrupt logrolling maneuver would ensue in which every territorial institution, including the capital itself as the main prize, was put on the block as the price of votes and influence; whatever plans there may have been for wise organization or placement of state institutions, including the colleges and normals, went out of the window. When Congress rejected a statehood bill in 1882, the governor, Nehemiah G. Ordway, a machine politician from New Hampshire who had invested heavily in Bismarck real estate, assumed the leadership of a cabal to move the capital from Yankton to Bismarck and to distribute the other institutions in whatever way was necessary to achieve that end.

The exceedingly complicated details of the capital removal affair need not be related here. It is enough to record that the issue was the dominating consideration in practically every measure that came before the Territorial Assembly in 1883. In the general game of grab, the main issue was of course surrounded by the smaller intrigues for the secondary prizes, among them the University. Ordway managed all the maneuvering and attempted at the same time to restrain the enthusiasm for indiscriminate college founding - provided that it could be done without interfering with his own grand designs. In addition to Ordway, the leading actors in the University subdrama were George Walsh, member of the Territorial Council from Grand Forks, James Twamley, and Dr. William T. Collins.

Walsh was a typical Dakota boomer, neither better nor worse than dozens of others who had come to a new country to seize opportunity by the forelock. Born in Quebec in 1845, the oldest child of Thomas and Eleanor Walsh, he had come with his parents in 1856 to Henderson, Minnesota, where his father established a clothing store. In 1862 when he was seventeen, he and his father enlisted in the 10th Minnesota Infantry. At the end of the war, Thomas, who was severely wounded, was a first sergeant and 
George was a quartermaster sergeant cited for "conspicuous good conduct at a charge." It is hardly surprising that a family of this sort should turn to the opportunities, hardships, and adventure of Dakota, to which their attention was directed by Alexander Griggs, who spent the winter of $1869-1870$ at Henderson. Griggs and the elder Walsh formed a partnership to operate a sawmill and store at Grand Forks, and in 1871 the Thomas Walsh family moved to Dakota.

Meanwhile George, a river steamboat clerk, had married Griggs's sister in 1867. He went into the newspaper business, setting up the first English-language paper in New Ulm, where he also read law; both pursuits were preparation for the next phase of his career, which began when Griggs urged him to come to Grand Forks to act as his legal adviser and to establish its first newspaper to advertise the Red River Valley. In the spring of 1875 Walsh, his wife, and four small children, all under five years of age, joined the Thomas Walsh family and the Griggses in the village on the Red River. The journey took five days, two by rail from St. Paul to Moorhead and two by steamboat from Fargo to Grand Forks. The Walshes were tough; that first year was spent in a four-room log house, originally built as a barn, which even by pioneer standards was inadequate shelter from the long, harsh Dakota winter. To the discomforts of the cold were added the monotony of a diet of such staples as could be brought in by stage and the inconvenience of having to provide shelter for a steady stream of prospective settlers. In the meantime a weekly paper had to be put out somehow, with only Walsh and his wife to do the work. Hardship was compounded by tragedy; the first year the two youngest children died of cholera, and Walsh's brother was drowned.

The Walshes were not only tough, but "on the make." Thomas was registrar of deeds in Grand Forks; another son, Edmund, was postmaster of Crookston, twenty-five miles east, and in the spring of 1876 George was appointed clerk of court in Grand Forks. This was his first step into the arena of Dakota politics, in which he was to be an important figure for a decade and a half. He was president of the first organized government of Grand Forks (1878), member of the upper house of the Territorial Assembly from 1879 to 1885 and again in 1889, president of the body in 1879 and 1881, and chairman of the North Dakota Board of Railroad Commissioners from 1891 to 1893 . In the meantime, Walsh sold his newspaper, his father his store, and they entered the land and banking business. When they organized the Bank of Dakota in 1879, the Grand Forks Herald, which opposed George politically, described him as "one of the most sagacious, successful and progressive men of affairs in Northern Dakota." By 1883, when his fortunes were at their peak, Walsh's grandiose full-page announcements of the opening of new land tracts were a regular feature of the Grand Forks papers. ${ }^{2}$

To a freewheeling "boomer" like Walsh, out to make a fortune in a land where restraints were few and opportunities many for the bold and energetic, winning a university for his town was more a prize in the game and a promotional advantage than a victory for culture and learning. His position of leadership in the Territorial Council made him a key figure in the capital removal plot, one who could demand a major prize for his own town, poorly located though it was.

Both Twamley and Collins, and undoubtedly a number of others, played lesser roles in winning the prize. As president of the Chamber of Commerce in 1882, Twamley had brought Ordway to Grand Forks to confer with civic leaders about the distribution of institutions, and by his own account, published some years after his death, Twamley suggested on that occasion that Grand Forks would be content with the University as its share. Active in civic affairs, a prominent Mason, and a neighbor and close friend of Walsh's-they owned adjoining farms where the Armour packing plant now stands-he also had more than a casual acquaintance with Ordway. Twamley's subsequent appointment to the Board of Regents was on Walsh's recommendation.

The claim for Collins as a founder rests partly on his prominence in civic affairs. A veteran of the Union Army who had lost a leg at Second Manassas, he was the second physician to come to Grand Forks (1878) and the only one for a time. He was the town's "A typical example was his sale, at bargain prices of course, of choice lots in the "town" of Harrisburgh, the "capital of North Dakota," whose situation on the lovely "the 
first health officer and also served as assessor, member of the school board, and vice-president and president of the Chamber of Commerce in 1880 and 1881 . Shortly after the 1883 Assembly opened he addressed a letter to Walsh urging that he secure a normal school for Grand Forks. Walsh's reply that he would have better luck getting a university was received with enthusiasm, and some weeks later (February 1) Collins complied with Walsh's request to submit a draft for a university bill (it was, however, never used). Because of this rather minor activity Collins was appointed to the first Board of Regents on the recommendation of Walsh and was subsequently elected its first full-term president.

In the meantime, Walsh was deeply involved in the complicated intrigues and politics of that crucial legislative session of 1883 at Yankton where so much of the present educational and institutional pattern of both Dakotas was set. Ordway had fired the opening gun in his annual message, in which he recommended the establishment of territorial institutions in the north. The next step, which had been prearranged, was to split the southern delegation, which was in overwhelming majority in both houses-ten to three in the Council. With the approval of Ordway and the northern crowd, J. O. B. Scobey of Brookings was quickly elected president of the Council. The South Dakota breach was further exploited when Walsh, after some talk of removing the capital to an entirely new town site on the open prairie, introduced a bill to move it from Yankton to Huron, also in the south.

In late January, while Walsh was held up by a blizzard in St. Paul, where he had gone on a short business trip, the South Dakota group attempted to re-form their lines by making overtures to S. G. Roberts and Johnston Nickeus, the representatives from Fargo and Jamestown, who were not satisfied with the plans for the north. They introduced their own set of bills appropriating a half million dollars for institutions, most of them in the south. Walsh hastily returned and pulled together his wavering northern colleagues, apparently by accepting a proposal that they draw lots for the university, the agricultural college, and the insane asylum and penitentiary. (He wrote years later: "I took the University, Jamestown the insane asylum and Fargo took the agricultural college.
The penitentiary went to Bismarck.") He then counterattacked by promising the north's support for establishment of an agricultural college at Brookings, Scobey's town, and for appropriations to launch the Dakota University established at Vermillion in 1862 and the normals established by the 1881 Assembly at Spearfish and Madison.

With his lines partially re-formed, Walsh managed to bury the South Dakota institutional bills in the appropriations committee, of which he was chairman. Fearing that his still restive northern colleagues might yet walk off with the prize, he hastily introduced into the legislative hopper some blank sheets of paper inscribed "A bill for an Act Locating the University of North Dakota at Grand Forks, N. D., and Providing for the Government thereto." In the two days required for first and second readings, which were by title only, Walsh prepared a bill modeled on the University of Wisconsin act and substituted it for the dummy when it was routinely referred to his appropriations committee. As he put it: "No one would be any wiser, and no harm would be done by anyone, and I would get my bill ahead of Fargo or Jamestown, which I succeeded in doing. The Jamestown member was very much disappointed."

The bill was reported out of committee without change; it quickly passed the Council and House, and on February 18, 1883, it went to the governor. Ordway wanted some amendments, which were accepted, and the final measure was back on his desk by the twenty-fourth. Three days later it was signed into law along with another act authorizing $\$ 30,000$ in territorial bonds to construct a building, the amount suggested by Collins. Another measure signed on March 7 appropriated $\$ 1,000$ for apparatus, $\$ 600$ for fuel, light, and janitor service, $\$ 1,000$ for incidental expenses. $\$ 400$ for improvement of grounds, and a maximum of $\$ 5,000$ per year for salaries. On the same day that the main University bills were signed, the governor signed measures to appropriate $\$ 50,000$ for a penitentiary at Bismarck and to authorize $\$ 30,000$ in bonds to complete Dakota University at Vermillion and to establish an agricultural college at Brookings and a deaf mute asylum at Sioux Falls. Other institutional measures of the session were appropriations for $\$ 7,000$ each 
to the Spearfish and Madison normals and acts to establish an agricultural college at Fargo and normals at Larimore, Minto, and Pembina, all in North Dakota, but all without appropriations.

The capital removal commission measure was signed into law on March 5. When in the following months the commission did the expected by selecting Bismarck as the new capital, the fortunate town enjoyed a tremendous boom in land prices. The fact that the removal had been accomplished in the manner it had, plus the obvious benefits it brought to Ordway, who established a bank there, has ever since shrouded the legislative session of 1883 , and to some degree the birth of the University, in controversy and charges of corruption.

There was much elation in Grand Forks upon receipt of the news that the "best territorial gift available" had been won. The Plaindealer was lavish in its praise for its former owner and happily declared: "Universities have long memories, and Mr. Walsh by founding the University of Grand Forks has gained as many tongues to his support and praise as fame herself is said to have possessed." Even George Winship's Herald freely acknowledged the city's debt to Walsh. On the evening of March 2 the Grand Forks Lyceum, a literary society, meeting at the Methodist church, resolved that it "tenders the Hon. George H. Walsh its sincere thanks for his unceasing efforts in securing the location of the University of North Dakota in this city."

When Walsh returned from Yankton a few days later the city honored him with a reception, but there the honors stopped. Walsh has been almost completely forgotten by the University of North Dakota. There is no record that he was ever invited to speak on the campus until President Webster Merrifield requested his presence at the first Founders' Day observance in 1904, an invitation he was unable to accept. His death in 1913-he is buried at Grand Forkswent unnoticed in University circles and not a single bulding or so much as a simple marker on the campus bears his name. In part the neglect was a result of Walsh's controversial and somewhat questionable role in state politics and of hostility toward him in influential circles in Grand Forks; in part it stems from the relatively minor role he played in Unive: sity affairs after the founding.
Although he could be counted upon to support the University as long as he was politically active, which was until the middle of the 1890's when he left the state, he never set himself up as its special guardian. That role he left to others along with the task of planning and development.

Whatever may be said in criticism of the "peculiar political methods" of the "trading member from Grand Forks," as the Herald once put it, Walsh had chosen a sound model for his organic act, and if the composition of the first Board of Regents, ${ }^{3}$ which he selected, has any significance, he had every intention of divorcing the new institution from politics. Every one of the five appointive members-the governor was an ex officio member-met the requirement of superior education established as a basis of choice. Collins. and Charles Teel of Grand Forks and R. M. Evans of Minto were physicians; only Collins was politically active and he was an opponent of Walsh's. The Reverend E. A. Healy of Grafton was eminently qualified. A native of Ontario and a Methodist minister holding both the B.A. and M.A. degrees from Victoria University, he was assistant superintendent of public instruction of Dakota Territory. in 1883. He was later to become the dean of the University of Southern California College of Theology when it was reorganized in 1907. Twamley was Walsh's friend and neighbor, but he was not active in territorial politics. He met the educational requirement and offered the additional qualification of a deep personal interest in the University project. Every one could boast a background and career in harmony with the motto "Intelligence, the Basis of Civilization," which was inscribed on the official seal, adopted March 4, $1884{ }^{4}$

The organic law, "An Act for Establishing a Territorial University at Grand Forks, Dakota," specifically designated the new institution as the University of North Dakota. It was to be coedu-

${ }^{3}$ The University has been governed by the following bodies: University Board of Regents, 1883-1889; University Board of Trustees, 1889-1915; State Board of Regents (all colleges), 1915-1919; State Board of Administration (eleemosynary, penal, and educational institutions), 1919-1939; and State Board of Higher Education and a salaried Commissioner of Higher Education (all colleges), 1939 to the present time.

"The design, made by a Chicago firm, was a simple one- "University of North motto. The words are a paraphrase of the title of Kiehle's cornerstone laying address. 
cational and free to all residents of one year. Political and religious tests of faculty and students were prohibited, as was the teaching of political or sectarian religious doctrines. In the expectation that the institution would qualify for a land grant under the Morrill Act when statehood was achieved, military instruction was required of all male students and an annual report was to be distributed to all other land grant colleges. The stated purpose of the institution was to "provide the means of acquiring a thorough knowledge of the various branches of learning connected with the scientific, industrial, and professional pursuits, in the instruction and training of persons in the fundamental laws of the United States, and of the Territory, in what regards the rights and duties of citizens . . .."

A separate college of liberal arts and letters and a normal college were initially prescribed. The college of arts was to include mathematics, physical and natural sciences "with application to industrial arts, such as agriculture, engineering, mining and metallurgy, manufactures, architecture, and commerce," and instruction "in such branches included in the college of letters, as shall be necessary to proper fitness of the pupils in the scientific and practical courses for their chosen pursuits and in military tactics . . . ." The normal deparment was to provide "proper instruction and learning in the theory and art of teaching, and in all the various branches and subjects needful to qualify for teaching in the common schools ...." It was also provided that "as soon as the income of the University will allow, in such order as the wants of the public shall seem to require, the said courses in the sciences and their application to the practical arts shall be expanded into distinct colleges of the University, each with its own faculty and with appropriate title. The college of letters shall be co-existent with the college of arts, and shall embrace a liberal course of instruction in language, literature and philosophy."

The absence of precise definition of the University's function was a reflection of the conflict of the time between the advocates of practical education and the defenders of the old classical-theoretical curriculum. The North Dakota university act is an indication that the Dakota legislature, dependent though most of its members were upon the practical exploitation of natural resources, was not ready to go nearly so far in the direction of practicality as were legislative bodies elsewhere when setting up new public institutions after the passage of the Morrill Act.

Yet the act was broad enough as it stood to have permitted the expansion into an agricultural college had there not been the pressure to scatter colleges in the form of patronage and thereby saddle a thinly populated region of limited resources with a larger educational establishment than it was able to afford. Part of the difficulty, of course, lay in the fact that at the time no one anticipated the fantastic expansion of higher education that lay ahead. The University was launched on a bond issue of only $\$ 30,000$ to construct a building, an appropriation of $\$ 5,000$ per year for salaries, plus the expectation that Grand Forks would contribute the ten acres of ground for a campus and a $\$ 10,000$ observatory. Even this small levy upon the host city, a common enough practice in such matters at the time, was larger than most towns had to put up to get state institutions.

On April 21, 1883, the Board of Regents met for the first time in the City Hall of Grand Forks. The several acts creating the University were read, and the Board was temporarily organized with Dr. Teel as president and Dr. Collins as secretary. The chief business transacted was to order advertisements placed for tenders of land and the $\$ 10,000$ for the observatory, to be made by May 16 when the Board would meet again to select the site for the University. The secretary was instructed to secure some preliminary plans and specifications from various architectural firms. At the May 16 meeting several offers were considered: two of them were highly desirable wooded sites near the Red River, one the present Riverside Park and the other immediately to the north; but only one, from the real estate firm of William Budge, M. Ohmer, and John McKelvey, included bond for payment of the $\$ 10,000$ to construct the observatory. Alexander Griggs, S. S. Titus, and M. L. McCormack were coguarantors on a bond for $\$ 20,000$. In fact, the Budge group offered a choice of two sites, one of ten and another of twenty acres. Both were on the open prairie, however, some distance from town, and the Regents postponed action in order to give the other donors time to raise the $\$ 10,000$ if they could. None 
did, however, and on May 18 the larger Budge site was accepted by a vote of three to two. It lay a mile and a half west of the nearest house in the town on the outer edge of a property which the Budge firm was hoping to develop into house lots. About the only improvement which had been made was the rough grading of a hundred foot wide street, Broadway (renamed University Avenue around 1900), from the city limits to the tract.

At the time and for many years after, the campus on the flat, windy, treeless prairie had little in its favor. Not only was it barren and singularly unlovely, but until 1904 when cheap and reliable public transportation became available, it was difficult to reach, especially during the long and violent Dakota winters and the spring thaws when Broadway became a quagmire. The apparently unwise choice of site has led to suspicions that corruption was an element in the decision. The Board actually had no choice. As for Budge, he was no philanthropist and had little interest at the time in the University except as a factor in the development of his extensive real estate holdings. There were some strong arguments in favor of the location, some of them noted at the time, others that came with the years. Situated as jt - zas on the highest ground between two coulees, the site was well drained, without risk of flooding by the Red River; it lay beside the St. Paul, Minneapolis, and Manitoba tracks, a real advantage in a land where the only reliable transportation in winter was the railroad; it was far enough from town to isolate the students, always an important consideration in placing colleges in that day. If it seems a bit more isolated than was necessary, it was expected in the optimism of the Dakota boom that the fault would be remedied in a short while. Time has provided the best argument of all for the site; the University of North Dakota is one of those few fortunate institutions not cramped for space in these days of rapid expansion.

The Regents lost no time in organizing the University. An architectural firm in Minneapolis, Kees and Fisk, was retained to draw up several sets of tentative plans; Collins, Teel, and Twamley were appointed as a building committee. The Regents also appointed an executive committee and various standing committees on the government of the new University-buildings and grounds, library, museum, and a farm committee. The latter, a clear indication of the uncertainty about the University's scope, was to have charge of the furnishing, improvement, and management of the experimental farm of the "college or department of agriculture." The secretary of the Board was designated as official librarian and directed to keep an historical record of the proceedings. The first by-laws for the University's government were also adopted. The faculty was defined as only those professors "duly elected," not to be confused with such "instructors" as were hired from time to time. The "Faculty of the University" was empowered to make all rules for instruction and discipline, but it was thought advisable to make one specific regulation, possibly a result of the Regents' memories of their own college days in the East:

Any student ... guilty of improper or indecorous conduct during commencement week or class day exercises shall be excluded from the honors of graduation, and any student who shall be guilty of making, printing, writing, or issuing scurrilous or indecent programmes, papers, or compositions, or making disrespectful, abusive, or improper allusion to the President, Professors, Tutors or other officers of the university in speeches, essays or otherwise, publicly, during examination and commencement weeks shal not be graduated from the university and such student may be liable to expulsion by the Board.

Although in a hurry to begin construction, the Regents were unable to agree on a building plan when they convened on June 6. The major disagreement arose over whether or not the building should include living arrangements for students. According to Merrifield, writing years later when he was president of the University, Governor Ordway added to the indecision by suggesting that the entire $\$ 30,000$ be spent for an excavation and foundation for a huge structure capable of providing classrooms, laboratories, and dormitories for two thousand students, but it is doubtful this proposal was ever seriously considered. Collins was elected president at this meeting, and he and Healy were named a committee of two to inspect other colleges and universities. Final decision was postponed until their return. At the University of Minnesota they learned from President William Watts Folwell of "useless expenditures in dormitories and the remodelling of buildings." At the Carleton College observatory they were pleased to learn that their 
$\$ 10,000$ observatory fund ought to be adequate "for years to come." They were told at the University of Wisconsin that $\$ 120,000$ had been "thrown away" for useless buildings-two dormitories and a ladies' hall. Their last stop was Cornell, "the ideal of all state institutions, at least so thought the professors, judging from the way it is visited by the professors of institutions visited by us. We . . . concluded to leave out a visit to the Michigan University and Harvard and Yale colleges on the account." Although there is no record of what they actually saw or concluded at Ithaca, it appears that the vigor and originality of the Cornell of Andrew D. White, with its bold combination of the practical and the theoretical and literary elements in higher education, impressed the North Dakota Regents more than anything else they saw. They observed with interest that the Cornell Trustees had rejected dormitories in the expectation that superior disciplinary restraints could be obtained by having students live with "quiet families" in the town.

There is no doubt that ideas for the North Dakota building were affected by the visit to Cornell. All plans for including dormitory space were dropped, in the hope that "private capitalists" might be interested in constructing boarding facilities. A number of other changes were made after Henry Montgomery (B.A., University College, Toronto; B.Sc., Victoria College) arrived on the scene to apply for the position of professor of natural science-or for the presidency. The Regents were impressed by his dignified bearing as much as by his qualifications and appointed him vicepresident and to the natural science chair on July 16; they also sought his advice, as the only experienced academician on hand, on plans for the building. The final plan, completed in time for contracts to be let on August 15, was for a building of three stories, a high basement and cupola, with professors' offices, classrooms for chemistry, natural science, mathematics, English, Latin and Greek, metaphysics and history, and space for a museum, chemistry laboratory, chapel, and a library and reading room. The low bid, $\$ 38,000$ for the main building and an observatory building without dome, was made by P. B. Broughton of Minto. The subcontractor and the actual builder was John L. Bjorquist, a Swedish immigrant. Broughton provided the brick from his Minto kilns. The plumbing con- tract, for a total of $\$ 493$, went to Stevens and Gavenjan of Grand Forks.

Unable to avoid the housing problem as the Regents were attempting to do, the contractor rebuilt Billy Budge's old claim shack on the coulee banks into a boarding and bunkhouse and hired Mrs. John Carroll from an adjoining farm to operate it. The construction work began immediately, and on September 18 the Regents appointed a committee to prepare a program for the laying of the cornerstone in October. 


\section{The First Year}

$\prod$

HE REGENTS were generally agreed that instruction at the University was to begin in September, 1884, although no formal decision appears to have been taken. Completion of the building was only one of a multitude of tasks that remained to be done in the short year the Regents had allowed themselves. Indeed, there were so many large and obvious tasks, such as the appointment of a president and faculty, that many lesser, but nevertheless vital, arrangements were forgotten or neglected. One could hardly expect otherwise of a Board composed of busy men meeting once a month with no clearly defined executive leadership other than that exercised by its elected president, Dr. Collins. Moreover, a poor season and an economic slump in 1884-wheat was 50 cents a bushel in September, half what it had been a year before-diverted attention and produced second thoughts about the wisdom of launching an enterprise as burdensome and economically unproductive as a university. In fact, Dr. Collins was considering leaving North Dakota altogether at the very time the University's fate depended in large part upon his leadership; he actually did depart in 1887. (It is of some significance that by the middle 1890's Twamley and Evans were the only members of the original Board still residing in the state. Twamley, who served continuously until 1893, lived in Grand Forks until his death in 1916.)

Construction went on steadily at first, and in December, 1883, the walls were up and the cupola and roof well along; a local newspaper reporter was carried away by the impression of a "bold and massive pile ... towering against the western sky with pretentious importance." His comment is not entirely exaggeration, for the building, four stories high including the basement, and 120 by 54 feet, would be the largest in the northern half of Dakota when completed. The work was temporarily halted because of the weather, and in the spring, owing to some difficulty with the contractor, it began so slowly that in the end the Regents had to employ their own workmen to bring the building to the point where it was at least partially ready for occupancy in September. The University was in session two months before the architects finally pronounced the building completed to their satisfaction. It was, in fact, so cheaply constructed that it began to deteriorate and settle in a matter of months. The architects were not entirely at fault, for quality had been deliberately sacrificed to size; as for the settling, it was to be years before builders learned that the Red River Valley subsoil was too unstable to support heavy structures without specially built foundations. Even so, part of the building, although much shored up, still stands in 1958 and is in full use for administrative offices. The shortage of funds was not without one advantage, for it prevented the Regents or architects from loading this first building with the gimcrackery that usually adorned expensive buildings of the day.

The observatory was never completed. Construction was begun with territorial funds in the expectation that they would be replaced by the payment of the Budge pledge, but building was haltedpermanently, it proved-when Budge and his associates, hard pressed by the economic slump, refused to advance the $\$ 3,100$ expended on an excavation and foundation. The Regents refused the offer of notes bearing 7 per cent and requested the attorney general and territorial treasurer to force payment or to collect from the bondsmen. The latter eventually paid $\$ 2,997$, and the territorial officials refused to press them further, despite persistent prodding 
by the Regents. Interest in the observatory faded in the face of other more pressing needs and with the realization that the structure not only faced in the wrong direction but vibrated too much with every passing train to be suitable for the mounting of delicate astronomical instruments. The gaping hole and unusually heavy foundations remained neglected and weed-grown until 1893, when they were used for a small men's dormitory (later enlarged and named Macnie Hall.)

Aware of their own limitations in dealing with the multifarious details of launching a university, the Regents began their search for a president not long after the cornerstone laying ceremonies. On the urging of Ordway who, whatever his faults, was genuinely interested in the University of North Dakota, they proceeded carefully in an attempt to find a man who combined executive ability and intellectual capacity. The secretary began corresponding in December with "all the presidents of all the universities within his knowledge," and by March he had collected a list of twenty-four possible candidates, most of them clergymen. The secretary then addressed to each the following inquiry:

You have been recommended to us for the position of President of the University of North Dakota, and I am directed by the Board of Regents to inquire of you your disposition toward this opening, and what salary would command your services. I will mail you a copy of our prospectus, giving some idea of our beginning, and such other information as you may desire, in case you look favorably upon the position and are within our financial reach. ${ }^{1}$

There is no record of how many replied affirmatively, but on April 9 the Reverend William Maxwell Blackburn, a graduate of Hanover College (1850) and pastor of the Central Presbyterian Church of Cincinnati, was unanimously elected president of the University and professor of mental and moral science and philosophy. After a visit to Grand Forks to look over the situation, he accepted the office. Blackburn had much to offer. Fifty-five years old, dignified and impressive in appearance, he was a polished and persuasive public speaker and a man of force and principle. His 'The prospectus mentioned had been published in January, 1884, part of a booklet containing a brief history of the founding and an account of the cornerstone laying ceremonies. experience as professor of Biblical and ecclestiastical history at the Presbyterian Theological Seminary of the Northwest (now the McCormick Theological Seminary) more than qualified him for his professorial chair, and he had a solid reputation as a scholar and writer. His publications ranged from a series of "Uncle Alick" stories for children to a History of the Christian Church from Its Origin to the Present Time (1879), which was regarded as the standard American work on the subject and widely used as a text. Before his death in 1898, he published no less than thirty-three books, including a History of Dakota (1897). Why he chose to come at his age to a frontier university without even one completed building can only be surmised, but apparently he had been infected by the Dakota fever. He had already visited the Devils Lake region for a summer, and after he left the University, he lived the remainder of his life in South Dakota.

In some respects the Regents had perhaps done better than they needed to. Webster Merrifield was to observe years later that "the young university did not need in its president great learning and wide reputation so much as it did energy, executive ability, and especially a faculty for drudgery, and often times, petty details, such as would naturally be irksome to a distinguished doctor of divinity and doctor of laws."

Yet the Regents can hardly be criticized for finding a man too big for their job who might expect too much of it. They had proceeded soundly, in the fashion still approved in academic circles, and they had studiously avoided awarding the post as a political favor. Their selection of a clergyman, although it reveals an oldfashioned, if not a backward-looking approach to higher education, was still a not uncommon practice among nonsectarian colleges, even among the new land grant institutions of the West. They had, to be sure, refused to give the post to Montgomery, who had campaigned for it ever since he had been elected vice-president and professor of natural science on his visit to Grand Forks the summer before. His letters bearing advice and suggestions had continued to appear during the winter, and he had also kept the local newspapers informed of his activities elsewhere, including the publication of his article, "Three Weeks in Dakota," in a Toronto journal. In 
April he had raised the question directly by writing "to know as soon as possible whether the duties of the President of the organization would devolve upon him." It is not clear, however, whether the Board held off because they shrank from the innovation of a scientist president or merely reacted unfavorably to Montgomery's self-promotion.

Blackburn, his wife, and two young daughters arrived in Grand Forks the middle of June. $\mathrm{He}$ and Montgomery, who had also recently arrived, met with the Regents at once and outlined their views on faculty and scheduling and on the rules they thought necessary for university government. They pointed out the necessity of a preparatory department, an obvious need in a land of no high schools. Fifteen hundred copies of a formal announcement of the University's prospective opening were distributed in the territory in July. The new president himself seized every opportunity to appear publicly up and down the Red River Valley. Shortly after the day of his arrival he and Montgomery accompanied Healy, who was assistant superintendent of public instruction, to the organizational meeting of the Dakota Education Association at Fargo. Healy was elected president of the new group and Montgomery vice-president. The latter, who was to prove to be an ineffective teacher, gave an address entitled "Success in Teaching." Blackburn's speech, "Individuality," was pronounced the "intellectual treat" of the session.

Yet it is difficult to discern much evidence that the president exerted effective leadership in preparing the University for its opening in September. Indeed, he apparently considered that his major function was to be the final arbiter of high policy and the link between the University and the public just as he had observed the operation of the office in large and established institutions. He had little to do with the appointments of Webster Merrifield and Mrs. E. S. Mott, the only additions to the faculty, made in July.

The appointment of Merrifield, who was destined to be one of the greatest names in University history, was related to the fact that he had property interests a few miles south of Grand Forks and to his earlier visit in the summer of 1879 . From 1878 to 1880 he had been on the faculty of the Siglar School for Boys at New- burgh, New York, where he became acquainted with the family of Mrs. Twamley, who had been reared there, and with other people who had connections in Grand Forks. A graduate of Yale (A.B., 1878), he had been tutor of Greek and Latin at his alma mater for the four years preceding his appointment to North Dakota. Thirty-three years old, dark-complexioned, smallish, none too robust looking, with a noticeable habit of twitching his shoulders, Merrifield was the least impressive in appearance of the three-man faculty. Yet he was to be the only one to leave a mark upon the University -and an important one, indeed. Mrs. Mott, the preceptress and fourth member of the teaching staff-she was not counted as faculty-came from Grafton, only forty miles to the north. A native of New Jersey, she had been educated at the Trenton Normal School. Her appointment was made through local connections, probably through Healy.

Unlike Montgomery, who had offered advice at every opportunity, the president gave far too little and paid scant attention to the multitude of vital details concerned with the University's opening. Student housing presented a serious problem, for not enough private "capitalists" in the town had come forward to offer accommodations, and the city could not be persuaded to build housing near the campus as an act of public service. Efforts to induce the railroad to provide morning and evening train service or to have Grand Forks County maintain Broadway also came to nothing. The University was thus faced with the responsibility of providing housing on the campus for some of the students, in addition to some of the faculty and staff. The problem was only partially solved by the Regents' decision in June to add a two-story wing, 30 by 50 feet, to the rear (west) of the University building to serve as a dormitory. Begun with an initial contract for $\$ 3,000$, this wing cost about $\$ 15,000$ to complete, an unanticipated expenditure which later legislatures made up with deficiency appropriations. At the last minute, when it became evident that the dormitory would be nowhere near completion in time for the scheduled opening, the faculty and Regents found it necessary to reassign the rooms in the main building. The whole third floor was made into a boys' dormitory, and the chapel and library (there were no books anyway) 
were turned over to the girls. Mrs. Mott was given quarters in a study and classroom on the first floor; a study and cloakrooms on the second floor, together with the reception room on the first, went to the Blackburn family. The basement was made into living quarters for the janitor's family and the boarding department that he was to operate as a sideline business. Most of these assignments were of empty rooms. The Blackburns had to buy their own furniture-the Board later reimbursed them. Almost none of the student furnishings, inexpensive and starkly simple as they were, arrived until weeks after instruction had begun; the money had been apportioned in July, but no orders went out until the first week in September. It was months before any classrooms were fitted out at all. The contract for a heating plant, no minor necessity in Dakota, was not let until September owing to the exhaustion of the funds for construction. A supplier was finally found who would accept a note for the contract, $\$ 6,480$ at 7 per cent, with no better security than the expectation that the next Territorial Assembly, which would convene in January, would probably vote the funds to pay it.

Academic preparations were in somewhat better order, although here, too, many final decisions were made at the last minute or postponed until after the students arrived. On August 31 the first meeting of the faculty-President Blackburn in the chair, Vice-president Montgomery, and Professor Merrifield-was held at the Richardson House in Grand Forks. The chief business at hand was the preparation of entrance examinations, which were announced for September 2-4. Blackburn agreed to examine in history, English composition, English literature, and sentence writing; Montgomery in English, grammar, geography, natural science, reading, spelling, and dictation; and Merrifield in Latin, Greek, and mathematics. The first of a long series of disagreements on admissions policies and academic standards appeared when it was necessary to refer to the Regents the question of admitting applicants who could not qualify for beginning high school work. The Board's decision to admit them as a subpreparatory class meant that practically all comers were welcome to stay if they could pass examinations in reading, writing, spelling, elementary grammar and geography, and arithmetic. Only a few appeared for the examinations, but on the following Friday Montgomery and Merrifield worked out a temporary "schedule of studies and recitations."

That same day the newspapers carried an inconspicuous announcement:

The University of North Dakota will open for the reception of students, Monday, September 8, at 9:30 A.M. A full attendance on the opening day is desired.

Signed: Webster Merrifield Secretary of Faculty

With a hastily drawn and indefinite program, with painters and carpenters still noisily at work, the University formally opened its doors only a week later than had been originally intended. In 1904, at the first Founders' Day celebration, Merrifield recalled his impressions and the contrasts between his new academic home and the one he had just left. "As a member of the Yale faculty, my intellectual and physical environment for some years had been such as only long generations of wealth and culture can afford." With its great elms, fine old buildings, and the scholastic and cloistered atmosphere of a venerable institution, Yale was just then starting the extensive construction which was to produce the Gothic-styled institution of today. There, Merrifield recalled, meeting scholars of international reputation was a daily experience. Distinguished visitors were commonplace, and students and faculty lived in an atmosphere of great names and old traditions. By contrast the University of North Dakota was dismaying indeed to any but the most devoted teacher or eager student: one lonely building surrounded by wheat fields, the campus twenty acres of freshly plowed earth, black and muddy from recent rains, with no walks or even a fence to separate it from the surrounding farms, and not a single tree or shrub. Here, as Merrifield recalled, there was nothing, no books, no laboratories, no museum, and hardly an immediate need for them-only expectations. It seems indescribably bleak and cheerless to any modern observer who cannot feel the pioneers' boundless hope and optimism. But the very inadequacies of the place must have held for Merrifield the fascination of adventuring into unknown and uncharted areas, the challenge of creation, the chance to leave his own mark-opportunities which Yale with all its 
tradition and cultivation might never have given him. And for the first students the bleakness was lightened by the golden mist of their own dreams or by the contrast with the lonely and even more barren bleakness of the environment from which they had come. Walter Marclay, one of the first to register, observed years later when he was a successful physician in Minneapolis: "That one building, standing like a wonderful beacon light on the barren prairie, was a splendid institution of learning in my eyes. I had lived since I was twelve on the prairies...."

Eleven registered and took examinations that first day; only seven were qualified to do work beyond the elementary level and none beyond high school. By the end of the first month twenty-eight had enrolled and others continued to trickle in and depart irregularly. Of the seventy-nine who eventually enrolled, ${ }^{2}$ none was classified as ready for college; only ten were classified as senior preparatory (senior in high school), eighteen as junior preparatory, and the rest as subpreparatory or specials, that is, not ready for high school. Even some of those students rated as senior preps had deficiencies. Marclay, seventeen years old, had had no formal education since he was twelve, except a "few weeks of private tutoring by an old one-eyed man who taught another boy and me a little arithmetic and grammar in an abandoned store building in a mushroom village, now defunct, out near Lakota." One of the senior girls had been educated by her two older sisters. One can well imagine the amount of learning those in the lower classifications had been exposed to. A good many were older than the usual high school or college student, some well into their twenties. Most were from close by, thirty-eight from Grand Forks and forty-eight from Grand Forks County; only eleven came from as far as fifty miles away. Most of them were native-born and of English, Scotch, or Irish descent. Only two were from the largest immigrant group, the Norwegians, and two were Icelanders. Not a single student had been born in North Dakota.

Many students did not appear until after the farm work had been completed in the late fall or until after Christmas when the II 1884 enrollment in the colleges of the United States was 120,000 students or 3 per cent of the $18-21$ age group. In 1955, the number was $2,755,000$ or 32 pe cent of the same age group. rural schools closed for the three-month winter recess. Although seventy-nine students enrolled, there were never more than sixty in attendance at one time. When the University closed in June, 1885 , only twenty-four were still on hand, eight of them residing at the University.

In December, in an attempt to adjust to the rhythm of farm work and to the rural schools' long recess, the faculty decided to adopt a three-term system for the next year, the first to begin in late September, the second in January, and the third at the end of March. The system was to remain in practice for many years. The daily routine was also subject to some peculiar variations. From December, when the railroad finally got around to making the University a flag station and consented to stop an outbound train at noon and another toward Grand Forks in the evening, classes were held only in the afternoons, because most of the students, as well as Merrifield and Montgomery, lived in town. Many students walked in good weather, along the railroad tracks most of the time. Marclay rode a mule.

Although the University charged no fees except $\$ 3.50$ per week for board to those who lived in the building, some of the nonresi. dents could not afford even that. Marclay lived with relatives, and Ben Ingwaldson, one of the two Norwegians, had a squalid little room downtown where he did his own cooking. Supporting himself with the bucksaw he had brought with him, he was the first of that long line of working students who have been so conspicuous a feature of this Great Plains institution. In the University the girls were lodged, two to a room, on the second floor of the new west wing, once it was completed; the boys occupied the two large recitation rooms on the third floor of the main building. Room furnishings consisted of a double bed, a washstand, a kerosene lamp, a makeshift study table, and some kitchen chairs. In the boarding department in the basement, the janitor and his family, the Blackburns, and the students had their meals together, family style. The janitor carved, and the president asked the blessing.

Lacking a furnace and storm windows, the building was exceedingly uncomfortable. Until November the only heat was supplied by three stoves in the study rooms; neither classrooms nor 
bedrooms were heated. Answering an urgent plea from Blackburn, Twamley lent two stoves from his store, and the Regents bought enough more to make the building habitable until the furnace was installed-it was not made ready for use that first winter. The water system was a failure from the start, because the only source of supply was a cistern which leaked. Drinking water had to be hauled from Grand Forks in barrels; the coulee furnished the only water for bathing and laundry. Outside toilets thus had to be substituted for the few water closets that had been installed in the summer, for they emptied directly into the coulee. The primitive and inconvenient accommodations that first winter are revealed in the Regents' allowance of $\$ 136$ in November for the purchase of two casks and a water set, a dozen slop jars, and twenty-five each of chambers, basins, and soap slabs.

Students' lives were strictly regulated in accordance with the old practices then on their way out in eastern colleges. "Rules of Conduct" published by the Regents and faculty provided for an almost military regimen. All students were required to be on campus after six o'clock in the evening between November 1 and May 1, and after seven thirty the rest of the year. Visits to Grand Forks were made only by permission of the president. The first morning bell was at six forty-five, the second at seven fifteen; prayers were from seven twenty to seven thirty, breakfast from seven thirty to eight fifteen, dinner at eleven thirty; from eight thirty to ten thirty in the morning and from seven thirty to nine in the evening were study periods. Doors were locked at nine and lamps had to be out at ten. The problem of young men and women living in close quarters occasioned a rule that no student could receive a visitor of the opposite sex in his room or any place except in the public parlor, and then only under supervision of a faculty member. Each student was required when he registered to sign a pledge to obey the rules, and infractions were punished with demerits or suspension if warnings failed.

Amusements were simple. The young men and women, many from isolated and primitive farms, enjoyed each other's company at meals, in class, or in supervised "socials" of games, songs, and talk in the public parlor. A literary society, Adelphi, offered a combination of fellowship, literary discussion, and oratory. Those fortunate enough to have relatives in Grand Forks got to town occasionally for an evening at the new Parlor Roller Rink or to see a performance by a touring theatrical troupe. Church was a diversion. Attendance here as well as at daily prayers was compulsory unless parents made a formal objection. The faculty was hardly less isolated from the town than the students.

The marked earnestness of the students and their almost pathetic gratitude for the opportunity afforded by the University may have been heart-warming to the faculty, but fine attitudes alone could not compensate for the students' deficiencies. Mrs. Mott, remembered less for her erudition than her exaggeratedly eloquent rendition of "Curfew Shall Not Ring Tonight," had so many enrolled in her classes of elementary arithmetic, geography, spelling, and handwriting that in January, Cora Smith, a bright senior from Grand Forks, had to be employed to assist her. Although Blackburn announced at the beginning of the term that, in addition to mental and moral philosophy, he would teach natural theology and the evidences of Christianity, logic, civil polity and political economy, and history, he soon "fell in with the spirit of existing conditions" and abandoned his high-toned courses in theology and philosophy in favor of reading and United States historythe latter was then considered a grammar school subject. At one time or another he also taught ancient history, history of Greece and Rome, algebra, and geometry. Montgomery taught English in addition to chemistry, physiology and hygiene, and botany-the latter was offered only in the spring when specimens were available. Merrifield taught algebra and geometry as well as Latin and Greek grammar and courses in Caesar and Xenophon. No effort was made that first year to establish the normal college prescribed in the organic act.

Fifty-five students took the first term examinations during the week of December 8-17. The president reported that all had passed with "high credit" to themselves, the faculty, and the University, a commendable record perhaps but hardly a remarkable one in view of the fact that a general average of 50 per cent was all that was required, with a grade of 40 per cent acceptable for individual 
courses. Not one student was dismissed for scholastic deficiencies during the entire year, although one or two were advised to discontinue and a half dozen were threatened with suspension for excessive absences.

Although standards were lax, to say the least, the tiny faculty compared favorably in training and experience with professors in more distinguished institutions, and the small amount of equipment and apparatus on hand was not the insuperable handicap that it would be today. Montgomery had $\$ 1,000$ available for scientific apparatus, enough to provide for simple demonstrations for supplementing his lectures and "familiar conversations." Merrifield once observed that even Yale undergraduates were not permitted to handle scientific apparatus as recently as the 1870's when he had been a student; and as late as 1880 "no vestige" of chemical, physical, or biological laboratories was available for the use of the undergraduate college at Yale. Likewise, the absence of a library, for which no funds at all had been appropriated, was felt less keenly than it would have been at a later date, for instruction in the nonscientific courses was mostly by drill and recitation from textbooks. Even so, Blackburn attempted to remedy the deficiency by appealing to the public for donations; he himself contributed over two hundred volumes and nearly that many magazines and pamphlets. His gift and that of W. R. Bierly, secretary of the Grand Forks Chamber of Commerce, the only one of any size received from outside the University, lay neglected in a corner throughout the term because there were no facilities for handling the books and no one with the time or inclination to make them available for use.

The museum received more attention than either laboratories or library, partly because of the popular interest in the new and strange but largely because of Montgomery's activities as a collector. He deposited on loan his own "very considerable" collection, which included forty-odd animal skulls as well as fossils, salamanders, and shells, and used it constantly to illustrate his natural history lectures. Possessing the curiosity of the scientist and alive to the opportunity for the collector in the virtually untapped Dakota Territory, he gathered specimens at every opportunity and aroused popular interest to the point that numerous private citizens went to the trouble to send in natural history specimens and curios. By Christmas he had sixty mounted birds and eight animals, including a horned toad. The Regents provided shelf space and in the summer of 1885 allotted $\$ 200$ to Montgomery for a collecting expedition to the Black Hills.

No one pretended that the first year was not experimental, or that the program, which changed frequently, was more than a makeshift suitable only for getting started. Much time went into the consideration and preparation of a systematic curriculum of genuinely collegiate level. Blackburn pleased both Montgomery and Merrifield by leaving this task to them; neither valued highly the president's views and theological experience. From December to May, Merrifield spent nearly every evening at the Montgomery house near the Wilder School on North Third Street working on the catalog. Although both were men of strong opinions and given to frank speaking, they got on well together. Merrifield, who was living in a rented room on Belmont Avenue, long remembered the cozy warmth of the long winter evenings in Montgomery's home and the cider and apples which followed their labors.

The final result of their work was one program leading to the Bachelor of Arts, another to the Bachelor of Science, and a threeyear normal course, with a fourth year contemplated, leading to a certificate to teach in the rural and elementary schools of Dakota. Two years of preparatory work were outlined, but the subpreparatory program was eliminated. Entrance to the preparatory department was by examination in arithmetic, spelling, English grammar through syntax, reading, writing, and political geography of the world. Normal department entrance requirements were the same, with the addition of a satisfactory examination in bookkeeping. The requirement for entrance to the college-a first year class was to be formed in 1885-was completion of the preparatory course or by examination in algebra, geometry, English composition and literature, Caesar, chemistry, history of Greece and Rome, and history of the United States. Those entering for the B.A. were also examined in Xenophon, while B.S. aspirants had to qualify in physiology, French, and advanced geometry. The B.A. curriculum 
prescribed three years each of Greek, mathematics, English, French, German, and Latin; two of history (general European and constitutional history of England and the United States); and one each of chemistry, physics, comparative anatomy and zoology, physiology, mineralogy, botany, logic, mental science, and political economy. The one opportunity for election came in the senior year, a choice between three programs: one built around advanced courses in Latin and Greek, another around modern languages, and a third around a miscellany of history, political economy, and science. Greek was eliminated in the B.S. curriculum and only one year of Latin was prescribed; other requirements were two years of biology, one each of astronomy, drawing, meteorology, psychology and ethics, and engineering (optional). Courses in calculus and Newton's Principia were outlined for the senior year. The normal program included such courses as bookkeeping, theory and practice of teaching, calisthenics, voice culture, school law, school economy, and elocution. It is hardly necessary to observe that this was the one course which made a gesture toward meeting the practical needs of those who took it.

Twenty-five years later, after he had been mellowed by western experience, Merrifield characterized his and Montgomery's work as "grotesque." It is too strong a word perhaps for an academic program most of which had seen service for generations in conservative American colleges of the East or in Canada where the Oxford-Cambridge influence was strong. But there is no denying that it was unrealistic in relation to the training of the Dakota students, their practical needs, and the equipment and faculty available. There is little evidence of the new currents in higher education that had already affected those eastern colleges taken for models-Harvard, for example, abandoned Greek as an entrance requirement that very year. Neither the faculty nor the Regents appear to have recognized that the organic act presented an opportunity to write a curriculum broad enough to please the proponents of both traditional education and practical training-that is, in mechanics and agriculture-and thereby possibly forestall the final establishment of the agricultural college. (Although an act to establish such a college at Fargo had passed the 1883 legislature, no appropriations had accompanied it, and it would be another half dozen years before the school was finally opened.)

The Regents' approval of the Montgomery-Merrifield curriculum was in effect a vote of no confidence in the president, for, although he made no systematic case for practical education and probably had little sympathy for it anyway, Blackburn opposed going as far in the opposite direction as his two professors. He openly favored admitting practically everyone who applied and providing instruction on whatever level proved necessary. He took the position that the University must strive for popularity and public support first of all, and he pointed out that such highly respected state institutions as the universities of Wisconsin and Michigan had done the same when they began. As for himself, he had cheerfully scrapped his own favorite courses in order to help out with the elementary subpreparatory classes. There was more than a little influential support for a practical or technical program in Grand Forks; both newspapers, the Plaindealer and the Herald, were scornful of the traditional curriculum. When the University bill was under consideration in 1883, the Plaindealer had declared that the new University must follow new and bold paths in keeping with its own raw environment, and the Herald's managing editor, W. R. Bierly, had nothing but contempt for "a foreign system of padding . . . fifty years behind the times." In the spring of 1885 when the question was being hotly debated in connection with the summary dismissal of Blackburn, the Herald editor wrote:

Is the university to be built as an American institution or shall it be run in a cramming, dry-as-dust, stilted 50-years-behind the times, dead-and-gone style . . . ? It is a fight of plain, practical, common-sense education adapted to the wants of a new population against the setting of a standard, a stilted curriculum so high that before you could enter the walls of the institution you would have to be trained at Oxford .... our university must walk before it can run.

A practical example of the effectiveness of a combination of an easy admissions policy and a practical curriculum, or at least a gesture toward one, was the successful start of the South Dakota State College. Although the offering there was likewise on a high school level, degrees were awarded at the end of the first year; in 
contrast to the University's 79 students, the Brookings college enrolled 262 in 1884-1885, its first year of operation.

The argument over classical or practical education, fundamental as the question was, was largely synthetic in relation to the University at this time. The real issue was the question of Blackburn's fitness for the presidency, and this in turn was involved with small-town politics and personal rivalries, all unrelated to either Blackburn's merits or educational policy. The president's position had been weakening for some months before the curriculum question became a public one. The chief reason for dissatisfaction was his failure to look after many of the small matters that needed attention at the University. In December the Board humiliated him, whether deliberately or not is impossible to say, by making the faculty directly responsible to the Board; this meant in effect that the Regents had taken over his executive duties. Blackburn's frequent public appearances, ostensibly in order to advertise the University, also produced dissatisfaction; he was often away over week ends and missed classes; what was more annoying to some, many of his appearances were in the capacity of a Presbyterian minister. Possibly there were legitimate grounds for suspicion of his sectarianism, for at the same meeting at which his relations with the faculty were restricted, the Board also expressly limited religious services at the University to daily exercises consisting of no more than a passage of scripture and a prayer and forbade all comment and discussion. The fact that the secretary of the Board, B. W. Iddings, was also a Presbyterian minister was viewed with suspicion by the antisectarians, and he was replaced in January by Dr. Teel's son, Charles. This move produced in turn the charge of nepotism from Blackburn's friends, among them the highly vocal Herald.

In the meantime, although there were vigorous differences between the president and his faculty over admissions and curricular policy, the disagreements appear to have been kept on a gentlemanly plane. Such was not the case in the friction between him and the janitor and between him and Mrs. Mott. Blackburn managed to oust the janitor, who was, in fact, insolent as well as incompetent, particularly in his capacity as keeper of the boarding department; but Mrs. Mott, a strong-minded little woman with a sharp tongue, was not so easily handled. Much of the difficulty with her arose from the fact that she and the Blackburns lived too close together. The president's lively adolescent daughters had the run of the University building without being subject to the general discipline. Mrs. Mott was hot tempered, openly disrespectful, and pettily irritating. The quarrel was well developed by November, and at the first of the year she angrily resigned. The Board called a hearing at which Biackburn charged, among other things, that she deliberately and regularly began eating while he was asking the blessing. Her heated retort that the food was equally poor before or after blessing hardly illuminated the inquiry. More serious were Blackburn's charges that she was a talebearer and not properly discreet in talking about students' misdemeanors. Relations were patched up temporarily, and Blackburn's daughters were admonished to cease mingling with the students. But the situation had gone beyond repair, and on May 12, the Board solved the problem by terminating the contracts of both. At the same time, Montgomery and Merrifield were reappointed, with substantial increases in salary.

Had the quarrel with Mrs. Mott been the sole difficulty Blackburn would probably have survived, but for one reason or another he was at odds with everyone in the University; he had become a center of controversy and had lost the confidence of a majority of his Board. In the final analysis the fact that he was a clergyman and theological professor proved unsuitable training for the task at North Dakota, and it had raised the sectarian issue. For their part, the Regents acted arbitrarily and even impulsively. No one denied at the time the Board's powers to dismiss the president, but Blackburn's defenders were on sound ground in their contention that the Regents failed to make a case against him for summary dismissal. They had, in fact, demonstrated their own uncertainty; it was only after Collins and Healy, whose terms had expired, were replaced by William N. Roach and F. R. Fulton, that the dismissal action was taken, and then by a vote of three to two. On the other hand, although some of Blackburn's defenders were sincere in their professions of confidence, among them the students who appreciated his many personal sacrifices on their behalf and 
who regarded him highly as a teacher, not a few of the more vocal critics of the Board's action were less interested in the fate of the president than in using him to air their own views and to discredit certain members of the Board, chiefly Teel and Twamley.

It is hardly to be wondered at that the action became a subject for public controversy, even without the added excuse of debating views on educational philosophy. In a citizens' meeting at the Syndicate Hall in Grand Forks, Dr. Collins, no longer on the Board, charged that Twamley's personal dislike of Blackburn was the chief source of trouble. Blackburn's defenders produced statements from Judge Cochrane, the city's most prominent lawyer, from a prominent Catholic, and from the Baptist and Methodist ministers to refute the charge of too much Presbyterianism in the University.

At the same time, Twamley and Teel were charged with using their positions to make money out of the University-Teel because he sold wood to the University for fuel and because his son had been employed to plow the campus and as secretary of the Board and teacher of business subjects and Twamley because he had supplied dishes and other equipment to the University through his store, some $\$ 250$ worth, for which he was said to have charged excessively. With the fur beginning to fly, Collins was accused of attempting to put his wife on the faculty and Healy of trying to become a faculty member himself. These charges appear frivolous or spiteful in retrospect. No one made much money out of an official connection with the University. The charge against Twamley was based on an alleged overcharge of only $\$ 86$, and Teel's wood contracts could not have been very lucrative, for before the winter ended the Regents began to use coal for fuel. Their error lay in not seeing clearly the division between public responsibility and private business, which is hardly surprising when one remembers that the hope of profiting from the presence of a governmental institution had been a powerful motive in Grand Forks's seeking the University in the first place. Nevertheless, the case was carried to the governor, Gilbert Pierce. He reluctantly ordered the attorney general to investigate the charges against Teel and Twamley. A public hearing at Grand Forks in August, before which the accused appeared repre- sented by counsel, failed to produce any evidence of malfeasance. Official exoneration, however, was not forthcoming until the following summer. Twamley, nevertheless, received repeated votes of confidence. He was elected president of the Board immediately after the investigation and served until 1887; he was reappointed several times and served ten years, longer than any other of the first Regents.

The experience provided some valuable lessons all around. The demonstration of support for Blackburn and for practical education undoubtedly jarred the self-confidence of the defenders of traditionalism. The Merrifield-Montgomery curriculum was never completely implemented, existing mostly as an ideal which had to be constantly modified to conform to the new views on education and to the competition of the agricultural colleges. Blackburn's easy admissions policy was partially vindicated in the policies of his successors. The Regents, having been subjected to charges and an official hearing, learned some lessons on the relative differences between a University president and a hired man. Moreover, having been charged with malfeasance, they took measures to insure more careful accounting and adopted the practice of making all major purchases by contract.

When all was said and done the University probably benefited more than it lost by Blackburn's dismissal. A general harmoniousness was established which lasted without a major breach for more than a generation. In the meantime, having made a series of blunders in their relationship with Blackburn, the Regents were overcautious about selecting another president. Several of them approached Merrifield, but he declined the honor, probably because he realized that if he accepted he would offend Montgomery, the vice-president, and would arouse the suspicions of Blackburn's friends. In the end, Montgomery was named acting president, and the final decision was postponed indefinitely.

Although the quarrel at the University received considerable attention, enough to involve the governor and attorney general, it had no serious consequences in the legislature which was in session at Bismarck from January to March. Many legislators and several other officials, forty-one in all, visited the Unjversity in February. 
They were entertained at a luncheon in the boarding department and treated to an address by Blackburn on the theme of the University's potential influence in bringing law and order to an era distinguished by a "wild hatred of wealth." "We must," he said, "educate our young men of today so that they will not become the mad socialists of tomorrow." It is the one statement on educational policy which has been preserved from Blackburn's year at North Dakota. No opportunity was missed to call attention to the "remarkable record" of the University, despite the absence of even such simple necessities as shoe scrapers or a plank walk to the flag stop on the railroad, or to explain the reasons for the $\$ 20,000$ deficit in University finances. The sources of the latter were an unexpectedly high fuel bill, $\$ 2,274$ to be exact (only $\$ 600$ had been appropriated for light, fuel, and janitor service), an expenditure of $\$ 6,800$ for salaries when only $\$ 5,000$ had been appropriated, $\$ 5,000$ spent on the observatory with only $\$ 3,000$ collected from the guarantors, and $\$ 15,000$ for the construction of the dormitory wing that had not been included in the original contract. The legislators proved to be sympathetic and even generous in view of the economic stringency that prevailed; $\$ 38,400$ was appropriated for the University, $\$ 20,000$ of which was for salaries, $\$ 4,000$ for fuel, and $\$ 10,000$ for a water main to connect the University to the city water system. In addition, $\$ 24,000$ of territorial bonds were authorized to pay up the debts, about $\$ 20,000$, incurred during the first two years, and to provide $\$ 1,000$ for a library, $\$ 1,000$ for laboratory apparatus, and the rest for improving the grounds and installing plumbing. The Regents' decision to charge all resident students an incidentals fee of $\$ 5$ and nonresidents $\$ 10$ promised a small additional income for minor expenses. George Walsh, who had played a major role in putting through the University bills, was awarded the contract for laying the main.

Despite its administrative difficulties and physical limitations, the University had survived its first year. It moved forward rapidly in the summer of 1885 . An adequate steam heating system was completed, along with the water and sewage system; the Grand Forks water was pumped directly from the Red Lake River and the University sewage was emptied directly into the coulee scarcely a hundred feet from the building. The first library purchases were made and some arrangements completed for shelving and lending; about $\$ 400$ worth of additions were made to the scientific equipment; and fifteen hundred copies of the first catalog were distributed over the northern half of Dakota Territory. Two new professors and a new preceptress, all of whom were to prove professionally competent and congenial as colleagues, completed the arrangements for beginning the session of 1885-1886.

Firmly launched though it was, the infant University bore no resemblance to the extravagant picture painted by a boomer newspaper advertisement: "Laid out in the highest style of comfort and convenience, [the building is] as fine a one as many a college and when both wings and the main center structure are done, it will vie with the great universities of Europe. [A faculty and] corps of lecturers . . . at the top of their professions [include] a celebrated author and divine . . . and one of the leading scientists of America." This was not an official statement from the University, but it is a fair representation of the dreams of its promoters in the Red River Valley. 
III

\section{The University Takes Root}

HE NEXT HALF DOZEN years, although not as dangerously critical as the first one, were not easy times for the University. The boom had come to a definite end. The farm depression of the late 1880 's was not of the disaster proportions of that of 1893 , but the slow times bore especially hard on the new Dakota country. While wheat prices hovered at 60 to 80 cents (boom time prices had been a dollar or more), there was a prolonged series of bad seasons. In 1890 the crop failure was so complete that Congressman Henry C. Hansbrough of North Dakota introduced into Congress a resolution to appropriate $\$ 500,000$ to buy seed wheat for destitute North Dakota farmers. The celebrated blizzard of 1888, which reached the peak of its fury in Dakota, seriously injured the ranching industry and further discouraged prospective immigrants. There were in addition periodic Indian troubles in the 1880's, climaxed by the Sitting Bull-Ghost Dancer uprising and the Battle of Wounded Knee in 1890.

Overwhelmingly rural-only two towns, Fargo and Grand Forks, had more than 2,500 people-the state was tributary to the railroads, eastern banks, and Minneapolis millers and hence highly susceptible to the farm agitations of the 1880's and 1890's. The Farmers' Alliance, committed to regulation of the railroads and the

grain trade and to cooperative enterprises, was a powerful force in public affairs. The situation was aggravated even more by the political instability and the rush for advantage by individuals and localities which attended arrival of statehood and separation from South Dakota in 1889.

At the same time, however, the state was continuing to increase in population-from 152,000 in 1885 to 183,000 in 1890 -and it was settling down. In Grand Forks, for instance, the newspapers shed some of their frontier robustness and gave increasing attention to such society events as a charity masked ball, the G.A.R. Washington's birthday dance, or a musicale at the Episcopal church. In 1889 the opening of the five-story Dacotah Hotel in Grand Forks was a major event, and one year later an even greater occasion which drew visitors from all over the Northwest was the opening performance at the Metropolitan Theater. The growing taste for "beauty and variety" was also manifested in such private dwellings as "the finest house in Grand Forks," constructed in 1887 at a cost of $\$ 4,500$. It had steam heat, a bathroom, running water, gas, and a "novel form" decorated with scroll work. In 1886, twenty-five electric "burners" were installed on Grand Forks streets by Dr. Charles Teel. Nine electric plants and four street railways were reported in the Territory in 1887. The Grand Forks business section was paved with cedar blocks, and board sidewalks were extended to the residential area. Regular garbage collection began in 1889 . House numbers appeared the same year, and mail delivery to residences began in 1890 .

There were also some advances in education. Three denominational colleges were established in the eighties by the Presbyterians at Jamestown, the Congregationalists at Fargo, and the Methodists at Wahpeton. Their open challenge to the University, if not outright attack upon it because it was secular, had much to do with the emphasis upon religious guidance which was a marked feature of University life for many years. As for secondary education, what advances there were had little form or direction until 1891 when the University took a hand in developing the high schools.

Meanwhile, the University was taking form, establishing patterns, and firmly setting its roots in North Dakota. Following the 
departure of Blackburn and the changes in the Board of Regents, a period of relative harmony ensued. Although Montgomery had not won the confidence of the Board to the extent that he could have the presidency, he nevertheless enjoyed its support in the two years he was acting president. Part of his strength sprang from the fact that the popular and increasingly influential Merrifield showed no regret for his decision to reject the presidency when the Regents approached him in 1885. Although he stood for the older classical tradition and Montgomery for increased emphasis upon the sciences, they were close friends who could come to satisfactory agreements on University policy. Moreover, Merrifield's strong position with the Board gave considerable weight to his advice. It was his view, the older educational tradition, which prevailed when Horace B. Woodworth and John Macnie, the two new faculty members added in 1885, were chosen. Both were conspicuously nonspecialists, and both were willing-and to a degree able-to teach nearly everything.

Woodworth, the new professor of mathematics, physics, and astronomy, was a Congregational minister with the B.A. degree from Dartmouth (1857) and a diploma from the Hartford (Connecticut) Theological Seminary (1861). He had been in Dakota Territory since 1881, having come for his health after a successful career as a preacher in Iowa. He was actually the choice of F. R. Fulton, a Grand Forks member of the Board of Regents appointed in 1885, who had known him well when both had lived in Decorah, Iowa. William Roach, likewise a new member, and Healy, the Methodist minister on the Board, were the other chief supporters of Woodworth's appointment. James Twamley, a Congregationalist who had been accused of sectarian bias against Blackburn, apparently had little to do with bringing Woodworth to North Dakota

Woodworth was willing to lend his hand to nearly everything, and in the first five years he was on the faculty, he taught almost every subject in the preparatory, normal, and college programs except chemistry. He was the first principal of the normal department, although he had neither experience nor training in teaching before he came to the University. It was not until he had been on the campus five years that he more or less settled down to the teaching of history and philosophy, the subjects for which he was best fitted by training. Montgomery had some doubts about his qualifications, for in his first annual report to the Regents he declared that the University's greatest needs were first-class men with specialized training in physical sciences, history, pedagogics, and metaphysics. Yet Woodworth's contribution to the University in the nineteen years he was on the faculty was considerable. Fiftyfive years old in 1885, a tall and dignified man, cultured and urbane, he brought to his students a conception of wise and civilized living and did much to make friends and to create respect for the University. He was an eloquent and lucid preacher, but no doctrinal zealot, and he frequently occupied Grand Forks pulpits. His gradual assumption of the unofficial post of University chaplain gave the needed assurance, to counter the claims of the church colleges, that the University was religious yet not sectarian.

John Macnie was chosen professor of English, French, and German on the recommendation of Merrifield. He had been headmaster of the Siglar Academy at Newburgh, New York, for many years and had become close friends with Merrifield when he taught there; they were to become inseparable figures on the University faculty for nearly a quarter century. From 1885 until Merrifield's marriage in 1903 they shared living quarters, first a house on Reeves Drive and later the president's apartment on the campus. Macnie's motherless son John, a preparatory student in 1885, was a part of the household until his graduation from the University and found in Merrifield an indulgent second father.

Born in Scotland in 1836, Macnie had spent his boyhood and attended school in France and Germany. Shortly after his graduation from the University of Glasgow he came to the United States. Some measure of his success as a scholar and teacher is the fact that in 1874 Yale University awarded him the honorary M.A. degree. In his own character, breadth of training, and depth of learning Macnie represented the best that the classical tradition could produce. Even after the University had begun to look to the new type of scholar holding a Ph.D. in a specialized subject, Macnie was to retain his position as one of the genuine ornaments of the faculty. He was the first productive scholar and writer whose aca- 
demic home was the University of North Dakota (excepting Blackburn, who remained only a year, and Montgomery, who was to bring some small attention to the University in Canada and England). In 1883 Macnie published A Far Look Ahead; or the Diathos, one of the earliest and most competent of those utopian novels which were highly popular in the 1880 's and 1890 's. It went into several editions and was translated into several languages. Edward Bellamy's better known Looking Backward (1888) quite plainly owed more than a little to Macnie's earlier work, although it was owed quite the plagiarization that Macnie's friends said it was. ${ }^{1}$ His not quite the plagiarization that Macnie's friends said it was. ${ }^{1}$ His literary work included another novel and a considerable amount of poetry. The University song, "Alma Mater," is his work. Macnie also published two mathematical works, a geometry text, and a book on the theory of equations which was being used at West Point when he came to North Dakota. ${ }^{2}$ One of those men who seem to have read everything and forgotten nothing, Macnie demonstrated in his twenty-three years on the faculty that he was equally at home in world history, classical languages, and English literature. The in world history, classical languages, and en and which he was appointed to teach were French and German; nevertheless, it is not surprising that in his first year at North Dakota he had a class in physics.

A gentle, school-masterish, impractical kind of man, almost childishly simple, Macnie was an easy mark for kindly student jokes. He was a sentimentalist and a romantic, claiming a tenuous academic connection with Alfred Lord Tennyson, and had idealized all womanhood from the cherished memory of his young wife who had died years before after less than a year of marriage. For many years at North Dakota he was the fatherly patron of the "young ladies." An unworldly idealist, incapable of promoting his own interests, Macnie was to influence the University less by the force of his personality than by the sentimental regard in which he was held by the students, by his own example of devotion to learning, 'The question of Bellamy's sources caused some lively debate in the 1890's, enough for J. B. Alden, New York, to publish

Looking Backward, by Marie A. Shl Sold (New York, 1895) and A Treatise on the ¿Elements of Geometry, Plane and Solid (New York, 1895) and $A$
Theory and Solution of Algebraical Equations (New York, 1876). and by the profound respect which Merrifield had for him. Contact with this peculiarly selfless man who cared nothing for place or position but much for learning, honor, and ideals could not help but enrich the lives of students reared in an unbookish, materialistic, and self-seeking pioneer environment.

Miss Jennie Allen, a graduate of the University of Michigan, was employed in 1885 at $\$ 750$ per year to replace Mrs. Mott as preceptress, or matron, as the position was now termed. A successful teacher in the Grand Forks high school, she also contributed to the new air of harmony which was to mark faculty relations after the first hectic year.

Total enrollment was down to forty-eight in 1885-1886, but the next year it rose again to seventy-five (thirty-eight boys and thirtyseven girls. There were a number of reasons for the slump after 1885 , among them being the hard times, disappointment with the reality of the University in contrast with the first glowing announcements, inadequate provision for housing, and the attraction of the new Congregational college at Fargo and the new Presbyterian college at Jamestown. Another factor was the raising of standards (on paper at least) signalized by the dropping of the subpreparatory department and the announcement of the formidable program outlined in the first catalog. While almost no student had been turned away in 1884, thirteen of sixty-one applicants were rejected in 1885 .

Between 1885 and 1887 the Merrifield-Montgomery program remained more or less in effect, with some minor modifications to accommodate the new faculty. In actual operation, of course, only the freshman college year was offered in 1885 and only the first two years in 1886. Since the subpreparatory work had been dropped, there were only two years of high school level work offered in either the preparatory or normal departments. What this meant in effect was that students were being admitted to college with two years of work beyond elementary school. By any current standard the requirement seems low enough, but for the day it was not unrespectable, particularly in new communities. Many of the new state universities and land grant colleges, South Dakota State at Brookings, for example, were admitting students to college, or what they chose to call college work, directly from elementary school. Moreover, 
the students in the North Dakota preparatory department were being taught by a college faculty, at least three of whom were well qualified by the standards of the time. Classes were so small that the students were practically tutored, and organization had not hardened to the point where there could not be quick adjustments for varying levels of progress. This informality, incidentally, was to continue for a number of years; alumni of twenty years later who had attended both preparatory and college departments found it difficult to remember exactly when they had moved from one to the other since no graduation exercises were held for the preparatory department. Perhaps the first clear differentiation that was drawn was the limitation of membership in the Adelphi Literary Society to college students in 1886 .

The science course was by far the most popular in the college, largely because no Greek was required. All but two of the fourteen freshmen who enrolled in 1886 signed up for science. The normal course also enjoyed an early popularity. Some students took it because the more difficult preparatory courses were not included, but the chief attraction was that it was the quickest road to a job that the University had to offer; University trained teachers were much in demand in the rural schools. Ten students enrolled in 1885-1886, and fifteen the next year. In his last report to the Board Montgomery urged that the department be developed and that standardized graded certificates be issued based on the amount and the quality of work done by the student.

There was considerable improvement in the physical plant and in equipment during the two years of Montgomery's presidency. The main building was finished and made reasonably comfortable, although it was difficult to heat evenly because there were no storm windows. More or less regular transportation to and from Grand Forks by omnibus was established. It was variously operated by a students' cooperative association, by a livery firm, and by the University itself. The boarding department, still privately operated, usually by the janitor, served fairly satisfactorily the dozen or so young women who lived in the building-after the first year the boys had to find their own quarters downtown. But the day students had no place set aside for waiting between classes or for eating their noon lunches except window ledges, the stairs, or the furnace room. Needless to say, recreational accommodations were missing almost entirely, which might have been the source of some serious problems had not students spent most of their time at the University in class.

The first library purchases were made following the legislature's appropriation of $\$ 1,000$ for this purpose in 1885 . By the end of the 1885-1887 biennium the book collection, including the Blackburn gift, which proved to be of little value, came to about a thousand volumes, mostly standard works on history and English literary classics. Current issues of such popular magazines as Scribner's, Harper's Weekly, Popular Science, and the Atlantic Monthly were also kept on hand. When the legislature appropriated $\$ 2,000$ in 1887-the faculty had recommended \$5,000 - the Regents voted to spend the entire amount for books, except for $\$ 100$ set aside for shelves and to make the reading room an "attractive resort." Rather ironically, however, in view of their own steady stream of recommendations on the need for more books and the students' obvious need and hunger for them, the faculty ruled that the library should remain open only a half hour, from one to one thirty in the afternoon, five days a week. No books could be taken from the reading room except on weekends, when borrowers were limited to one book each.

Classroom equipment continued to be meager. Some wall maps, nearly all of the ancient world, were bought in the fall of 1885 for the classes in Greek, Latin, and history. Maps of the United States and modern Europe were apparently not regarded as immediately necessary. The science departments, thanks to the fact that Montgomery was acting president, fared somewhat better. It is a point of some significance that Montgomery launched science teaching on the level of theory and principle-the approach in favor at the more venerable institutions in the country-instead of on the practical shop level in vogue at many of the land grant institutions of the West. Montgomery's emphasis upon science was not without its practical side; it would, he believed, eventually play the leading role in developing the natural resources of North Dakota. When the 1885-1886 term opened, the science equipment on hand consisted 
of two microscopes for the biology classes and a chemistry laboratory with enough test tubes and chemicals to permit a few advanced students to conduct some simple experiments. Three thousand dollars was appropriated for apparatus in 1887 , in contrast to the $\$ 1,000$ allotted at the legislative sessions of 1883 and 1885. Appropriations of $\$ 2,000$ for the museum ( $\$ 1,000$ was allotted to it in 1885 ) and $\$ 1,000$ set aside for a chair in medicine further enlarged the expenditures for science. Although the total was somewhat less than the $\$ 20,000$ Montgomery insisted ought to be spent for such purposes each biennium, his enthusiasm was infectious. When in 1886 he urged the immediate establishment of a chair in medicine, arguing that all that was necessary was a "dissecting room" to serve as a laboratory for the local physicians who would serve as faculty, the Regents proceeded to elect a dean, Dr. Henry Wheeler, an associate of Dr. W. T. Collins. After doubts were raised about the legality of such an action, establishment of the medical chair was postponed to await specific legislation. In 1887 the legislature established a medical school and appropriated $\$ 1,000$ for its support, but nothing came of all this for Wheeler had meantime resigned and the election of a new president in the fall of 1887 removed Montgomery, the chief sponsor of the idea, from the direction of University affairs.

Montgomery's own activities, largely as archaeologist and collector for the museum, brought some local notice to the University. He made a collecting trip to the Black Hills in the summer of 1885 , and in 1886 he began investigating the Indian mounds in the Devils Lake and Red River Valley areas. One mound alone in Grand Forks yielded twelve skeletons. Montgomery's views on the origin and nature of the mounds and their builders, as well as his investigations, attracted some academic attention, including an invitation to read a paper on "Aboriginal Monuments of North Dakota" before the American Association for the Advancement of Science. Meanwhile the museum prospered and the room with its neat glass display cases and eighteen hundred specimens (by 1887) was the one showpiece of the University.

Montgomery's activities at times had the look of self-advertisement, but there is no doubt that he was earnest in his efforts to bring the University to the attention of the public and to make friends for it. In February, 1886, the first public reception in the University's history was held. Two hundred guests attended, among them all but one of the Regents. After a tour through the building, "brilliantly lighted by . . . Rochester lamps," the visitors were entertained with a program of speeches and music. A student quartet performed "with fervor and strength," and the acting president discussed the need to develop the work in science and the need for a secondary school system to feed the University. Montgomery also regularly attended the annual meetings of the Dakota Education Association, held offices in it, and read papers before it. It was undoubtedly his doing that Woodworth and the self-effacing Macnie had a part in the association's program in their first year at the University. These early connections with the public schools, gratefully welcomed by the superintendents and principals, were to have impressive results for both the schools and the University in a few years. Nevertheless, Montgomery's public relations efforts were sporadic and unsystematic.

Montgomery's interim presidency closed on a note of optimism. The legislature appropriated $\$ 44,000$ for the 1887-1889 biennium and authorized a $\$ 20,00 \mathrm{C}$ bond issue for a dormitory. This was $\$ 17,000$ less than had been requested, but it was also slightly more than the 1885 appropriation. It is true that the appropriation was $\$ 3,000$ less than that of Dakota University at Vermillion and $\$ 9,000$ less than the Brookings Agricultural College received. Their bond issues were also larger- $\$ 30,000$ and $\$ 54,500$ respectively. There were also appropriations for two South Dakota normal schools and a school of mines. Favoritism to South Dakota was involved, of course. Had it not been for the fact that statehood and separation from South Dakota were imminent there might have been considerable indignation among the University's friends. As it was, the appropriation was enough to open the way to several significant steps in its development. An immediate improvement was the construction of a board fence to keep livestock away from the newly seeded grass and the hundreds of young trees planted the year before. The building was repainted, and there was even talk of spending $\$ 500$ for an ornamental fountain. The city of Grand Forks 
was moved to start the construction of a board walk along Broadway, although this was not completed for many years. The Board voted to appoint a new professor, someone "with extended experience in practical laboratory work," to relieve Woodworth of his classes in astronomy and physics.

The most significant evidence of the optimism of 1887 was the decision to appoint a president. Montgomery was passed over with hardly a second thought, despite the fact that under his leadership the University had made some progress. It had demonstrated its ability to survive while holding to some ideal of college performance instead of engaging in an unprincipled search for students and an unscrupulous awarding of degrees for less than college work. Montgomery had also made a case for a high level approach to science and for the necessity of appointing specialists to teach science courses. On the other hand, there were aspects of Montgomery's administration and his own character which in the eyes of the Board rendered him unsuitable for the presidency on more than an acting basis. Such matters as military and physical training had been almost totally ignored. The general discipline of the students was lax, and little had been done for their welfare. Montgomery's own teaching left something to be desired, and he was unpopular with the students, no minor matter in an institution as intimate as the University in the 1880's. His too obvious ambition may have been a disadvantage, and his judgment could be faulty, as when he urged the organization of a medical school with little plan for it except the setting aside of a dissecting room. But the main count against him was the University's continued low enrollment. In his biennial message to the legislature in 1887 Governor Gilbert A. Pierce declared himself "at a loss to account for . . . the entirely too small a number considering the character of the institution, the terms, and the excellent course of study offered." He went on to point out that where the current enrollment at North Dakota stood at about 60, South Dakota State had enrolled 250 the year before and South Dakota University not quite 200. He might have added that the University of North Dakota was regarded as a Grand Forks institution and that few representatives in the territorial legislature, even from the north, regarded it as their responsibility.
Likewise convinced that "under the present management we are going backward," the Regents set out to remedy the situation by choosing a president who could properly publicize the University. They had their eye on the outgoing governor, Pierce, whom President Grover Cleveland removed in January in favor of Louis Kossuth Church, a Democrat, and they made no search at all among academicians; one Board member wrote that they already had "enough of that class now." On June 8 Pierce was elected as president and professor of constitutional history, political economy, and moral philosophy. His salary was fixed at $\$ 3,000$, or $\$ 500$ more than Blackburn had received. Pierce, who had been an able and popular governor (1884-1887), was the University's first and last venture into the nonacademic world for a president, and even he was not without some academic qualification. He had attended the old Chicago University, although taking no degree, and had practiced law in Indiana. Following service in the Civil War and several years as an appointive officer in Washington, he turned to newspaper work and professional writing. He published two novels on Washington political life $(1876,1883)$ and a play, One Hundred Wives (1880), which ran two seasons with DeWolfe Hopper as the leading man. As managing editor of the Chicago Daily News he had taken a prominent part in the Republican campaign of 1884 which explains his appointment to the governorship of Dakota Territory. His election to the presidency of the University found general approval. Something of a national figure and well liked in Dakota, he was eminently qualified for the role of popularizer of the University and the defender of its interests in the legislature against its rivals.

The rosy prospects were quickly blasted, however, by a series of misfortunes. On June 16, 1887, the day after the University closed for the summer, a violent wind storm accompanied by hail and heavy rain struck Grand Forks. Four people were killed, the Catholic church was wrecked, and fifty houses were demolished. The lonely and totally unprotected University building was seriously damaged. The flimsy west wing added in 1884, in which the museum was located, was swept away; the cupola and chimneys 
crashed through the roof, and there was considerable flooding of the interior. Most of the young trees were ruined.

The damage itself, though severe, was not as serious as its dampening effect on the optimism of only days before. At first, when it was believed that the building was beyond repair, all the old objections to the location were revived. Some of the Regents, Twamley in particular, who had always thoroughly disliked the location, seized the opportunity to press for abandonment of the site for a more suitable one near the town. Roach, president of the Board, went to Bismarck to consult Governor Church. Fearing that a dangerous precedent might be set, Church wisely advised that no such action should be taken without approval of the legislature, and the Regents, on taking second thought, concluded that to bring the question of moving before a legislative session might very well produce a complete reconsideration of the whole matter of location and the abandonment of Grand Forks altogether for some point more centrally located. The fact that statehood was near made the situation especially unstable and dangerous to Grand Forks interests. The action that Church did suggest was that, since no funds were available, the Board should borrow what it needed and proceed immediately with repairs. On June 28 local banks arranged to len up to $\$ 10,000$ at not more than 10 per cent interest, and work was begun soon afterward.

Arrangements for the new dormitory, for which contracts were let on July 8 , were likewise disappointing. The plans submitted by the architects (Kees and Fisk) were too elaborate for the funds available, and numerous economies were necessary, the most drastic being the elimination of all clothes closets and the storm sashes on the south and east sides. The top floor, a full-height attic, was left unfinished. It was soon apparent that the basic design of the building was unsuitable for its purpose. The Board disregarded faculty advice and every other consideration except that the new building must not resemble the first one, which was much criticized once initial enthusiasm for its size had worn off. The result was a nearly square structure with much space wasted in wide halls and stairways and unnecessarily large entrances, yet the over-all effect was no more beautiful than the main building. Nevertheless, the addi- tional space would ease conditions all around. Forty girls could be accommodated in the dormitory, although only a few more than half that many moved in the first year. With the girls out of the main building, housing for boys could again be made available. There was, moreover, a three-room suite for the president, and the basement provided space for the kitchens and dining room and for a much needed laundry and drying room for the girls. The main building, with the exception of the rooms for boys on the upper floor, was in turn available for its original purpose, including space for two new laboratories and an assembly hall capable of seating about two hundred people.

Meanwhile, Pierce changed his mind and turned down the offer of the presidency. He came to Grand Forks on July 4 to deliver the oration of the day, and it has been suggested that what he saw of the half-wrecked building caused his decision. A more likely explanation is that he had concluded that his popularity could be turned to better account if he stayed in Bismarck. ${ }^{3}$

Having had enough of public figures, the Regents turned once more to the academic world but still sought a man who as president would represent the University more effectively before the public than Montgomery had. In September, with the University about to open, Merrifield was hastily dispatched to the East to find a man. The reception he encountered, in some quarters at least, is revealed in the statement of the head of a Boston high school, who, when asked if he thought Homer B. Sprague, the leading candidate, would accept the presidency, replied that he did not know but that he would not take it himself for $\$ 100,000$ a year. Sprague was willing, however, and it was his name that was presented to the Board. He came for an interview, and on October 3 he was unanimously elected at a salary of $\$ 3,000$ plus reimbursement for his traveling expenses.

The new president had everything: academic reputation, administrative experience, imposing physical appearance, and, what ${ }^{3}$ Pierce remained in Bismarck as a correspondent for St. Paul newspapers until 1889, when on North Dakota's being admitted to statehood, he was elected to the United neapolis and became part owner of the Minneapolis Tribure. He was appointed minister to Portugal by President Benjamin Harrison in 1893. 
was most important in the eyes of the Regents, a reputation as one of the most popular lecturers in the country. His lectures on Milton and Shakespeare were favorites on the lyceum circuits, and he was considered by some of his contemporaries as second only to Wendell Phillips as a platform orator. For a struggling and obscure institution he seemed a dazzling catch indeed. The Bismarck Tribune, which had scarcely mentioned the University since its founding, hailed with delight the appointment of "this educator among educators," an event comparable in significance to Minnesota's discovery of Cyrus Northrop. "It means success," concluded the editor. Fiftyeight years old when he came to Grand Forks, Sprague already had several careers behind him. A native of Massachusetts, he had entered Yale in 1848 with little more than a common school preparation yet had graduated at the head of his class four years later. While teaching Greek and Latin in Worcester, Massachusetts, he read law, and in 1854 he was admitted to the bar. Yale awarded him the M.A. degree in 1855 . He practiced law until the Civil War, in which he served with distinction-brevetted colonel for bravery. Returning to teaching, he was successively principal of the Connecticut normal school, member of the Connecticut legislature, professor of rhetoric and English literature in the distinguished faculty Andrew D. White assembled in 1868 to launch Cornell University, principal of the Adelphi Academy of Brooklyn and the Girls' High School of Boston, and president of the newly reorganized Mills College in California. Between times he had found time for extensive periods of professional lecturing, a journey to Europe, the publication of annotated editions of several of Milton's works, the presidency of the New England Society for the Suppression of Vice, and the invention of a windmill.

Sprague knew and was respected by some of the foremost educational pioneers of his time. New York University had conferred the honorary Ph.D. degree upon him in 1873. Andrew D. White was an old friend from Yale days (he graduated the year after Sprague), and Daniel Coit Gilman, first president of Johns Hopkins when it was founded in 1876, was a friend since boyhood. Sprague had done some educational pioneering himself. During his one year in the Connecticut legislature he had led a successful fight to enlarge appropriations for summer teachers' institutes, to abolish tuition charges in the public schools, and to reopen the normal school he had briefly headed-it had been closed by the legislature in order to save money. In 1878 he had founded the Martha's Vineyard Summer Institute, a pioneering venture in the summer school movement which eventually was taken up by the universities as part of their regular offering.

Why this man who knew the great and near-great, who had a well-earned reputation as educator, popular orator, and war hero would accept the appointment at North Dakota is a question worth a moment's consideration. Sprague's own answer to it is undoubtedly true as far as it went: "I came to this region because I wished to give the last fifteen or twenty years of my active life to the work of building up a great university; and I was assured by those who knew the situation best that the people of Dakota were disposed to be liberal ....." Ambitious and something of a reformer, confident of his talent, Sprague's restlessness sprang from a lifelong search for a project worthy of his abilities, one which would enable him to match the opportunity and achievement of his friends, White and Gilman. Sprague had some strong views of his own on education, and North Dakota provided the opportunity for translating them into action in a milieu where they would not be thwarted by tradition and by entrenched interests. It was entirely characteristic of the man, and for that matter of the Yale tradition of educational mission work, that he seized the opportunity for, as he termed it years later, "a romantic undertaking in the "wild and wooly" west." He may also have noted too, as Gilbert Pierce obviously had, that North Dakota would soon become a state, with an accompanying increase in the opportunities for a personable man with an unrivaled gift for oratory.

The central points in Sprague's educational philosophy he stated many times. Perhaps because of his own poverty-ridden youth, he had long been an advocate of free education on all levels, with the federal government as well as the states and local communities accepting responsibility for the schools and colleges. As he saw it, "the supreme object of the public schools is to enable and dispose the young to be valuable members of the body politic." He reasoned 
that, since the processes of operating democratic society had gone beyond the scope of common school education, the only course open was to provide the proper kind of higher education on a mass basis. Yet he never really spelled out the details of this education for citizenship, because he was not exactly clear on them himself and was feeling his way in the situation he found in North Dakota. In general its core was the humanities, and there is considerable resemblance between his emphasis and the views of White and Gilman, ${ }^{4}$ although Sprague appears to have clung more closely to the older tradition than either of his friends. Sprague recognized the necessity of studying the mechanics of society, but he was mostly concerned with the development of proper attitudes, a firm standard of morality, and a sense of history. In a way he was seeking to recover the true spirit of classical education. He had no patience with the methods or the educational philosophy which had reduced the classics to an exercise in discipline, but he revered them as humanistic studies which gave tone and character to an institution, brought the learner into contact with the intellectual world, and inculcated in him a chaste literary style. Sprague had none of that classics bigotry which affected to despise the sciences. As a humanist he respected what science could and was about to do for man, and in his administration the sciences received their share and more of his attention and the funds available. No faculty members were more carefully chosen than were the science professors. Nor was he, despite his insistence that teaching people how to make a living was not educating them, blind to the need to train public school teachers practically for their jobs or to the University's function as a source of certain practical services to the public which supported it. Sprague deserves his niche in the University history because he was the first to make an attempt to define the University's functions and the over-all purpose of the education it dispensed.

"Gilman believed that education should be of practical use. At Johns Hopkins he emphasized the biological sciences, especially those basic to medicine, and what he termed modern humanities: "the study of man in his relations to society: history, jurisprudence, political economy, legislation, taxation; the study of the earth sciences: a revolt against the education he, White, and Sprague had experienced at Yale before the Civil War, where according to White, even the able professors were "fettere by a system which made everything of gerund.grinding and nothing of literature."
The new president assumed office almost immediately, for the fall term had already begun. Onc of his first tasks was to establish proper chaperonage and discipline. Since the dormitory was not completed, both boys and girls were occupying the same building, and there were some disturbances beyond the powers of Matron Jennie Allen to control. The Spragues bought carpets and furniture and took up temporary quarters in the main building. When the girls' dormitory was ready in December, they became the first occupants of its three-room president's suite. It had no cooking facilities; the president and his family were expected to take their meal with the students. (This arrangement for the presidents continued until 1903 when a house was built on the campus.)

Sprague set out immediately to publicize the University. Before the end of October Grand Forks heard him in a full-voiced performance at the Gotzian Hall on the subject of "Money and Manhood." In the course of the next four years he made dozens of such appearances all over the state. "Colonel" Sprague was much admired. His style of perfervid oratory may have been losing favor in the East, but his speeches were a welcome diversion in the dull little Dakota towns. Listeners came long distances to hear him, and Sprague observed years later that "never were audiences so hungry for speech." Once he arrived at Towner at eleven in the evening to find his audience still waiting and expecting him to proceed. His favorite subjects were Milton and Shakespeare; "Milton as an Educator" or "Shakespeare's Youth" were typical titles. Others were "Oliver Goldsmith," "Public Speaking," "How to Study a Poem," and "The Bright Side of Confederate Prisons." The latter, the one concession to humor by a not very humorous man, brought down the house many times; it was later expanded into a book which was published after Sprague left North Dakota. Barely two months after his arrival in the state the members of the newly organized North Dakota Education Association responded to a lecture on Milton before the annual convention by electing him their first president. The effect on prospective students was equally favorable. One alumnus recalled a generation after Sprague was gone how she gained her "first impression of the University" when she heard him speak at a teachers' institute: "During the course 
of that lecture any doubts as to the wisdom of attending the new school vanished." She added that the "impression of his polished speech and organized eloquence have lasted these thirty-two years." As for Sprague, speech making was the breath of life which gave him the respite he required from his exile, as he once termed it, at the University. The occasional tours he took outside the state only added to his prestige at home. It is a little amusing to note that, earnest though he was in pushing the University's interests, he never managed to shake off completely his professional lecturer's expectation of sharing in the proceeds whenever admission was charged.

Sprague did considerably more than rely on his oratory to attract students. Regular train service to Grand Forks was quickly established after his arrival. The boarding department was thoroughly reformed; the dignified and fastidious Mrs. Sprague herself undertook its supervision. The weekly charge was reduced from $\$ 3.50$ to $\$ 2.50$ in order to meet the competition of other territoria colleges (the price was $\$ 2.17$ at South Dakota State). This expense and a $\$ 5.00$ incidental fee remained the only charges levied on students until they were required to pay for their chemical supplies in 1889. The quality of the food was also greatly improved-it had been so bad that on one occasion students had thrown it on the floor.

Another change was a relaxation in admissions requirements. Unqualified students once rejected were now classified as "specials" and assigned "uplifting" and "edifying" work. Thirteen were in this group in 1888-1889. Sprague defended the policy as a realistic acceptance of the fact that some students would find no opporunity for educational advancement at all if the University refused them. Making education cheap and available to every student capable of doing the work was in his view the first and most essential step in educating citizens.

The effects on enrollment were dramatic. In 1887-1888 the figure climbed to 98 , and the next year to 199 . Sprague had no illusions about the dangers in seeking numbers alone, but he felt it necessary first of all to satisfy the Regents' desire for more students. As soon as the enrollment was up, he began pressing to drop the preparatory department altogether on the ground that it tended to lower the University's standards and to damage its prestige abroad. The proportion of college enrollment to that in the preparatory and normal departments was a strong argument: 20 to 179 in 1888-1889, 24 to 127 in 1889-1890, and 20 to 131 in 1890-1891.

Sprague also lent his support to the agitation for high schools. It is significant that at the annual meeting of the North Dakota Education Association in 1888, over which he presided as president, the most important resolution adopted was one to urge immediate steps toward the establishment of a uniform tax-supported territorial high school system. At the same time, realizing that the preparatory department was essential until such schools actually existed, Sprague lengthened the preparatory curriculum by adding a third year in 1888 . This meant that the preparatory seniors of that year were required to continue precollege work for another year before being admitted to the freshman class of the University, and it accounts for the absence of a graduation class in 1892. The nature of the change was the addition of Greek and the general lengthening of the courses. The difference between the University preparatory standard and that of even the best territorial high schools was demonstrated when in 1890 the University experimented with accepting a few graduates of Grafton and Grand Forks high schools directly into the freshman class. Without exception they were in adequately prepared for college work and direct admissions were discontinued.

It was to be expected that Sprague would embark on a considerable revision of the curriculum in order to implement his idea of education for citizenship. The changes were less in the way of alterations than additions. A good many of them, as well as the specialization, were as much the natural accompaniment of growth as anything else. The most important change in the college program was the requirement, begun in 1888, that all freshman student must take the same general course of natural science, classical language, literature, and mathematics. The major addition, made the same year, was a third college curriculum leading to the degree of bachelor of letters. Emphasizing literature, modern languages, and history, the new program provided scope for Sprague's talents as a scholar and teacher. It contained no Greek and Latin except 
as a course in literature in translation, no mathematics or science except one hour a week of descriptive astronomy. The last three years of arts and science courses remained substantially unchanged. ${ }^{5}$

The most important single element in the new program was Sprague himself as a teacher of literature. A student has recalled that "the difference between his teaching of Shakespeare, Milton, Tennyson, and Wordsworth, and most of the other teaching of English to which I was exposed was ... the difference between the tones of a pipe organ and the sounds of an old-time village school melodeon ..... He read and interpreted and filled us with the glorious genius of the old English poets to such a degree we couldn't escape the marvel and wondrous beauty of it all." The effect of the inauguration of the new course can be seen in the shift of students from the science course. In the first two graduating classes, only three of the thirteen college graduates took the B.A. degree; all the rest took the B.S. degree. In the class of 1891, only one degree was in science.

The social sciences, although they had no such protagonist, also enjoyed some increased emphasis, mostly in the addition of general courses in history. Economics and political science remained combined in one course required of all seniors. None of these courses was taught by a specialist; still more or less the teaching province of any cultured gentleman, they had not yet declared their independence at North Dakota. History received its first formal recognition in 1890 when it was appended to Woodworth's title of professor of mental and moral sciences.

Although the teaching in all of the courses in literature and history was mostly of the textbook recitation variety, the students began to receive some benefits from the library. Its holdings expanded from about 1,000 in 1887 to almost 2,300 in 1891. After Merrifield became the librarian in 1889 , it was open from eight to five daily, and students were permitted to take out books without bringing a note from a professor. This "most useful" department's supply of standard works was fairly good, but its defects need no elucidation.

'The Cornell University curriculum in the 1880's included five courses: arts or classical, philosophical or literary, science, science and letters, and "optional" (no
specified course). The specified courses were abolished for free election in 1896.
It is indicative of Sprague's broad view of education and his acceptance of the new developments that, despite his own high regard for the humanities, it was the sciences which were most fully developed in his administration. Opportunity and rivalry had some part in Sprague's policy. With the completion of the dormitory there was space for separate laboratories in biology, chemistry, and physics; there had been only one before 1887. The imminent launching of an agricultural college, already established by law but without appropriation, undoubtedly had its effect. The three major faculty appointments made during Sprague's administration, and the first specialists in any field excepting Sprague, were in the sciences.

The first was Ludovic Estes, appointed professor of mathematics, physics, and astronomy in 1888 . He held the $\mathrm{Ph} . \mathrm{D}$. in physics from the University of Michigan and was an instructor there when he received the offer from North Dakota. Physics doctorates were hardly a common article at the time; moreover, the Michigan department of physics was a strong one, one of the earliest in any state university to develop a graduate program. Estes was an extremely thorough and conscientious teacher. He introduced laboratory instruction in his department and made the first major purchases of apparatus-and the first that were systematic, for his predecessors had lacked training. Estes was later to describe the apparatus he found on hand as "a jar of iron filings, a horseshoe magnet, and enough odds and ends to cover the top of a not very large table."

In 1889 , because of the large enrollment of the year before, it became necessary to add an assistant for Montgomery in the natural sciences. Earle J. Babcock, a twenty-four-year old graduate of the University of Minnesota, was appointed instructor of chemistry at a salary of $\$ 816$. Fresh out of college and scarcely more than a boy, the redheaded and enthusiastic Babcock was not as well trained as the other two new appointments, yet he was to exert a larger in fluence on the University than either, partly because his stay was much longer but also because he more than compensated for his lack of technical training by his energy and imagination. During his first year both he and his wife accepted extra responsibilities. Together 
they monitored the boys in the main building; when the normal department needed a supervisor for practice teaching but lacked funds to employ one, Mrs. Babcock did the job without pay; and when the University got a post office in 1890, Babcock was its first postmaster.

When Montgomery resigned shortly before the fall term began in 1889, a fine young scientist, William Patten, was appointed professor of biology. The twenty-eight-year-old graduate of Harvard held a Ph.D. from the University of Leipzig and had studied at Vienna, Trieste, and Naples. A specialist in marine zoology, he was one of the mere handful of thoroughly trained biological research scholars in the United States. Although Patten was to remain only four years (he was enticed away by Dartmouth), he left his mark, for he had a zest for teaching and a skill that Montgomery lacked. Montgomery had talked much of laboratory work, but it was Patten who gave North Dakota students their introduction to biology via the laboratory. He spent his own money in the summer of 1890 at Wood's Hole, Massachusetts, to acquire as many laboratory specimens for his classes as storage facilities at the University could accommodate. It was perhaps only natural that he was the first professor to attract postgraduate students. ${ }^{6}$ In the fall of 1890 two members of that year's graduating class were given permission to work in his laboratory with the understanding that the privilege would be withdrawn if they interfered with Patten's regular duties. They were listed in the catalog as "resident graduates." It is worth noting that in this era of heated debate between biologists and clergymen over the Darwinian theory of evolution, Patten held and taught the most advanced biological views without any diffculties. Indeed, his studies corroborating the evolutionary theory in regard to man's origin were the subject of a friendly Herald Sunday feature article in 1890 entitled "The Missing Link."

These three men, with the assistance and urging of Sprague, took the first steps, aside from the collecting and archaeological work of Montgomery, toward making science an instrument of direct service to the state. In 1890 the University was designated as a weather signal station by the Department of Interior, and the ${ }^{\circ}$ The total graduate enrollment in the United States was less than 2,400 in 1890. physics department supplied daily weather reports to the Dakota newspapers. That same year Patten spent half his summer gathering grass specimens for the United States Department of Agriculture and for the newly established experiment station at Fargo. Babcock meantime had made his laboratory the "testing room" for the state, and in the summer of 1890 he made the first effort at systematic investigation of sugar beet culture and lignite and clay deposits. His report, published by the state commissioner of agriculture and labor, contained analyses of North Dakota soils and the sugar content of beets raised in them. Highly optimistic, it was in the nature of inspired prophecy. The significance was not lost on the state legislature, whose members realized the dangers of one-crop farming, and in 1891 a joint resolution instructed the department of agriculture and labor to pursue the investigation of sugar beet culture. Development in this field belonged, of course, to the experiment station and the Agricultural College, to which it was soon transferred. Most important from the standpoint of the University were the sections of the report dealing with the fuel properties of lignite, of which there were vast deposits in North Dakota, and the suggestions that North Dakota clays might become a source of industrial development. Babcock was to carve out a career in research in coal and clay that was to become the source of whatever early reputation the University of North Dakota made in science and technology. The potentialities of the mineral deposits were also to become the University's most persuasive argument for appropriations and equipment to expand its School of Mines, established in 1890, into a college of engineering.

Actually not much was accomplished in technical training or research beyond the birth of an idea. By 1891, the year Sprague left, the combined equipment of the three little laboratories was probably worth less than $\$ 5,000$. But the laboratories were in the hands of trained and enthusiastic men, and laboratory work had been firmly established as an essential teaching device in the sciences. As for the quality of the teaching, the tiny classes made up mostly of the juniors and seniors provided the opportunity for a perceptive student to learn almost as much as his instructor knew.

Implicit in the changes in all branches of the University was 
the raising of academic standards. This was not an easy matter for an institution seeking to establish itself in the regard of a community, but whose entering students were often not only incredibly unprepared but unwilling to submit to the discipline of the academic calendar. It was difficult not to be more merciful than just, and few students were failed out of hand and sent home. Before 1890 a score of 1-20 per cent was called "total failure"; $20-40$ per cent was "conditional failure" and simply subjected a student to reexamination. In May, 1890, however, the faculty voted to raise the minimum passing grade from 40 to 50 , with an over-all average of 60 required in all-courses. Grades of normal and prep students were to be reported to their parents. That same year, in an effort to halt the loose practice of attendance only in midwinter, courses were put on a term basis. Until then courses had been offered on no regular calendar but might begin any time during the term and conclude in an equally arbitrary fashion.

The normal department also developed and expanded and received trained leadership. Enrollment grew from twenty-eight in 1887 to fifty-seven in 1888 . In 1889 George Hodge, a graduate of the Michigan State Normal School at Ypsilanti and the University of Michigan, was appointed vice-principal and instructor in normal branches, vocal music, and drawing; he moved up to the principalship the following year, replacing Woodworth, who had never cared for the job. The chief difference between the normal and preparatory work was the substitution of normal subjects like pedagogy, vocal music, drawing, school law, citizenship, and practice teaching for the ancient and modern languages. Eighteen of the seventy hours (computed by the year) of courses outlined in the four-year course in 1880-1891 were in such subjects. Although a four-year program was outlined in the public announcement, it remained more an ideal than anything else. Few students bothered to qualify for the two highest of the four grades of certificates offered after 1889. In 1888-1889 all but six of the students in the department were taking the first two years' work. This proportion remained unchanged until 1891, when total enrollment dropped because of the establishment of normal schools at Mayville and Valley City. In addition, normal students were the most irregular of any group in attendance; they rarely stayed longer than three or four months in the year. In 1890, all but one or two had departed by the end of March. Nevertheless, although Sprague's efforts to get the normal certificates validated by the superintendent of public instruction were unsuccessful, the students holding the University certificates were in demand; they were the first group of University "graduates" to be scattered widely over the state.

Several semicurricular activities were added which required special instruction. About all that had been given before 1887 in the way of music was a little instruction in "voice culture" by Cora Smith, the student instructor of all work. In 1888 Margaret Boasberg was appointed, at a salary of $\$ 800$, to teach music and drawing. The University rented four pianos, and Miss Boasberg made her music courses enormously popular, although she remained only one year. So many yearned for the mark of culture and accomplishment represented in the ability to play a musical instrument, especially the piano, that in the following year free instruction had to be limited to college students who were doing satisfactory work in a minimum number of courses. The first preparatory class was excluded from such instruction altogether. Drawing was taught almost entirely to the normal students, or as an optional course to the college science students.

Military training had its beginning in the Sprague administration. Although it was specifically required in the organic act, nothing much had been done, chiefly because the War Department was indifferent. When in 1885 the Regents had requested the detail of a military officer they were informed that the only one available to the whole northern plains region was already assigned to the University of Nebraska. In 1887, before Sprague was appointed, W. H. Topping, a retired colonel and later adjutant general of Dakota Territory, had been employed to operate the boarding department, to chaperone the students living in the University building, and to drill the boys in calisthenics and the school of the soldier. He proved unsatisfactory in every department and was discharged at the end of a year. A "student company" was organized and in December Governor Church loaned thirty-eight militia muskets for drill. From 1888 to 1890 student officers conducted a 
half hour of drill at noon or between four and five in the afternoon -out of doors when the weather was good, otherwise in the halls of the main building. Cora Smith conducted a daily class in girls' calisthenics. In 1890, after the War Department increased the number of officers detailed to college military departments, the first regular officer, Lieutenant Leon Roudiez, then stationed at Fort Pembina, was assigned to the University. A uniform of "Baldwin Gray" was adopted, and in June, 1891, "Springfield Cadet" rifles and the proper accoutrements were obtained. Roudiez was given full faculty status as professor of military science and tactics and also taught classes in French. The military department was popular. Students liked the uniforms so well that they frequently wore them home for the holidays, and there was talk for a time of making the cadet uniform the official daily dress at the University. Before the novelty wore off the girls organized their own military company (1889), and for a time Roudiez directed their drill.

Sprague also introduced the first organized athletics to the campus. Attendance had been too irregular for such activity during the first years, and none of the early professors were much interested. Something of an athlete himself, Sprague had observed with interest the rise of competitive athletics in the East during the 1870's and 1880's. Thoroughly convinced of the physical benefits to be derived from sports, he looked upon them also as a factor in good discipline. Well-exercised students, like the soldiers he had once commanded, were not so likely to give way to the "baser passions," nor were they so likely to become involved in the riots or destructive mischief that sometimes had disgraced eastern and southern campuses in the days before athletics became popular. In the winter of $1887-1888$ the space in the basement of the main building formerly occupied by the dining room and kitchen was put to use as a gymnasium until the attic could be fitted up. Equipped with dumbbells, Indian clubs, trapezes, and bars, the attic-gym was described by a newspaper reporter as "one of the grandest gymnasium rooms to be found in any educational institution in the Northwest." Merrifield, on the other hand, found it to be entirely unsuitable; dark and low-ceilinged, its floor was so thin that more than once students exercising on the horizontal bars broke through into the rooms below.

In the spring of 1888 the Olympic Athletic Association was formed. A student organization inspired and named by Sprague, its chief function was the preparation of playing grounds for such outdoor activities as croquet, baseball, and tennis. Its expenses, such as they were, were borne by the president and faculty. There was much student enthusiasm and practically complete participation, for the opportunity for group play was doubly attractive to students coming from isolated farms. A field day scheduled in the spring of 1888 had to be canceled because of bad weather, but the next year the events, for which a half holiday was allowed, were so successful that the field day became an annual affair. Sixty dollars in prizes were distributed in 1889 for proficiency in such events as the longest hop right foot, the longest backward jump, the barrel race (with the student on top propelling the barrel with his feet), the one-tenth mile foot race, the quarter-mile bicycle race (on high wheelers), and the slowest one-rod movement of a bicycle. The marks in some of the conventional track and field events are of interest; the 100-yard dash was won in a sprint of thirteen seconds, and the 220-yard in twenty-seven seconds; the winner of the pole vault achieved a mark of seven feet. That same spring competitive sports had a small beginning when the baseball team met the Grand Forks nine for two games, both won by the University with Goldwin S. Sprague, the big, heavily mustached son of the president, on the mound.

A considerable part of Sprague's program of education for citizenship appears also in such semicurricular activities as literary societies, a student magazine, and elocution and oratory. Before Sprague's arrival the only activity of this nature had been the weekly meetings of the Adelphi Society. Two new literary societies appeared in 1887-1888, the Per Gradus, limited to boys living on the campus, and the Normal Literary Society, limited to women normals. All of them were under close faculty supervision, being forbidden to meet unless a professor was present. It was in these societies that students received training in public speaking, in the conduct of meetings, and in creative writing. Sprague set a high 
value on this kind of work "in a country like this" and gave much time to it. He inaugurated the custom, which continued for many years, of having the more advanced students present their declamations, orations, or essays before the daily chapel exercises. The quality of the students' performance in these activities was considered along with their class work in calculating their standing.

The establishment of a monthly magazine, the Student, in April, 1888, provided an opportunity for student writers. ${ }^{7}$ Macnie was appointed faculty adviser and censor. The key editors were selected by the faculty. Three associate editors were chosen by the students. As could be expected, the Student was devoted as much to literary effort as news, its tone set by the opening statement of the first issue: "We do not send our paper forth as a great luminary seeming to lay on it a duty of dispelling all darkness and ignorance from this region blessed with light, any more than the soft Aurora seems to diffuse her feeble rays to hide the glorious sun." The faculty contributed as much or more than the students, and the magazine expressed a strictly faculty point of view. The first issue contained an article by Sprague, "Training for Citizenship"; "Volapuk," an article on a new international language by Macnie; "The Normal" and "Frances F. Willard" by Cora Smith; unsigned articles on "Our History," "College Athletics," and "The Physical Laboratory"; "Shakespeariana" by Sprague; with some news items concerning the doings of students, faculty, and other colleges. Sprague's "Shakespeariana" appeared every month, and other faculty members contributed regularly. The then current issue of the purpose of education and the form it should take received attention in such articles as "A College Education as a Training for Business" by Merrifield and "Scientific Methods and Their Place in the Educational System" by Ludovic Estes. "A Plea for Some Sweetness as Well as Light" (unsigned) discussed the controversy between the classicists and scientists. Students contributed poetry, essays, and articles - on noncontroversial subjects. The amount of student creative writing was considerable, and although most of it ran to the 7 An earlier paper, the University News, had been published for a short time in 1886 by $A$. R. Griffith, a twenty-year-old preparatory student who had been a forema
on the staff of the Grand Forks Herald. florid and sentimental, it at least had the merit of some grace and a remarkable freedom from grammatical error.

Other activities also showed the influence of Sprague. After the girls' dormitory opened, he and Mrs. Sprague held weekly receptions on Friday evenings. A program of music and literary exercises was usually concluded with a short lecture from the president. $\mathrm{He}$ reported to the Board that "pains were taken" to introduce the young people to each other and that the gatherings had "improved in a marked degree the manners of some of our students." In his first year, when the winter weather made it impracticable for students to walk to town to church, he inaugurated Sunday afternoon lectures in the parlors on "great moral and religious poems." The next year lectures by other members of the faculty and local clergymen were given. In 1890-1891 a weekly series of more secular lectures was offered by the faculty on Friday evenings on such varied topics as "Paradise Lost," "Our Water System," "Value of History," "Coral and Coral Islands," and "The Atmosphere."

The students were held under a tight rein, after the manner in an eastern school. In his first year Sprague inaugurated the policy, which he continued throughout his term, of regular Sunday morning inspections, military style, of the students' quarters and their possessions. It is not to be wondered at that Sprague, despite the high respect in which he was held, failed to win the love of the students. Not a single student reminiscence mentions the warm human relations between president and students which are so profuse in the recollections of the presidency of his successor, Merrifield. Yet students managed to have a good deal of fun. The weekly gatherings in the dormitory parlors were something to look forward to. The Spragues deliberately encouraged boy-girl friendships, which no doubt prospered, even under the strict rules. Dancing was permitted and even encouraged among the girls, and at times among the boys. During the long, bright winters the coulee was crowded with skaters in the late afternoon recreation hours. Occasionally Grand Forks students or those with enough money to hire a livery rig indulged in lively buggy or cutter races along Broadway. In the spring after the ground had dried, there was quoit pitching, baseball, tennis, and other pastimes. Bicycling was also popular. 
(The Wheelman's Association was founded in Grand Forks in 189n.) Croquet may not have been very lively, but it could be fun when mallets were used on "coeducational principles." For the completely nonathletic, the huge woodpiles provided secluded nooks for téteâ-tétes out of sight of prying faculty members. On warm spring days the contemplative-or lazy and sleepy-student could drowse in the sun on the coulee bank in the silence of the vast prairie.

The preoccupation with athletics which in the 1880's became a matter for concern in eastern colleges, particularly Yale, had not yet touched the University of North Dakota; nor was there the restiveness and beer drinking roistering which erupted in the riots and rebellions that were a disturbing feature of nineteenth-century life in many more sophisticated colleges. Time after time faculty reports comment on the "exemplary behavior," the "earnestness and industry" of the student body. Yet there was a considerable amount of horseplay in the boys' quarters, two large rooms on the top floor of the main building appropriately named the "Ram's Pasture" and "Bull Pen." The usual signal for a raid or prank was lights out at ten o'clock. An occasional student was "initiated" by being "stretched," tossed in a blanket or given an involuntary cold bath but no hazing tradition was yet established. In 1888-1889 appeared the first secret organization, the Lime Kiln Club. The faculty outlawed it immediately and placed the members on probation. It was in the Sprague regime that the University acquired its first spontaneous and authentic tradition. This was the student shout of "Rag's out," which became a sort of rallying call. It had its origin in Mrs. Sprague's custom of hanging a napkin out of the window of the dining room in the girls' dormitory to announce that meals were ready. Faculty members, whose own conception of proper traditions came from ivy-clad campuses of the East, deplored it as crude and uncollegiate.

A major milestone in student affairs, as well as in the University's history, was the graduation of the first college class in 1889. A faculty committee was appointed in February to plan the exercises. In April the student body met and chose the school colors, the pink and green of the prairie rose, "suggestive of our green prairies and rosy prospects." On June 13, a cool, fair day, the cere- mony began at ten o'clock in the University assembly hall, which had been decorated with flags and flowers and a large "89" centerpiece. A capacity crowd of students and spectators (perhaps as many as 250) was on hand as the graduates-"the ladies . . . dressed in white" and "the gentlemen ... neatly attired"-marched to their places on the stage to the accompaniment of music by Hall's Cadet Band. Special guests were the Regents, H. M. Mellette, governor of the Territory, several other territorial officials, and Nehemiah Ordway, who as governor had signed the organic act of the University. Sprague presided and introduced the speakers. Mellette observed that it was a "Red River letter day." Ordway spoke with pride and feeling on the University's founding. One of the Regents relieved the occasion with a touch of unconscious humor when he explained: "As to the faculty we have done the best we could with the money at hand." Following the official commemoration of the occasion, the main part of the program began; there were essays and orations presented by each of the eight graduates, six from the college and two from the four-year normal course: Frances M. Allen (B.A.), Clinton S. DeGroat (B.S.), Ben F. Ingwaldson (B.S.), Cora Smith (B.S.), Marie Teel (B.S.), May Travis (B.A.), and Genevieve Arnold and Irene Mares (normal certificates). The orations, on current as well as literary and moral subjects, were printed in full in the Grand Forks newspapers.

Three of the college graduates were from Grand Forks; none had come from farther than Hillsboro. Not one had been born in North Dakota; Ben Ingwaldson had been born in Norway. In the class of 1890, of seven college graduates, four were from Grand Forks, three were women, and six took the science degree. A considerable proportion of the early graduates entered medicine, law, or teaching. Cora Smith, a member of the first class, took a degree in medicine at Boston University; Mary Crans of the second class completed the course in dentistry at the University of Michigan. Ben Ingwaldson went on to the University of Minnesota law school. North Dakota's first appointee to West Point, Joseph Travis, graduated in the class of 1890 . Few returned to farming; the University was a means of escape from such drudgery, a fact which partly explains the suspicion of the University in rural circles and the 
tendency to regard it as an aristocratic place where farming was looked down upon as an occupation.

Such significant landmarks of progress as the first graduation were matched by lesser ones, most of them directly traceable to the indefatigable zeal of the president. In the spring of 1888 he, the janitor, Joseph Guyot, and a dozen students observed Arbor Day, that genuine plains holiday, by planting cottonwoods and box elders they had dug up along the Red River. Because of the lack of facilities for watering, not many of the trees survived except one clump of cottonwoods east of the dormitory and another south of the main building; the last of these "groves of memory" were removed in 1949 to make way for a new driveway and parking lot. For years after Sprague had departed, Arbor Day was celebrated regularly and ceremoniously. Groups of students, for example the Norwegians, or a lone Icelander, would dedicate a tree or grove to their Dakota homes or native lands.

The year 1890 was especially marked by signs of progress and growth. The appointment of an accounting and purchasing officer for the Trustees, growing out of measures passed at the first state legislature, was reflected at the University in the introduction of requisition forms for faculty supplies requiring the approval of both the president and secretary of the Board. The first full scholarship was given in 1890. E. H. Thursby of Towner donated full expenses for a year for one student under seventeen who was chosen from Towner County by competitive examination. The winner, Willie Wick of Ely, entered in the subpreparatory class but failed to return a second year. This was the year of the first appropriation $(\$ 400)$ for hospital rooms (it was never spent for the purpose, however), the first telephone, the weather station, and the post office. The first private residence in the University area was erected. Owned by William Budge, it was first occupied by the Babcocks. ${ }^{8}$ More important than any of these, perhaps, as a mark of the University's development, was the election of a former student, Horace F. Arnold of Larimore, to the state legislature. Arnold quickly demonstrated by his loyal support of the University's interests the advantages of having alumni located in influential positions.

${ }^{8}$ It was razed in 1956 to make way for the Lutheran Student Foundation building.
Yet despite the general improvement and progress, there was much that was disappointing to the Spragues. The romance and adventure they had anticipated was often isolation and bleakness close at hand, especially for the fastidious and somewhat elegant Mrs. Sprague, a native of New Haven. Moreover, the University failed to develop as rapidly as Sprague, afflicted with more than his share of the reformer's impatience, had expected. The magnitude of his hopes and of his disappointment appears in his recommendations in 1889 for the early establishment of schools of law and medicine and the immediate construction of a $\$ 10,000$ gymnasium, a $\$ 55,000$ science building, and a $\$ 25,000$ dormitory to house a hundred boys.

At the same time there was some disenchantment with the Spragues. The missionary character of their work was a little too obvious. The patronization that is implicit in bringing light to the unenlightened, Mrs. Sprague's obvious distaste for North Dakota, and the fact that the family not once remained in Grand Forks during the summer, all were signs that were noticed by the touchy boomers of the region. Sprague could be inept or unlucky in his relations with the public. On one occasion he put himself in a bad light by trying to hide the janitor and two students, seriously ill with diphtheria, in an unheated attic when the University was being visited by a legislative delegation in February, 1889. The patients were discovered in the most embarrassing of circumstances. To be sure, Sprague was overanxious rather than callous; he was desperately trying to win a large appropriation, and the cases had been brought to his notice on the very eve of the visitation upon which so much depended. But such excuses were hardly adequate for men who had been unnecessarily exposed to a deadly scourge for which there was no known cure at the time. (Three of the janitor's small children died.) Even after the discovery, the University was not closed until the local board of health insisted that it must be, and when the buildings were being disinfected preparatory to reopening, it was discovered that the plumbing was in ruinous condition from neglect. That same spring several salary reductions, for which Sprague was in a way responsible, disturbed the harmony of the faculty. On the president's advice, the faculty had agreed to the equalization of salaries on the professorial level- 
the basic scale was $\$ 2,000$ but Montgomery was receiving $\$ 2,350$ and Merrifield $\$ 2,100 .^{9}$ Sprague then urged the Trustees to bring all the salaries up to Montgomery's, but on the ground that there was insufficient money for such action, they proceeded to reduce all to $\$ 2,000$. A direct result was the resignation of Montgomery hefore the fall term opened.

But errors and hazards such as these beset most university presidents, and Sprague could probably have survived them had he not become involved in more serious difficulties arising from the struggles for power and position occasioned by the achievement of statehood in 1889. On February 22 President Grover Cleveland signed the Omnibus Bill admitting four new states: North and South Dakota, Montana, and Washington. The election of delegates to the North Dakota constitutional convention was held on May 14 For a time there was some talk of Sprague's running for election as one of the three delegates from the Grand Forks district, and a number of prominent citizens urged him to do so. He declined, however, pleading the press of business at the University-the first graduation was in the offing.

He did consent to submit to the convention a recommendation for the constitutional provisions on education and proceeded to do this after consulting the county superintendents of schools in a meeting held in Bismarck in July, when the convention was in session. The following proposals, which he drafted, were submitted for the section on education: a tuition-free educational system, complete from common schools through college, should be established immediately; all public officials, especially teachers, should inculcate principles of right conduct; all schools should teach citizenship and government; and the legislature should act to secure a uniform course of study, and to promote "literary, industrial, scientific, and moral improvement." In the end, following some lobbying by Sprague and a brief address to the assembled convention, most of these principles were incorporated into Article VIII on education,

"According to Sprague, professors' salaries in 1890 at other "comparable" universities were as follows: Minnesota, \$2,400; Michigan, \$2,200; Wisconsin, $\$ 2,200$; Nebraska $\$ 2,000$. The presidents of these institutions received $\$ 6,000, \$ 5,000, \$ 4,000$, an and the professors somewhat less than those at North Dakota. and the introductory statement to the article was incorporated as Sprague wrote it.

Of more immediate importance was the added restriction placed on the disposal of school and institutional lands-two sections in each township for common schools and 500,000 acres for state institutions and colleges-which was proposed by the educators assembled in Bismarck and adopted by the convention with almost no change. Most of the delegates apparently shared the concern for safeguarding the land endowment for education. The only limitation put on the disposal of these lands by the enabling act had been a minimum price of $\$ 10$ an acre. The constitution limited sale further to one quarter of the total in the first five years of statehood, a half in the first fifteen, three quarters in the first twenty-five, and the remainder not at all. Acts passed at the first session of the state legislature placed the lands under the management of an ex officio board and a salaried and bonded commissioner. The Dakota system of university and school land disposal has come to be regarded as something of a model.

Whether Sprague would have been wiser to attend the convention-provided he could have been elected-than to follow the course he did is impossible to judge. The broad general principles that he thought so important were not the main issues at stake. Far more important than they or even the disposal system of school lands, as far as many delegates were concerned-and Sprague should have been aware of this-was the placement of the state institutions. To be sure, the Omnibus Bill had already prejudiced the case against centralization by its direct division of the South Dakota lands among its various institutions and its statement that the pattern should be followed in North Dakota "in like proportion as far as practicable." 10 There were other commitments to scatter the colleges dating back at least as far as 1883. A territorial act of 1885 had reestablished the Agricultural College at Fargo, and the final territorial legislative session had reaffirmed it when a Fargo-Bis-

${ }^{10}$ The distribution in South Dakota was 50,000 acres for the capitol building, 80,000 for the normal schools, 40,000 each for the University, Agricultural College, and School of Mines, Severty General of the United States ruled in 1889 that this should mean seventy-two sections each for the Universities of North and South Dakota. 
marck combination had beaten off a Valley City-Grand Forks attempt to shift it to Valley City. Although no appropriations had yet been made, the pattern was firmly set, and the Fargo promoters were no more disposed to give up their promise of a college than Grand Forks was to give up the one it already had. Moreover, the idea of a separate agricultural college had strong appeal in the constitutional convention where the percentage of farmer delegates was high. F. B. Fancher, vice-president of the Dakota Farmers' Alliance and later president of the North Dakota Alliance, was elected president of the convention by an overwhelming majority. The fact that the University was poorly located from the standpoint of the state as a whole provided additional argument, if any were needed, for scattering other colleges.

In the meantime, the Northeast-Grand Forks forces in the convention, led by William Budge and Alexander Griggs, made a determined effort to shift the capitol and the Agricultural College from Bismarck and Fargo and to add these or other state institutions to the University. The Bismarck-Fargo lines held, but both sides had incurred heavy debts, with the result that the principle of appeasing every local interest was the one adopted, and little if any consideration was given to whether the best interests of higher education might be served by concentrating all of the colleges in one place more or less centrally located. It is more than coincidence that nearly every prominent politician got one or more institutions located in or near his home town. Normal schools were established at Valley City and Mayville, the Agricultural College at Fargo, and the School of Mines at the University, the latter a tribute to the strength mustered by Griggs and Budge. Political logrolling, prior decisions, and the fact that there were only four delegates from west of the Missouri River, and two of them from Mandan, all played their part in the illogical college placement pattern of North Dakota that exists today, firmly embedded in the state constitution. ${ }^{11}$

There was considerable apprehension at the University and

"Nine state schools or colleges were established by 1918 (dates are opening dates) The University, Grand Forks, September, 1884; Agricultural College, Fargo, October, 1891; Normal School, Valley City, October, 1890; Normal School, Mayville, De Science, Wahpeton September, 1904: School of Forestry Boptineau, January, 1907; Normal School, Minot, September, 1913; Normal School, Dickinson, June, 1918 among its friends concerning the possible effects of the establishment of a separate agricultural college; normal schools caused little concern at the time because they were secondary schools with no power to confer degrees. In a rural state with a strong Farmers' Alliance an agricultural college was a dangerous rival, particularly when its organic act was broad enough to permit duplication of most of the University courses while at the same time it had a monopoly on the courses in agriculture and the mechanic arts. It also received a larger land grant $(130,000$ acres $)$ than any other college, and it would benefit from cash subsidies from the federal government: $\$ 15,000$ annually for the attached experiment station under the Hatch Act (1887) and $\$ 15,000$ per year with a yearly increase of $\$ 1,000$ up to a maximum of $\$ 25,000$ under the second Morrill Act of 1890 . The University and the attached School of Mines had nothing but their land grants, 86,080 and 40,000 acres respectively, in the way of endowed support. And that would be of little immediate use, because the minimum price ( $\$ 10$ per acre) was too high for the land to be sold in the difficult 1890's. Meanwhile, it was apparent soon after the deed was done that scattering the institutions would mean financial starvation and slow development for them all. In the fiscal year ending October 31, 1891, the institutions of higher learning alone cost the new state over $\$ 100,000$ of its total receipts of $\$ 689,000$ (the figure on state receipts includes $\$ 150,000$ realized from the sale of bonds). University enrollments reflected immediately the appearance of the new institutions. From the peak of 199 in 1888-1889 they dropped to 151 in each of the two succeeding years, and the 1889 figure was not equaled again until the term of $1895-1896$

Just why Sprague chose to remain aloof from an issue as important to the University as the establishment of new institutions is a little mysterious, because almost simultancously he became involved in the turmoil of the new state's half-formed and roughhanded political factions on two other matters. The first was the controversy which arose in the first session of the state legislature when a lottery company, recently ousted from Louisiana, sought to secure a license to operate in North Dakota. The chief argument in its favor, that it would bring in revenue, had a strong appeal. 
But Sprague and the whole faculty, even though the University might have benefited, opposed it openly and vigorously, thereby earning the enmity of the powerful Alexander McKenzie organization which had led the fight for the lottery company. George Walsh, then in the House, was friendly with McKenzie and supported the bill. McKenzie's chief lieutenant, Judson LaMoure of Pembina, openly vowed vengeance when it was defeated. He had his chance when the University appropriations bill sponsored by George Winship, an opponent of the lottery, was reported out of committee in the senate. By a vote of twenty-four to five the president's salary was reduced to $\$ 2,000$ and the professors' to $\$ 1,800$. All but four of the lottery supporters voted for the reduction. Although calmer councils prevailed, thanks largely to the efforts of Winship, and all the professorial salaries were restored to their old levels, Sprague's was put at $\$ 2,500$, that is, $\$ 500$ below the figure in his contract-and $\$ 500$ less than the first president of the new Agricultural College was to receive. The Trustees sought to restore his pay to the old level, but they were overruled. Sprague was naturally disappointed. He himself had been generous with his own funds as well as with his time in the interests of the University. Moreover, the arbitrary action had blasted his expectations that separation from South Dakota would be reflected in more generous appropriations, especially in higher salaries for the faculty and for himself. He had frequently pointed out the relation between high salaries and a strong faculty and the unfavorable comparison between the pay at North Dakota and that at other midwestern universities. Actually, the University's salary scale was no worse than the scale in other institutions of its class in the area, if not somewhat better. The president at South Dakota State College received only $\$ 1,500$ in $1884-1885$.

Meantime the contests for United States Senator in 1889 and 1891 were getting Sprague further enmeshed in matters which he knew little about. He apparently entertained some hopes that he might be chosen, and before the election held in the first legislative session in November, 1889, some efforts were made to launch a boom for him. The Grand Forks Herald, which thoroughly detested Walsh, a prominent dark horse candidate, was strong for Sprague, and he had some support in public school circles. But no effective support was developed, and he received only a few scattered votes on early ballots. When his name came up again in connection with the election to fill the short-term seat in January, 1891, he scotched the rumors with a statement clearly indicating that he had ceased to care about what anyone in North Dakota thought. Winning an election to the Senate, he said, required behavior and commitments that would unfit the victor for the office. "Many recognized leaders in American thought" had often urged him to try for the Senate, but he could accept the honor only if it came with no strings attached. "I am not for sale," he declared.

One can only conclude that he had already made his decision to leave. In early December Mrs. Sprague resigned from the supervision of the boarding department, and after the Christmas holiday, which she and her husband spent at the new Dacotah Hotel, she departed for California. On February 24 Sprague submitted his own resignation, effective on March 31. Merrifield was appointed acting president on April 2. The reasons Sprague gave for his somewhat sudden departure were his own need for a rest and the bad effects of the Dakota winters upon the health of his wife. His going was not delayed by the disappointing appropriation of 1891 , $\$ 64,800$, which was $\$ 45,000$ less than the Trustees had recommended and only a little more than had been appropriated in 1885 and 1887. His own salary had again been left at $\$ 2,500$, and requests for $\$ 30,000$ for a men's dormitory and a power house and $\$ 2,000$ to employ a secretary for the president were denied. Another circumstance which hastened his decision was the appointment of three members to the Board by the new governor, Andrew Burke, who owed his election to the support of the McKenzie organization that Sprague had offended. The new appointments were men with whom he might find it difficult to work. One of them, William Budge, who would soon develop into the leading figure among the Trustees, had been a vigorous supporter of the lottery proposal. Of the two holdovers only James Twamley, a member since 1883, was an unwavering supporter of Sprague. Significantly, Sprague's resignation went to the old Board at its last meeting on March 3. Perhaps the deciding factor was that Sprague had discovered a new 
project with glittering possibilities, a progressive girls' school at Berkeley, California.

Resolutions of appreciation adopted by the Trustees and by the faculty summed up his work at the University. The Trustees noted his "unselfish devotion to [the University's] advancement and greater usefulness" and gave him credit for "the present high position which the University has attained." The faculty noted the "marked advances in organization and standard of scholarship ... the profound knowledge of literature" he had brought to his students, and the "great ability and eloquence" with which he had represented the University and the cause of education in general. That Sprague himself had some pride in his handiwork appears in the fact that his son, Goldwin, remained at the University two more years until his graduation in 1893.

Sprague stayed only a year at the California girls' college. $\mathrm{He}$ returned to the East for his final career as a writer and editor. Between 1902 and 1916 he brought out four studies and commentaries on Shakespeare, and he had another under way when he died in 1918. He returned once to the University of North Dakota in 1916 at the age of eighty-seven to deliver the commencement address and to receive an honorary degree, the third awarded by the University.

\section{IV}

\section{The 1890's---Years of Crisis}

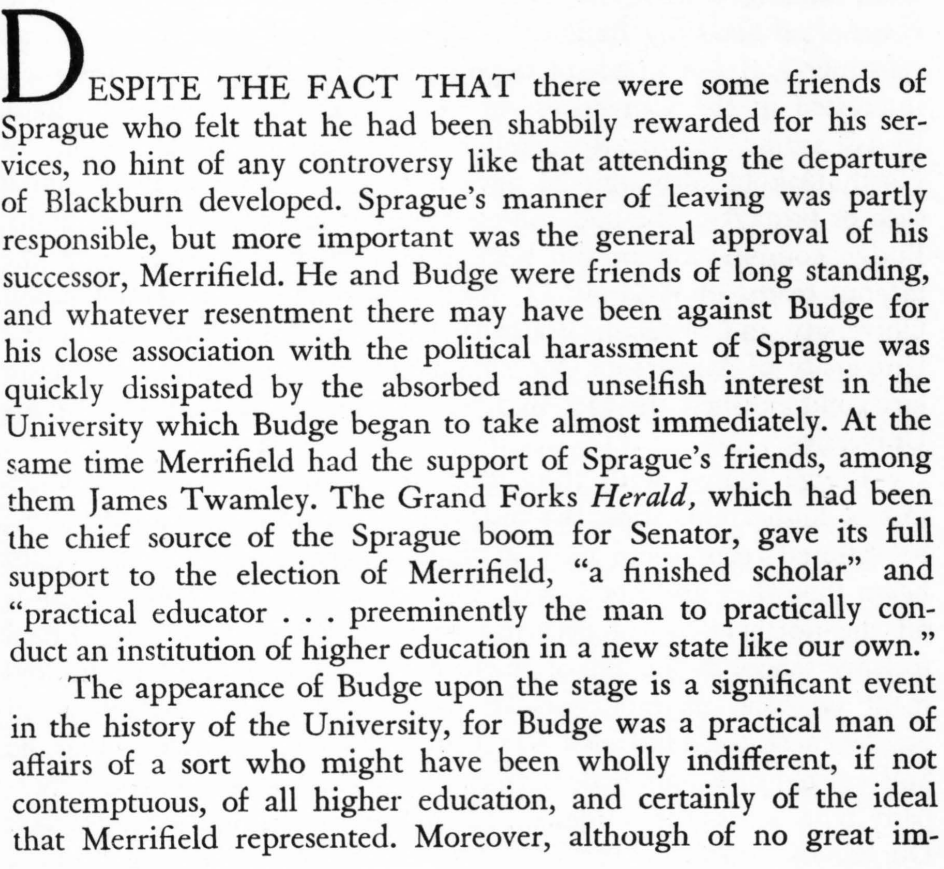


mediate benefit, his connections with the oldest and most consistently powerful political organization in the state, the "Old Gang" of Alex McKenzie, was eventually to prove an asset of considerable importance to the University. Budge's tenure on the Board of Trustees (1891-1907) has added significance because it coincides almost exactly with Merrifield's as president (1891-1909). They were already close friends by 1891, and their efficiency as a team, along with their mutual respect, ripened with the passing of every year. Budge's increasing involvement in University affairs gave him a position of great potential influence, but his respect and personal regard for Merrifield were safeguards, scarcely if ever breached, against the possibility that his power and interest might degenerate from looking out for the University's welfare to interference in its internal affairs. Billy Budge was no educational theorist, he was no reformer and not much of a philanthropist, but he was intensely interested in the University-or at least in his friend Merrifield. In a sense he was the Rockefeller or Stanford of the University of North Dakota, although he gave little to it in the way of actual cash or property. The best contemporary parallels to the MerrifieldBudge combination in the history of higher education were the famous teams of Andrew D. White and Ezra Cornell at Cornell University and William Watts Folwell and John Pillsbury at the University of Minnesota. Merrifield not only recognized the similarity but relished the fact that he had found a benefactor for his University.

Budge shared with those more famous businessmen benefactors of higher education the distinction of being a self-made man; he differed from them only in that he was perhaps more roughhewn than they and not as rich. Born on one of the Orkney Islands off the northern tip of Scotland in 1852, Budge had been forced to leave school at the age of thirteen. After a few years of employment on local fishing boats he came to Canada in 1869 as an employee of the Hudson's Bay Company. The following year he half drifted and half fled, having stolen some food from his company post, across the border into Pembina in the Red River Valley. During the 1870's he was in a variety of enterprises: operating a stage station and tavern on the Breckenridge-Winnipeg stage line, fighting Indians, running a general store, speculating in land, and freighting supplies from Bismarck to the gold rush towns in the Black Hills. Meantime, he and a partner, Jake Eshelman, had acquired a considerable amount of land in what is now the Grand Forks townsite, and when the population swelled with the Dakota boom, Budge, barely thirty years old, found himself one of the wealthiest men in Grand Forks. His affluence and early arrival also gave him political connections, and in the 1880's and 1890's he held a variety of public offices. Most were local, but he spent a term in the state legislature, and in 1898 he was a leading contender for the Republican party's nomination for governor. A big, florid man, rough in speech and manner, he had nevertheless a large fund of hearty geniality and kindliness. As his relationship to Merrifield and the University was to indicate, he also possessed an almost overwhelming respect for the education and culture that he had missed.

Budge was to prove himself perhaps the most devoted friend the University has ever had outside its own immediate family. This is not to ignore the importance of the work of men like Walsh and Twamley, or of William Roach of Larimore, another vigorous and lucid pleader of the University's interest in the early days; the latter, a graduate of Georgetown University, was a member of the Board from 1885 until his election to the United States Senate in 1892. Budge's career on the Board, like the history of the University itself in the Merrifield regime, falls roughly into two phases. In the first, from 1891 to 1898 , his relationship was chiefly one of his own effort on its behalf, largely local in scope-ranging from his leadership of the canvass for contributions to keep the University going from 1895 to 1897 to his overseeing the repair of the main building and the construction of a small dormitory. He even drove some nails himself and planted trees every spring on the campus and along the barren Broadway. He made daily visits to "his" University to talk with his friends, the president, or the janitorengineer in the boiler room, continuing this practice until he left Grand Forks in 1907.

In the second phase, as the University itself won full acceptance as a state institution, Budge's contribution to University welfare 
moved to a broader and higher level. Here his greatest service was his initiative and leadership in the unorthodox-and unauthorizedallocation of funds in a period when University development and finance were in transition and his aggressive and successful defense of such measures before the executive officials and legislators at Bismarck. This phase, beginning roughly in 1898, continued through the last period of the McKenzie organization's ascendancy and came to an end with its defeat by the Progressive-Democrat coalition of "Honest John" Burke in the political revolution of 1906. There have been no more Budges-or Merrifields-nor are there likely to be, for the end of their influence marks the point at which the University became well enough institutionalized to possess its own vitality and hence to be less dependent on any individual president or Board member than it was in its first quarter century.

It would be difficult to find a more exact opposite of Budge than Merrifield, the man he admired so greatly and who in turn admired and liked him. What the fastidious, bachelor professor of Greek saw in Budge was the adventuresomeness and vitality of the plains frontier itself and the essential similarity between himself and Budge that lay beneath the surface. Merrifield too was a pioneer developing a new country and making his mark in the process; he too was a self-made man from humble beginnings (he had earned nearly all of his expenses at Yale by tutoring and doing odd jobs). He was joined sympathetically not only to Budge but also to the poorly prepared yet earnest and forthright students who came to him for an education. Their virtues as well as their deficiencies-and Budge's as well-were his problem and his opportunity-the softening and modification of the raw, undisciplined strength of the West with the refinement and morality that to him were the true aims of higher education and the marks of civilized society.

More than any of his predecessors, Merrifield viewed education as a highly personalized process, less dependent on what was taught than who taught, a system in which the student was shaped mainly by his daily contact with high-minded and cultured men. By the end of the decade the faculty that Merrifield had gathered around himself, especially those key members in whom he had the most confidence, reflected his ideal for professors as well as for education in general. The Merrifield faculty was most influential and most conspicuous as a group in the 1890's and in the first three or four years of the new century. It was a community of scholars and friends, bound together by their interest in education and by congenial personality. Not a single major instance of friction within this group is recorded or even rumored. Only one or two of them would qualify as a modern scholar specialist, and only one could be classed as a productive scholar. These men were primarily teachers, and by any modern standards their qualifications for some of the subjects they taught were meager indeed. Yet they had a true regard for learning; they shared and appreciated a common culture, an urbanity, and an experience with the larger world of learning and the arts. They knew the eastern colleges, and of the eleven who made up that select band of the Merrifield faculty, two were Europeans by birth and education, another had been trained in the graduate schools of Germany, one had lived abroad for several years, and two more had traveled extensively abroad.

Four of the group-Babcock, Estes, Macnie, and Woodworthhad been appointed before 1891; they with Merrifield were the "old guard" around whom the rest of the faculty was built. During the 1890's several professors came and went, ${ }^{1}$ but six more were added to the permanent cadre: St. John Perrott, Kennedy, Mrs. Davis, Thomas, Brannon, and Squires.

The first to come was George St. John Perrott, who was appointed in 1891 as instructor in Latin and Greek. He had been born in Stratford-on-Avon (1857) and had received the A.B. at Oxford in 1878. After several years of teaching in a boys' school in Brighton he had come to North Dakota with a group of young Englishmen to try his luck in the Dakota land boom. The venture had failed, and he was looking for a post when he received the offer from the University. A shy and retiring man, his Oxford background and English manner and speech nevertheless made him a figure of interest and a point of contact with the world of ${ }^{1}$ Willis West, who would become famous later as the author of a series of widely
used school histories, was on the faculty for a few months in 1891-1892. 
English education for faculty and students. For years his engaging lectures on English school and university life were a part of every student's experience. He remained until his death in 1916.

The second to be added was Joseph Kennedy, appointed assistant professor of pedagogy and principal of the normal department in the spring of 1892 . He continued in the latter post through its successive evolutions to dean of the Teachers College and dean of the School of Education until his retirement from administration in 1928. The University's first registrar when that office evolved from the secretary of the Board of Trustees (1894), he also became the University's second-professor of philosophy, succeeding to this portion of Woodworth's portfolio in 1901. A graduate of the University of Minnesota (1886) where William Watts Folwell, with whom he corresponded for many years, was a favorite professor, he had been successively superintendent of the Hillsboro town school and of the Traill County schools from 1886 until his appointment to the University. He caught the attention of Sprague and Merrifield and won their respect for his vigorous stand in behalf of moral principle and sound public education. He was a leader in the fight against the state lottery scheme and strongly supported the high school plan inaugurated by the University in 1891. For many years he was to share with Merrifield the role of University representative to the public schools, and his guiding hand can be seen in a great part of the school legislation enacted in North Dakota before World War I. The fact that Kennedy was a second generation Irishman (who spoke with a slight brogue) and a Roman Catholic afforded the opportunity, of which Merrifield was fully conscious, to win friends for the University in the large Catholic community in North Dakota. Kennedy's own high-minded character and broad tolerance, his non-Catholic philosophical viewpoint (he was an ardent disciple of the pragmatists William Jame and John Dewey) made him an easy colleague for the otherwise Protestant faculty, while his open opposition to his church's position in favor of parochial schools gave the University and the public schools an effective spokesman who could not be impeached on the grounds of religious bigotry.

The only woman to be accepted in the Merrifield coterie was
Mrs. Hannah Davis, who was appointed in 1892 as preceptress of the girls and instructor in English. A native of Indiana and a graduate of Earlham College, where she had known Estes, and like him a Quaker, Mrs. Davis had studied art for two years in Italy after the death of her husband, a college professor. On her return to the United States she had done advanced study in English at the University of Michigan. In addition to all her cultural and academic qualifications she was a tremendously hard worker and a sympathetic, unusually wise person. She took great pains to teach her charges the niceties of social behavior and some appreciation of cultural and artistic values. She was genuinely mourned by faculty and students when she died in 1898, and no completely adequate replacement for her was ever found-in Merrifield's estimation at least.

The outstanding addition to the Merrifield faculty was George S. Thomas, who arrived in January, 1893, to become professor of Latin and Greek. The work of administration had become so heavy by this date that Merrifield no longer had time for his classes in Greek. Thomas was a native of Richmond, Virginia, and a graduate of the University of Virginia (1879), where he had also received the M.A. He had taught Latin and Greek at Louisiana State University for a short time and then went to Germany for advanced study and a Ph.D. at the University of Leipzig. He taught for two years at the University of South Dakota before accepting the offer from the University of North Dakota. The most thoroughly trained of the Merrifield faculty, Thomas was an able teacher; although somewhat lenient in his own classes he established his place as the most persistent advocate of high academic standards on the faculty. He was quickly recognized as a faculty leader and regularly took the chair at faculty meetings whenever Merrifield was absent. When the College of Liberal Arts was finally differentiated from the rest of the University, his appointment as its first dean was accepted as a natural step.

Only one addition to the Merrifield group, Melvin A. Brannon, was trained in the sciences. He was appointed professor of biology and curator of the museum in April, 1894, at the age of twenty-nine. A graduate of Wabash College (B.A., 1889; M.A., 1890) he had 
done his advanced study under the guidance of Dr. John Coulter, an eminent botanist of the day who later became head of the botany department of the University of Chicago. Some additional summer work at the marine laboratory at Wood's Hole, Massachusetts, and four years teaching experience at the Fort Wayne, Indiana, high school were the preparation he brought to fill the vacancy left by William Patten, who had resigned in September, 1893, to accept an appointment to the chair of biology at Dartmouth College. Although Brannon's academic qualifications were considerably less than Patten's, he had other compensatory qualities. Merrifield had chosen him after a careful search for the right kind of man.

Brannon's vigorous personality and considerable ability as an organizer and promoter led to the steady expansion of the department of biology; from it eventually grew a medical school and a system of state public health laboratories. When the military department faded away after the officers left for the Spanish-American War, Brannon took over the management of athletics. He was the first dean of the medical school when it was organized in 1905, and he succeeded Thomas as dean of the College of Liberal Arts in 1911. In 1914, after twenty years at the University, he resigned to become president of the University of Idaho; he ended his career as chancellor of the University of Montana from 1923 to 1933 . Indicative of the impression that Brannon made upon his colleagues as well as upon students and the general public is the fact that he was twice strongly considered for the presidency at North Dakota, in 1917 and 1933; he might very well have been elected each time had he been willing to accept.

The last major addition to the Merrifield group was Vernon P. Squires, appointed in 1897 as assistant professor of English. This native of New York had graduated from Brown University in 1889 and from 1893 to 1897 had held a fellowship in English in the graduate school of the new University of Chicago, where he had received the M.A. in 1895 . Thirty-one years old when he was appointed to North Dakota, Squires quickly gave the leadership that had been missing in the field of English since the departure of Sprague. His predecessor, Adolph Bechdolt, professor of English from 1892 to 1895, was a German Forty-Eighter with a Ph.D. of sorts from Franklin and Marshall College and experience as a teacher of chemistry and a city school superintendent before he came to North Dakota. There had been no one at all regularly in the post from 1895 to 1897 . Promoted to a professorship in 1899 Squires was for over thirty years a major force in the development of the English department and its off-shoots, dramatics, speech, and journalism. From 1914 until his retirement shortly before his death in 1930 he was dean of the College of Liberal Arts.

None of these men, with the possible exception of Macnie, was a productive scholar in any modern sense. They wrote no books of note, nor did they contribute much to the scholarly journals and learned societies which were taking form toward the end of the nineteenth and beginning of the twentieth century. They were too busy with teaching and too far from centers of learning to do the conventional scholarly study, but it should be pointed out also that there was little pressure from Merrifield in this direction. Research and writing as qualifications for university teaching were not given much weight until Frank McVey became president in 1909. Indeed, some of their more thoroughly trained successors and colleagues were to find when they began to arrive in some numbers after 1900 that a good many of the faculty were not even keeping up very well with the results of the new German-Johns Hopkins scholarship which was becoming the standard of the academic world. Thomas alone had German training, but his specialties were Latin and Greek, both rapidly falling from favor. Only Estes and Squires had any training at all in a modern American graduate school; Squires's was never completed, and Estes died in 1898. Brannon did demonstrate a marked capacity for specialized scholarship, if not an inclination for it, by winning high honors at the University of Chicago when he completed work for the doctorate in 1911-1912.

But all of these men had qualities of integrity and earnestness, plus an old-fashioned faith in the value of knowledge-almost any knowledge-for its own sake, which rubbed off on their students and gave them something they cherished for the rest of their lives. It was association with a faculty that in its own character exemplified the Merrifield educational ideal, joined with the camaraderie 
of community living, which was the source of the uncommonly high morale of the students of the 1890's and the strong sentimental attachments of the students for the drab little university on the prairie.

This faculty was also drawn together by shared triumph over adversity. The 1890 's were difficult years all over the country, and especially so in the Plains states, where, it will be recalled, the People's party and the Bryan Democrats produced three spectacular political campaigns from 1892 to 1896 . The University experienced a long period of financial starvation that was well-nigh fatal. There were, in addition, a number of other events that contributed their bit to making the 1890's a decade of unhappy memory. In 1897 Grand Forks suffered the worst flood in its history and two of its worst fires, one destroying the valuable Syndicate Block owned by William Budge and the other the much admired Dacotah Hotel. In March, 1898, within the short span of two weeks both Ludovic Estes and Mrs. Hannah Davis died of pneumonia. Woodworth spoke at the memorial service for Estes at the Presbyterian church the bluster of a raw March day added poignancy, as if there were not already more than enough, to the funeral for Mrs. Davis, which Merrifield, deeply moved, conducted himself in the University assembly hall. His suggestion two years later that the girls' dormitory built in 1887 be renamed Davis Hall had general approval.

The most tragic event of all was the outbreak of typhoid, endemic in the region and commonly known as Red River fever, which paralyzed Grand Forks from December, 1893, to mid-February, 1894. Over five hundred people, about 10 per cent of the total population of the town, became ill; more than a hundred died. The source of the disease was the Red Lake River, polluted from the nearby town of Crookston, Minnesota, from which water wa pumped directly into the city mains without filtration or purification of any kind. Babcock's warning of a year before that the city water was heavily polluted had gone unheeded by the city engineer on the plea that a filtration plant was more than the town could afford, but it saved the University, for Merrifield had insisted immediately that all water used for drinking be boiled. Three students died, nevertheless, but all were infected elsewhere or had violated the University rule. An immediate consequence of the disaster was the drilling of two wells on the campus. Kept in use, partly to reassure apprehensive parents, long after the city water had been made safe for drinking, the wells provided one of the vignettes of University life of the 1890 's - the early morning scene of boys with soap and towels waiting their turns at the pumps before hurrying to breakfast. Meanwhile, with the aid and advice of Babcock and Brannon the city installed a slow sand filter plant, one of the earliest of its kind in the United States. It was completed in December, 1894. Tales of the epidemic and the fact that the University's own sewage disposal plant, the coulee, was primitive-and on warm days, offensive-caused a drop in enrollment that was not recovered for a year or more.

These were also the years of North Dakota's transition from Territory to state with the consequent necessity for adjustments in the University's position. With the creation of the Agricultural College and the two normals, and now no longer overshadowed by the larger state colleges of South Dakota, the University suddenly found itself projected into the position of the leading state institution and the object of jealousy and criticism that it had never before experienced. Official opinion at the University was openly contemptuous of the new schools but apprehensive as well. Merrifield wrote to Governor Eli C. D. Shortridge in 1893 that he feared the University was "doomed from now on" because of its "disadvantageous location and inadequate appropriations." Shortridge's reply was hardly reassuring: "The Agricultural College will do all they can to defeat you." Indeed the first shot in the war had already been fired. What had occasioned Merrifield's gloom was the Agricultural College's successful coup in having the only military officer detailed to North Dakota colleges transferred from the University to Fargo. Merrifield managed to get the officer reassigned to the University only by raising the technical point that the Agricultural College had less than the minimum enrollment of 150 that was required for the assignment of an officer and by enlisting the aid of Senator Roach and Governor Shortridge. Roach had been president of the University Board until 1892, and Shortridge, although an agrarian recently elected as a Populist-Democrat, was a resident 
of Grand Forks County with a strong parochial loyalty for the University.

The two normals, whose opening had been reflected in a sharp drop in the enrollment of the University normal department, were meanwhile insisting that the constitution gave them a monopoly on the preparation of elementary and rural teachers. Kennedy's appointment to head the University normal department in 1892 was a move to retrieve the situation. The struggling new sectarian colleges were the sources of the usual "earnestly propagated" rumors that the University was a godless place. Agrarian friends of the Agricultural College, looking forward to the triumph of practical education, said that the University was aristocratic and scornful of agriculture as an occupation, a charge not entirely without foundation. By way of contrast, the Student could glory in the University as the poor man's gateway to opportunity, and Merrifield could complain that the well-to-do in the state refused to send their children to live in the "steerage conditions" that the University could provide. The high schools, which the University was doing its best to develop, complained that the preparatory department robbed them of their only good students. And there was an uninhibited critic who denounced the "Grand Forks High School ... a University by courtesy" and its faculty of "barnacles on the body politic . . . a gang of educators who are looting the state treasury." When this extraordinary statement appeared, the faculty was teaching virtually without pay, and the state treasury was contributing nothing to what they did receive.

Much of the sharpened rivalry had its origin in the dissatisfac tions and distress that attended the Panic of 1893. The new state was caught ill-prepared for even a minor economic dip, with its already small revenues, its narrow tax base, its large expenditures, a good part of which were occasioned by the bad planning and duplication of state institutions, and its unrealistically low debt and taxation limits set by the state constitution. The debt limit had been reached and the panic had not yet closed in when, in his inaugural address of January, 1893, Governor Shortridge advised cutting expenditures and pointed to the state institutions as the place to begin.
In the face of this warning, the University's request that year $-\$ 100,820$ for maintenance plus a bond issue to build a dormitorywas the largest in its history. Under better circumstances the request might have been timely, for George Walsh was speaker of the house of representatives and $\mathrm{H}$. F. Arnold was an influential member of the senate; W. N. Roach, president of the Board of Trustees, on the ground to push his candidacy for the United States Senate, also lent a hand. As it was, the legislature came through with the most generous provisions for the University in its short existence: $\$ 73,920$ for maintenance, plus an additional $\$ 5,000$ to launch the School of Mines, and a $\$ 50,000$ bond issue to be secured by the University lands. Shortridge vetoed the last two items, but the maintenance appropriation was allowed to stand.

It was indicative of the University's need, and of a not quite realistic appraisal of the general financial situation, that, despite the veto of funds for construction, Budge and Merrifield got the Trustees to approve the diversion of $\$ 6,000$ from funds already allocated for other purposes, including salaries, to construct on the long-abandoned observatory foundation a small dormitory capable of housing about fifty boys. ${ }^{2}$ It was an ingenious maneuver but one for which the science departments and the faculty paid dearly, for the economy of the whole country collapsed that same year. The last vestiges of the already deflated Dakota boom disappeared in a wave of farm bankruptcies-wheat prices were at record lows by 1894-and such other signs of the times as a scourge of tramps begging at back doors, the appearance of contingents of General Jacob Coxey's Army on the way to Washington, and a prolonged and bitter strike on the Great Northern railroad. State tax revenues dried up almost entirely. By the time the next legislature met (1895) faculty salaries were six months in arrears, many of the University's bills were unpaid, and the science departments were unable to replace even their expendable materials. The other state schools and institutions were in similarly desperate situations.

In the elections of 1894 the Populist-Democrat coalition that

"First known simply as the prep dormitory - "the doghouse" among the studentsit was later named the Cottage. The building was enlarged and extensively remodeled
in 1906 and its name was changed officially to Macnie Hall in 1908. From 1901 to 1930 it was a dormitory for girls. 
had carried the state in 1892 was turned out, largely because of alleged mismanagement of state finances. At the same time a proposed constitutional amendment to raise the state debt limit failed to pass. The new governor, Roger Allin, was pledged to a balanced budget. Lacking both revenues and credit, he took the one course that was left, which was to cut expenses to the bone. He gave ample warning of his intention in his inaugural address. Under the circumstances it is difficult to account for the fact that the University's request was for $\$ 152,320$. It was hardly the time to increase the request for library funds from the usual $\$ 2,000$ to $\$ 5,000$, or to ask for a number of entirely new items, as for example $\$ 25,000$ for an electric light plant and boiler house. Even Arnold, the usual sponsor of University bills, balked at the amount and introduced a bill for only $\$ 88,620$. This was cut to $\$ 66,840$ by a legislative committee which visited the University to assess its needs, and when the bill went to the governor in early March it had been further reduced to $\$ 63,000$. Appropriations for other institutions had also been scaled down.

It was not until this point that it was fully realized that the governor meant what he said about balancing the budget. His method, simplicity itself, was to reduce the $\$ 800,000$ appropriations until they matched the estimated $\$ 725,000$ in income. Allowing for fixed expenses and unpaid bills, appropriations exceeded expected revenues by $\$ 120,000$ to $\$ 130,000$. Rumors that the University would be the chief victim, that it might very well be closed permanently, began circulating in Grand Forks. On March 17, Merrifield and W. A. Gordon, a son-in-law of Woodworth, hastened to Bismarck. Merrifield offered to forego his salary and suggested $\$ 40,000$ as a minimum figure for the biennium. Allin refused to compromise, pointing out that the recent rejection of the amendment to raise the debt limit was a mandate to balance the budget that he could not ignore, regardless of consequences to institutions or individual communities. Two days later a mass meeting was held in Grand Forks and a committee appointed-F. R. Fulton, a banker formerly on the University Board; R. B. Griffith, a merchant, and George Brennan, a student-to draw up a statement to Allin; but he remained unmoved. When his decision was announced on March
22 it was even worse than had been expected. Only $\$ 15,980$ was allowed for the biennium- $\$ 3,200$ to pay the janitor and the rest to maintain the buildings; there was nothing at all for a faculty. Allin reasoned that the University would actually receive about $\$ 45,000$ because of the warrants that had to be redeemed. The other institutions, with the exception of the penitentiary and the insane asylum, received similar cuts: Mayville Normal from $\$ 24,000$ to $\$ 7,700$; Valley City Normal from $\$ 24,860$ to $\$ 4,600$; the Agricultural College from $\$ 19,000$ to $\$ 11,250$. None of the school or college appropriations included any funds for faculty salaries. Allin fully expected the University and the normals to close at the end of the spring term. The Agricultural College alone, having a biennial income of $\$ 70,000$ from the federal government, was expected to continue whatever higher education North Dakota was to have for the next two years.

When the news got around that the University was to close, sentimental expressions of regret for the fate of the state's first college appeared from areas heretofore completely indifferent. And there was violent criticism from the University partisans in the Red River Valley. Much was made of Allin's approval of an appropriation of $\$ 30,000$ to eradicate Russian thistle; the fact that the weed threatened the whole agricultural industry on which the state depended accounts for the legislators' and governor's approval of the measure. Yet few outside the immediate vicinity of Grand Forks or on the campus itself realized fully how much damage even a temporary closing would do to the University. A warning of what was almost certain to happen appeared when Professors Estes and Bechdolt posted their houses for sale almost immediately after the governor's decision was announced.

Although Allin had been adamant in the face of all argument, it was he who opened the way to a solution by suggesting to the Trustees that, with the exception of what was allocated for the janitor's salary, the entire appropriation could be diverted to paying the faculty. At their April 2 meeting the Trustees were presented with a communication from the faculty urging that Merrifield at least be retained if the University had to be closed temporarily. Reassured by this evidence of loyalty, the Board then called upon 
the off-campus friends of the University for a comparable demonstration of support, and for inspiration as well, with the following resolution:

Whereas we the board of Trustees of the University of North Dakota realize the grave responsibility placed upon us at this critical time, and feel that we should not be justified in allowing the Institution to close without making a final effort and appeal to tide over the difficulty for the coming two years: and whereas we believe the closing of the University to be such a loss to the higher and secondary education in this state that ten years will not suffice to repair the dame its reputation abroad and

Whereas we believe that by a well directed movement by the friends of education throughout the state a sufficient amount, about thirty three thousand dollars will be contributed: therefore

$\mathrm{Be}$ it resolved that further action on the part of the Board be postponed until such time as public sentiment shall indicate to the Board what course to pursue and that we recommend prompt action in justice to all concerned.

The resolution was reinforced by an energetic buttonholing of potential supporters. The mayor of Grand Forks, W. J. Anderson, called a meeting at the courthouse for April 9 where Budge explained that the University could be kept open if $\$ 33,000$ was raised. This figure, arrived at only after some careful calculations, was predicated on the president and faculty's willingness to accept a 25 per cent reduction in salary. (Bechdolt, the professor of English, and George Rygh, the assistant professor of Scandinavian languages, refused to agree to such an arrangement and left the University. Estes consented to stay only with considerable reluctance; he subsequently offered his resignation in 1897 , to take effect in 1898.) On the motion of the highly respected Judge Guy C. Corliss, first chief justice of the North Dakota supreme court and later the first dean of the law school, the mayor was empowered to appoint a committee to plan a money raising campaign. The men chosen were all Grand Forks business and professional men: Sidney Clarke, F. R. Fulton, R. B. Griffith, S. W. McLaughlin, M. F. Murphy, S. S. Titus, and Orange Wright. Anderson's name was added by general consent. He was then made the committee chairman and Murphy and Titus, secretary and treasurer. Subcommittees in the counties throughout the state were appointed. The terms in which the appeal for aid was made appear in the address to the state distributed by the committee:

Shall the University of North Dakota be closed? This is the question which confronts the people of the state. The closing of the university would be a calamity in many ways. It would advertise to the world that North Dakota is either in is either unwille be believe that the people are botling institution of higher learning. Wly to the support of their university. The and able and that they will rally to the support state is not poor. She has come through the critcal depression of the past few years as only few states have- without either crop failures or business disasters. Her debt limit is extremely low. The necessary money could easily be raised by taxation, but for the low tax rate as fixed by the constitution. She encourages immigration to her fertile fields, but she will certainly neutralize all her efforts in that direction, by proclaiming herself unable or unwilling to maintain her University which she inherited from territorial days. She has ever been foremost in education. Will she now take her place farthest in the rear? The announcement that North Dakota closes her University will mean irreparable injury to our state in business, population, education, and honor .... During the last twelve years this state has expended large sums of money and the best energy of many men and as expenders las intelligent clientage a result has gathered a learned corps of profsors, an momentum such as of students, a university reputation, dors for two years and if they ever is an honor to a great state. Close the doors for two years and if they ever open again you cannot regather in ten years your scattered forces....

Basing the appeal on the University's service to the state, rather than on the economic benefits it might confer on Grand Forks and the surrounding area, was in a way an announcement of a new conception of the University's role, which was further emphasized by concentrating on small contributions ranging from two to a hundred dollars. Subscribers were given a numbered certificate in the form of a promissory note which, it was understood, would probably be repaid in time.

According to all contemporary comment, the man who deserved the most credit for formulating the idea, as well as for the eventual success of the drive, was William Budge. The fact that two of the Trustees were recent appointees and the other two holdover Populist-Democrats without strong financial connections threw the responsibility on Budge almost by default. He was a whirlwind of energy not easy to resist. Not only did he work indefatigably to raise money, more or less assuming the management of University finances, but he frequently went into his own pocket to 
pay University bills-over $\$ 700$ for fuel on a single occasion-and waited indefinitely for repayment.

Spurred on by the inspired leadership of Budge and the news that Merrifield had been offered the presidency of the University of Montana, the finance committee collected $\$ 17,500$ by May 7 . Reassured and touched by the demonstration of confidence in him, Merrifield turned down the Montana offer; when it was repeated in two weeks with the additional promise to employ the entire faculty, he again refused. Members of the faculty met at Kennedy's house one Sunday afternoon to consider their course of action and voted to stick with North Dakota. The final demonstration of loyalty from president and faculty was the turning point in the crisis, and the University's opening in the fall was assured.

For the next two years, nevertheless, the situation was precarious, and funds continued to be raised by subscription or by various benefit enterprises. In the final accounting rendered by the maintenance committee on May 4, 1897, subscriptions and donations totaling $\$ 25,900.27$ were reported; $\$ 23,379$ of this had gone to pay faculty salaries and $\$ 1,470$ to cover expenses of collecting. About two thirds of the maintenance fund came from two sources. The faculty contributed $\$ 8,250$ by giving up 25 per cent of their salaries; Brannon's share, for example, was two $\$ 500$ certificates. Citizens of Grand Forks raised $\$ 9,130$ and the Tri-County Educational Association pledged $\$ 1,000$. Most of the remaining third came from the Red River Valley, although Burleigh County ranked fourth among the counties in the size of contribution. About $\$ 1,300$ was subscribed from outside the state. The total available to the University in the biennium of 1895-1897, including the money raised by subscription, the biennial appropriation, and some small sums contributed by the state for special expenses, came to not quite $\$ 43,000$. Only the salaries were paid in cash; all other expenses were paid by warrants to be honored at some future date.

The uncertainty continued until the end of the decade. The $\$ 50,720$ appropriated by the legislature in 1897 , only the barest minimum and passed over the veto of Governor Frank Briggs, was generally viewed as merely the postponement of the final decision on the University's fate. Briggs's veto of a bill to make up the deficiency in faculty salaries was upheld, and salaries remained in arrears for years. The contributors to the maintenance fund were never repaid.

Yet in this era of serious, seemingly insurmountable difficulties, a number of factors worked in the University's favor. The fact that it was North Dakota's first institution of higher learning, and by far the most advanced, gave it a reservoir of sentiment and tradition not available to the other institutions. In the drive for funds, houseto-house solicitation, benefit performances, and the like, all drew attention to the University, to its high standards, to its practical usefulness, and to its contributions to the state's reputation for intellectual interests. These points were emphasized by a series of academic milestones in the year 1895-1896. The first book published by a resident professor, the only one for many years, Macnie's Elements of Geometry, Plane and Solid, appeared in the summer of 1895 and was in its third edition by November. It was adopted by number of North Dakota high schools. Enrollment for 1895-1896 equaled the high mark of $1888-1889$, but there were twice as many college students and fewer preps than had been included then. The class of fifteen which received B.A. degrees in June, 1896, was the largest until 1903. The propaganda that accompanied the campaign for funds as well as the University's record of solid achievement and the increasing frequency with which Trustees were drawn from outside the Grand Forks area after North Dakota became a state did much to wipe out the "Grand Forks University" idea and to create the first stirrings of pride in the "U," or the state university. It was not until 1893, however, that anyone from as far west as Devils Lake was appointed to the Board; he was Siver Serumgard, a Populist-Democrat. (A territorial law had actually required that a majority of the trustees of any institution must reside in the county in which the institution was located.)

Whatever the critics or rivals of the University might say, no one seriously questioned its position as the capstone of the state educational system, the only institution which really completed it and made it whole. The name "university" was itself a priceless asset with its implied monopoly of those courses traditionally associated with true college education. The Agricultural College, 
its one really formidable rival, was on the other hand limited tacitly by its very name to the specialized programs of a trade school of practical nature somewhat below collegiate level, at least in prestige. Moreover, Merrifield and his predecessors had succeeded in winning a reputation for holding to a high standard. The University may not have been "the equal of the greatest institutions of Europe" nor even "among the first in the country" but the frequent repetition of such claims by its enthusiastic friends was reinforced by the boomer will to believe in a new country. There was no denying that the University insisted on a higher entrance requirement than any of its sister institutions-three years of preparatory work or its equivalent compared to only one at the Agricultural College and none at the normals.

The supposed favors that an agricultural college should enjoy in an agricultural state with a strong Populist-Farmers' Alliance movement did not materialize in actuality. By a stroke of luck, the one Populist elected to the governorship, Eli Shortridge, was friendly to the University, an attitude that was reinforced while he was in office by the sharp quarrel he had in 1893 with the administration and trustees of the Agricultural College. Moreover, despite the doctrinaire sentiments of organized agrarians on agricultural and practical education, the Agricultural College had little grass roots support in the 1890's. Farmers looked upon it as a Fargo enterprise and disliked paying taxes to support it for that reason, while the people of Fargo, contemptuous of the "cow college" set down on the fringe of their town, gave it little support either, far less than had been developed in Grand Forks for the University. Not many farmers of the time saw much reason for sending their sons away to school to learn what they could be taught at home, and even the promoters of the Agricultural College had been less interested in its educational side than in the experiment station.

Nor were the church colleges as serious rivals as they might have been. Depending entirely upon small donations, they had an even more difficult time in the 1890's than the publicly supported colleges. Their one strong argument against the secular collegestheir godlessness-was likely to affect the Agricultural College, with its emphasis on science, more than the University. Whatever effect the charge might have had in the days of Sprague was lost when Merrifield assumed the presidency. Although he was not one to parade religion, Merrifield emphasized moral training and his 1890 faculty was almost wholly a church going one. Woodworth, an ordained clergyman, was as much a college chaplain as any of the church colleges could muster. The full stamp of approval was given by the Synod of the Presbyterian Church in its meeting at Grand Forks in 1896, when a committee appointed to visit the University reported that the moral and religious atmosphere there was "not only safe but highly satisfactory and perfectly reliable" and that the supervision of students was as "personal and perfect as in any large public institution it can possibly be."

Of great importance to the University's future were the close ties that were developed or anticipated in the 1890's between the University and the public school system, between it and the development of the state's mineral resources, especially clays and lignite, and between it and the largest single immigrant group, the Scandinavians. The necessity of developing high schools to feed the University had been pointed out by Governors Ordway and Pierce. Every one of Merrifield's predecessors had encouraged their development and had sought to establish ties between them and the University. In 1890, the year before he left North Dakota, Sprague urged the high schools to adjust their courses so that students could proceed without any break directly into the freshman class at the University. No one understood as well as he that as long as fewer than six hundred students were attending North Dakota high schools, ${ }^{3}$ the University would either have to maintain its own preparatory department or lower its admission standards. Sprague left before he had time to take any action, but his successor was likewise concerned.

One of Merrifield's first official actions, taken in the spring of 1891, was a suggestion to the state superintendent of public instruction to hold a conference of interested public schoolmen to consider the problem of coordinating high school and college and establishing standards along the lines followed in Minnesota. In October ${ }^{3}$ The exact figure was 570 , nearly all of them enrolled in schools offering less than
three years of work. In 1893 North Dakota had only twenty-eight high schools. 
fifteen high school principals met with representatives from the University at Fargo. It was agreed that three years be established as the minimum high school course, and two committees were appointed-one to bring the proposal before the educators of the state and the other to persuade the legislature to subsidize those high schools which complied with the plan; Merrifield was a member of both. In December, the North Dakota Education Association, meeting in Grand Forks, unanimously adopted the plan and endorsed Merrifield for the post of state high school examiner. A classification for state high schools was also agreed upon: those that offered the same work as the preparatory department at the University were ranked as first class, those that offered two years as second class, and one year as third class. Two courses of study were also outlined: a classical course to consist of one term of mathematics, three of algebra, three of plane geometry, two of physics, one of physiology, three of English and rhetoric, one of history of Greece and Rome, one of general history, one of English literature, two of review, and nine of Latin; and an English and scientific course which in place of the nine terms of Latin prescribed two terms of solid and spherical geometry, two of physical geography, an extra term of general history, and one term each of civics, astronomy, botany, and bookkeeping.

Until the legislature could act, which was not until 1893, the plan would have to function without funds and on a purely voluntary basis. Merrifield went ahead; in February he announced that he would send out examination questions to any high schools that wanted them and that students who passed the examinations would be admitted to the freshman class at the University. Seventeen schools participated the first year and by the end of the following year nearly every high school in the state had fallen into line. Making up and grading the steadily increasing numbers of examination papers, for which the already underpaid and overworked faculty received no additional pay, became a real burden within a few years. In 1893 a bill to legalize the plan and to appropriate an $\$ 800$ subsidy for each participating high school passed the legislature with no difficulty, but it was vetoed by Governor Shortridge on the ground that the state could not afford the measure at that time. Two years later the nearly bankrupt state government was even less able to consider any state aid measure, but the legislature did enact a law to establish a state high school board composed of the governor, the state superintendent of public instruction, and the president of the University. Since the latter was the only really active member of the new board, the act in effect gave control of the curriculum and classification of the secondary school system to the University. It was not until 1899 that the legislature made its first appropriation, the sum of $\$ 8,000$ to provide small subsidies for classified high schools and to defray the expenses, which had been borne for years by the University or Merrifield himself, of inspecting the high schools and examining their graduates. Meanwhile in 1898 the University admitted five high school graduates to the freshman class, the first since the unsuccessful experiment of 1891. When Merrifield retired in 1909, 166 high schools were applying for examinations.

The University influence on the secondary school system went considerably beyond examination and inspection. Merrifield had brought about the formation of a State High School Council (later renamed Conference) which in its annual meetings at the University worked out procedures and curricula for the high schools. Members of the faculty regularly attended the annual meetings of the North Dakota Education Association; at the Fargo meeting in 1896 five University professors, including the president, appeared on the program. Meanwhile, to avoid the appearance of competing with the high schools, the University advised high school students not to enroll in the preparatory department if a local school was within their reach. A number continued to come, nevertheless, because the prep was unquestionably the best high school in North Dakota, and it carried some of the prestige of a private boarding school. The fact that the University was the only source of high school teachers in North Dakota-the normals trained only elementary and rural teachers-gave it connections in every corner of the state. The job of inspection itself, an increasingly important portion of Merrifield's work almost to the end of his administration, gave him opportunities to publicize his institution and to demonstrate its practical usefulness. 
Nor were the University public school activities limited to the high school field. A major consideration in the appointment of Kennedy in 1892 was his high standing in general public school circles; there was a good prospect at the time that he might become president of the Valley City normal. Kennedy soon proved his worth to the University. He revived the enrollment of the normal department in the face of stiff competition from normal schools and raised its standards as well. It was largely his doing that in 1895, when University fortunes could hardly have been worse, the buildings were opened without charge to the annual Tri-County Educational Association summer institute. A hundred students enrolled for a month of refresher courses in elementary and high school subjects taught by Merrifield, Estes, Kennedy, Brannon, and W. L. Stockwell, superintendent of the Grafton schools. The charges were reasonable in the extreme: $\$ 1.00$ for room for the term, $\$ 2.75$ a week for board, and $\$ 1.50$ tuition for each course. The faculty, already down to three fourths of their pay in the regular term, worked for nominal pay or none at all. The summer school was a success from the start, for it not only provided a chance for teachers to raise their certification but also was an annual time of fellowship and organized recreation. A state law of 1897 permitting the pooling of the funds appropriated for the county institutes gave official sanction to the summer school at the University and insured its permanence.

There is no measuring the benefits for the public schools in the work of Merrifield and Kennedy. Merrifield was memorialized when he retired as "father of the state high school system," and Kennedy's contribution was scarcely less noteworthy. A major beneficiary was the University itself. By the end of the 1890's no other educational institution in the state was so thoroughly and directly tied to the public school system.

Another opportunity for the University to strengthen its position in the state came in relation to the dormant School of Mines that had been placed at the University by the constitutional convention. Here the University made its appeal "to those who [were] constantly seeking the utilitarian in this institution." In every official report in the 1890's, Merrifield, the Trustees, and Babcock pointed out the practical advantages to be derived from appropriations for the mining school and for geological research. The collapse of agricultural prices in 1893 provided an argument for economic diversification and an impetus toward utilitarian technology and engineering at the expense of the pure and theoretical approach to science. Babcock's two pioneering pamphlets (1891 and 1892) on coals and clays in North Dakota were repeatedly cited in appeals to the legislature. In their reports of 1894 and 1896 the Trustees devoted as much space to mining and geology as to all of the other sciences combined. With times as hard as they were it was impossible to get any additional appropriations, certainly no such sums as the $\$ 10,000$ that was requested for launching a mining school in 1895 , the year of disaster. But there was even some progress that year, for the office of state geologist was created and Babcock appointed to it. It was encouragement enough for him, although he lacked formal training in geology and his new office carried neither additional salary nor funds with which to operate. $\mathrm{He}$ expanded his popular testing service in the chemical laboratory and carried on some rough fuel investigations with the University heating plant. In the summer of 1896 he began a geological survey of the northern part of the state. A year later the Trustees formally opened the School of Mines and appointed Babcock director. This, too, was accompanied by no appropriation, or even by any new courses, being mostly, as Babcock wryly observed, a "splendid opportunity for the incumbent to donate time and money." It was an important step, nevertheless, for good times and appropriations were not far in the future, and with them the development of the investigations which were to be the University's most conspicuous public service-the one that promised most for the future of North Dakota.

The opportunity to ingratiate itself with the largest single ethnic group in the state, the Scandinavians, was unwanted and actually thrust upon the University in 1891 when a state law was enacted requiring the teaching of Scandinavian languages at the University and the immediate appointment of a professor. Its purpose was to satisfy an old demand of the large Norwegian minority for representation in the University. As early as 1884 the Fargo 
Scandinavians had memorialized the Board of Regents to appoint one of their "race" to the faculty. Although there had been a few Norwegians and Icelanders among the first students to arrive at the University when it opened, their representation had not nearly approximated their proportion of the state population. In 1891, for example, a tabulation of the 129 preparatory and normal students showed only ten born in Norway. The distribution of church membership was even more revealing; although the various Lutheran denominations outnumbered every other church group in North Dakota, only ten of the 129 were Lutheran; 37 were Presbyterian, 27 Methodist, 12 Baptist, 11 Episcopalian, 11 Catholic, and eight Congregational.

Neither the faculty nor the Trustees appeared to recognize an opportunity in the law of 1891 . University opinion, as expressed in the faculty controlled Student, was that there were a number of things that were more necessary at the moment than the Scandinavian chair. So reluctantly that there was even some talk of legal action to enforce compliance, the Board appointed a local Lutheran clergyman, George T. Rygh, as assistant professor of Scandinavian languages and instructor in English. Rygh spent most of his time teaching English, Greek, and United States history. In 1893, for example, he taught only one course in Norwegian each term; his largest class had eight students and his smallest only one. $\mathrm{He}$ resigned to return to the ministry in the financial crisis of 1895 , and no successor was appointed for three years. In 1898 the law was observed by the assignment of some classes in Scandinavian to C. J. Rollefson, Estes' successor as professor of physics. It was not until after 1900 that the chair of Scandinavian languages came into its own, less a scholarly post than an important instrument of contact with the large Norwegian population.

It was time more than anything else that was on the side of the University in the crisis years of the 1890's. The largest factor of all perhaps in the survival of the University was the economic upturn that started in the summer and fall of 1896. At the same time a cycle of good crop years began in North Dakota. The University also benefited from the general rise in high school attendance. Signs of improvement were already appearing while the economic crisis was at its worst. The enrollment of 223 in 18971898 was a record. More significant than the total figure was the fact that the number of college grade students nearly tripledfrom 30 to 83 -between 1892 and 1898. At the same time the preparatory department declined; from a few over a hundred in 1891 1892 it had leveled off to about sixty or seventy by 1898 .

The change in the composition of the student body made heavy demands on a physical plant that expanded very little in the 1890 's. The increasing number of students from outside Grand Forks created a pressure on housing that was only partly relieved by the construction in 1893 of the Cottage and by such makeshifts as fitting up the attic in Main for sleeping quarters for boys. The attics in the two dormitories were used for gymnasiums, and the Cottage attic served as the armory for the military department.

But makeshifts could not provide the funds to purchase laboratory equipment, maps and charts for classrooms, and books for the library. Total appropriations for the sciences, including $\$ 1,000$ for the museum, were only $\$ 9,000$ from March, 1891, to January, 1899. In the same period the library received only $\$ 3,000$, all in the 1891 appropriation. The library collection, five thousand by 1893, increased by only five hundred books in the next six years. The biology laboratory, which possessed fourteen compound microscopes, four aquaria, and one terrarium by 1893 , expanded by a total of two microscopes. The department of physics, which required expensive equipment, reported almost no acquisitions; apparatus described in 1893 as suitable "for taking the complete elementary course required for admission to Harvard University" was still the basic equipment in 1898. Although the 1893 catalog described the electrical apparatus as adequate for some advanced work, the cata$\log$ of five years later stated that the equipment on hand was suitable only for elementary courses. The effects of the depression appeared in a comment in the 1898-1899 catalog that "much excellent apparatus had been constructed in the laboratory itself by the various assistants." In chemistry the ingenious Babcock might make do with a carload of lignite and the University heating plant for his own research, but supplies were necessary for teaching. Although since 1894 he had been permitted to charge students for 
the chemicals they used, he reported in 1897 that his stocks were nearly exhausted. As for the work in geology, it was hardly even begun except for the designation of Babcock as state geologist. The one major improvement in the science laboratories was a gas plant installed in 1897.

The departments of biology and geology were the chief beneficiaries of the University museum as well as the chief institutional contributors to it. This department was revived after Brannon became curator in 1894. The most valuable acquisitions, from the standpoint of instruction, were a collection of minerals acquired from the exhibits at the Columbian Exposition of 1893 in Chicago; shells, skeletons, some marine animals, corals, and the like from the National Museum at Washington; and the North Dakota collection of plants begun by Brannon himself the first summer after his arrival. Other contributions of a miscellaneous nature arrived from time to time-eggs and nests of North Dakota birds, weapons, Indian and foreign wearing apparel, and so on. Nevertheless, the museum, although still a matter of pride, declined somewhat in relative importance as a separate department, largely because the science departments depended not so much on the miscellaneous collection of curios as upon materials which were more directly related to teaching.

Science was also seriously handicapped by a shortage of personnel. Although the University faculty was augmented considerably in the first years of Merrifield's administration (seventeen professors and instructors were listed in 1893, and at the low point of 1895 there were eleven), there were no additions, save for a few student assistants, in the sciences. Two key men, Patten and Estes, were lost. In neither case was the replacement as well trained as the man who had gone. After Patten left in September, 1893, it was not until the following April that his successor, M. A. Brannon, arrived at the University. Estes' successor, C. J. Rollefson, had had excellent graduate training at the University of Minnesota and Cornell, but he had not completed his work for the Ph.D. when he came to North Dakota. Moreover, he was expected to teach some classes in the Scandinavian languages in addition to his regular duties as professor of mathematics, astronomy, and physics.
(It was undoubtedly a desire to get into an easier kind of work which caused him to leave in 1903 to attend medical school.)

The shortage of funds, the example of the Agricultural College, and the attitudes of a new country all forced the sciences in the direction of practical technology, in orientation at least if not in actual fact. Reports of the faculty and Trustees struck this note repeatedly as the University faced the threat of closing. Other important factors in the shift were the fact that Brannon and Babcock became the spokesmen for the sciences, and the attitude of the president himself. A practical minded man, Merrifield responded sympathetically to the opportunities for practical services that a university could offer the state through its science departments. Trained in the classics himself and believing as he did in character training as the chief function of college education, he tended to regard the nonscientific fields as the chief means to this end, that is, as the real essence of higher education. The distribution of the faculty, both in numbers and general quality of training, favored the traditional subjects of the curriculum. To be sure, well-trained men in these fields were more plentiful than in the newer disciplines. In the 1897-1898 catalog, of the thirteen professors and instructors listed, only three men plus some student assistants taught all of the sciences, but two men, a professor and instructor, taught Latin and Greek; three more had been trained chiefly in the classical tradition although they were teaching other subjects-Macnie in modern languages, Merrifield in political science and economics, and Woodworth in history.

Yet Merrifield, despite his predilections, was aware of the trend toward the elevation of the sciences to full college status and cognizant of the necessity to keep pace with the times-cautiously, to be sure. When in a major curriculum revision in 1894, the bachelor of science degree was dropped, ${ }^{4}$ his explanation was that this was in line with the policy of Harvard, Johns Hopkins, and other progressive institutions and was no more than "a simple recognition of the fact that prolonged courses in Latin and Greek and Mathematics are no longer considered the sole conditions precedent to a liberal education." Under the new plan the B.A. degree was offered "It did not appear again until 1913. 
for a classical course, concentrating on Latin and Greek; a Latinscience course, in which modern languages and literature took the place of Greek; and the science course requiring neither Latin nor Greek, but four years of work in French and German and a concentration in science. An elective system was also announced. Although in his annual reports Merrifield spoke of this step as generally conforming to the trends elsewhere, it was really not much more than an extremely cautious step toward freedom of choice. The first catalog statement on the subject is revealing: "The required courses of instruction are such as are deemed essential for a liberal education, while the electives permit as much specialization as is thought wise for undergraduates."

The first program leading to a graduate degree-the master of arts-was also inaugurated in 1894. It was a year's program of one advanced course in a major subject, two minor courses in regular subjects not previously taken, a thesis, and a final general examination. Five students enrolled the first year, but only one, Harrison Bronson of Grand Forks (B.A., 1894), completed the requirements for a master of arts degree-the first ever granted by the University. Again the orientation of the University is revealed in the fact that Bronson's advanced course was Latin, one of his minor courses Greek, and his thesis was a study of Greek life as shown in the plays of Terence. George Thomas, professor of Latin and Greek, was his adviser. It will be recalled that when in the Sprague days the first postgraduates had stayed on it had been to study biology in the laboratory with Patten. The postgraduate program begun in 1894 was to remain more a declaration of intent than a reality. Following the first year's burst of enthusiasm, the number of graduate students fell to only one in each of the next two years, and no more M.A. degrees were awarded until 1900, when there were two.

A more solid improvement came in the normal department. In 1892 the course was enlarged to include two years of college work; by $1895-1896$ it was designated as the Normal College. In addition to the considerable expansion of course work, organized practice teaching was carried on in the elementary classes in the preparatory and normal departments at the University.
A good part of the general improvement in the University curriculum was a matter of reorganization and sharp definition of old courses, the use of more descriptive titles, and improved scheduling. In 1894 a full course was defined as the pursuit of a subject four times a week for a full year. Students were limited to a maximum (with exceptions) of sixteen hours in class per week; the minimum passing standard, once 40 per cent, was raised to 65 . There was in addition a considerable expansion in the number of courses offered, no small achievement considering the limitations of the faculty and the meager resources available. It was possible because everyone was primarily a teacher, and everyone on hand was pressed into service. The resident military instructor, who had full faculty status after 1891, was expected to teach whatever academic courses were assigned unless they interfered with his primary duty. Charles Farnsworth, a popular officer at the University from 1893 to 1897 (he would retire as a major general) won high praise as a teacher of mathematics. The department of Greek and Latin, the strongest in the University after the arrival of Perrott in 1891 and Thomas in 1893, offered new courses in Roman philosophy and the life and manners of the Romans. Brannon generally reorganized the biology program, introducing such courses as higher cryptograms, phaenogamic botany, vegetable physiology, and theoretical zoology. The announced aim of this new program was to meet more definitely the needs of students preparing for teaching, medicine, and continued study of "economical biology." The arrival of Squires in 1897 marked the beginning of a thorough reorganization and expansion of the offering in English language and literature, with such new courses as history of the English language, history of the English novel, studies in structure and style, Old English, and dramatic and lyric pottry. Merrifield himself, retooled from Greek and Latin, produced some of the most significant innovations in his domain of political and social science: money and banking, applications of political economy. public finance, anthropology, sociology, and even a course in socialism.

The major additions on the fringe of the regular curriculum were physical culture for women and a conservatory of music. George Hodge, Kennedy's immediate predecessor as principal of 
the normal department, never cared much for teacher training work, and when in the summer of 1891 Merrifield offered to make him the head of a self-supporting conservatory with its headquarters in rented space in Grand Forks, he leaped at the chance. It was Merrifield's expectation that if it proved successful it would eventually be developed into a music school in the University. According to the reports for the year 1891-1892 the venture was exceedingly popular and a financial success as well. One hundred ninety students enrolled in the three departments of piano and organ, voice culture, and orchestral instruments, and at the end of the first year the conservatory was confidently expected to continue. Hodge, however, resigned to take a position with the YMCA, and his departure plus the financial difficulties that were beginning to close in put an end to the conservatory. Throughout the rest of the decade the study of music, except on a more or less informal basis, was neglected at the University.

A one-year commercial course, not actually a part of any department on any level, also appeared for a year, 1893-1894. It, too, disappeared with the collapse of the economy and the departure of the instructor.

The department of women's physical education had more success, largely because the teacher, none other than Cora Smith, now a physician in Grand Forks, undertook the work for only a nominal salary. The course, required of all women students after 1893, was patterned on the Sargent system in use at Harvard and included the "best features of the Swedish, German, and French or Delsarte systems." These included drills, calisthenics and marching accompanied by piano music, breathing exercises, "Swedish movements," "aesthetic movements," and exercises with wands, dumbbells, and Indian clubs. The prescribed uniform, described as "simple, artistic, and inexpensive," had a "full divided skirt, pleated to the waist-band, and gathered above the knee into Turkish trousers." This garment was buttoned to the blouse at the waist and worn with a sash, black hose, and gymnasium shoes. "No corset or other stiff garment" was allowed. The first statement on women's physical education, which appeared in the catalog of 1893, concluded with the observation that "in order to be ready for drill with little trouble, the young women usually wear their gymnasium suits all day, with an ordinary dress skirt added."

Significant also as a sign of the arrival of a genuinely collegiate status was the development in the 1890's of various organized activities, together with the first signs of conventionalized student behavior. The two literary societies, Adelphi for the college students and Per Gradus for the normals and preps, took a new lease on life with the appearance of intercollegiate debate. Forensic activities in general were fostered by the "rhetoricals," begun in Sprague's day and continued by his successor until 1905. One declamation or one original essay or oration, to be delivered at the daily chapel exercise, was required each term of all freshmen, sophomores, and junior normals. One original oration was required of all juniors, seniors, and senior normals. In the spring of 1893, after having rejected several earlier overtures for a debate contest, the faculty finally consented to appoint a student committee ${ }^{5}$ to make the necessary arrangements with representatives of the University of South Dakota for a contest on March 7 at Vermillion. The subject was a timely one for those depression times: "Resolved, that the nationalization of all railroad property is both defensible and desirable." George Brennan, Bardi Skulason, and S. J. Radcliffe, the University's first debate team, came home the winners. In May, 1894, the two universities began negotiations for an interstate oratorical league, which was formed in 1896 as the Western League of Oratory among the colleges of North and South Dakota. Following a local elimination contest at the Methodist church in January, 1897, the University, the Agricultural College, and the Red River Valley University competed for the state title and for places on the team to debate with South Dakota. Both were won by the University, which went on to defeat South Dakota in May. Although the University managed to win most of the contests within the state, it did not beat South Dakota again for a decade. From these beginnings forensics became a conspicuous feature of University life. An opportunity for those who sought prominence and notoriety, the debates were a major rallying point for group enthusiasm and a duty-for the glory of society and University${ }^{5}$ Henry Vick, Bardi Skulason, George Brennan, Fred Bechdolt, and Henrietta Paulson. 
which the student with ability found difficult to evade, even when he preferred the quieter satisfactions of diligent study.

On a less serious and formal basis were the student entertainments of one sort or another that appeared in the 1890's. The first of which there is any record was given at the Metropolitan Theates in December, 1895, to raise funds to keep the University open. Directed by Dr. Cora Smith-Eaton, it featured a freak show, shadow pantomimes, selections by the Mandolin and Guitar Club, and a farce entitled "Throw Him Out." In the spring of 1897 the military and physical education department staged a miscellaneous program of bugle calls, band music, sabre drills, bayonet exercises, club swinging, and tumbling. It proved highly popular. The next year it was performed at the Metropolitan Theater, and in 1899 it went on the road-to Grafton and Larimore. This "brilliant and daring achievement" was hailed as the "best advertisement the U has ever had in all its history ...." The minstrel show, that easy outlet for the amateur ham, was also popular on the campus; for example, the "White Coons" was presented in February, 1897.

Meantime, there were sporadic attempts to create the usual collegiate musical organiaztions, but because of the almost total absence of musical instruction or leadership following the demise of Hodge's conservatory, they were all short-lived. A military cornet band, a choral club, a mandolin and guitar club, and a glee club or two had their brief moments. The only musical organization that achieved any permanence in the decade was the Cadet Band, first organized in the spring of 1893 . The fourteen members were equipped with whatever instruments they owned or could purchase with $\$ 275$ raised by subscription, mostly from the faculty. The Trustees allowed $\$ 25$ for instruction. This organization had its ups and downs and periodic reorganizations and renamings, but by the end of the 1890's it was a fixture on the campus. More or less associated with the military department, it became more closely related to athletics as football rose in popularity and the military department disappeared with the loss of the full-time professional instructors in the Spanish war crisis of 1898

The chief contributor to the collegiate atmosphere was football. Sprague and Merrifield, both alumni of Yale, the athletic colossus of the time, actively encouraged college sports, but nothing concrete developed until some of the faculty took an interest. In the fall of 1892 a "first" team was formed under the guidance of Professor Bechdolt, although no match games, except with other campus teams, were played. Captained by John S. Macnie ('93), it included also Goldwin Sprague and William Patten, the young professor of biology, who had played at Harvard. Some other members of the team were Bardi Skulason, S. J. Radcliffe, Colby Rucker, and Rolla Currie. With the arrival of Lieutenant Charles Farnsworth as military instructor in 1893 the team acquired a coach with experience as well as enthusiasm and time. He had played baseball and football at West Point. Some local interest had developed in the game around Grand Forks by 1893, and at the end of the season the athletic department received perhaps the first recorded criticism from downtown quarterbacks when it missed an opportunity to schedule a game with Hamline University. In the spring of 1894 the Olympic Athletic Association, moribund since the departure of Sprague, was reorganized by Farnsworth as the University Athletic Association, and the following autumn the football team, captained by Fred Bechdolt, son of the English professor, played its first games against off-campus teams, twice with the Agricultural College and twice with teams from Grand Forks. The first intercollegiate athletic contest in the University's history was the game against the Agricultural College on November 3, 1894, played on the YMCA field in Grand Forks. The University lost 12-4, and on November 12 lost again, 24-4, to the Agricultural College at Fargo. At both games the spectators barely outnumbered the players. In the first game both teams, being short of players, used a professor-Farnsworth played with the team he had coached. In the second game only the Agricultural College used a faculty member and thereby gave some cause for the University to charge unfair tactics. Although the University soon joined the state athletic association formed by members of the Agricultural College faculty, bad feeling was a semipermanent feature of the athletic relationships of the two North Dakota colleges in the 1890's. The lack of any firm rules of competition was of course a major cause, for even without the irritations produced by faculty or semiprofessional 
"ringers," the manner of play itself was bound to cause trouble. Poorly refereed and played by inexperienced but grimly determined young men whose only tactic was the line buck, those early games were bruising affairs, scarcely more than officially sanctioned gang fights.

Each college won one game in the 1895 series. The next year a light but fast University team, led by William Nuessle, later chief justice of the North Dakota state supreme court, overwhelmed the Agricultural College 58-12 in the one game that was played. The first college from outside the state to play on the University field was Carleton, which came and won 20-7 in 1897. The next year the team played its first game outside North Dakota, against the University of Minnesota. Viewed as a minor contest in Minneapolis, it attracted only a handful of spectators. But it was a milestone for North Dakota, and the low score, 15-0, was hailed as a moral victory-Minnesota had an enrollment of over three thousand. Having stopped over at Fargo and beaten their "foxy rural rivals" 39-5 on the return trip, the team had a triumphal arrival in Grand Forks. The heroes-among them Nuessle, Joe Flanagan, the University's greatest all-round athlete, and Lynn Frazier, the first graduate to be elected governor-were feted that same evening by faculty and students in the Davis Hall dining room.

Enthusiasm for baseball, which had been the first team sport to develop, declined somewhat with the rise of football. Games continued to be scheduled each spring, however, with teams from Grand Forks and surrounding towns. Basketball, invented in 1892 was introduced as a game for girls. After it became the yearly custom to flood a skating rink on the campus every winter (on the present site of Budge Hall), there was some talk of forming a hockey team, but nothing came of it. Aside from football, the only intercollegiate athletic competition in which the University engaged in the 1890's was the annual state track and field meet. The first one was held on a main thoroughfare in downtown Fargo in June, 1896. Eighteen hundred spectators turned out to watch the thirtyfour participants-fourteen from the Agricultural College, six from the Red River Valley University at Wahpeton, seven from Fargo College, and six from the University. Of fourteen events, the Uni- versity entered eleven and won first in ten. Patrick D. Norton, who was the first alumnus to be elected to Congress, won first place in the pole vault.

The usual accompaniments to the rising interest in athletics soon made their appearance. There was the first athletic hero, Joe Flanagan, who in 1895 began an unforgettable career of six seasons in football, baseball, and track. There was the first noncollege fan, E. H. Thursby, who gave the football team an engraving to commemorate its victory over the Agricultural College in 1897. In the spring of 1892, the same year that football play was organized, a student committee, composed of Goldwin Sprague, George Brennan, H. G. Vick, John S. Macnie, and Mattie Glass, was appointed to compose a suitable college yell. The result, derived from the Greek and the Sioux, reflected the character and the milieu of the University of North Dakota, the embryo Yale of the prairies:

$$
\begin{aligned}
& \text { Odz-Dzo-Dzi! } \\
& \text { Ri-Ri-Ri! } \\
& \text { Hi-yah! Hi-yah! } \\
& \text { North Dakota } \\
& \text { (Sioux war cry) }
\end{aligned}
$$

Although the first line was a free adaptation of a Greek verb meaning "to cry out," the yell was not satisfactory to a purist like Macnie. Merrifield was agreeable, however, and the student body unanimously adopted it.

A growing sense of pride in the University was marked by the development of commencement ceremonies. One of Merrifield's first acts after he succeeded Sprague was to emphasize its importance by shifting from a semiprivate performance in the University chapel to a public ceremonial at the downtown Metropolitan Theater. For two years the usual student orations were dropped for a formal address by an invited speaker. Cyrus Northrop, president of the University of Minnesota, gave the address of 1897. Speaking on "The Education Which Our Country Needs," he warned that overemphasis on technical training would sacrifice the genuine education of culture and broad information for a four-year apprenticeship. The faculty returned to the student-centered program in 1898, a 
form that was not changed again in Merrifield's time. Other ceremonies and observances connected with commencement elsewhere made their appearance: a baccalaureate sermon, usually delivered by Professor Woodworth ("Old Woody" to the students) in the college chapel or a local church, the junior-senior banquet, and class night with its serio-comic program of music, class play, class poem, prophecy, and the like. Commencement week was also the occasion for the annual meeting of the alumni association, formed by the first class of graduates in 1889. Clinton S. DeGroat was the first president. Although the only active function of the association was to plan the reunion-and dinner of commencement week, the fact that it was a highly select little band stimulated pride in the University, and each annual meeting helped to fix the body of recollections and memories that go to form a tradition.

The North Dakota tradition grew out of close association and a benevolent paternalism, colored by an element of bachelor prudishness in Merrifield and an old-fashioned class consciousness in himself and his faculty. Not easily impressed by newly acquired wealth unaccompanied by gentility or culture, they often used such terms as "best people" and "the better element." Although Sprague's semimilitary regimen was abolished immediately on his departure, it was replaced by another that was hardly less restrictive. It is rather difficult to distinguish exactly between Sprague's conception of education as preparation for citizenship and Merrifield's as the building of character and training in morality. The differences exist more in the approach than in the final aim. With time, the growth of the University, and the broadening view of Merrifield himself, the ideal tended to be blurred; it was most marked in the 1890's when faculty, student body, and resources remained small.

Merrifield's own relation to his faculty and especially to the students exemplifies his approach. To the latter, the president and faculty, and the institution itself, stood in loco parentis. Merrifield took over the guidance of the boys as his special province, as Macnie had that of the girls-or at least shared it with the preceptress. The most conspicuous part of the small body of Merrifield correspondence that is preserved is that relating to the boys. On first arriving, very possibly astride a trunk on a dray from town, the new student might find the president personally supervising his getting settled. Upperclassmen forwarded their baggage to him ahead of their own arrival in the full confidence that he would look after it. His bank account was the student loan fund-he wrote once that he constantly had several thousand dollars lent out to students and old grads, all without interest. And for years after they left the University, "his boys" wrote regularly to report on their state of progress, to borrow money, or to get his letter of recommendation. Even occasional expellees, the most conspicuous being Vilhjalmur Stefansson, remained on his list of correspondents and called at his office or rooms when they returned to the campus. He watched the boys' morals, their manners, and their associates and was quick to warn student and parent when he detected or suspected questionable conduct or to advise on the proper means of rearing children.

Once he and Macnie moved out to the president's suite the active encouragement of boy-girl friendships more or less ceased a hand-holding walk down Broadway or on the Great Northern tracks, the favorite promenade, was likely to bring upon the guilty ones a sharp scolding from the president himself. Edna Twamley, daughter of James Twamley, has related that he once called her father to report that one of her associates was not well-supervised by her family and had a reputation as a "dancer." The Merrifield correspondence contains numerous letters to parents, reporting what would seem minor offenses nowadays and deploring the waste of time and health they entailed. One student's pledge is preserved: "1 hereby pledge President Merrifield that I will not taste intoxicating liquor in any form so long as I am a student at the university." This is to say nothing of the hours that he and the rest of the faculty put in maintaining discipline in the dormitories and in the chapel where preparatory students were required to sit when not in class. Record was kept on an elaborate and detailed demerit system. Much of the time of the weekly faculty meetings was taken up with such matters as weighing the demerit value of offenses and deciding the status of students on the basis of deportment. Three demerits were the penalty for an unexcused absence, two for tardiness, twenty for insubordination in the military de- 
partment, and three for failure to present an oratorical exercise. For a time, any student who accumulated thirty-five demerits was obliged to leave the dormitories.

Yet one cannot read contemporary comment in the Student, local newspapers, and reminiscences without catching a sense of joie de vivre, buoyant hope, and youthful resiliency and optimism. These qualities seem more apparent in the rather heavy literary efforts of the Student of the 1890's than in the light-minded student publications of more recent times. Having few privileges, the 1890 students valued and used to the fullest those that they got. It was a red-letter day when the one night per term off-campus privilege begun in Merrifield's time was increased to two nights each termthat is, six per school year. These were usually used for attending approved performances at the Metropolitan Theater or to hear some visiting lecturer. Attainment of junior status in the college was a milestone when it meant that lights could be kept on until eleven instead of the ten fifteen hour required of underclassmen. Savored to the fullest was the daily recreation period in the late afternoon, which was also the only weekday time when boys could call on the girls in the dormitory - that is, if they first got permission from the preceptress. Mealtimes in the Davis Hall dining room also provided opportunities for camaraderie and courtship. The Saturday evening receptions, begun by Sprague, were social hours devoted to college songs and to lively visiting among couples and groups. Tableaux were a favorite entertainment; another was a conversation game in which each boy was required to engage a random partner from among the girls in conversation on some assigned topic chosen from science, the arts, or the like.

The receptions, Professor Macnie's annual "treats" for the girls, the walk to church on Sunday with Macnie and Squires, the religious services on campus in midwinter, an occasion given more to lusty singing than to devotion, and the Sunday night Bible lesson constituted practically the entire social life of the University in the 1890's. To be sure, the general tranquility was broken at times. The sharp rivalry between the college men in Main and the prep boys in the Cottage not infrequently erupted into a fight or impromptu hazing, often precipitated when someone over- stayed his assigned time in one of the two bathtubs in the basement. There was at least one minor scandal, the discovery in 1892 that a number of couples were meeting at night and slipping away to Grand Forks to attend the theater or parties. "Too shocking" for the faculty to deal with, the matter was turned over to the Trustees for action; a few suspensions resulted.

The salvation of the system was "Prexy's" own capacity for growth and his kindliness and nobility of character, the genial good sense of the men he had gathered around him, the complete support that the University policies had among students' parents, and especially the students' own strong sense of serious purpose. The people who came to Dakota had been fired by an extra charge of ambition, and attendance at the University was a manifestation of the same will to succeed. An anonymous writer (probably Squires) recorded in 1898 that the students were

undaunted, intrepid ... and ambitious, [that the] hardy, independent, bold life of a western state has stamped itself indelibly [upon the University] .... the one thing that is done here is to study; here everyone studies; here everyone talks of study; here the days and hours are laid of in regard to study . . . . there is something delightful in the way in which the students form a little world by themselves, in the way in which they have learned to rely on their own resources to round out their lives within the college confines.... The life here in some respects may be within the college confines. it is certainly pleasant and delightful ... Who can say that the years spent here with Western skies, amid vast pho can say that environment to prairies, encircled by wheat fields, may not be the vilton, a Chaucer, arouse and develop the genius of a Shakespeare, a Milon, a Chaucer, scott? [What the Lake Couius of a Shy to Wordsweth] the un ... may be to ... may be to some youth of the state university.

The still undeveloped campus did not appear ugly to the student from the lonely Dakota farm, and the virtues of the single bathroom for boys in the prep dormitory basement, with its neighboring noisome toilet, outweighed its failings in the eyes of one used to no plumbing at all. The same may be said for the modern steam laundry privileges available to the occupants of Davis Hall or the single telephone in the president's office, where only the most intrepid student had access to it. One entering freshman recorded "My First Impressions of the University": "I shall never 
forget how bright and cheery the lights gleamed through the windows as we drove up to the buildings; nor how long the halls seemed when we entered; nor how strange and lost I felt when shown into the large parlor to wait for the preceptress." This student met the president that same evening and was also introduced to "the inmates" of the dormitory. Impressed by the "air of refinement and the kindly spirit," she noted also the smooth and orderly business-like atmosphere. "I had often read stories of college life, but this seemed different in many ways from what I had expected. There was not that coldness and reserve on the part of the students, the rigid rules, the terror of instructors. It was not a cold, bare place, but warm, home-like, full of great possibilities."

Neither the opportunities nor the beauties of the University were apparent to the more sophisticated observer at first glance. When Brannon arrived "in the gloaming of an April evening" at the University railroad station, a "shack-like and box-like cube" painted red and completely unfurnished, he was met by a small and unimpressive man with dark hair and beard who introduced himself simply as "Merrifield." A hundred yards or so down a foot-wide plank walk was an "indistinct object," the residence hall for girls, "illuminated (?)" by a "few, huge, kerosene oil burning lamps." Here the new arrival was received and fed by Mrs. Hannah Davis and Mrs. Babcock. He spent the night in a "small, two-story brick building containing possibly twenty small plain rooms for men students." The following morning the rest of the physical plant was visible: the main building which contained the whole teaching and administrative part of the University, the barn for the janitor's horse and cow, and the huge woodpile.

Three years later, Vernon P. Squires, fresh from the graduate school of the University of Chicago, was similarly unimpressed. Arriving by foot along the railroad track, the usual pedestrian approach from Grand Forks, he was first struck by "the loneliness and barrenness" of the "three plain buildings" in a "twenty-acre lot in the midst of a great wheat field." A few tiny trees, the janitor's cow grazing on the campus, and the huge woodpile "extending north from the big red building half way across to the road on the north" only emphasized the rusticity of the scene. With a "feeling of disappointment" he inquired for the president, only to learn that he had not yet returned from Europe. Squires never forgot his first night at the University. Assigned temporarily by Macnie to a small bare bedroom off one of the classrooms, he discovered to his consternation that it was infested with bedbugs. He spent this night in a rocking chair with his feet propped on the window sill: "I had a variety of thoughts ... [and] really wondered how long I could endure life in such a place." Things were better when he got a room at Brannon's house the next day, and his students turned out to be a refreshing experience: "rather unsophisticated, but whose ability and character steadily grew on me ...."

In spite of these depressing first impressions, both men came under the spell of the university in the wheat field. Brannon stayed twenty years and left only to assume the presidency of the University of Idaho. Squires, who succeeded Brannon as the dean of the College of Liberal Arts in 1914, remained until his death in 1930 Indeed, he left once to accept a position in Kalamazoo College but returned at the end of a year.

In addition to the opportunities and the vistas of a larger world that the University offered to the students, there were also the social and cultural attractions afforded by residence in the second largest town in North Dakota. At the Metropolitan Theater, although its repertory was mostly the farcical and second-rate, there appeared many of the leading actors of the time and most of the great plays. In 1894, on one of their nights out, the students went to see a performance of Richard III. Eugene Debs lectured from the stage of the Met in 1895 and favorably impressed his hearers; John L. Sullivan appeared there in a play in 1896 and sparred a few rounds between acts; in 1897 Dwight Moody drew the largest crowd in the theater's history with one of his famous revival-sermon performances. In the spring of 1898 the University faculty took the first steps to enlarge such opportunities by inviting any lecturers or artists who happened to be in the vicinity to appear in the chapel. Within a few weeks the students heard a concert by a professional pianist of some repute and lectures by a traveling humorist and a University of Chicago Shakespearean scholar. 
It is something of a paradox that the difficult 1890's, when the Midwest and Great Plains appeared in imminent danger of being torn asunder by the resentments and frustrations which resulted in the Populist Revolt, were an era of good feeling in the University's history. The decade was a time of considerable progress, too, particularly in the University's enlarged relation to the state of North Dakota. Fearing that the fatal blow might fall at any time, students, faculty, and friends of the University were impelled to get along, to forego the luxuries of factional and personal differences. Having been drawn together by adversity they also shared the rising optimism that followed the easing of economic conditions as the century closed. The war with Spain provided the disruption which hastened the break with the old and difficult past and the turn to a new era of prosperity and optimism. It was symbolic of the broadening horizons when nineteen University students volunteered their services to the governor for the war in Cuba.

It was at the end of the 1890's that the former "Grand Forks University" began a rapid shift from its old status of a liberal arts college and preparatory school to that of a true state university; and although much was gained in the change, there was also some regrettable loss. One can criticize with justice the narrowness of the training and the somewhat superficial learning of some of the faculty, the all too frequent rote learning from textbooks, the unimaginative emulation of eastern colleges. The conception of a university's function was limited at times to nothing more than service as a preparatory school for professional schools elsewhere. Most students did not learn very much in total quantity, and they learned little very deeply. Yet it cannot be denied that the Merrifield program of character training was beginning already to show some results, which were to become more marked in the half dozen or so years ahead. The University awarded sixty-eight degrees between 1891 and 1898. Among those graduates and among the students in attendance in 1898 were several future congressmen, two governors, two United States Senators, two state supreme court justices, and a high proportion of public school teachers and professional men, particularly physicians and lawyers.

\section{PART TWO}

THE STATE UNIVERSITY
1899-1945 


\section{The Making of a University}

$\mathrm{T}_{\mathrm{H}}$

UNIVERSITY OF North Dakota entered a long upward trend in 1898-1899. The change from the struggle for survival is sharply marked almost to the month by a series of significant events. In part, although no cause for the change, the war with Spain, the excitement of University boys' departure, and the enthusiastic reception on their return broke the spell of preoccupation with the seemingly permanent hard times in North Dakota. The rate of college enrollment began to accelerate, thanks to the University's creation of a state high school system. Only nine schools offered a full course of a standard acceptable for entrance into the University in 1899; there were thirty such schools in 1902 and seventysix in 1909 with a total enrollment of nearly four thousand. The number of college students passed the hundred mark for the first time in 1898-1899. There were 422 a decade later, and the preparatory department, for years the largest division in the University, was reduced to the position of a practice school for the Teachers College. In the same period, seven new buildings were erected and three more appropriated for. University finances, formerly so precarious, achieved a state of relative stability, if not affluence, with the passage of a special mill levy (1899) for the support of 
higher education. In addition, the land endowment began to produce revenues large enough to be of real significance.

The University began to assume a new character, moving from the small liberal arts college it had remained for nearly two decades toward the state university that it proclaimed itself to be. The models in this new phase shifted from the private eastern colleges to the great public institutions of the West. What this meant in the University of North Dakota was a change in organization, the appearance of professional schools, the enlargement of function to include direct public service, and a new "Merrifield faculty," tripled in size in a decade from seventeen to fifty-one and differing conspicuously from the first one in the prominence of $\mathrm{Ph} . \mathrm{D}$. specialists from such graduate schools as Johns Hopkins, Cornell, Wisconsin, and Michigan. With these developments came standardization and the beginning of recognition.

This growth was by and large a reflection of national trends in higher education. Total enrollment in American colleges was about 240,000 in 1900; in the next half century, while the population was doubling, college enrollments increased ten times. Standard procedures and more or less fixed standards of scholarship arrived in the same period with the full development of graduate schools, professional societies, and institutional accrediting associations. The Association of American Universities, its members joined together largely by recognition of each other's capacity to offer graduate training for the Ph.D., was formed by fourteen of the leading institutions in the country in 1900. Other such organizations to appear were the National Association of State Universities and the Association of Land Grant Colleges. In 1913 the North Central Association of Colleges and Secondary Schools, founded in the 1890's, began accreditation of colleges and universities.

Along with the influences penetrating from the world of higher education, there was also the profound impact of the larger thinking and the optimistic reformism of the Progressive Era. Its manifestation on university campuses was a heightened emphasis on service activities and on social consciousness; its influence was apparent in the increasing number of courses in sociology and economics, the appearance of social service clubs, student settlement houses, and public health and pure food testing laboratories, and the popularity of the ideas of such leaders as Jane Addams, Robert M. La Follette, William Jennings Bryan, and Theodore Roosevelt.

North Dakota was particularly receptive to the spirit of the age and in 1900 was itself on the verge of an era of reform. The state had entered its second boom, of more substance and of longer duration than the speculative frenzy of the 1880's which had given birth to the University. The growth of population is an index of the good times. From 183,000 in 1890, growth had been slow until 1896 or 1897 when population inclined sharply upward. There were 319,000 people in the state by 1900 , and 577,000 a decade later, about 100,000 short of the maximum figure the state has attained to this writing. Grand Forks had 12,000 people by 1910 The flush times were accompanied by a better than usual ratio of good crop years and an unusually long period of good farm prices; there was no serious break between 1897 and 1921. The University's income rose from $\$ 32,625$ in $1898-1899$ to $\$ 173,427$ in $1908-1909$.

Included in this rise was the income from the University and School of Mines land grant (126,000 acres), up from about $\$ 2,000$ to nearly $\$ 40,000$ annually in the decade. With prosperity came a marked change in the North Dakotan's attitude toward his state. The complaint of the 1880's and 1890's that "North Dakota is a poor state" was heard no more. The state exhibit at the Seattle exhibition of 1909 proudly proclaimed that "North Dakota had more wealth per capita than any other state in the Union; it has no millionaires and no paupers." The problem of the University, and of the other colleges as well, was to see to it that this pride bore fruit-that is, support of higher education commensurate with the increasingly heavy demands being made upon it.

The University had its first stroke of good fortune in a decade when the legislature of 1899 enacted a two fifths mill levy for its support instead of a fixed sum. The measure was not entirely the result of the legislature's prescience; in 1896 Merrifield had recommended such a measure, then in use in other states, and the Trustees had incorporated the recommendation in their report of 1898. The bill was passed largely because it appeared to be for a smaller amount than the $\$ 127,000$ appropriation that Horace Arnold had 
introduced. The mill levy was expected to yield $\$ 70,000$ for the biennium, only $\$ 20,000$ more than was appropriated for $1897-1899$. But it brought in $\$ 85,000$ in $1899-1901$ and $\$ 100,000$ in $1901-1903$ The unexpected result aroused the jealousy of the supporters of the other colleges, and in 1901, a year of almost total crop failure, the incoming governor, Frank White of Valley City, recommended the repeal of the levy because it was providing more income than the University needed. A repeal bill was introduced, but the attack was turned aside by extending the principle to all the institutions with the levy of a full mill divided among them: two fifths to the University, one fifth to the Agricultural College, .12 mill to each of the two normals, .13 mill to the school for the deaf, and .03 mill to a proposed school of forestry at Bottineau. This distribution continued until 1907, when the University's portion was cut to one third mill, the saving being added to the portion of the two normals and the new forestry school.

The effect on the University and the other state educational institutions of having at their disposal an assured and enlarged income was electric. Even so, it was inadequate for the expansion that was suddenly necessary to meet the expenses of institutions faced with mounting enrollments at the same time they were also expanding their services. Disposed to be generous by comparison with earlier standards, the legislators as well as some of the governors (the most conspicuous being White) were nevertheless slow to appreciate fully the expanding requirements of higher education in North Dakota. They were faced with a new phenomenon that few of them had the experience to understand; indeed, it was not fully comprehended by all the heads or faculties of the institutions themselves. State officials were, moreover, beset by enlarged demands upon state revenues for a multitude of other purposes and beseiged by conflicting claims from the institutions, each with its coterie of local supporters whose selfish motives were not always easy to separate from the legitimate needs of education.

The University and the other institutions encountered serious difficulties as they searched for a solution to the problem of longterm funding of construction costs within the boundaries of the low limits on taxation and indebtedness set years before by the state constitution. Two loopholes, both of which had to be tried to be found wanting, suggested themselves: one was that the legislature bypass the debt limit by borrowing against the land endowments of the institutions; the other was to allow the boards of trustees to borrow against the credit of future appropriations. The latter would mean, of course, that maintenance appropriations would be diverted to construction unless a forgiving legislature would appropriate increased funds to discharge institutional debts. In the case of the University, it will be recalled that in 1893 money from general maintenance funds had been diverted to construct the prep dormitory. This expedient was tried in the spring of 1899 , following the passage of the two fifths mill levy. Thirty thousand dollars was borrowed at 7 per cent (a not unreasonable rate for the time) from local banks, against the estimated income of $\$ 41,000$, to erect a boys' dormitory and drill hall, to install a central heating plant and electric lighting system, and to remodel the main building, largely a matter of converting vacated sleeping quarters into classrooms. In September $\$ 16,000$ more was borrowed on the same terms to complete the work.

Despite some suspicions that the University was using the loans to commit the legislature to enlarged appropriations and despite Governor White's opinion that the mill levy was providing the University with more money than it needed, the legislature of 1901 passed a bill to legalize borrowing up to $\$ 50,000$ on the security of the land endowment. The fact that Budge, who bore the chief responsibility for the Trustees' actions, stood high in the councils of the dominant Republican party was an invaluable asset. Whatever objections White had raised were matched by the enthusiastic endorsement of the outgoing governor, Joseph M. Devine, for an enlarged building program at the University. The following December the Board borrowed $\$ 36,000$ more for a science building. In May, 1902, Merrifield lent $\$ 16,000$ to the Trustees to erect a campus residence for himself; he was soon to be married. Having decided at this point, as Merrifield later observed, that it was no worse to be hung for a sheep than for a lamb, the Board borrowed $\$ 25,000$ for a mechanical arts building and $\$ 20,000$ more for a foundry and an enlargement of the heating plant. 
As the author of these bold actions, Budge came in for a good deal of sharp criticism when the 1903 legislature met; but times were good, spirits high, and his friends still in power and indulgent of his methods. Governor White observed once to Merrifield: I don't know what to do with Billy Budge. As a member of the Board of Trustees of the University he rides rough shod over the laws of the state and even of the constitution. Technically, he ought to be sent to the penitentiary, but he comes down here at the beginning of each new session throws his arms around the legislators and gives them a big hug, and instead of prosecuting Billy as they ought, they say, "Oh well, Billy is a good fellow, let's give him what he wants, and that's the end of it."

Which is exactly what they did in 1903. Instead of reprimanding Budge, the legislature passed a bill, introduced by his friend Judson LaMoure, McKenzie's chief lieutenant, to make him a permanent "honorary member ... for and during his good pleasure" of the Board of Trustees. The limit on the Trustees' borrowings on the land endowment was raised from the $\$ 50,000$ figure set in 1901 to $\$ 150,000$ in order to legalize the recent borrowings and to permit more for a gymnasium and an administration building.

In August, 1903, while plans were being made to break ground for the new buildings, which had been confidently promised in the new catalog, disaster fell in the form of a state supreme court ruling, in a case arising out of Valley City Normal's borrowing on its lands, that debts so contracted were part of the general state debt and unconstitutional because the $\$ 200,000$ limit had been exceeded. The University was caught with a $\$ 92,000$ debt and no way to meet it. The 1905 legislature appropriated only $\$ 68,000$ for debt retirement, leaving the University Trustees with the prospect of paying the rest out of operational funds. In 1907 school land income was specifically restricted to maintenance expenditures by another court decision rendered in a Montana case. That same year the legislature passed laws making individual board members subject to prosecution for spending in excess of appropriations, authorizing the governor to require each board to furnish full das for his financial and statistical report on state institutions, and establishing a uniform system of accounting for them. Likewise associated with the tightened control of institutional finance growing concern with the increasingly valuable endowments of the colleges. In 1909 Governor John Burke urged a broad reform of the legislation controlling investment of funds, closer investigation of the lands put up for sale, and stricter control and higher charges for leases on the lands. These measures marked the attainment of a certain maturity in the development of University finance. The Trustees, confronted with an emergency situation and the usual legislative lag, and in the absence of precedents or legislation to guide or curb them, had followed the only course open to them, but the period in which they had explored the limits of their financial resources and their control over them was at an end.

Further construction was meantime brought to a halt, but only temporarily. In 1907 the legislature appropriated $\$ 25,000$ for the gymnasium and armory that had been lost in $1903, \$ 20,000$ for a School of Mines building, and $\$ 12,000$ to remodel and double the size of the old prep dormitory, the Cottage. Two years later, in the last months before Merrifield left the University, $\$ 60,000$ was appropriated for a Teachers College building, $\$ 40,000$ for a dining hall and visitors' rooms, $\$ 30,000$ for a mining experiment station and lignite briquetting plant at Hebron and equipment for a special lignite laboratory in the mines building, $\$ 20,000$ to enlarge the heating plant, and $\$ 3,000$ for a biological substation at Devils Lake. Indicative of the enlarged vision of the legislators in 1909 was the fact that the total appropriation for construction alone at all of the state educational institutions was $\$ 648,000$, nearly equal to the entire yearly income of the state in $\mathbf{1 8 9 5}$.

The increasingly impressive cluster of campus buildings was augmented in 1908 by a library donated by Andrew Carnegie. A $\$ 30,000$ grant for the library had been approved in 1906 after months of negotiations and several refusals. ${ }^{1}$ The new structure was a great improvement over the cramped quarters in the main building and possesed more architectural grace and special utility than the other buildings, having been designed by a Chicago firm specializing in libraries, but it was to prove inadequate almost from the beginning. Merrifield was fully aware of this but was unable to persuade the legislature of 1907 to add $\$ 30,000$ to the Carnegie ${ }^{1}$ The Agricultural College received a similar grant in 1905 . 
gift. The entire grant was put into the building; Merrifield lent the money to build stacks, and odds and ends of cast-off furniture completed the initial equipment.

It was also in 1906 that the Red River Valley University (Wesley College) affiliated with the University of North Dakota and began laying out a ten-acre campus directly to the north across University Avenue. ${ }^{2}$ The first building, Sayre Hall, a dormitory accommodating fifty-two boys, was opened in 1908. Larimore Hall, a matching dormitory for girls, and Corwin Hall, a classroom building, were completed in 1909. Arranged in suites of two bedrooms and a living room, the Wesley dormitories, open to University students under certain conditions, were the most attractive student housing available on the University campus until the completion of Johnstone Hall in 1952. Wesley College also led the way in adopting a unified campus plan, including a single style of architecture, a modified Italian.

The construction program was accompanied by almost constant renovation and remodeling of older buildings, additions of new facilities, and moving of departments. As has been mentioned, the Cottage was extensively remodeled and enlarged in 1907 and the dormitories in Main converted to classrooms and offices. The new science building of 1901 absorbed the museum and all the laboratories from Main. The completion of the two engineering buildings left Science Hall to the basic sciences and the School of Medicine, and the library freed additional space in Main for offices and classrooms. Several enlargements of the heating and lighting plant were necessitated by the increased number of buildings, and in 1907 the University joined the Grand Forks sewer system-not without some objection from Grand Forks citizens. The old coulee disposal system had become something of a scandal before the change, noxious enough to sicken his dog, one visitor declared. In all, about $\$ 100,000$ was spent on such miscellaneous improvements and renovations.

One of the most important accomplishments of the period was the establishment of reliable transportation to Grand Forks. In 1899 the completion of the last half mile of the plank sidewalk 'See page 163 . from town, begun years before, provided the first route suitable for the now widely used safety bicycle. (The bicycle was useless, however, in the drifted snow and biting cold of midwinter.) That same year the University bought its first omnibus, the famed Black Maria, and established its own regular service of about four trips a day. The Black Maria became rich in legend; it provided such memorable vignettes as that of the rotund professor of Scandinavian languages arising like Santa Claus from a snow drift after one of its upsets. University Avenue, renamed from Broadway, was graveled in 1900-it would not be paved completely until 1921.

But the really significant development in transportation was the opening of the trolley line in September, 1904, a decade after the first such project had been planned. Hopes for the University trolley had been revived when a Grand Forks line was opened in 1903, but no local entrepreneurs came forward to build it. As happened so often in such circumstances, Merrifield and Budge took the initiative and organized their own company, capitalized at $\$ 10,000$, which numbered several of the faculty among its subscribers. The line, running from the Dacotah Hotel to a loop on the campus north and west of Main, was powered at first by the University dynamo, but this proved inadequate. With the added handicap of poor conditions on University Avenue in midwinter, breakdowns in service as well as sudden campus blackouts were 1909. The inefficient little line with its toylike cars, all secondhand, was soon surrounded by its own legends of car-rocking, derailing, trolley snatching, and student quarrels with conductors and company management. Whatever its failings, the line contributed much to the rapid growth of the University by freeing it from its previous heavy dependence on its own housing facilities.

The trolley and the sewer were major factors in the residential development that presently began in the University neighborhood. The Babcock house was still the only one in the area in 1899, and the nearest town house was a mile or more away to the east. By 1909 there were several new houses already completed in the University Place that Wesley College had platted, and residential building had begun along the line of University Avenue. 
Important for the future growth of the University and as a guarantee of control over its surroundings was the acquisition of large tracts of land adjoining the original campus-the twenty acres bounded by University Avenue, the coulee, the railroad, and a line about midway in the present quadrangle. It was largely good fortune that in 1897 the state legislature transferred the permanent home of the North Dakota state fair from Grand Forks to Mandan and two years later transferred the fairgrounds to the University. This tract was the sixty acres lying immediately west of the campus although not quite contiguous to it; with the addition of the strip of land lying between, acquired by exchange with Budge who owned it, the fairgrounds enlarged the University holding to a solid block of about a hundred acres. The new tract, however, was across the coulee and even farther from town than the original site and so was not used for many years. Meanwhile the University needed more land to expand eastward. Budge owned the adjoining land in that direction but he made no move to give it; since he was a member of the Board, there was a question of propriety if public funds were used to buy it from him. Merrifield solved the problem in 1906 by buying the adjacent twenty acres himself for $\$ 4,000$ and deeding it to the University. The Carnegie Library and the mines building were the first built on this land, on which now stand about half the University buildings. The twenty acres immediately east of this tract were bought in 1910 from Budge, then no longer on the Board.

The building program and the addition of enough land to provide a really commodious campus led to the first organized attention to planning and beautification. Although Merrifield always valued highly the educational as well as the aesthetic effect of campus beauty, neither he nor any of the faculty members were much concerned with the external appearance of the new buildings, at least before 1906. Poverty was a limiting factor, and in a way a fortunate one, for cheaply constructed and undistinguished in style though the old buildings were, they at least had the merit of simplicity, which is more than can be said for the castellated Budge Hall and the pretentious and badly proportioned Mansion. They were also small; nowadays the Merrifield buildings, with the ex- ception of the old Science Hall, are dwarfed by the later structures. Unity of style received little attention in Merrifield's day. The first signs of the present red brick with stone trim appeared in the Carnegie Library and the gymnasium; this style was not adopted officially, however, until 1909, after Merrifield had gone.

Merrifield's chief concern was with campus landscaping (partly no doubt because it was cheap) to relieve the "barrenness, not to say ugliness" of the flat prairie campus. His plantings, as not to say ugliness of the without much plan save for the extensive use of native trees and the hopeful planting of ivy to soften the harsh outlines of the buildings. There planting of ivy to soften help in planning from the United States Bureau of Forestry in 1902, and in 1903 the first official designation Bureau of Forestry in of a superintendent out until 1905 when Professor C. B. Waldron, botanist of the Agricultural College at Fargo, prepared a " work was begun in the summer. plan for "parking" the campus. Work was begun in the "powe The ground was smoothed down enough to permit use of a "power cylinder" lawn mower, gravel walks and a winding drive were laid cylinder lawn the old fence was taken down, and willows were out, the last of the coulee. The Adelphi Society installed a fountain, the first piece of decorative masonry to grace the campus. As part the old baseball and football playing field lying between the Cottage and the science building was cleared out and planted to grass. In 1907 the first regulation track and general athletic field on the campus, with enough bleachers and general athletic field on the campus, with enough bleachers to seat four or five hundred spectators, was laid out in the northwest corner of the grounds between the president's house and the west corner of the was out coulee. This field was used until on the east side of the campus. A University greenhouse was added in 1909; intended primarily for the botany department, it was also used for growing flowers and shrubs for transplanting. That year landscaping and grounds upkeep reached such proportions that it required a biennial appropriation of $\$ 5,000$.

In 1907 a firm of architects, Patton and Miller of Chicago, the designer of the Carnegie Library, was employed to prepare a longterm plan for building placement for the entire University. The 
first step was to place the new library at the head of a projected quadrangle. Even allowing for the exaggerations of local pride, the ugly duckling had come a long way when the local press confidently predicted in 1907 that the University would some day have one of the finest campuses in the West.

No less rapid than its physical development was the metamorphosis from what was essentially a liberal arts college offering some teacher-training work to a modern state university. Every school or college (Science, Literature and the Arts, Engineering, Medicine, Law, and Education) now in existence except the College of Business and Public Administration was organized between 1899 and 1905.

Although the School of Mines, with its own land endowment and benefiting from the vigorous propagandizing of Earle Babcock, had a head start in the race to be first among the professional schools, the School of Law, opened in 1899, was the first to begin operation. Budge was opposed, wanting to get on with the mining work, but Merrifield and the rest of the Trustees favored the law school. It could be set up with little or no additional cost to the University, which would not be true for any technical school, and there was a considerable need as well as popular demand for it. The man chosen to be the first dean-the first to bear the title in the University-was Guy H. Corliss, a prominent Grand Forks lawyer and the first chief justice of the North Dakota state supreme court. He was available because he had failed in his bid for reelection in 1898. Even though he had never attended law school or even college, he was appointed because he could bring local prestige to the school, at virtually no cost. He took no pay the first year, and the second received only $\$ 2.50$ per lecture, the rate for all of the seven local lawyers who made up nearly the entire faculty. There was only one full-time instructor, John E. Blair, who was a year out of Harvard law school; he received a salary of $\$ 1,500$ per year. In his capacity as secretary of the law school, it was he rather than Corliss who actually directed the school's operation.

At first the college had few connections with the University except that small sums were supplied from the University budget; a major part of its support came from its fees. It occupied rented quarters in the Syndicate Block in Grand Forks for three years and in 1902 moved to the Clifford Building on Fourth and Demers, where it remained until it was moved out to the campus during World War I. In the absence of an adequate library or money to buy one, the students had to depend for the most part on the good will of local lawyers for the use of their private book collections. The University was not even concerned with prelaw preparation, for the only requirement for admission was the arrival of the applicant's eighteenth birthday and completion of grammar school; some special students were not even held to that. Teaching and standards were extremely lax; local lawyers did most of the work and the school all too frequently took second place to the demands of private practices. Hardly any member of the faculty, with the exception of Blair, had as much formal training in law as other members of the faculty had in their fields. ${ }^{3}$

Although Blair had more than his share of energy-in his three years at North Dakota he found time to woo and marry a local girl, to assist with the football coaching, and even to play occasionally-he had only indifferent success, largely because he introduced the study of law on too high a plane for the students and faculty. Few of them were prepared for the legal reasoning approach or the Harvard case books that Blair tried to use. The Harvard law school at the time admitted only college graduates and required three years to complete the course, a year more than was required at North Dakota. Blair left in 1902 to teach at Stanford; the gap was partly filled by Samuel Peterson (Ph.D. and D.C.L., Yale), who taught political and social science as well as courses in law.

In the meantime, Andrew Bruce, the man who was actually to put the school on its feet, joined the faculty in 1901 . He was assistant dean of the University of Wisconsin law school when he was appointed at North Dakota and had a background of sound formal training (LL.B., Wisconsin, 1892) and successful practice in Chicago as well. Possessed of an agreeable and genial temperament, he also brought to his job a cosmopolitan background, for he had been born and reared in India, the son of an English army

${ }^{3}$ William Nuessle taught law classes when he was himself a student. 
officer. He was dean in fact from his arrival, although not in name until after Corliss returned to full practice in 1904. Bruce soon shifted the school's emphasis from legal reasoning to practical procedure, and he also deliberately lowered the already low standards to attract students. Whatever the shortcomings of such a policy, it was popular. Enrollment, which had been disappointing during the first years, began to climb rapidly. In its first decade the school turned out two hundred lawyers, sixty-nine more graduates than the liberal arts college produced in the same period. The rapid development is hardly surprising; practically no one failed, and from 1901 to 1905 all graduates were admitted to practice in the state without further examination.

But the level of the school was gradually elevated after it had been made firmly popular. There were three full-time faculty members by 1909. Despite the low standards for students, the faculty was always chosen with considerable care. The fact that Blair left North Dakota to teach at Stanford, that Peterson left to teach at the University of Texas, and that Bruce eventually went to the state supreme court as chief justice and from there to the University of Minnesota and Northwestern is sufficient commentary on the early faculty. Direct measures to improve the school were the beginning of general state bar examinations in 1905 (on Bruce's recommendation) to replace the automatic admission of graduates to practice, and the requirement of two years of high school for entrance in 1906. That same year a new law required that all lawyers admitted to practice must possess three years' training in a law school or three years' training and reading in a law office. In the meantime the library of the school was enlarged from one to six thousand volumes in 1905 when the legislature appropriated $\$ 10,000$ to buy the law portion of the private library of State Supreme Court Justice John M. Cochrane, a resident of Grand Forks and former Trustee, who had died the preceding year. (Mrs. Cochrane gave two thousand books to the general library, its first gift of any size, and more than a hundred books on medical subjects to the new medical school.)

Perhaps no other college paid off so quickly in broadening the University's influence in North Dakota. It had a widely drawn clientele; there was no other law school nearer than Minneapolis and there was an active demand for lawyers in this new state where property titles and many human relationships had not yet been clearly defined. Moreover, the legal profession had high social prestige and was an obvious road to business success and public office. It was the latter which accounts for the fact that, despite its low standards of admission, the school attracted a large number of the leading graduates of the liberal arts college, among them William L. Nuessle, William Langer, J. F. T. O'Connor, Olger Burtness, William Lemke, Victor Wardrope, Ragnvold A. Nestos, and Fred Traynor, every one of whom became a figure of considerable influence in North Dakota within two decades after the school had been founded. By 1909, according to the Student, law school graduates were practicing in seventy-eight North Dakota towns, four were in the state legislature, and one, Victor Wardrope, was on the Board of Trustees, the first alumnus to be appointed. The services of the law school were not limited to the state alone, for the widening public influence of its graduates became an important factor in maintaining the position of the University in the years that followed.

Indicative of the almost immediate effects of the school in broadening interest in the University and of the deliberate exploitation of that interest by the faculty and administration, was the first law school dinner at the 1901 commencement. Said at the time to be the "most elaborate" affair of its kind ever held in Grand Forks, its guest list included Governor and Mrs. Frank White, United States Senator Porter J. McCumber, Asle J. Gronna (later Congressman and Senator), former Congressman Martin N. Johnson, and most of the prominent judges and lawyers of the area. The thirteen members of the first graduating class received their diplomas next day from Governor White.

The new law school was the first step in a thorough reorganiaztion of the University. This development was hastened by the unexpected yield of the two fifths mill levy and by the easy forgiveness obtained in 1901 for the unauthorized building program. After months of discussion and planning, the faculty designated three new colleges and named their deans in May, 1901-Liberal 
Arts headed by Thomas, Mines and Engineering by Babcock, and the Normal College by Kennedy. Recognizing that although Babcock was industrious and deserving, he actually lacked the training to launch an engineering school, Merrifield spent considerable time in the spring and summer of 1901 visiting engineering colleges to seek both guidance for himself and a man "well grounded theoretically and who had been successful in some form of engineering." He found the best example of what he wanted at the Hiram Sibley College of Engineering at Cornell, perhaps the leading institution of its kind in the country, particularly noted in the fields of mechanical and electrical engineering. Cornell also led him to his man, Calvin H. Crouch (M.E., Cornell, 1892), who was then employed by the Baldwin Locomotive Works of Philadelphia. Crouch had spent some years in Europe as a representative of the company, a cosmopolitan touch that appealed to Merrifield. Since Crouch was unwilling to take a position second to Babcock, who had no engineering training at all, enginering at North Dakota was organized into a School of Mines or College of Mining Engineering, headed by Babcock as dean, and a College of Mechanical and Electrical Engineering headed by Crouch, who was designated as director for a year and then as dean. Crouch arrived at North Dakota in the early summer and began his duties immediately by supervising the construction of the science building. Merrifield, meanwhile, remained at Cornell for six weeks preparing himself for his own changing role by studying economics and sociology.

The science building was opened for use just before Christmas. Engineering occupied the basement floor, physics and mathematics the first floor, chemistry the second, and biology and the museum the third. The next year the inexpensive but spacious (two stories, fifty-four by one hundred feet) mechanic arts building, which Crouch designed, was erected as part of the new power house on the west side of the Davis and Cottage dormitories. The College of Mining Enginering remained in Science Hall until 1908 when the mines building was completed on the east side of the campus next to the library.

The two colleges were at first merely high sounding names for what were really severely limited offerings, little equipment, and tiny faculty. The only faculty additions necessary to launch two new engineering colleges were Crouch and Frank Wilder, the University's first professional geologist, who succeeded to Babcock's title of state geologist and his courses in 1901 when the department and the Survey were organized within the School of Mines. Each of the faculties consisted of the one or two special technologists who were necessary to give the school its name plus their counterparts in the other college and those members of the liberal arts faculty who taught courses that were taken by engineering students. For example, the University announcement of 1906-1907 listed the College of Mechanical and Electrical Engineering faculty as Merrifield, Crouch, Babcock, Squires, Elwyn Chandler (mathematics), G. Walter Stewart (physics), Macnie, Marcia Bisbee (instructor in chemistry), Albert Becker (instructor in mechanical engineering), and Casimir H. Wallinger (instructor in foundry, forge and shop, and superintendent of buildings and grounds.) The mining faculty did not list Wallinger and added the name of the professor of geology; otherwise the faculties were identical. All but Crouch, Wallinger, and Becker were also counted as members of the liberal arts faculty.

The programs had other obvious deficiencies arising from the uncertainty at first about what the engineering courses should contain. Part of this was due to competition with the Agricultural College, which was operating short midwinter artisans' courses, including one in gas engine operation, along with its developing engineering program. ${ }^{4}$ Neither the Agricultural College nor the University had yet decided firmly whether its mission was to train the farm youth to solve practical mechanical problems for himself or to train him for industrial employment. That the work was at first heavily weighted with vocationalism and what would now be called industrial arts is apparent in the mechanical engineering laboratory equipment list of 1902: a wood-working shop, a machine shop equipped chiefly with a dozen bench vises, a couple of lathes and a milling machine, a blacksmith shop with a dozen

'The University's artisan course was discontinued in 1903. The establishment of the State School of Science at Wahpeton in 1904 relieved the colleges of any responsibility for such practical training. 
forges and anvils, a foundry or molding shop, a tensile and compressive tester, a twelve-horse-power electric motor, and a few gauges. In 1904 Crouch declared that the laboratory had but a small part of the equipment necessary to provide a course "comparable with those offered by the majority of other colleges of mechanical engineering ...." A half dozen years later, shortly after $\$ 5,000$ had been appropriated for laboratory equipment ( $\$ 16,500$ less than had been requested), Crouch reported that it would require $\$ 40,000$ to bring the laboratories up to date. Despite the glaring deficiencies, the College of Mechanical and Electrical Engineering soon achieved a small measure of recognition. By 1907 Crouch had arranged with Cornell to accept his students without condition or loss of credit, and he could report with pardonable pride that two of his graduates had given "entire satisfaction" as teaching assistants at his alma mater.

The School of Mines on the other hand enjoyed a position of special favor; it had its own grant of land, it had Babcock, and it was established on the crest of the wide public interest created by the publication (March, 1901) of the first North Dakota Geological Survey report. In 1899 the Survey had received its first appropriation, $\$ 600$ for the biennium. It was little enough, but Babcock made the most of his opportunity and turned out an elaborate illustrated report in which he summarized the work of ten years. It contained information on water resources and clay deposits in addition to the main section devoted to the vast lignite deposits of the state, complete with analyses of production of various mines, tables of comparative fuel values, and an optimistic discussion of future possibilities. Although the report made no mention of it, there was solid evidence of Babcock's own confidence in his findings. He was at the time president of the Pembina Portland Cement Company and, with Merrifield, among the principal investors in its venture of operating a plant near Hoople. The Babcock report, coming as it did on the crest of good times, aroused much public interest. The Bismarck Tribune pronounced it "one of the best public documents ever issued in the state."

No one realized better than Babcock the effectiveness of the practical approach in a new state like North Dakota. In the catalog of 1909 he announced: "The hope is to make the School of Mines a department from which the people of the state may secure practical tests or any other aids .... There are few people who appreciate the great value of these undeveloped resources or the economic advantage which might be derived by successfully building up manufacturing and mining industries in an industrial region." It was this approach that won for the School of Mines the first public support for research of any sort in the University. In 1907 the legislature specifically instructed the Trustees and the school to "provide suitable means" for experimentation and testing of mineral resources, with special attention to the briquetting of lignite, its use for gas or electric power, the uses of clay deposits, and the building properties of North Dakota stone. The appropriations made in 1909 to equip the new mines building and for the plant at Hebron were a direct result. By the end of the 1908-1909 term the school could boast separate laboratories for general chemical work, analysis, ore testing, cement and clay testing, and gas and coal testing. In addition the equipment included mill machinery and models of a concentrating plant, gold mill, cyaniding plant, and brick plant. Whatever claims the University had to being a center of scientific research in 1909 rested on the work being done to find uses for lignite and clay in the technological School of Mines. This brought the University some reputation outside North Dakota and it was important in its competition for funds and public favor with the Agricultural College, which was also in the process of expanding its engineering work. Like the School of Law and the Teachers College, the School of Mines was reaching out to put the University into direct contact with the life of the state.

By 1909 the engineering faculties had increased to eight, and degrees had been given in all but two of the major branches (civil and chemical) now taught at the University. There was actually no great demand for engineering among the students at the University, one reason being that those who were interested in technology tended to gravitate to the Agricultural College. Only one student, Thomas Campbell (B.A., 1903), graduated in the first class in 1904; he took a mechanical engineering degree. The first electrical engineering graduate did not come until 1908. The 
classes of 1908 and 1909, each with ten graduates, were the largest in Merrifield's day. Despite the deficiencies of the training of those formative years, some of the early graduates have been highly successful in the business and industrial world. During World War I Campbell, who married Merrifield's step-daughter, made a reputation in Montana as the "world's biggest wheat farmer"; Charles Boise (E.M., 1908), became a director of Selection Trust Limited, one of the world's largest mining companies; Herbert Treichler (M.E., 1908; E.M., 1909) won recognition as a world leader in sulphur mining while director of operations with the Texas Sulphur Company:

The Geological Survey was, of course, closely connected with the School of Mines. The survey work as well as the teaching of geology courses was first put on a professional level with the appointment of Frank Wilder, who had a Ph.D. from Chicago and had done additional work abroad. Although Wilder stayed only a year before he moved to the University of Iowa, he and H. L. Wood, a graduate assistant from the University of Chicago, extended Babcock's studies of lignite during the summer and fall of 1902, and in 1903, following the establishment of the United States Reclamation Service, headed joint United States Geological Survey expeditions to investigate the feasibility of irrigation in the western part of the state. Much of the travel was by bicycle.

Wilder's successor, Arthur G. Leonard (Ph.D., Johns Hopkins), formerly assistant state geologist of Iowa, was the real father of geological study in North Dakota. A solid scholar, he was perhaps Merrifield's strongest appointment in the sciences. Gentle, kindly, firmly upright, a man of broad culture (he had graduated Phi Beta Kappa from Oberlin), Leonard more than any other man bridged the gap between the old and the new Merrifield faculties and between the old and the new viewpoints on the proper course and aim of higher education. His long tenure-he remained on the faculty until his death in 1932-and his indefatigable and singleminded concentration on the problems of the geology of North Dakota were to produce a priceless body of information on the extent and value of the state's natural resources. Between 1903 and 1909 he and various assistants in cooperation with the United States
Survey continued the systematic mapping of North Dakota's resources of lignites, clays, and cement rock. Leonard had published a dozen articles and reports by 1909. Meantime, Elwyn Chandler, professor of mathematics and surveying, began in 1903 his measurements of stream flow in North Dakota and western Minnesota for the United States Reclamation Service. Basic and valuable as this work was, it suffered somewhat from being in the shadow of Babcock and the mining school experiments. State appropriations for the Geological Survey were never above $\$ 1,000$ a year before the First World War; they were, however, supplemented by federal funds from time to time for joint projects.

In 1905 the third professional school in six years was added, a two-year school of medicine. Here too the beginnings were almost ridiculously small. As was true with engineering, however, the University entered the field of medical education at an opportune time, when the general outlines of modern professional training had been worked out elsewhere, yet before it had become so complex and expensive as to discourage making the start. The University was also in the fortunate position of having no rival for the school among the other state colleges, nor did it have to compete with established proprietary schools willing to cut standards to attract students. The fact that a physician, Dr. J. D. Taylor of Grand Forks, had become the more or less official guardian of University interests in the legislature, replacing Arnold, was no minor factor in the successful establishment of the medical school.

The first step came in 1902 when a school of pharmacy was announced in the catalog. This was actually a premedical course, and it lasted only until the medical program worked out by a faculty committe headed by Brannon, to whom most of the credit for launching the school belongs, was approved by the faculty in March, 1905. The legislature at almost the same time enacted a law, sponsored by Taylor, to insure a supply of cadavers. Although Brannon himself then possessed no degree higher than the M.S. in botany, he was well aware of the existing conditions in medical education. He had conferred with the deans of various medical schools as well as with other leaders in the medical world; he also had advice and, more important, support from the North Dakota 
medical profession. The four-year program that Brannon's committee outlined consisted of two years of premedical work in the liberal arts college and the first two years of a four-year medical course; graduates were to receive the B.A. degree and a certificate in medicine. The North Dakota school was one of nine two-year or half schools established in a period of a few years; it was one of the first medical schools in the country to establish two years of college work as requirement for entrance-Yale did not match this requirement until 1909. It is true that not all of the first students were held strictly to the premedical program; a few of the early applicants were admitted directly from high school, but this short course plan was dropped after only a couple of years.

The school began, by any modern standard, with practically no equipment, laboratories, or faculty. It shared the top floor of the science building with the department of biology and the museum-this was to be its home until the new medical building was completed in 1949. The library was started with a hundred volumes donated from the library of Judge Cochrane, who apparently collected anything, and three hundred books and magazines on medical subjects contributed by Orin G. Libby, professor of history. Partially concealed by the usual practice of duplicate faculty listings in the catalog was the fact that there was actually only one full-time medical professor, Archie McDonald (B.A. North Dakota, 1901; M.D., Johns Hopkins, 1905). Brannon, the dean, was also head of the biology department; John Sweetland (M.D., Rush), the professor of hygiene, was primarily the director of athletics. All of the other members of the faculty, including Senator Taylor, were physicians practicing in Grand Forks. The faculty was strengthened and the school's services to the public accented in 1907 when Taylor successfully put through a measure, advocated by Brannon since his first year at the University and vetoed by the governor in 1905 , to establish a public health laboratory in connection with the medical school; $\$ 5,000$ was appropriated for maintenance and $\$ 2,000$ for equipment. The director was also to be ex officio state bacteriologist and professor of bacteriology and pathology in the medical school. The man selected for the position, Gustave Ruediger (M.D., Rush; Ph.D., Chicago), was on outstand- ing choice. Only thirty-one years old, he possessed vigor and imagination, and the laboratory developed rapidly in the seven years he was at the University. He resigned in 1914 to accept an attractive offer as head of a private laboratory in Illinois. He was the second full-time professor in the medical school, and Brannon himself became the third in 1907, when Robert T. Young (Ph.D., Nebraska) was appointed to the department of biology.

It was a tribute to the careful planning and organization of the program, as well as to the careful selection of the faculty, that the School of Medicine was the first branch of the University to win formal accreditation. The Association of American Medical Schools approved its work in 1907; in May, 1909, a month before the first medical certificate was awarded-to Sverre Oftedal, ${ }^{5}$ the only member of his class-it successfully passed the inspection of Dr. Abraham Flexner, who was making his survey of medical education in the United States for the Carnegie Foundation for the Advancement of Teaching. The famous Flexner report of 1910 to which Americans are so heavily indebted for the present high technical and scientific quality of medical practice, was fatal to dozens of weak schools. Of the 150 medical schools then in operation, North Dakota's was one of only sixteen requiring as much as two years of college work for entrance. Flexner noted nine students, nine professors, and seven instructors "taking part" in the work at North Dakota, a budget of $\$ 6,300$, a $\$ 450$ income from fees, a "well-equipped" and "very active" bacteriology laboratory, good provision for those subjects taught in the regular laboratories in the University, "slighter" provision for purely medical subjects, and a start on a library and a museum. In view of his destructive criticism of many older and better known insitutions, his concluding comment was high praise indeed:

The two Dakota schools have taken time by the forelock; before any vested The two Dak ot state practice proprietary interest could be created, they have The state though thinly requirement at two years of college wigh standard will settled is prosperous, and no anxiety is felt that the high standard will deplete the medical profession of the state. On the contrary, it has been sOftedal finished his studies at Rush Medical College, Chicago, and practiced for many years in Fargo. 
adopted as a means of protecting a people already supporting twice as many doctors as it needs. ${ }^{6}$

Graduates of the course were readily accepted at other institutions to complete their training; the first firm affiliation was established with Rush Medical College of Chicago. The North Dakota school had been well launched, and it established a fine record as a teaching institution. With its orientation almost entirely toward teaching and with limited resources, however, the school developed practically no research program for another forty years, except that deriving from the practical services rendered by the public health laboratory.

In the same year that the School of Medicine opened, there occurred the first of a series of events which were to bring to full college status the Normal College, then offering a five year program. Here the factors at work were not only the generally rising standards but also a strong attack from the normal schools and the Agricultural College, all of which had been observing with growing concern the University's expansion into fields they claimed as their own. The point they were to choose for attack was the University's continued enrollment of subcollege students, especially those it trained for rural school teaching. Although the University's preparatory department was dwindling proportionately as college enrollment expanded, it had actually grown somewhat with the general enrollment increase; in addition there had been an expansion of the subcollege program in several new directions, although not actually as college preparatory work. A three-month winter course for teachers began in 1899, and a three-year commercial course opened in 1901 under its own "principal"; moreover, three years of the five-year normal course were on the secondary level. In 1904-1905 only 201 of the 657 students reported in attendance for the year were in the colleges; 54 were in the normal department, 89 in the school of commerce, 111 in the preparatory department, 163 in the summer school for teachers, and 39 in the winter school for teachers.

More immediately alarming to the other institutions was the University control of the public high schools. Although the state ${ }^{6}$ North Dakota had 552 doctors and a population of 577,000

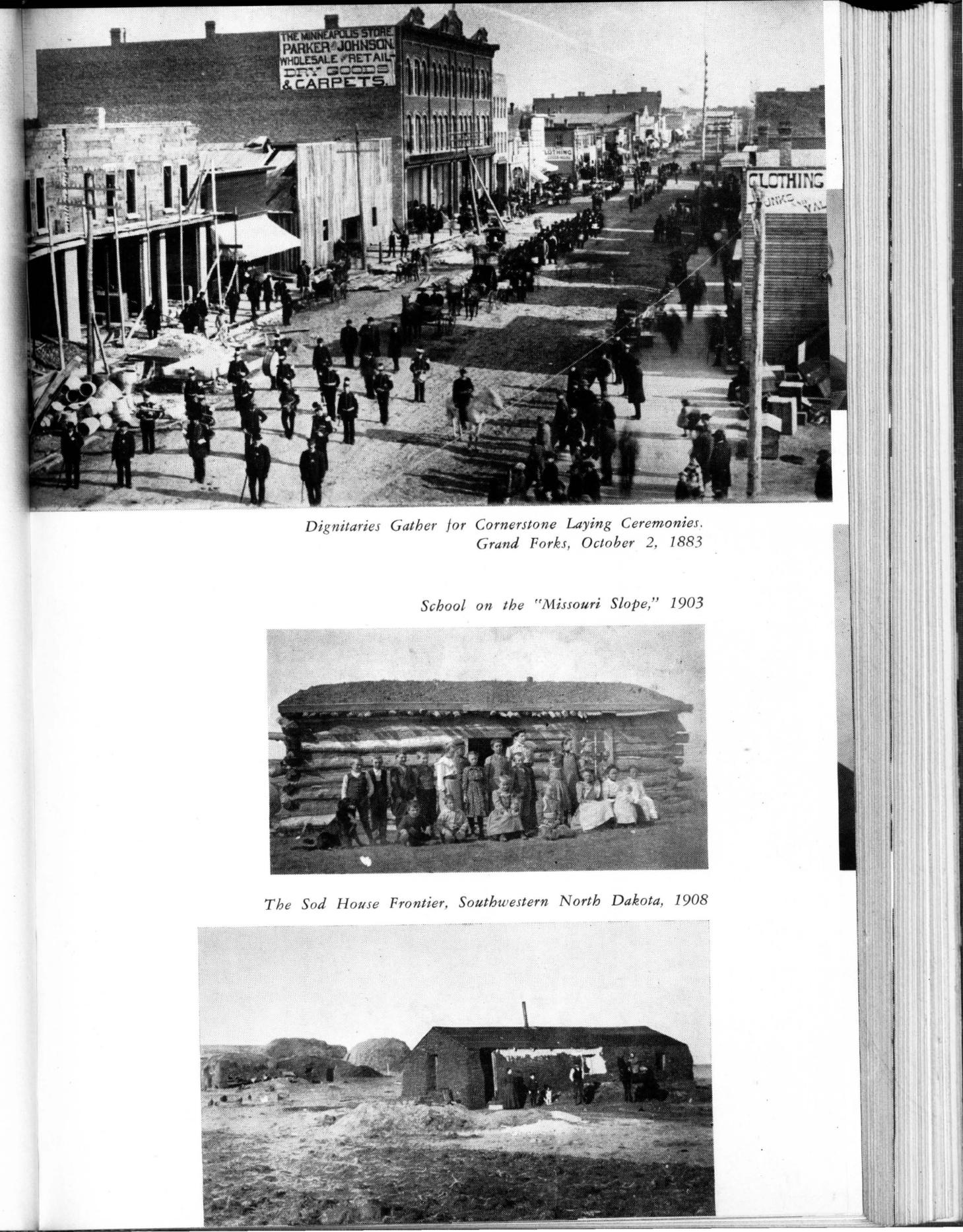




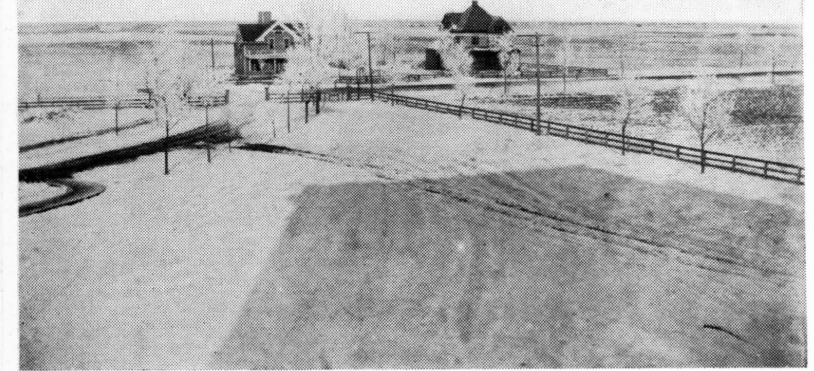

The Babcock Houses, 1904

(looking north from campus)

After the Tornado, June, 1887

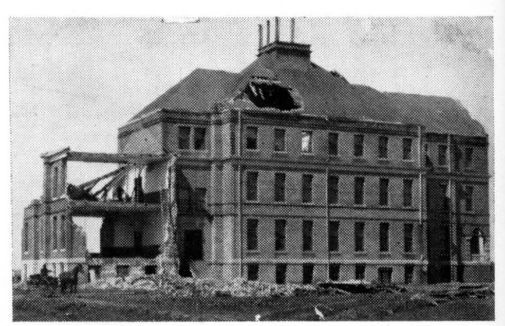

The University, 188

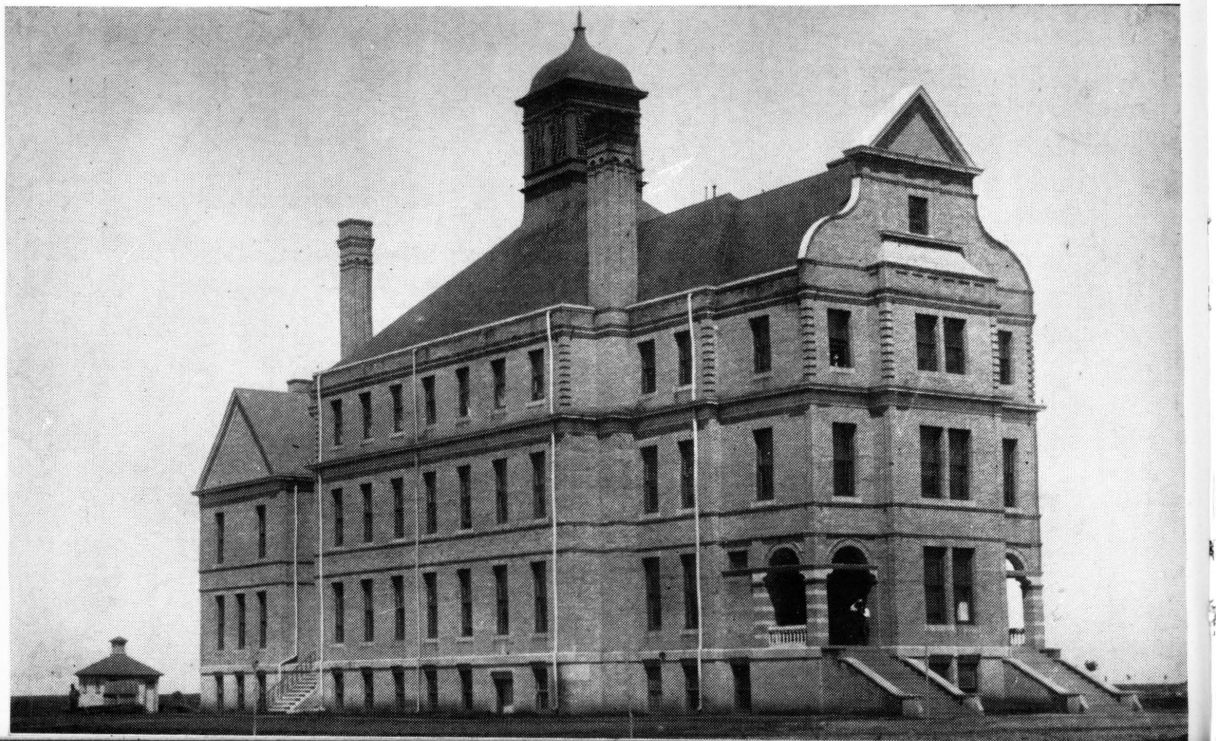

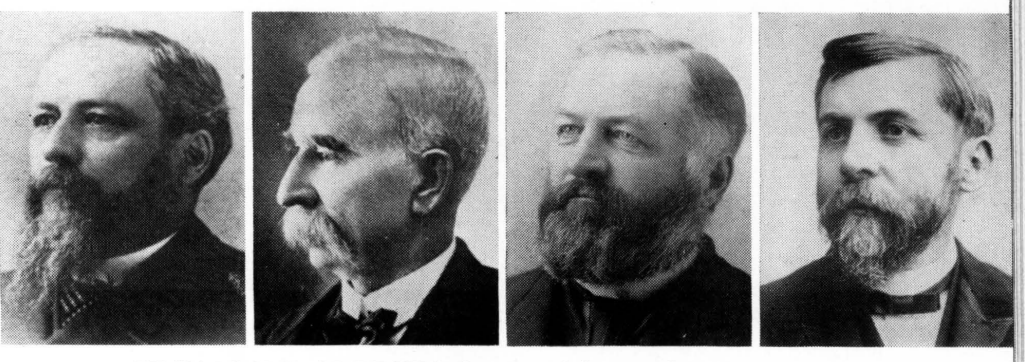

FIRST BOARD OF REGENTS, 1883 (left to right): Rev. Ezra
A. Healv, Dr. William T. Collins, Dr. Robert M. Evans, Dr. Charles E. Teel, James Twamles

George H. Wals
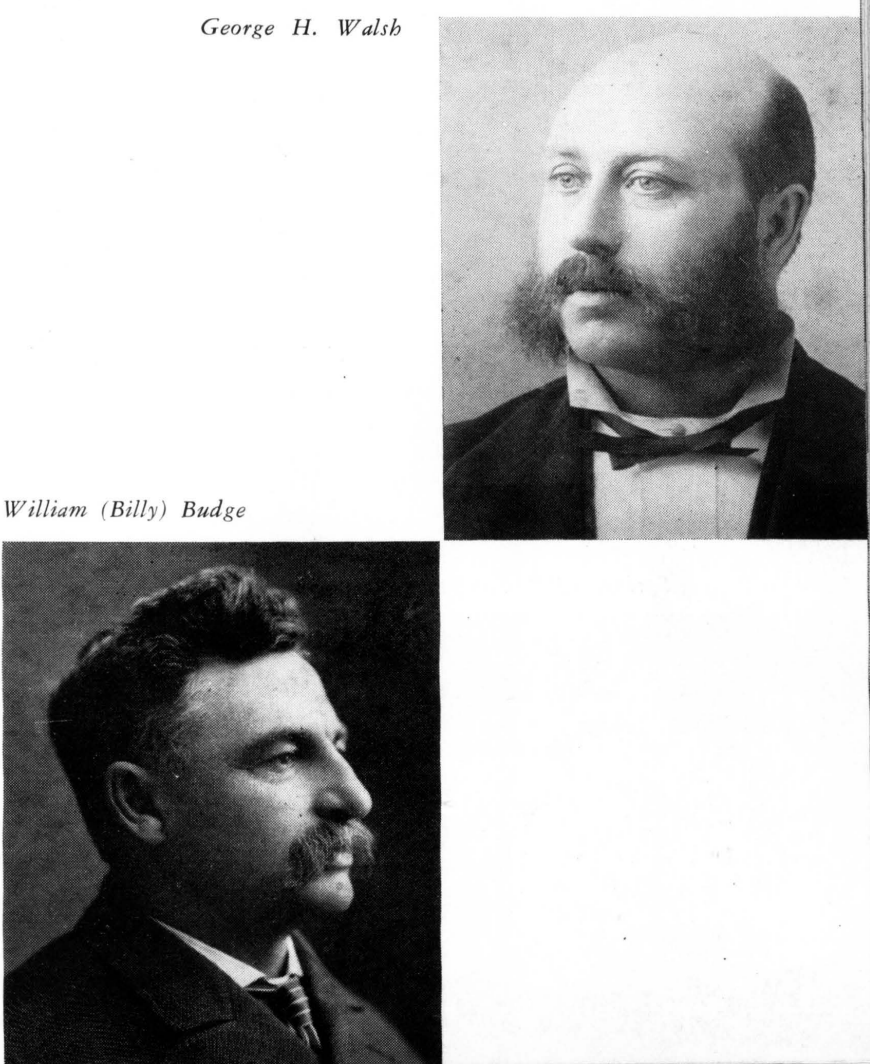


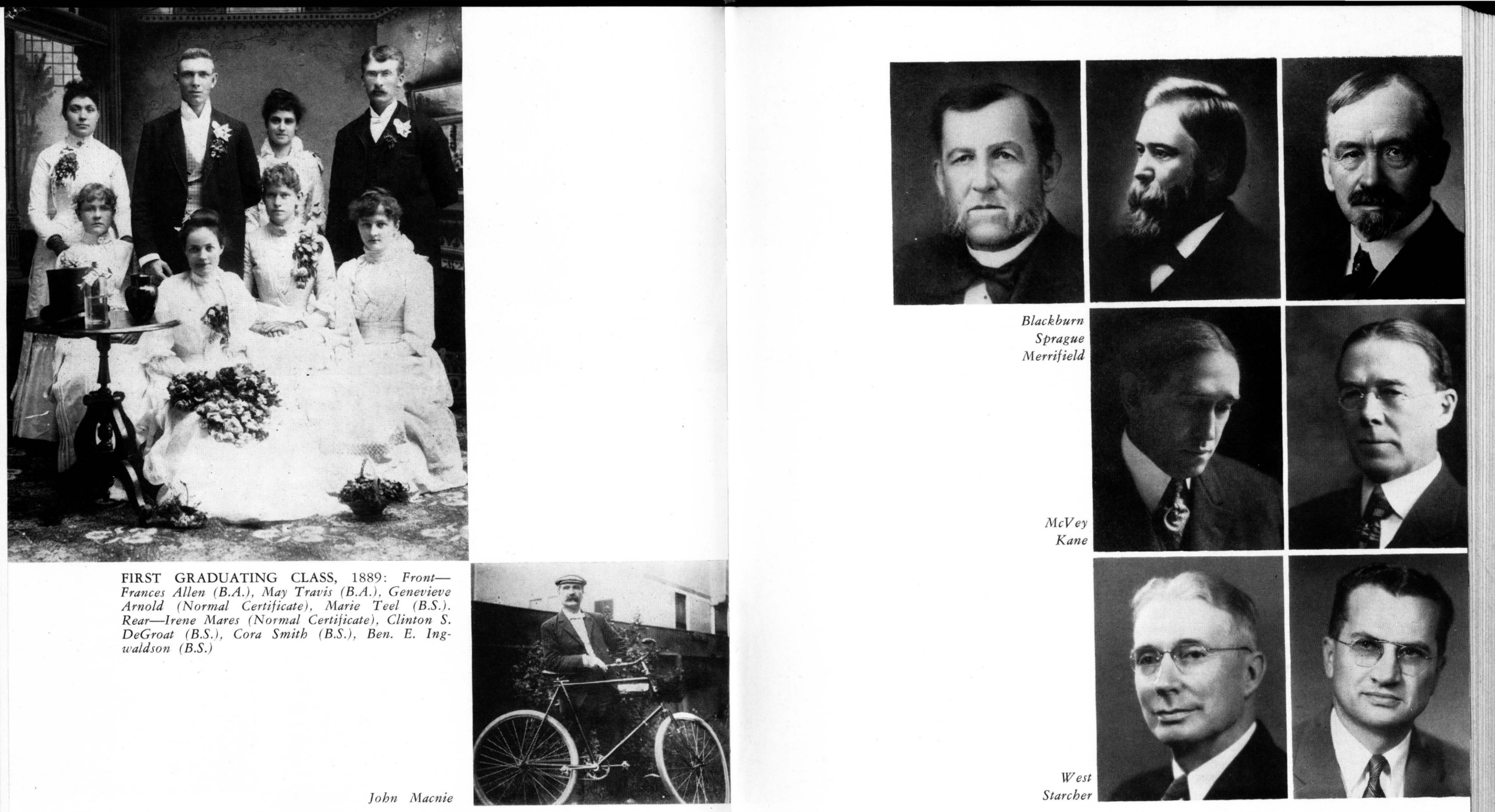

Spring, 1900

Jobn Macnie

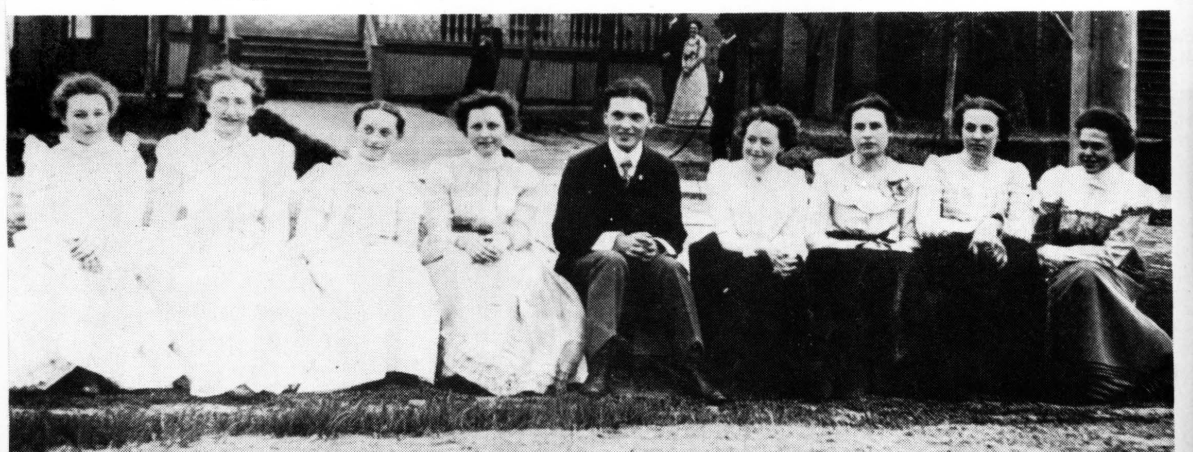

Babcock
Montgomery

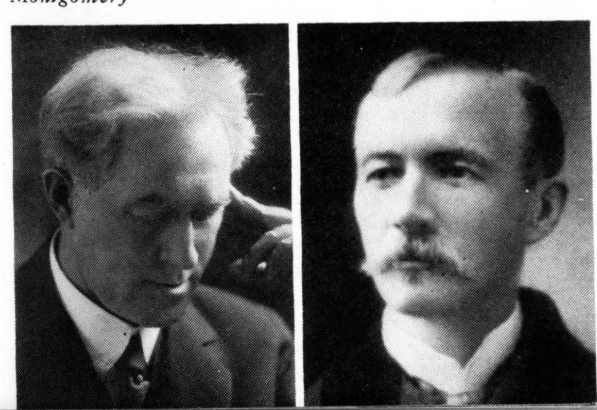

PRESIDENTS: William M. Black-

burn, 1884-1885; Homer B. Sprague,

1891-1909; Frank L. McVey, 1909 -

1917; Thomas F. Kane, 1918

1933; Jobn C. West, 1933-1954;

acting presidents Earle J. Babcock,

Montgomery, 1885-1887. 


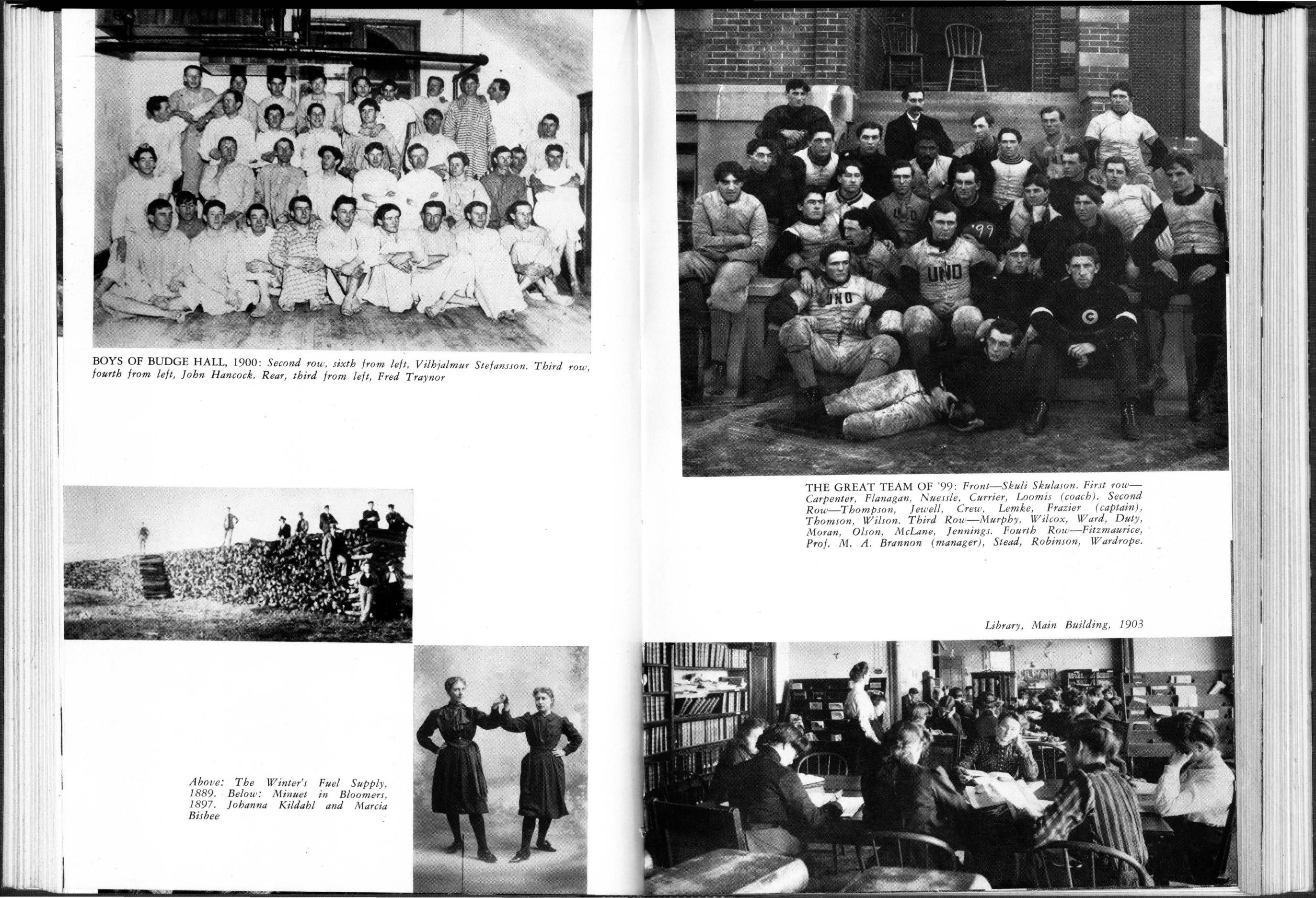




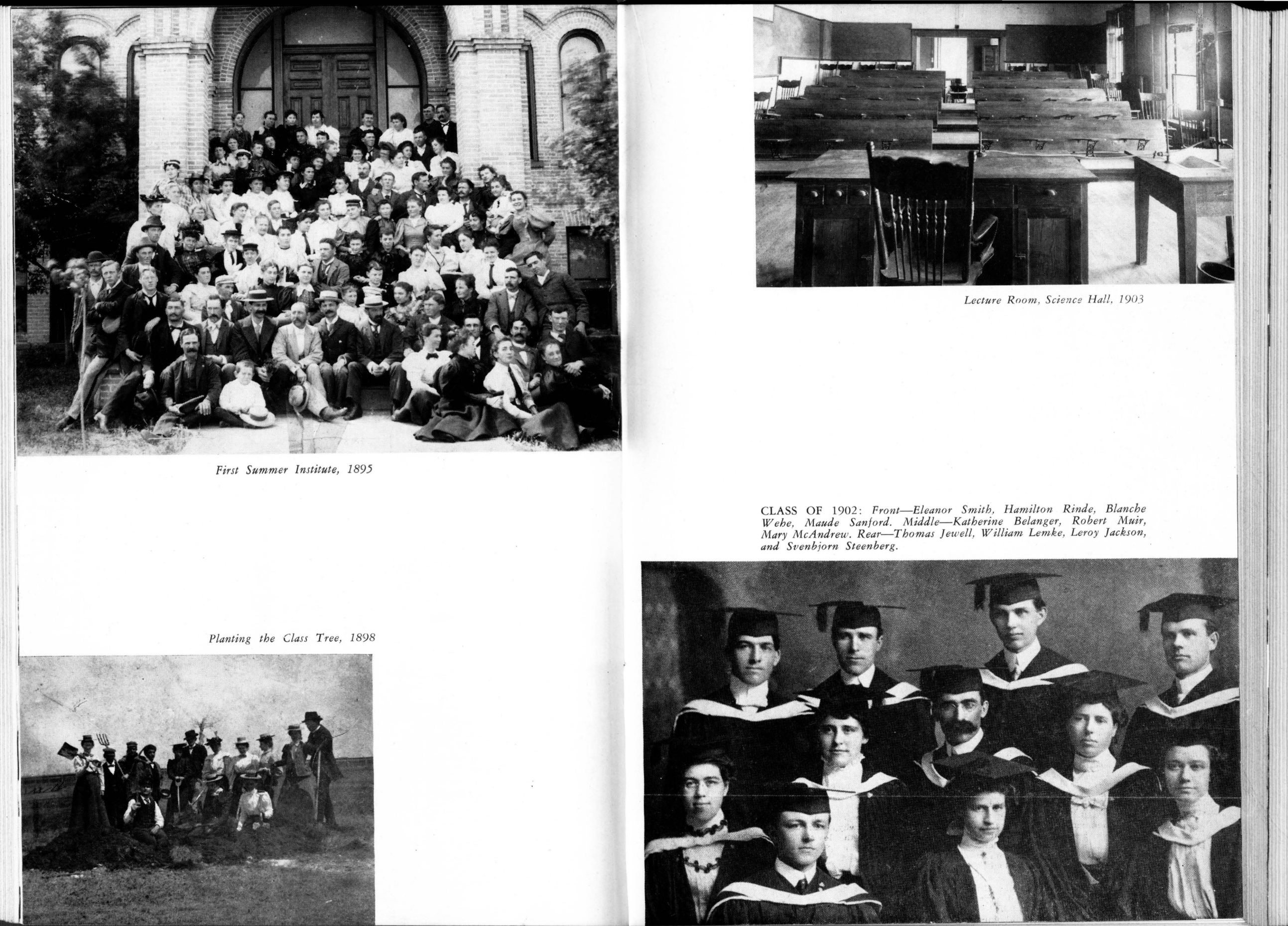




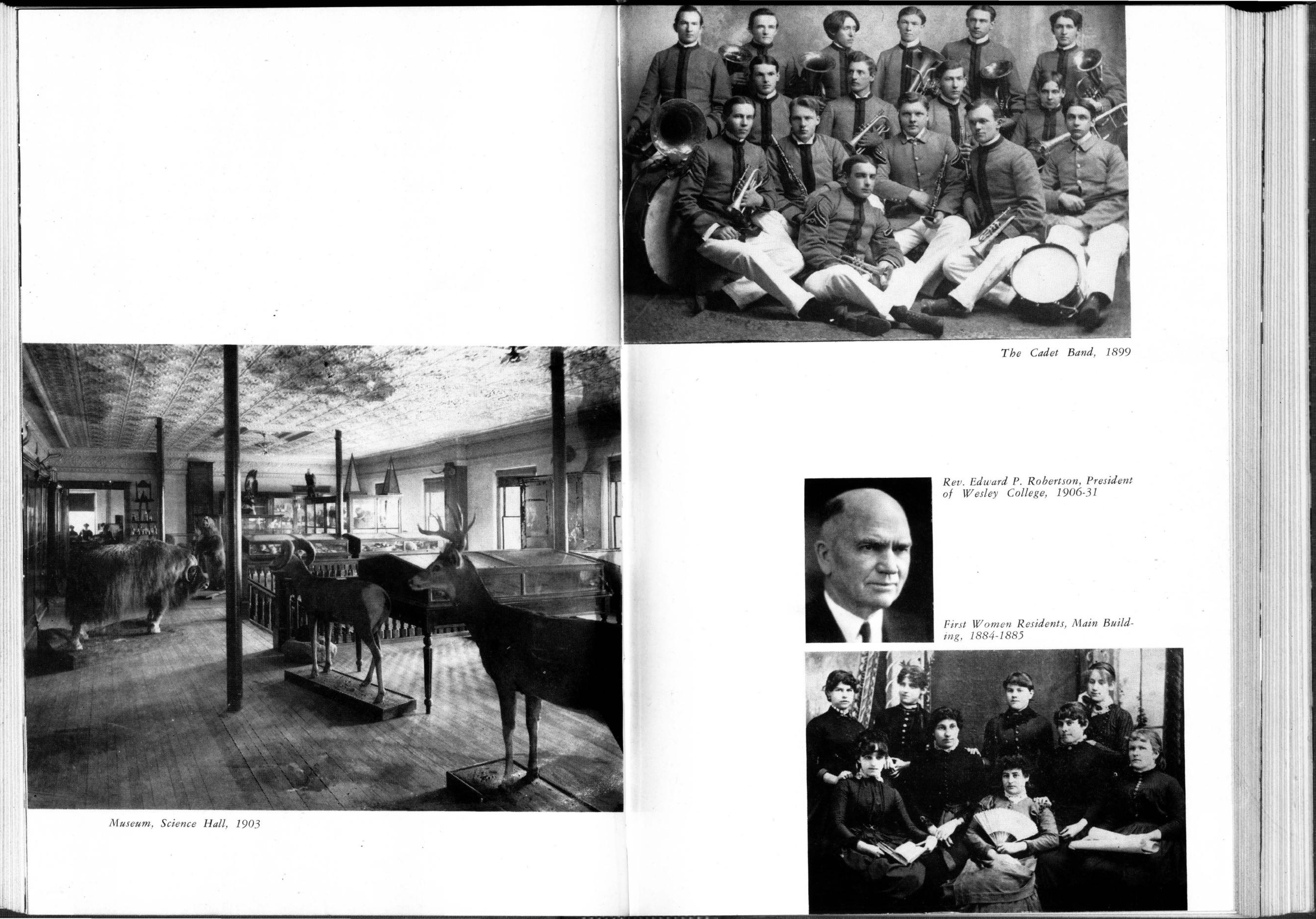


superintendent of public instruction and the governor were ex officio members of the high school board, it was Merrifield, acting as high school inspector and armed with the University control of the matriculation examination, who was the arbiter of the high school teachers' qualifications and the high school curriculum. He had more or less created a University monopoly of high school teaching by his insistence that any new vacancies in first-class high schools be filled only by college graduates. Merrifield's position was fortified by numerous teachers and superintendents trained at the University and likely as not in his debt for the jobs they held. The fact that the high school curriculum accredited by the University was largely oriented to preparation for college not only favored the University but also ran counter to the new views that high schools had other functions.

The first strong assault on the University's control of the high "Pageant of the Northwest," Bankside Theater, 1914

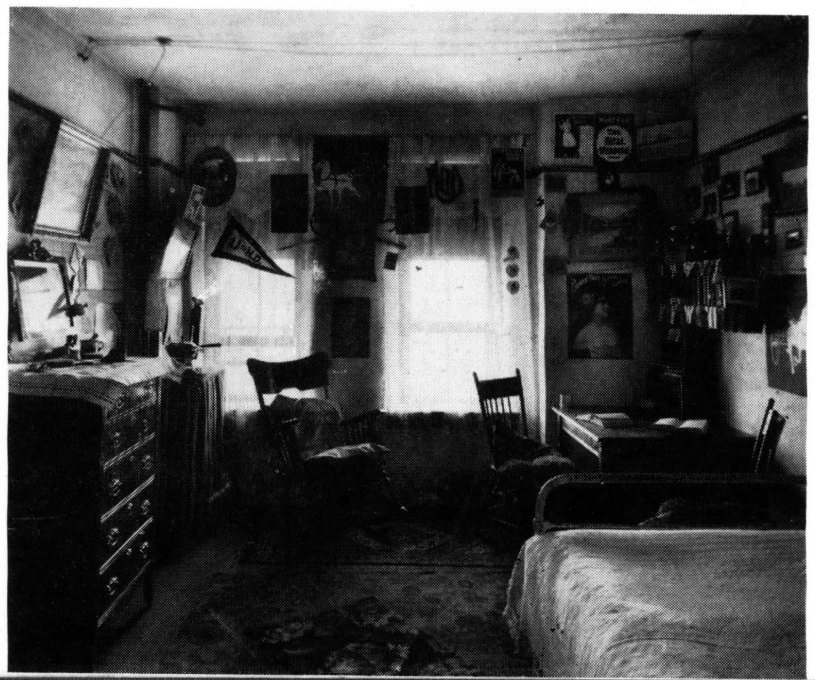
schools came in the legislative session of 1905 in the form of demands from the normal schools for representation on the state high school board. Some supporters of the Valley City Normal had a bill introduced giving places on the board to normal presidents, authorizing the normals to train high school teachers and permitting them to grant degrees. Thoroughly alarmed by this measure, which they branded as "inimical to the best interests of higher education," the University administration and faculty made their first open and direct effort to influence legislation since the days of the Louisiana lottery. High school principals, legislators, alumni, and other influential people were circularized. Merrifield wrote vehemently to one legislator that if he allowed the bill to pass without protest he (Merrifield) would go down as the "Judas or Arnold of North Dakota" instead of leaving to the state "such a monument in the way of service rendered to the cause of Education as I hope to leave." The effort was successful and the bill never got out of the education committee.

The University next attempted to head off the normals by establishing a Teachers College offering a four-year college course modeled on that of Teachers College, Columbia University, for training high school teachers. The appointment in 1905 of Adoniram Judson Ladd (Ph.D., Michigan) brought to North Dakota 
its first professionally trained professor of education. The concession or hedging action, whichever it was, was insufficient to prevent a renewal of the attack in 1907. This time it came in the form of a bill forbidding the University to admit any students below college grade; this proposal also carried the implied threat that the engineering colleges might be closed.

This move called forth a meeting of the college presidents at Bismarck. It was agreed there-the main points were later enacted into law by the legislature of 1907 -that the University Teachers College should be permitted to continue but that all preparatory level work in the University should be discontinued except for a model high school to provide facilities for practice teaching. The normals were limited to offering two years of college work. Eloquent appeals were made for the model school by Kennedy and Charles Christian Schmidt, the former superintendent of the Jamestown schools recently appointed professor of elementary education at the University; both pointed out that it was a forward step which as yet only a few of the major universities in the country had taken. The winter school for rural teachers was ended, but the summer school, which had offered its first college work in 1905, continued to offer secondary work for a number of years. In 1908 the preparatory department became officially the Model School and was assigned quarters on the third floor of the main building, where it remained until the Teachers College building was completed. Schmidt became principal of the school in 1909. The work in the school of commerce was divided between the Model School and the liberal arts college; the latter courses were the first step toward the establishment of a collegiate school of commerce in the 1920's, the last professional school to be added to the University.

The agreement and the act of 1907 marked the beginning of a series of legislative efforts-investigations, reports, reorganizations of governing boards-to keep the colleges within their boundaries and to rationalize the higher educational system. It was a problem which the founders had not worried about, but one which was increasingly important because of the rapidly mounting costs of higher education and the expansion and expensive duplication of college programs. As early as 1903 Governor White had proposed a single board to manage all the state institutions, and in 1909 the first bill for a single board of regents was introduced into the senate.

One of the most important developments of the 1907 settlement, because it marked a major break in the University control of the high schools, was Merrifield's retirement from the position of state high school inspector and the employment of a full-time official who represented none of the colleges. Merrifield, already thinking of retirement, was ready to give up the job; he had found it increasingly arduous and distasteful. As for the normals, their progress to full college status, already begun in 1901 by the University's admission of their graduates to sophomore standing, was not complete until the 1920's. As late as 1916 a large proportion of their entering students still came directly from the grade schools.

A significant addition to the University offering and to the community in general resulted from "affiliation" with the Red River Valley University, a Methodist college, which was moved from Wahpeton to a new site directly across the street from the University in 1906. The move was under discussion from 1899 when it was suggested to Merrifield by the Reverend Edward P. Robertson, president of Red River. Merrifield was enthusiastic, for he saw in the proposal an opportunity to lay the "godless university" myth once and for all, to eliminate a rival as well, and possibly to set a precedent for drawing in the other church schools in the area. In 1905 he and Robertson drew up an affiliation agreement whereby each institution would promise to accept thirty credits from the other toward its degrees; that is, in the case of the University thirty credits in religion courses could be applied toward an undergraduate degree as electives. The Annual Conference of the Methodist Church and the faculty Council accepted the proposal in the spring of 1906, and in the following September the new institution, renamed Wesley College, began instruction in the basement of the Grand Forks public library. Robertson meanwhile had raised $\$ 65,000$ in contributions, including $\$ 25,000$ from the Grand Forks Commercial Club, \$5,000 from James J. Hill, and $\$ 1,000$ from Merrifield, to finance the move and to begin 
his new campus. An eighty-acre tract of land immediately north of the University was purchased, and a ten-acre campus laid out. In October ground was broken for the first building, Sayre Hall, named after one of the principal supporters of the college.

The presence of the college broadened the base of support for the University and made it an indirect beneficiary of some local philanthropy. Two significant gifts came within a few days of each other in 1907. J. P. Hilborn of Wimbledon gave $\$ 1,000$ to provide an annual prize fund for the best thesis or oration on "religious progress," and \$10,000 was given by Mr. and Mrs. Thomas Hazlett of Valley City to endow a yearly course of lectures by some recognized religious leader (these lectures continued until the 1920's).

The college almost immediately made a considerable contribution to the cultural and intellectual tone of the University, in addi. tion to providing some relief in housing-there were no denominational restrictions in the Wesley dormitories. The courses in theology, religious history, and Biblical criticism were an enlargement of the University offering. Wallace Stearns (Ph.D. Boston University), professor of religious history, was a scholar of some distinction. The Hazlett lectures, of which the first series of six, on the higher Biblical criticism, was presented in 1908, were the first event of their kind at the University; the "artist series" that same year sponsored by the Conservatory of Music was another first. The Conservatory proved to be of particular importance for the University; for years it supplied practically all of the vocal and instrumental instruction for the University music department. Dependence on Wesley College was a factor in the slow development of music in the University and the chief cause for the failure to establish a school of fine arts, or even to consider such a step seriously.

"Affiliation" was a fresh idea in which the faculty and administration took much pride, professing to see in it the dawn of a new era of unification of public and sectarian higher education. There was at the time considerable comment in college circles, and on several occasions Merrifield was called upon by other state university presidents to explain the North Dakota arrangement. $\mathrm{He}$ read a paper on the subject at the annual meeting of the $\mathrm{Na}$ tional Association of State Universities at Baton Rouge in 1906. No other university appears to have adopted the plan, and in North Dakota no other sectarian college chose to copy the action of the Red River Valley University. ${ }^{7}$ Indeed, it was twenty years before any other religious establishment even resembling the Wesley College arrangement was made at the University; the Roman Catholic Newman Foundation, established in 1926, was a compromise which has been partially followed by several other religious organizations.

The specialization and expansion of program which produced the new schools and colleges were also manifested in the appearance of many new courses and the fission of old multiple purpose departments into newer and more specialized ones. In 1899, a faculty of seventeen was divided into twelve clearly differentiated departments or courses of study. Only four departments had more than one instructor. Ten years later there was a faculty of fifty-one divided into twenty-five departments or programs. In addition to such staples as economics, political science, and sociology, now offered in separate departments, there had appeared such new courses as household economics, practical library work, journalism, physical training, and manual training; they carried from one to four college credits, usually applicable to the B.A. degree (editors of the Student received one half credit in English). Such new courses reflected the currents of the time in higher education-the fads and dilutions of solid intellectual content as well as the enlarged conception of the role of the University.

For a time the liberal arts college was retarded, or at least overshadowed, by the growth and popularity of the new professional schools, especially the more practical-and easier-law school. By the end of the decade, however, its position as the core of the University was reasserted by such measures as the two-year liberal arts entrance requirement of the medical school, the development, or at least the catalog listing, of combined engineering-liberal arts programs, and the elimination of the subcollege work. The arts college was closely related to the Teachers College-about four ${ }^{7}$ Merrifield may have been influenced by the affiliation pattern that was already well developed in the University of Manitoba at Winnipeg. 
fifths of the work for the B.A. with certificate in teaching offered by the Teachers College was actually given in the College of Liberal Arts. Moreover, its sheer numbers gave the liberal arts faculty a strong position. Of the fifty-one faculty and instructors of 1909, about half were primarily in liberal arts, although their names also appeared in the lists of the professional school faculties. This meant, of course, that to a far greater degree than now, the college exerted a very real leavening influence, an intellectual integration by close associations, if not necessarily by the deliberate planning of special courses. Even so the matter was not left entirely to chance. The program of general public lectures offered by various members of the University faculty that was begun in 1907 is evidence of the concern over the growing tendency to compartmentalize knowledge at the expense of a broad education.

An important factor in the reassertion of the position of the liberal arts college was the fact that its faculty, as much or more than any other, was in the forefront of the revolution commencing in the intellectual outlook of the University. The most important exponents of the old general educational ideal had retired by 1909; Woodworth, the first to go, left in 1904 at the age of seventy-four and Macnie retired in 1907. It was the close of a chapter in the University's intellectual history when Merrifield followed his old colleagues into retirement in 1909. The men who replaced the first Merrifield faculty were of an entirely different type; whether they actually had the degree or not, they were of the $\mathrm{Ph} . \mathrm{D}$. specialist breed that the American graduate schools were beginning to turn out in considerable numbers after 1900 . Of the regular faculty of seventeen in 1899, only Thomas possessed the Ph.D. (even he belonged to the old tradition by temperament and training) and only one, Macnie, had any record of publication. By 1909, in the faculty of fifty-one, nine had the Ph.D. and a considerable number had taken advanced work in graduate school. The athletic coach, David Dunlap, possessed a medical degree from Michigan. All but one (Ruediger) of the Ph.D.'s were in the College of Liberal Arts.

This new type of professor introduced to the University a specialized and professional approach to scholarship and a concern for scholarly reputation in professional societies as well as for teach- ing reputation among undergraduates. It meant some shifting in teaching methods, influenced also by larger classes, from textbook recitation to lectures and self-education in the library and laboratory, these in turn accompanied by less faculty policing of students' study. It meant the arrival of the seminar and the beginnings of graduate study in the true sense. And, finally, it meant an expanding conception of the University's function as an instrument of direct service to the state. By the standards of the great universities, the total productivity of the second Merrifield faculty was still in significant by 1909; nevertheless, one or two had won some recognition and a number of the rest were to win it at North Dakota or elsewhere. The new faculty was young for the most part; only two were past fifty and most were under forty-mature scholars were difficult to attract to North Dakota with its harsh climate, meager facilities, uncertain University financing, and a salary scale, unchanged since 1883, which was slipping behind those in better financed institutions.

It was significant of the shifting emphasis and growing awareness of the need for University publication that in January, 1904, there appeared the first issue of the University Bulletin, a quarterly publication devoted chiefly to public information but on a level somewhat above purely promotional material. It is no less significant that the Bulletin's editors should deem it important in 1907 to compile a list of publications by the faculty in the year gone by. The list included fourteen articles by Bruce in such journals as the American Law School Review, the Central Law Journal, the Green Bag, and the Michigan Law Revicw; three by A. G. Leonard in various geology journals; three by George Stewart (physics), one in a German journal; two by Kennedy; three by James Boyle (economics) in The Arena, Outlook, and the American Journal of Sociology, and his book in press, The Financial History of Kansas, and Squires's edition of Tennyson's In Memoriam.

Of those who came to make up the second Merrifield faculty, the man who could boast the best established professional reputation was Orin G. Libby (Ph.D., Wisconsin), appointed in 1902 to the department of history to relieve Woodworth, who was about to retire. A tall, spare man of thirty-eight, Libby had a passion for 
accuracy that was equaled only by an inflexible, almost fierce integrity. He established a campus reputation as the guardian of student academic standards, faculty rights, and administrators' ethics. An assistant professor at Wisconsin when he accepted the offer from North Dakota, Libby was one of the first Ph.D. candi. dates to be advised by Frederick Jackson Turner, the famous historian of the frontier. Libby's published dissertation, Geographical Distribution of the Vote of the Thirteen States on the Constitution, 1787-1789, is still referred to by historians. The year after his arrival at North Dakota he was a leader in the revival of the moribund North Dakota State Historical Society. He became its first secretary and editor of its publication, the Collections (now North Dakota History), positions he held for forty years. The first volume of the Collections appeared in 1906. By 1909 Libby's work with the Society and his own studies of early exploration in the northern plains had won him a place as the state's semiofficial historian. His professional standing, based on a formidable publication list of nearly forty scholarly and popular articles, was recognized that year in his election to the presidency of the Mississippi Valley His. torical Association, the regional society of historians that he had helped to form two years before.

In the related fields of economics and sociology there were two strong additions by 1909, Boyle and Gillette. James Boyle arrived in 1904 shortly after receiving the doctorate from the University of Wisconsin (he was also a graduate of the United States Naval Academy) to take over the teaching of economics and political science. These had formerly been the responsibility of Merrifield, and, for a brief period, of Samuel Peterson, a member of the law faculty. Boyle was a native of Kansas, deeply interested in the problems of the plains region and thoroughly indoctrinated by the historical and activist school of economic thought that had been developed by the famous Wisconsin department of economics gathered around John R. Commons and Richard Ely. A dynamic little man of thirty-one, Boyle was a vigorous scholar and active in public and student affairs as well. Among his first moves was the organization of a campus civics club and a state branch of the National Tax Association. He had been on the campus barely two years when he persuaded James J. Hill to donate $\$ 4,000$ to the library for the purchase of a collection of books on transportation. Boyle remained until 1916; he ended his career as professor of rural economics at Cornell University.

The University acquired its first professionally trained sociologist in 1907 in the person of John M. Gillette, another native of Kansas. "Discovered" by Libby on the faculty of the Valley City Normal, where he had been since 1903, Gillette was brought to the University as assistant professor of sociology and history-he was promoted to professor of sociology in 1908-almost solely through Libby's intercession. Forty-three years old, Gillette was one of those men who mature late. He was an active intellectual seeker who had tried the ministry and abandoned it for the study of sociology when he lost confidence in the effectiveness as well as the validity of his message. He received the Ph.D. from the University of Chicago in 1901. Like Boyle he had taken his training with some of the most stimulating and original scholars in his fields of interest, the outstanding ones being Albion Small and John Dewey. Although his dissertation dealt with an urban sociological question, he soon turned to the problems of his own milieu. By 1909 he already had under way those investigations of rural life and conditions which resulted in the numerous books and articles that won for him the accolade of "founder" of rural sociology and the presidency of the American Sociological Society in 1928.

The negotiations surrounding Gillette's appointment have a particular interest because they reveal Merrifield's educational viewpoint as well as some of his administrative methods. Impressed with Libby's enthusiasm for Gillette, Merrifield was willing to listen to his advice. Yet he carefully investigated Gillette himself, to the extent of making numerous inquiries about him in Valley City and inviting him to the campus for a convocation lecture. $\mathrm{He}$ was particularly concerned with Gillette's "radical" views on public issues and on religion. Gillette was a fervent Progressive, undoubtedly more than a little sympathetic to the views of such socialists as Eugene Debs, and a religious agnostic, beliefs which he made no great effort to conceal even in Valley City. Assured 
by Libby that next year they would "spoil the Egyptians," Gillette frike safely passed Merrifield a conservative tone. Mimself, but he was impressed by his intellectual integrity and trusted to his good sense not to embarrass the University. In the course of the correspondence with Gillette, Merrifield undertook to set down his own approach to the perennial problem of intellectual freedom for the faculty of a publicly supported university:

I judge that your views in regard to certain social doctrines are considerably 1 judge the that would no more necessarily prejulice I judge from what I learn that your views are those of the individualists. I judge freedom of individual of a collectivist of the colloctivis same time I should belief is conceded to everyone our faculty express in public or in their be unwilling to have members of our faculty expe north Dakota community classes views which would be so distasteful to the North Dakota community in general that their expression would alienate from the University the cordial sympathy and confidence of the average citizen of the state. While every man may justly claim for himself the right to his honest views, I do not feel that a man connected with a public institution has a right to exploit his honest views to the detriment of the institution with which he is connected. I am confident that whatever your views in regard to social questions may be, your good sense would prevent you from exploiting these views to the disadvantage of the institution. The charge was very these viel brought against the University at Bismarck last winter that the commonly brought agared of anarchy. While this charge was absolutely instiction without fout constituency upon which the Unicareful not to give offense to ther state institutions has to depend for its versity together with the oth vich support. I am perfectly aware that views with in some of the class rooms personally are given expression to every day in some of the University. I would not have it otherwise, but I must recognize, of course, as the final responsible head of the University, that the average citizen and taxpayer has not been trained to the exercise of the same measure of tolerance and recognition of the many sided aspects of truth that one must have been who is fit to be connected in any responsible way with an institution of learning .... I will promise to be absolutely candid with you and I am sure that you will be the same with me.

This is the first hint of the academic freedom issue that was to raise some serious difficulties and demand an attempt at precise definition in the administration of Merrifield's successor.
The sciences and mathematics, neglected in the 1890's and more or less in the shadow of the engineering and medical schools, were materially strengthened. Elwyn Chandler (M.A., Ripon), appointed in 1899, quickly won a local reputation as a brilliant mathematician. He became the first professor of civil engineering in 1910 and was dean of the College of Engineering from 1927 to 1932. Appointed hydraulic engineer for the United States Geological Survey in 1903, he early began the detailed investigations which established his reputation as a leading expert on water resources and stream flow in the northern plains. Wilder and Leonard in geology were both strong appointments. George Stewart (Ph.D., Cornell), who came in 1904, gave a fresh start to the physics department. When he left for the University of Iowa in 1909, where he remained until his retirement in 1942, his successor was the brilliant Albert Hoyt Taylor (Ph.D., Göttingen). In 1907 the appointment of Robert T. Young to the department of biology filled a gap occasioned by Brannon's heavy duties in the medical school. When Brannon left in 1914, Young became the head of the department; he remained until 1926.

Languages and literature received four important additions, Koch, Hult, LeDaum, and Tingelstad. The appointment of Frederick Koch in 1905 as instructor of English and public speaking marked the beginning of the first serious study of dramatics at the University. Koch fitted almost to a $\mathrm{T}$ the qualifications once outlined by Merrifield for a new English instructor- "strong on the oratorical side rather than the philological side . . . an inspiring teacher [and] an incomparable speaker." A graduate of Ohio Wesleyan, he had spent five years at Boston and Harvard where he had come under the influence of George Pierce Baker, one of the great playwriting teachers of his time; he had also studied at the Emerson School of Oratory and had won some recognition as a monologist and impersonator. With his flowing hair, beribboned pince-nez, and Windsor tie, habits of dress copied from Baker, his idol, Koch was the first authentic campus "character." It may be added that he understood the value of personal publicity as well as he understood his job.

The appointment of Gottfried Hult (M.A., Minnesota) in 
1908 as professor of classical languages brought to the campus the nearest thing to a writer in residence that the University has ever had; he was also the only representative of the older tradition in the new Merrifield faculty. Speaking for new faculty members at a reception in their honor, he declared: "I am here to work for the leavening of the University with the Greek spirit." He had been professor of English from 1901 to 1908 at the Agricultural College and had traveled extensively abroad, studying at several European universities, including the University of Rome. An impressive lecturer on a wide variety of subjects in the fields of ideas, English literature, and the classics, he was also the most accomplished poet, certainly the most productive, ever to serve on the faculty. His admirers among writers and critics included Richard Watson Gilder, editor of the Century magazine. Gilder told a University of Minnesota audience in 1909, shortly before the publication of Reveries, Hult's first book of poems: "When Professor Hult's book is published, America will know that she has a poet of distinction." Hult's poems were appearing regularly in the Century when he came to North Dakota, and he continued for nearly forty years as a teacher, lecturer, and writer of considerable merit.

Henry Le Daum (B.A., Harvard; M.A., Ohio Wesleyan), who came in 1907 to replace Macnie in the department of French and Spanish, was the first Romance language scholar on the faculty. A native of French Switzerland, he had been an instructor at Iowa and Northwestern universities. In 1908 he published an edition of Rostand's Les Romanesques.

The most significant development in the field of languages from the local standpoint was the appointment of the Reverend John Tingelstad in 1901 as the first full-time professor of Scandinavian and German languages. He came from Norway in 1879 at the age of seventeen, graduated from Luther College, Decorah, Iowa, and for fifteen years had been a Lutheran clergyman and principal of a small academy in North Dakota. Chosen less for his distinction as a scholar than for his high standing among the Norwegian population, he was nevertheless required to spend a year of travel and study in Iceland and Norway before beginning his duties. The appointment was enthusiastically received in the large and self-conscious Scandinavian community. Within a few months after Tingelstad's arrival on the campus, the Icelandic alumni, among them Gudmundur Grimson and Bardi and Skuli Skulason, had formed an association with the announced intention of buying the "finest Icelandic library in the world." The next year Asle J. Gronna, a member of the Board of Trustees, fired his compatriot Norwegians to launch a campaign for a library of five thousand volumes. The Trustees voted to add $\$ 500$ to the Icelanders' and $\$ 1,000$ to the Norwegians' funds. Although neither group collected more than half what they hoped to get, Tingelstad was dispatched to Europe in 1905 to buy the first installment of the Scandinavian collection. It was officially opened on May 17, 1906, the independence day of Norway, with an all-day celebration, the first official observance of the date ever held at the University. A Norwegianlanguage program at the Opera House in the morning was followed by another in English in the afternoon, at which Merrifield presided. The main addresses were by the president of St. Olaf's College and Gronna, then a Congressman. The inauguration of the collection marked the University's belated recognition of the intellectual and cultural tradition of the state's major immigrant group. The ceremonies were accompanied by a performance of Jeppe on the Hill, or the Transformed Peasant, by the eighteenthcentury Danish playwright, Ludvig Holberg. The play had been translated by two students, Waldemar Westergaard and Martin Ruud, both of whom were to have distinguished academic careers at the universities of California and Minnesota respectively.

The Scandinavian department's achievement of full status had much to do with the rapid increase in the numbers of students of Scandinavian descent. The change in the character of the student population from that observed by George Hodge in 1891 appears in the religious census for the winter term of 1904-1905. Of 337 students enrolled, 78 were Lutheran (i.e., mostly Norwegian), 64 Methodist, 54 Presbyterian, 37 Catholic, 28 Congregational, 20 Baptist, seven Episcopalian, three Christian Scientist, three Spiritualist, and one Unitarian; 42 declared no preference. ${ }^{8}$

${ }^{8} \mathrm{~A}$ half century later, of 3,440 students, 1,499 were Lutheran, 801 Catholic, 344 Methodist, 309 Presbyterian, and 75 Episcopalian. Only 46 declared no preference in 1956 . 
The quality of the new faculty was matched by appointments in such diverse areas as the library and the department of athletics. The first full-time librarian, Cora F. Dill, was appointed in 1901. In 1904, after George F. Strong, a graduate of Wesleyan University, became librarian, the second professionally trained staff member was added. Strong left in 1908 for a position at Boston University; he eventually became head librarian at Western Reserve. He was succeeded at North Dakota by Charles Compton (1908-1910), a recent graduate of Melvil Dewey's New York State Library School. the foremost institution of its kind in the nation. He, too, had a distinguished career after leaving North Dakota. Meantime the library grew from less than 8,000 volumes in 1899 to nearly 25,000 by 1909 . It had achieved the distinction of several special collections or the beginnings of them: the Cochrane collection in law, the Scandinavian collection, and the Hill collection on history of transportation. By 1909 it had developed the practices common to University libraries the country over: systematic cataloging using the Dewey system, two-week loans with two-week renewal, small fines for overdue books, and service in the evenings and Sunday afternoons.

It was fully in keeping with the character of the new faculty that the first full-time athletic directors to serve for any extended time were licensed physicians. Dr. Sweetland was succeeded in 1908 by David Dunlap, an M.D. from Michigan. Dr. Dunlap was also a specialist in his field of athletics, having played football on some of the famous teams of "Hurry-Up" Yost.

The University was depending for the most part on young men, a number of them in their first post after achieving the Ph.D. A good many did not stay long, although enough did to hold the institution to its course and to indoctrinate the newcomers. The University's remoteness and other obvious inadequacies were insuperable handicaps to many scholars, but to ingenious men like Babcock, Libby, Gillette, and Boyle, North Dakota offered a virgin field of inquiry. Salary and promotions were generous within the limits set in 1887. It is worth noting that the older faculty who had weathered the hard times of the 1890's were prepared to advance the able young men rapidly. Promotions could have been a serious sticking point, because they were often taken up in full faculty until 1906 when the establishment of the Council excluded the junior instructors and assistants. The terms on which Gillette was appointed were the usual ones for mature men: assistant professor for a year (this varied of course) at a salary of $\$ 1,500$, promotion to professor and a salary of $\$ 1,750$ if satisfactory, salary increased to $\$ 2,000$ at the end of a year as professor, and up to $\$ 2,250$, the maximum for the University, at the end of the fifth year. The fact that deans also taught a full schedule and were paid the same or only a little more than professors and that the president received only $\$ 3,000$ emphasized the democratic quality which was one of the University's most attractive features. Without any rules, or even much discussion apparently, tenure was firmly established in practice. The absence of any provisions for retirement pay was not a serious objection for most appointees; few institutions anywhere offered such benefits, and most of this Merrifield faculty was young. Yet considering the other handicaps of the University it could have benefited enormously had it taken an advanced position in providing pensions at this early date. Merrifield sensed the opportunity; when Woodworth retired in 1904 at the age of seventy-four, the president persuaded the Trustees to vote his old friend the title of emeritus and an annual pension of $\$ 600$. Their additional resolution that henceforth all professors reaching the age of seventy-five and having fifteen years of service at North Dakota might receive a pension of 30 per cent of their salaries was meant well, but was hardly realistic. When the Carnegie pension system for professors was established in 1905, Merrifield asked the Trustees to recommend that the University be brought under it, but the legislature turned down the proposal in 1909.

The higher academic standards represented in the new faculty, the multiplication of schools and courses, the growing prestige of the professional societies and college accrediting associations all had the effect of forcing the University into the prevailing mold of higher education. In 1907 the three-term system was dropped for the semester plan; with that came the semester-hour system of counting student credit, ${ }^{9}$ and the division of the 124 hours required 'The semester-hour system of measuring students' progress was in more or less general use in American colleges by 1907. 
for the B.A. degree into a basic required course of 48 credits, a major-minor combination of 32 to 48 credits, and the rest elective. It was not until the 1920's, however, that the major-minor system fully evolved into its present form. Grades, formerly recorded in numbers or percentages, were given in letters (A-F) by 1908 ; the minimum standard for graduation, begun in 1908, was the grade of at least "C" in no less than half the courses counted toward the degree. The high school entrance requirement had been raised to fifteen courses, including two in foreign languages, and one in geometry for prospective engineers. After the University lost con trol of high school inspection in 1907, the principal's mark was acceptable for entrance, even if the student applying for admission failed the University high school examination.

In 1903 the faculty inaugurated a "credit for quality" scheme, whereby good students could make extra credit and hence accelerate their progress toward graduation. Although much was made of the plan when it appeared, it seems never to have been very effective; it was dropped immediately after McVey became president. An honors system was also begun in 1903: students with an average of "B" could do extra work, take special examinations, or write an essay to win an honors degree in a designated subject. In 1907 the program for the master of arts degree, the only graduate degree, and offered only by the College of Liberal Arts and the Teachers College, was put on a formal basis; an effort was made to elevate it to true graduate level by placing the direction of such work under a faculty committee and requiring that the major work be in courses "designed primarily for graduates."

The departmental study clubs, nearly a dozen of them, ranging from the French Academy through the Homiletic Club (Wesley College) to the Von Haller Medical Society, also stimulated higher academic achievements. Although, it is true, only one prize was offered in the University purely for scholarship, the ambitious were spurred on by the fellowships and assistantships that were being offered in increasing numbers elsewhere. In 1902 the announcement of the terms of the Rhodes scholarships, one of which was to go to North Dakota, excited great interest and vigorous competition. A geology student, Henry Hinds, won the first award in 1904, and his progress was watched with loving pride. Hinds distinguished himself in athletics and won a First in geology at Oxford. Two more prizes, fellowships at Wisconsin and Chicago, went to John Lee Coulter and Gudmundur Grimson in 1905. Coulter, who completed his work in 1908, was the first University graduate to obtain the Ph.D.

There were evidences on every hand of the rising standard of the University, including the increase in the number in the college graduating class from ten to 75 from 1899 to 1909; at the Agricultural College, where high school students still outnumbered college students by 329 to 231 , only 17 received the B.S. degree in 1909. Recognition of a sort had been achieved through the professional standing of some of the faculty and in the acceptance of University students by other colleges without loss of credit. The medical school had been approved. The University as a whole, however, had not been accredited by any of the large associations. In fact, in 1908 an application for a charter for a local chapter of Phi Beta Kappa was turned down.

The University was in the process of earning the approval of North Dakota. This was to be won partly on the evidences of merit, of course, but in part it was accorded when faculty and administration descended from their ivory towers to search openly for friends, to advertise the University's achievements, and to claim for it the title of "leading educational institution in the state." The observance of Founders' Day, begun in 1904 on the University's twenty-first birthday, offered an annual opportunity for self-advertisement as well as for sober reflection on the past. The first celebration, held on Saturday, February 27, 1904, although so simple as to be nearly private, received wide newspaper coverage, even headlines, and called forth many expressions of sentimental pride in the progress of the state's one university. The observance occupied the whole day and marked the anniversary of the signing of the organic act, a date selected by the faculty as the official birthday. A debate on Friday evening opened the ceremonies. On Saturday morning Gottfried Hult, then at the Agricultural College, addressed students and faculty in the Budge Hall Armory. In the afternoon there were students' speeches and a girls' basketball game in which the Uni- 
versity trounced the Fargo High School 15-4. The main program was presented in the evening at the Baptist church. Bardi Skulason ('95) spoke on "The University and the State"; the major address, "The University-Its Past," was given by Merrifield. George Walsh, then living in Minnesota, was unable to accept an invitation to attend but submitted a long letter relating the story of the events of 1883 at Grand Forks and Yankton, which was incorporated into Merrifield's speech; it remained for years the official version of the founding. In his address, Merrifield outlined the history of the University and emphasized his conception of the high role it must play in North Dakota:

What North Dakota is going to do on its 100th or 500th anniversary will depend not so much upon when she was born into the sisterhood of commonwealths as upon the store she sets upon those things that affect the finer issull of life. In a recent number of the Outlook, George F. Kennan, the well-known witer on Russia, likened the banishment of well-known Russian scholars and writers to Siberia to the suppositious banishment of W. D. Howells, Richard Watson Gilder, and John Burroughs to North Dakota. The only .... answer to George Kennan was, not to cite the fertility of North Dakota soil-Siberia has soil almost if not quite as fertile-but to cite to him ... the fact that North Dakota spends annually more money per capita for education than any other state in the union

Massachusetts occupies a great place in history in spite of her sterile soil; North Dakota may occupy a very insignificant one in spite of the boasted fertility of our Red River Valley. If, 250 years hence, North Dakota's leading institution of learning shall number among her graduates, as Harvard does today, nearly one-sixth of all the presidents of the United States, together with great jurists, statesmen, scholars and writers almost without number, it will be to Nort sumber, it will be known as philosophers and Roman statesmen.

The University made much of this annual event, finding in it an opportunity for review of accomplishments and reemphasis of its role. The date of Founders' Day was moved to February 23, the day the organic act was passed, and the celebration was usually held on Washington's birthday. On the twenty-fifth anniversary, celebrated in Merrifield's absence (he was wintering in California), Governor John Burke was present, and Chancellor Frank Strong of the University of Kansas delivered the main address, entitled "The Present Age and Its Universities." Gottfried Hult read an ode he had written in honor of the event.
From the standpoint of the general quality of work over a broad area and of the number of college grade students there was no gainsaying that the University outranked all other institutions in the state, public or private, by a wide margin. Its academic and intellectual leadership was generally accepted, not without some irritation, even by the supporters of the other institutions as well as by the general public. On one occasion a parent canceled room reservations for his sons with the explanation that they were "not far enough advanced" for the University and would do better to go to the Agricultural College. An important aspect of this acceptance of the University's role was the bearing of the faculty. Perhaps at no time since has it been so highly confident of its intellectual preeminence in the state. In part this was related to the fact that in a day when most people had not even been to high school there was a wide gap indeed between the holder of the Ph.D. and the average citizen. Economic independence was also a factor. Once times improved and salaries had recovered their previous level, the professors were in a not unfavorable situation. The top salary of $\$ 2,250$, less perhaps than was paid by richer institutions, was nevertheless more than either the Agricultural College or the normals paid and compared favorably with the average income of lawyers and physicians in North Dakota. This amount went far in a day when few of even the largest houses in town sold for more than $\$ 5,000$ and when four-room cottages could be had for $\$ 900$ to $\$ 1,500$. Salary payments were frequently delayed, partly because Merrifield did not follow proper budgeting procedures, and most members of the faculty and instructors received considerably less than the maximum. But the professor of the 1899-1909 period considered himself no downtrodden member of the lower middle class and was accustomed to move in the higher social circles of North Dakota.

When it came to direct services to the state and public recognition of them, however, the University found itself outstripped by the Agricultural College. To be sure, the Geological Survey and School of Mines had a clear claim to credit for whatever development of mineral and water resources there had been, and the professional schools provided North Dakota with both trained 
personnel and opportunities for low-cost professional education. But these services touched fewer people in North Dakota, depending as it did almost altogether on agriculture, than did the Agricultural College's more practical curricula, including its winter short courses for the working farmer and mechanic, and its active experiment station. By 1909 it was a rare farmer-and hence a rare North Dakotan-who was not grateful for the Agricultural College's work in eradicating the Russian thistle, finding new seeds and improving old strains, solving the problem of "flax sickness," and developing the cultivation of sugar beets and potatoes. The names of C. B. Waldron, H. L. Bolley, and E. F. Ladd were more widely and affectionately known by 1909 than those of any mem bers of the University faculty. Ladd was well on his way to being recognized by every man, woman, and child in North Dakota because of his experiments and work as inspector of foods, seeds, paint, the milling quality of wheat, and nearly anything else one could name. It was competition like this, plus the conception of expanding University service introduced by the new faculty members and by Merrifield's acquaintance with men like Charles R. Van Hise of Wisconsin and Cyrus Northrop of Minnesota, which caused a growing concern in University circles about its relation to the state. Indicative of how far such thinking had progressed by the end of the decade was the faculty Council resolution in 1907 to "endeavor to make the University a larger factor in the life of this state." During the 1907-1908 term the subject of the monthly faculty meeting lectures, a custom begun in 1906, was "The University and the State" on two occasions and on another, "The University and the Alumni."

The University's efforts to improve its public relations were much advanced from the day when the sum total of its publicity consisted of a few folders and the annual catalog announcement with a hole punched in one corner for hanging in post offices. The faculty resolved to launch a publicity program in 1903, most of which consisted of planting feature articles in the newspapers. Beginning about the same time, high school principals were circularized each spring for the names of those graduates "who may be induced to attend" the University. Those named received a five-page circular detailing the advantages offered by the University that twenty-five years hence would "enjoy as great prestige in this state as the University of Minnesota or Wisconsin does at present in their respective states. I am told by professional men and politicians from Minnesota and Wisconsin that everything in those states is controlled by graduates of the local state universities . . .." The first student annual, the Dacotah of 1904 , went to every high school. The quarterly Bulletin appeared in 1904, and in 1907 the semimonthly newsletter for distribution to the state newspapers, which in one form or another has continued to the present day. The touring student organizations-band, glee club, and the dramatists-were also a regular feature of the publicity program. On one occasion the North Dakota-Montana debate was held in the House chamber of the state house; Governor John Burke presided. The lecturing professor was also heard in the land; two of the most popular were Squires and Brannon, but Libby, Gillette, and Boyle also had their followings. Each year the University issued lists of lecturers and their subjects for the season. The fees were nominal, usually no more than expenses.

The professors also played an important role as leaders or active participants in a number of semi- or nonacademic state organizations: the North Dakota State Bar Association, the North Dakota Academy of Science, the North Dakota State Tax League, and the North Dakota Science and Mathematics Association. In Grand Forks, professors were the most active half of the town and gown Fortnightly Club, formed in 1898 to promote intellectual discussion as well as rapport between townspeople and the University. For half a century Fortnightly enrolled every University president and leading members of the faculty. A similar organization, the Franklin Club, appeared in 1907. Not the least importan was the University's leadership in developing the Alumni Association. By 1909 the University had 628 alumni, about three fourths of whom were living in the state. Recognizing their potential power as well as their usefulness in recruiting students, Merrifield and the faculty enthusiastically approved the formation of the first local alumni group at Devils Lake in 1907. Koch was sent to address the opening meeting. One of Merrifield's last acts on behalf of the 
University was to circularize friends and alumni to support Wardrope, one of his "boys," for appointment to the Board of Trustees. Nor was the role of the students overlooked. The fine hands of Merrifield and Squires were plainly visible when a 1,500 Club, ostensibly a student enterprise, was formed in 1908 with the announced goal of bringing enrollment to 1,500 within the year.

At the same time the University was welcoming the public to the campus at every opportunity. The high school principals came each spring after 1901 for a conference with Merrifield; a high school track and field meet held in connection with the meeting in 1903 was expanded in a half dozen years into a high school day of contests in track, field, and forensics, which attracted contestants from seventy-five schools. Public receptions and open houses also became a regular feature of the University year. The reception in January, 1899 , to mark the completion of the remodeling of Davis Hall was the first such public affair since 1886, but thereafter it became the custom on the completion of each new building. Some four hundred guests brought out by special train from Grand Forks attended the reception and open house that celebrated the opening of Budge Hall and the installation of electric lighting in December, 1899. The new building and its "magnificent drill hall" (that is, the basement) were much admired, as were the young ladies who "daintily served" the "light refreshments." The outdoor reception at commencement in June, 1900, when "hundreds" of Japanese lanterns made the campus a "veritable fairyland" and "all was the scene of pleasure," launched another annual custom. These affairs reached a high point in 1908 when the reception and open house were combined with the dedication of three new buildings-the Carnegie library, the new gymnasium, and the mines building.

The smaller, less official visit was no less encouraged. Two young preceptresses, Emily K. Reynolds (1899-1901) and Annie Long (1901-1905), did much to awaken local interest in the University by holding teas in Davis Hall for Grand Forks women, who in turn responded with teas for the girls in their homes. Mis Reynolds, who left in 1901 to accept the presidency of Rockford College for Women, arranged the first art exhibit when she secured a collection of etchings from New York and invited the public to view them in the Davis Hall parlor. Merrifield entertained frequently at dinner, particularly after his marriage and the completion of the Mansion. His guest list included practically every public figure in the state. Budge, high in the councils of the conservative Republicans, in power until 1906, was extremely valuable as a go-between. When his political friends were in town he seldom failed to bring them out to the University. ${ }^{10}$

The countless details and problems arising from public relations activities, which were after all only a side issue to the main business of the University, illustrate the increasing complexity of the whole problem of administration, to say nothing of the shifting personnel relations that accompanied this development. In 1899 the president could seriously seek someone to combine the functions of personal secretary, stenographer, registrar, and librarian. Within a few years each of these jobs had become the responsibility of at least one person. Five years later, however, the position of registrar was still expected to occupy only about half the time of one person except during enrollment and examination periods. The offices of secretary of the University (business manager) and of the Board were clearly differentiated by 1909 because of increased appropriations, incomes from fees and land endowment, building programs, the laws of 1907 and 1909 requiring tighter accounting procedures, and the concentration into the University's hands of such functions as full control of the boarding department (1899). The growing importance of the administrative function had produced the first consideration of a separate administration building as early as 1901 . This matter was settled when the old chapel and rooms on the main building's first floor were converted to offices in 1907.

For better or worse, the specialization of the administrative function also had a fundamental effect on personnel relationships. The University had been almost wholly faculty-run in the 1890's; ${ }^{10} \mathrm{~A}$ hint of what too close identification with one political faction might mean ousted. The administration was openly accused of silencing student activity on the part of the reformers in order "not to hurt the University." To what extent the University had been identified as the protege of a political faction is impossible to measure, of course, but there is ample evidence that it was so regarded in some
circles. The infiltration of this conservative political climate by liberal spirits traineed at institutions like Wisconsin was to be a major factor in the controversy and factionalism that would prevail on the campus in a decade or so. 
everyone taught, including the president, and practically every one of the permanent corps had the same rank. The heavy reliance on faculty initiative and decision continued, but with some inevitable modifications after 1900. Merrifield's full acceptance of faculty control was traceable to his own teaching apprenticeship at Yale, where the tradition of faculty government was fully developed, and to his long experience in the close faculty relationships of the 1890's at North Dakota. Moreover, he never ceased to regard himself as primarily a teacher, and by temperament he was unfitted for the role of dictator; nor should it be overlooked that the new faculty which came in the revolution of 1900 was able enough to be spirited. Merrifield's frequent absences from the University, which increased with the years and with the growing complexity of the job, were a demonstration of confidence in the faculty and in Thomas, the usual acting president; the absences also resulted inevitably in the delegation of a great deal of responsibility to the faculty. Merrifield suffered from hay fever and, as he frequently said, required the spiritual renewal of contemplating the humanized landscapes of Europe and New England; he was away from North Dakota for three months or so nearly every summer of the twentyfive years he spent at the University. Each spring he was absent from the campus for most of the quarter on the high school inspection tours, and in 1907-1908 he took a long midwinter leave to California.

By 1909 there had developed, partly by tacit consent and partly by definition, some demarcation of spheres of administrative and faculty functions. It was conceded, of course, that Merrifield was the University's public representative, especially in dealing with the Trustees. Actually, even this function was modified to some degree because a good many of the faculty knew Budge and Stephen Collins, both residents of Grand Forks, nearly as well as Merrifield did. It was not until both of these men resigned in 1907 and N. C. Young of Fargo became Board president that the faculty lost its connections with the Trustees. Merrifield also had a major voice in new appointments, in part at least because it fell to him to interview candidates on personnel hunting trips. It is doubtful, however, whether he appointed anyone to any key position without the general consent of the faculty. Much of his influence sprang from his encyclopedic knowledge of and concern with the smallest details of University affairs, ranging from the smoking or study habits of some obscure student, through the quality of the Davis Hall food, the exact financial status of literally dozens of students, to the color of the paint to be used on the bicycle shed. Moreover, the revolution in the University after 1900 was more his doing than that of any of the rest of the 1890 faculty, with the possible exception of Babcock and Brannon. Merrifield's outlook on education, considerably modified by his years in North Dakota, had been further broadened by his summer at Cornell and through his associations with other state university presidents in the National Association of State Universities, whose meetings he regularly attended.

Meantime, growth and specialization inevitably narrowed the field of faculty government, or at least relieved faculty members of having to worry about inconsequential details. Once the whole faculty had met every week to deal with the most trivial mattersand to debate longer over some of them than over fundamental questions. The appointment of deans in 1901 was the first major move toward permanent administrative officers, and the appointment of a dean of women in 1908 was a formal recognition of the need for specially designated personnel to supervise student manners and morals. In 1901 there also appeared the University Interests Committee, forerunner to the Administrative Committee, composed of deans ex officio and elected faculty members. In the next half dozen years the rapid growth of the faculty brought gradations in rank and salaries. These differences were particularly accented because, owing to limited funds, only one or two first-rate men could be appointed to each department; the other positions, if any, were filled with partially trained instructors or recent local graduates. Recognition of the difference in standing and competence, rather than the development of unwieldy size, caused the formation of a University Council in 1906. Composed of deans, professors, and assistant professors, this body attempted in 1907 to define the function of the various faculty branches: the Council took to itself all matters of University policy, assigned to the deans such matters as dealing with student petitions and other petty details, and made 
of the general faculty meeting a discussion group in which senior professors presented papers on University policies for their juniors' consideration and discussion. This decision on policy had special consideration and discussion. This decision on then firmly resolved to resign, and he was leaving more policy making decisions than ever to the Council and the deans.

Merrifield's decision to retire had apparently been in the making for a half dozen years before he finally took the step at the age of fifty-six. His loyalty to the University remained as deep as ever, but it was no longer the center of his life that it had once been. His marriage in 1902 to Mrs. Elizabeth Bull, a very wealthy Grand Forks widow ${ }^{11}$ with three nearly grown children, had introduced him to full family life at the very time his administrative duties and the expanding enrollments made impossible the personal relationships with students that he valued so highly. He knew fewer students by name each year, and at the last was likely to see many of them only once a year in the stiff little groups which came when they were invited in turn. His old friends were going: Woodworth died in 1904, Macnie in 1908; Budge left Grand Forks never to return in the spring of 1907; and Stephen Collins, another Grand Forks Trustee, resigned at the same time. Mrs. Merrifield wanted to move to California, where she spent nearly every winter; the president wanted to travel. The fact that he had never liked North Dakota's physical environment was no small factor in his decision to go. Such of his correspondence as is preserved has not a single reference to the beauties of the rolling prairies or the superb summers of his adopted state, but there are many to the beauty of New England, of his native Williamsville, Vermont, "mountain girt and embowered in ... elms and maples," and the ived buildings and winding walks of Yale. His wife's fortune, more than supplementing his own respectable accumulation, removed whatever financial obstacle there might have been to giving up his position.

There was an element of hurt and mortification involved in his first decision to retire, which was announced in March, 1907; it followed closely on the legislature's decisions to reduce the Uni${ }^{11} \mathrm{Her}$ first husband was one of the founders of the Cream of Wheat Company, ${ }^{11}$ Her first husband was one
which began in Grand Forks. versity portion of the mill levy and to curtail the University's activity in favor of the other colleges. He did, it is true, allow himself to be persuaded to continue, but it was obvious that he would not stay very long. $\mathrm{He}$ and Mrs. Merrifield spent the summer in Europe, returning only in late September, and in January they left for three months in Pasadena. It was no surprise to anyone when in July, 1908, he announced that, owing to his wife's ill health, he would retire at the end of the 1908-1909 term.

There was much speculation about his successor; several faculty names were mentioned, among them Brannon, Kennedy, Thomas, and Squires. The position was offered to N. C. Young, a Fargo attorney and former justice of the state supreme court who had been a member of the Board of Trustees since 1907; he declined the offer, however. Merrifield circularized the faculty following the news of Young's decision to ask whether they preferred one of their own number or an "outsider"; the result of the survey has been lost, but in any event the Board turned to other campuses for candidates. In January, 1909, three candidates were invited to meet with the Board. Two were from the University of Minnesota, John Gray, chairman of the department of economics, and Frank LeRond McVey, professor of economics from 1896 to 1907. It is significant that two economists were in the final round of selection, a break with the old tradition of choosing presidents from among classical scholars or the clergy.

The election of McVey was announced January 12, 1909. He was the third Yale man in succession to occupy the presidency and also the last.

Meanwhile the Merrifield administration came to a close in a round of ceremony and sentiment. Merrifield delivered the annual Founders' Day address in 1909; the 1910 Dacotah was dedicated to him (as the 1904 issue had been). In March he presented $\$ 1,000$ for an annual oratorical prize. He held his last reception during commencement week. On June 17 he delivered the commencement address and received from a grateful faculty and Board the University's first honorary degree, the LL.D.

Merrifield did not find his retirement an entirely happy state $\mathrm{He}$ missed his old friends and the University; idleness sat heavily 
upon him after so many years of complete immersion in a career. Reports from Grand Forks about "the complete reversal of my policies as president which were the expression of conviction" were likewise disturbing, however much he recognized the wisdom of his move. He wrote to his old friend Joseph Kennedy in 1910: "I realize fully that my retiring when I did was not only a good thing for me-and my family-but was an even better thing for the University." With the exception of a few minor lapses, he firmly resisted the temptation to criticize his successor or even to invite such criticisms from those old friends "still on the firing line." He began to find increasing compensations in his new life. Within a year he was appointed to the board of Occidental College. $\mathrm{He}$ indulged to the fullest his insatiable love of European travel; the Merrifields returned from their last tour of Europe in November, 1914, having witnessed the first phases of the World War in both Germany and England. Although Merrifield pined at first for the greenery and sparkling water at Lake Bemidji, Minnesota, where he and Mrs. Merrifield had a summer cottage, the "dream house" and its five-acre estate at Pasadena, the mild climate of California and its scenery soon proved so diverting that the writing he had planned to do never materialized, except for a few articles of reminiscence which appeared in the Student in 1911. The Merrifields' visits to North Dakota were infrequent and short. Many old grads, including Victor Wardrope and his son Merrifield, were on hand when "Prexy" returned for the last time at commencement, 1915. On January 22, 1916, he died suddenly of heart disease. A memorial convocation was held at the University, and newspapers throughout the state paid tribute to the man who had won his place as the University's greatest hero.

Merrifield's monument had been firmly constructed. He had seen the University through the days when its chief preoccupation was survival, when it was the poverty-stricken and tiny "Grand Forks University," and he had also seen it well on its way toward becoming a full-grown state University. He recognized only belatedly, and then imperfectly if not unwillingly, the need and opportunity for making it a vital factor in the life of the whole population of the state. Yet his legacy to his successor was con- siderable: a respectable physical plant, the nucleus of a modern faculty, and public confidence and respect. Moreover, Merrifield had left the University his educational ideal, Yale's Lux et Veritas tradition of education for "sound character and moral integrity," supported by the New England virtues of thrift and industry. 
VI

\section{An Era of Progress---and Poverty}

$\mathrm{F}$

RANK McVEY CAME to the University of North Dakota in what appeared to be a particularly happy combination of circumstances. His leadership was welcomed for the reforms it promised, Merrifield having eased his path by pointing out the University's need for a president with fresh ideas, enthusiasm for the new developments in higher education, and familiarity with modern administrative practices and routines. A strong nucleus of a modern faculty, men to whom McVey could turn for sympathy, and courageous support as well, had already been gathered. The times appeared to be extraordinarily good. Prosperity was general; population was still on the increase, as was the enrollment of the University; and the state was basking in the optimistic progressivism of the long administration of John Burke, one of the ablest governors in its history.

Yet beneath this happy situation there lurked a multitude of problems for the new president, and more quickly followed. The considerable progress of the preceding decade had been uneven, owing partly to faulty planning and faulty administrative control and partly to the failure to find or to hold men of equal merit in every field. The departments of history, economics, and sociology were each headed by an active scholar and a vigorous personality.
Chemistry and mathematics, both appendages of the engineering colleges, were conspicuously weak. Engineering was divided between two tiny colleges, each with its own dean; the School of Mines enjoyed a disproportionately favored status, and civil engineering had not developed at all. The University offered almost no courses in the fine arts except on the practical or public school level. The deans also posed a serious problem; all of them were well entrenched with long records of devoted service to the University, yet only Thomas held the Ph.D., and only Crouch and Bruce were trained in the profession of their colleges. Brannon, Kennedy, and Babcock were all inadequately trained by the standards that McVey hoped, indeed had, to establish for his faculty if the University was to achieve academic recognition.

The favorable external circumstances were also near an end. The prolonged good times which had begun after the war with Spain soon leveled off. Serious crop failures in 1910 and 1916 reminded the new generation of boomers of the essential uncertainty of the highly specialized agricultural economy of North Dakota and revived the pessimism which has been more characteristic of the state's outlook than the optimism of the early years of the century. A rise in the demand for public services in general created an increasingly sharp competition for available funds at the very moment that the colleges were themselves expanding in enrollment and services. A third normal was added in 1913, and the 1917 legislature appropriated funds for a fourth at Dickinson in the southwestern part of the state. The financial problems of the colleges were aggravated further by a long public debate over the advisability of centralizing control of higher education and by the development of violent political strife in the state after 1915.

The result was that the administration of McVey was marked by almost as many frustrations as accomplishments. No more buildings were added after those included in the appropriations of 1909, although several were desperately needed; essential equipment was always in short supply if not lacking altogether, and many new projects failed or languished because of inadequate financial support. Yet it was in this period that the University gave its most convincing demonstration of the key role of strong scholars, for at no 
time were administration, faculty, and student body more vigorous, more adventuresome, or more intellectually alive.

Considering the size of the institution, its remoteness from other centers of learning, its precarious finances, and its somewhat limited reputation, the Board of Trustees could hardly have improved upon its selection of the man to guide the University through the last phases of its development into a modern state university. Following their initial fumble, the Trustees had avoided "popular idols" and sought a "scholar and experienced educator of tried executive ability . . poise . . . judgment and character," one who "knew and understood the Northwest, its conditions, and its people," and whose "helpmate was college-trained and thus interested in his work and in student life." It was a test which Frank McVey met with ease. Born in Ohio and reared in Des Moines, Iowa, he was an alumnus of Ohio Wesleyan University, where his father, a judge, had graduated before him. In 1895, at the age of twenty-six, he received the Ph.D. degree in economics at Yale, where he had studied under such distinguished scholars as William G. Sumner and Arthur T. Hadley. After a year in New York doing research for the Reform Club and teaching history at the Horace Mann school, he joined the faculty of the University of Minnesota as instructor in economics. In the next eleven years he climbed the academic ladder to a professorship, married Mabel Sawyer of Minneapolis, fathered three children, and published three books and twenty scholarly and popular articles in such journals as the Dial, Gunton's Magazine, the Yale Review, and the American Journal of Sociology. His short monograph, The Populist Movement (1897), was the first academic study of the subject to appear, his History and Government of Minnesota (1901) was a public school textbook, and his Modern Industrialism (1904) a college text. Active in community affairs, he had headed the United Charities of Minneapolis while on the faculty of the University of Minnesota. ${ }^{1}$ In 1907 he left ${ }^{1}$ In 1908 the University of Minnesota annual, the Gopher, took note of his extreme busyness with the following limerick:

An industrious man is McVey.

Writing books, meeting classes,

Uplifting the masses,

We fear he will soon pass away. the University to accept appointment as chairman of the newly created Minnesota Tax Commission; it was from this post that he came to the University of North Dakota in 1909.

The contrast between the training, career, and interests of Merrifield and McVey was matched by an equally marked difference in personality and appearance epitomized in the contrast between the neat professional beard and black broadcloth suit of the older man and the smoothly shaven face and well-tailored English tweeds of the younger. Whereas Merrifield was physically unimpressive, short and slight, almost frail, modest to the point of being shy, McVey was well over six feet, younger appearing than his thirty-nine years, bursting with physical vitality, and radiating a calm self-confidence. Merrifield, although thoughtful and sincere, was a barely adequate public speaker; McVey was a polished performer. Merrifield was kindly and approachable, wrapped up in the personal problems and everyday concerns of students and faculty; McVey tended to be remote and impersonal, almost standoffish. Old grads, looking back a half century, remember how much they were struck by his resemblance to Woodrow Wilson in personality, mannerisms, and even appearance. Merrifield was weak in administrative matters; $\mathrm{McVey}$ had a real flair for them. And while one regretted the passing of the old University and accepted the new only because he recognized its inevitability, the other welcomed the change and set himself to hasten and extend it.

Far better trained than Merrifield in an academic specialty, McVey possessed as well the catholicity of interest and accomplishment that was the justification of the traditional nonspecialized curriculum which he would do much to usher off the stage at North Dakota. His interest in literature, both prose and poetry, was genuine and was revealed in the high literary quality of his carefully prepared public addresses. An insatiable desire for learning and accomplishment was reflected in his German conversation lessons while at North Dakota and in his learning to paint in oils at the age of fifty.

An ambitious man, McVey undoubtedly viewed North Dakota as a stepping stone in his career. Yet he also brought to his task a high integrity and a well-formed ideal of what a state university. 
should be, one that was derived largely from the precept and example of Charles R. Van Hise and Cyrus Northrop. This he attempted to set forth in the address he delivered at the elaborate inaugural ceremonies held more than a year after he took office: The institution will meet its duty to the people of the state by preparing thoroughly the young people who come to its doors for service in specific callings after they have had adequate preliminary preparation ..... The University must not only be equipped as the very best institution anywhere, but ... men of renown and fame, full of personal power, shall become the instructors of youth, while at the same time there shall be quick response on the part of the institution to the need of changing the curriculum and enlarging the number of professions and callings to meet the demand for educated men and women, in business, in the industries, in the professions, and in the home, that is sure to arise in the new commonwealth ...

It is time to recognize the fact that the University is a great latent force that can be utilized in many directions. It ought to be closely related to every department of the state. It should be the medium through which statistics are gathered, information collected, advice given, problems solved, in fact a real part of the state government

It is not beyond the truth to say that a University is a beacon light to the people of a commonwealth, pointing out to them not only where advances are to be made in the realms of commerce and trade, but in the fields of morals, general knowledge, and better living; and vice versa, we may say that there is no clearer indication of the advances a people have made than that set by their university. Once free from political control, and truly of the people in the larger democratic sense, it means that the people of a commonwealth where such an institution exists are truly turned toward real progress and the light of the lamp of civilization.

It was a high ideal, considerably broader than that upheld by his predecessor, and McVey conscientiously strove to live up to it He did not succeed completely, which was not entirely his fault, of course, and even in the process of his achieving the larger part of his goals, there were some undesirable subsidiary developments. The combination of a firm purpose, often seen only dimly by others, an inexhaustible energy, and the impatience of the reformer was to result in his undertaking far too much responsibility himself. He did not intend it to be so, and his concern for the faculty was genuine, but it was in his administration that the faculty lost some of the initiative and sense of responsibility it had enjoyed with Merrifield. Although the trend did not pass unnoticed and some remedies were undertaken, it was not until the regime of his less able and less high-minded successor that its serious consequences became fully apparent.

That the University of North Dakota was in for a burst of activity was manifest almost the moment McVey's election was announced, although he did not officially replace Merrifield until June. McVey proceeded swiftly on a broad front, making his first moves while Merrifield was still president. He visited the state legislature and appeared before the appropriations committees of both houses to discuss the needs of the University and to give his views on its relations to other educational insitutions; he also delivered a speech on tax reform before a joint session of both houses. The gratifying appropriations for buildings and laboratories made at that session were a result, at least in part, of the favorable impression he made.

In the eighteen months that elapsed between his assumption of office in June, 1909, and his formal inauguration in September, 1910, the University experienced the most thorough-going and rapid revolution in its history. Major reorganizations were begun in every college except medicine, in the summer school, and in most departments. Graduate training, supported by the University's first fellowships and scholarships, was formalized and expanded. A faculty committee was appointed "to push for a charter" from Phi Beta Kappa. Off-campus laboratories were established for the department of biology, the Public Health Laboratory, and the School of Mines. The library staff was enlarged, a formal set of library rules published for the first time, books reshelved-McVey inspected the collection himself and offered numerous suggestions, urging, for example, that a number of art books should be bought-and a state-wide bibliographical and lending service was begun. Faculty salaries were increased, a salary schedule adopted, and a sabbatical program outlined. The editors of a new Quarterly Journal, launched to stimulate faculty research and writing, consciously symbolized the progressive spirit injected by McVey when they adopted the simplified spelling then sweeping the country.

Many administrative procedures of the University were also reformed. A budget system was adopted and the several student 
fees consolidated into one ( $\$ 12.50$ per semester and $\$ 5.00$ additional in the schools of law, medicine, and engineering). The faculty committees were reorganized and new ones added. Enrollment procedures were systematized and waiting lines eliminated by procedures were systematized and waiting lines eliminated by issuing time-stamped cards. An official stationery was adoptedthe form has been changed but little since-a weekly activity calendar issued, and the first genuine infirmary in charge of the first full-time University nurse was established (there was no official University physician until 1916 when Dr. James Grassick contracted to spend two hours each week on the campus to receive ailing students). The first steps were also taken toward the reform of the University bookstore and the installation of boxes for campus me The store for years a plum passed down through successive student generations, was reorganized in the summer of 1911 as a faculty-owned cooperative, paying a 7 per cent dividend to the fifty stock holders and rebating the rest of the profits to the customers, and a full-time manager was employed. (The University bought out the stockholders and took over the store in 1941.)

It was to call attention to what had been accomplished as well as to emphasize the University's place in the world of learning and its respect for the standards of that world that McVey's inaugural, September 26-29, 1910, was celebrated with elaborate ceremonies. This was North Dakota's first experience with academic pomp in the grand manner; the first faculty procession in cap and gown had been held only the spring before at commencement. Opened on the evening of the twenty-seventh by Professor Hult's lecture at the Baptist church on "The Purpose and Meaning of Inauguration Week, "the event drew together the largest collection of notables Week," the event drew together the largest collection of notables colleges and of fourteen colleges and universities outside the state, colleges and of fouree supreme the governor and his staff, all the court, representatives of all the major branches of the state government, James J. Hill of the Great Northern railroad, and Howard Elliott, president of the Northern Pacific. Assemblies, a round of dinners, and the formal dedication of the Teachers College building filled the next day and a half. On the afternoon of the twenty-ninth the academic procession proceeded from building to building on the campus before assembling in the gymnasium for the final presentation of the president.

Impressive enough to win the plaudits of the Boston Transcript, the celebration of course provided the occasion for some justified self-congratulation on the accomplishments of a few short yearshow short was emphasized by Jim Hill's remark that only forty years before he had crossed the University site by dog team. Of equal or greater importance was the fact that it became the occasion for the first public consideration of the role of the University in the state's history. The titles of the speeches provide a quick review of the major issues of the day in the world of higher education, particularly in public institutions: "The Two-fold Function of the University" (research and teaching), "The Unification of a State's Educational Forces," and "The Relation of the State University to the Commonwealth." The subject of McVey's address was "The University and Its Relations."

An important result of the celebration was the sense of pride that it brought to the University family itself, no small measure of which was due to the prominent part given to established members of the faculty. Morale was important to $\mathrm{McVey}$, for he needed the faculty's support in order to continue his program of innovation and wholesale reform. Although moving swiftly, he honestly strove to work through the faculty rather than over its head; he was extremely careful from the beginning about the manner in which new policies were launched and about the order in which they made their appearance. It is significant that the first large innovations-the details of which were worked out by faculty committees and the Council, scrupulously consulted by the president-were the adoption of a formal schedule of salaries, a system of tenure, and a policy on sabbatical leaves of absence. The salary plan, the first of any kind since the University had opened its doors, ${ }^{2}$ provided for orderly increases and a scale of $\$ 800$ to $\$ 1,500$ for instructors, $\$ 1,500-\$ 2,000$ for assistant professors, $\$ 2,000-\$ 2,500$ for associate professors (a new rank), $\$ 2,500-\$ 3,000$ for professors, and $\$ 3,000-\$ 3,500$ for deans. The president's salary was $\$ 6,000$ when he was appointed, twice Merrifield's. Instructors were to be ap${ }^{2}$ Merrifield had followed a more or less regular practice in this matter, but never as
a formal or announced policy. 
pointed for one year, assistant professors for three, associate professors for five, and professors permanently; deans were to be appointed for three-year terms. Sabbatical leaves of one year at half pay, limited however to no more than three faculty members a year, were to be awarded after eight years of service, or one semester after four. In practice these reforms were effected only gradually; by 1916-1917 salaries in every rank averaged only slightly above the minimums. ${ }^{3}$ The sabbatical leave program was never fully developed either, although by 1917 a half dozen or more members of the faculty, three of them deans, had received leaves with pay. There was more success with tenure, although the principle was not firmly established until the adoption of a constitution in 1916 following an arbitrary dismissal of a law professor by the Board of Trustees. The three year rule on the terms of deans, undoubtedly an attempt by McVey and his faculty allies to ease his own reorganization plans, was never invoked. No retirement age was set at all, although McVey did attempt, without success, to bring the University into the pension system of the Carnegie Fund for the Advancement of Teaching.

An effective device for building faculty morale and rallying support for other parts of his program was McVey's carefulness to reward distinguished service by various tokens of recognition. These took the usual forms of appointments to new committees and other posts that developed after the reorganization. Adoniram J. Ladd was made editor of the new Quarterly Journal, director of the college section of the summer school, and chairman of the graduate committee. Libby, Gillette, Boyle, and several of the new appointees, among them William G. Bek, Albert H. Taylor, and Harley French, were encouraged to assume the role of faculty leaders. The establishment of honorific positions of one sort or another served the president's purpose too. One was the post of annual faculty commencement lecturer, inaugurated in 1910; another was the annual exchange of two lecturers, one in humanities and one in science, begun in 1911-1912 with the University of Manitoba. Faculty promotions were announced at commencement.

${ }^{3}$ Average salaries by 1916-1917 were: deans, $\$ 3,266$; professors, $\$ 2,516$; associate remained at $\$ 6,000$.
Perhaps equally important was the deliberate encouragement of sociability among the professors. Although not a naturally gregarious man himself and handicapped by his wife's somewhat distant attitude to the faculty, McVey worked as industriously to improve social relations on the campus and to win the friendly regard as well as respect of his colleagues as he did to solve any other University problem. He faithfully attended the monthly dinner meetings of the campus club of professors and their wives that was formed at his suggestion in 1909. In addition, the McVey dinners for the faculty in the mansion, small intimate affairs after several dinner-dance events proved unsuccessful, were a part of every University year. The McVeys were also active in a number of small faculty groups, among them a Sunday night poetry club, more or less managed by Hult, and the canoeing enthusiasts who often gathered at the Taylor home, which had a fine river frontage 4 The president carefully avoided, however, the appearance of building his own faction or of conducting University affairs secretly with a few favorites, although his dependence upon the "Ph Club" for advice and ideas as well as for support was too obvious not to be noticed and resented by the older men who had not completed their graduate studies. Squires assumed a reserved attitude toward the president, Kennedy was openly hostile, and even the good tempered Babcock was distrustful once he realized the possible consequences of McVey's reforms upon his own position. The situation was eased and perhaps saved by the resignation of Bruce and the well-to-do Thomas in 1911 and of Brannon in 1914. But McVey's strongest asset in his faculty relationships was the overwhelming evidence of his frank honesty, fair dealing, and devotion to the University. Babcock and Kennedy, the one mollified by an honorary degree and the other by a sabbatical leave and his own small journal, had not only become supporters of the president by 1917, but both had been stimulated to the most solid academic achievements of their careers.

Sociability was not synonymous with relaxed standards. The faculty was under constant pressure to obtain advanced degrees, to 'It was in McVey's time that members of the faculty began to establish summer
cottages in the neighboring lake country of Minnesota, made accessible by improved
roads and the arrival of the automobile. 
be active in professional societies, and to be productive. It was well known that the president kept a file on every professor's activities and that research and publication were the surest road to recognition and promotion. McVey himself set the example. He spent his mornings and from four o'clock until dinner in his University office; the hours from noon until four were set aside for writing in his study at home. Between 1909 and 1917 he published no less than twenty articles and three books and edited a social science textbook series. He not only encouraged faculty writing but found publication outlets for it. For the first time the University budget included a fund, albeit a small one, to subsidize faculty travel to meetings of professional societies; the Council had recommended to the Board of Trustees in 1908 that a "reasonable" sum be set aside for such purposes. No opportunity was lost to publicize scholarly achievements. In 1916, for example, he specifically assigned to members of the faculty the responsibility for supplying designated scholarly and educational journals with appropriate items about the University. An even more direct stimulus was the establishment of publication outlets at the University. In $1909 \$ 500$ was budgeted to establish a Quarterly Journal devoted to semipopular articles and University news as well as to scholarly material; that same year the University Bulletin, begun in 1904, was expanded into a bimonthly departmental series. In 1915 there appeared the first issue of the monthly School of Education Record, devoted largely to comment on current educational problems and addressed to the public school teachers in North Dakota. The State Historical to the public school teactions, edited by Libby, was almost altogether a University publication. A monthly Alımni Register, published from 1910 to 1912, added to the publication burden assumed by the faculty.

The Quarterly Journal alone came to about four hundred closely printed pages per year; it is indicative of the activity on the campus that when the first issue was published in October, 1910, there was enough material on hand to fill the next seven issues. In McVey's eight years no less than twenty books were published by the president and faculty; Gillette published three, and Boyle, Kennedy, and Roger Cooley (law) two each. Granting that not all of these publications were of major importance, they represented a remarkable achievement for a faculty which numbered only fifty in 1909 and seventy in 1917, and whose teaching load averaged at least fifteen class hours per week. In the first quarter century of the University's existence the total literary and scholarly output had been less than a half dozen books.

The improvement in faculty morale smoothed the path for the reorganization of the colleges and departments which was also begun in 1909-1910. The first step, largely a clarification of relationships, was the designation of several "Divisions" under which were grouped related but hitherto semiautonomous functions: the Division of Engineering included the two separate colleges of mining and mechanical engineering and a new course in civil engineering; Medicine included the College of Medicine, the Public Health Laboratory, and a new course in nursing; Education included the Teachers College and the Model High School.

The most serious reorganization problem lay in engineering, where two deans, Babcock and Crouch, directed a total faculty of ten. Since both were men of force and influence, it required time as well as tact to effect the necessary consolidation. Following the addition of a new course in civil engineering under Chandler, who had the title of director, a committee of the deans, the director, and the president was formed to coordinate the work of the colleges. On Babcock's urging, an instructorship in ceramics was added to the School of Mines, while the departments of mathematics and chemistry were transferred to the College of Liberal Arts where they rightfully belonged. The new ceramics instructor appointed in 1911 was Margaret Cable, whose name in the next forty years was to become as synonymous with her subject as Babcock's was with lignite. In 1912 a uniform course for all engineering freshmen was adopted. But it was not until 1916, after the state Board of Regents demanded the change following the recommendation of a panel of experts employed to survey higher education in North Dakota, that consolidation was finally completed. Babcock was appointed dean, a post he held until his death in 1925. His reputation in the state was too great for him to be passed over. ${ }^{5} \mathrm{McVey}$ ${ }^{5}$ In 1915 the United States Department of the Interior had published his bulletin
announcing a successful solution to the problem of adapting lignite for industrial use. 
seems to have preferred Crouch at first, but Babcock's somewhat more attractive personality and his reasonableness-he was known among the faculty as the "great compromiser"-made their impression. His honorary Doctor of Science degree, conferred by the University in 1914, satisfied at least technically one of McVey's requirements for deans. Crouch's resignation in 1918 was probably a result of disappointment. He had been for years the chief support in the engineering colleges for McVey's general policies to broaden the engineering programs and to elevate their standards. It was the College of Mechanical Engineering that in 1909 first set up an optional five-year program requiring a senior thesis and additional work in the College of Liberal Arts. Crouch, who had lived abroad, was also a strong advocate of a foreign language requirement for engineers.

Meanwhile, the engineering colleges grew slowly. There were ten graduates in 1909 and fifteen in 1916; the faculty increased from ten to fourteen and three assistants in the same period. Factors in the slow growth of the enrollment were not only the tightened standards but also the increased competition of the Agricultural College, where a civil engineering program had begun in 1907 and one in chemical engineering in 1910.

The law school provided a better subject for the president's reforms, owing to two nearly complete turnovers in the faculty, which was increased to four in 1910; the office of the dean changed hands both times. It is not to minimize Bruce's achievement as the real founder of the school to observe that he had neglected standards in order to increase enrollment or that he narrowed the curriculum to the learning of a craft. The considerable number of students enrolled each year from outside North Dakota, some from as far away as New York, was no compliment to the course or to the North Dakota state bar examinations. Soon after McVey became president a high school certificate was required for entrance, and the course was lengthened to three years. An immediate result was that the school was placed on the approved list of the American Association of Law Schools; only about forty of the more than two hundred schools in the United States were included at that time. In addition the program was considerably broadened to in- clude such goals as giving young lawyers a general education as well as a sound technical one and providing general law education for nonprofessional students. Law students were given the opportunity to take a six-year combined law and liberal arts program ending with both the B.A. and LL.B. degrees; beginning in 1915 the Juris Doctor degree was established for students who entered the school with the B.A. and maintained a high standard in their law courses. The year McVey resigned, 1917, the entrance requirement was raised to two years of college, but the war and other difficulties prevented the application of the new requirement until the 1920's. Meanwhile, in 1914 the library received an appropriation of $\$ 3,000$, its first major one since the purchase of the Cochrane collection, and a systematic classification of the holdings was begun. The teaching schedule was also reduced to eight hours per week that year. Although this was too much of an innovation to last, the load did not rise above ten hours again until after McVey left.

The general level of the law faculty was kept extraordinarily high. Robert Henry, appointed dean in 1912 after Bruce resigned to accept appointment to the state supreme court, was a former Rhodes scholar with degrees from Oxford and Chicago. His successor, George Wells, with a background somewhat less impressive, nevertheless possessed sound training and considerable practical experience. Three of the most productive writers the school has ever had joined the faculty in this period. Roger Cooley, who left a post as editor with the foremost legal publishing house in the country to come to the University in 1911, had a wide reputation as a pioneer in the teaching of legal bibliography; a former editor of the Century Digest, he was author of a five-volume work on Briefs on the Law of Insurance. Hugh Willis also had a solid reputation when he joined the faculty in 1916 to replace Birdzell, who had been elected to the state supreme court. Willis was a member of the University of Minnesota law school faculty for eleven years, a former dean of the Southwestern University law school at Los Angeles, and an authority on the law of damages and contracts. He had four widely used books in print and would publish his fifth in 1918. The youthful Lauriz Vold came in 1914, the year 
he took the D.J.S. degree at Harvard and launched the career which was to win him a wide reputation as an authority on torts and sales.

The general elevation in tone was marked in March, 1914, by the appearance of the school's first publication, the Law Bulletin, as a number in the departmental bulletin series. Although the quality of the school improved considerably, the total enrollment was somewhat reduced as Bruce had feared; in contrast to the thirty graduates of 1909 there were only twenty-three in 1916. The state benefited, however, from having fewer but better trained lawyers. Two of the graduates of this period, George Shafer and John Moses, were to be numbered among the state's ablest governors.

In the new Division of Education, the first major change, begun in 1909, was the complete separation of the Model School from the collegiate department by giving it a separate faculty and its own director, Charles Christian Schmidt, professor of elementary education since 1907; its transition to a practice school was also completed. In 1912 the Teachers' College was transformed into a School of Education, a development in line with trends elsewhere, and given sole power to issue teachers' certificates. What this meant in effect was that after completion of two years in the College of Liberal Arts candidates for teaching certificates registered in both liberal arts and education. Graduates of this program received the B.A. with Certificate in Teaching. The school also shared with the College of Liberal Arts the graduate level work in the University. Although technically it had become a two-year professional school, education continued to offer two-year special courses for freshmen and sophomores built around music, drawing, manual arts, commercial subjects, and home economics. By 1917 these had all risen to the status of small separate departments offering majors in the School of Education and the College of Liberal Arts. Home economics, begun in 1905 as "domestic economy" and regarded largely as a preparation for marriage course by $\mathrm{McVey}$, joined the commercial subjects and manual arts as a course for prospective high school teachers. As such these courses marked a significant shift in the University's relation to the high schools. Where Merrifield virtually dictated the high school curriculum it was now the Uni- versity which adjusted its program, at least in part, to meet the needs of the high schools.

One of the most significant additions to the School of Education was the appointment in 1912 of its first professional psychologist, J. W. Todd (Ph.D., Columbia). A former student of Lynn Thorndike and once in charge of the Columbia Teachers College freshman psychological testing program, he set up the University's first psychological laboratory shortly after his arrival; two years later he opened a clinic to provide testing services for the public schools, and this was in turn expanded into a Bureau of Educational Measurements, which provided a testing service by mail.

The education school was also affected by the expansion of the summer school into a full college program. Although there had been some additions of college courses in Merrifield's last years, the school had continued mainly to provide secondary level work for elementary school teachers. Only sixty of the 275 summer students in 1909 were enrolled in college courses. Its relation to the University was actually ill-defined, for although the University supplied the director (Kennedy), most of the faculty, and the buildings, it supplied no funds and shared control of the summer institute with the parent body, the Tri-County Teachers Association. In 1910 several more county institutes were brought in, and the college and elementary sections were separated completely, with separate faculty and directors. The following year the University received its first appropriation for the summer school, $\$ 3,000$ for the biennium. By 1917 about half of the three hundred students were enrolled in college courses. On one or two occasions a man of moderate distinction was invited to teach, although the limited funds available permitted few such luxuries.

The by-passing of Kennedy in the changes in the School of Education was obvious. Schmidt was put in charge of the elementary section of the summer school and Ladd of the college section. Ladd's rapid rise was particularly noticeable. Kennedy was less in sympathy with the professionalization of education than Ladd or Todd; enormously respected by his students and in public schoo circles, a courageous and high principled man, he might have made himself a formidable opponent had he chosen to do so. But the 
changes were in keeping with contemporary patterns, a point he apparently saw after a leave of absence at half pay in 1912 to observe and study at Columbia and Harvard. It is some measure of Kennedy's acceptance of the new order that in 1915 he published the first book of his long career, Rural Life and the Rural School, and in 1916 his second, Fundamentals in Methods.

The one part of the University requiring "no change in the fundamental plan of organization" was the medical school. It had passed Flexner's inspection only a month before Merrifield left the campus, and the attached Public Health Laboratory had already given it a vigorous start in the area of general public service. Yet it was not entirely immune from McVey's busy hand. Determined to expand occupational opportunities for women, the president and the dean started a preparatory nursing program and added a trained nurse to the faculty in 1909. A short course in embalming was begun in 1915 as a service to the North Dakota Funeral Association. Neither nursing nor embalming proved successful, however. The former attracted few students and was kept on until 1917 only because McVey refused to admit it had failed; embalming lasted only a year, possibly because it was uncomfortably suggestive in connection with a medical school.

A major problem in the medical school was Brannon's lack of a medical degree. Having only three physicians on the regular faculty, the school could hardly afford the luxury of an administrator. However, Brannon was too influential-and too valuable to the University-to be thrust aside. McVey's opportunity came in 1911 when Dean Thomas resigned from the liberal arts college and Dr. Archie McDonald, professor of anatomy, from the School of Medicine. Brannon was "raised" to the liberal arts deanship, and a single appointment, Harley E. French (M.D., Northwestern), a professor of anatomy at the University of South Dakota, filled the gap in the medical school. Having grown up, attended college, and taught school in the state of Washington, French knew and understood the problems of a state like North Dakota. He was, moreover, a tireless worker who possessed an inflexible integrity that was many times to serve as the school's most important asset. It is no depreciation of the work of Brannon, a founder whose work had won Flexner's approval and defied even McVey's passion for reorganization, to regard French, dean from 1911 to 1947 , as the father of medical education in North Dakota. His single-minded dedication to his profession provided a living example of the meaning of the Hippocratic oath.

By 1917 the faculty had been increased to four, all except French new since 1911; fifteen seniors received medical certificates at commencement of that year. With a minuscule budget and equally limited equipment, French deliberately narrowed the scope of his school to good teaching and public health work, with hardly a gesture toward research. In a half dozen years North Dakota's medical school had won a firm reputation for a high order of teaching, and its dean was well known for his reliability and in tegrity when recommending students for entry into other colleges. The day was to come in the 1930's when the reputation, inseparable from French himself, the one continuous factor in the school, was all that stood between it and dissolution.

Although it was subjected to no specific reorganization, the College of Liberal Arts found its role changed somewhat by such measures as the addition of liberal arts courses to professional curricula and the simultaneous transfer of nonprofessional departments to its jurisdiction. Moreover, while professional training was becoming more specialized, the definition of what constituted liberal arts was expanding. The catalog of 1917 listed no less than twentyeight majors acceptable for the B.A. degree, among them such newcomers as art and design, commercial subjects, home economics, manual training, and mechanical drawing. It was this college which reflected most the increasing emphasis upon productive scholarship, and it was here that the effects of the rising enrollment were most apparent. Only eighteen graduates took the B.A. in 1909, thirty the LL.B.; eight years later there were fifty who took the B.A., thirty more the B.A. with Certificate in Teaching, and one the B.S., a degree revived in 1913 .

The caliber of the liberal arts faculty as well as its numbersabout half the total in the University-gave it a position of leadership, not only in campus politics but also as the center of scholarly activity. McVey constantly sought to enlarge the tiny nucleus of 
trained scholars inherited from Merrifield. The steady growth of the University and the normal turnover gave him many opportunities to add new men, and the fact that the office of dean changed hands four times between 1909 and 1914 increased his influence in internal affairs in the college. It is unnecessary to detail the faculty changes that were made, except to comment on the most significant developments and to note the trends. Most of the expansion came between 1909 and 1914; thereafter, the faculty did not grow much, largely because the legislature held back on appropriations until the imminent surveys of higher education had been made and the question of a central board of regents had been settled. There was a high rate of turnover; a few changes were a result of friction, but most apparently stemmed from the fact that $\mathrm{McVey}$ was persuasive enough to attract men to the faculty who were bound to receive better offers elsewhere than North Dakota could match. McVey's own policy of attempting to keep departments ranked down from one full professor was likewise a cause, for it inevitably frustrated able young men and drove them to seek their advancement elsewhere.

Some of the most marked improvements were in the sciences. Chemistry, transferred to liberal arts from its subordinate position as the handmaiden of mining engineering, achieved full departmental status, and in 1910 the University's first professionally trained chemist, George Abbott (Ph.D., Massachusetts Institute of Technology) was lured from the Agricultural College. Abbott was a lucid popularizer as well as a competent chemist who soon developed a student following large enough to require additional faculty. Forced to operate for nearly a decade with less than the minimum essentials in equipment, he nevertheless began a modest program of research. Mathematics also finally achieved separate status in 1914 when Chandler was appointed professor of civil engineering and relieved of his duties in the mathematics department. Raymond Hitchcock (M.A., Northwestern), on the faculty since 1910, became head of the department now altogether in the College of Liberal Arts, a position he held until his death in 1937.

The department of physics, one of the University's oldest, entered its greatest period when Albert Hoyt Taylor, formerly assistant professor at the University of Wisconsin, came as the new head in 1909. Two young Ph.D.'s, Edward B. Stephenson (Illinois) and Eartholomew J. Spence (Princeton), were added the next year. By 1916 when Taylor resigned to become director of research for the Ninth Naval District, the department had made a local as well as a professional reputation by its work in wireless telegraphy. A radio station established in 1911 was one of the first three college stations in the United States. In 1912, the same year that the use of wireless was dramatized in connection with the sinking of the Titanic, a crowd of 250 people came out to the campus one cold winter night to witness wireless communication in Morse code with the town of Grafton, forty miles to the north. Taylor's work was of a truly significant nature; his continued close associations with scholars at the University of Wisconsin not only reinforced his own work but also provided an outlet for his own students. Raymond Heising, one of several North Dakota students who went to Wisconsin for graduate study, worked out numerous basic experiments in radio transmission; he ended his career as vice-president in charge of research at General Electric. Taylor himself became head of the Bureau of Research in the United States Navy and in the 1920's he and an associate developed the system of radar detection, which in turn has been basic to the development of television. Stephenson entered naval research work in the 1920's and eventually became chief physicist in the Naval Research Laboratory

Although the sciences had been lifted from the completely utilitarian status they had occupied, it is clear that their orientation was toward applied rather than pure research. In the nonscientific fields there also was more than a little infusion of the current and useful. When, for example, Thomas, dean of liberal arts and professor of Latin, retired in 1911, thereby reducing the classics faculty to two, he was not replaced. Meantime, there were appearing in the curriculum various courses on classical culture taught in English. At the same time the modern languages were expanded rapidly. In 1911 William G. Bek (Ph.D., Pennsylvania) was brought from the University of Missouri to head a new department of German, separate from the Scandinavian languages. More a historian than a linguist, the genial and forceful Bek was a popular 
teacher who developed his department to the point where it required a second teacher within a year. The Romance languages, for a number of years stronger than Scandinavian and German, were meanwhile strengthened further in 1913 when Henry Brush (Ph.D., Chicago) was brought from a professorship at Hope College following Le Daum's untimely death from pneumonia. Le Daum had been anything but idle, and at the time of his death he had completed a critical study of Don Quixote and had nearly finished a revision of the international phonetic alphabet, a revolutionary approach to the study and teaching of Romance languages. Brush was an active scholar who brought the modern language departments their first notice in academic circles.

For a variety of reasons the English department did not follow the usual pattern of development; not a single Ph.D. was appointed, and research, creative writing, and criticism received little attention. Squires, head of the department, was devoted to his courses and to student affairs; his campus activities took nearly all of his time after he was appointed dean of liberal arts in 1914. Moreover, the department was responsible for such semicurricular activities as the Student, dramatics, and forensics. All of these achieved curricular status during McVey's administration. Only public address and journalism were given for credit in 1909; by 1917 there were seven such courses including one in magazine writing and another in technique of the drama. Courses of this sort and the extracurricular activities that accompanied them called for a type of instructor not usually interested in scholarship, and in some cases not much interested in teaching courses in English. Koch, for example, was identified almost completely with his Sock and Buskin society and John Adams Taylor (M.A., Amherst), who joined the faculty in 1911, had been chosen mainly for his ability to direct debate. These were, of course, the first stages in the development of new departments which in the 1920's would offer their own full curricula.

Two other areas of study that achieved curricular status were library science and physical education. The former, begun as a short compulsory orientation course for all freshmen, died after only a few years, but not until it had been given a thorough trial as an elective and as a service course for summer students, most of them teachers. Physical education, however, achieved the status of both a requirement (one year) for all students and credit toward graduation. In 1913, following inspection of the facilities by Dr. C. H. Hetherington of the University of Missouri, a leader in the "new" movement, a general director, Fred Thompson of New York, was appointed. After women's physical education classes were transferred to the basement of Woodworth Hall (formerly Teachers College), some progress was made toward developing intramural sports, largely in the form of campus baseball and basketball leagues.

The departments of history, economics, and sociology all enjoyed a considerable rise in prestige with the coming of McVey. Not only were they his own fields of interest, but Boyle, Gillette, and Libby each measured up to the president's own professorial ideal-a combination of the productive scholar, an effective and exacting teacher, something of a publicist, and a willing servant of the state's welfare. Enjoying a considerable vogue because of the reformist atmosphere of the times, these departments revealed the drift from the theoretical and classical to the more practical and immediate in such courses as problems of social justice-this was taught at times by McVey-charity and philanthropy, social welfare and the liquor and narcotics problem, salesmanship, advertising, and accounting. Gillette, having completed his transition from the study of urban social problems, was offering a course in rural sociology. In 1913 he achieved a nationwide reputation with publication of his Rural Sociology, the first formal textbook in the field. These three departments were also the first to develop specific graduate courses. The seminar, it will be recalled, had been introduced at the University by Libby shortly after his arrival in 1902 . In 1914 the University conferred its first Ph.D., the only one for many years, upon George R. Davies, a candidate studying in the departments of sociology and history. The first graduate to hold a permanent faculty appointment, Davies taught in the sociology department until 1928 when he resigned to join the University of Iowa faculty.

Among the first of the McVey reforms had been measures to 
develop a genuine graduate program, as much for the purpose of elevating the general intellectual tone of the faculty and students as of providing advanced training. The first step, in 1910, was the Board of Trustees' allocation of funds for graduate scholarships and fellowships "to stimulate research and genuine scholarship"; these were open to candidates from other colleges as well as from the University. After a few minor changes in the first plan, three $\$ 300$ general fellowships, one $\$ 400$ industrial fellowship, and three $\$ 150$ general scholarships were awarded each year. Meanwhile, the questionable practice of awarding graduate degrees for work done in absentia was abolished, in theory at least if not altogether in practice. The catalog of 1910 devoted a separate section to the graduate department. George Thomas continued as chairman of the graduate committee until he resigned in 1911; he was succeeded by Ladd. Until 1912, when the faculty Council "wisely voted" to discontinue the practice, some departments declared their readiness to offer the Ph.D. degree. The only candidate to complete this program was Davies. The number of graduate students increased steadily, although McVey's hope for "fifteen or twentv" was not realized until 1916-1917. That year there were twenty-three; there had been only two in 1909-1910. The total graduate offering of the University remained extremely modest, however. Nine departments offered the M.A. degree-chemistry, biology, economics, political science, English, geology, history, romance languages, and sociology; but only one listed more than two graduate courses, and that one, sociology, had only three.

All of these measures for the general improvement of the University were matched by an equal attention to its relations with the students. For better or worse, it was in the McVey period that the final steps were taken toward the minute bookkeeping of student credits. Two policies adopted in 1909-1910 were the designation of a faculty adviser for every student and the substitution of the "C" grade average requirement for graduation for the old "credit for quality" acceleration scheme. The advisement system worked poorly and was dropped in 1912; the "C" average requirement repoined on the books. Although it is doubtful whether it was strictly observed, it became a sort of symbol of numerous other regulations to raise standards: the ending of the time-honored practice of excusing seniors from final examinations, the limiting of students' courses to sixteen credits per semester ${ }^{6}$ the establishment of November 1 and April 1 as final dates for withdrawal from courses without prejudice, the threatened dismissal of all students failing 60 per cent of their work, and the adoption of a five and a half day week (until 1910, Wednesday afternoons and Saturdays were holidays). The tightened rules produced considerable "grousing" among students and some public criticism as well, the latter arising largely from a misunderstanding of the purposes of academic bookkeeping. Nor were the faculty entirely in favor of the tougher policy. Kennedy, Thomas, and Schmidt objected vehemently to the " $\mathrm{C}$ " average rule, and not infrequently the faculty found it difficult not to be lenient when brought face to face with the task of dropping seniors from the graduation lists on the eve of commencement. On one occasion in 1915, when two seniors were dropped for having less than a "C" average, a faculty dispute developed; off-campus friends of the students appealed to the Board, which stepped out of its proper role and awarded the degrees.

McVey was also aware of the advantages of positive incentives. His first reports pointed to the need for loan funds and similar aids. There was not a dollar available for such purposes when he came, and there were only four prizes for scholarship, the largest only $\$ 75$. Not much progress was made in obtaining money for loans; only a few hundred dollars, administered by a faculty committee, were available by 1917 . But McVey fared considerably better in getting awards for academic achievement: the seven University scholarships and fellowships alone provided $\$ 1,750$ annually, and there were in addition nine prizes or loans related to scholarship, including money from new gifts from Thomas, Merrifield, and the family of James Twamley.

One reason for the need for such incentives was the changing nature of the student body, which by 1912 was almost entirely recruited from the public high schools, over which the University was losing control. It was significant of the change that in 1914 "From the 1920's seniors were again excused from finals, and "excess hours" were permitted on petition to increasing numbers of students. 
the University considerably modified its entrance requirements following the recommendation of the High School Conference "to adjust itself to the conditions under which the high schools work and to . . . their needs." Where three years of English, two of languages and mathematics, and one each of history and science had been required, the new regulation called for three years of English, one of mathematics, and as little as only one year taken in any of the other three subjects. Modeled on the recently revised Chicago, this was an advance requirements of the University of Chic position among American colleges. It meant, and this was in line with the progressive thought of the time, that the University had accepted the view that high schools had their own special functions and had virtually abandoned the effort to impose its standards upon them. One result of reducing entrance requirements while raising standards within the University was the appearance of the "bonehead" class; special drill classes for entering students deficient in mathematics and English were opened in 1911, and five years later there appeared a full-time no-credit course for engineering students deficient in mathematics.

When the student advisement system was dropped, the faculty resorted to orientation lectures. These began more or less informally in 1911 when McVey gave a series on such subjects as "Why We Are Here" and "What Makes a Man." In two years these had developed into a formal weekly program of matriculation lectures required of all freshmen and offering one hour of credit. The president also had his own "Between Us Day" convocation when he discussed University problems "privately" with the student body.

It may truly be said that in no other period have University students been so talked at, not only by the faculty but also by literally dozens of reformers, statesmen, preachers, and others who appeared on the campus between 1909 and 1917. Some of the better known visitors were Secretary of State William Jennings Bryan, Gifford Pinchot, Robert M. La Follette, E. A. Ross, the famous sociologist, Irving Fisher, the Yale economist, David Starr Jordan, president of Stanford, James Rowland Angell of Michigan, Frederick C. Howe, the Wisconsin reformer, and Russell Conwell, who gave his 5,256th rendition of his famous "Acres of Diamonds" address in 1916. The annual Hazlett lectures of Wesley College introduced the students to such religious leaders as Harry F. Ward of Boston University; his series, given in 1915, was entitled "Christianizing the Social Order." A similar series was begun at the University in McVey's first year, but lack of funds forced its discontinuance after a year or two. Faculty members were also encouraged to offer general lectures from time to time. In 1910-1911 the department of English presented a series of six "lecture-recitals" on English literature, and Wallace Stearns gave another on Hebrew literature.

In spite of the failure of some of McVey's plans and programs and the slow development of others, the University during his administration was characterized by improved standards and, what is more important, a vigorous campus intellectual life. Nor did the improvement pass unnoticed. For the first time members of the faculty were contributing in some numbers to professional journal and the meetings of their societies. When the American Association for the Advancement of Science met in Minneapolis in 1910, no fewer than six of the North Dakota faculty appeared on the program: Abbott, Babcock, Brannon, Chandler, Leonard, and Young. Gillette was active in the American Sociological Society, Brush in the Modern Language Association, Libby in the Mississippi Valley Historical Association. No one was more active than the president himself. In addition to writing books and articles, he read papers before scholarly societies and gave dozens of speeches and lectures. In the summer of 1912, when touring Europe to study German cooperatives, he turned aside briefly to lecture twice at the University of Oslo on "The Evolution of America" and "Recent Social and Industrial Tendencies in the United States." He was vice-president of the American Economic Association in 1909 and in 1917 was elected secretary of the National Association of State Universities and secretary of the North Central Association of Colleges and Secondary Schools.

Members of the faculty were also, for almost the first time, receiving invitations to serve as visiting lecturers on other campuses. Gillette taught one summer at the University of Indiana and another at the Utah Agricultural College, George P. Jackson (Ger- 
man) at the University of Chicago, Dean George Wells (law) at the University of Michigan, Dean Robert Henry (law) at the University of California. J. W. Todd (psychology) spent a year organizing a psychological laboratory for the University of Indiana, and Hult delivered a series of lectures on literary criticism at Stanford in 1913. Koch and Norton were regular lecturers for summer Chautauqua circuits. Two major recognitions, both in 1914, were the election of Brannon to the presidency of the University of Idaho and Brown University's award of the honorary Doctor of Letters degree to Squires, Brannon's successor as dean of the College of Liberal Arts. Squires was the first member of the North Dakota faculty to receive an honorary degree from another university.

When in May, 1914, the Mississippi Valley Historical Association held its meeting on the campus, the University had passed a significant milestone. No professional society had ever come before -and, it may be added, none of equal prestige has come since. The president and faculty made much of the event by efficient planning and publicity. Governor Louis B. Hanna was present to welcome the visitors; McVey presided at one session, Kennedy at another. Gillette read a paper on the "Training of the History Teacher" and Bek gave one on "The Germans of North Dakota." On the evening of the twenty-ninth the history professors attended the dedication of the Bankside Theater on the coulee immediately west of the president's house and witnessed the opening performance of "The Pageant of the Northwest."

Of equal or perhaps even greater importance in impressing the governing board and the general public was the official recognition afforded the University by various accrediting organizations. The medical school, it will be recalled, had been the first branch to win approval of any kind, just a few months before Merrifield retired. In 1914 it won a "Class A" rating-the top was "A+"from the American Council for the Advancement of Medical Education. In 1910 the Association of American Law Schools gave its approval to the law school. The University as a whole also won general recognition; it was rated "Class A" by the United States Bureau of Education in 1910 and included on the first list of approved colleges published by the North Central Association of
Colleges and Secondary Schools in 1913. In 1915, of a faculty of sixty-nine, twenty-five had doctor's degrees and twenty-three had master's degrees. These proportions represent a standard somewhat above that of institutions of the size and class of North Dakota. The Phi Beta Kappa honorary society, which had rejected the first application some years before, installed a chapter in 1914 . The first students to be elected, in May, were Hilda Olson, Margaret Plank, Anne Poupore, and George St. John Perrott (he was completing the work for the M.A.). Eighty alumni were also elected.

No one understood better than the president that no amount of progress in "scholarship, in efficiency in instruction, and in general reputation" could do as much to win the regard of the state as an active program of public service. In his 1912 report he observed that it was his intention to make the University an

increasing factor of value to the people of the state, not only as a teaching institution, but as a place where research and investigation are carried on and where information is available to the people through its Bureau of Educational Cooperation, thus bringing it in contact with the Commonwealth of North Dakota in a way that will be productive of betterment to the state as a whole.

With the University of Wisconsin as his example, McVey had set out in his first months at North Dakota to develop the University's program of adult education and other services. The idea at least was not new on the campus. It had been a topic for considerable discussion among the faculty for some years, and some slight progress had been made before 1909, although there had been little coordination or organized direction of the work.

During McVey's first year the University adopted a motto, the slightly used "To Be the Servant of the People," and an attempt was made to organize the scheduling of faculty members' lectures. An ambitious program of adult education was worked out on paper, and the 1910 catalog devoted eleven pages to a new department of University extension. What all this actually came to was the appointment of a faculty committee headed by Gillette, the publication of a panel of lecturers available for a fee, the announcement of correspondence courses (the University's first), and in- 
structions on how communities might organize a series of extension courses to be taught by members of the University faculty. The 1911 legislature approved only a cautious appropriation of $\$ 3,500$ for the biennium, considerably less than McVey had wanted, but it was enough for an immediate reorganization and enlargement of the program. A field organizer, N. C. Abbott, formerly instructor at the Agricultural College, was appointed, the name Bureau of Educational Cooperation adopted, and the work reorganized into four divisions: general information, University lectures, correspondence instruction, and public speaking-the latter was largely the promotion of state-wide high school debate and declamation contests. A forty-page bulletin was published in the spring; it listed correspondence courses, thirty faculty lecturers, and the nearly three hundred topics they were prepared to discuss. McVey was listed for a half dozen or so, ranging from such subjects as "The New Schoolmaster" to "The Business of Housekeeping." Squires's list included "The Ring and the Book" and "The Battle of Gettysburg." William W. Norton, the director of band and glee clubs, offered an illustrated performance on "The Ballad, the Song, the Oratorio, and the Opera." During the year there was also some experimentation with the short institute: on one tour McVey, Ruediger, and Gillette ran two-day sessions at Lisbon and Williston.

The governor's veto of the 1913 appropriation $(\$ 3,500)$ for extension work was a severe blow; the work had already been retarded by Abbott's inability to get along with the faculty committee in charge of his department-he resigned at the end of a year. But McVey was determined to demonstrate the full possibilities of the work, and in the summer John J. Pettijohn, extension secretary at the University of Wisconsin, was appointed to a newly created post of director. There was another reorganization; community surveys were begun, and the Wesley College faculty was brought into the system. An entirely new feature was the joint sponsorship, with the universities of Wisconsin and Minnesota, of a low cost lyceum course of music programs and of scholarly and popular lecturers. It is significant of the ambitious plans as well as of the activity that the largest single departmental section in the president's 1914 report was that submitted by Pettijohn. The severe financial crisis of 1914 and Pettijohn's resignation blighted the program again after only one year of trial. Thereafter it was somewhat decentralized; much of the work reverted organizationally to whatever University divisions provided it. However, the lyceums and the correspondence courses were continued; the latter enrolled about two hundred students by 1916. The exterısion division also sponsored the scheduling of high school commencement addresses by faculty members. This was, to be sure, considerably less than McVey's dream of a widespread program of adult education, county institutes, traveling symphony orchestras, and the like. Even so, about $\$ 6,000$ was budgeted annually for extension services until 1916 , when a sharp reduction could not be avoided. Meanwhile, the passage of the federal Smith-Lever Act in 1914 gave the Agricultural College an advantage in the field of extension work that the University could never hope to overcome.

Yet in the broader sense University services, which had made their first appearance when Ludovic Estes had established his weather reporting station, were expanded to embrace practically every branch of the University. McVey's first annual report contained a section on "Investigations," and in his biennial report of 1912 he devoted three full pages to listing services to the state and investigations directly related to solving its problems. In 1912-1913, for example, about $\$ 40,000$ of the total University expenditure of $\$ 246,000$ went for services of one sort or another, and by 1917 there were some significant results to show for the effort expended.

The work of the Geological Survey and the College of Mining Engineering, both with a long record in the area of services, progressed steadily. Leonard's mapping of the state's resources, less immediately useful, attracted far less public attention than the lignite researches, however. The addition of Howard Simpson (B.A., Harvard) in 1909 to the geology faculty was a fortunate one; not only was he the first geographer on the facuity but his investigations of ground water resources meant much to the state and earned him a reputation throughout the whole plains region in the next quarter century. Although Chandler was not directly connected with the geology department, his measurements of 
stream flow supplemented its work in an important area. Meantime, Babcock's researches on the uses of lignite were supported adequately for the first time after the completion of the briquetting and gasification laboratory in the lignite fields near Hebron. Despite the discouragements and inconveniences caused by two disastrous fires, one in the campus building and the other at Hebron, he and his faculty managed by 1915 to complete a monograph, Economic Methods of Utilizing Western Lignite, which was in effect a summing up of his life's work. Published by the United States Department of Interior, it appeared at the time to offer a workable method of using solid lignite for industrial fuels. It was Babcock's report more than any other factor which assured the University engineering colleges a favored position over similar departments at the Agricultural College in the 1915 report of the special survey commission on higher education in North Dakota. The timeliness of Babcock's lignite bulletin also ensured his appointment as dean of the consolidated engineering colleges.

Second only to the resources development work in immediate usefulness and in winning public favor for the University were the services of the Public Health Laboratory. No small part of its success was the quality of the direction it received from its founding. When Ruediger resigned in 1914 he was succeeded by another man of extraordinary ability and initiative, Dr. L. D. Bristol, formerly associate professor of bacteriology at Syracuse University. By 1917 three substations, drawing half their financial support from the towns in which they were located, had been opened at Bismarck, Minot, and Fargo. The total number of analyses made each year had risen from about two thousand in 1907-1908 to more than twenty thousand. The laboratory had also issued more than twenty bulletins on such subjects as Pure Water and How to Obtain It and Sporotrichosis in North Dakota. One of its most practical produc tions was the issue on The Sanitary Privy, complete with plans and specifications.

Another project initiated by the imaginative Brannon, which won less notice but was perhaps even more symbolic of the freewheeling spirit of adventure and the determination to make the University directly useful, was the biological station, established in 1909 with an initial appropriation of $\$ 5,000$. Located on the shores of the barren and alkaline Devils Lake, it was both a summer teaching and experiment station. Under the direction of Brannon, a half dozen seasons were devoted to experiments with transplanting or acclimatizing steel-head trout to the lake. When this effort failed, Robert T. Young, who had succeded Brannon as director, turned to a project, likewise unsuccessful, for developing a mussel industry on the Red River.

The basic sciences, although not blessed with special laboratories, also undertook to be useful. The chemistry department performed many routine analyses, as it had been doing for many years, and experimented with the commercial uses of flax fiber. George Abbott began a forty-year career as toxicologist for the state. The physics department experimented with generating electricity by windpower, one of the state's most abundant resources, and published a bulletin on the subject, The Development, Storage, and Utilization of Windpower. Something might have come of this had not an economy-minded governor vetoed appropriations to continue the studies. This department was of course fully alive to the great potential usefulness of radio communication and went to some lengths to arouse public interest. In 1913 the University obtained a license from the United States government to operate a "technical experiment" radio station and began broadcasting standard time signals and the official forecasts of the University weather station. Only a short time before, the latter had been raised to the status of a special meterological station and equipped by the United States Weather Bureau. By the time Taylor resigned in 1916 there were four college radio stations and possibly fifty amateur ones operating in North Dakota. The departure of Taylor and Stephenson ended the experimental stage of the pioneer station at the University during which a "very creditable number of papers . . . on radio communication" had been produced. The station was dismantled when the United States went to war in 1917. When it was reopened in 1923 it was under the control of the department of electrical engineering and was used primarily for broadcasting and demonstration in electronics work.

Perhaps the most enthusiastic support for the "Wisconsin Idea" 
came from the departments of history, economics, and sociology. Libby more or less abandoned the studies of the federal Constitution which had made his professional reputation to become the mainspring in the state's rediscovery of its history. $\mathrm{He}$ also undertook a vigorous campaign for the state park system that stands today as one of his monuments in North Dakota. Gillette shared with McVey the sponsorship of a student-operated settlement house in Grand Forks. Of more general importance were the intensive studies sponsored by the sociology department of North Dakota prisons and asylums and the county poor relief system. The economics department-and the economist president-turned to a search for solutions to the perennial problems of farm marketing. Both McVey and Boyle were active in the National Conference on Marketing and Farm Credits, McVey serving as chairman of its annual meetings in 1915 and 1916. Lynn Frazier, the newly elected Nonpartisan League (NPL) governor, accompanied him to the 1916 session and gave one of the featured addresses. Just how much influence these efforts had in shaping North Dakota's answers to farm problems is impossible to estimate, but it appears not to have been great. North Dakota farmers had already turned to more unorthodox solutions than the conferences proposed, solutions frankly distasteful to Boyle, and probably to McVey, although both were fairly liberal in their economic views.

Wherever it could the University made itself useful and influential by bringing expert, or at least educated, opinion to bear upon matters of public policy. When a State Board of Accountancy was established in 1913 by the legislature, largely upon the recommendation of McVey, he was made its first chairman. Deeply interested in city planning, he was the leading spirit of the Municipa Reference Bureau that was formed at the University. ${ }^{7}$ It was partly through his influence that Luther Birdzell of the law faculty, Democrat, was appointed by Governor Burke to head the newly formed State Tax Commission in 1912. A major opportunity to influence public policy, or so it appeared at the time, came when $\mathrm{McVey}$ was appointed to the chairmanship of a temporary educational commission called into existence by the 1911 legislature to ${ }^{7}$ In 1913 he published a small book on town planning. The Making of a Town. examine the state system of higher education and to recommend measures for reform. The other members were the presidents of the Agricultural College and the Valley City Normal, Lieutenant Governor Usher L. Burdick, the superintendent of public instruction, the speaker of the house, and a representative of the governor. The commission's report, published in 1912, was little more than a cautious endorsement of the plan of college government that already existed: separate boards for the University and the Agricultural College, and the single board for the normals that the legislature had formed that same year. Its most significant section from the standpoint of the University was the general statement on the role of the various institutions in the higher educational system. The University, it was declared, could "have no rivalry with any other part of the whole, but should coordinate, strengthen, and develop the work of all .... [It] is the highest institution of learning in the state." (It was also the largest by a wide margin; in 1916-1917, when the University enrollment was about 900, the Agricultural College's was about 250.) The Agricultural College was warned against expanding its courses into the University areas. As for the normals, their role was to be limited to the training of elementary teachers as had been intended originally. Perhaps the major effect of the report was to delay for one legislative session the final decision to form a single governing board for all the colleges.

Owing to the keen regional and institutional rivalries, the University was not permitted to give much leadership to the other colleges, except as they might imitate it. But it continued to have considerable influence in the public schools, particularly the high schools. Boyle's two textbooks, The Government of North Dakota (1910) and Beginners' Civics for North Dakota (1911) were a service of no small proportion. The University still trained most of the secondary teachers and superintendents, and the expansion of the college side of the summer session was chiefly to serve them. The public schools generally were the beneficiaries of the psychological clinic and the bureau of measurements, and North Dakota's teachers were the chief audience for the monthly School of Education Record. 
There was a frank combination of promoting good public relations and rendering service in the continued faculty activity in the North Dakota Education Association (NDEA) and the University sponsorship of the State High School Conference each spring on the campus. The elections of Neil C. Macdonald (B.A., 1900; M.A., 1908) to the NDEA presidency in 1910 and of M. Beatrice Johnstone in 1915 marked the rising influence of the alumni in public education circles. The annual high school conference had more than a little of the air of an alumni reunion. The serious work of the meeting was often obscured by the fact that it was accompanied by track and forensic contests. The latter were final contests of the State High School Debate League promoted by the Extension Division. While their students frolicked and explored the University the principals and superintendents undertook such solid work as the writing of new syllabuses for high school courses and the discussion of general policies. Recommendations of this conference eventually resulted in the discontinuance of the state high school examinations in 1919 and the revision of state high school administrative organization.

The influential role of the alumni in the public schools serves to illustrate their increasing importance in the state, particularly in the professions and public affairs. This was the fruition of the primary service of the University, the education of the state's young people. Although there had been one or two alumni in public life as early as the 1890 's, the highest state posts that any of them had attained up to 1909 were seats in the state legislature and in 1909 the appointment of one of them (Victor Wardrope) to the University Board of Trustees. In 1910 Patrick D. Norton (B.A., 1897) became the first alumnus to be elected to Congress.

The opportunity for a large number of relatively recent graduates to rise quickly to prominence came in 1915 with the sudden rise of the Nonpartisan League, a revolt against old party organizations growing out of farmers' disappointment at being thwarted in their pet state-owned terminal elevator project and fostered by the organizational genius of Arthur C. Townley. ${ }^{8}$ A fiery young liberal, William Lemke (B.A., 1902), attorney for the NPL, exer-

${ }^{8}$ See Chapter VIII for a discussion of the NPL and the University. cised much behind-the-scenes influence in the movement. When the NPL swept the state elections in 1916 its successful candidate for governor was Lynn Frazier (B.A., 1901), Lemke's old friend. Carried into office with him were William Langer (LL.B., 1906) and Neil C. Macdonald, candidates for attorney general and state superintendent of public instruction. One of Frazier's first appointments, to fill a vacancy on the State Board of Regents, went to Robert Muir (B.A., 1902), who was Lemke's brother-in-law. In 1918 the NPL elected Harrison Bronson (M.A., 1895) to the state supreme court. Albert Stenmo (B.A., 1898) was the NPL chairman of the senate committee on education in the session of 1919. The League's opposition, the bipartisan Independent Voters' Association (IVA) drew equally heavily from the alumni. Macdonald's successful opponent for the office of superintendent of public instruction in 1918 was Minnie Nielson, a former student. The final defeat of the League in 1922 was largely the work of Olger Burtness (B.A., 1906; LL.B., 1907), elected to Congress in 1920; Ragnvold Nestos (LL.B., 1904) and Sveinbjorn Johnson (B.A., 1906; M.A., 1907), elected governor and attorney general in a general recall election in 1921; and J. F. T. O'Connor (B.A., 1907; LL.B., 1908), the unsuccessful IVA candidate for governor in 1920. The IVA sent William Nuessle (B.A., 1899; LL.B., 1901) to the state supreme court in 1923.

The rise to prominence of the alumni called forth the first really systematic approach to University-alumni relations. Although Merrifield had been a vigorous exponent of an active policy, only a small start toward any organized program had been made when he retired; in fact, cultivation of alumni was a comparatively new development in most colleges, particularly in the Middle West. One of the first numbers in the Bulletin series issued after $\mathrm{McVey}$ arrived was devoted to an alumni roll, and he had not been on the campus a year when the University's first alumni magazine, the Alumni Register, appeared. It lasted only two years, but there were other developments of more permanence. The alumni clubs begun by Merrifield were expanded, and in 1915 the Association was incorporated and the office of secretary elevated to the status of a department of alumni organization and University publicity in the 
Extension Division. The first Homecoming Day, a highly successful event, was celebrated in the fall of 1916 . As for University publicity, one of the most effective ventures was the expansion of the old bimonthly newsletter, which had had its ups and downs, to a twicea-week release distributed to every newspaper in North Dakota.

The effectiveness of these policies defies measurement, of course, but they were necessary to McVey's winning public acceptance for his conception of the enlarged University. Innovators usually have difficulty in the best of circumstances, and in McVey's case some extraordinary developments served to throw him and his program in an undeservedly bad light. Institutional and regional jealousies were stirred by the usual fears of University encroachments. More dangerous because it had an element of plausibility was the charge that the University was costing too much; the fact that the enrollment climbed steadily from fewer than five hundred in 1909 to nearly nine hundred in 1917 was overlooked. An unfortunate combination of circumstances also gave the impression that the mounting expenses were caused by poor management. Times were especially good in 1909; the University's appropriation that year- $\$ 181,000$ above the millage tax and land income-not only was the largest in its history but included funds for such expansive projects as a new dining hall, a new Teachers College building, the lignite experimental laboratory at Hebron, and the biological station at Devils Lake. McVey's first year was encouraging from the financial standpoint; there were some funds remaining at the end, owing to an unexpected rise in income from the lands. It was to be McVey's last surplus. A general crop failure in 1910 cut revenues so sharply that at the end of his second year he was faced with a deficit of $\$ 53,000$. In 1913 a new governor, Louis B. Hanna, a Fargo banker determined to run the state in a businesslike manner, opposed any increases in funds for the colleges until a suitable plan could be developed which would eliminate rivalry and duplication of offering. The University requests for $\$ 300,000$ above fixed income were cut by the legislature and the governor to $\$ 84,000$. Hanna vetoed appropriations for extension work, new equipment for the medical school, and even a small sum for replacing dangerously obsolete wiring in some of the Uni- versity buildings. Continued delinquencies in the payments of the millage tax and for land rentals, to which was added the unexpected necessity of having to pay insurance premiums out of current appropriations, reduced University finances to a critical state by the summer of 1914. A deficit of $\$ 50,000$ promised to increase when a State Board of Equalization ruling that the millage tax exceeded the constitutional limit was upheld by the supreme court.

The charge of extravagance and bad management, aimed mostly at the University, was then raised in the newspapers. McVey was particularly sensitive on these points; an economist who prided himself on his business acumen, he appears to have been the first president of any North Dakota college to introduce modern methods of accounting and management. Meanwhile, the University resorted to public appeals and explanations. A bulletin entitled An Open Letter to the People of North Dakota explained the reasons for the increased costs of the University. In January, as the legislature was convening, McVey released two articles in the Grand Forks Herald in which he defended his policies and attributed the financial difficulty to the low taxes of the state and the loose budgeting and financial practices at Bismarck. He urged the adoption of a general budget system and a single governing board for all the colleges; the latter was contrary, it will be recalled, to the recommendations of the temporary educational commission of which he had been chairman.

In the months before the 1915 legislature could meet there was no choice but to economize rigidly and to resort to warrants to pay obligations. The fact that tight finances were nothing new, plus the still relatively loose restrictions upon the use of income, except in the matter of buildings, made the burden somewhat easier to bear than it would be nowadays. A few figures for the period 1909-1917 will serve to indicate the limitations under which McVey and his faculty operated; and they will serve also as a reminder of the small size of the University operation. Excluding the 1917 appropriations (which McVey had no chance to spend), the total appropriations made specifically for extension work came to less than $\$ 10,000$. In eight years the medical school got one $\$ 2,500$ appropriation for equipment; the department of chemistry, in 
"pathetic" condition when McVey arrived, received the same; physics nothing. Not a single dollar was received by appropriations for scientific research by the medical school or any department; in one instance $\$ 1,000$ was voted for the physics department's windpower experiments but vetoed by the governor. The failure to receive support for a botanical research project he had planned was partly responsible for Brannon's decision to leave the University. For the humanities and social sciences, expenditures for equipment, largely in the form of books for the library, were also limited. The general library received an annual book appropriation of about $\$ 2,500$; its periodical collection was supplemented, however, by exchanges for the Quarterly. The law library received one appropriation of $\$ 3,000$, the first one of any size since the Cochrane purchase.

Although discouraging enough, the legislature's record of meager appropriation was not entirely unrelieved. The income from the millage tax and the land endowment, the major portion of the total yearly income of the University, was not earmarked and could be diverted to practically anything but buildings. Probably an average of $\$ 6,000$ per year went for extension, for example. A "mechanician department"-another innovation that came with McVey and Taylor-operated by a trained technician brought from the University of Wisconsin, constructed much of the equipment, still relatively simple in comparison with the standards of today, for the science departments. The chief recipient of funds for equipment and research continued to be the College of Mining Engineering, which got more than $\$ 50,000$ in special appropriations for constructing and equipping its plant at Hebron alone. In 1917 a sum of $\$ 4,000$ was appropriated for ceramics research, the first for this purpose. The College of Mechanical and Electrical Engineering, which had actually received very little equipment since the completion of its barnlike building in 1902 , got $\$ 20,000$ for machines and benefited too when it inherited the old power plant after the construction of a new one; but it received practically nothing for research. The laboratories of public health and biology, which combined public service with some research, received $\$ 10,000$ and $\$ 3,000$ each per year.

Small as these amounts were, they nevertheless represented substantial increases over the expenditures of Merrifield's day. Of the major services only the Geological Survey received no increase in its regular biennial appropriation of $\$ 2,000$. The museum, once a vital part of the University, had ceased to figure in the legislature's calculations even after McVey reassembled it on the top floor of the mines building. When he came he found it neglected and many of its specimens scattered in professors' offices and department display cases. It was operated for a time as a lending library of teaching aids, but the shortage of funds soon reduced this to the point where the museum was merely given space and kept open.

The same pattern of scrimping for money while expanding and improving was also apparent in the development of buildings and grounds. The only building appropriated for and completed during McVey's administration was a small plant house, which remained unused for several years because there was not money enough to install heating. The Commons and Teachers College (Woodworth Hall) were actually erected and equipped after McVey came; moreover, he was responsible for their being in a new campus style, a red brick modified gothic, which was to become the model for all subsequent construction on the campus. When the mines building was repaired and enlarged after the fire of October, 1910 (fortunately the loss was covered by insurance), its exterior was altered somewhat to harmonize with the new buildings. Old Main's appearance could not be altered, but it was renamed Merrifield Hall in 1912. The two new buildings made possible the removal of faculty offices from the already crowded little library and provided the first adequate eating facilities for the large body of offcampus students as well as for dormitory residents. A minor thing, perhaps, but a mark of progress was the installation of the first telephones in the offices of deans and professors in 1913. There was also considerable improvement in the arrangement and appearance of the grounds. In 1910 the addition of twenty acres of land directly west of the Merrifield purchase permitted the removal the next year of the cramped athletic field from the president's back yard to the east side of the campus; the old field was planted to trees and the Bankside Theater was added on its western edge. Telephone and utility poles were removed from the quadrangle, and 
the first half of a horseshoe drive, its entrance marked by a pair of brick pillars, was laid out from University Avenue between Science Hall and the Commons in 1910. That same year the city paved the avenue to Twentieth Street, a half mile from the campus. In 1915 the University contributed some money as well as teams and labor toward widening the avenue, constructing a central boulevard, and regraveling the roadway on each side.

Although the total value of the University plant, including its substations and laboratories, increased from $\$ 660,000$ in 1910 to more than $\$ 1,000,000$ in 1916 - it had been $\$ 171,000$ in 1895-the evidence of inadequate funds was apparent on every hand. The new drive was "paved" with gravel and was a quagmire each spring; the Bankside Theater, despite the promise of its name, was no more than a plot of grass on the naturally sloping bank of the English Coulee; University Field was distinguished from the level empty space that surrounded it by a running track, the football posts, and a few wooden bleachers.

The year 1915 was the turning point financially, however, for when the legislature met in January, one of the major considerations was the condition of the colleges. Hanna, now fully converted to the single board plan, urged its immediate adoption in his annual message, and he recommended too that a joint legislative committee be appointed to investigate the colleges preparatory to remedial legislation. The committee's report, completed some weeks later, not only endorsed his recommendation to consolidate the boards but also included some of the sharpest criticism ever directed at any of the colleges by a branch of the state government. The committee had found "too great a disposition of those in control of our educational institutions to disregard or forget the financial conditions of this state .... [They believe] that the final aim and obligation of statehood is higher education." Recent proposals for increasing faculty salaries were declared to be "entirely out of proportion to the natural increase in salaries or [what] the condition of this state in any way warrants." Institutional rivalry, duplication of programs, and high overhead in "faculty and apparatus" were found to be widespread. Fortunately, the committee discovered no graft, only wastefulness and inefficiency.
Yet the situation was more favorable than these sharp comments might indicate. The economic upturn brought on by the war in Europe had softened tempers considerably, and the investigations had revealed the fact that all the other colleges were in much the same plight and generally not as well managed as the University. The governor and the majority of the legislature apparently recognized that the unprecedented rise in enrollments and the flaws in the management of the state itself were the chief sources of difficulty. For the moment, the colleges were rescued with appropriations adequate to carry them another two years; the University's $\$ 185,000$, which included nothing for new buildings, was the most it had ever received, more than twice the 1913 figure The millage tax was replaced by a fixed appropriation equal to its yield in 1914-1915- $\$ 102,700$ in the case of the University. This measure was intended to eliminate the uncertainty in institutional financing which had been the cause of no end of embarrassment since the 1910 crop failure. (The fixed sum, which had no meaning in its new form, was abolished altogether in 1919.) Of more fundamental importance were the unanimous adoption of the investigation committee's report and recommendations and the passage without a dissenting vote of an act to replace the existing college boards, including the recently created (1911) normal college board, with a single State Board of Regents. The new body, to be appointed by the governor, was empowered to "coordinate and correlate" the work of higher education, to prepare a biennial budget, to require an annual budget from each college, and to permit no expenditures for any purpose in excess of the appropriations for it. The law also required that a "competent expert, or experts, from outside the state" be employed to make a thorough survey of all the colleges and that following its completion a salaried commissioner be appointed; he was to be professionally qualified and also "drawn from outside the state."

The men that Hanna appointed to the new Board were able and conscientious and, as far as the University administration and faculty were concerned, a considerable improvement upon the Board 
that had been abolished. ${ }^{9}$ Lewis F. Crawford of Sentinel Butte, the chairman, possessed the M.A. degree from Harvard, Frank White, Valley City, was a former governor, and Dr. J. D. Taylor, Grand Forks, was a former state senator who had made something of a specialty of looking out for higher education, particularly for the welfare of the University. The other two members were Emil Scow of Bowman and J. A. Power of Ellendale. It was unfortunate that the appointments were drawn altogether from Hanna's conservative side of the Republican party and that in February, 1916, the Board saw fit to remove the Agricultural College president, John Worst, who had a large popular following in farm circles and had only a month before expressed his open sympathy for the Nonpartisan League movement in a widely publicized public address. The dismissal, accompanied by an announcement that other administrative changes might be made, aroused to fury the liberal and sharply partisan NPL, which was already well on its way to winning control of the state government. What had promised to be an intelligent and conscientious reform was dissipated immediately in a cloud of political controversy.

These events were unforeseen, however, as the survey required by law was begun. In August, 1915, the United States Commissioner of Education, P. P. Claxton, was invited to select some members of his staff to make the survey in North Dakota. The commission, as it was finally completed in November, consisted of Claxton as general director, William T. Bawden, a Bureau of Education specialist in industrial education, Lotus D. Coffman, dean of the College of Education at the University of Minnesota, and Edwin Craighead, former president of Tulane and the University of Montana. A professor of Greek before he became an administrator, Craighead had studied at Leipzig and Paris and was a member of the Carnegie Foundation for the Advancement of Teaching. He had lost his position at the University of Montana for too persistently advocating a consolidation of the Montana colleges.

By July, 1916, the Board had the drafts of the survey commission's report, most of which had been prepared by Craighead and ${ }^{\circ}$ The old University Board had the year before mishandled an academic freedom case (see Chapter VIII); its action in overruling the faculty by permitting the
graduation of two seniors whom the faculty had turned down has been mentioned.
Bawden. It is unnecessary to enumerate here the forty recommendations it contained. Those affecting the University most directly were (1) that all public school administrators and high school teachers were to be trained at the University or the Agricultural College, depending upon their major interests, (2) that the University and the Agricultural College were to offer graduate work only as far as the master's degree and only within their legitimate fields, and (3) that all professional training and a full liberal arts program be offered only at the University. Concerning engineering, the recommendation was that the Agricultural College's offering be limited to agricultural and industrial courses and that professional engineering courses be developed at the University. ${ }^{10}$ The first concrete results of the commission's report were the endorsement by the Regents of the same University salary schedule that had so aroused the ire of the legislative investigating committee and the recommendation that $\$ 15,000$ be added immediately to its appropriations to employ additional faculty. The Regents also took note of the fact that only the University and one other college were making out annual budgets.

Moreover, despite the fact that the NPL press and the friends of the Agricultural College were extremely critical of the "Craighead report," the 1917 legislature, with each faction in control of one house, appropriated $\$ 276,180$ for the University, the largest amount to that date, including $\$ 90,000$ for a chemistry building. The one building that McVey ever got, it was the only major building appropriation allowed; all other construction items, except an extension on the science building at the Agricultural College, were vetoed by Governor Lynn Frazier. The second serious financial crisis in twenty years had been successfully negotiated. The total income of the University for $1916-1918$ was about $\$ 640,000$, a marked increase over the low point of 1914 , and a 50 per cent increase over the annual rate of 1909-1910. Another crisis was in the making, however, for the United States was about to enter the ${ }^{10}$ The division of the engineering program was essentially what Babcock had recomment was ratified and worked out in detail, with provision for close cooperatioand the exchange of lecturers, by Babcock and Dean E. S. Keene of the Agricultural College in May, 1917. 
war in Europe. The reforms in accounting, purchasing procedures, and general management undertaken by the Regents were to be sources of strength when inflation, burgeoning enrollments, and a serious agricultural depression would strike all at once at the close of the war.

In the meantime, the reorganization of the state college system had come to a stop. As soon as the Nonpartisan League took over the state executive offices in January, 1917, the Regents came under attack, largely to avenge the firing of Worst and to save the Agricultural College. Craighead, who had been appointed to the permanent post of commissioner of higher education after the completion of the survey, was removed immediately by Frazier's vetoing the appropriation for his salary. This was the first step in what was to develop into a long fight for control of the Board.

The deterioration into quarreling factionalism of what had promised to be the opening of a new era for higher education in North Dakota was probably a factor in McVey's decision to accept the presidency of the University of Kentucky when it was offered to him in the summer of 1917. The main reason, however, was that he perceived in Kentucky the larger opportunity for which North Dakota had prepared him. The Regents recognized this in their somewhat humble letter of farewell: "We have felt for some time that your standing in the world of scholarship and educational administration would soon draw you to a more ancient and honorable seat of learning ..... Your new field will offer a larger opportunity than we could." The University of Kentucky, larger than the University of North Dakota but generally inferior to it in 1917, was on the eve of a revolution. The selection of McVey, said to have been recommended by many leading educators on the strength of his achievement at North Dakota, followed the completion of an extensive survey made by a committee of college and university administrators. One of them, Thomas F. Kane, president of Olivet College, Michigan, would be McVey's successor.

No outpouring of sentiment comparable to that manifested for Merrifield attended McVey's departure; the changed nature of the presidency and the growth of the University, as well as the somewhat less approachable nature of the man, had prevented the intimacy of the old days among administration, faculty, and students. Yet he had come to be genuinely liked if not loved; what is more, he had earned universal respect for his great services to the University. In the years to come the faculty that he left, recalling with nostalgia the great days of McVey, would establish them as the standard of measurement for future administrations. At the farewell reception given by the University Club in the Women's League rooms in Davis Hall, Squires read a sonnet, "We Have Been Captained Well," composed for the occasion by Hult. Professor Karl Stolz spoke for Wesley College, and the club presented a portrait of McVey to the University. Editorials and speeches at various other farewell dinners all noted the great changes he had made. In a perceptive comment on "the progress . . . little short of marvelous" since 1909, the Grand Forks Herald observed that his major contribution had been the ennobling concept of the duty of universities and university men to make the solution of society's problems their main business. The University's own estimate of his achievement appeared in an informal note in the Quarterly:

So many and so great were the needs of the University of North Dakota when Dr. McVey was called to its presidency, and so varied and extensive have been his services, that it is difficult to tell briefly what he has done at and for the institution during these eight years. He came at a crucia time in its history-just when it was throwing off its swaddling clothes. Established in a new state and among an immigrant people, its growth had necessarily been slow, especially as numbers go. In its brief twenty-five years of existence under such conditions it had done scarcely more than to root itself in the life of the commonwealth. It lacked organization; it lacked fixt standards of scholarship; it had no high or broad ideals of service save to the student on the campus; its broad function as a State University had not yet been grasped save by a few of its administrative and instructional staff; it was not appreciated at home and it was unknown abroad. But in spite of all this, its foundation had been well laid and its pioneer days were gone by the time that Dr. McVey came. It was in pioneer days were gone by the time that Dr. McVey came. It was in stage and useful fure, needing, most of all, firm and skillful leadership. This was secured in the selection has enjoyed renarkable progress, and the above weaknesses have been strengthened and limitations removed. Owing largely to his efforts the University is now ranked, in standards of scholarship, in ideals of service in the personnel of its faculty, in the ability of its student product, and in its physical equipment, with the strongest in the land. It is well organ- 
ized, is on a sound financial basis, and enjoys the respect and confidence of educational leaders the world over. This is no small contribution to be made in the short time of eight years.

McVey's parting words, delivered in an informal speech at a dinner given by the Grand Forks Commercial Club, appear too prophetic not to have been deliberate when considered in the light of events even then in the making. He advised his hearers to regard the University as more than an economic asset to the town and continued:

It must be a beacon light to hold up the highest things for the city and the state. The men who are to control and to teach must be left free to think for themselves, for-if they are hampered in any degree, the University can never prosper. It is for you in Grand Forks to see that the institution comes to full fruition. There must be the widest and most universal tolerance, and the men, those who are to lead, must have the right to express themselves after having arrived at conclusions through sincere study, even when their views do not fully meet your own .... The things that will wave this nation after the war are the universities.

\section{VII}

\section{Student Life in Transition}

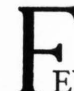

EW PERIODS OF COMPARABLE length in the history of the University of North Dakota have witnessed as many changes in student life and manners as the years between the war with Spain and the declaration of war upon Germany in April, 1917. The transition was marked by relaxing rules, a less formal and livelier social life, yet at the same time an intensification rather than a dwindling of students' concern with public affairs and civic responsibility. There was a proliferation of diversions pouring in upon the students from every side-oratory, debate, drama, musical organizations, fraternities, societies, athletics, class organizations, social doings, public lectures (an endless stream of them), artists series, and numberless minor unscheduled activities, all contributing to the destruction of the scholar's quiet which was once a prized feature of the University. The studiousness so marked in the 1890's was giving way before the first waves of the frenetic activity which would later become so familiar a feature of American student life, a phenomenon which appeared on more sophisticated campuses a generation before it reached North Dakota.

In the spring of 1909 the North Dakota faculty took notice of the change that had occurred in the preceding decade when it 
discussed the excessive social distractions at the University and resolved to form a committee of ten students, representing each college class and the law school, to confer with the University Interests Committee on means of remedying the situation.

Although by 1917 the quality of University athletic teams was vastly improved as a result of the introduction of professional coaches three years before, sports were never again so all-absorbing as they became immediately following the encouraging football season of 1898. The first athletic field was laid out the following spring. With the assistance of William Budge, the Athletic Association was able to acquire a tract near the present Washington Avenue underpass by paying up the back taxes of $\$ 150$. Budge also helped Lynn Frazier and William Nuessle sell advertising space to buy material for fencing, and students contributed the labor of enclosing the field and leveling the ground. All paid admission games were held here and in a nearby ball park with a covered stand until the first complete field on University property was laid out west of the president's house in 1907 . The teams' self sufficiency also extended to the provision of their own uniforms; half the members bought green stockings and half red, and every man wore one of each color.

In the fall of 1899 Bardi Skulason (B.A., 1895), a Grand Forks attorney, stirred up the Alumni Association to raise $\$ 200$ to employ a former University of Minnesota athlete, Harry Loomis, for six weeks of coaching; the University's contribution was board and room in a dormitory. The results justified the expenditure, for the University team won every one of the four games it played, beating Moorhead Normal, Henley Athletic Club (Minneapolis), Macalester College, and the Agricultural College. The football that the team had used in every game was inscribed with a large " 99 " and enshrined in the Davis Hall dining room; it was joined in a couple of weeks by a cup given by a Mr. Phelps of Fargo to the state champions. Merrifield, speaking on that occasion, gave his full blessing to football:

I encourage athletics because I believe they do more than all the preaching and all the teaching in our colleges toward keeping young men in the colleges of our land from dissipation and toward promoting among them clean living and pure thinking ....The Yale gymnasium was far more highly promotive of good order and clean living among the student body than any other single influence, not even excepting the Yale pulpit I do not believe that either the preaching of the gospel in the pulpit or the teaching of hygiene in the classroom will repress appetite in the young or check the most insidious and dangerous of all forms of licentiousness, impure thinking, one half as effectively as does the thorough fatiguing of the body . . . . Certainly the gospel was never preached with more directness and power from the Yale pulpit than during the very decade in which drunkenness and licentiousness were the most prevalent among the student body. That both these vices are rapidly falling into disrepute in our leadin colleges today, I attribute chiefly to the introduction of athletics into the college life.

The high place the season of 1899 has in University athletic legend is evidence of the general rise in University fortunes as much as it is of athletic accomplishment. If for no other reason, however, that legendary team is deserving of its place because of its outstanding personnel-Lynn Frazier, captain and center (the first alumnus to be elected governor), William Nuessle, right tackle (later chief justice of the state supreme court), William Lemke, right guard (attorney general of North Dakota and Congressman, and a major figure in the Nonpartisan League), Victor Wardrope (first alumnus to be appointed University trustee). Fullback Joe Flanagan and quarterback Skuli "Scoop" Skulason, brother of Bardi, were also the varsity baseball battery. They with Lemke were the brightest athletic stars of the day; Flanagan and Skulason especially are still remembered. Of the players on the 1899 team Nuessle had been captain in 1895, Frazier would be captain again in 1900, Lemke in 1901, and Wardrope in 1902, 1903, and 1904. The roll of athletic heroes would soon include big Olger Burtness (later a Congressman), captain of the team in 1906.

Although enthusiasm continued high, the next few seasons were not very successful. In early 1903 Walter Hempel became the first full-time coach; he lasted only a year. His contribution to University athletics was the annual high school track meet. Football developed rapidly under the coaching of his successor, Dr. Walter Sweetland; the team went through two undefeated seasons in 1904 and 1905, save for the annual beating by the University of Minnesota, and in 1906 it managed to hold Wisconsin to a 10-0 score. Meanwhile all the traditions and paraphernalia of college football 
became fixtures: the first caravan of students and rooters went to the Agricultural College game at Fargo in 1902; the first eligibility rules, requiring one term's residence preceding varsity play, appeared in 1903; the varsity letter, a blue cap with a monogrammed "N.D." in pink and green, came in the spring of 1904 (players had worn such caps earlier but had paid for them themselves). In 1905 and 1906 occurred the University's first debate about overemphasis of football. The enthusiasm engendered by the varsity-alumni game of 1907, when old heroes like Frazier, Skulason, Flanagan, and Burtness returned to beat the varsity, indicated clearly enough the defeat of the game's opponents.

The traditional rivalry with the Agricultural College was brought under control via the rules of conference play. Complaints about the University's playing of men like Flanagan for a half dozen years were partly met with the formation in 1901 of the Northwest Conference, which included the two North Dakota institutions, Hamline, South Dakota State, and Carleton. For another half dozen years, however, relations were explosive enough to be broken off twice, once in 1903 and again in 1907 and 1908. In 1903 the issue was the University's insistence on playing a man in his fifth year. Although the University did not know it at the time, the Agricultural College was playing men who were receiving pay from Fargo businessmen. Another quarrel ensued in 1905 over the alleged ineligibility of two University players. The issue is clouded, for there were countercharges from University supporters. Of one thing there was no doubt-the superiority of the Fargo team of 1906 under the coaching of Gil Dobie, later famous and "gloomy" at Cornell University. The University was beaten by $32-4$ in the one game that was played. At this point the University stiffened its eligibility rule to two terms of twelve credits each of passing work and resolved to play no state teams that did not observe it. Relations came to such a pass in the spring of 1907, however, that the faculty decided to discontinue athletic relations with the Agricultural College "in the interest of good fellowship." Both Sweetland and Dobie resigned in 1908, and the next year relations were resumed with an agreement that one football game would be played each year, and two boys' basketball games, two girls' games, and two baseball games. Eligibility requirements agreed upon were one term of ten hours completed at the Agricultural College and one semester at the University, no player to be eligible for competition for more than four years, and all compensation strictly forbidden. An arbitration board of one member from each institution and a third to be chosen jointly was to settle all disputes. This settlement also marked the beginning of the University's elevenyear association with the Minnesota-Dakota Athletic Conference, made up of all the colleges, exclusive of normals and the University of Minnesota, in both Dakotas and Minnesota. The first game in four years between the University and the Agricultural College was a basketball contest in March, 1910. The atmosphere of good feeling, which was to suffer no major impairments thereafter, was marked by the presence of a trainload of Fargo rooters and their forty-piece band. Competition with Fargo could never be completely easy in that day, however, and in the fall little Fargo College was dropped from the football schedule because of the alleged "brutality" of its team. This series was not resumed until 1915.

The Agricultural College settlement was no guarantee of good times, for athletics went into a sharp decline with the resignation of Sweetland. His successor, Dr. David Dunlap, despite his experience on Yost's teams at Michigan, had four unsuccessful years. The 1911-1912 season, Dunlap's last, was one of the worst in University history; the football team eked out one victory over the alumni and a tie with the Grand Forks high school; the baseball team lost all games except the one with the little Mayville normal; and the basketball team managed to win only slightly more than half its games. A major factor in the sudden decline was the inadequate financial support provided by the outmoded student-run Athletic Association. Also responsible was McVey's neglect of intercollegiate competition for his program of general physical education and broad student participation in intramural athletics. Shortly after his arrival even the old student athletic fee, practically the sole support of the Athletic Association, had been dropped and no adequate arrangement substituted.

How far McVey would have allowed the situation to drift is impossible to say; the mounting dissatisfaction of the alumni, some 
of whom talked darkly of taking over the management of intercollegiate athletics, was too serious to be ignored. Early in 1914 a general reform of University athletic policy was begun. A faculty proposal that the Athletic Association be replaced with a new Athletic Board of Control, composed of three students, three faculty, including the athletic director, and one alumnus was unanimously accepted by the students in a mass meeting. Some months later the Trustees reluctantly approved the students' petition to be charged an athletic fee of $\$ 2$, which provided for gymnasium supplies and tickets to all contests. Appointment of an able coaching staff completed the reform; Fred Thompson (B.A., Amherst; M.A., Columbia) came as athletic director and track coach in 1913, and in 1914 Andrew Gill (M.A., Columbia), a former Indiana star, was appointed as football and basketball coach. Gill's first basketball team was a success; in 1915 he had a strong football team, and in 1916 he produced a winner which lost only one conference game and, as usual, the game with Minnesota.

The coming of Gill and Thompson meant, more than the mere winning of a few games, the completion of the evolution from student control to professional coaches and faculty and administration management. The role of alumni dissatisfaction in producing the change was a harbinger of the next stage in athletic history, which would come in the 1920's, when athletics, particularly football, became an important instrument in generating public and alumni support for the University. Minor landmarks in the development of intercollegiate athletics were the adoption of the name, "Flickertails" (ground squirrels), in 1912, the celebration of the first Homecoming Day in the fall of 1916, and the naming in 1915 of University Field, completed in 1911. A stadium and athletic scholarships were still in the future, however. In Mcvey's day eligibility rules were more consistently enforced than was the custom in the less systematic Merrifield administration; moreover the minimum standard for participation in intercollegiate athletics was raised to twelve credits of passing work completed and twelve in progress.

The discovery of football as well as the lack of facilities and an organized program served to prevent the full development of other sports. Track and field sports and baseball were handicapped also by the lateness of the northern spring in which snow remains a possibility until May. Such activity as there was in these sports was without much direction until the last years of Merrifield's administration, usually being limited to no more than one track meet each year and a half dozen or so baseball games, mostly with neighboring towns. Low marks tell their own story of the casualness of the training in running and field events; Skuli Skulason, one of the leading athletes of his time, set a state pole vault record in 1903 with a mark of nine feet and two inches. Hockey made a few fitful starts but never got further than an occasional game against a Grand Forks team. Basketball became increasingly popular as a boys' game after the Budge Hall Armory was completed in 1901; to note the height of the Armory ceiling, only nine feet, is sufficient comment on the caliber of the play. The University lost a 52-7 game to the Agricultural College in 1905 but in 1906 and 1907 won every game played against a variety of teams including high schools, normals, towns, and a few colleges.

All of these sports except hockey developed rapidly after the completion of the first adequate athletic field and track in 1907 and the gymnasium in 1908. The beginning of full conference competition in the Minnesota-Dakota Athletic Conference in 1909 and McVey's policy of maintaining a year-round program of athletics helped to stimulate development. Fred Thompson did for track what Gill did for football, although he developed no great teams or individual stars. Basketball quickly came to the fore as the second major sport after the gymnasium was completed, and a source of players was ensured by the fact that it had also become the major sport of most North Dakota high schools by 1909. A good 1913 season became a near great one when Minnesota was beaten 18-16; the next season was even better, although Minnesota refused to go down a second time; and in 1916-1917 the University team lost only one game, one of the two it played with its traditional rival in Fargo. It may have been coincidence and not cause and effect that the intramural sports program began to run well only after intercollegiate athletics recovered prestige. A campus 
baseball league, organized in 1915, followed by a basketball league the next year, won considerable popularity by the eve of the war.

It was partly owing to the emphasis on athletics that the military department was closed in 1904. After the Spanish-American War, when the resident officer was called to active duty, the War Department refused to detail any more officers to the campus, despite repeated requests from Merrifield. As time went on, whatever enthusiasm there had been dwindled away in the absence of any war threat, Indian or foreign, and under the indifferent drilling of student instructors. Sweetland was appointed commandant of cadets as well as athletic director in 1904, but shortly after his arrival he persuaded a not unwilling faculty to drop military training for a course in "physical culture," which could be taken for credit as an elective. Military training received hardly another thought until the European war and then only after the preparedness movement was well advanced. Faculty and student attitudes had indeed undergone a change since the day when students strutted home in their cadet uniforms, girls petitioned for drill instruction, and faculty and Board seriously considered making the uniform the daily article of dress.

For a decade after 1899 forensics was football's chief rival for student attention. It too went into a sharp decline, at least in its capacity to hold student interest, shortly after Merrifield left the University. Unlike athletics, however, it never fully recovered, despite strenuous efforts by some of the faculty and various interested people outside the University. Oratory fell increasingly under the shadow of debate despite the stimulation of regular campus and intercollegiate contests, the continuing practice of commencement orations, and the addition of the Merrifield and Stockwell prizes in 1903. It was a sign of the changing times when the "rhetoricals," which had been so hard a chore for Lynn Frazier and a difficult challenge for Lemke, were made elective in 1905, worth two credits toward a degree.

By 1909 the ten literary societies on the campus, enrolling more than half the student body, were existing primarily for debate. The semiformal debates between Adelphi and Per Gradus, the only societies on the campus in 1899, had developed into a program of annual Inter-Society Debates; the Gansl Medal Debate between the girls of Adelphi and A.D.T.; the Intercollegiate Debate, that is, the contest with South Dakota held since 1901; and the International Debate with the University of Manitoba begun in 1902. Over the years there had also been debates with other colleges, usually one each year with Fargo College and occasionally one with Hamline and Carleton. Women's debate, despite the stimulation of the Gansl prize, had gone the way of women's competitive athletics by 1909. It was revived, however, for a few years in the 1920's.

Yet even at its peak, forensic activity was something of a hothouse flower deliberately encouraged by faculty sponsorship of the literary societies (the training ground for forensics) and by the existence of the largest number of prizes and cups offered for any. University activity. By 1909, when football players could look forward only to their letters and sweaters and a conference title, and when University scholars could compete for only three modest prizes, there were available no less than a half dozen major awards for the debaters and orators, who were further honored by having their names published annually in the catalog. The most enthusiastic contributor of prizes was J. Gansl, a Grand Forks jeweler. Between 1901 and 1904, the year he left Grand Forks, he established six awards for forensics and scholarship, among them a $\$ 100$ gold medal for girls' intersociety debate (1903), a prize for the best commencement orator (1904), a trophy for drama (1904), and a cup for the highest academic record in the College of Liberal Arts. He renewed the latter with a larger trophy in 1925.

Stimulated also by the selection of topics of lively current interest in that day of extraordinarily vigorous public discussion and enjoying a unanimous faculty support not shared by football, forensic activities even more than football offered a broad and varied opportunity for student recognition before 1909. Although one may question the value of the training provided, it is a fact nevertheless that a considerable number of the University's more illustrious alumni from that day were prominent in debate and oratory. Three football captains, Lemke, Wardrope, and Burtness, were as prominent on the platform as on the field. Others who 
were to be numbered among the noted alumni were Vilhjalmur Stefansson, judged the best individual orator in 1900, Gudmundur Grimson, J. F. T. O'Connor, Sveinbjorn Johnson, E. Claude Carney, William Langer, Ragnvold Nestos, Martin Ruud, and Waldemar Westergaard. O'Connor (B.A., 1907; LL.B., 1908), a founder of th Ad Altiora society, was probably the most accomplished orator the University ever produced. Entering the Yale law school in 1908, he won a number of important oratorical awards there, including a place on a Yale debate team which defeated Harvard in 1910. After his graduation from Yale (LL.B., 1909; M.A., 1910), he remained for two years as instructor in public speaking. The 1910 Dacotah devoted a full page to the distinguished young alumnus. O'Connor's mediocre academic record at the University of North Dakota is probably indicative of the effect of extensive forensic activities upon student scholarship.

The change of administration from Merrifield to McVey was the highwater mark for broad student participation in forensics. The ten literary societies of 1909 were reduced to four by 1920 . As early as 1912 Adelphi, the oldest organization on the campus, seriously considered the abandonment of debate altogether; four years later the Student complained that no one was turning out for debate contests. A major factor in the change was that other organizations had appeared, among them the fraternities and professional clubs, to take over much of the activity and the socializing formerly monopolized by the literary societies. With old-fashioned oratory going out of style and with the appointment of John Adams Taylor as instructor of English and public speaking in 1911, the literary societies lost their last reason for existence. University orators and debate teams had improved considerably in general technique and finish by 1917, but the student of average ability was as likely as not ignoring forensics altogether. The affinity between forensics and students who would make their mark, particularly in public life, was still close; George Shafer, John Moses, and Fred Aandahl, all future governors, were prominent debaters.

Student music and dramatic organizations developed rapidly after 1909. Music groups of a more or less impromptu nature had always been a part of student life, but the quality of the training available was about what one might expect when the main job of the University music teacher, who also had classes in freehand drawing, was to teach girls' gymnastics. The Cadet Band, conducted for years by "Professor" W. W. Hall of Grand Forks, and the informal Guitar and Mandolin Club were the only musical organizations with any claim to permanence in the University's first twenty years. The first glee clubs did not appear until 19021903, the year the University catalog listed for the first time an instructor in "music and elocution." Two years later there was a musical director, William F. Potter, but it was another two years before the University appointed its first coach for student musical organizations. The affiliation with Wesley College afforded the opportunity for the University to share the services of George Stout, who directed the band and glee club. Although Stout appears to have made some progress, including a start toward a University orchestra, it was not enough to impress McVey, whose sharpest criticism of the University as he found it in 1909 was reserved for the generally low state of the work in music.

The renaissance-one might better say the beginning-of music organizations and music training as a formal discipline dates from the appointment of William W. Norton as instructor in music and director of musical organizations in 1910. As also happened with athletics, student musical organizations were vastly improved in quality by the introduction of formal training and expert coaching and by the assumption of control and direction by the University faculty and administration. The self-confident young Norton (he was only twenty-eight), who had made his mark in campus politics as well as in his chosen field at the University of Minnesota, combined considerable ability as a violinist, baritone, and conducto with the dynamic qualities of the promoter and public relations expert. He quickly became and remained throughout his tenure one of the most popular men on the faculty. Some measure of his impact on the community is indicated by the fact that at the end of his first year the 1912 Dacotah, edited by that sharp critic of the faculty, Maxwell Anderson, gave eleven pages to musical organizations, including a full-page picture of Norton and a glowing account of his career and achievement at North Dakota, which he 
had "set to music." His first year's accomplishment included the formation of two glee clubs and a Grand Forks Symphony Orchestra and the arrangement of the first glee club tour. Fifteen pages of the 1916 Dacotah were devoted to music organizations. That year the University had a men's glee club of thirty voices, a women's club of forty voices, a forty-piece band, a twenty-piece philharmonic orchestra, a Haydn string quartet, and various other groups. The symphony orchestra gave its first concert in the spring of 1911, and its once-a-month, free-admission concerts were thereafter a regular feature of the University year. Norton earned the high regard of not only the University but also the Grand Forks community, and when his resignation to accept an attractive offer from the city of Minneapolis was announced in the summer of 1918, local businessmen made a vain attempt to hold him by offering to raise a fund to augment his University salary.

General student interest in music reached a peak in Norton's time, partly as a result of the appreciation fostered by such services as free lectures on symphonic music and the open rehearsals of the orchestra on the days preceding symphony concerts. For the most part, of course, music organizations were popular because they provided opportunities for some fun as well as serious work. The annual glee club tour, begun in 1911, was a happy week; it furnished endless opportunities for the Dacotah and Student to allude to contretemps of the tour or to the favorite theme of the sophisticated collegians' huge success among the naive and easily impressed, yet ravishingly beautiful country lasses who gathered to hear them in the little Dakota towns favored with their presence.

In dramatics, under the leadership of the ingenious and energetic Frederick Koch, another opportunity developed for the extroverted or forensically inclined student, and for the creative one as well. When Koch came to the campus in 1905 forensics were at the peak of their popularity while drama was at the low state of the minstrel show or farces like Throw Him Out and The Merchant of Venice Up-to-Date. Koch set out to awaken North Dakota students to an appreciation of serious drama through his own skillful readings of such works as Everyman and She Stoops to Conquer and by presenting mature works instead of the usual campus foolishness. The senior class play given at the end of his first year, Sheridan's The Rivals, was successful enough to be taken on a week's tour to a half dozen Dakota towns. His second year's effort, Dickens' Tom Pinch, was equally successful.

By 1908, when Koch returned to Harvard to finish his work for the M.A. degree and for further study in George Pierce Baker's "English 47," he had completed the first phase of his work at North Dakota and had won the affection and confidence of his students, to whom he had become "Prof." On his return to the Dakota campus in 1909 following a tour of Europe, during which he had with characteristic dash become engaged to an eighteen-year-old American girl after a three-day courtship in Athens, Koch found the imagination and expansiveness of the new McVey administration a milieu hospitable to the maturing of his own half-formed dream of developing a "school" of regional drama in North Dakota. Not original with Koch, it was an idea stemming from the works of such contemporary Irish writers as William Butler Yeats and John Millington Synge, then enjoying a considerable vogue in the United States. In January, 1911, Koch launched his Sock and Buskin dramatics society "to study the literature of the drama, to stimulate and develop higher ideals for the drama in America, and to initiate a movement to establish, as soon as practicable, a University Theater at the University of North Dakota." This genuinely serious, though perhaps overambitious, intention appears in the society's programs, usually devoted to the discussion of some subject like "The Theater: Its Origin and End" or to the analysis of a dramatic scene presented by club members. The new organization was limited to forty members, half elected from the faculty and half students chosen by a test of their ability to write literary criticism or to read dramatic lines; it soon became the most important student group on the campus, combining as it did some of the intellectual prestige of Phi Beta Kappa and the exclusiveness of the Varsity Bachelor Club, the leading social fraternity. Koch was the director, of course; his assistants were Arthur Netcher and Maxwell Anderson. Sock and Buskin's first public performance was an outdoor production of Twelfth Night during commencement week in 1911, and its second, given in the following spring before a sold-out house in the Metro- 
politan Theater, was the morality play Everyman with Koch in the title role.

While such performances kept interest alive, Koch was preparing himself as well as his organization to write and produce original compositions. The year 1912-1913 was spent on the work of the contemporary Irish dramatists; among the plays performed were Synge's Riders to the Sea and Yeats's Hour Glass. Ibsen and Shaw occupied the next two years, and the Irish writers were again the subject of study and performance in 1915-1916. Meanwhile, writing had begun. The first public production of the society's work was The Pageant of the Northwest, dedicated to George Pierce Baker and performed May 28 and 29, 1914, in connection with the meeting af the Mississippi Valley Historical Association. Written cooperatively by eighteen students under the supervision of Koch and Libby-the latter to ensure historical accuracy-the pageant was an elaborate costume spectacle, employing scores of students and even a few Indian extras to portray the four successive stages in the exploration of the Northwest. Widely advertised, it drew spectators from many surrounding towns and won considerable praise beyond the borders of North Dakota, a source of great satisfaction to the new state and its new University. The local press gave it enthusiastic coverage, and the significant event was recorded for posterity in a handsomely printed book and in the first movie ever filmed in Grand Forks. In local eyes it dwarfed into insignificance the Bankside Theater performance a week later of As You Like It by the eminent Charles Coburn's traveling company of Shakespeareans.

The opening performance of the pageant had also provided the occasion to dedicate the new Bankside Theater immediately west of the president's house on a curve of the English Coulee "where in years long past the Indians met the English fur-traders of the Hudson's Bay Company." In a brief dedicatory address Koch voiced the ambitious hopes of the folk drama idealists whose vogue that year produced no less than forty-six pageants or masques in the United States; he looked forward to "a new drama . . . which will interpret for all time the dream of an emancipated people, a drama which will yet give us a new Shakespeare, an American."
In his enthusiasm, Koch expected that the site, at the moment no more than an untouched little natural amphitheater, would be transformed within a matter of months by the construction of rows of grassy seats divided by stone steps fanning out from the stage and set off by a curving row of Greek columns around the rear; thi dream never materialized.

The opportunity for the second elaborate pageant came in connection with the nationwide celebration in 1916 of the tercentenary of Shakespeare's death. Numerous events at the now dramaconscious University marked the occasion. In March and April Koch delivered five Sunday afternoon lectures on Shakespeare and his work before large and appreciative audiences at the Metropolitan Theater. Sock and Buskin performed Much Ado About Nothin as its annual presentation. The commencement address, delivered by the aged but vigorous Homer Baxter Sprague, an almost forgotten voice from the University's past, was entitled "Shakespeare's Greatest Character: A Woman." The main event in the celebration was Sock and Buskin's cooperatively written and "audacious" pageant-drama, Shakespeare the Playmaker, presented at the Bankside Theater during commencement week, June 12 and 13, 1916. This marked the end of pageantry at the University, save for one last effort in 1921 (except as it appeared in the increasingly elaborate May fetes performed annually after 1907 under the direction of the women's physical education department).

Koch was moving toward his ultimate goal, the production of dramatic pieces written by the students themselves. Sock and Buskin had become almost entirely a student organization by 1915 In 1915-1916 Koch offered his first formal course in playwriting, the techniques of the drama; known as "English 31," it was a frank copy of Baker's famous course. The machinery for production was meanwhile improved by the completion of a little theater laboratory, consisting mostly of a movable stage and an attic room for prop construction in the small auditorium in Woodworth Hall. With the added stimulation of the announcement of the first annual dramatics prizes, $\$ 40$ donated by Dr. John G. Arneberg ${ }^{1}$, an alum"In 1957 Dr. Arneberg established a $\$ 25,000$ trust fund to "encourage and improve
education in foreign languages" at the University. 
nus living in Grand Forks, for the best plays written and produced by students, Sock and Buskin turned to staging and performing the plays written in English 31. The first to be performed, in December, 1916, were Turribly Sot by Clara Struble and The Long Exile by Arthur Cloetingh (later director of dramatics for many years at Pennsylvania State University). Another series was presented a month later, and three student plays, Turribly Sot, Morgan of Hinchenbrook, and Down on the Old Farm, were performed on the annual spring tour in April. Between 1916 and 1918, twentyeight plays were written and seventeen actually produced. Rural and farm life was the most popular subject, undoubtedly because of the urging of Koch, who proudly described these "native" products as "vigorous with the life of the soil." Among the best of them were Barley Beards, written by Howard DeLong, born of French homesteaders in a sod shanty forty miles from a railroad; Me and Bill by Ben Sherman of Judith Basin, Montana, dealing with the tragedy of a half-crazed sheepherder Sherman had actually known; Dakota Dick, a comedy of frontier days in the Bad Lands by Harold Wylie; arid Arthur Cloetingh's Back on the Old Farm, which suggested the "futility of an outlived culture on the new western soil."

Koch actually made no fair test of the possibility of evoking a strong tradition of dramatic writing at the University, for in 1918 he resigned to go to the milder climate and larger field afforded by the University of North Carolina. His efforts to extend play writing to the high schools by organizing an annual contest to be judged by the University faculty had already failed. A half dozen years after his departure Sock and Buskin, renamed Dakota Playmakers in December, 1917, after a diligent search for a suitably indigenous name, lapsed into a conventional campus dramatics club. Yet Koch's influence had not been inconsiderable. The example of the students' work at the University had inspired several Dakota communities to undertake the cooperative production of their own historical pageants, and the other state colleges had emulated his work, the most successful being the Agricultural College where Alfred G. Arvold launched his own Little Country Theater in 1914. Moreover, to make the hard work of dramatic criticism, serious performance, and creative writing popular student enterprises was no small achievement. The work of Koch and the in fluence and example of such a mature literary man as Hult had much to do with the fact that this period in the University's history produced two professional writers, Vera Kelsey, a novelist and travel writer of considerable ability, and Maxwell Anderson, one of America's foremost men of letters. Interestingly enough, the only Anderson plays produced at the University were two more or less conventional senior farces: Lost Labors Love, written in collaboration with R. H. Montgomery and performed in 1909, and A Masque of Pedagogues, performed in $1911 .^{2}$

The University newspaper and annual were indispensable semicurricular activities which, although they involved a relatively small number of students, provided opportunities for expression and recognition-and added to the ever widening circle of distractions from academic work. The first annual-really a biennial-appeared in the spring of 1903. Published by the junior class (hence the practice of dating it one year ahead), the Dacotah appeared in alternate years until 1915; no 1917 or 1919 numbers were published because of the war. The Student became a weekly in October, 1904, a change which completed its transition from a literary magazine to a newspaper. A year later its importance was emphasized by the addition of a journalism course in the English department with a half credit given for working on the paper. In the next dozen years it went through numerous changes in size and format; in McVey's day it was a six-column four-page sheet, its serious-mindedness a fair reflection of the purposefulness so much a part of the times in general and of the University in particular. The editorial page was well developed and supplemented with a "public opinion" column; McVey also revived Sprague's old custom of writing a regular column himself, "Paragraphs from the President." The paper's appearance every Friday was a vital part of the University week. The highly prized positions on the staff of both the Dacotah and the Student attracted a fair share of those students whose names were to be numbered among prominent alumni. Stefansson, Lemke, Moses, O'Connor, and Waldemar Westergaard ${ }^{2} A$ Masque of Pedagogues was published in the North Dakota Quarterly, Spring, 1957. 
all served on the paper; John Hancock, the New York financier, was editor-in-chief in 1902-1903. Maxwell Arderson edited the 1912 Dacotah, and Carl Ben Eielson was selected for the 1919 number, which did not appear because of the war.

The multiplication of organizations was perhaps the most marked development in student life. The literary societies were, to be sure, a part of this, but even at their peak they represented an era of college life that was passing. Meanwhile, there was developing alongside them a number of new organizations more representative of the time and the changes occurring in the University. The most important of these were the professional societies and the Greek letter social fraternities. The former reflected the shift in emphasis in the University that accompanied the rise of the professional schools, and the fraternities marked the end of the day when the whole student body was a kind of club. Two secondary groups that developed rapidly after 1900 were the semisectarian religious organizations, a reflection of the decline of direct faculty supervision of religious life, and the nationality societies, whose popularity during the decade and a half before the World War indicated the presence of a significant number of students from the large immigrant population of North Dakota.

The vogue of the professional societies began with the formation of the engineering clubs shortly after the engineering colleges were opened. Organizations of this sort came and went, depending upon the enthusiasm of some professor or group of students, but by 1910 each professional school and a number of departments had their more or less permanent clubs attached. A variation on the form, which began to appear in McVey's time, was the honorary or professional Greek letter society. A chapter of Delta Sigma Rho, an honorary society for orators, was installed in 1911. It was followed in a few months by national charters from Phi Alpha Delta and Phi Delta Phi for the Corliss and Bruce law clubs. The organization which mirrored most faithfully the progressive ideal of public service and McVey's effort to make the University a factor in the everyday life of the state was the Civics Club. Founded by Boyle in 1907, it expired in 1917, a year after he resigned. Some measure of its caliber as well as of its earnest purpose is apparent in its 1908-1909 program: United States Senator Martin N. Johnson, Congressman Louis B. Hanna, and Walter L. Stockwell, the state superintendent of public instruction, appeared before it, and student papers were presented on such serious subjects as "Taxation in North Dakota" and "Methods of Choosing Supreme Court Judges in Vermont, Massachusetts, New York, Wisconsin, and North Dakota." In 1912 the club sent George Shafer and Clyde Duffy as delegates to the International Civic League convention in New York. Gillette's Sociology Club, organized in 1907, was no less serious minded or timely; it claimed credit for persuading Theodore Roosevelt to make the Bad Lands into the Dakota National Forest in 1908. This club also served as the nucleus of the University Settlement House established in 1914. Modeled on Hull House and operated by a dozen students under the sponsorship of Gillette and McVey, it was designed to care for eighty needy families. The public spirit which prompted activities such as these was also reflected in a lively student interest in political campaigns and the campus popularity of that North Dakota hero, Robert M. La Follette of Wisconsin. After their first appearance in the campaign year of 1908, political clubs were a regular feature of University life. For a brief period, around 1912, a generally liberal spirit seemed to prevail, partly no doubt a result of the growing influence of the new professors who joined the faculty after 1899, but the student body reverted to its habitual conservatism by the eve of the war. The attitude was most noticeable during the political revolution brought about by the Nonpartisan League in 1915.

Nationality societies, partly social and partly literary and study groups, had a brief vogue between 1900 and 1910. The organization of the Norwegian society, Mimer, had been followed quickly by the Icelandic Association and the Celtic-American Society; the latter was largely the work of J. F. T. O'Connor. All but the Icelandic Association, and even it went through periodic "revivals," succumbed in a few years to the stronger attractions of the professional and social organizations and to the rising American nationalism, which was emphasized even more with the outbreak of war in Europe. Even if the situation had been ideally tolerant, the feeling which caused Norwegian-speaking students to avoid 
Tingelstad's "immigrant" language classes, except perhaps to pick up an easy grade, would have worked against the long-term survival of these societies.

Unlike the organizations considered thus far, the nonsectarian religious societies, which also rose to positions of considerable influence after 1900, were not new on the campus, the YMCA having been founded in 1899 and the YW in 1892. But it was not until the University had retreated from its early close supervision of student religion that these organizations came to be regarded as "the most effective agency of moral and religious training ... in a state university." Growing enrollments and the steady drift of the University from the emphasis upon development of character and morals to intellectual and professional training, as well as the growing secularism of the times, were responsible for the change. The way was well marked by such events as the abandonment of the daily compulsory chapel service in 1903 for the secular weekly convocation and the retirement of such custodians of students' religion as Macnie and Woodworth. Meanwhile the proportion of students who did not attend church rose steadily. Twelve per cent of them professed no church preference in 1906, and in 1912-1913 only 366 of the 650 enrolled were members of any church and 111 disclaimed any preference. Affiliation with Wesley College had been one measure to counter the trend, but its effect was limited, for no other denominations followed the precedent. It was therefore left to the Y's and the Catholic Association, which between them enrolled more than half the student body by 1910 , to do what they could, with whatever assistance there might be forthcoming from such organizations as the Homiletic Club and the Young People's Branch of the WCTU. To all of these McVey gave every encouragement. An important sideline of these organizations was the operation of various studen 1 services. The Y's set up the first campus employment bureau in 1914, the same year that the YMCA assumed responsibility for the only recreation room on the campus, the Budge Hall basement, after the Men's Union started by McVey had collapsed.

By 1917 all of these organizations, however, were secondary to the Greek letter social fraternities, none of which had any pur- poses more serious than to provide some sense of "belonging" in an increasingly complex University community and to offer some opportunities for organized partying. No trend in student life at North Dakota, and for that matter at dozens of other state universities, was more marked in the two decades before the World War than the increasing emphasis upon strictly social doings and the increasing elaborateness of their nature. An early milestone in this social revolution at North Dakota appeared in 1901 when the faculty, by a margin of one vote and despite the misgivings of Merrifield who gloomily predicted the withdrawal of twenty students, permitted the students to schedule a dance in the Budge Armory. Old habits being what they were, this first dance, held January 12, 1901, was preceded by a short literary and musical program, including a humorous speech by Lemke, and it goes without saying that the hours were short and the supervision close from dormitories to dance floor and back again. No parents objected, however, at least to the extent that Merrifield had feared, and in a few years the "hops" had become the most popular form of student entertainment, important enough to require a special committee to manage their financing. The junior prom made its appearance in 1902 and quickly developed into an elaborate affair costing $\$ 3$ or $\$ 4$ a couple, a large sum for most students of the time. The prom of 1905 began with a dinner at the Dacotah Hotel at five in the afternoon and concluded with a four-course supper on the campus at two in the morning. There were thirty dances on the program, mostly waltzes, one-steps, and hesitations; the twostep and the "moonlight" were favorites by 1908. The gentlemen wore full evening dress at the 1906 prom, and the "leading lady" was in gray brocade and diamonds. A canopy was stretched between the Dacotah Hotel ballroom and the Antlers Hotel across the street where a banquet was served to more than two hundred guests. The senior prom appeared in 1908, the year these formal dances were moved out to the new gymnasium on the campus. The elaborateness of these parties aroused some criticism, and Merrifield and his faculty were concerned with the growth of ostentation, although they generally looked with favor upon the introduction of a bit of elegance into social affairs, a not uncharacteristic 
faculty attitude in a day when the average professor considered a full dress suit an essential part of his wardrobe. Indeed, they had done their bit to assist the shift, once it had begun, from the homey little Saturday night receptions, a custom for fifteen years, to the more open and sophisticated activity symbolized by the dancing. The president's marriage in 1902 and the construction of a mansion had been factors in the development. The mansion, looked upon as totally unfit for family living in 1954 by a new president, was deliberately designed to be a sort of "union," a focus for the social life of both faculty and students, and an example of a gracious and cultivated scale of living which students of this pioneer commonwealth knew only from books, if at all.

The house could never really serve Merrifield's purpose, for the day was passing rapidly when stiff entertainments like receptions at the president's house held much charm for anyone. Although the custom was continued with waning enthusiasm by McVey, the chief effort of the president and faculty in his time was directed toward making student social affairs more informal and all-inclusive, and less formidably expensive. After the Commons building was completed in 1911, the formal class parties were held there, in what was easily the handsomest hall in Grand Forks. The gymnasium, completed in 1908, was meanwhile pressed into use for dancing on practically every weekend: a half dozen semiformal all-student dances each year and informal no-escort dancing parties on most Saturday evenings. The popularity of dancing, which outdistanced either football or forensics by McVey's time, was of course the first symptom of the coming of the jazz age. At North Dakota, although the orchestras still played reasonably sedate music, the new unrestrained rhythms were making their appearance on the eve of the war in such new dance steps as the "grizzly," "bunny hug," "tango," and "Boston dip," all of which were banned by the dean of women, and all of which many students managed somehow to learn.

It was in this milieu of relaxing social standards and restrictions on the campus that the social fraternities had their beginnings. The first had appeared in February, 1902, when ten "turned-down, heart-pierced young men ... in short, ten unsuccessful lovers" formed the Varsity Bachelor Club. Although professing to lead a life of "one continued round of pleasure," it was characteristic of the time that the organization, which was originated by William Lemke, considered it necessary to announce the more serious purpose of "the advancement and the upholding of the University." Comparable to the more recent Blue Key society, as well as a social organization, the Bachelor Club became a society of student leaders and enjoyed special favors from the faculty. Its vigor and influence were at their peak in 1909 when the legislature approved a bill, introduced into the house by Fred Traynor, an alumnus, to lease a site on the campus for a chapter house, the first one to be built and owned by any fraternity. In addition to Lemke and Traynor, the chief promoters were such old Merrifield boys as Burtness and Wardrope. Merrifield, Congressman Hanna, and M. F. Murphy, a member of the Board of Trustees from Grand Forks, each lent $\$ 1,000$ for the project. Located on the banks of the English Coulee directly west of the gymnasium, the house was completed in 1910 at a cost of over $\$ 20,000$; it provided space for more than twenty residents. The high caliber of this first fraternity-the Bachelors gave the first annual prize for academic excellence-caused the faculty to approve more willingly than they might otherwise have done the petitions of other groups. In April, 1906, the Banded Brothers of Bungaloo (originally Phi Tappa Kegga) was formed; the first sorority, Alpha Delta (Kappa Alpha Theta), was formed in the fall; in 1907 came the second sorority; the next year the first local Greek letter fraternity, Alpha Kappa Zeta, was organized; and in 1909 the first national charter was granted from Sigma Chi to Bungaloo. The latter event was celebrated in a round of ceremony and festivity said to have cost more than $\$ 1,000$. These developments may not have been the entrance into a "larger world" that a young student editor believed, but they were steps nevertheless, as were the dances, in North Dakota's progress toward the conventional patterns of college and the development of such familiar figures of the time as those blasé young men with their "turned up trousers, padded shoulders, and everlasting pipe," noted by President $\mathrm{McVey}$.

In McVey's administration the Greek letter societies prospered 
like the green bay tree. There were ten, five fraternities and five sororities, on the campus by 1917. Five-Sigma Chi, Phi Delta Theta, Kappa Alpha Theta, Alpha Phi, and Delta Gamma-had national charters, and nine had chapter houses; only the Phi Delts owned a house, however. There were more than a few misgivings about their development. Some of the Varsity Bachelor alumni, who had strained their purses to raise the money for their chapter house, feared that their beloved society would lapse into just one more social fraternity when it succumbed to the vogue and applied for a national charter from Phi Delta Theta; and so it did.

For the University the fraternities posed the usual problems of regulation. The first code of fraternity behavior was prepared by the faculty in 1907: no freshmen permitted to live in chapter houses, rushing and pledging postponed until after the Christmas holidays, and house mothers required in all sorority houses. Drinking and gambling were expressly forbidden, probably not without good reason. These regulations, which were augmented by others, were enforced more and more rigorously during the next ten years, particularly after 1913 when the disgracefully poor academic record of the Greek societies could no longer be ignored even by the students. There was marked improvement after the formation of the Interfraternity and Pan-Hellenic councils and a general tightening of faculty rules, including the enforcement of the neglected one banning the freshmen from living in fraternity houses and the postponement of initiations until the sophomore year and then only if the candidate had maintained an average of about three quarters "C" for two semesters preceding. By 1917 the societies could boast an academic record slightly above the average of the University.

Although the importance of these organizations steadily increased, their function was more to provide fellowship and housing than to provide amusement or the opportunity to play campus politics. Signs of the latter were beginning to appear in class elections, to be sure, but the sharp rivalries of Greek vs. "barbarian" were still in the future when McVey left the University. As for furnishing organized social entertainments, the fraternities and sororities still had no great advantages, being limited to only one formal and one informal party each year. The fraternity party of 1910, incidentally, differed little from that of nearly a half century later. The Grand Forks Herald described a Bachelor Club dance in their new house in February, 1911-dancing from seven thirty to eleven thirty, a red rose for the "favor dance," subdued red lights, gray suede and gold programs, and supper by candle light.

The problem of exclusiveness might have come earlier and become more acute had it not been for measures taken by the administration and faculty. The appointment of Ella Fulton, preceptress of Davis Hall, as the University's first dean of women in 1908 was an effort to counteract the splitting of the student body into groups as much as to provide discipline. One of her first important steps was the organization of a Women's League, enrolling cvery girl in the University, both on and off the campus. Almost immediately after his arrival McVey undertook to extend the idea with a Men's Union, modeled on a similar organization at Harvard. The Budge Hall basement was furnished as a clubroom complete with newspapers and magazines and several pool and billiard tables. A year later, after the new Commons was completed, the Women's League was given the old Davis Hall dining rooms for its headquarters. Neither organization was wholly successful; the Men's Union, in fact, passed out of existence within three years of its founding. Nevertheless, the activity of the Women's League as a center for teas and receptions and the University policy of permitting weekly dances in the gymnasium served to postpone until after the war the complete domination of campus social and political life by the fraternities.

The pattern of conventional customs and ceremonies was rounded out in the eighteen years between 1899 and 1917. Seniors first wore the cap and gown in 1900. Commencement ceremonies filled a week by 1902. The first senior class gift came in 1904: a nine-foot Winged Victory, it was described as "the same as the original in the Louvre." Four years later the senior prom had arrived, and the graduation exercises were transferred from the Metropolitan Theater to the new gymnasium. Faculty academic dress and the first procession were introduced in 1910; also added were a senior farewell "pilgrimage" to every campus building with 
a pause at each to receive some "appropriate remarks," a formal address by a distinguished professor (the first one was given by Hult), and some athletic events. Following the commencement exercises, a farewell dinner wound up the week. Since the Commons was not yet completed in 1910, the first dinner was held in two large tents north of Main Building; the fickle North Dakota weather obliged with a blazing sun and a temperature in the nineties. McVey also introduced the practice of inviting distinguished commencement speakers, and in 1915 the student orators, a feature of the program for more than twenty years, disappeared forever.

Other ceremonies and observances, reflections of the customs elsewhere or of deliberate faculty transplantations from older institutions, were Founders' Day (1904), "Clean-Up Day" (1908), which had formerly been Arbor Day, the May Fete (1909), the Carney Sing (1910), "Between-Us Day" (1910), when the president talked "privately" to the assembled student body, and Homecoming (1916). The first observance of the latter event, organized by a committee headed by William G. Bek, featured a morning mass meeting in the gymnasium, an afternoon football game with the University of South Dakota, and in the evening a student-alumni dinner in the Commons. M. Beatrice Johnstone, the toastmistress, called for remarks from such alumni as Governor-elect Lynn Frazier, Neil C. Macdonald, and Ragnvold A. Nestos.

Homecoming belongs properly to the era of the 1920's, however; more typical of the prewar University was Founders' Day. First observed in 1904, it soon became and remained the most significant University celebration, second only to commencement. The usual pattern of the events of this day from about 1910 included an afternoon basbetball game, a faculty-student dinner in the Commons, and speeches in the gymnasium by prominent alumni, Board members, or some state official. A popular feature, introduced in 1912, was Squires's illustrated lecture on the history of the University, dramatically divided into ancient, medieval, modern, and contemporary ages. In 1915 an honored guest was James Twamley, the Grand Forks businessman who had been a member of the original Board of Regents. M. Beatrice Johnstone and George Shafer
(B.A., 1912) were the main speakers, and Squires read a nine-stanza poem, "Founders' Day, 1915," that he had prepared for the occasion.

Many of these customs. differing little from those of other colleges, had been introduced as more or less ready-made traditions. Such, for example, was Koch's annual custom of reading Dickens' Christmas Carol, usually in the late afternoon of the Sunday preceding the Christmas holidays. It had become a major event of the year by 1917 , attracting as many as a thousand students and townspeople. Two traditional symbols, genuinely linked to the University's past, the colors and the old seal, were cast aside or forgotten. For a decade before 1917 there was considerable agitation to discard the pink and green for the more conventional and masculine black and gold. In fact, in McVey's administration the new colors were unofficially adopted and would no doubt have become permanent had it not been for protests from influential alumni and students. ${ }^{3}$ The old Regents' seal, inscribed with the happy and spontaneous sentiment, "Intelligence, the Basis of Civilization," was not so fortunate. In 1908 a committee of students and faculty (Bruce, Squires, and Thomas), unaware of its existence or not caring, adopted a suitably conventional emblem, complete with Latin motto, Lux et Lex, inspired by Yale's Lux et Veritas.

Despite the rapid transformation in the character of the University-indeed because of it-there remained a nostalgic awareness of the past, which was reinforced by the determination of the older men, and some of the younger ones as well, to keep it alive. Squires particularly was convinced of the benefits in student and faculty morale, and in prestige as well, that derive from a widely known historical tradition. His lectures on the history of the University, in time a part of every student's experience, kept vivid the educational ideal and the memory of the unselfish service which had been the main ingredients in the University's survival in its first decade and a half. Illustrative of the appreciation of the past as well as an acknowledgment of the great debt to the founders was the decision in 1912 to rename the main building and the new Teachers College in honor of Merrifield and Woodworth. The 'In the 1920's green and white were adopted as the team colors and have continued in use since. 
gesture came none too soon. Within a few years death removed such living reminders of the early days as Merrifield and Perrott (1916), Twamley (1917), and Sprague (1918). Sprague was honored by the LL.D., conferred at the 1916 commencement. Twamley's memorial, the only one to any of the originators of the movement for the University, was $\$ 1,000$ contributed by his family for the first student loan fund. The interlude of the war and the troubles which followed drew so heavy a curtain across events preceding 1917 that of the three new buildings erected in the 1920's only one (the new Merrifield Hall) was named for anyone.

Meanwhile, for better or worse, old habits and customs of the unorganized, unofficial student life had been transformed in the decade and a half preceding the war. Gone with the old fence and its inscriptions were the railroad track promenade of the lonely, gesticulating orators, the courting couples walking the rails hand in hand, and the early spring botanists. Macnie's annual "spreads" for the girls, one in the fall on his grandson's birthday and a strawberry feast in late May on his son's, ended with his retirement. The double beds in the dormitories were replaced with single cots in 1910-1911. "Chapel sitting," which was supervised study hall for the preps, went out in 1902, and compulsory daily chapel followed in a year. By 1909 the two "nights out" per term for dormitory residents had been extended to all weekend evenings and to other nights if the hall proctors gave permission. Girls were, however, required to have written permission from their parents to be in town after six o'clock unless they were in groups attending church or properly chaperoned. Restrictive rules steadily lost meaning as enrollments rose and an increasing proportion of students lived off campus where they received scarcely any supervision at all. The development of the professional schools with their mature students, especially the off-campus law school, was accompanied by an increase in the usual student vice of drinking, and undoubtedly there was some frequenting of the red light establishments still operating more or less openly in Grand Forks and East Grand Forks as late as 1910. It is significant that abhorrent as drinking and even smoking were to Merrifield, Squires, and others, by 1905 the only penalty for indulging in either-off campus, that is-was expulsion from the dormitories. Only those who violated the nodrinking rule repeatedly, or who brought liquor on campus, were expelled from the University. The demerit system, which included penalties for such offenses as tardiness, the use of profanity, or noise making in the halls, although not abolished officially, had for all practical purposes broken down by 1909, and it vanished without a trace when McVey assumed office. Yet despite such evidences of adjustment, the only really positive measure undertaken in Merrifield's last years to meet the new problems arising from students' living off campus, the growth of social fraternities and sororities, or the "dating" that inevitably accompanied the relaxing socia standards was the expansion of Miss Fulton's duties from those of Davis Hall preceptress to those of dean of women.

Confident that students' parents supported the old rules, despite their being better suited to an eastern boys' school than to western University, and lacking as yet any formal organization or special personnel for handling such problems, the president and faculty spent an increasing amount of their time on disciplinary matters in Merrifield's last decade at the University. A surprising number of the campus leaders were disciplined at one time or another. Frazier and Lemke were ousted from Budge Hall on one occasion, and Burtness, the "big man on campus" in his day, also received his share of faculty censure.

The legendary case is the expulsion-or suspension-of Vilhjalmur Stefansson in 1902. A brilliant young Icelander who had made his own way for some time, "Stef" ignored the "children's" rules and achieved the reputation of being a champion prankster. Legend has it that he translated daily for the slow students in the French class of the myopic Macnie, that he was the author of the verses that appeared all over the campus on the mornings following Squires's calls on the student he was "sparking" and later married, that once when finding Merrifield's carriage parked on a downtown street he climbed in and brazenly ordered the driver to take him out to Budge Hall, that on another occasion he stole Woodworth's easily recognizable storm buggy and abandoned it at the door of one of the most notorious "houses" in town, that once when 
Merrifield caught him drinking beer on the front step of Budge Hall, he invited Prexy to join him in a bottle. Convinced that he was the ringleader in the general disorder that had given Budge Hall a reputation for rowdyism, the faculty voted in March, 1902, to suspend him "for the rest of the year, for failing to attend to his duties." His manner of going, trundled to the campus depot in a wheelbarrow amid a crowd of sympathizers and admirers, was a minor triumph. His repeated appeals for reinstatement or for special examinations were refused, although his final status was never firmly clarified. The refusals, the public announcement in chapel of the faculty decision to eject him, and the fact that Merrifield had indicated to him in a visit to his room the night before the announcement that he did not expect Stefansson to return, finally convinced him that he was through at North Dakota. The manner of his dismissal provides yet another glance at the method of Merrifield, as well as a measure of the small-scale, intimate nature of the University at the turn of the century. In 1930 Stefansson wrote the following account of his dismissal to his old friend Joseph Kennedy:

When I was dismissed from the University the news came to me in one of President Merrifield's friendly visits. He sat in my room at Budge Hall, chatted about various things for a while, then said I might have noticed that he had already stayed longer than usual and that this was because he found it difficult to get down to a disagreeable task, that of informing me that the faculty had decided on my dismissal. He explained, in substance, that the technical reason was my having been absent from classes without excuse but that the real reason was a feeling that I more than any other single person was at the bottom of a student ferment which made it difficult to maintain discipline. He gave me no written statement to this effect that time or, so far as I remember, at any other time, but said that the that time or so far as At Chapel the hall was crowded with most of the students and many of the faculty. The announcement of the faculty's action was read from the platform and constituted, therefore, a uniform announcement to myself and to all others as to what action the faculty had taken. My understanding . was that I could not re-enter the University of North Dakota

Stefansson enrolled at the University of Iowa-without transcript apparently and without mentioning his dismissal from North Dakota-took a degree in a year and then went on to Harvard. In a half dozen years, famous as an anthropologist, Arctic explorer, and writer, Stef was the University's most famous graduate and one of its most loyal sons. He wrote frequently to Merrifield, visited the University at every opportunity, and contributed pieces to the Student. In 1912 he was back on the campus at the invitation of the faculty to deliver a series of formal lectures, and in 1930, having officially decided that he had only been suspended after all, the faculty voted to award him the honorary LL.D. degree, the third conferred on any alumnus by the University. In the meantime, owing to his quick rise to fame and to his encouragement of tales about himself, a Stefansson legend had become a part of the University's history. For a generation after Stef had been on the campus it was an unimaginative alumnus indeed who could not add his own "Stef story" to the file.

An unfortunate aspect of Merrifield's last years was the drift from the prankishness of a more innocent day to outright rowdyism. Disturbances at convocation became enough of a nuisance to require faculty action in 1906 . The streetcar line, never run very efficiently at any time and often out of service for weeks on end in mid-winter, was not infrequently the object of vandalism; a conductor was assaulted on one occasion and badly beaten. Organized hazing in its more vicious forms was on the verge of becoming a permanent campus problem by 1909 , accompanied as it was by class rivalries so intense that mass class fights were a constant threat, particularly in the early fall. Often erupting in the buildings, they could and did produce smashed furniture and broken windows. One brawl that developed when seniors attempted to break up a junior class sleighing party was serious enough to be noticed by the Minneapolis Tribune. When in 1908 posters were circulated forbidding freshmen to wear derbies or class pins or "to fuss with girls outside their own class," the resulting free-for-all, swirling from the railroad station and gymnasium, attracted a large crowd, disrupted classes, and was halted only by Merrifield's personal intervention.

The disturbances were accompanied by a note of rising acerbity in faculty-student relations, once so intimate and friendly. On one occasion students attempted to break up a faculty meeting by creating a hubbub outside the door of the meeting room. When the 
faculty declared an important player ineligible to play football on the eve of the Agricultural College game in 1906 there was talk of a team strike. A Student editorial had suggested shortly before that the faculty should confine itself to its academic role and leave students' private affairs to them. A faculty-student disagreement in 1908 over the date for the junior prom led to the Council's considering plans to restore better relations. Merrifield's term drew to a close amid persistent talk about a student council; the movement seemed on the verge of success in 1909 but did not get beyond some proposals by McVey for a student court to deal with the alarming increase of cheating at examinations and to regulate smoking on the campus. In fact, the only student government organizations to develop before the war were the dormitory councils.

Nevertheless, McVey had not been on the campus long before he recognized the need for positive action, and it is greatly to his credit that his administration achieved a return of tranquility in students' relations with each other and with the faculty, and that the era of sharp rivalries, hazing, and "politicking" was at least postponed until after the war. It is even more to McVey's credit that the improvement was not at the price of pampering the students, or of his posing as their friend who stood between them and a hostile or unsympathetic faculty. In 1913 he centralized the handling of students' discipline problems, heretofore the responsibility of the Student Work Committee and the Council, by the formation of a three-man committee on discipline responsible to himself. William G. Bek was set on the road to becoming a dean by being appointed as its first chairman, a post he held as long as McVey was president; Gillette also served throughout the period. Technically this committee had no power, but in practice its recommendations for punishments, including dismissal from the University, were regularly accepted by the president, from whose office all notices of disciplinary action came by formal letter. Al though McVey assumed the responsibility for discipline more explicitly than Merrifield had and frequently had students into his office for advice or for "severe reprimand," the system was no longer the highly personalized one followed by Merrifield.
For the most part general regulations continued to be restrictive by current standards. In 1912 a dozen girls were suspended from attending social affairs because they had gone to a theater performance without a chaperon. The 1914 University handbook forbade girls to go beyond the city limits in carriage or automobile without permission from the dean of women; all such excursions had to end by six o'clock. (It may be noted in passing that the first student auto fatality occurred in 1916.) Men students had somewhat more freedom than formerly. Although the first rule in the handbook of 1914 was the prohibition of smoking on the campus or in the University buildings, everyone knew that men students smoked everywhere else, and the University depot, in plain view of the president's office and only technically off the campus, was the between-class rendezvous of the devotees of Bull Durham and Duke's Mixture. The fact that the president himself smoked cigars (at home) undoubte 1 ly had much to do with his indifference. Men students had somewhat more freedom to come and go than before, for instance to see every change of bill at the moviesthe old Metropolitan became a movie house in 1915. Drinking and immoral escapades-off campus, that is-were less likely to result in dismissal than before, provided no laws were violated. In 1913, for instance, one young man, who was past twenty-one, and a couple of noncollege girls likewise of age became involved in a drinking party in a cheap Grand Forks hotel room, where the young man was arrested. The discipline committee's only recommendation was that the president reprimand him severely in his office.

On the positive side McVey encouraged or provided activities which could absorb the excess energies of youth or channel rivalries into manageable situations. One of his first moves, hastened by the sadistic ducking on a raw October day of one Samuel Pyes in the coulee before a yelling crowd, was the announcement of the first annual freshman-sophomore "cane rush" in the first weeks of the 1910-1911 term. Held on the athletic field and supervised by upper classmen, this free-for-all, clothes-tearing struggle became a popular annual event. Another was the annual singing contest between classes begun in 1911 when E. Claude Carney (LL.B., 
1904) offered a gift to endow some activity that would stimulate loyalty to the University. On the suggestion of Squires, who had in mind a similar event at Amherst, the money was used for an interclass singing contest. Although class rivalries were keen, the Carney Sing held on the eve of every Founders' Day before a panel of judges imported from neighboring colleges or towns was perhaps the most good-natured of any of the interclass competitions. In addition, there was for the first time some serious attention paid to the provision of recreational facilities-the club rooms of the Women's League and the Men's Union or the YMCA, the frequent and informal dances, and the beginning of an intramural athletic program. The new Commons, with its handsome, vaulted dining room, was used extensively as a center for various ceremonies and celebrations. Most of the student body gathered here three times a day for meals; 350 could be served at one sitting by the whitecoated student hashers, otherwise known as the Waiters' Union.

There were to be sure minor instances of hazing or an occasional prank like the burning of a neighboring farmer's strawstack, as occurred on the night before the Agricultural College game in 1912. Nor could such opportunities for student expression as the president's "Between-Us Day" or the annual publication of a humorously critical "yellow" edition of the Student accommodate every student resentment. The Student had angrily denounced the "kindergarten methods" which required the disciplining of the twelve young women who had attended the theater without a chaperon. The increasing practice of teaching by lecture instead of by recitation produced in another instance enough criticism for the president to feel obliged to defend lecturing publicly. And in March, 1917, the law school's sub rosa scandal sheet, the Harpoon, the University's first experience with this type of annoyance, devoted a good part of its space to attacks on some faculty member and one or two deans. Denounced by one irate professor as a "muckraking piece of trash from beginning to end, a disgrace to the University of North Dakota," declared libelous by a student mass meeting, and the occasion of at least one speech to the students from the president, it set afoot a faculty investigation which might have had serious results for the students responsible had not the general excitement and temporary demoralization surrounding the declaration of war in April thrown this affair into another perspective.

It is Merrifield's time, not McVey's, which has evoked the most nostalgic reminiscences from alumni and evidences of their gratitude for the alma mater which provided a golden age for their youth and a priceless opportunity as well. Few alumni have been more loyal than Carney, Hancock, or Neil Macdonald. Stefansson was drawn back many times from all over the world in the twenty years following his dismissal. O'Connor rose to a law partnership with William Gibbs McAdoo and the position of comptroller general of the United States, but he never got over wanting to shine in the eyes of his university, and on his death in 1949 left it one of the largest bequests it ever received. Henry Lykken (1906), a world-famous engineer and inventor specializing in fine grinding machines, returned countless times to reunions and commencements. Chester Fritz, a boy from Lidgerwood who attended only two years (1908-1910) and went on to become an international banker with offices from Shanghai to Buenos Aires, became one of the largest benefactors of the University. But perhaps the most touching demonstration of the loyalty of Merrifield's boys was made in 1905 when Lynn Frazier, the old-time football hero then farming near Hoople, named his twin daughters Una and Versa.

All the signs of change notwithstanding, the University on the eve of the war was a simple and informal place where relationships of students and faculty-in a numerical ratio of about eleven to one-were still close. Nor had the increasing fragmentation yet produced really serious social divisions, partly because of the precautions taken after 1909, but chiefly because of the homogeneity in economic and social background of the students. Almost without exception they had been reared on farms or in rural towns. In 1913-1914, 40 per cent of the 679 students enrolled lived on farms, and of the 868 enrolled in 1916-1917, well over half (556) reported that their parents owned farm land. Even in the apparent diversity of national origin there was an essential similarity. Almost everyone was of Northern European origin. By 1910 the immigrants enrolled in the University in force, a reflection of the high per- 
centage of foreign-born in the state's population-27 per cent in 1910 , and 67 per cent foreign-born, or one generation removed, in 1920. By 1912-1913, the first year that University enrollment passed the five hundred mark, nearly one third (156) were immigrants from Scandinavia or the children of such immigrants. That year the May Queen was Olga Serumgard, and a Scandinavian won the state's Rhodes Scholarship for the first time-David Nelson of Mayville, a former University student.

Students from such backgrounds were not likely to be rich; many found the extremely modest costs- $\$ 118$ for board, room, and fees in 1899-1900, $\$ 166$ in 1908-1909, and $\$ 223.50$ in 1916-1917more than they could afford. The working student had been a University fixture from its opening day in 1884 when Ben Ingwaldson arrived carrying a bucksaw to earn his way cutting firewood. Stefansson, who came wearing a $\$ 7$ suit and enjoying his first train ride, earned his entire expenses by teaching school and working at odd jobs, including the herding of an old lady's cow, a post he lost because his employer objected to his views. Gudmundur Grimson (later a justice of the state supreme court), Frazier, Nuessle, and Burtness, all were University postmaster and manager of the bookstore at one time or another; Thomas Jewell managed the University railroad station; Carney interrupted his law education to teach school and to prove up a homestead; the weekly washing and ironing for Merrifield and Macnie provided income for a succession of girls; Maude Sanford kept the Davis Hall lamps filled with kerosene; Ethel Wood, who married Vernon P. Squires in 1902, waited tables in the private faculty dining room. In 1912 1913 nearly 40 per cent of the students were reported to have earned or to be earning all of their expenses, and only 21 per cent said that they depended entirely on their parents. In 1916-1917 more than half were earning all or part of their expenses. It is hardly necessary to comment that a student body with so large a proportion of immigrants or immigrants' children, few well-to-do, many self-supporting, and nearly all dependent in some way upon the uncertain fortunes of Northern plains agriculture was not likely to be frivolous whatever their deficiencies in general culture might be. The quality of earnestness so often remarked in the early days remained as one of the most engaging characteristics of the North Dakota students in 1917. Thoughtless critics might.denounce the University as a refuge for the idle rich, as undemocratic, but in fact few institutions had better claim to the title of "University of the Common Man."

The era closed on a note of high excitement with the nation at war. Yet it was actually not until the last months of the 19161917 term that the war in Europe began to make itself felt in student affairs. There were, of course, student editorials from time to time on the issues of the war, but a more engrossing subject, raised by the enactment of the National Defense Act in the summer of 1916, was the prospect of the revival of military training. The even tenor of University life continued as before; its rhythm of classes, rushing, athletic contests, cane rush, and the like was uninterrupted, and in this year of crisis the first Homecoming celebration was held-and well attended. There were also a number of exciting developments which diverted attention from what was going on in Washington and in Europe. The Mexican border troubles called several students into National Guard service; most of them were home in time to enroll for the second semester. The high excitement of the Nonpartisan League's first campaign for state offices partially obscured the war issues being debated by Woodrow Wilson and Charles Evans Hughes, the presidential candidates.

When these matters were out of the way, however, more and more attention was taken by the war. Not long after the election a YMCA drive for funds to aid inmates of European prison camps brought in over $\$ 1,000$ contributed by faculty and students. Following the War Department's offer to provide one commissioned and one noncommissioned officer for each three hundred students if a training program was organized, the faculty Council voted in January, 1917, after a heated session, to revive compulsory military training; then by a vote of sixteen to thirteen it was postponed for a year. The debate over this issue only waxed hotter as a result. Meanwhile, the patriotic motif appeared with increasing frequency in campus affairs; the 1917 Founders' Day program was constructed 
entirely around the theme of "The Privileges of Being an American."

The tension as well as the debate was ended by the declaration of war on April 6. From then on events moved swiftly and confusedly, and it is highly doubtful whether much serious work was done in the next two months by the students while the faculty and administration sought to contribute to the war effort without being very clear on what to do. Military training was begun almost immediately on a voluntary basis; it was not compulsory until the following September. Less than half of the eligible students turned out to be drilled by inexperienced faculty members. Fifty-two of the more dutiful or martially minded took advantage of the offer of full credit for the semester without examination to anyone who enlisted in the armed services. More than twice as many (124) hastened to their farms to win the war with food. Part of the cam pus was plowed and planted to war gardens before the term ended. Taylor's radio station was dismantled on orders from the War Department. Plans for the Dacotah were dropped, and the spring formals went austere. Track and baseball also gave way to the war but not without some sharp exchanges between McVey and Lewis Crawford, president of the Board of Regents, who had interfered unnecessarily. On June 5, the day appointed for the first registration for the draft, the entire faculty and student body marched in a great patriotic parade, and at the ceremonies which followed at Central Park McVey gave a thoughtful speech on "The Test of Democracy." That evening the University band played a concert of marches in the lobby of the Dacotah Hotel.

Two weeks later, at the twenty-eighth annual commencement, Professor Irving Fisher, the Yale economist, addressed a solemn audience on "Public Health in Wartime." Degrees were awarded to 155 graduates and two-year teachers' certificates to 63 . Condensed to one day without the usual festivity, commencement of 1917 marked the end of an era in University affairs and in student life as well.

\section{VIII}

\section{Stresses and Strains}

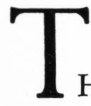

HE UNIVERSITY'S COMING of age, as well as such extraordinary external developments as the Great War and the rise to power in North Dakota of the Nonpartisan League, introduced situations and pressures that were either altogether new in University history or previously so undeveloped as to receive little or no attention. The growth of enrollment and expansion of functions before the war produced problems enough, but they were nothing compared to those that arose from the loss of faculty and students and the disruption of normal routines occasioned by the war, and from the mounting costs, low salaries, and burgeoning enrollment that appeared after it ended. No less productive of difficulties were the passions and fears that accompanied the war and the "red scare" that followed it; these were immeasurably complicated and intensified in North Dakota by the appearance of the NPL, coincidental with the very moment when the University and its faculty were moving into a larger field of action.

Except for the local phenomenon of the NPL, the pattern at North Dakota was not greatly unlike that elsewhere. The same may be said for the appearance on the North Dakota campus of the issue of "academic freedom." Although narrowly defined at times as the right and duty of the scholar to speak the truth as his 
studies reveal it, in its broadest sense the principle had come to include the immunity of institutions themselves from outside interference and the freedom of the professor to exercise his duties and rights as a free and responsible citizen. The issue, a point of increasing concern in academic circles after 1900, owed its origin to the introduction of a number of new factors into the world of higher education: the shift from the old fashioned schoolmasterprofessor to the European-type scholar-specialist, professionally selfconscious and jealous of his independence; the arrival of the administrator-president, whose duties as personnel manager and budget officer were steadily encroaching upon his role of chairman of the faculty and public exponent of the ideals of the institution he headed; and the addition of the concept of public service, particularly in state institutions, along with the expectation that the college or university should be a positive force in the community it served. As could be expected, the transition was marked by frequent conflicts between faculties and administrations, between institutions and governing boards, and by a simultaneous search for a workable formula for the protection of academic freedom and faculty status. Dramatized by the widely publicized difficulties of such distinguished and independent-minded scholars as Edward A. Ross of Wisconsin and Thorstein Veblen of Stanford and Chicago, and coupled with the fact that the separate professional societies afforded no united professorial front, the issue led to the formation early in 1915 of the American Association of University Professors (AAUP), an organization devoted to the definition of the limits of the scholar's freedom and the protection of his tenure from violations of it.

These developments, which first appeared in the older and more mature institutions, were reflected at the University of North Dakota where the scholar-specialists had begun to make their appearance in some force in the last years of Merrifield's administration and where for some time there had been growing concern about "service to the state." Perhaps most important of all was the arrival in 1909 of the administrator-president in the person of Frank McVey. His administration would experience the first real discussion in North Dakota of the academic freedom issue. It is no de- traction from the credit McVey deserves for having done more to bring the University into high repute than any other president in its history, to say that this "young man in a hurry" could be arbitrary and at times high-handed; one former dean has observed: "He thought he was very democratic, but he was an aristocrat at heart."

Although nothing came of it except some talk, the first example of the difficulty inherent in professors' taking seriously the role of impartial expert and responsible citizen occurred in 1911 when James Boyle of the department of economics volunteered to testify before a committee of the United States Senate in favor of a reciprocal trade treaty with Canada. Boyle was on sound economic ground perhaps, but his views were unpopular in North Dakota because such a treaty would have reduced tariffs on Canadian agricultural products. The senior senator from North Dakota, Porter J. McCumber, gave him a difficult time before the committee, and Boyle found himself roundly criticized by some of the Board of Regents as well as by most North Dakota newspapers. The propriety of the professor's action was even debated with some heat in the Student, the chief criticism being that he had improperly dragged the University into partisan politics. The president, although himself an economist in essential agreement with Boyle, said nothing in his defense, at least publicly; on the other hand, he refused to be pressed into asking for the professor's resignation as some critics were demanding, and in a short while the little tempest had blown itself out.

More serious in its immediate consequences and more farreaching in its results was the quarrel that developed over the political activity of Joseph Lewinsohn (J.D., University of Chicago), appointed to the faculty of law in 1912 to replace Birdzell when he was given a leave of absence to head the North Dakota State Tax Commission. Before coming to North Dakota from Salt Lake City, Lewinsohn had served on the platform committee of Theodore Roosevelt's "Bull Moose" party at its Chicago convention in August. After he joined the University faculty he made several speeches for the Progressives during the fall campaign. McVey remonstrated with Lewinsohn about these activities, saying that he 
believed professors should limit their political activity to municipal affairs, but when Lewinsohn offered to resign, the president said no more. Postponed rather than solved, the issue was revived a year later by the Board when Lewinsohn attended a Progressive party meeting at Fargo. The chief objection came from N. C. Young of Fargo, the Board president, whose hand had been strengthened by the appointments made by the new governor, Louis B. Hanna, a conservative. A Taft supporter himself, undoubtedly blaming the Progressives for his man's defeat, Young demanded that Lewinsohn get out of politics or leave the University. McVey supported this view and Lewinsohn thereupon resigned. In an exchange of letters with the professor, the president outlined his conception of the professorial role in public affairs:

There is no restriction placed upon the teaching of a professor, or upon his speaking upon social and economic questions but as soon as he allies himself with a political body which seeks to control the political power of the state there is danger. The life of the Universities . . . depends upon their being able to keep above this kind of politics . . . . I do not acquiesce at all in your view that the educational life of the universities and of the states is endangered by this attitude . . . . It is good sense and good policy.

At the time McVey wrote this the University was already being criticized on several counts. Gillette and others had recently investigated the state prison and poor relief systems and had roundly denounced them, while the administration was being charged with loose accounting of University funds as well as extravagance.

Although Lewinsohn was safely out-he arranged to return to the quieter haven of private practice in Los Angeles at the end of the spring term-the controversy about him and the issue that had been raised continued. As such disputes do, it soon drew in other participants, in this case largely the law professors. That there was more involved than the single issue of academic freedom appeared in an exchange in the Herald letter column between the law school dean, Robert Henry, and Lewinsohn. The dean took sharp issue with the president's views on the proper limitations of professors' political activity, but he said that Lewinsohn, being only a temporary appointee, had to be released anyway because Birdzell would be returning from his leave of absence in the fall of 1914. Henry added a charge of his own, that Lewinsohn was an unpopular and ineffective teacher. Actually, he appears to have been able enough, but being a stiff marker he received more than his share of the criticisms aroused among law students by the sharply raised standards introduced by the dean. Ironically, in view of the unfavorable comments about his abilities, the lead article in the first Law Bulletin, issued in the spring of 1914, was Lewinsohn's "Agreement under the North Dakota Code."

The president, meanwhile, fearing the possible consequences of the widening dispute and probably embarrassed by the quarrel, announced a policy of having the faculty review academic freedom cases. The Board, aggrieved at the "widely misunderstood and misrepresented view of its position upon the matter of academic freedom," officially adopted this policy as its own in May:

The Board of Trustees of the University of North Dakota stands for academic freedom and also for individual liberty, which does not impair efficiency. We approve the policy of the president to have each instance in which a breach of academic freedom or individual liberty is charged submitted to the group, or the faculty, of which the instructor is a member, before the case is considered by the Board or any action taken thereon.

Young offered to resign but was persuaded by his colleagues to reconsider. The faculty officially accepted the definition as a satisfactory settlement, and there the matter might have rested had the Trustees been prepared to abide by their announced principles. Incensed once more by the publication of charges in a Los Angeles paper that academic freedom was being violated regularly at the University of North Dakota, the Trustees on June 15 summarily dismissed Professor Charles E. Carpenter, largely on the insistence of Young and Tracy Bangs of Grand Forks. A member of the faculty since 1909, Carpenter had made the mistake of criticizing the Board's behavior toward Lewinsohn. Carpenter was quite evidently not incompetent, for he soon joined the faculty of the University of Illinois and some years later became dean of the University of Oregon School of Law. When Dean Henry, who was teaching at the University of California summer session, learned of Carpenter's dismissal, he promptly submitted his resignation. Young then resigned from the Board, in November. Two other key members of the faculty, Brannon and Ruediger, also resigned in 1914. Their 
departure was apparently unrelated to the law school affair, for both went to better positions, but Brannon declared some years later that his going was caused partly by "unnecessary interference on the part of State authorities" in halting his proposed plant breeding experiments.

The arbitrary behavior of the Trustees in the law school dismissals plainly emphasized the insecurity of the whole faculty. In the next year or so the subject of the scholar's right to speak his mind and to exercise the rights of citizenship was a topic frequently discussed in University circles. Libby chose "Scholarship and Politics" as the subject for one of his University of Manitoba lectures in the spring of 1914. The president prepared a paper on "Academic Freedom" for delivery before the annual meeting of the American Economic Association in December. Gillette actually read the paper and then hastened on to New York as the faculty's official delegate to the organizational meeting of the American Association of University Professors. The fact that North Dakota had one of the charter chapters in the organization, the only one in the Northwest west of Minneapolis, and that it was larger than AAUP chapters at many older and more mature institutions is significant, not only of the vitality on the campus but also of the deep concern aroused by the events of 1914. The charter members were Albert J. Becker, president, Boyle, Brush, Crouch, French, Gillette, Hult, Kennedy, Ladd Leonard, Libby, Simpson, Squires, A. H. Taylor, and Tingelstad. ${ }^{1}$

The next step in the movement toward defining faculty status and the conditions of tenure came sooner than had been anticipated, an outgrowth of the general reorganization of the state system of colleges that was undertaken in 1915 with the creation of centralized control under a State Board of Regents. Early in 1916 the Board requested the head of each institution to appoint a committee of the faculty to submit suggestions "for institutional and student government," including majority and minority reports, with a view to forming a uniform system for all the state colleges. It is evidence of the Board's earnestness in this matter that for its guidance it secured a copy of College Government, a publication of the United "When the AAUP was formed membership was limited to university or college ing for ten years.
States Bureau of Education. The committee appointed, headed by Dean French of the medical school, ${ }^{2}$ submitted a draft of the University constitution in May. The work was well and thoroughly done, for the constitution was accepted before the end of the year, with only minor revision, by the faculty Council and the Board of Regents and has not been the object of a major faculty movement for revision since. Following the lines of university government generally approved in progressive academic circles of the time, the committee made, according to French, a studied effort to inject "a little more of democracy" wherever feasible into the workings of the institution. Significant sections were those limiting the president's powers over appointments and dismissals and creating two new faculty bodies, the Deans' Advisory Committee and the Administrative Committee, both intended to enlarge the faculty voice in University government: "It is . . the duty of the President to consult the advisory committee and also the deans of the faculties concerned, on the appointment, promotion or dismissal of any member of the faculty, on the reorganization of schools and departments, on disputes arising between schools, and on matters of budget apportionment." Final decision was "reserved to the President," but in case of dispute between the president and a dean or a majority of the faculty of a school or a majority of the Council, the views of both parties were to be presented in writing to the Board of Regents. Professors and associate professors were declared to enjoy permanent tenure, and Article XII stated: "Before dismissal or demotion, particularly when there is an alleged breach of academic freedom or individual liberty, any member of the faculty is entitled to have the charges against him stated in writing, to have a fair trial before a special committee of the Council and to have the recommendations of such committee presented to the Board of Regents, upon whom rests final authority for the promotion, appointment or removal of the teaching staff." Provision for a sabbatical year at half pay each eighth year of service was also included, but only on advice of the president. The constitution came too late in McVey's administration for him to test it if he were so in'Other members of the Committee on Rules and Regulations were Albert J. Becker P. Squires, and Heiskell Whaling (economics). 
clined. Judging from his record preceding its adoption there is no reason to believe that he had any intention of doing so. However, it was to be severely tested by his successor.

The constitution was the product of a remarkably favorable combination of circumstances, one that was not to be duplicated again for nearly a decade. Indeed, it was ratified on the eve of an era of turmoil, a product of external factors as well as difficulties within the institution, which would have made even the writing of a satisfactory document virtually impossible for years had it been postponed. Perhaps the most unsettling development was the sudden success of the Nonpartisan League, a left-wing agrarian movement, in the state elections of 1916. Although the Board of Regents was hardly mentioned in the campaign, the NPL was vitally interested in controlling it in order to save the Agricultural College from being "wrecked" by the implementation of the Craighead Report and to avenge the firing of the college president, John Worst. Lynn Frazier, the newly elected NPL governor, was scarcely inaugurated before he attempted to remove two of the Regents, whose terms would have expired anyway in July, and to appoint in their places George Totten, a former Congregational minister turned socialist, who was better known for his outspoken advocacy of agrarian causes than for his views on higher education, and Robert Muir (B.A., 1902), a brother-in-law of William Lemke, attorney for the League. Frazier's attempt failed because the state supreme court, dividing on party lines, upheld the incumbents; the senate, controlled by the League's opponents, then refused to confirm Frazier's nominees to fill the vacancies when they would normally occur and turned down a League sponsored bill to abolish the Board altogether and to place all state institutions-eleemosynary and penal, as well as educational-under a Board of Administration which would be partly ex officio and partly appointive. In the absence of any confirmation for their replacements, the incumbents then refused to vacate their positions when their terms expired, contending that their terms were automatically extended until the next legislative session in 1919. Meanwhile, the old Board attempted, without success, to force Edwin F. Ladd to resign from the presidency of the Agricultural College because of his open sympathies for the NPL movement. It was not until September, when exGovernor Frank White resigned to go on active duty with the National Guard, that Frazier was able to place on the Board his first man, C. E. Vermilyea of Valley City, another minister, and it was another two months before Totten and Muir were finally confirmed for the two regular vacancies on an order from the state supreme court. Even so, the widely publicized trouble about the Board was not settled. In January, 1918, on the very day that the final interviews were being held with candidates to succeed McVey, who had resigned the preceding August, the Board was involved in another quarrel about its own organization. This too went on for months before Muir replaced Lewis Crawford as president of the body and an NPL approved permanent secretary was appointed. By that time the reorganization plan had been abandoned entirely and was all but forgotten.

Although it would be difficult to say which side was most careless of its methods in the long fight over the Board of Regents, it was the NPL's effort to get control which excited the most suspicion, chiefly because some well-known socialists were numbered in the NPL membership. It was comparatively easy therefore to raise the cry that the NPL, which was in fact frankly trying to protect its sympathizers in college faculties and to ensure college administrations which were at least not hostile to its agrarian program, was out to "socialize" the colleges and to make them a haven for spoilsmen. Even Frazier and Neil C. Macdonald's enlightened plans to improve the rural and small town elementary and high schools were twisted into a sinister move to subvert the schools and to wreck the colleges, especially the University.

This explosive political situation in which fact and fancy were all too frequently intermingled was one that might at any moment have caused the University administration and faculty to be frightened into partisan attitudes or into timid inaction. Having no easily identifiable class or area to support it comparable to those behind the Agricultural College, the University was in a difficult position, caught as it was between the League controlled state government and the violently anti-League Grand Forks community where the Herald early established itself as the leading organ of 
the opposition. The passionately hostile reaction of the NPL press to the Craighead recommendations, which unquestionably favored the University at the expense of the Agricultural College-an attempt to make "our college" into a "trade school for peasants" the NPL editors charged-could easily be interpreted as hostility to the University by anyone inexperienced in North Dakota politics or unfamiliar with the background of some of the most prominent League leaders. Here the University was far better represented than the Agricultural College, none of whose alumni figured prominently in the early stages of the movement.

McVey avoided the dangerous pitfall of being cast in the role of a League man. Apparently profiting from the lessons of the mishandled Lewinsohn affair, he avoided commitments to either camp, but not at the price of repressing faculty opinion. McVey's restraint is all the more admirable in the light of his own conventionally moderate progressivism and his doubts, as a professional economist, about the wisdom of the League's homegrown economic panaceas.

Several members of the faculty were politically active in the League's first campaign in 1916. Birdzell was elected to the state supreme court with League support, and Bronson, a part-time lecturer in the law school, to a district judgeship. Gillette wrote for NPL publications and spoke to NPL gatherings on several occasions in the role of the sympathetic expert on rural problems. Various avenues of friendly understanding, without partisan commitment, were quietly maintained. At the 1916 and 1917 Homecoming celebrations Frazier and Macdonald were accorded full honors as the University's most prominent alumni, which indeed they were. When McVey was chairman in 1916 of the annual meet ing of the National Conference on Marketing and Farm Credits, he invited Frazier to make an address; it was undoubtedly his doing that the governor was elected president of the organization. In this instance the president was certainly also hoping to influence the new governor's economic views as well as to keep him well disposed toward the University.

The successful result of McVey's careful policy was that although the League was ideologically friendly to the "farmers' own college," it was not unfriendly to the University. On several occasions enthusiastic articles were published in the official organ, the Leader, about the University's lignite research, a matter of particular interest to the NPL because of its ambitious plans for developing the state's natural resources. Even more solid evidence of the University's strong position in the middle of the warring factions was that in the 1917 legislature neither side, each of which controlled one house, showed any inclination to thwart the University's aims for partisan reasons. Although the anti-NPL senate and the NPL governor each made some drastic reductions in appropriations for new buildings, including $\$ 161,000$ for a new college at Dickinson, an appropriation of $\$ 90,000$ was approved for a new chemistry building at the University, an amount considerably above what any other institution received, including the Agricultural College. Having alumni in positions of power and well disposed to the president and faculty more than once served the University's interests during the League's first session. McVey's success in bringing the University through the first stages of an increasingly difficult political situation was no mean achievement. Almost alone among the presidents of North Dakota colleges, he enjoyed the confidence and respect of two political factions not distinguished by their calm or good temper. Whether he could have continued to walk the political tightrope himself or to permit the faculty to express itself freely on the issues being raised, particularly after the war when passions had risen considerably under the added stimulus of the national "red scare," is impossible to say. In any case, McVey was in no difficulty when he left in October, 1917, whereas his successor was in trouble almost immediately after he arrived.

From the University's standpoint, perhaps the worst aspect of the appearance of the NPL and the issues it raised was its coincidence with a number of other unsettling factors, the most serious of which was the war in Europe; in one way or another it contributed to the development of frictions within the faculty for a half dozen years. The early debate on the war was largely academic, with the majority of the most respected professors, as well as the president, sharing the general reluctance of North Dakotans-and of Americans in general-to become involved in the conflict. Yet 
once war was declared, without any conspicuous exception the faculty rationalized the changed situation and supported President Wilson's interpretation of America's new role. It is worth noting that there were no loyalty controversies or dismissals such as occurred at many other institutions, including the University of Minnesota and the Minot Normal School-the president of the latter was ousted in 1918 because he advocated the conscription of wealth as well as of manpower. Nevertheless, some faculty were subjected to suspicion and criticism. Bek was publicly attacked by Roger Cooley for making a plea for moderation and tolerance, and a local committee of overheated patriots summoned him to appear before it for an examination of his loyalty. Characteristically, he defied them, a stand which received vigorous approval from Kennedy. Bek's German courses were actually continued without interruption, but he suffered the humiliation of seeing his students melt away and of knowing that the study of German was being prohibited in all the North Dakota high schools. The extravagant anti-Germanism of vehement Anglophiles like Squires offended not only Bek but also the moderates, including McVey, an enthusiastic admirer of the advanced social planning of prewar Germany. The triumph of the official line of the federal propaganda agency, the Committee of Public Information, probably did little to assuage their feelings. What was worse, a habit of extremism developed, a substitution of emotion for thought, which found its reflection in the pages of the Student in such screeds as "The Hymn of the German Sword" and "O, Kaiser, Obsessed with Power ... Slayer of Age and Infancy."

Even without the element of emotionalism, the war was bound to pose problems and require adjustments disturbing to long-established routines and dangerous to internal tranquility. Enrollment at the beginning of the 1917 term was down about 11 per cent, mostly in the upper classes and in the downtown law school. As the year advanced the increasingly pervasive war motif was emphasized by the introduction of military training. Scheduled for September, instruction did not actually begin until November owing to the lack of training personnel and equipment. Even then there was only one officer assigned to the University, Captain
Charles McVey, brother of the former president; the only equipment was some wooden muskets-students were expected to provide their own uniforms. Only freshmen and sophomores were required to take the course, a few hours of drill each week and two hours of hygiene instruction by some member of the medical faculty. In May Captain McVey was called to duty elsewhere, and for the rest of the term the classes in drill were conducted by student officers. Meanwhile, more and more young men departed for the training camps; the service flag unfurled on Founders' Day, 1918, carried 281 stars, and by the end of the year the law school was so depleted that it was moved out to the campus. The University's first service death, that of Lyle Rich (B.A., 1914), was announced in December. Other signs of the times were the introduction of war slang, for example, "Hooverized" parties and the "over the top" victory of the seniors at the Carney Sing; the public lectures on such subjects as "Freedom under the Law" or "The Triumph of Civilization"; an essay contest on "Why We Are at War" sponsored by the Grand Forks Commercial Club; the inauguration of a course in contemporary history; and a hand grenade throwing contest at the spring track meet.

A constantly widening circle of war activities occupied the attention of students and faculty. Hardly a month passed without a "drive" for a Liberty loan, the Red Cross, the YMCA, or relief for war prisoners in German camps. Dean Babcock was made chairman of the North Dakota Defense Council, and other members of the faculty, including the president, were appointed to the North Dakota branches of the various federal war agencies. A surgical dressing station was set up in. the Commons, and the Women's League rooms became the center for Red Cross work. A number of the faculty planted war gardens, and the manager of the Commons undertook, with the aid of student labor, to grow the potatoes and fresh vegetables that she used. As a representative of the Defense Council, Henry Brush, professor of Romance languages, organized classes in radio telephony and telegraphy about the state; J. B. Spence (physics) opened a new course in radio telegraphy on the campus; Charles W. Sumner, the librarian, sponsored the American Library Association's book drives; and other 
faculty members did their bit as "four-minute men" lecturers. In the spring of 1918, at the suggestion of the faculty Council, the new president, Thomas F. Kane, appointed a five-man Faculty War Committee, headed by Libby, to act as the liaison between the faculty, the students, and the United States government. One of its first acts was to shift the emphasis in the home economics courses to food conservation and food production and to enlarge the teaching staff to meet the demands for these courses and for nurses' training. The committee also compiled a list of the names of students who volunteered for summer war work and published a circular urging high school students to prepare themselves for war service by attending the University.

All of these activities were, however, more or less peripheral to the regular function of the University and the regular routine that continued despite the excitements and interruptions. The student calendar of 1917-1918 differed little from that of other years. Intercollegiate athletics, temporarily dropped the preceding April, were resumed, and the second Homecoming Day drew back many alumni, among them Frazier, Macdonald, Nestos, and that old time football hero, Joe Flanagan.

During much of the year the selection of a new president shared the spotlight with the war, for the faculty at least. Immediately after McVey's resignation was announced in August, 1917, the rumors began to fly about, intensified of course by the welladvertised controversy over the membership of the Board of Regents. Despite the difficulties about the organization of the Board, which were not completely resolved until after McVey's successor had been elected, the representatives of both factions appear to have been honestly conscientious about selecting a man fitted by education and experience for the position. The decision, taken early in the search, to seek a man from "outside the state" was partly to divorce the selection from local politics; political consideration were not entirely absent, however, for it was soon clear that the NPL side of the Board was in search of a "progressive" and that the IVA was equally determined to find a man whose views were safely conservative. The Board (this was the old Hanna Board), on being petitioned through $\mathrm{McVey}$, agreed to accept the advice of the faculty in the form of a joint Board-faculty screening committee composed of the five deans, Bek, Gillette, and Spence from the faculty, and Crawford and Dr. J. D. Taylor (Grand Forks) from the Board. After ex-governor White resigned from the Board, his NPL replacement, C. E. Vermilyea, was added to the committee. On September 17, Babcock, the senior dean, was appointed interim president with an additional salary of $\$ 100$ per month; this appointment was made in response to a faculty petition drafted by Libby. The support for Babcock was frankly based on the belief that he alone could muster wide support on the campus and also from both of the political factions contending for control of the Board. Although these expectations were justified by events, one of the deans, ambitious for the post or for the presidency himself, resented keenly the honor to Babcock; his disappointment contributed its bit to the friction that developed on the campus shortly after the new president was installed.

Throughout the search for a president the role of the facultyBoard committee was a major one. Dean French, chairman of the faculty section of the committee, recalled twenty years later:

The Board called the committee together, announced its membership and the idea that the Board had in mind; the committee was given several names suggested I suppose, either by members of the Board or by $\mathrm{Mr}$. McVey. We were asked to investigate these men to determine their desirability and availability, to write to the other universities and ask for nomibility and a villability, to wite to the other universities and ask for nominations and suggestions and in general to act as if we were seeking a man for any position. We were asked to narrow the field to from two to four names and to subit mittee carried on a vigorous correspondence and met many times, several times with the Board or with a committee of the Board.

By November a list of sixty-two had been reduced to ten, "not more than half of whom might really be available candidates." It was a strong list; the three most favored candidates were Dr. Lotus D. Coffman, dean of the College of Education, University of Minnesota (he later became president), who had served on the Survey Commission a year before; Dr. Robert Slagle, president of the University of South Dakota; and Dr. U. S. Grant, professor of geology and dean of the College of Liberal Arts, Northwestern University. One of the nominees included on the list of ten was Dr. Frederick 
C. Howe, La Follette's old ally, then commissioner of immigration of the Port of New York. The fact that the final supreme court decision confirming the appointment of Muir and Totten was not rendered until late November delayed the final choice, and there was further delay occasioned by the submission of some new names late in the search, including that of Thomas F. Kane, president of Olivet College, Michigan, and formerly president of the University of Washington. In December when representatives of the faculty met once more with the Board the list had been reduced to seven; the favorites continued to be Slagle and Coffman, with Howe now up to third choice, and Grant and Kane fourth. Having agreed to offer a salary of $\$ 6,000$, the same that McVey had received, plus a house, utilities, and janitor service, the Board instructed its secretary to write to the seven on its list. By January the field had been narrowed to three-Slagle, Grant, and Kane-who were invited to Bismarck for interviews. Slagle now withdrew; Grant and Kane met with the Board on January 18, 1918. Four days later the "unanimous" election of Kane was announced.

In the light of subsequent events it is important to note that although the NPL majority had good reason to believe that Kane was the IVA candidate, none of them except Totten appears to have expressed any serious doubts about him. Tall and impressive looking, dignified to the point of stiffness yet capable of an ingratiating manner, Kane was mature (fifty-two years old) and had had much administrative experience. These qualities were apparently enough to win the confidence of the suspicious NPL majority in the course of the interview. One of them, probably Totten, is said to have declared exultantly that they had found "our man." Whether or not Kane won them over by professing a sympathy for the NPL that he did not feel, as Gillette was to charge a generation later in his autobiography, is impossible to prove or disprove. There is some evidence, however, that he at least permitted them to believe that he was a political liberal and that his liberal views were responsible for his leaving the University of Washington. Although the Board had begun its search for a president in a highly commendable manner, at the end individual members gave far too much weight to superficial political views and not enough to such vital considerations as boldness, imagination, high principle, and the capacity to deal harmoniously with a faculty.

Kane came highly recommended by other college presidents, among them McVey. A graduate of DePauw, he had taken the Ph.D. in Latin at Johns Hopkins in 1895 where he had studied under Basil Gildersleeve, one of the great classical scholars of his time. From 1895 to 1900 he had been principal of the preparatory department and professor of Latin at Olivet College. Appointed professor of Latin at the University of Washington in 1900, he had been elevated to the presidency in 1902, a post he held until midterm of 1913-1914 when he was ousted by the Board of Regents after he had refused to submit the resignation that had been demanded of him. The details of the long controversy that preceded the action are too complex and too clouded by differing opinions even yet to repeat here, but it is important to note that an admiring biographer tacitly admits that there was as much to be said for the Board as for the president. Yet Kane could also point to a record of remarkable growth at the University of Washington in his twelve years as president: an increase in enrollment from 600 to 3,000 , in faculty from 48 to 170 , an increase of 40,000 books in the library, and the establishment of most of the University's professional schools. Following his departure from Washington he had spent a brief period registered as a student at the University of Chicago until he was elected to the presidency of Olivet College. He appears to have been popular at Olivet. In the spring of 1917 he had served on the three-man commission to survey the University of Kentucky and to make recommendations for its general reform. The final report had reflected considerable credit on the commission. One of its immediate results had been the decision to invite the dynamic McVey to Kentucky.

It was an impressive record. Yet the Board might have been well-advised to investigate the successful candidate more thoroughly than it apparently did. Had it done so the NPL majority might have been interested in the fact that Kane's chief off-campus support at Washington had been among conservative political circles. More important, they might have discovered that his administration had been marred by a succession of controversies and by serious faction- 
alism within the faculty. The Board might have surmised also, had it speculated on the matter, that Kane probably wanted the presidency too much to be an entirely free man. Shunted aside in a tiny liberal arts college, he probably saw if the Board did not the possibility of ending his career there. Nor is it unreasonable to suggest that some of the North Dakota deans nostalgically hoped to recover the past in this man trained in the classics and to gain perhaps a not unwelcome respite from the restless energy and heavy demands of McVey.

No such doubts were raised immediately, however, and the new president assumed his duties in an atmosphere of general good will. Babcock, the acting president, introduced him to the University at the 1918 Founders' Day convocation, and he immediately won the students' hearts with his warmly personal and ingenuously humorous speech and his promises to learn their first names and to install a system of student government at the earliest opportunity. The $\mathrm{Y}$ reception held for him and his wife in April (he began his duties in that month) was also successful, and the Grand Forks business community was much impressed by the "splendid" speech he gave at the Commercial Club. The atmosphere of good will and the optimism about the future of the University were a welcome relief in those dark days in the spring of 1918 when the great German drives were in progress on the Western Front, and when the demands of the war were steadily encroaching upon the life of the University.

The inauguration was limited to an afternoon ceremony in the gymnasium and a dinner in the Commons on Commencement Day, June 18. The only official guests were Lewis F. Crawford and Robert Muir, representing the two factions on the Board; Edwin F. Ladd, president of the Agricultural College; T. A. Hillyer, president of Mayville Normal, representing the normal schools; James MacLean, president of the University of Manitoba; and the governor, Lynn Frazier, who presided. Following an academic procession, the program opened with a piano concerto composed for the occasion and performed by Professor Paolo Conte of Wesley College. MacLean introduced the new president briefly and warmly, and Crawford delivered the installation speech; he predicted that the
University would reach its greatest heights under the guidance of this man of sound scholarship, compelling personality, broad and successful experience, cool judgment, rare diplomacy, and high ideals.

His words were hardly the proper preparation for the president's address, which burst like a bombshell on the ears of an incredulous faculty. The speech began harmlessly enough, although it was somewhat less than distinguished in phraseology or sentiments. The University's role, Kane said, was to provide training for good citizenship first of all, to give sound vocational training to the state's young people, to reach all the population through extension work, and to provide direct public service. "A state University," he observed, "is education of all the people, by all the people, for all the people." Although commonplace enough in academic circles, these ideals undoubtedly bore repeating before a general audience. And it took more than a little courage to issue the warning that he did about the dangers of political interference in University affairs:

Some persons have dreamed that the University was to be governed by politics .... I would ask the person with the dream "Who is to be president of the University when its policies are to be determined by political influence?" . . . members of the board of regents, of all the political factions represented on the board, told me personally ... that they were having their controversies within the board itself and that all five of them were a unit in the matter of keeping these controversies within the board ... and not allowing [them] to affect the University in any way soever.

It was when he endeavored to define the role of the faculty that he got into difficulty. The worst interpretation that can be put upon his remarks is that, having ingratiated himself with the students and public, he deliberately set out to put the faculty on the defensive; at best, his remarks were ill-advised. Proud of the record of hard work and solid achievement they had made over the preceding decade, the faculty was not disposed to be good-humored about such remarks as the following, no matter how well intentioned:

I am inclined to think that if the faculty in any university in the country were submitted to as severe tests [as the football coach], it would lose 
probably one-fourth of its members .... I may assure you, if you need assurance, that the men at the University are going to earn their salaries. We are going to drive them hard.

Nor was his implication that the professors were callous and capricious in their interpretation of high academic standards well received:

I have been associated with a good many professors who assumed that it was evidence of strength in their departments to fail a noticeably large number of their students.... With students who have completed a course of training in standard high schools, the presumption is that we ought to be able to have them succeed in their work at the University, we do our job wisely enough.

He offered as an example an oversimplification of a faculty squabble a few days before about permitting a student to graduate whose record was "seven-tenths of one per cent" below the minimum standard.

But it was his version of another recent difference between himself and the committee on discipline over a fraternity drinking escapade that was disastrous and unforgivable:

before I referred the recommendation of that discipline committee to the council for final action, as is my invariable custom, 1 called in a representative of the students concerned .... I was dumbfounded [sic] to find that the committee had recommended the most severe penalty that could be devised, against one of the student organizations, without even having a conference with any student involved and without giving anyone, on whom sentence was being passed, the slightest chance to be heard I should like to add further, without thought of criticism, that one of the I should like to add further, without thought of cricism, that one of the diciogy social justice or whether we are just preaching social justice.

This was in effect a public announcement that severe friction had already developed between the president and elements of the faculty in the short space of two months. What the president did not mention in his speech was that he had worried members of the faculty because he consistently took the side of leniency, whether it was on academic standards or discipline, and that he had alarmed them by his casual regard for the University constitution. He could have added that his manner of recommending Kennedy for the honorary LL.D. had needlessly offended certain members of the faculty; that very morning he had called the faculty Council in special session to approve the honor which would be conferred only a few hours hence at the commencement exercises. Any one of these incidents was a small matter, but when taken all together they had an ominous look. Whatever may be said for the provocation that Kane may have suffered from such sticklers for standards and protocol as Libby, there is no excusing the execrable taste, to say nothing of the lack of ethics and the dubious academic statesmanship, of carrying his troubles and irritations before the forum of the public under circumstances in which the faculty was unable to reply.

Worst of all, the president was more than a little careless with the truth or told it only incompletely. In brief, the episode to which he referred was a drinking party staged by the Alpha Kappa Zeta fraternity. Some of the brothers had procured liquor in Minnesota (North Dakota was dry), brought it to their house, and in company with members of other organizations, chiefly Synergoi, had proceeded to get riotously drunk. Noisy, parading in their night shirts, some of them climbing to the porch roof of a neighboring sorority house to peer into bedroom windows, they created so much of a disturbance that some faculty members living nearby called the police. The students fled and escaped arrest. Kane then called upon the committee on discipline, a three-man body responsible to himself, to investigate the situation. Although, as the president said, the committee had not formally interviewed the culprits, the essential facts had been easy enough to come by from the neighbors and police. Owing to the fact that the fraternity had been guilty of repeated offenses of this nature, and that it had in addition a bad record of nonpayment of its bills, the committee recommended that it be dissolved and that Synergoi's contemplated national affiliation be delayed a year. A point that Kane also failed to note was that the membership of the committee, Bek, Gillette, and Spence, had been almost continuous since it had been formed in 1913, that McVey had rarely if ever failed to act on its recommendations, and that a more sober, judicious, or respected group than these three could hardly have been gathered on the campus; they also constituted three of the four elected faculty members of the Ad- 
ministrative Committee. The only immediate public reply to the inaugural speech was the publication in the September issue of School and Society of Gillette's restrained and detailed refutation of the president's version of the fraternity episode and the committee's action.

Meanwhile hostilities had to be suspended temporarily to make way for the war in Europe. Although the United States government had not then completely worked out its plans for mobilizing the universities, arrangements were made in May, 1918, for the University to provide, for a fee of $\$ 1.70$ per man per day, an eight-week vocational training program. The first class of trainees arrived in July and were quartered in the gymnasium, which promptly became a "barracks." Babcock was appointed general director of training and most of the courses, in such subjects as auto mechanics, blacksmithing, and carpentry, were taught by the engineering faculty. Three hundred and sixty men passed through this course before it was discontinued in November. The summer school operated as usual but with the addition of such wartime courses as military French, contemporary American history, home nursing, war cookery, and special work in physical education; the latter was included in response to the reports that an alarming proportion of draftees was physically unfit for military service.

In late August plans for a national Student Army Training Corps (SATC) were finally completed. Following a conference of college and army representatives at Fort Sheridan, which Kane and Libby attended, the latter in his capacity as chairman of the Faculty War Committee, hasty preparations were made to receive the first contingent of four hundred student soldiers who were to arrive in September. The vocational corps, expanded to two hundred, was also continued, which meant that the University campus was in the process of becoming an army camp when the term opened on October 1; quite properly the opening ceremonies were of an entirely military nature. The regular students that appeared, only a fraction of the normal enrollment, had little choice but to adjust to the requirements of the Army. Davis and Budge Halls were reserved as SATC barracks and the Phi Delta Theta house as the Army headquarters; the main dining room of the Commons be- came the mess hall, the first floor cafeteria being reserved for the civilians. In addition the vocational trainees occupied the gymnasium, and construction was soon under way on a $\$ 30,000$ armory. The Student never began publication, and in November an army paper, The Camp Barrage, began to appear in its place. The University changed from the semester to the quarter system, and only those courses having some bearing on the training of officers and technicians were continued: English, law, physics, chemistry, French, German, Spanish, medicine, engineering, and a new war issues course which became the charge of those departments whose subjects were not included in the list of vital courses. Owing to the influenza epidemic and the end of the war in November, the SATC did not last long enough to be fully worked out, although it was soon apparent that crowded barracks living and the high priority of drill and camp duties were not conducive to efficient study.

Not all the trainees had arrived and the work was hardly begun before the great influenza epidemic of 1918 paralyzed the campus. Classes were suspended and a general quarantine imposed on October 9, and soon all but the most essential camp duties were abandoned. The Phi Delt house and the third floor of Budge Hall were hastily converted into hospitals, but they lacked all the sick room necessities, including even sheets and toilet articles. Moreover, the number of patients increased too rapidly for anyone to receive anything but cursory care. From the beginning the situation was beyond the capacity of the attached army physician; inexperienced in military procedure, he failed to make the most elementary preparations for such an emergency or even to persuade his equally inexperienced and stubborn superior officer that unnecessarily rigorous training measures were unlikely to "toughen" men who were sick. Both officers were victims of the haste and lack of planning that characterized the entire SATC program over the nation. Moreover, only about half the usual number of physicians and even fewer nurses were available in Grand Forks to deal with this extraordinarily general epidemic-about 3,000 cases developed in the city in a few weeks. But the officers were partly to blame nevertheless for the tragic proportions that the epidemic reached on the campus; 320 of the 470 trainees became ill and 29 died, six on one 
awful day. Not an institution in the country had a worse record. By way of contrast the situation at the Agricultural College, where there were more trainees, was not nearly as desperate. Even more significant is the fact that only one of the comparatively small number of University women died. Dean French, responsible for their care, hastily cleared a sorority house and equipped it as a hospital at the first sign of trouble. Indeed, the SATC situation might have been even worse than it was had it not been for the work of Dr. James Grassick, the University physician appointed as Army contract surgeon after the epidemic had begun, and that of Mae McCullough, the heroic nurse who organized and ran the Budge Hall hospital; medical students and dozens of Grand Forks women also literally risked their lives by volunteering to nurse the sick.

Mixed responsibility for the SATC delayed any decisive action by the University administration while there was yet time. The worst was over when Libby's War Committee recommended to the president that a joint medical committee composed of the SATC medical officer, Dean French, and the city and county health officers be formed to assume responsibility for the health of the soldiers. This action was a facet of another serious consequence of the influenza tragedy, the conviction among some faculty members, Libby for one, that the new president had failed in his duty to act when it became plain that the Army was floundering. Accustomed to McVey, they had learned to expect vigorous and resourceful leadership from the president, and Kane had failed to provide it. While it is true that he was technically not responsible for Army personnel, his official position as well as what must have been his firsthand knowledge of the situation imposed a moral responsibility to act or to stir others to do so in this emergency. That he had outrageously offended the faculty in his inaugural address the preceding June made his critics more willing than they might otherwise have been to blame him for what was largely the result of the inexperience of the local Army officers and the War Department's inadequate preparation for the SATC program. Talk about the president's "failure" was widespread at the height of the epidemic, and by the time it was over, a faculty cabal was taking form, with Libby as its unofficial leader, to remove Kane from his position.
The quarantine had been lifted about a week and everyone who could had gone home, when the war came to an end. Of course there was much jubilation among the SATC men when they received the news at four in the morning on the eleventh of November. The companies hastily formed a parade and marched downtown; in the evening they paraded again. Training was over, although there were some perfunctory efforts to continue it until demobilization was completed just before the Christmas holidays. Meantime, the shaken administration and faculty, after a half dozen or more announcements that the University would soon reopen, gave up and postponed the event to the first of January, with the promise that students enrolling then would receive full credit for a year's work. The war had ended on a low note of tragedy and ill feeling at the University of North Dakota, with little sense of glory or achievement to relieve it.

Yet students and alumni, as well as the faculty, contributed their full share to the great national effort. Three hundred twentynine undergraduates saw service, and thirty-three students or former students lost their lives. One alumnus, Lieutenant Colonel Fred E. Smith (B.S., 1894) was awarded a posthumous Congressional Medal of Honor. Major General Charles S. Farnsworth, commandant of the cadet corps from 1894 to 1898 , commanded the 37th Division AEF in the fighting in the Argonne. Thirty-two members of the faculty left the campus for war service. Several of the most distinguished never returned, among them Taylor (the first to leave) and Stephenson of the department of physics, Dean Wells of the law school, and Crouch, head of mechanical engineering since 1901. These were all key men whom the University could ill afford to lose.

Others had left or were soon to leave, partly because of the changed conditions created by the war. Boyle resigned in 1916 to join the Agricultural College faculty and a year later moved to Cornell. In 1918 Koch left for the University of North Carolina and Norton for public school work in Minneapolis. The successful coaching combination, Fred Thompson and Andy Gill, left in 1918 and 1919, and in 1920 the University lost Albert Becker, on the engineering faculty since 1905 and its only Ph.D., and Bartholomew 
Spence, the last of Taylor's triumvirate in physics. These losses plus others weakened the University seriously as it entered a new era of extraordinary growth and faced such immediate problems as the increasingly violent partisan debate between the IVA and the NPL and the resumption of the quarrel between powerful elements of the faculty and the president.

The NPL won complete control of the state government, including the state supreme court and the state senate, in the fall elections of 1918. In the legislative session of 1919 the Board of Regents was abolished and a single Board of Administration, two members ex officio and three appointive, was placed in charge of all state institutions. Although this change was partly motivated by the NPL determination to strengthen its control of every public agency in North Dakota, it was also in the natural course of the trend, in progress for a decade, toward centralization of governmental administration. Meantime, the antagonisms between the farmer and the middleman or "Big Biz," already sharpened by the habits of extremism engendered by the emotions of the war, were increased still more by the postwar "red scare" which manifested itself in the irrational fears and immoderate talk of the imminence of a Bolshevist revolution in America. The League's opponents were not slow to announce the close similarity, if not real connection, between the triumph of the unorthodox NPL and the communist revolution in Russia. The NPL was equally immoderate in its countercharges and for nearly a half dozen years the political air of North Dakota was rent with epithets like "Bolshevist," "red," "reactionary," "Wall Street tool," and so on and on.

Faculty members, once comparatively free to express their views on most issues, including even religion, found themselves increasingly subjected to the indignity of having their opinions ridiculed and attacked. Gillette was denounced as an atheist because he openly criticized organized religion and as a "red" because an article he published in a highly respectable national magazine at tempted to make an objective appraisal of the NPL movement. Of the literally dozens of articles written on the subject at the time it is one of the very few which can be read with profit even today. ${ }^{3}$ It was entirely in the spirit of the times when a prominent alumnus announced that the state library at Bismarck was circulating subversive and immoral literature to the schools of the state; the list of such books that he published might have been less disturbing to the University faculty had it not included such standard texts as Charles A. Beard's American Government and Politics.

The NPL press and vehement zealots like George Totten, president of the Board of Regents and later of the Board of Administration, were equally sensitive. Captain Charles McVey, military commandant in 1917-1918, was attacked for having commented unfavorably on the League's attitude on the war, and a year or so later Squires earned his place in the League's black book by delivering a paper denouncing Bolshevism before a semiprivate meeting of the Fortnightly Club. Totten took this to be an attack on the NPL, which it probably was in part although Squires denied having intended it as such.

The attitudes of faculty conservatives like Squires and Hitchcock and of campus liberals like Gillette, Brush, and Ladd were matched by sharpened political divisions among the students, partly because their elders had set about arousing them with such devices as a statewide antisocialist oratorical contest. There was an ideological overtone in the ducking of one "Bolshevik" Smith in the English Coulee early in the fall of 1919; Smith became a minor cause célébre, the center of a local press controversy. The episode provided the opportunity for Kane's critics on the faculty to throw into relief their lack of confidence in him by winning from the faculty Council a vote to reject the recommendation of the committee on discipline (now composed of administration supporters) to exonerate the culprits.

In short the situation that prevailed after the war was one requiring a high order of academic statesmanship, a calming hand from the president, some courageous words in behalf of tolerance, moderation, and academic freedom, and a clear policy in dealing with such matters. But these were not forthcoming. Instead the conviction grew on the campus and in NPL circles as well that the

3"Political Harvest of the Nonpartisan League," Survey, March 1, 1919. 
president had aligned himself with the IVA, particularly in Grand Forks. Whatever justification Kane may have had for taking such a personal stand, his behavior and increasingly open sympathies were to have the effect of placing the University in the position of being the protégé of a political faction, something that McVey had consciously and successfully avoided. Lacking friends in the NPL, which was in control of the Board and the state government, the president would have been wise to set an example by counseling his friends to moderation.

The sharpened ideological divisions within the University in turn intensified the breaches that were developing for other reasons. Most of these differences were almost entirely unrelated to any interferences from outside the University, although the external political climate was an excellent nursery for controversy and, worse, offered the temptation to appeal these internal differences to the court of public opinion. The issue of compulsory military training, raised immediately after the war ended, provided material for a sharp division between the progressive wing of the faculty, which opposed it or feared its implications, and the conservativeadministration faction. The debate spread to the pages of the Student, the School of Education Record, and to the Grand Forks newspapers. The Herald supported military training, and the newly launched NPL paper, the Grand Forks American, attacked it in such terms as "the menace of Prussianism" and "the blight of militarism." It was only with much reluctance that the faculty Council finally voted to establish the ROTC; indeed the measure was watered down with a proviso that students requiring time for other duties would be excused by the Administrative Committee. The assent of the Board was equally reluctant, and the president found it necessary to explain publicly that the faculty could vote out the ROTC if it proved unworkable. It is a point of some interest that although the faculty and administration were nearly evenly divided on the subject of military training they were overwhelmingly in favor of the League of Nations, which was then being formed at the Paris Peace Conference.

The League of Nations and even the ROTC were secondary, however, to the near-at-hand problems caused by the war, all of which contributed to the restiveness and dissatisfactions in the faculty. Wartime inflation, which by 1919 had pushed the cost of living to nearly 80 per cent above the level of 1914, caught the University with a salary scale low even by the standards of 1910 when it had been adopted. Some small increases in 1919, none above 10 per cent, satisfied no one, and even the fairly substantial acrossthe-board increase of $\$ 500$ in 1920 did not make up what had been lost in inflated prices; by that time the cost of living had risen another 25 per cent. The new scale was $\$ 1,500-\$ 2,000$ for instructors; $\$ 2,000-\$ 2,500$, assistant professors; $\$ 2,500-\$ 3,000$, associate professors; $\$ 3,000-\$ 3,500$, professors; and $\$ 3,500-\$ 4,000$ for deans. Only a few actually received the maximum. The president took up the cause of salary increases only belatedly, leaving most of the work to committees of the Council, the AAUP, and a newly organized local branch of the American Federation of Teachers (AF of L) which, actively promoted by the NPL, soon enrolled nearly half the faculty. The low salaries, as well as the general dislocations produced by the war and the opportunities appearing elsewhere because of rapidly rising college enrollments, produced a rate of turnover in the faculty unprecedented in the history of the University. The replacement of established scholars and teachers with young men still struggling for a foothold in the academic world had the effect of weakening the faculty and strengthening the administration.

Pressed by the realization that time was on the side of the president and exasperated by what they considered mounting evidence of his incapacity, Kane's critics on the faculty determined to make a formal, not to say a desperate, move to oust him early in 1920. For a year or more before their decision they engaged in a quiet campaign to persuade their NPL friends on the Board and in the state government to take action against the president; the right moment never seemed to appear, and the quarreling at Grand Forks, much of it no better than petty squabbling, continued. Yet there was no previous warning that something was afoot when on February 6, 1920, the Herald suddenly published the startling news that Totten and Muir had appeared on the campus, briefly investigated charges formally filed by a faculty group, and had then asked 
Kane to resign, all within a few hours. Although the facts of the affair were at once almost hopelessly garbled by the injection of irrelevant political issues and student excitement, it was soon known that two deans, Babcock and Willis (law), and three professors, Gillette, Libby, and Ladd, had signed the twelve-page document of charges, "Memoranda of the Unfortunate Happenings at the University of North Dakota." Other names prominently mentioned in connection with the move against the president were those of Brush, Kennedy, Leonard, Simpson, and Towne. Squires quickly established himself as the unofficial spokesman of Kane's supporters; other prominent members of his party were Abbott, French, and Hitchcock.

The Memoranda has never been published and it has disappeared from the Board's records, but enough of what it contained came out at the time to indicate that the anti-Kane group prejudiced their case by overstatement and by the angry tone of their accusations. The president was described as "irresponsible, inefficient, negligent, intellectually weak, morally vacillating, and wholly incompetent ... jealous of his prerogatives . . . and [possessing] the stubbornness of a weak man." Apparently the only really solid charges against him were that he had been lax in the fraternity discipline case in 1918, that he had acted in bad faith in attacking the faculty in his installation address, that he had done nothing to prevent or alleviate the influenza epidemic the winter before, and that he was responsible for the generally disorganized state of the law school, which was forced to operate in inadequate quarters in the basement of Davis Hall, without replacements for the two faculty members who had been given leaves during the war.

Kane refused to resign on the grounds that only a small minority of the faculty opposed him and that Totten and Muir did not represent the view of the majority of the Board. He was not entirely incorrect. To be sure, the Board stood at least three to two in favor of dismissal, but only Totten and Muir were eager to push the case. As for the faculty, Kane's opponents had allowed themselves to overestimate the solid support beneath the chorus of complaint that Kane's methods had aroused. It was apparent all too soon that only a bare handful of professors were willing to risk their jobs and perhaps their careers if matters came to that pass. Indeed, before the affair was over even the little group that had signed the charges failed to hold its lines.

Meanwhile, as the next move was being considered at Bismarck, Kane's friends, as well as all the enemies of the NPL-they are not always easy to distinguish-rallied to his support. There was some success with a letter campaign to alumni and students, but the most effective support came from the IVA, eager for the opportunity to belabor its enemies. In no time at all the real issue, the validity of the charges against the president, was lost sight of in the war of words between political factions. Kane's most vocal Grand Forks supporters included the Herald, the Commercial Club, officers of the Alumni Association, and F. Halsey Ambrose, the rabble-rousing minister of the Presbyterian church, which Kane attended. Their line was that the professors were radicals and that the League was bent on filling the University with reds or with lame-duck politicians. From the standpoint of the effectiveness of this counterattack, the timing could hardly have been better, because the "red scare" was then at its peak. Arthur C. Townley, founder of the NPL, had been convicted and jailed the summer before by a Minnesota court for "conspiracy to discourage enlistments," and hardly a month had elapsed since United States Attorney General A. Mitchell Palmer had staged his spectacular raids on "red headquarters" all over the country. Not all of Kane's support was of this variety of course. Some of it undoubtedly was simply of the sort that one employer would feel for another who was having trouble with insubordinate hirelings; moreover, the president had won many admirers by his dignified and scholarly yet pleasant manner in public meetings and on casual acquaintance.

The vigor of the counterattack alarmed the leaders of the NPL, who, contrary to the charges being made about their interference in internal affairs at the University, actually paid too little attention to the University troubles until they exploded into a dangerous public row. With an eye to the possibly disastrous effects in the crucial elections to be held that same year, the practical politicians now took a hand, but only to insist that the mess be cleaned up immediately before Kane was magnified into a martyr whom the 
IVA could display in the forthcoming campaign. They might well have begun by counseling their Grand Forks paper, the American, to moderation; its extravagant fulminations against the president, including one charge that he encouraged immoral behavior among the University students, fully equaled those being made against the professors. Had the Board been able to offer a replacement who was reasonably acceptable to both sides, they might yet have made the change they wanted, but they had none. Although they honestly attempted to find an able scholar and administrator, they lacked the experience to make a systematic search. They and their faculty allies approached Brannon, then president of Beloit College, and possibly Gillette. But Brannon was too old a university hand to accept the sort of tentative offer that could be made while Kane held the fort, and the charges that Gillette was a "red" and an atheist rendered him unavailable.

It was evidence of the deep concern in the NPL that Frazier himself came to the campus on February 17 and spent most of the day interviewing the aggrieved parties and local businessmen and, according to the Herald, holding a "secret" conference with the "radical" members of the faculty. Three days later Totten, Muir, and John Hagan returned, apparently instructed to get the imbroglio settled. They remained five days, one of the most bizarre periods in the history of the University, interviewing faculty, students, and such interested citizens as came to their headquarters at the Frederick Hotel. They would have been wiser to hold their hearings outside the heated atmosphere of Grand Forks, particularly since the students, overwhelmingly pro-Kane and anti-NPL, were returning for the opening of the second semester. Overnight, Kanefor-President buttons were all over the campus, and during registration, which was proceeding half-heartedly, printed cards were passed out bearing the pledge: "I am a member of the KANE FOR PRESIDENT CLUB. I refuse to take any work from Gillette, Willis, Brush, Libby. WE STAY IF KANE STAYS." A letter circulated among the students demanded: "Are you going to graduate from a University that flies a red flag from its standard or one that flies the Stars and Stripes? Do you want to go out in the world and tell your friends that your alma mater was a disciple of Gold- man and Debs....? The Kane-for-President Club stands for Americanism in the nth degree." Indicative of the emotional state of many of the students supporting Kane is the letter, said to have been written by a student to his parents, quoted in Andrew Bruce's The Non-Partisan League, published in 1921:

If you want to have a state university for the younger children to go to when they get out of high school, I advise you to work to get Totten and Muir off the board of administration.

They call President Kane "mentally unsound and morally unfit" to be president of the University. You have heard him speak. I leave it to you to judge if he is mentally unsound and you know Totten and Muir and I will leave it to you to judge if a man who backed Stangeland in the public library it to you to judge if a man who back
deal, can judge who is "morally unfit."

They have a reason to be down on President Kane. Didn't he refuse to ratify the appointment of $\mathrm{N}$. C. Macdonald for head of the extension division! ${ }^{4}$ Didn't he remove extension lecturer George Wilson from the payroll because he was a doddering half-baked socialist? Hadn't he bucked roll because he willette and Libby and Willis, Townley's best friends here on the against Gillette and Libby and Wilis, Townley's best friends here on the faculty? He has tried to keep the school out of politics. These few thing alone are enough to cause him to be hanged, drawn and quartered by that bunch of character assassins. They ask him to resign and he has without dent we ever had could do in five years...

You can tell people that discuss the matter with you that ninety-nine out of a hundred of the students here are with President Kane.

It is small wonder that members of the faculty were subjected to abusive language and that on several occasions the members of the Board appeared to be in danger of being violently handled. Whether Kane or his supporters on the faculty were directly responsible for the students' behavior is impossible to determine, although it is clear that the president profited from it and that he made no effort to stop it. Libby noted privately in his own records that Kane supplied the students with derogatory material about the professors from his files.

The end of the students' part in the episode was heavily dramatic. On the afternoon of February 23, at the close of a mass meeting of alumni and students assembled in the gymnasium to hear speeches and to draw up resolutions, Ralph Stewart, the stu"Macdonald was at Harvard at the time completing a doctoral dissertation; he was 
dent in charge, announced in a "tense silence" that the president had been saved. As a matter of fact, the settlement was complete before the meeting even began. Two days later a grateful president announced at convocation: "You have shown that you are capable of self-government, and you are to be given a student council." Somewhat ingenuously he added that the personnel of this body had already been "selected," apparently by himself.

The terms of the settlement between the president, Board, and deans were published next day in the newspapers:

The deans have each and all agreed to use their best endeavor to work together with the faculty members in a new and higher university it is distinctly understood and agreed that no members of university .... it is distinctly understed and agreed that suffer adverse discriminations because of any position taken in the past toward the administration or the president .... This means that every member of the faculty is free to feel safe in his position except for sufficient cause that may arise subsequent to this date.

The president was said to be "definitely committed" to this policy, and although the faculty was not a party to the agreement, it was assumed "that there shall be a responding pledge in the heart and attitude of every member of the faculty appropriate thereto." For its part the Board declared that it had no intention of interfering in minor matters and that it considered the president the official channel of communication between itself and the faculty.

The Board had clearly dodged any assessment of responsibility. Perhaps it was correct to do so, for even now the task is no easy one, partly because no party involved was completely blameless. The governing board had itself invited trouble, particularly George Totten, its dominant member. A bona fide socialist full of the crusader's impatience, he was ignorant of the proper procedures in college administration and too egocentric and thin-skinned to be a successful public official. One cannot read the Board reports published while he was president without sensing good intentions; the NPL Board sought to hold to a high educational standard, and it gave considerable thought to the problem of creating a genuinely coordinated system of higher education out of the miscellaneous collection of colleges and normals under its supervision. But the Board, chiefly Totten, was guilty of numerous errors of procedure, among them the elementary one of bypassing the president to deal directly with certain members of the faculty. Totten was also indiscreet in the matter of faculty appointments, although neither he nor other members of the Board attempted to load it with radicals or lame-duck politicians in the wholesale lots that the president and the IVA charged. The president himself later admitted that there was no "positive evidence" of Totten's interference, that it was "implied . . . between the lines."

The faculty was also at fault. The president's critics permitted personal dislike to blind them to every good quality he had and to color their responses to anything he did or proposed, an obstructionist position which could not help but damage the best interests of the institution. Hardly less blameworthy than those who risked their careers were those who gossiped about the president and contributed to his harassment, but at the moment of crisis shrank from an open stand; their attitude contributed materially to the public misunderstanding of the issues involved. As for the president's supporters on the faculty, there is no record that any one raised his voice to denounce the slanderous attacks being made on his colleagues, accusations which were known to be untrue. Only Robert T. Young, professor of biology, a conservative Republican who took little or no part in the affair, had the moral courage to do so.

Nor were the prominent citizens of Grand Forks and some of the University alumni blameless. Only half-informed about University affairs, unfamiliar with the peculiar character of facultyadministration relationships, and not enlightened by the man they championed, they nevertheless irresponsibly lent themselves to an effort to hound from the campus men to whom the University was most indebted for whatever academic reputation it had-half the University's Who's Who list were numbered in the anti-Kane group. It was inexcusable for these otherwise decent citizens to be party to the character assassination of men whom they had known and associated with for years. From the vantage point of a generation later it is difficult to understand how intelligent and kindly people could have been swayed, as many were, by the fulminations of a pulpit demagogue like Ambrose, a man who sowed seeds of dissension wherever he went-between the town and the University faculty, between Protestants and Catholics, and within his own 
congregation, which he seriously divided before he departed. In extenuation of the people of Grand Forks and their newspapers, it should be said that they were behaving neither better nor worse than millions of other Americans of the time in those days of the great "red scare."

But the major part of the blame rests upon Kane himself. In the short space of two years he had gotten into difficulty with both the faculty and the Board. This might have been excusable had the cause been his advocacy of an advanced reform or a stand for a high principle, but it was not; it was instead largely the result of his inability to win the faculty's confidence and respect or to provide the leadership that his position demanded without appearing autocratic or stirring up irritations. Nor were these difficulties his last. The administration of no other president has been so marred by faculty factionalism and unpleasant episodes. Although one cannot help admiring his doggedly courageous battle to hold his job, there is no excusing his no-holds-barred tactics of dealing lightly with the truth and fanning the flames of intolerance and bigotry.

Moreover, subsequent events were to indicate that he apparently never intended to keep the agreement of February 24. At the very time the settlement was being announced the president placed all the blame for the troubles on radical faculty members in a thirty-four-page "President Kane's Statement of the University Trouble," which he placed on file "for the absent members of the Board." The names of Babcock and Gillette, originally included, were deleted, but Ladd, Libby, and Willis were accused of being driven by jealousy and thwarted ambitions and needlessly fearful that Kane was lowering academic standards. Willis was described as "notoriously untruthful" as well.

Barely a week after the settlement the president found an opportunity to deal with Libby when the latter recommended that an assistant professor of European history appointed the year before, John W. Taylor, not be reappointed. The reasons Libby gave were that Taylor's appointment had been only temporary and that he had found a candidate possessing the Ph.D. who would be capable of developing a department of European history. Kane took the position that Libby was acting unethically, that he could not dismiss Taylor unless he was unsatisfactory; his own inquiries among students, said the president, revealed that he was both able and popular. After the exchange of numerous letters, in the course of which Kane told Libby he was unfit for his position, the matter came before the Board. What happened there is not clear, but late in April Libby was suddenly notified that a new department of European history had been created, which in effect cut his little domain in half. Taylor, the bone of contention, disappeared in the shuffle, and Clarence Perkins (Ph.D., Harvard), an associate professor at Ohio State University selected by Kane, was appointed to the new position. Meanwhile, Ladd was quietly dropped as director of the summer session, a position he had held since 1910 .

Although the president was unquestionably the first to break the spirit of the February agreement it is actually unlikely that anyone ever really regarded it as final. Babcock and Gillette, it is true, turned from campus politics to their books and laboratories. ${ }^{5}$ But there was no real peace between Libby, Ladd, Willis, and the Board (Totten) on the one hand and the president on the other. It is impossible to say how much the three professors continued to agitate, but apparently their contempt for the president was unconcealed, and he was waiting for his chance to be rid of them. The appearance of McVey's ten-page article, "The Office of the University President," in the April, 1920, issue of the Ouarterly Journal, of which Ladd was editor, was obviously more than coincidental, although McVey did not intend it as the pointed rebuke to his successor that could be read into such passages as the following:

The essential elements in the successful administration of the presidential office are patience, tact, good sense, and knowledge. The president must provide initial vancement within the conft in his office as a kind of umpire between the contending factions of a University faculty. There should be no factions in a un complete understanding and brotherly outlook from the educational towers of the university.

${ }^{5}$ Gillette appears to have gotten on civilly with the president throughout most of the 1920 's. However, in 1925 he was to write that he had not been in the president's office in three years. His personal correspondence contains many uncomplimentary references to Kane. If he wrote one word of approval to his friends, it has not been 
The following June Kane was humiliated by the Board when it practically forced him to recommend Willis for permanent appointment as dean of the law school-Willis had been acting dean for two years while Wells, who resigned in 1920, was on war leave. Kane made strenuous efforts to discredit Willis before his hand was forced. He charged that the school had been practically wrecked by Willis' poor management and unreasonably high standards, remarking: "As the matter now stands, we should have to regard the law school as almost abolished." A year later several Board members ostentatiously "investigated" the University following a "night shirt" parade by some men students through a women's dormitory. One girl was dumped or pulled from her bed; there was some debate over which it was, for the president contended she had been "dumped," apparently a less reprehensible offense than "pulled."

When in November, 1921, Governor Frazier was defeated in a recall election by Ragnvold A. Nestos, the president's opportunity seemed to be at hand. The new governor's Founders' Day speech the following February, in which he deplored the tendency of some college professors in the state to ridicule religious faith, was taken as a rebuke to the anti-Kane faction, particularly to Gillette. In May, Totten resigned from the Board, and the IVA had control, three to two. The president appeared to be riding high when only two days later the Board approved his recommendation to create the offices of graduate dean, dean of men, and assistant to the president. These organizational changes were made in deliberate and open defiance of the University constitution, which required the approval of the Deans' Advisory Committee and the faculty Council for such major changes. The members of the Board, being inexperienced, were probably unaware of this limitation on the president's powers; for his part Kane contended that the constitution was no longer in force, never having been ratified by the Board of Administration. Abbott and Hitchcock, two of his most loyal supporters-Hitchcock was also chairman of the president's committee on discipline-were appointed to the deanships, and the dean of Fargo College was made presidential assistant. Abbott's appointment as graduate dean ousted Ladd from one more position, the chairmanship of the faculty graduate committee which he had held for years.

Two weeks later the expected blow fell when Kane informed Ladd, Libby, and Willis by letter that they were to be dismissed, and simultaneously recommended such action to the Board. Again the constitution had been ignored; the president had followed none of the procedures prescribed, specifically the requirements that he consult the Deans' Advisory Committee and the individual deans concerned and that the men to be dismissed be accorded a hearing. The president had overplayed his hand, for although two members of the Board voted for immediate dismissal, the majority approved the professors' request, which was filed immediately, for a faculty investigation of the charges against them, as provided in the constitution. Kane hastily appointed a committee, but the faculty Council, aroused at last by his obvious intention to ignore all limitations upon himself, challenged his authority in the matter and authorized Squires to appoint another. Although a defender of Kane two years before, Squires had arrived at a sort of neutral position in the controversy, having lost confidence in Kane while at the same time remaining unfriendly to Libby. None of the five men appointed was involved in the feud, and all but one, Chandler, were comparative newcomers on the campus. ${ }^{6}$

The faculty investigation, unlike the one by the Board two years before, was conducted quietly and without interference, except for Ambrose's attacks on the professors from his pulpit. ${ }^{7}$ On the ground that the constitution was no longer in force, the president refused to present witnesses or to document his charges. Most of the faculty, fearing reprisal, refused to testify for the record. Nevertheless, the committee spent more than eighty hours in session, most of the time hearing testimony. A thorough analysis was made of the charges; those against Libby were "outrageous treat ment" of students, erratic teaching and erratic administration of his department, vacillation in politics, membership in the most radical organization in North Dakota (unnamed, but so exclusive ${ }^{8}$ Chandler, Karl Fussler (head of the department of physics), Francis Garver (professor of elementary education), David Jenkins (professor of electrical engineering),

${ }^{7}$ At this time Ambrose was closely identified with the Ku Klux Klan. 
it had only nine members), overzealous patrioteering during the war, violation of the agreement of 1920, and inability to do team work. Charges against Ladd and Willis were similar. Every charge was rejected in every detail as untrue or unsupported by evidence, with the exception that, owing to conflicting testimony, no decision was rendered on Libby's ability to work with other people. As for the nine-member organization of radicals, the president was unable to substantiate even its existence. The concluding paragraph of the faculty report expressed the general weariness on the campus with the feud and the feuders as well:

this committee is unanimously of the opinion that these three men and the President cannot work together in harmony. It is, therefore, the judgment of this Committee that, within a reasonable time after this date, one or both parties to the controversy that has for so long menaced the efficiency of our service to the State should sever official connection with the University. It is the suggestion of the Committee, made in all friendliness to both sides, that the initiative in such action be taken by the parties me parties themselves.

This Committee is moved to recommend ameliorative measures because of the fact that both sides, including practically the entire University faculty, the spirit of the Hagan Armistice [the agreement of February 1920]

Confidential testimony presented at the hearings clearly shows that the Board has also .... violated the armistice by ignoring the provision of the agreement which makes the President the channel for all communications between faculty or students and the Board. Where all have sinned, judgments should not be too severe.

The Board of Administration accepted the report in full, although it acted more drastically than the committee recommended. Willis was dismissed outright, an action later modified to dismissal with half pay for one semester; Ladd was dismissed with half pay for a year with the explanation that the termination of the twoyear elementary course in the School of Education, recommended by Kane a year before, made his services no longer necessary. Libby, because of "his great service to the state and to the Northwest," was given the chance to make his peace with the president. On his failure to reply to the Board's communications, he was notified that he would be dismissed at the end of the 1922-1923 term with half pay for a year.
The action on the president was less drastic, but in a way somewhat more humiliating. The Board not only accepted the investigating committee's refutation of the truthfulness of his charges but also rescinded the establishment of the new deanships and the administrative assistant post. It addressed a letter to Kane instructing him to proceed henceforth in the manner prescribed by the University constitution and concluding with the strong hin that his resignation would not be unwelcome in Bismarck. The combination of hint and sharp rebuke was enough to cause several newspapers to report that the president had been dismissed.

Whatever might be said about the inequality of punishments meted out by the Board, it had, for good or ill, finally resolved the one truly disastrous internal quarrel in the University's history. Where the NPL Board had hopelessly bungled, this combined IVA NPL body had behaved judiciously and calmly and avoided the involvements of student emotions and public prejudice in Grand Forks. It is a point of some significance that the Board's final decisions in the University affair were arrived at unanimously. The calmer atmosphere of 1922, when the "red scare" and the NPL movement had much abated, of course played no small part in the success of the last effort.

All parties to the controversy, with the exception of Ladd, escaped serious consequences or were vindicated by time. The Board took no action to force Kane's resignation as it had apparently intended. According to one of Kane's admirers, writing some years later, "a miracle happened .... . Dr. Kane's arch enemy on the State Board died, ${ }^{8}$ and the Governor replaced him with a friend. That, of course, saved Dr. Kane."

The president had learned some lessons, however, and he acted with somewhat more restraint in the future. His administration was never a truly harmonious one, owing to his own uncertain understanding of executive prerogative, to his incapacity for objectivity, and to the permanent residue of distrust in many of the faculty. Kane conspicuously lacked those qualities and attitudes that $\mathrm{McVey}$ thought to be essential to a university president. Unlike $\mathrm{McVey}$, an introspective man who gave much thought to the con${ }^{8}$ F. S. Talcott, appointed in May, 1922, died January 22, 1923. 
duct of his office and to its place in relation to the faculty, the Board, and the public, Kane appears never really to have thought through these fundamental questions. He has left no record anywhere of his views on the subject. Gillette was to say that Kane regarded the presidency purely as an honorific position, and Bek would come to believe that his only interest in it was the pleasant position in life it afforded until he had reached the age of retirement and his Carnegie pension. These are probably harsher judgments than he deserves, for there was considerable progress in the last ten years of his administration, a good part of which was the result of his leadership. An important element in the improved situation after 1922 was the requirement that the president operate according to the limits imposed by the University constitution. McVey wrote in his "The Office of University President" that the "foremost" cause of faculty-administration conflict was the "absence of clearly stated rules of organization that set down definitely the relationships existing in the complicated organization of a modern educational institution." It was a point that the Board saw at last if the president did not, and by its action of 1922, it not only established the important precedent of approving a constitution that had been approved by its predecessor but accepted the principle of definite limitations upon the president, and to a degree upon itself, in the conduct of the internal affairs of the University. The University constitution has not been openly or specifically flouted by Board or president since Kane's effort to set it aside in 1922, although to be sure, it has not always been observed to the letter by either.

Gillette received his highest professional honor, the presidency of the American Sociological Society, in the 1920's, and in 1933 when Kane was retired by request of an incoming NPL governor, Gillette had the satisfaction of being tendered the presidency on the recommendation of the faculty. Libby's dismissal was rescinded in the spring of 1923 because of pressure from alumni, and although his best days were past, he continued as a vigorous scholar, and if not a teacher popular with students seeking easy marks, he was a highly respected one. The 1926 Dacotah was dedicated to him. The University's grand old man, he retired in 1945 at the age of eighty-one, his prestige on the campus and in North Dakota fully restored. Babcock, who had once declared that either he or Kane must go, devoted his last years to research; when he died suddenly in 1925 he was one of the most widely known and honored men in North Dakota. Willis, whom the president had declared to be incompetent, joined the faculty of the Indiana University law school in the fall of 1922, eventually was appointed dean, and in 1945 professor emeritus, having earned a reputation as one of the foremost legal scholars in the United States, praised even in the Grand Forks Herald. The one exception to this otherwise happy outcome was the fate of Ladd, ousted at sixty-two after sixteen years as one of the most active members of the faculty, editor of the Quarterly Journal from its founding, chairman of the graduate committee, director of the summer session, and in March, 1922, elected president of the local chapter of the American Association of University Professors, which incidentally did nothing in his defense. Too old to seek another academic appointment and with his slender resources practically wiped out by the depression of the early twenties, he worked for a short time for a Chicago publisher and ended his days making a lean living on a tiny fruit farm near his old home in Michigan.

Any attempt to assess the effect of the troubles of the early twenties on the University is risky indeed. There is no way of determining how many resignations were occasioned by the prolonged quarrel. Bitter against Kane, Brush resigned in 1921 to accept an appointment to the faculty of the University of California at Los Angeles. Robert Young, head of the department of biology, was not involved in the feud, but because he spoke out against the tactics of the Kane supporters in 1920 he got into the permanent bad graces of the president, a circumstance which was a contributing factor in his resignation in 1926 after twenty years on the faculty to accept an appointment at the University of Montana. The two law professors appointed by Willis in 1921 disappeared with hardly a trace as soon as Willis was gone. There were no doubt others who departed quietly at the first opportunity. News of the quarreling must have prevented some professors from accepting appointments at North Dakota. Even more difficult is any attempt to measure the effects upon the University's prestige in the state. Unquestionably 
it had been damaged for a time, but public memories are short, and the postwar boom in enrollments and the conservative swing in state politics assisted in bringing a rapid recovery. Perhaps the worst effect of all, one also impossible to measure, was upon the students who had been appealed to in terms of prejudice and mob spirit by leaders of an institution devoted to the fostering of a spirit of tolerance and objectivity in its students and to the welfare of the state.

\section{IX}

\section{The Golden Twenties}

U

NDER THE MOST favorable of circumstances an abler man than Thomas F. Kane might have found it difficult to match the record of his predecessor and to shine in the eyes of his faculty as well as in the records left for the historian. McVey had won his place in the University's history as its innovator, the man who had transformed it into a modern institution, but much of what he had begun was far from complete when he left for Kentucky. A man more brilliant, more energetic and imaginative than Kane would have found the role of consolidator difficult to escape; it was the one he was willing to accept. The fifteen years between 1918 and 1933 were marked by much expansion but little innovation or bold experimentation, in fact, by remarkably few deliberate changes in the general form or orientation of the University.

The relationship in time of the two administrations and the vast difference in the personalities of the two presidents were, however, only two of the factors responsible. The war and with it the coincidence of a change of administration and an interim presidency seriously disorganized the University's operation, so much so that the task of reviving some of its functions or branches was hardly different from beginning anew. Even more serious was the difficult economic situation in which an almost totally agricultural 


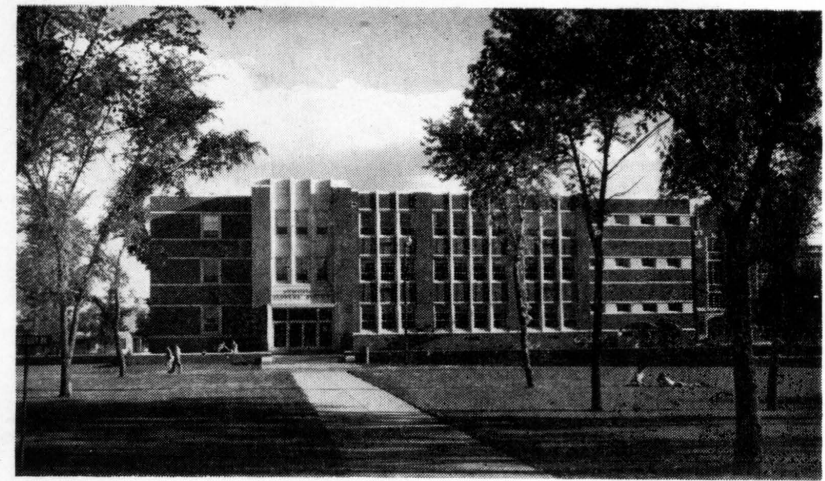

Memorial Student Union

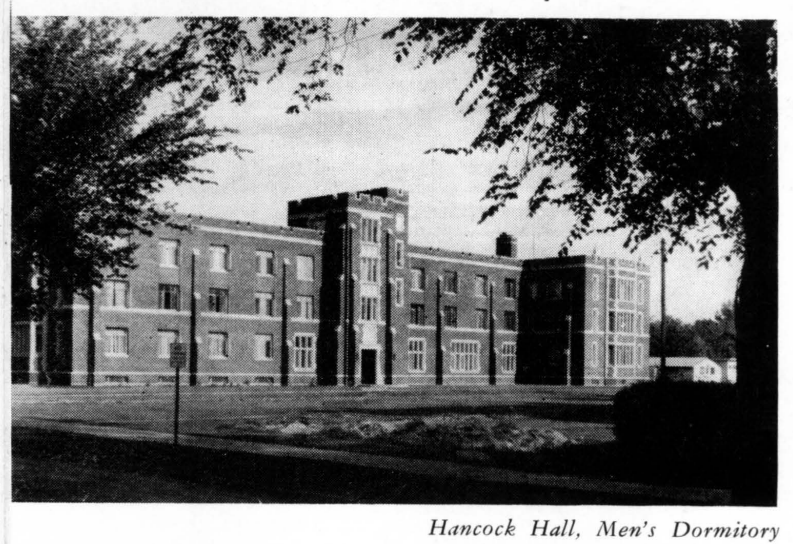

Medical Science

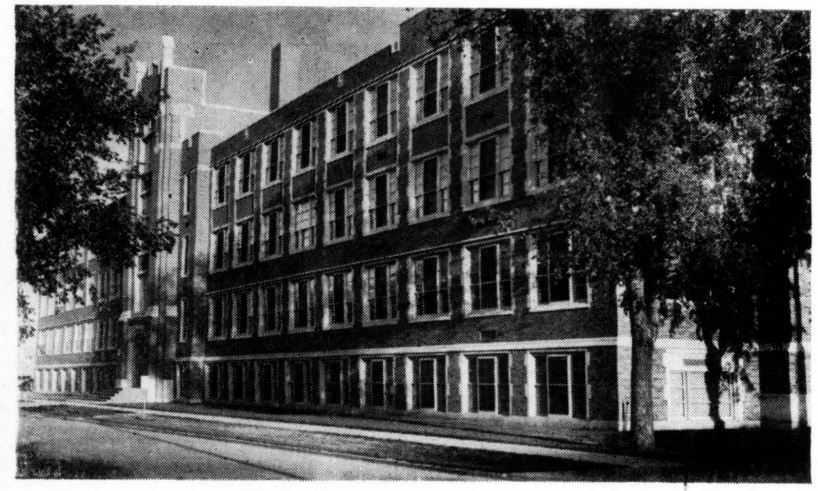

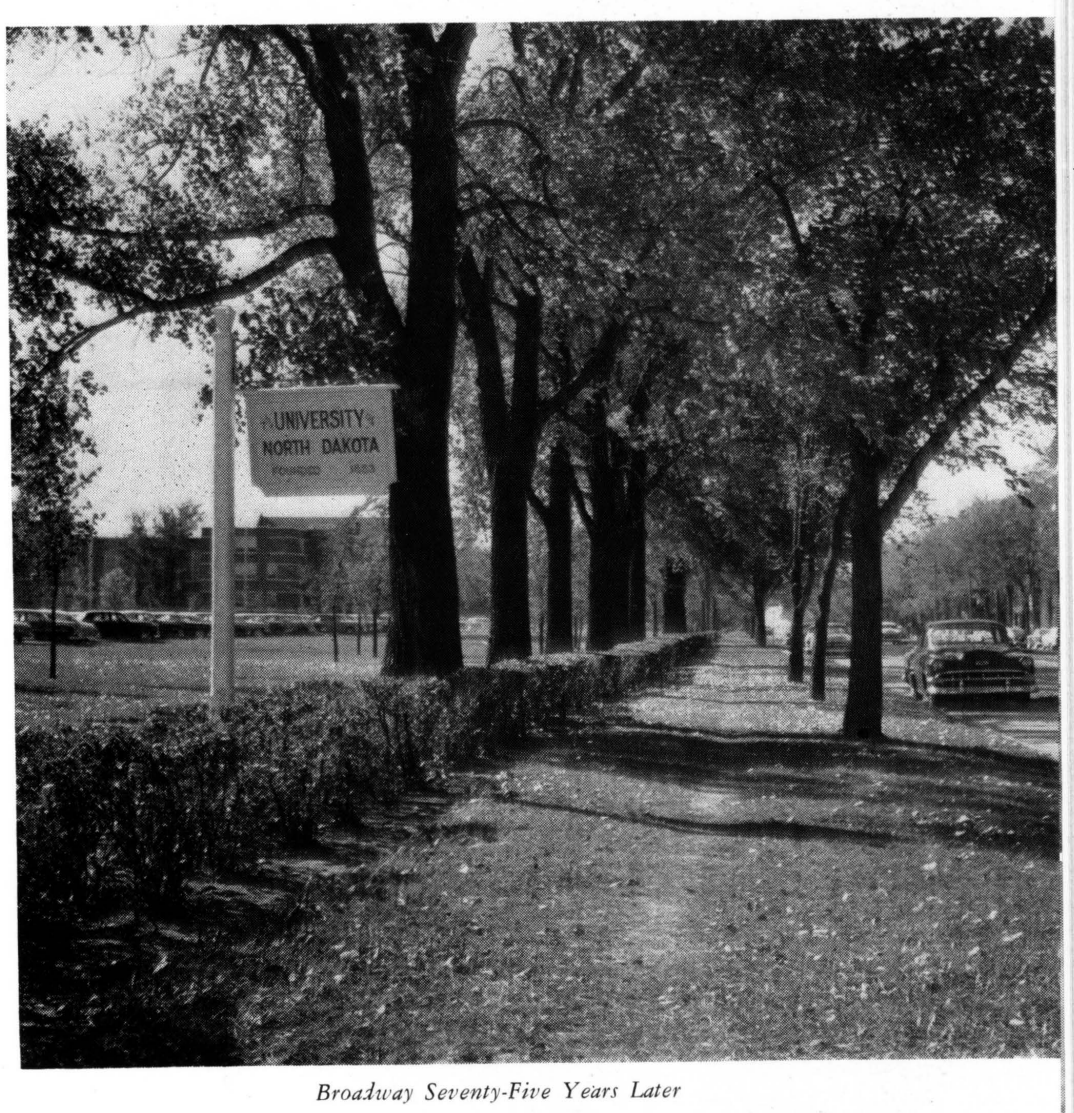

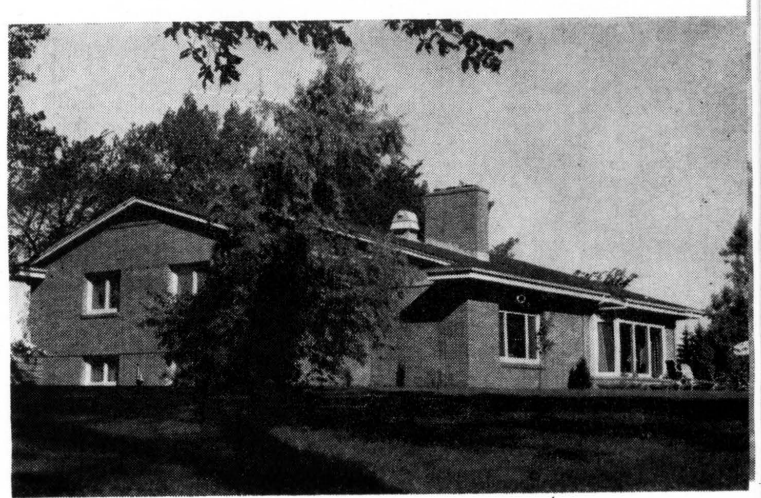



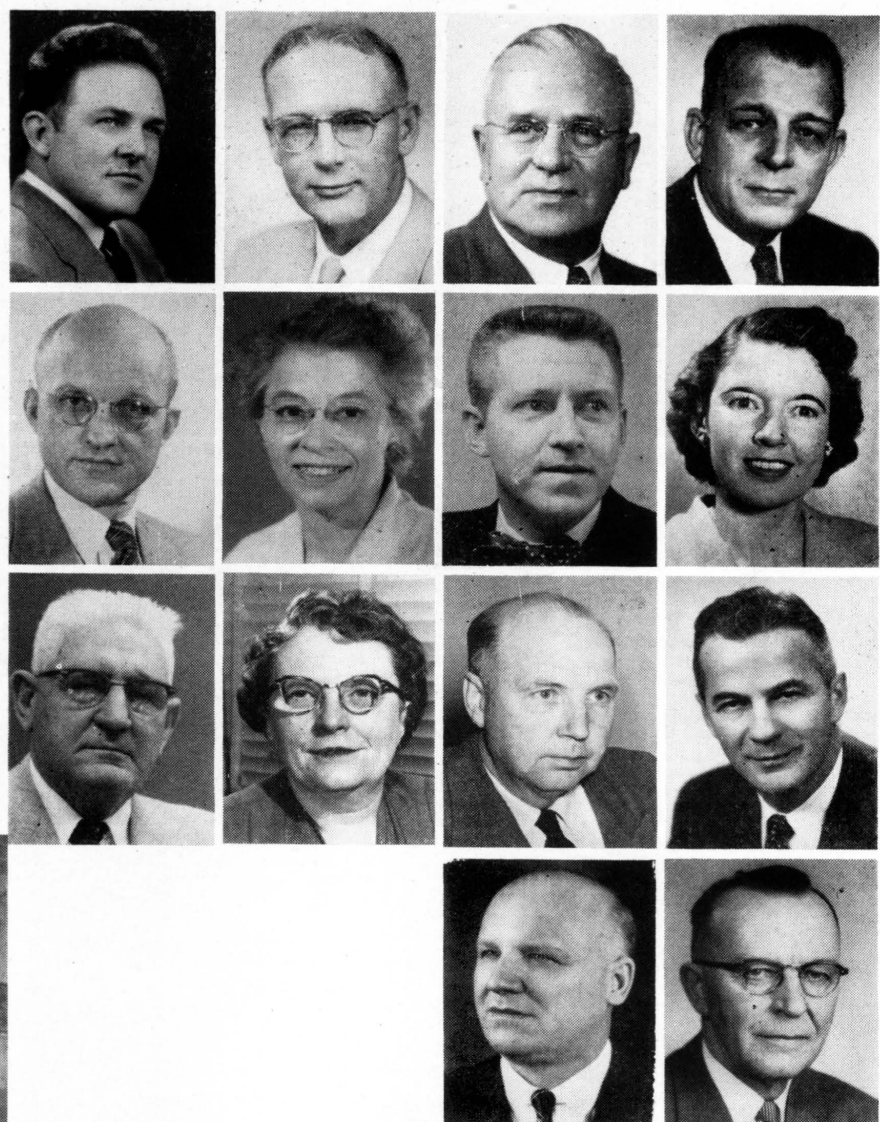

Thormodsgard Witmer hasty rush season by the fraternities and sororities, and the usual spring formals, mildly affected by lingering habits of wartime austerity, marked the return to normalcy in social affairs. A state-wide tour by Beatrice Olson's "Merrymakers" variety show, the bacchanalian theme of the May Fete-a festival in honor of Dionysusand the celebration of Friday, June 13, as Hoodoo Day thrust into the background the tragic events of the war years and the flu epidemic.

Nevertheless, the first year or so after the Armistice abounded with reminders of the great effort and adventure of the war. The fall term of 1919 opened with a "flannel shirt mixer"; the presence of a considerable number of veterans who had "seen Paree" or at least Fort Sheridan provided the student body with an unfamiliar leavening of maturity and experience (the state legislature of 1919 had voted a bonus of $\$ 500$ to every veteran of twenty months service, to be applied toward an education, or the purchase or improvement of a farm or home). The war and the League of Nations were the subjects of numerous convocation lectures and the like. The October, 1919, issue of the Quarterly Journal was devoted entirely to articles about the University's role in the war, and the 1921 Dacotah (published in the spring of 1920) reserved a large section for war pictures and an honor role of the University's dead. There was considerable enthusiasm for a suitable war memorial, and in the spring of 1919 the faculty Council resolved to launch a campaign to raise funds for an auditorium. The quarrel between faculty and president as well as the economic collapse of 1920 prevented the fulfillment of this project and delayed an Alumni Association proposal for a memorial student union so long that it too was abandoned later in favor of a stadium.

In the meantime, the fall term of 1919 was redolent of change, of the entry into a new era. Along with such hardly noticed milestones as the sale of the president's horses and carriage and the purchase of a Dodge automobile were a record appropriation of $\$ 675,000$, voted the preceding spring by the state legislature, and a record enrollment of more than a thousand. An ambitious football schedule which included Marquette University and the University of Minnesota gave a hint of future expectations. A clear portent

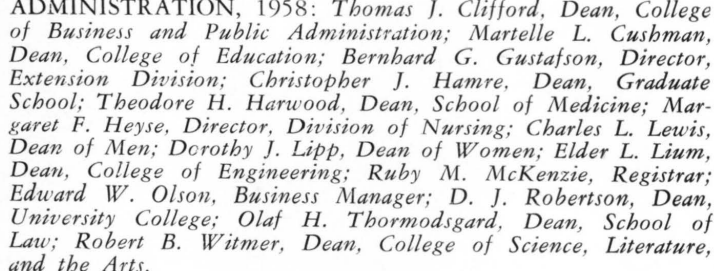

Law; Robert B. Witmer, Dean, College of Science, School of 
of the student life and activity of the 1920's was the Homecoming celebration in October. A gala all-day affair, it included all of the familiar trappings: crowds of sentimental and successful old grads (among them the state's leading public figures), speeches, parades, and rallies, two football games, and a dinner and dance in the evening. It was symbolic of the change in mood from the dedicated seriousness of the Progressive Era and the war to the more frivolous concerns of the 1920's that the University War Committee's "Reconstruction Conference" held at the same time attracted little notice.

No other University activity, academic or otherwise, provided a pattern more typical of the 1920's than competitive sports. And no activity was as great a source of satisfaction to most of the students and alumni, for University teams reached the highest peaks in their history by the eve of the depression. All of the usual practices and symbols of over-emphasized intercollegiate sports made their appearance at North Dakota: spring training, recruitment of players, mounting alumni enthusiasm and with it signs of alumni interference in University internal affairs, the inevitable construction of a stadium, intersectional competition, the dismissal of a coach who had ceased to win, and finally the appointment of an athletic director at a salary second only to that of the president. From the students' standpoint what this meant was that football, and to a lesser degree basketball, were shifting from games for the exercise and pleasure of healthy young men to spectacles for the entertainment of sports-minded alumni and partisan North $\mathrm{Da}$ kotans. As such they became a kind of public service as well as a major instrument in the University's relations with its public, of considerably more weight in some influential circles than the standards of instruction. Moreover, the major sports became competitions between specially trained "experts" of a sort, with the bulk of the student body reduced to the role of providing the necessary background of cheering sections for the Saturday spectacle. One coach gave unconscious expression to the new attitude when he rejected an invitation to join a hockey league on the plea that the sport could not be made to pay.

A new coach, Paul Davis, a graduate in law from Dickinson
(Pennsylvania) and former coach at the Agricultural College, was appointed in 1919 and appeared to promise well for the future. In his first two years his basketball teams lost only a single game, and although he had less marked success with football, his record was not entirely unsatisfactory, particularly when in 1922 his team held the University of Minnesota to a score of 19-0 and Marquette to 7-3 and finished second in the conference. Davis' success ended here, however, because of the stiffened competition provided by the new North Central Intercollegiate Conference formed in 1922Creighton, Des Moines University, North Dakota Agricultural College, St. Thomas, South Dakota State College, University of South Dakota, Morningside, and the University of North Dakota. ${ }^{1}$ The amorphous old Minnesota-Dakota Conference, in existence since 1909 , had included every college in the three states except the University of Minnesota. Within a few years, owing to pressure from alumni, to whom he was extremely deferential, Kane set about relieving Davis, formerly a close friend, of his coaching duties by elevating him to the post of athletic director. Clem Letich was appointed basketball coach in 1925, and shortly afterward the Flickertail Club, organized primarily to raise money for a stadium, set out to raise a fund of $\$ 3,000$ to hire a new football coach. Kane was only too anxious to oblige; in fact he was willing to appoint anyone the club wanted. But Davis had powerful alumni friends too, among them Walter Schlosser, recently president of the Alumni Association, and Robert Murphy, president of the state Board of Administration. Davis managed to select the football coach, over the vigorous objections of the president; moreover, he refused to resign as he was obviously expected to do. Without consulting the advisory committee of deans or Davis' dean, Kane thereupon asked the Board to dismiss Davis in December, 1927. Unlike the hapless professors who found alumni, press, and students arrayed against them in 1920, Davis and his friends managed to embarrass the president acutely in the sharp quarrel that spread to the pages of the Herald, and even to the Student. In the end Kane won his ${ }^{1}$ The conference was modified again in 1928 when St. Thomas was dropped and Drake replaced Des Moines, which it had absorbed. Chandler, who had succeeded
Brannon as the major faculty adviser on athletics, is remembered at North Dakota as the father of the new organization. 
point by withdrawing his request for dismissal in return for Davis agreement to resign with a half year's pay. The new football coach, Tod Rockwell, soon followed. According to the gossip, Kane came very near being ousted himself. ${ }^{2}$

The president's vindication came quickly. Davis and Rockwell's successors were the "wonder coach" of South Dakota State, C. A. West, and his former star player, Clyde "Buck" Starbeck. West's teams had already won three football championships in the sixyear-old NCI, and his first North Dakota team brought home his fourth title, clinched at the Homecoming game of 1928. Floats and bands, a downtown parade, "thousands" of old grads including members of the team of 1898 , seven thousand spectators, the biggest crowd in history in the new brick stadium (the "pride of the Northwest"), the "Tribe of Sioux" rooting club cavorting on the field, and a championship team, all combined for one of those memorable occasions which, viewed from the dark days of the depression, gave the 1920's their golden glow. At the victory dance in the gymnasium, the gridiron heroes were escorted to a huge throne and gold crowns placed upon their heads by "maidens dressed in white."

North Dakota had entered its greatest athletic era, for that same year the basketball team, in the hands of another wonder coach, the taciturn Clem Letich, who came to the University from Yankton College, likewise won the conference championship; in 1924, the year before Letich's arrival, the team had finished last. A tall team for the time, averaging a little over six feet, Letich's cagers of 1928-1929 beat Minnesota 25-24. During the Christmas holidays they toured from Chicago to the West Coast, the first such junket in University history, to play Loyola, Illinois, Brigham Young, University of California at Los Angeles, Washington, and others. The Letich teams were a major conference power for fifteen years. The North Dakota football team won its fourth NCI title in 1931, a year in which it performed more than creditably in intersectional contests with Oregon (0-0), George Washington (6-6),

'In June, 1928, Gillette wrote to his old friend Robert T. Young, then on the faculty of the University of Montana: "Today is the day when T.F.K. is called on by the half pay for a year with the understanding that he is not to return or be fired. I hear that Dean Kennedy is to be acting president in the interim . . and Duquesne (lost 13-7). In 1932 the "Sioux" (renamed from "Flickertails" in 1930) defeated Loyola of New Orleans, De Paul, and Howard University. West's teams lost only five conference games from 1928 to 1932 . Only some of the faculty were critical when in 1930 the Board of Administration approved a three-year contract with West at $\$ 6,000$ per year, more than was paid to any dean ( $\$ 4,600$ was budgeted by the University and $\$ 1,400$ paid out of athletic funds). Probably no others connected with the University were more widely and favorably known in North Dakota at the turn of the decade than West and Letich, whose annual recruiting trips took them to every corner of the state, and the fiery little football hero, "Red Rabbit" Jarrett, named to one New York sports writer's All-American team in 1930 and given an honorable mention by Knute Rockne. West, Letich, Jarrett, and the "Sioux" had taken the high place in the regard of alumni and general public once occupied by such men as Babcock and Kennedy.

Just how solid was the support aroused by athletics? There was some public support as a direct result, but it should be noted that during the 1920's the Agricultural College, under the leadership of John Lee Coulter, perhaps its ablest president, grew more rapidly than the University; although the College did not match the University in athletic prowess, it overtook it in public regard, so much so that in the legislative session of 1933 the University was hard pressed to defend itself against the expansive ambitions of the friends of the Agricultural College. On the University campus itself the improved athletic teams assuredly contributed to student morale. Moreover, intramural sports prospered in proportion to intercollegiate success. In 1929-1930 a dozen campus teams competed in touch football leagues, twenty in basketball, nine in hockey, and twenty-five in baseball and diamond ball (intercollegiate baseball had finally disappeared entirely). According to the athletic department and the sports enthusiasts, the program was made possible by the enlarged gate receipts from football and basketball, but it is worth noting that the annual appropriation for athletics rose from less than $\$ 9,000$ in 1925 to $\$ 18,000-\$ 20,000$ in 1929.

But there is no doubt of the direct relationship that existed between intercollegiate sports and the growth and activity of the 
Alumni Association. With the reserved encouragement of McVey, who valued alumni support but realized that it might easily become unwanted interference, the organization had increased rapidly in importance in the decade after 1910 as it grew in size and as its members climbed the ladder of success. ${ }^{3}$ Aside from the rather unorganized support that influential alumni had given for years, the association's first really significant role in University affairs was the assistance rendered by some of its more active Grand Forks members in the successful defense of Kane's position in 1920. Aware of his debt as well as of his continued need for such backing to counter a restive faculty, Kane actively promoted the organization. His direct connection with it was emphasized in 1926 when his office assistant, Frank Webb, also assumed the duties of alumni secretary and editor of the Alumni Magazine.

In 1924, the alumni launched their first major project on behalf of the University, a campaign to raise a half million dollars for a stadium and a gymnasium-fieldhouse as a memorial to the University's war dead. The preliminary steps, including the formation of a Flickertail Club headed by Dr. M. G. Ruud of Grand Forks, were taken at the 1924 Homecoming, and the drive for funds began a year later. The memorial board included Ruud, Walter Schlosser, president of the Alumni Association, James W. Wilkerson, business manager of the University, Philip Bangs, and Fred Goodman, all of Grand Forks, and Arthur Netcher of Fessenden and John Hancock of New York. Paul Samuelson, a graduate of 1923, was made director of the drive; because of his involvement in the quarrel over Coach Davis he was replaced after two years by

${ }^{3}$ In the 1920 's the University could boast alumni with more than a local reputation such as Vilhjalmur Stefansson, the first to achieve fame; Maxwell Anderson, whose What Price Glory was the broadway hit of 1925; Thomas Campbell of Montana the "world's greatest wheat farmer"; John Hancock, president of Jewell Tea Comof the Concrete Pile Company of New York; Dr. Colby Rucker, assistant surgeo general of the United States; J. Francis Douglas, the "man who built Seattle" Howard Huston, chief of international services of the League of Nations at Geneva; and Cora Smith Eaton King, a physician and prominent suffragette of Boston an Los Angeles. The Student proudly reported in 1924 that thirteen former students were listed in the current edition of Who's Campbell was second (1929), and Stefansson was third (1930). Most of the brightest stars in the local political firmament were alumni; heading the list was Lynn Frazier,
the first to be elected governor and the first to go to the United States Senate (1922).
Jack Stewart. Using the medium of the new Alumni Magazine, begun in the spring of 1925 to advertise the movement and to stimulate the formation of local clubs, Samuelson had more than $\$ 150,000$ pledged by early 1926, enough to begin construction. At the Homecoming celebration on October 8, 1927, a handsome brick stadium seating 8,000-still adequate in 1958-was dedicated to the University's war dead and to Webster Merrifield. The new plant cost about $\$ 220,000$. Although only $\$ 90,000$ had been paid in, more than $\$ 300,000$ was pledged, and the memorial association directors confidently looked forward to the next step, the gymnasium and a student union.

The stadium drive and the enlarged role of the alumni in general were not without their ironies. Kane's difficulties in ousting Davis might not have resulted had he not tacitly encouraged intervention in the University's internal affairs. To a considerable degree Kane's own forced resignation in 1933 was the work of alumni, some of them the very people who had rallied to save him in 1920 . The stadium pledges, symbolic of enthusiasm and good will in the 1920 's, were to become during the depression the source of much ill feeling toward the Alumni Association and the University when the memorial fund officials persisted in their efforts to force payment from financially embarrassed alumni. At the moment, however, the immediate and marked rise of attendance at football contests appeared irrefutable justification for the expenditure of energy and substance to provide the University with a stadium. Before 1927 the largest crowd ever assembled for a North Dakota football game was fewer than fifteen hundred; two years later a crowd of seventy-two hundred produced a revenue of $\$ 6,100$.

The development of music and forensic activities was likewise influenced by the emphasis upon their role in the University's promotion of good public relations. The Philharmonic Society, organized in 1911 by Norton, gave way to the smartly uniformed Concert Band, whose closest academic relatives were the ROTC and the athletic department. Hywel Rowland, who joined the faculty in 1927 as director of glee clubs and head of the department of music, introduced regular performances of Gilbert and Sullivan 'This was the first permanent publication of its kind. An Alumni Register, begun in
1910 , had been discontinued after only two years. 
operettas. The glee clubs and the band, the latter directed by John Howard from 1926, were highly popular performers. A performance of Patience attracted a crowd of two thousand to auditorium on one occasion, and on another the band drew a record audience of over twelve hundred to a morning convocation.

The appointment of William Schrier as instructor of public speaking in 1927 in a sense marked the transition from the old fashioned, elocutionary tradition in forensics to the trained specialist in speech and a separate department of public speaking. The new emphasis upon expertness and audience appeal brought a revival of popularity for forensics not experienced since the days of Merrifield. Matches with the traveling teams of Cambridge and Oxford Universities drew large and appreciative audiences in 1927 and 1929.5 In 1928, a great year for University organizations to take to the road, the debate team was away for three weeks on one fourteen-state tour. The first annual forensics celebration was held that year: the King extemporaneous speaking and dramatic reading contests, competitions for the Merrifield, Stockwell, and Peace oratorical prizes, and a round of debate against a traditional rival, the University of Manitoba. Among the outstanding orators and debaters of the period were Gjems Fraser, Edmund Belsheim, Harold Shaft, Fred and Sam Aandahl, and Duane and Alden Squires, sons of the dean. Fraser and Belsheim both won Rhodes Scholarships; Fred Aandahl was elected governor in 1944, and in 1952 he was appointed Assistant Secretary of the Interior by President Eisenhower.

For all practical purposes creative dramatic writing ended with the departure of Koch, although his successor, Franz Rickaby, another Harvard graduate, attempted to keep the old tradition alive until he departed in 1923 to join the faculty of Pomona College; he was, to be sure, less single-minded about the work than Koch, and his collection of Minnesota lumberjack and Dakota prairie ballads was of at least equal importance to him. The Playmakers' last effort in pageantry, a commemoration of the Pilgrims' landing presented in 1921, was a dismal failure. Rickaby's successor, Emanuel D. Schonberger, frankly abandoned creative effort ${ }^{5}$ In 1956 a match between the University and Oxford teams drew only a handful
of listeners. altogether for the teaching of dramatic technique and the presentation of entertaining contemporary Broadway plays, as many as seven or eight each year. He also revived the North Dakota tour, and in 1928 a small cast of Playmakers participated in a dramatics competition at Northwestern University. The shift in the Playmakers' orientation did not pass entirely unnoticed; a letter in the Student in 1926 mourned the passing of "one of the few things of a cultural sort for which our state and University were known."

Entertainment and showmanship were increasingly emphasized in response to the example as well as the competition of such annual events as the May Fete of the women's physical education department and the annual campus variety show, the Flickertail Follies, which made its appearance in 1925. The May Fete had been a feature of the University year since 1909; begun as a modest and traditional event, it was presented in the gymnasium or on the lawn north of Merrifield Hall until it fell into the hands of Nell Martindale, who joined the faculty in 1917 as head of women's physical education. She quickly expanded the festival into a spectacular dance-drama, a huge affair of elaborate sets and as many as five hundred performers, requiring weeks, even months, to prepare. In 1923 the presentation moved to the refurbished Bankside Theater, abandoned long before by the Playmakers. An estimated five thousand people attended the May Fete of 1926; hailed as the "most magnificent production ever given at the University," it was developed around the theme of The Rubaiyat. The fetes ended abruptly when Miss Martindale resigned in 1927 to be married. Her successor looked upon them as expensive luxuries of little use for purposes of physical education and turned to an annual dance or ballet performance in the gymnasium.

In the meantime the Flickertail Follies had arrived, full grown on the first effort, to provide an annual student entertainment and spring show. Variety shows had come and gone for years, but no permanent tradition was established until the Sigma Delta Chi journalism fraternity, itself new on the campus, invented an appropriate name and formulated the pattern, still being followed, of selecting the acts to be produced in preliminary competitions. Armin Rohde of Grand Forks was production manager of the first 
show in 1925, and the Follies played to a full house at the Orpheum Theater. Thus one of the University's most enduring traditions was launched. It has also been at times one of the most controversial in faculty circles, because of the inordinate amount of time and effort that go into producing it. It was a money-maker-it grossed well over \$2,000 in 1927-and the use of some of the proceeds for such worthy causes as the purchase of printing equipment for the University Press and journalism department were arguments which its critics found difficult to counter. ${ }^{6}$ Moreover, in some influential quarters the show came to be regarded as second only to a winning football team as a source of favorable publicity for the University.

As a matter of fact, only a small minority competed in intercollegiate athletics or debate, and the Flickertail Follies show was more or less the exclusive province of the fraternities and sororities. The Dacotah and Student staffs were also by necessity limited to only a few students, more often than not from the Greek letter societies. ${ }^{7}$ But the prominence accorded to activities and those who excelled in them colored the whole fabric of campus life and revealed, if it did not create, the student values of the time. To be sure, extracurricular activities had been given considerable prominence since the days of Merrifield, but then campus leaders werc expected to shine academically also, in other words, to approximate the Rhodes Scholar ideal, while the activities man or campus champion of the 1920's could safely ignore Phi Beta Kappa, and even the "C" average necessary for graduation, with no great loss of face. Of 225 students taking part in activities in 1924, one quarte were reported delinquent in one or more subjects. It should be remarked that student attitudes in this regard were not unique, but largely a reflection of the general contemporary interest in the spectacular champion, whether it was Babe Ruth or Shipwreck Kelly.

'University regulations required that the Follies funds be deposited in the University business office.

${ }^{7}$ The Dacotab began appearing annually in 1922; in size and quality the issues of a department of jare favorably with those of the 1950 's. With the development of 1920 's, and from 1924 to 1928 a Daily Student appeared four times a week durin the regular term. In 1928 the Administrative Committee, concerned with its low quality, took steps to cut it back to a semiweekly.
The competitiveness in students' relations with each other was accented by the fraternities, which were at the peak of their prestige and influence in the 1920's. By 1933 nineteen organizations, including one Jewish fraternity which no longer exists, had national charters. With the exception of the new Theta Chi house opened in 1955, the fraternity row was complete by 1933 . The size of the new houses-most of them cost about $\$ 30,000$-indicated not only the importance of these societies but also the optimism of the years immediately preceding the depression. Some professors deplored the mounting influence of fraternities, and the Nonpartisan League press frequently attacked them as instruments of snobbery and class consciousness. But the president, and probably a majority of the faculty, looked upon them as signs of progress and accepted their argument that they taught proper social behavior and provided the "contacts" so necessary for success after college. Their best defense was that they provided much needed student housing in the vicinity of the University. The size and number of the societies, to say nothing of the size of their debts, did much to mitigate their exclusive tendencies.

But there is no denying that they were a divisive force, particularly in the atmosphere of the 1920's. A writer in the Student commented in 1924 on the decline of "comradeship" on the campus. The nonfraternity students, particularly the lowly "roughnecks" of Budge Hall, were habitually referred to as "barbarians," and a clear line divided fraternity and nonfraternity in the campus politics of the period. With the already competitive atmosphere heightened by the ill-feeling bred of exclusiveness, it is hardly surprising that student politics was vigorous and voter turnout extraordinarily high. ${ }^{8}$ Contests were not infrequently corrupt, with framing of tickets, ballot-box stuffing, and ballot stealing common enough to be of much concern to the faculty as well as to the unorganized nonfraternity students, the usual victims.

For the students, there seemed much to "politic" about. The customary contests for class offices and the editorships of the Student and Dacotah were augmented by elections of a long list of campus

${ }^{8}$ Student interest in campus politics and student affairs in the 1920's is in sharp contrast to the situation after World War II. By 1958 class organizations had disappeared entirely. 
queens, kings, and "eminents." The ROTC sponsored the first of these in 1919-1920, the selection of the nine most popular girls in the University. The next year Norma Young won the distinction of being the first University beauty queen. Variations on the theme were seemingly endless: the most athletic girl, the sixteen most popular men, the campus who's who list, the best marriage prospects - a contest between the "sheiks and shebas" and the "homelovers" the Student termed it-and finally a "queen of queens." One Student editor was moved to wonder if the term of 1925-1926 would end without every co-ed's having been chosen queen of something or other. Nor were faculty and alumni overlooked. The 1926 Dacotah published the pictures of the ten most prominent alumni, "selected by popular student election." Two years later the immortal Joe Flanagan, then a leading citizen of Towner, was elected the greatest athlete in University history. (He died that same year at the age of fifty-one.) In 1929 came the turn of the most popular professors; all those chosen were deans or department heads save one lone ROTC instructor, Sergeant Edmund T. McCann. The greatest all-round University hero of the period was Carl Ben Eielson (B.A., 1921), the daring arctic aviator. His flight over the North Pole in 1928 as the pilot for Sir Hubert Wilkins was, in North Dakota eyes at least, second only to the achievement of Charles A. Lindbergh. All the University mourned when its most spectacular hero was lost and killed a year later on a mercy flight over the arctic wastes. Blue Key enshrined his parka in a glass case inside the entrance of the new Merrifield Hall.

Organized hazing reached its peak shortly after the war. Factors in this development were the fashion of the times, the president's lack of concern, indeed his rather favorable attitude toward hazing, and the presence of returned war veterans somewhat older and considerably more experienced than the callow freshmen just out of small-town high schools. The general pattern was set when on a September evening in 1919 the sophomores marched the freshmen through downtown Grand Forks to the music of a jazz band and raided movie houses to stage impromptu vaudeville performances. The faculty, having troubles enough of its own at the time, took no action except to pass a resolution deploring the epi- sode. For a time at least townspeople viewed the downtown paddle lines and theater raids each autumn as more amusing than reprehensible; the Herald observed that freshmen probably were the better for having been "shown their place," a view shared by the president. The dark side of the practice was that it frequently degenerated into fighting, coulee ducking, and mass bullying of the insecure newcomer. Fortunately, changing fashions, the disappearance of the veterans after a few years, and the overwhelming numbers of each incoming freshman class as compared to the sophomores gradually reduced hazing to such harmless initiatory rules as wearing the green cap and the rolled pant leg and "buttoning," and even these were being ignored with impunity by the close of the decade.

The appearance of hazing and the emphasis upon activities were actually a part of the general revolution in social behavior which affected manners, morals, dress, and even diet. From the standpoint of the average student the chief effects as well as manifestations of the change were his greater freedom of movement, the increasing informality of relations between the sexes, and the enlarged attention to purely social activity. The classic prototype of the co-ed of the times-who had her place at North Dakota as elsewhere-was the John Held, Jr., caricature of a flapper, scantily clsewher, short-skirted, short-haired, and dangling a cigarette. The Student reported in 1924 that only two co-eds still wore their hair in long curls, and the pages of the Dacotah devoted to the Flickertail Follies display considerably more leg and bare flesh than would have been permitted by faculty censors of stage or publications on the eve of the war. Moreover, although the no-smoking tradition on the campus was kept up as long as Squires was alive and drinking on University premises was not tolerated under any circuming on University prements in the Dacotah and Student indicate clearly enough that co-eds were taking up cigarettes and that some of the more daring were not unwilling to share the contents of pocket flasks or bottles hidden in the shrubbery at college dances.

Socializing got off to a vigorous start when the war ended. A faculty Council ruling of 1921 permitted any organization in good standing to hold an informal party on any Saturday night or on 
any evening preceding a holiday. The last remnants of wartime austerity soon disappeared, even in the face of the generally poo economic conditions of the early 1920's; expenditures for bands favors, and dress mounted steadily, and a half dozen new major events were added to the time-honored proms and fraternity formals, among them the annual military ball, a by-product of the ROTC department installed in 1919. In 1930-1931, a year of economic distress, it was estimated that direct expenditures for student parties, no fewer than 125 informal and formal dances, were more than $\$ 7,000$. In the meantime, closing hours were gradually pushed toward midnight, and restrictions upon the movements of women students were relaxed, particularly after the retirement of straitlaced Dean Fulton in 1923 and her replacement by the much younger Beatrice Olson, an alumna. But even Miss Fulton had been moved to abandon the chaperon requirement for all but first semester freshmen girls immediately after the war and to extend dormitory closing hours to a quarter of eleven on all weekday evenings.

Perhaps more important than such relaxations of rules were dean's ban (1920) of cheek-to-cheek dancing, "unn ing," cuddling, of on ing," cuddling, or dancing the shimmy indicates what was going on. On one occasion the Women's Senate, dominated to a degree by Miss Fulton, resorted to a committee of secret observers who would report the aforementioned offenses. "Moonlight" dances were also a source of concern, but the practice was soon sanctioned by the purchase of a moonlight machine for the Armory and a careful effort to define the point at which legitimate moonlight became total darkness. In fact, if not in applied to any but campus affairs or the officially approved parties of organizations. With more and more students living off the campus each year, many at a considerable distance, and with the pearance of the student automobile and the practice of informal dating, or "stepping," it was exceedingly difficult if not impossible to maintain really effective control. Even when it was still officially off-limits, a much-frequented resort was the States Ballroom in East Grand Forks, where the Charleston and Black Bottom were in high favor. The prominent place of the saxophone band in the Homecoming parade of 1923 indicated well enough that the critics of jazz and freedom were fighting a losing battle, on campus as well as off.

Management of student affairs went through numerous changes because of the rising enrollments, social change, and the growing student resentment at having no voice at all in University affairs. A so-called "self-government" plan was put into effect in 1920, largely on the initiative of the president. There was much enthusiasm in student circles for a while at this opportunity to "run the University," but within a year disillusion set in when it was realized that the Men's Conference and the Student Court plan provided only empty honors for the fraternities to monopolize. The system continued half-heartedly until 1927 when it was abolished for a more practical and realistic student advisory committee of four to sit with the faculty Student Affairs Committee. Another reform aimed at tempering campus politicking was the rule (1928) that candidates for the editorships of the Student and Dacotah must be passed upon by the Student Board of Publications, which would in turn submit the names of three candidates for each to the sophomore class.

Although the president enjoyed considerable popularity among students because of his friendliness toward them and his general leniency in matters of discipline, the actual supervision of their morals, morale, and health as well, devolved upon specially designated personnel. Following the first specific appropriation $(\$ 4,400)$ in 1925, the dispensary was kept open for the entire day (until 1924 it had been open only an hour), with a comparable expansion of diagnostic and preventive medical service. No general medical insurance plan for students was even proposed, however. The Student Affairs Committee, headed by Hitchcock until 1925 and the reafter by Captain Lawrence Quinn of the ROTC department, had the general supervision of social activities and organizations; its chairman was a sort of ex officio dean of men. When the post was formally created in 1927, Earl K. Smiley, a young assistant dean at Lehigh, was the first appointee. The office of freshman or junior college dean, to which William G. Bek was appointed, appeared in 
1922. An educational guidance committee, which he headed, sponsored general orientation and vocational guidance talks and a regular program of psychological testing. Bek also dealt with many disciplinary matters.

There was, however, a growing realization in some quarters that the University-student relationship was increasingly impersonal. The Luther and Newman Foundations were established on the campus in the middle 1920's to provide religious training as well as personal guidance to two of the largest religious groups at the University - by 1930 roughly one quarter of the student body gave Lutheran as their religious preference, about double the number who preferred Presbyterian, Methodist, or Catholic. Both the Newman and Luther Foundations were permitted to offer a few religious courses for credit toward a University degree. Such affiliated religious groups had some influence, for the North Dakota students were drawn almost altogether from religious homes. In 1929 the president of Wesley College reported that of the 254 members of the University graduating class, 99 had taken at least one course in religion. But the frequent complaints from Wesley College and comments in the Student about undergraduates' indifference to Wesley College courses in religion indicate that their influence was not as great as was wished, and less in the 1920's than it might have been at an earlier time.

Actually, despite the symptoms of change and the new problems in student behavior, one can discount most of the alarums about the effects of the jazz age upon the almost excessively normal and homogeneous student body, still from small town or rural backgrounds, still no more than a generation removed from pioneering, and still all too aware of the uncertain fortunes of prairie agriculture. The Scandinavian element in the campus population continued to increase, although the replacement of the old nationality societies with a flourishing Cosmopolitan Club indicated the decline of immigrant self-consciousness. The proportion of students from farms declined somewhat, to about a fifth of the total, largely because of the rapid expansion of the college offering at the Agricultural College. There were a few well-to-do, and a very few like Ruth Hancock who were actually rich, but the college playboy was so rare as to be practically nonexistent. Yet students were less seriousminded than before, and the emphasis on organizational and extracurricular activities indicated some falling off in the general intellectual tone of the campus, even for those who took no interest in activities. The low prestige of "grinding" and students' open objections to convocation programs because they were too high-brow were symptomatic. Reading tastes were unadventurous to say the least; informal surveys revealed strong preferences for the works of Rafael Sabatini, Homer Croy, and John Erskine, and such magazines as the Saturday Evening Post and the American, with True Story and True Confessions high on the list of favorites. Henry L. Mencken's American Mercury, the campus intellectuals' bible in eastern colleges, received not one vote in several polls conducted at North Dakota.

The pattern was not greatly different from that in many other American colleges perhaps, but the leavening element of a citybred avant-garde was not on hand to write rebellious poetry and to rail at the campus Babbitts. The Student was devoted almost entirely to activities and sports; what serious discussions its editors or readers engaged in were on such issues as the too frequent changing of textbooks ${ }^{9}$ or the "atheistic" teachings of Professor Gillette. Its most vigorous stand on a serious issue was against the continuation of compulsory ROTC in 1926-1927. As much or more heat was generated over the dismissal of Paul Davis, the coach. The nearest thing to intellectual rebellion on any organized scale that came to light was a sub rosa "Mooncalves" society. It was coeducational and held its meetings in "boxcars, cemeteries, and garages"; members were pledged to shun "convention, modesty, tact, and anti-radicalism." Naturally, the Mooncalves fell under the ban of faculty disapproval.

It is hardly necessary to remark, however, that a great many students were intellectually inclined and that they ignored the frivolousness about them to find stimulation among kindred spirits on the campus, in the library, or from some favorite professor. Several of the University's outstanding contributions to the world ${ }^{\circ}$ A state law of 1931 forbade such changes more than once every three years. This was perhaps a minor annoyance compared to the anti-evolution laws that appeared 
of education and science were graduated in this period. James M. Reinhardt, a student of Gillette's and the third to receive a Ph.D. from the University (1929), made a reputation as a criminologist in a long career on the faculty of the University of Nebraska. George Lundberg (B.A., 1920), also a student of Gillette's, became one of the nation's most original scholars in the field of behavorist sociology; he was elected president of the American Sociological Society in 1942. Cushman Haagenson (B.A., 1921) earned a worldwide reputation as a cancer surgeon and authority on cancer of the breast. One of Libby's students, Elmer Ellis (B.A., 1924; M.A. 1925), became a distinguished American historian honored for his work by election to the presidency of the Mississippi Valley Historical Association. Ellis became president of the University of Missouri in 1954

Within the limits of its ideals or rationalizations, the Kane administration was a period of considerable progress. Fed by the rapidly growing public high schools,${ }^{10}$ the University enrollments climbed steadily from the prewar peak of 868 in 1916-1917 to 1,826 in 1929-1930. The latter figure was not equalled again until 1937. Kane observed with pride in his report to the Board of Administration in 1930 that the University had turned out twice as many graduates $(2,889)$ in his administration as it had in all the years preceding 1918. What he did not note was that the University had actually lost ground to the other state colleges. The Agricultural College grew from 375 in 1921 to 1,330 in 1929. The normals, meanwhile, including the last one opened at Dickinson in 1918 , had been brought into direct competition with the University by their elevation to teachers college status.

The growth in the size of appropriations was also considerable, although they failed to keep pace with the growth and needs of the University. Exclusive of amounts granted for buildings, appropriations were increased from $\$ 675,000$ in 1919 to $\$ 1,160,000$ in 1921. But owing to the postwar slump in farm prices, the 1921 figure was cut by about 7 per cent in 1923, and in 1925 the threat of the North Dakota Taxpayers' Association, which narrowly missed putting over its initiated Gunderson Bill for a mandatory ${ }^{10}$ There were 6,123 enrolled in high schools in North Dakota in 1910-1911; 17,428 in $1920-1921 ; 32,819$ in $1932-1933$.
25 per cent tax cut, was a major factor in another reduction of about 8 per cent in the University appropriation. Enrollments continued to climb, and the next three legislative sessions were somewhat more generous, the $\$ 1,338,000$ appropriated in 1927 being the highest for many years. But the increases were not enough to prevent a widening gap between University budgetary needs and resources available.

Appropriations for buildings were only barely adequate for the most pressing needs for classrooms and laboratories with nothing left over for a suitable auditorium, a student building, or dormitories. The total construction, by private as well as public funds, in the University area between 1918 and 1933 was considerable, however. Two new buildings, the Armory and chemistry building, were ready for the opening of the fall term in 1919. The former, begun with the aid of a federal grant of $\$ 11,000$, had been intended for an SATC drill hall, but the war ended before it was completed. Unfloored, and practically unusable as it stood, it was fitted up as a men's gymnasium, a makeshift auditorium, and the home of the ROTC, following an additional state appropriation of $\$ 35,000$. The old gymnasium was converted for women's physical education, hitherto housed in the basement of Woodworth Hall. The new four-story chemistry building, the one major construction project allowed in McVey's eight years, cost about $\$ 125,000$ including furnishings. Placed directly east of Woodworth Hall, it was the first in the new enlarged quadrangle plan developed by Morrell and Nichols of Minneapolis, architects for the Board of Administration. The outline of this plan took definite shape when the new law and commerce building, for which $\$ 150,000$ was appropriated in 1921-largely owing to Willis and Towne's friendliness to the NPL-was placed directly north of chemistry. Dedicated on Founders' Day, 1924, the new structure provided not only the first permanent campus home for the law school and its eleven-thousandvolume library, but also permanent quarters for the new College of Commerce and temporary shelter for the departments of art, sociology, and geology. Although the chemistry building had a flat roof, both new buildings were in the stone-trimmed red brick style introduced by McVey. The stadium was completed in 1927; 
it was placed on a sixty-acre tract acquired by the memorial corporation immediately east of the campus. Part of this tract was used for a small University golf course for some years.

The last Kane building, the new Merrifield Hall to house the College of Liberal Arts, was dedicated on Founders' Day, 1930. By a considerable margin the largest building on the campus-four stories high and three hundred feet long-it was also the first to be entirely fireproof and the first with some concessions to elegance and comforts beyond the bare necessities. The architect was Joseph Bell DeRemer, whose first campus building was Budge Hall, completed in 1899. The need for the liberal arts building had become acute in 1924 upon the discovery that the old Merrifield Hall, housing both offices and classrooms, was settling so rapidly on its weak foundations that it was in imminent danger of collapse. It was necessary to remove the upper floors immediately and to erect a one-story barrack, quickly dubbed the "cow-barn," on the mall for temporary classrooms. Despite the desperate need, however, the economy-minded legislature of 1925 refused to vote any money for a new building. An appropriation of $\$ 225,000$ was approved in 1927 , with the intention of providing a building that would be usable but not entirely finished. The Board of Administration, largely on the initiative of its chairman, Robert Murphy, proceeded to let contracts to start a building costing about $\$ 350,000$ when completed, on the chance that the 1929 legislature would provide the additional funds. Not a few of the legislators in the 1929 session considered this a pressure tactic, and although an appropriation of $\$ 161,000$ was finally approved, it was not done without considerable criticism of the University.

With the exception of the funds allotted for the enlargement of the heating and power plant, the only other building allowance worth noting was the $\$ 38,000$, likewise appropriated in 1927 , to interchange the Commons and the Carnegie Library. The latter had been clearly inadequate almost from the day it opened (1908), and by 1928 a change was imperative; general library holdings of cataloged books (exclusive of the law and medical libraries which were housed separately) exceeded sixty thousand, considerably beyond the library's capacity, and enrollment was a half dozen times what it had been in 1908. The move was complete in time for the opening of the fall term of 1928. Although the new library would always be something of a makeshift, it did however enlarge facilities for storage and service enough to permit the University to "get by" for another generation. But the students had lost their only gathering place on the campus, and gracious dining with white-coated waiters at white-clothed tables had disappeared forever in favor of the bare utilitarianism of the noisy cafeteria and the waiting lines at the converted Carnegie building.

No funds at all were appropriated for student housing. In 1923-1924 when 1,448 were enrolled, Kane reported that 379 students were living in unsupervised housing off the campus and that parents of another hundred felt it necessary to move to Grand Forks in order to provide suitable living conditions for their children. Another three hundred local students lived at home. The University itself housed a bare two hundred in its three small dormitories, all of which were entirely unfireproof, old-fashioned, and none too comfortable. Kane repeatedly called attention to the need for dormitories, and he took the lead in urging a scheme for borrowing money on the security of rental revenues. $\mathrm{He}$ appeared to have won his point when the 1927 legislature enacted the SchlosserHamilton Bill authorizing the incorporation of nonprofit industrial holding associations for building dormitories on state college grounds. Frankly intended to bypass the prohibition against institutions' borrowing money, these associations were empowered to bond themselves for construction costs; the completed buildings were to be leased to the colleges until the bonds had been retired from the collection of rents, after which ownership was to be transferred to the college. The act was set aside by the state supreme court in 1928, but a similar self-liquidation bill, passed in 1929, was upheld in 1930. The moment had passed, however, for the depression closed in before any of the corporations could be set up at the University.

Had it not been for the extensive building of the fraternities and sororities, enough to house nearly five hundred students, and the private residential construction in the Wesley College area, the University might have been seriously handicapped by a shortage 
of housing. As it was the sorority houses so relieved the pressure for women's housing that Macnie Hall was turned over to men students in 1925. The refurbishing of the trolley line, the paving of the last section of University Avenue (1921), and the increasing use of the automobile also relieved the situation by making downtown rooming houses more accessible. The Alumni Memorial Corporation's stadium was a handsome addition to the campus, on a far more generous scale than the legislature would ever have provided. The completion in 1929 of Robertson Hall (classrooms), the fourth and last building at Wesley College, rounded out the architectural scene, if it did not directly benefit the University.

The general impression of great improvement was enhanced by the adoption of the new campus plan, the first on a truly generous scale, and by the first professional touch in campus care that came with the employment in 1921 of Charles L. Ellis, an architectural engineering graduate of the University of Illinois, as superintendent of buildings and grounds. In his nine years at North Dakota Ellis did much to lay out and plant the grounds in their present form and to set a high standard of general care. Owing as much to the long campaign of Professor Charles Christian Schmidt, principal of the Model High School, as to Ellis, evergreens were introduced to the grounds in quantity; many of those set out had been grown by Schmidt himself in his campus nursery. Orderly planting of permanent trees, mostly elms, was begun to replace the cottonwoods and box elders set out more or less indiscriminately by faculty and students of the early days. Ellis might have been well advised to consider the historical and sentimental significance of the groves of Sprague and Merrifield, and had he not been from Illinois he might have appreciated the beauty of the noble cottonwood and its appropriateness to a western campus. In any event, the replacement has continued and practically all of the old plantings are gone.

It was in the faculty, the curriculum, and the conception of the University's service and relation to the state that the true spirit of ${ }^{11}$ This hall for the School of Religion and the department of expression was named cost for building and furnishing, $\$ 46,000$, was donated by John Hancock, a University alumnus. the Kane administration was revealed-the points of advance and stagnation, the problems and frustrations, and the institutional ideal or direction. When McVey resigned in 1917 the faculty proper numbered a few over seventy; by 1930 it had doubled, with sixteen graduate assistants in addition. Administrative and service personnel had also expanded considerably: four professional librarians, a staff of four in the extension division, a dean of men, a dean of freshmen and junior division, a director of the graduate division, a full-time presidential assistant or secretary, and a business man ager. (The latter post, a refinement of the position of the secretary of the University, was held by James Wilkerson; on the staff since 1903, Wilkerson continued in this capacity until his death in 1948.) Old Merrifield Hall, robbed of its name as well as of its upper floors, was taken over completely by administration and services: the offices of the president, business manager, registrar, extension division, stenographic bureau, the post office, and the bookstore.

The gratifying expansion was unfortunately accompanied by an abnormally high rate of faculty turnover. Between 1920 and 1924 there were no less than 76 resignations to match 115 new appointments. In the biennium of 1924-1926 the five-man faculty of law lost five men, four of them to accept better positions in the universities of Southern California, Kansas, Nebraska, and North Carolina. The dean of the new School of Commerce reported in 1930 a complete faculty turnover since 1927, largely, he said, as a result of low salaries. That same year the president reported an average of thirty or more resignations per year from 1921 to 1929. The postwar restlessness which afflicted young professors particularly in those days of rapid college expansion was undoubtedly a major reason for the difficulty-that and the low salary schedule of which the president complained year after year in his official reports. A University pamphlet, Facts on Salaries, published in 1921, showed North Dakota's maximum salary, $\$ 3,500$ for a full professor, to be the lowest among fifty-two colleges of varying sizes and classifications; Pennsylvania's $\$ 8,500$ maximum for professors topped the list, and the $\$ 4,500$ maximum of Minnesota was near the median figure. In his report of 1930 to the Board of Administration Kane asserted that a United States Office of Education study of salaries 
of "the other forty-eight state institutions" in 1926-1927 showed North Dakota ranking thirty-eighth. The faculty and president painted the picture somewhat darker than it was at the moment. The really significant point was that North Dakota salaries were falling behind the rate of increase elsewhere in the 1920's. ${ }^{12}$

The state's abnormally slow recovery from the postwar economic slump and the general leveling off of the second Dakota boom bred an atmosphere of uncertainty and pessimism that had not been known in the state since the dark days of the 1890's. The lack of an adequate retirement program was likewise a handicap. On the eve of the depresssion all that a superannuated professor at North Dakota had to look forward to was a very small annuity under the state teachers retirement fund system to which college faculties had been admitted in 1919. If he served twenty-five years he might be designated emeritus by the Dean's Advisory Committec and the president, and if he died in harness after long service his widow might receive a half year's pay (on Kane's request the Board voted such allowances to the widows of Babcock, Squires, and Leonard).

But probably the chief cause of the turnover was the uneasy relation between the president and his faculty. Merrifield and McVey had each surmounted a full measure of financial difficulties to develop a permanent faculty core of considerable merit, chiefly because they had achieved a high state of faculty and student morale. Under Kane, many factors contributed to the creation of an unhappy atmsophere-the stiffness, even protocol, in the president's conduct of his office, and at the same time his tendency to reduce official relationships to terms of his own personal likes and dislikes, even to subjects for gossip by himself ${ }^{13}$ and his wife, his playing of favorites, his suspicion of and aversion to the intellectual 12

North Dakota, 1917-18 Average large state universitie state universities \begin{tabular}{rccccc}
\multicolumn{1}{c}{$\begin{array}{c}\text { Associate } \\
\text { Deans }\end{array}$} & $\begin{array}{c}\text { Assistant } \\
\text { Professors }\end{array}$ & $\begin{array}{c}\text { Professors } \\
\text { Professors }\end{array}$ & Instructors \\
$\$ 3,300$ & $\$ 2,600$ & $\$ 2,100$ & $\$ 2,000$ & $\$ 1,350$ \\
& 2,677 & 2,012 & 1,714 & 1,114 \\
4,800 & 3,600 & 3,000 & 2,500 & 1,950 \\
& 4,407 & 3,345 & 2,775 & 1,995
\end{tabular} ${ }^{13}$ Kane's official correspondence contains frequent slanderous insinuations about the character of people who at one time or another crossed him. More often than no
his comments are entirely irrelevant to the matter at hand. leaders and independent-minded men on the faculty, and his apparently deliberate encouragement of factionalism. Newcomers quickly discovered that not a few of the most respected members of the faculty, among them Babcock, Bek, Gillette, Kennedy, Libby, and Ezra T. Towne, dean of the new School of Commerce, were deeply distrustful of the president's integrity and respected only his ability to hang onto a job they thought him totally unfitted for.

Promising young scholars, particularly the more independentminded, all too frequently looked elsewhere for their rewards in promotion and salary increases. As Squires once observed, the University of North Dakota was a training and testing ground for other institutions' faculties. Replacements were always available, to be sure, but all except a few departments failed to develop the faculty cohesion and the long-term research and publication programs essential to a ripe scholarly tradition and to the reputation which would attract other scholars to the campus, or develop the regional specializations necessary for a small university if it expects to win fame and attract graduate students of high caliber.

The faculty problem was accentuated by the fact that the University was losing some of its ablest veterans, men who not only gave continuity to their departments but who also contributed much to the University's standing. The news of the mysterious death at Niagara Falls of John Adams Taylor, on the English faculty since 1910, shocked the campus on the eve of the opening of the fall term of 1924. Although his reputation was a local one, Taylor had been a cultured and skillful teacher. Almost exactly a year later Babcock, a veteran of thirty-six years, died of a heart attack while swimming at his summer home on Lake Bemidji. The December issue of the Quarterly Journal was devoted to memorializing the "dean of lignite," who had surmounted the handicap of a rather meager formal training to win a solid reputation as an applied scientist, and who had devoted a lifetime to the welfare and development of his adopted state. The mines building was named in his honor in November. The work in lignite research suffered a second blow the following spring in the death of George Wharen; for a half dozen years he had supplemented 
Babcock's briquetting experiments with similar work on the use of pulverized fuel.

In August, 1930, the death of Squires, on the campus since 1897 and dean of the College of Liberal Arts since 1914, removed one of the University's strongest exponents of old-fashioned standards of public decorum and moral integrity and one of its most vigorous guardians of academic standards in the classroom for both faculty and students. A sentimental man, and a deeply religious one, whose feelings and tears were never far from the surface, he was a campus personality whose teaching was much admired by the very students who poked fun at his lectures on the history of the University as an "annual bawl." He was hotheaded and explosive, and his relations with the faculty were not always easy, but his willingness to "spend half his life apologizing" softened many an offended colleague. In a very real sense the new Merrifield Hall was Squires's memorial on the campus, for he had worked tirelessly to get the appropriation for the building and equally hard at planning it and preparing it for occupancy. Desperately ill during the last stages of its construction, he died only six months after it was dedicated. One of the most fitting tributes anyone associated with the University has ever received was the University funeral for Squires: laid in state in his building, with final services in the Armory.

Roger Cooley, the most productive scholar the law school had ever had, died in the fall of 1931; he had returned to the University in 1923 after an absence of five years in government service. Arthur G. Leonard, head of the department of geology and state geologist since 1903, died in the late fall of 1932. Soundly trained and devoted to his work and to the public interest, an active student with more than fifty articles and long reports to his credit, he had done much to outline the geological map of North Dakota. Kennedy's retirement from the office of dean of the School of Education in 1928 removed from active affairs another veteran who was widely known in the state and loved and respected on the campus. Indestructible as the ancient bicycle that he rode between his home and office until he was nearing seventy, he continued to teach, however, until his death in 1937. Tingelstad, the only man anyone could remember as professor of Scandinavian languages, retired in 1929.
These men had all meant much to the University; not all were replaced with men of equal caliber. Moreover, some of the rest of the surviving veterans upon whom the University had leaned for years were past their peak by the end of the 1920's. Gillette's presidential address at the American Sociological Society in 1928 was in a sense a valedictory. His significant contributions were behind him, although he was still remarkably vigorous for his years, active as a writer and teacher, and able at sixty-six to devote a summer to hacking out a woods road at his Minnesota summer cottage. The resignation of George R. Davies in 1928 to join the faculty of the University of Iowa removed Gillette's right bower and anointed successor; it was a blow from which the widely known little sociology department never fully recovered. Libby, as ageless as Gillette, was nevertheless slipping in professional prestige as well as in influence in the University. And Gottfried Hult, whose very name had personified the classics to a generation of students, retreated into semiretirement in his office by the end of the 1920's to commune with his poetry writing and his translations of Ibsen.

But the passing of the grand old men is an ever present phenomenon of a university, and it is not always a total disaster, for old men, whatever their past accomplishments, can and very often do stand in the way of change and growth. Not all of those who passed out of the picture were adequately replaced, but in not a few instances the new man had virtues of his own that the older one had lacked, or he represented an advance in the conception of the chair or administrative office to which he succeeded. Squires's successor, William G. Bek, who was chosen by the Board without the approval of the president, brought to his office warmth and breadth of view and a lively respect for faculty research and writing; he eventually left his own tradition of a sharp-eyed yet kindly adviser of students and an exemplar of industry and forthrightness for the faculty. Elwyn Chandler was a worthy successor to Babcock as dean of the College of Engineering, painstakingly conscientious, much respected, and hardly less a veteran than Babcock himself. Alfred W. Gauger, who succeeded to Babcock's experimental work under the new title of director of the Division of Mines and Mining Experiments, was a finely trained engineer-scientist (Ph.D., 
Princeton). Flanked by Irvin Lavine (Ph.D., Minnesota), a native of Russia, Gauger raised the lignite studies from the level of immediate practical utilization at which Babcock had worked to the more fundamental considerations of basic properties and composition. His departure after five years for a professorship at Pennsylvania State College was a major blow to the University's one unique research program and its chief claim to attention beyond the borders of the state. Richard Beck, who succeeded Tingelstad, was the first actively publishing scholar to occupy the chair of Scandinavian languages. An Icelandic publisher brought out his first book in 1932, an edited volume of Icelandic lyrics. Beck was to prove equally energetic in his unofficial capacity of University ambassador to the Scandinavian community. Kennedy's successor, Joseph V. Breitwieser, a former associate professor of psychology at the University of California, was the chief architect of the modern School of Education emphasizing professional courses and graduate study for administrators; he also, more than anyone else, shared with Kane the responsibility for the expansion of the graduate division that began in the late 1920's. The appointment of George Wheeler in 1926 to replace Robert Young continued the department of biology in the sound tradition of Young and his predecessors, Brannon and Patten. Formerly assistant professor at Syracuse University, Wheeler won a solid professional reputation as an authority in myrmecology and local respect as a champion of faculty rights.

Nor were these appointments untypical of the Kane administration; whatever may be said of low faculty morale and the president's contribution to it, a policy of matching or surpassing salaries elsewhere by offering a notch higher in rank attracted at least temporarily a number of young or semimature scholars who would make academic reputations, and even a few who were established. Most moved on, but there were some who stayed. The first dean of the School of Commerce, which he organized in 1924, was Ezra Thayer Towne. Appointed by McVey shortly before he left, Towne came from a professorship of economics at Carleton where he had taught ten years. Trained at the University of Halle under the eminent German economist William Rocher, he had published The Organic Theory of Society in 1903 and a high school economics text in 1916. Clarence Perkins left an associate professorship at Ohio State University in 1920 to become head of the newly formed department of European history. A specialist in English history, and the University's first fully trained scholar in any European field, the kindly Perkins had a wide acquaintance in his profession and was frequently invited to teach at the summer sessions of other universities. He visited Europe regularly; his articles appeared in the leading American and English history journals; and his half dozen high school and college textbooks and study guides made him one of the few members of the faculty who enjoyed a regular income from royalties. When Libby retired in 1945 Perkins became head of the recombined departments of history.

A number of others came and stayed, leaving a permanent imprint from this era-the years from 1925 to 1930 are particularly important in this respect: Henry Humpstone and Charles W. Telford, psychology; John Hundley, head of the department of physics from 1929; Felix J. Vondracek, who succeeded Perkins as head of the department of history; Wilson Cape, Gillette's successor as director of social work and head of the department of sociology; Paul Barr, head of the department of art from 1929; George A. Talbert, pharmacology and physiology; Henry Haxo, Brush's successor as head of the department of Romance languages; Raymond Staley, who followed Hitchcock as head of the department of mathematics; Alexis J. Diakoff, mechanical engineering; David Jenkins, electrical engineering; Walter H. Moran, chemistry; Adolph M. Rovelstad, Hult's successor as head of the department of classical languages; Emanuel D. Schonberger, director of dramatics Hywel Rowland and John Howard, directors of glee club and band; and Olaf Thormodsgard, who became dean of the law school in 1933. Alumni who began long careers at the University in the 1920's were Margaret Beede, English; Ernest Coon, chemistry; Robert B. Witmer, professor of physics and Bek's successor as dean of the College of Science, Literature, and the Arts; and Arthur K. Saiki, bacteriology and pathology.

The list of distinguished men who came and went was considerable; some stayed only long enough to leave a name in a cata$\log$, others left behind the title of a book, or some other bit of 
reputation that the University could share. This role includes Albert Hyma, whose Christian Renaissance won him a post at the University of Michigan after two years at North Dakota; Thomas Atkinson, an active legal scholar, who moved on to the University of Missouri; George R. Geiger, whose Philosophy of Henry George, widely acclaimed by scholars, appeared the same year (1932) he was dismissed as an economy measure; Jacob Perlman, a sociologist of great promise, who left in 1933 to carve out a distinguished career in government service; Karl Fussler, physics, who left for a professorship at the University of North Carolina; and Fowler V. Harper, who founded the Dakota Law Review in 1927, and whose distinguished legal scholarship eventually won him a place on the law faculty at Yale. Others were Lawrence W. Murphy, first head of the department of journalism, who moved on to the University of Illinois after receiving the M.A. degree at North Dakota; Jesse Bond, business administration, who returned to his alma mater, the University of Oregon; Orville Cockerill, dean of the law school from 1924 to 1927, who left to accept an appointment at the University of Southern California; and Earl K. Smiley, the dean of men, who returned to Lehigh University, his alma mater, when his office at North Dakota was abolished in 1932. The two head librarians appointed by Kane, Alfred D. Keator (1918-1928) and William H. Carlson (1929-1935), launched distinguished careers at North Dakota. The registrar from 1923 to 1927, Ernest Miller, left for a similar position at Tulane and eventually moved on to the University of Chicago.

The president played a leading role in recruiting the faculty and in promoting them or increasing their salaries. This is not to say that he ignored the advice of deans or department heads as a general policy. Although no standards were firmly fixed-at least none were ever published-Kane went farther than McVey to work out, in consultation with deans and department heads, some firm standards of training and scholarly achievements for each professorial rank. It was on his suggestion that the colleges set up promotion committees in 1925.

Yet he not infrequently overrode his colleagues entirely or ignored them, and not always with good reason. His judgment, though sound for the most part, could be erratic, not to say capricious and entirely subjective. The case of Robert Forsythe, appointed associate professor of English in 1927, illustrates the virtues of the president as well as his weaknesses. Kane played the major role in persuading Forsythe to give up an assistant professorship at Northwestern for a post at North Dakota. Forsythe lived up to every expectation-or so it seemed. His study of A Noble Rakethe Life of Charles, Fourth Lord Mohun, published by Harvard University Press in 1929, was the English department's first major publication in a half century. His edition of Melville's Pierre was published by Knopf the following year; it was one of a series on American literature under the general editorship of Bernard DeVoto. In 1931 Forsythe was invited to lecture in the summer session at Harvard. DeVoto added to his local prestige by dedicating his own Mark Twain's America to him, and he was much sought after by serious undergraduates, particularly those with ambitions to write. When in 1930 Squires's death left the headship of the English department vacant, Dean Bek immediately recommended Forsythe for it. But the president, who had somehow conceived a cordial dislike for him, not only refused but without any further consultation with Bek proceeded to appoint James Cox, a professor at Drury College, Missouri. Although the official news releases about Cox were highly complimentary, it was soon discovered that he had no scholarly record beyond a Ph.D. degree and that he was temperamentally unfitted for a position of leadership. Moreover, the campus gossips were soon repeating a story, said to come from Cox himself, that Kane expected him to "run" Forsythe and Henry Doak, a veteran of nearly twenty years and a highly respected teacher, "out of the department." The friction aroused can well be imagined. When some reductions in the faculty were necessary in 1932, the president included Forsythe and Doak on the list of seventeen who were to go. Although Bek managed to save them, Forsythe resigned in 1933 to take a position with the Newberry Library in Chicago.

The important consideration, of course, is how such situations affected the quality of the University, and that is not an easy matter to assess. In total amount the faculty output in books 
and articles was well below the level of McVey's day; the considerably larger Kane faculty averaged about a book a year while McVey's had produced at the rate of about two and a half per year. It is of some interest to note too that a dozen of the books credited to the Kane administration were the products of the old faculty hands appointed by his predecessors..$^{14}$ Gillette's steady output, Libby's reviews and active editorial work as secretary of the state historical society, and the fact that the most significant articles on the subject of lignite and such other North Dakota natural resources as oil and gravel came from the pens of Leonard and Babcock, all were further tribute to the debt the University of the 1920's owed to the solid foundations laid by Kane's predecessors. The falling off in publication activity was undoubtedly related to campus morale, although the higher standard of professional journals and commercial publishers, which was marked after the war, had something to do with the decline. Administration policy appears to have been encouraging, if not particularly inspiring. The president himself set no such example as McVey, but he nevertheless reviewed books regularly for the Quarterly Journal and in 1923 accepted the invitation to give one of the exchange lectures at the University of Manitoba. The Quarterly Journal continued to provide a stimulus to publication and, as long as it was edited by Towne (from 1923 to 1930), to set a standard that was respectable, if not brilliant. Two new publications, the Dakota Law Review and the North Dakota Engineer, particularly the former, offered additional local opportunities for the faculty to publish. Allowances for travel to professional meetings and for sabbatical leaves were made in the biennial appropriations. Both were increased substan${ }^{14}$ In addition to those by Beck, Forsythe, Geiger, and Hyma, the most important faculty the Law of Insurance (1919) and his money two-volume Supplement to Briefs on Briefs on the Law of Insurance; Charles C. Schmidt's Natr-volume second edition of (1920) and Teaching and Learning the Common Branches (1929); Gilletre's Rural Sociology (1922), which was translated into several European languages and Rural ese; The Lignite Deposits of North Dakota, a long report by Leonard, Babcock, and (1923) Dove that was published by the United States Department of the Interior Gynt (1933); Libby's Arikara Narrative of the (1920), and his translation of Peer kotas, June 1876 (1920); Bek's translation of Gottfried Duden's "Report" Hostile DaBallads and Songs of the Shanty Boy (1926). Problems (1933); and Franz Rickaby's. tially in 1927 ; that year $\$ 4,000$ was budgeted for sabbaticals, and in 1928 no fewer than eight leaves were granted, for at least a semester and at half pay.

The University curriculum, in the meantime, was rounded out and brought to a level of maturity it had never before attained. The medical and law schools each added another faculty member; the engineering faculty grew from thirteen in 1917 to twenty in 1931. Admissions to the medical school, which grew steadily, had to be limited to about thirty annually; graduating engineering classes climbed from about a dozen to thirty in number. Equally indicative of the expansion and thoroughness of the offering was the growth in budgets; that of the engineering college, for example, rose from $\$ 25,000$ annually to $\$ 60,000$ and the medical school's from $\$ 6,000$ to $\$ 22,500$. For almost the first time a number of departments became large enough to permit specialization in teaching. The department of chemistry, for example, which had first achieved separate departmental status in 1910, grew from a regular faculty of four to six and four assistants, the department of history from Libby and an instructor or two to two full departments of three men each. A number of new departments also appeared, threechemical, architectural, and ceramic engineering-in the College of Engineering alone. The departments of public speaking and journalism separated from the department of English, and geography was growing out of geology. The School of Education completed the process of its separation from the College of Liberal Arts. One new professional school, commerce, was added, made up largely of departments drawn from the liberal arts college. And a graduate division under its own director was created to crown the academic structure. The ROTC department was added in 1919.

The movement toward a School of Commerce had commenced with Towne's appointment to head a new business course in 1917. The course had a faculty of six and more than two hundred students enrolled by 1924 when it was elevated to the status of a school and Towne made dean. Although the curriculum was worked out only after long examination of similar schools elsewhere, the fact that the dean, who was to remain until his retirement in 1948, was an economist and not commercially minded 
delayed the movement in the direction of practical business training that the name indicated. The department of economics, continuing in the tradition of James Boyle, its founder, has remained one of the school's strongest and most fully developed departments.

The change in status of the School of Education, in existence since 1911 as a kind of twin of the College of Liberal Arts, was occasioned by the growing demand for professionally trained superintendents and principals and for teachers whose major and minor subjects were tailored to the public school curriculum instead of to the requirements of the B.A. degree, and by the education faculty's desire for autonomy and professional school status in the University hierarchy. The trend toward professionalization, that is to say, increased emphasis upon special advanced courses for administrators, was hastened by the pressure from the newly formed state teachers colleges. Because of the drive for economy after the war and Kane's willingness to use almost any excuse to get rid of Ladd, the University dropped its two-year program for an elementary teacher's certificate in 1923 , its major source of enrollment. ${ }^{15}$ The school continued to offer a major in elementary education until 1932, when it had to be dropped, ostensibly as an economy measure but mainly to please the teachers colleges.

In the spring of 1919 the Board of Administration approved a University "reorganization" whereby certain departments were firmly placed under the jurisdiction of the School of Educationart and design, music, commercial subjects, home economics, mantial arts, physical education for women, psychology, education, and school administration. This was the structure already in existence, including such anomalies as the separation of the departments of men's and women's physical education under two colleges-for no better reason than that women's physical education had occupied the basement of Woodworth Hall for a half dozen years. The possibility of gathering fine arts together into a single autonomous division was not mentioned. In 1924, however, Ernest Wilcox, Norton's successor as head of the music department, recommended in his biennial report that such a division be organized immediately. ${ }^{15}$ In 1923 thirty-four seniors graduated with the B.A. with Certificate in Teaching degree, and 152 with the two-year certificate.
The failure to do so and what was more important, the continued subordination of the art courses to the purposes of various schools, was to hinder seriously the work in fine arts for many years.

The problem of the music department was made the more difficult because of a divided jurisdiction in the field between the University and Wesley College. In the original affiliation agreement of 1905 only courses in religion, up to a maximum of thirty-two credits, were to be transferable to the University. However, Wesley developed its conservatory and added a department of expression. The University, having neither money nor space for such facilities during the days of Merrifield and McVey, gradually fell into the practice of accepting a few credits in applied music or expression from Wesley College and more or less informally agreed not to compete with the Wesley conservatory in the area of applied music. After Stout, whose salary had been shared by the University and Wesley College, resigned in 1910, the University undertook the full responsibility for all of its ensemble groups and for the teaching of such courses as theory and the history of music. The University music department began to grow rapidly in the early 1920 's, expanding from one full-time professor and a student assistant in 1918, when Norton resigned, to a faculty of four by 1923 . With the tacit support of the president and the enthusiastic encouragement of Joseph V. Breitwieser, appointed dean of the School of Education in 1928, Wilcox and his successors, Hywel Rowland and John Howard, set out to divorce themselves entirely from dependence on the Wesley conservatory by establishing an applied music program of their own. Because his college depended heavily upon music fees, President Robertson of Wesley carried the issue to the Board, and in 1930 he won a formal agreement, approved by the Board and signed by both himself and Kane, which gave to Wesley control of the work in applied music. It should be added as epilogue that although Kane's successor, John C. West, undertook to respect this agreement, the process of University expansion had gone too far to be reversed, particularly when Wesley College, which never fully recovered from the effects of the depression, proved unable after the Second World War to live up to its responsibilities to the 
University. The final result was that in 1953 Wesley abandoned the field of music entirely.

The separation of the School of Education and the College of Liberal Arts became formal in 1924. In practice this meant that as a two-year professional school, education was empowered to confer the B.S. in Education degree, which differed mainly from the old B.A. with Certificate in Teaching in the waiving of the requirement for any foreign language courses and a watering down of the requirement in science. Kennedy's more or less forced retirement as dean in 1928 was the final step in the professionalization of the school. Breitwieser was not only younger and more vigorous but was also an exponent of the newer education trends. Within a few months of his appointment, he persuaded the University Council to permit the School of Education, in consultation with the academic departments concerned, which were, however, no longer counted as members of the education faculty, to organize its own majors in the academic teaching fields. The opportunity for a less circumscribed curriculum, the growing demand for teachers of industrial arts and girls' physical education (required in the high schools after 1920), and rising state requirements for professional training, that is, courses in education, all contributed to the school's rapid growth in importance as a degree granting division of the University.

Directly related to the development of the School of Education was the expansion of the summer session and the graduate department; the latter became a division in 1927, with its own director and a small budget. This was one of the proudest achievements of the Kane administration, the one most frequently extolled, next to growth of enrollment and faculty, as evidence of the University's progress in the 1920's. Although McVey had anticipated the need for a graduate department, being particularly conscious of the healthy effect of a graduate program and the presence of graduate students upon the faculty and the undergraduates, growth had been slow before the war. Indeed, only seventy graduate degrees of any sort, only one of them a Ph.D., were awarded between 1895, when Harrison Bronson took the first M.A., and the end of the regular session of 1921-1922. Organization had not progressed beyond the faculty committee to supervise graduate study.

Kane was eager to expand this part of the University program and despite an indignant faculty's frustration of his unconstitutional effort to establish a graduate school in 1923 he persisted in his efforts. It was in the natural course of the University's development, both in the direction of emphasis upon professional training and in the fashion of the time, that the degrees of master of science in commerce, master of science in education, and master of science in engineering should be added in 1926. Largely on the president's initiative, a graduate division was created in 1927. One of the inducements which brought Breitwieser from the University of California was the creation of this division and his appointment as its first director, in addition to the other posts he was to occupy. In December the broad regulations for the Ph.D. and the Ed.D. degrees were adopted by the Council. This meant that the old policy whereby any candidate for the doctorate could be admitted by vote of the Council (only Davies ever was) was relaxed to permit the admission of candidates on the unanimous consent of the director and an advisory committee created to consider the merits of each applicant and the University's resources for training him. In theory every department offering any graduate courses could, at the discretion of the director and advisory committee, accept candidates for the doctorate. In actual practice the offering was limited almost altogether to education, sociology, and in a tentative sort of a way, history.

Within the next two years a half dozen applicants were admitted to candidacy, and the first of the new series, a Ph.D., was conferred on J. Frederick Weltzin in 1929. John C. West, superintendent of the Grand Forks schools and destined to be Kane's successor, received the first Ed.D. in June, 1930. His dissertation, written under the direction of Kennedy, was entitled An Analysis of Senior High School Sociology. Another Ed.D. was conferred in the summer; three graduated with the Ph.D. in 1931 and one in 1932. In the spring of 1930, following the appointment of committee demanded by the University Council to study "cardinal principles" in use elsewhere, the University adopted the customary 
regulations for the doctorate: residence and foreign language requirements, preliminary and final examination, the approval of a major and minor program, and the like. The Council also undertook to define more closely than it had the graduate director's responsibility to itself.

The fact that sixteen of the thirty-nine graduate degrees of 1932 were conferred at the summer commencement indicates the growth and development of the summer session and its relation to the expansion of the graduate division. No advanced degrees had been conferred at the first summer commencement held twelve years before. ${ }^{16}$ Total enrollment of the summer session, that is, on the collegiate level or above (the elementary section was not discontinued until 1927), rose from 95 in 1918 to 697 in 1932, the faculty from 17 to 50 , and the budget from $\$ 2,000$ annually to $\$ 19,000$.

The official pride in the increase in graduate and summer enrollment was understandable and a good part of it justified. Yet several aspects of the expansion were somewhat less gratifying than was publicly admitted. Despite Breitwieser's efforts to give the summer school a more than local appeal by exploiting the superb summer climate of Grand Forks and its proximity to the lake country of Minnesota, his hopes were never realized because his small budget prevented his obtaining the distinguished visiting faculty he needed to make the school widely known and attractive to outsiders. Indeed, one may well question the wisdom of the University's decision to offer a doctorate in any department or branch in view of the limitations of the faculty, the curriculum, and the library and laboratory resources. In 1930 there were fewer than 75,000 books in the library, including the 14,000-volume law collection; about 1700 books were purchased that year. The periodical and document collections had deficiencies that were only too obvious. No money at all was appropriated for research, with the exception of $\$ 5,000$ annually for lignite testing and another $\$ 2,000$ for ceramics. Both of these fell more properly in the category of public service than scientific investigation. Otherwise, research funds ${ }^{10}$ In 1957 eighty-one advanced degrees were conferred at the summer commencement,
fifty-five of them in education. had to come from the departments' already tight maintenance budgets, made all the tighter after the war by the stricter supervision of institutions' finances by the Board of Administration and a new state budget board. Teaching loads were high, ranging from sixteen class hours per week for instructors to twelve for deans. The graduate division assumed no responsibility for encouraging research or finding time or funds for it. Moreover, although a great many departments had doubled in size after 1917, only a very few could boast a distinguished professor, and none had the depth in men and curriculum essential for sound graduate training. In its report, published in 1934, on the quality of the various universitie and departments offering the doctorate, the Committee on Graduate Instruction of the American Council on Education failed to list a single department of the University of North Dakota as adequate in faculty or equipment-in fact the University was not mentioned at all.

Although the University appears to have moved forward at some sacrifice of standards in order to get the graduate program under way, or simply to expand, there was being waged at the same time a constant battle to hold up academic standards or to raise them. North Dakota generally conformed to the pattern of the time in other state universities in these matters and insofar as was necessary to meet the accreditation requirements of various agencies. Such were the rules that students maintain an average of "C" in order to qualify for a degree (revived after the war), that they take a minimum number of courses on the senior division level (the College of Liberal Arts was divided into junior and senior divisions, each with its own dean, in 1929), and that they pass a minimum number of courses or be suspended from the University. Various devices, all entailing considerable bookkeeping, were tried to ensure class attendance. The custom of mass examinations in the Armory, a source of much annoyance to new faculty twenty years later, was begun in 1929 in order to curb cheating. Bek attempted, unsuccessfully, to launch a system of comprehensive examinations for graduating seniors shortly after he became dean; the custom of excusing them from finals entirely, ended in McVey's time, had been resumed after the war. Positive inducements to 
better academic effort included a revival of reading for honors and the establishment of honors sections in freshman English. Although McVey's University fellowships were abolished after the war, graduate assistants, usually appointed from the ranks of the senior class, were used more and more after 1925 . They were supplemented by a series of exchange scholarships with the University of Buenos Aires, arranged in the early twenties by Brush for Romance language students, and the annual Rhodes Scholarship competition. A dozen or more new honorary or professional societies, including Sigma Tau, Sigma Xi, Phi Delta Kappa, and Order of the Coif, added their bit to honor the industrious.

Requirements of the professional schools, particularly law and medicine, were also steadily raised. Although technically continuing to require only two years of college for entrance, the medical school was practically requiring three or more owing to the limitation of thirty placed on the number allowed to enroll each year. In the law school the two years of college entrance requirement, scheduled for 1917 but delayed because of the war and Dean Willis' quarrel with the president, was gradually imposed. The engineering college raised its own professional standards, although hardly its cultural level, by inserting so many technical courses into its four-year program that it was divorced almost entirely from the College of Liberal Arts. The five-year engineering curriculum disappeared. Whatever may be said about the overemphasis upon professional training-the proportion of liberal arts graduates was declining-the policy was an officially approved one. All of the major accrediting agencies and all of the major honorary societies as well put their stamp of approval upon the quality of the University.

Notwithstanding these evidences of acceptable academic standards, it is difficult not to sense that beneath them the University as a whole had slowed its intellectual pace. For the high value set on character and culture by Merrifield and for the emphasis placed upon scholarship on the campus and leadership and service to the state by McVey there had been substituted a complacent pride in the mere increase in enrollment and buildings, the acceptance of publicity and athletic prowess as major achievements in themselves, and the equating of a college education with a high potential income. The decline of faculty publication has been mentioned, and by the late twenties the Student, itself no model of serious-mindedness, remarked more than once upon the low level of performance expected of the undergraduates. With the exception of the new reputation of the Sioux athletic teams and the expansion of graduate training, mostly for school administrators, the University was in a sense living off the reserves accumulated before 1917 in academic reputation, faculty loyalty, and public gratitude for services to the state. All of which was to mean that the impact of the depression would be doubly painful, in fact nearly disastrous.

The various public services provided by the University present a mixed picture of development-a few advancing modestly, several standing at dead center, and others slipping backward. The public health work continued with the three substations that existed in 1917 at Minot, Fargo, and Bismarck, with the expansion of service that could be expected from an annual budget increased from the $\$ 12,000$ per year of 1917 to $\$ 21,000$ in 1929 . The biology substation at Devils Lake was lost to the State Game and Fish Board in 1923. Babcock's resources development work made no great strides, if it went forward at all; when it seemed clear that neither briquetting nor pulverizing were the answers to making lignite industrially available outside North Dakota, the Hebron plant was closed (1924), and funds for research were cut back to about $\$ 5,000$ per year. Gauger's work had only well begun when he resigned in 1931. The clay testing work, begun with an appropriation of $\$ 2,000$ per year in 1917, continued steadily, with no change in budget, but with no outstanding results as far as development of a new industry was concerned.

It was the department of geology rather than the School of Mines which made the most conspicuous contributions to resources development in the 1920's. A member of the geology faculty, Leonard Dove, made the discovery that a water-soluble wood dye could be made from lignite. He left the University in 1925 to open and manage a plant near Minot for the manufacture of "Dakalite," as the dye was named. A number of the faculty bought stock in the enterprise, and for a time it was confidently predicted that the first 
great lignite industry had been finally launched. Meanwhile, supported by a special fund appropriated in 1919, Leonard expanded his mapping of the lignite fields, and in 1923 he was commissioned by law to continue the gravel location work that had already begun in connection with the state highway department's "good roads" program. Leonard and his colleagues also devoted an increasing amount of time to checking on the possible oil resources in North Dakota. They did, in fact, indicate the broad outlines of the oil fields that were opened in the 1950's, but in the 1920's most of the work consisted of warning the gullible against the promoters who were drilling anywhere their fancy dictated. One of the most conspicuous and valuable public services developed by the University geologists was their awakening of public and official interest in the necessity to conserve the state's artesian waters. This was the work of Howard Simpson. Because of his efforts the post of state water geologist was created, and in 1921 the state legislature made its first appropriation $(\$ 2,500)$ for conservation and control work. Simpson worked closely with such organizations as the state association of well drillers. By the 1930's he had become a widely recognized authority on the subject of ground waters, in heavy demand as a consultant in Canada as well as in the northern plains region of the United States. Some evidence of the public's evaluation of his services was the fact that on several occasions during the 1920's the only appropriation made for the Geological Survey was for the artesian water work.

The Extension Division enjoyed a substantial growth; its budget increased from $\$ 4,000$ annually in 1917 , the most McVey was ever allowed, to $\$ 17,500$ by 1931 . The staff was expanded to five full-time employees, including the director, Albert $\mathrm{H}$. Yoder, former president of Whitewater Teachers College (Wisconsin) and an old friend of Kane's from his University of Washington days. As director from 1919 to 1934, Yoder brought to the office the permanence and continuity of policy that it had lacked, as well as the advantage of his long administrative experience. The appointment in 1925 of M. Beatrice Johnstone to the position of secretary of the department of correspondence instruction provided a close connection with the public schools-Miss Johnstone had been for years a prominent figure in state public school organizations. The correspondence program was expanded considerably (the Agricultural College offered no competition in this field until 1925), and extension classes in downtown Grand Forks became a regular feature of each University term. The division also carried on a varied program which included organizing the state Parent-Teachers Association and serving as its general headquarters, circulating educational films and projectors, booking lyceum artists and lecturers, encouraging the development of high school dramatics, supervising the annual state high school contests in music, declamation, and commercial subjects that were held on the campus, and operating a bureau of general information.

Nonetheless, it ran a poor second to the extension division of the Agricultural College, which enjoyed the support of federal funds under the Smith-Lever Act of 1914. Where the University's maximum annual appropriation for all such work was $\$ 17,500$, the College's was well over $\$ 100,000$ on several occasions (matching federal funds were in addition). A good part of the disproportionate development was not the fault of the University administration or of Yoder but rather resulted from the decision of the Board of Administration and the legislature of this agricultural state to concentrate extension work at the Agricultural College, where federal funds would be added to match what the state spent. In addition to its extension division the Agricultural College had a half dozen or so other services to offer, testing for purity of seeds for example, for which state funds were regularly appropriated. Moreover, the absolute legal prohibitions placed upon institutional deficits in 1923 and the establishment of a state budget board prevented the semilegal diversion of funds that had enabled McVey to show results, even when lacking specific appropriations.

The development of the radio station was a fair demonstration of that mixture of foresight and absence of imagination characteristic of the policies of the University and the Board in the 1920's. Recognizing the rapidly growing importance of radio communication, the University acquired a license in August, 1923, to operate a hundred-watt Class A limited commercial station. A small studio, with $\$ 750$ worth of equipment bought from a Grand Forks firm, 
was installed in the basement of the Commons building and placed in the charge of the department of electrical engineering, which added a new instructor in radio and several new courses. On the evening of October 22, 1923, the first formal broadcast was presented before an interested audience in the Armory.

Although no firm policy was developed in the 1920's on the station's use, partly because it was licensed for commercial purposes, its value for maintaining good public relations and for extending the University's teaching program were not overlooked entirely. The first faculty committee appointed to manage the programing included Yoder, the head of the extension division, and members of the extension staff offered some more or less regular program from the beginning. By 1929-1930 station KFJM, the only one in the Grand Forks area, had expanded from a daily noon broadcast of one hour, plus an hour or so every Wednesday evening, to about twenty hours a week, with special broadcasts of such events as the Carney Sing, high school music contests, and sports events in addition. A regular announcer was employed (at $\$ 37.50$ per week, with $\$ 1.00$ per hour for overtime), and wires were installed to broadcast points in several Grand Forks business establishments. The station charged $\$ 3.00$ per hour for its time and was almost entirely selfsupporting.

This represented a considerable development to be sure, but it was also development toward commercial rather than educational uses. Considerable pressure was arising in Grand Forks to force the University either to shift altogether to full-time commercial broadcasting or to relinquish its license to someone who would and could. Indeed, the Board of Administration actually was persuaded to sell the station to an insurance company, and failed to do so only because the company found itself prohibited by law from making the investment. In the spring of 1929 Kane moved to satisfy public demands by employing Dalton LeMasurier to manage the station on a commission basis, an arrangement which was changed in a year to LeMasurier's assuming the position of informal lessee. Operating hours were increased from twenty per week to sixty, and a full schedule of commercial fees established. This arrangement, under which the University still had the opportunity to add frequent special broadcasts to its regular offering, continued until 1938. Although it would remain for Kane's successor, John C. West, to make the first deliberate effort to use the radio station directly to serve the University's interests, the broad potential value of the station was becoming understood before Kane left the University. In his biennial report of 1932, Jenkins observed:

The use of radio broadcasting as an educational factor is steadily increasing. It is reasonable to expect that within a few years sound broadcasting will be supplemented by sight broadcasting, or television. Undoubtedly in KFJM the University has a very valuable asset whose possibilities should be made known to our state legislators so they may properly appreciate its worth and supply funds for its development.

It may be added that the Agricultural College actually lost its station in 1932 and that few colleges in the country made effective use of their radio stations during the 1920's. 
$\mathrm{X}$

\section{The Depression and World War II}

$\mathrm{T}$ were more favorable than not for the University. A biennial appropriation of $\$ 1,215,000$ had been voted the preceding spring; in addition to funds for completing Merrifield Hall, it provided for modest increases in the maintenance budgets of every branch and division of the University - the allowance for the engineering colleges was raised from $\$ 145,000$ to $\$ 153,000$, for the medical school from $\$ 43,000$ to $\$ 45,150$, liberal arts from $\$ 290,770$ to $\$ 309,000$, the library from $\$ 41,240$ to $\$ 46,440$, and so on. The president's report of 1930 revealed no sense of impending disaster but emphasized the usual complaints about the heavy faculty turnover, inadequate salaries, and excessive teaching loads. There was even a note of optimism in the recommendation for a new engineering building and a gymnasium. The 1931 appropriation reflected caution but not panic, for although no building requests were approved, maintenance budgets were left at the 1929 figure, which represented a substantial increase in the purchasing power of both the University and the members of the faculty.

Economic conditions began to worsen rapidly in the state in 1930. The average price for wheat was down to sixty cents a bushel that year, and in 1931 the crop was cut in half by drouth and prices averaged forty-six cents. A year later the crop was fair (for nearly the last time in the decade), but the price fell to an all-time low of thirty-six cents. And things grew worse. At no time since it was settled was North Dakota in such straits as it was in the 1930's. The combined effects of a decade of crop failures and depressed farm prices were appalling. Between 1930 and 1940 the state's population declined from 680,000 to 642,000 -it was down to 619,000 by 1950 , although by then a slow upturn had set in. Between 1930 and 1945 about one third of the farmers of the state lost their land. Total income fell from $\$ 315,000,000$ in 1929 to $\$ 111,000,000$ in 1932 and it had risen to only $\$ 232,000,000$ by 1937 . Per capita income in the 1930's was about 30 per cent below the average for the United States. Nearly 230,000 people, more than a third of the total population, received relief assistance in 1937 in the amount of $\$ 22,500,000$, most of it from the federal government. In 1939 about one third of the total taxes due from the year previous were delinquent.

It was only to be expected that North Dakotans would provide a more than receptive audience for the preachments of the economic soothsayers who sprang up in the land during the 1930's. Indeed, the University contributed one of its own sons to their ranks, William Lemke, who ran for President of the United States in 1936 on the Union party ticket. He and Frazier achieved national prominence with the farm bankruptcy laws that they pushed through Congress. Few governors attempted more dramatic or drastic measures to save their state's economy than William Langer, and it may be added that few won more notoriety. Between 1934 and 1939 North Dakota had six governors. Langer was removed from office before the end of his first term but was reelected in 1936-four years later he defeated Frazier in the race for the United States Senate. Meantime, John Moses, another University alumnus, won the governorship in 1938; the first Democratic governor since 1912, he was reelected twice and then won the Senate seat held for years by Gerald P. Nye. Although some measure of political tranquility had been achieved in the state by the eve of the war, it would be years before the ill-feeling and heated rivalries of the turbulent thirties had entirely subsided in North Dakota. 
Throughout the period the University, and for that matter all of the state colleges, were under the almost constant surveillance of the economizers, who included in their ranks open enemies of the colleges and of taxation in general, as well as many sincere and well-intentioned people who feared that the whole system of higher education would collapse if it were not reorganized on a more efficient basis. The depression had brought home to the public as nothing else could have the absurdity of a half million people's attempting to operate nine separate schools and colleges. A law of 1933 ordered the elimination of all "unnecessary duplication" of courses in the state college system, and a senate resolution of 1935 endorsed the immediate consolidation of the University and the Agricultural College. Two surveys of the state government arrived at similar conclusions. The most complete study of the colleges, the results of which were published (1936) in the "Higher Education" section of the North Dakota Tax Survey Commission report, was sharply critical of the disorganized state of the existing system and recommended that some of the teachers colleges be adapted for vocational education and that the rest be required to concentrate their efforts in prescribed fields. It also outlined a plan for a nonpolitical board of higher education and a professionally trained commissioner to govern the entire state system.

Combined as it was with a highly charged political situation, this search for economy was more than a little menacing. It was also plain in the legislative sessions of the 1930's that many legislators were for one reason or another entirely out of sympathy with the University and were unwilling to acknowledge it as the apex of the state's educational system. In turn, the combination of poverty and a sense of being unappreciated produced a campus psychology of caution and undue sensitivity to public opinion that was apparen to newcomers on the faculty for the next decade and a half. It would be years after the depression had passed, when it was entirely forgotten by a student body reared in prosperity and even by many of the younger faculty, before the University would again stir with some of the boldness, experimentation, and the sense of intellectual ${ }^{1}$ The commission was established by law in 1935. Dr. Spencer Larsen, professor of marketing and merchandising at the University, acted as chief consultant to it and
wrote the reports. adventure that had so enlivened the campus in the last days of Merrifield and in the administration of McVey.

The depression's impact upon the student body was not immediately apparent, however. Enrollments declined only gradually, to a low of 1,580 in 1934-1935. This was by no means a disastrous slump, but it was significant as the first reversal of the steady upward trend that had begun in the 1890's. Student activities went on much as before, particularly in the first year or two of the depression when an early recovery was generally expected. The "Land of Oz" junior prom of 1930 was an elaborate affair, and the seniors had a last fling at 1920 foolishness that year when they invited the King of Siam to their "Dragon Prom." The eighty-odd organizations on the campus continued to occupy much of the students' time; the fraternity "frames" occasioned the usual adverse comment in the 1930 and 1931 elections. The football and basketball teams, only recently arrived on the heights, continued to play their intersectional games and to excite the fans. The Sioux played West Point in 1930, losing 33-6. In 1932-1933 both the basketball and football teams placed second in the conference. For the most part, the undergraduates probably viewed the successful teams as the one bright spot in an increasingly dark picture; however, in 1930 a letter to the Student complained that there was rising resentment against these tours on money "taken from depressed students' pockets." The Flickertail Follies were dropped in 19311932, and the Student reverted to one issue a week, a not entirely unmixed misfortune. Informal all-campus "hobnobs" became popular as times got worse, and in the spring of 1932 fraternity formals were canceled and the junior and senior proms were combined.

It was not until 1931, when the effects of the hard times were plainly visible on the campus, that the University administration took its first steps to provide some extraordinary assistance for needy students. In the summer the Board of Administration acted to permit the employment of student labor in digging for a campus water main, and that fall the University opened an employment office which was manned by a student working part-time. ${ }^{2} \mathrm{Al}$ though swamped with job hunters, he could report only fifty-nine ${ }^{2}$ Until 1931 the YMCA operated the only employment service on the campus. 
placements by Christmas. An active canvass uncovered a few more jobs around Grand Forks in the fall of 1932, but the chief assistance for students was the by-product of the heavy economies that the University was required to make that year; that is to say, the University made increasing use of student help for classroom and laboratory assistants, janitors, and campus laborers to replace fulltime employees. More than a hundred students were reported on the University payroll by Christmas 1932 . Only about $\$ 20,000$ was available in the various loan funds until 1931 when $\$ 15,000$ was bequeathed by one John W. Casel of Albuquerque, New Mexico. When the University received notice of the gift, no one, including the alumni secretary, knew anything about him, nor has any information come to light since.

In the meantime, the temporary advantage that the University and the faculty enjoyed from having a fixed income soon ended. Tax receipts fell off sharply after 1930, with the result that by 1932 funds were not available although they had been appropriated. One partial solution voted by the Board was to increase out-of-state tuition fees to $\$ 300$ a year, but the protest from nearly every quarter was so vigorous that the differential was brought back to a modest $\$ 30$ or so. In the spring of 1932 , after conferring with the heads of the institutions under its jurisdiction, the Board put through a general budget reduction of 20 per cent. In actual fact, the University's share of the cut, $\$ 125,000$, was about a quarter of the income that had been expected for the year of 1932-1933.

In March Kane wrote to all deans and department heads explaining the situation and asking for their suggestions. He himself suggested that equipment purchases be reduced, small classes eliminated, and that teaching loads (already at sixteen hours) be increased. The implication that there would be reductions in staff was plain. An inevitable tenseness and the usual flurry of rumor appeared as soon as news of the letter was out. Late in May, following much weighing and balancing, and considerable pulling and hauling among schools and departments, all of which further exacerbated everyone's feelings, it was announced that seventeen faculty members would be given a year's leave of absence at half pay or less or dismissed.
The seventeen selected were distributed fairly enough among the schools and departments, and there were logical arguments for most of the decisions taken. A number of young men who lacked the Ph.D. were given leaves of absence to pursue advanced work. A fair case could be made for the retirement of four of the campus veterans, Chandler, Hult, Kennedy, and Schmidt. Both of the latter were in their middle seventies, and both lacked much formal training in the modern educational school that Dean Breitwieser and the newer appointees of the 1920's represented. The closing of the University High School and the elimination of the elementary teacher training work which soon followed also served to justify putting both of them on a part-time schedule and salary. ${ }^{3}$ Chandler, who was named dean emeritus by the Board, was in failing health and found it increasingly difficult to discharge his duties. The justification for placing Hult on a part-time basis was the need to reduce the overmanned classical languages department, which had two full professors and not many students. Hult's colleague, Adolph Rovelstad, on the faculty since 1930, was younger and held the Ph.D. (Hult held an honorary Doctor of Literature degree conferred by Beloit College in 1921.) Hult's withdrawal into his private world of research and translation of the works of Ibsen and his growing eccentricity were also factors. On the grounds of their being more expendable than some others, one could also make a case for the proposal to eliminate the brilliant young philosopher, George R. Geiger, and the able and popular dean of men, Earl Smiley.

But there was no justification for Kane's recommendations that Robert Forsythe and Henry Doak be dropped from the English department. Few members of the faculty had any illusions about the reasons for this decision. The president might have passed through the ticklish retrenchment maneuver safely enough if he had acted wisely, for by 1932 his relations with the faculty were perhaps the best they had ever been. Two years before he had given his support to a faculty investigation of the constitutionality of the Board's arbitrary dismissal of Charles Ellis, superintendent of buildings and grounds and professor of architectural engineering. As ${ }^{3}$ Kennedy and Schmidt were restored to their positions in 1933 by a new president, old men who would work for low salarie. 
it was, this final display of insensitivity or indifference to faculty opinion had the effect of galvanizing the most influential dean on the campus, William G. Bek, to launch a quiet agitation for Kane's removal.

With the tacit support of Bek the whole matter became the subject of sharp discussion in the newspapers, including a vigorous criticism of the president and Cox by "alumnus" in the letter column of the Student. William Langer, the gubernatorial candidate of the revived NPL, lost little time in paying his respects to the trouble at the University in order to embarrass the state administration. A campaign of sorts to save Forsythe also made its appearance among the students. Following an interview with Bek, the Board rejected the president's recommendations on Doak, Forsythe, and Hult, and began what proved to be a desultory investigation of the University situation. "Through some agency," as Bek put it, the matter came to the attention of Governor George Shafer, an alumnus, who was in the process of launching a campaign for nomination to the United States Senate. On one of his visits to Grand Forks he spent hours in an interview with Bek. Bek probably minced no words, if what he wrote some weeks later to Sveinbjorn Johnson, another alumnus, then chief counsel for the University of Illinois, is a fair sample of his views. ${ }^{4}$

Even while the local controversy over the reductions of 1932 was in progress it was becoming increasingly apparent that much worse was ahead, either in the form of further reductions in salaries or in the limitation of the offerings of each state college to certain special fields. One of the initiated measures placed before the voters in the general election of 1932 was a mandatory 20 per cent reduc"Six closely typed pages bristle with such statements as: "We have no real presiits president since $1917 \ldots$. The faculty is in a constant state of turmoil [because he] likes to keep things stirred up .... [He] calls men to his office under one pretext or another and then gossips about other men and their work. This gossip is studiously disseminated .... in order to harm the persons gossipped about ... Certain members of the faculty $\ldots$ are directed to approach downtown people in
his behalf and to the detriment of those whom he dislikes BEEN AN INTELIGENT AND CONSTRUCTIVE EDUCATIONAL LEADERSHIP AT THE UNIVERSITY OF NORTH DAKOTA FOR 14 YEARS. The situation is utterly bad." Bek went on to suggest in this letter that Johnson should get in touch with such men as William Nuessle, Gudmundur Grimson, and others, to bring about an investigation at the University. tion in the salaries of all state employees; sponsored by the North Dakota Taxpayers' Association, it was so worded as to limit all college salaries to a maximum of $\$ 2,400$ per year. Acting through a committee of the AAUP, the University faculty waged their most active political campaign since the days of the lottery. Although they aroused wide support, including that of the NPL and the Grand Forks branch of the taxpayers' association, the measure carried in November. It was a mandate not to be lightly ignored by an incoming administration, nor were such problems as the state's half million dollars in unpaid bills or the lag of one to two months in the payment of state college salaries.

The University request in 1933 for an appropriation of more than a million dollars was probably intended more as a gesture or as a bargaining base than as an indication of any serious expectation of receiving the entire amount. The state budget board lost little time in reducing the figure by nearly 30 per cent to $\$ 840,000$. The new governor, William Langer, in turn recommended only $\$ 604,000$, a request that was further modified in the legislature; the bill as finally signed in March called for only $\$ 518,000$ for the 1933-1935 biennium, or about 45 per cent of what had been appropriated in 1931. When the bill came before him, although it was for considerably less than he had originally recommended, Governor Langer struck out the $\$ 5,000$ set aside for lignite research. Nothing was allowed for the summer session, graduate division, dean of men or dean of women, leaves of absence, purchase of equipment, or for the Fargo and Minot substations of the public health laboratory. The Extension Division was reduced to offering correspondence courses. Both the Quarterly Journal and the Dakota Law Review stopped publication. The initiated measure and the appropriation bill together reduced the president's salary from $\$ 8,000$ to $\$ 3,000$, the deans' from an average of $\$ 4,800$ to $\$ 1,920$, professors' from an average of $\$ 3,650$ to $\$ 1,914$, and instructors' from $\$ 1,943$ to $\$ 1,322$.

The University and the other colleges as well had not been struck so hard a blow since 1895, and the situation in 1933 called for the same measure of loyalty and resourcefulness from the faculty and a new president-Kane submitted his resignation 
while the appropriation bill was under consideration. The appropriations of 1933 left a legacy of bitterness on North Dakota college campuses that has not entirely disappeared even yet. It should be said in extenuation of the action of the legislature and the governor that from January to March, 1933, the country was passing through the most extraordinary internal crisis it had ever experienced, the very nadir of its worst economic depression. Emphasized by the paralysis of the presidential interregnum in Washington and the wave of bank closings, it seemed to threaten ruin for the entire economic and financial structure of the United States.

An integral part of the economy drive and one that was reflected in the pattern of University appropriations was the strong movement that developed to eliminate expensive duplications of courses and programs in the state college system. In fact, the thorough airing of the duplication issue before the appropriations committees opened the eyes of many legislators and undoubtedly damaged the colleges' campaign for sufficient funds to operate. The issue itself was an old one; it had produced surveys in 1911 and 1916. The opposition of the Agricultural College and the rise of the NPL had killed the Craighead plan. But the question was raised frequently in the 1920's as college expenditures rose steadily with the growth of enrollments and offerings: the Agricultural College expanded its teacher training and liberal arts programs, the normals became teachers colleges training secondary as well as elementary teachers, and the University continued to train elementary and special home economics teachers and to expand its offering in engineering. In 1930 the Board of Administration appointed W. E. Peik to survey the teacher training program in the University and the Agricultural College. Peik's report, published by the state department of public instruction in 1931, recommended a redistribution so as to reduce the duplications that existed from fifteen to two. The chief function of the report was to provide ammunition for the advocates of drastic consolidation.

Early in 1933 Dean Bek took the opportunity afforded by a polite request for suggestions from Governor-elect Langer to urge the merit of the semicentralized organization, headed by a chancellor, that existed in Montana, and to warn Langer against a plan recently adopted in Oregon whereby the agricultural college was limited to engineering and technical courses and the University to the professional and nontechnical. The senate actually adopted a resolution, sponsored by friends of the Agricultural College, to establish a "Greater University of North Dakota," in which "classical and humanistic fields" would be limited to the Grand Forks branch and the "sciences and technological groups of study" to the Fargo branch. It also passed (32-16) a measure to abolish military training at the University, that is, to limit it to the Agricultural College. Both were beaten down in the house, but not without the aid of vigorous agitation against them from University supporters, one of them William Lemke, recently elected to Congress, and some sharp exchanges between the administrations of the University and the College. In the end the legislature passed and the governor signed an act to instruct the Board of Administration to eliminate "all unnecessary duplication of courses as may be found between our state educational institutions and to coordinate the courses of study in our state educational institutions in so far as is practicable." The work was to be completed within three years.

It is hardly to be wondered that the Golden Anniversary celebrated on Founders' Day, 1933, was a sober event. A faculty committee headed by Bek had begun planning in the spring of 1932 The events on the campus followed a traditional pattern: the Carney Sing on the evening of February 21, a formal address next morning delivered by Lotus D. Coffman, president of the University of Minnesota, two basketball games, the announcement of student honors, and the election of Gillette, Hult, and Libby to Phi Beta Kappa. About a hundred alumni, among them four of the origina student body of 1884, were present for the alumni luncheon. Many high schools in North Dakota had a ceremony to mark the day, and alumni clubs the country over observed it. A significant event connected with the anniversary year was the appearance in the spring, 1932, issue of the Quarterly Journal of the eleventh and final chapter of the first history of the University. Begun by Dean Squires in the early 1920's and about two-thirds complete at the 
time of his death, the history had been finished by his son, Duane. ${ }^{5}$ But with the state near bankruptcy, with the legislature heading no one knew where on economy and consolidation, and with the president's resignation announced the evening before, the thoughts of many were not on glorifying the past but on the uncertain future.

Although Kane's resignation or removal was more or less expected, its timing was something of a surprise. The Quarterly Journal reported later that he had for years intended to resign in 1933 when he reached his seventieth birthday and became eligible for his Carnegie annuity. However, said the Quarterly, in a paraphrase of the president's own statement: "A certain spirit of conciliation and self abnegation impelled an earlier action; he resigned when the state legislature was in session in the hope that this move might cause the legislators to act more favorably upon the needs of the University." The news produced more than the usual concern and speculation, because of the unstable situation in the legislature and uncertainty about the temperament and inclinations of the new governor.

A short time after Kane's resignation, Governor Langer, stopping in Grand Forks on business, invited Gillette, whom he had known for years, to visit him at the Dacotah Hotel. Much to Gillette's surprise, or so he wrote in his autobiography, the governor offered him the presidency. Gillette asked for time to think it over, and, after discussing the matter with a "little group" of colleagues ${ }^{6}$ who had been meeting informally and more or less secretly for some time to discuss University matters, he decided to turn down the offer. He felt himself too old at sixty-seven to undertake a job as arduous and unrewarding as this one promised to be, and he wanted to continue with his work in sociology-he was seeing a manuscript through press at the time. Meanwhile, the news leaked out, and Gillette had at least the satisfaction of knowing that he ${ }^{5}$ The first chapter of the history, "The Founding of the University," had appeared as the leading article in the Fortieth Anniversary issue of the Quarterly Journal, cock gave the principal address in the first of many apperances year, John Hanalumnus. Other honored guests on that occasion were Mrs. George Walsh, widow of one of the founders; Mrs. E. A. Mott, a member of the first faculty; and Dr. R. M. (Bek, allo

${ }^{8}$ Bek, Gillette, Libby, Simpson, Wheeler, and several others. All were generally
known to be anti-Kane men. had every dean's support and apparently that of the majority of the faculty. Fearful that an impatient governor might fill the vacancy with someone they did not want, one possibility being an alumnus who was rallying support for himself, the "little group" dispatched Gillette to Bismarck to urge their views upon the governor. After trying vainly to persuade Gillette to change his mind about accepting the appointment, Langer in some exasperation demanded: "Then what the hell will we do?" Gillette seized the opportunity to win the governor's tacit consent to consult with the "little group" on other possibilities.

After further consultation in Grand Forks the group agreed upon the name of John C. West, superintendent of the Grand Forks city schools. It is not clear who first thought of him; no fewer than three members of the faculty, Bek, Gillette, and Breitwieser, claimed to have done so. In any case, there was little apparent disagreement with the suggestion, which was soon endorsed by the deans, not all of whom had been party to the secret deliberations. West was well known on the campus. He had taken the M.A. degree at the University in 1926 and had received the doctorate in 1930. Gillette had played a major role in his election to the school superintendency of Grand Forks, and Bek had sat on the school board which appointed him. West had a number of points in his favor, although he lacked academic experience or a scholarly record: his reputation for shrewd management of school finances, his harmonious relations with his teaching staff and the public, his wide acquaintance in North Dakota, and his years of experience in small Dakota high schools. Moreover, although not all of the deans or even the "little group" may have been aware of it, he was a lifelong friend of Frank Vogel, an intimate friend and adviser of Langer's. Yet Langer and the Board hesitated about the appointment for a time, partly because they had under consideration M. A. Brannon, whose position of chancellor of the University of Montana had been abolished as an economy measure. Brannon declined to come to Bismarck for an interview, however. In the meantime support for West was developing. Gillette, for one, continued a private campaign for his friend with wires to the Board and the governor; one to the latter stated: "West absolutely straight. You 
can trust him implicitly. Best prospect." On May 9 the Board of Administration announced the unanimous election of John C. West to the University presidency. He was to take office in July.

Kane's departure was attended by the usual expressions of commendation and regret; although he had had many disagreements with members of the faculty, the president enjoyed the support of a good many people on the campus and in Grand Forks as well. In the reviews of his administration that appeared at the time, the accomplishments most often mentioned were the University's growth, the new buildings, and the expansion of offerings. Admirers would remember decades later that "the students were back of him," that he was "a gentleman in every sense of the word," that he "worked untiringly for the Memorial Stadium [because] his heart was in it," and that "he taught us to be in a good frame of mind and to look well-groomed before we appeared in our offices." Usually overlooked was the fact that the faculty and administrators who would be the backbone of the University for the next twenty years were almost all of his choosing. Most of the department heads and all of the deans except Bek and French were his appointments. Only a few days before his own resignation Kane appointed Olaf Thormodsgard, chairman of the law faculty since the death of Cooley, and Louis Harrington, director of the division of mines and acting dean of engineering since Chandler's retirement in 1932, to the permanent deanships of thei colleges.

Kane also bequeathed to his successor a faculty too factionridden to be able to form a committee to choose a president, except informally and half secretly. He left behind a general public impression that the University was the protégé of the state's political conservatives, no minor matter in the liberal thirties with the NPL once more in power in Bismarck. West also inherited from the depression, rather than from his predecessor, an impossibly small budget and an institution set back to the bare essentials of undergraduate teaching. His own personal future was by no means certain; at the age of forty-eight he had accepted nearly a 50 per cent reduction in salary to shift from the narrow sphere of a town schoo system, a field he knew thoroughly, to the infinitely broader arena of a state university, one for which he had little training and no experience. Moreover, no president of North Dakota assumed his duties under more unfavorable circumstances-and none served through a longer period of unrelieved crises.

John C. West, the son of a Civil War veteran who had migrated to a semifrontier farm near St. Cloud, Minnesota, was the youngest of seven children. Born in 1885, West grew up on the farm, taught rural school, and attended the nearby St. Cloud Normal, from which he graduated in 1907. In 1915, at the age of thirty, he received the B.A. degree from Fargo College. By then he was a school superintendent with a record of a half dozen successful years in small towns in North Dakota. From 1912 to 1929 he headed various school systems in Minnesota and rose to the presidency of the Minnesota association of school superintendents. As superintendent at the resort town of Bemidji from 1920 to 1929 he earned a reputation as a community leader, an expert in public school finance, and the promoter of a $\$ 400,000$ school building, a considerable achievement for a town of that size in the 1920's and one that was much admired in public school circles. His four years as superintendent in Grand Forks had been equally successful. During that time he had regularly taught courses in educational administration during the University summer session. In addition to his close acquaintance with the immediate situation, West also brought to his new position the advantages-and also some of the disadvantages - of the thorough familiarity and sympathy with the region that could be expected of a loyal native son.

In physical appearance and personality West was in considerable contrast to his predecessor. Middle-sized and sandy-haired, he possessed a natural unpretentiousness, a trait he emphasized with an earthy humor drawn from the rural plains society which had nurtured him. He was by nature a conciliator, an inclination reinforced to nearly an obsession by his familiarity with the consequences of disharmony to his predecessor. A professional school administrator, West was proud of his craft and thoroughly convinced of the primary function of administration in the educational process, and of the necessity for respecting the prerogatives of the administrator, however minor his function. 
As president, West took for himself the roles of campus harmonizer, the University's representative to the legislature and the Board, and its interpreter to the public at large. Where McVey and Merrifield, and Kane also to a degree, had attempted to enlarge the University's role in developing the state, to give the University intellectual leadership, and to bring it to the favorable attention of the academic world, West gave first priority to making it popular with all parties and factions as well as with parents and students. Convinced by his long grass roots experience as a school superintendent that most people had little understanding of the University's multiple functions, West set out to explain in simple terms how it operated, what it was supposed to do, the significance of accreditation associations, and other such matters that are the commonplaces of the academician's life. He once explained to the faculty: "Things that seem obvious to us seem obscure to the person who has never been to college or had a child in the University. We need all the help that we can get in setting forth the value of the staff in the field of research, custodianship, and public service." It was largely his doing that the name of the College of Liberal Arts was quietly changed to Science, Literature and the Arts (the name used by the University of Minnesota); West believed that the general public had no conception of the meaning of the term, "liberal arts."

Faculty members who possessed aptitudes for public relations work were pushed forward. Miss Johnstone, director of correspondence study and one of the older alumni in the state, became one of the most familiar representatives of the University in West's time, particularly before public school or parent-teacher audiences. Hardly less well known to rank and file North Dakotans was George Abbott, head of the chemistry department, whose "Science from the Sidelines" radio addresses, regular fare of the University radio station for years, provided entertainment as well as education for thousands of people who would otherwise have hardly been conscious of the University's existence.

Abbott's felicitous little talks had their origin in a "Greater University of North Dakota" broadcast series launched in the fall of 1934 as a device to impress favorably the forthcoming legislative session. The popularity of the original venture, which consisted mostly of numbers by University music groups and interviews with Grand Forks citizens on the value of the University to the state, led to the organization of a regular program of "educational" broadcasts in 1935. In addition to the lectures by Abbott, the major performer, these included contributions by various other members of the faculty. Rowland's music appreciation hour was a popular feature. The "Greater University of North Dakota" broadcasts, continued through the 1930's, also presented lighter fare, including music by University dance bands, intercollegiate debates, and Playmakers' performances.

West's policies and outlook were also reflected in his close personal relationships with many students and the inauguration or revival of such events as Dad's Day, a high school week, a spring advisement week for high school students, a freshman orientation week, a "religion and life" week, and so on. In 1942 a new "Constitution of the Student Body . ..." established a student council of ten members-the three officers of each upper class and a representative from the freshmen. This body had considerable power to regulate student activities. The constitution also gave official standing to the system of student government introduced by Smiley fifteen years before by empowering the council to select two students as advisory members of a new faculty Student Relations Committee. In several of his early reports West indicated the direction of his efforts when he called attention to the number of students who earned their way and to the increasing enrollment from the western counties and from farm families-the proportion of the latter had been in decline since the end of the First World War. The registration in 1935 of Franklin Dog Eagle, the first genuine Sioux to enroll, was hailed-prematurely, it turned out-as the beginning of a connection with a hitherto neglected segment of the state's population.

It would be impossible to measure with any exactness the total effect of West's efforts to popularize the University. Various individual signs point to considerable success. His interest in the personal affairs of students and in their parents, and his genuine desire to put a university education within reach of the student 
without money was rewarded by a personal popularity on the campus and by hundreds of grateful acquaintances throughout the state, many of them on a first name basis. In a comparatively short time West also established friendly personal relations with dozens of legislators, with the members of the governing boards, and with their wives as well. He liked to refer to himself as a "politician," a term which none of his predecessors could have accepted easily, but politics in his lexicon was maneuver, not partisanship. Although more than any of his predecessors he owed his appointment to the intervention of a political faction, the Nonpartisan League, of his major contributions to the University was to remove it from the embarrassing and dangerous position of being a factional protégé, which was where he found it.

The heavy emphasis upon public relations was not without its disadvantages. In time it proved increasingly difficult not to become content with general good will at the expense of intellectual leadership, scholarship, and public services, to make a virtue of the limited role of a "teaching university," nor to prevent the development of an institutional softness, that is, a reluctance to fail and send home the indifferent or incompetent for fear that "sore spots" of hostility toward the University might be thereby created. The disappearance of the reading for honors program may have been symptomatic, although to be sure the inauguration of an annual honors day, largely the work of Bek, did offer a substitute incentive for academic achievement. But even Bek's own college retreated somewhat from its stiff language requirement for the B.A. degree by adding the Ph.B., requiring no languages at all, in 1935. Standards for the faculty were also inevitably affected by the emphasis upon harmony, public relations, and popularity in the classroom. ${ }^{7}$

When West assumed office on July 1, 1933, the problem which overshadowed all others was the necessity for adjustment to the reduced appropriations. The seriousness of the situation had been emphasized only shortly after the legislative session ended by the "In one memorandum to the faculty (August 24, 1944) suggesting criteria for
promotion and salary increases West indicated service" (at a maximum of thirty points) as second only to "effectiveness as reations (worth a maximum of forty points), and considerably above training or as teacher" The latter he suggested might be rated at two points per book for the first three published, and one point each for any additional ones. closing of the First National Bank of Grand Forks and the impoundment-permanently it seemed at the time- of $\$ 52,000$ of sorely needed University funds. ${ }^{8}$ The faculty did not receive their April checks until June, and then only because the Board had borrowed the money from the Bank of North Dakota. In the last weeks before West took office difficulties arose with certain Nonpartisan League leaders, including the governor, when the American Association of University Professors chapter uncompromisingly rejected a proposal that the faculty contribute 5 per cent of their salaries to the League's organ, the Leader. When a group of students threw the solicitor for the paper into the coulee and then escaped punishment there were more sharp reactions in Bismarck. It was perhaps fortunate for the University that the legislature was no longer in session.

With the exception of the dismissals of the faculty in 1932, which were made permanent by the Board in 1933, and those which resulted from the closing of the University High School, practically all of the cutbacks were absorbed in greatly reduced salaries all around and in drastic reductions in the realm of purchases of supplies and equipment, including materials for the library and laboratories, for administrative and internal services, public services, and of course for research. University offerings, and those of the other colleges too for that matter, were altered very little, although in addition to the initial measures there were repeated efforts by the legislature and the Board to revamp the whole system of higher education. Indeed, the only marked changes which were accomplished, after the hue and cry about duplication and reform were over, were the grant of a monopoly of elementary teacher training to the teachers colleges and the creation by constitutional amendment in 1938 of a separate Board of Higher Education. The only significant changes in the form and offering of the University were the elimination of the high school, the one-man department of architectural engineering, and the major offerings in elementary education and home economics. A cooperative arrangement for ${ }^{8}$ Forty thousand dollars was eventually recovered. The bank was opened partly through the efforts of the Universitys then most tamous alumnus, J. F. T. OConnor, ap-
pointed Comptroller General of the United States in 1933 . He was responsible for the reorganization of the nation's banking system that was undertaken in the $1930^{\circ}$ 's by the Roosevelt administration. 
practice teaching in the Grand Forks public schools proved to be a satisfactory adjustment, and the home economics major was restored before the end of the decade. The summer session continued without interruption because the faculty agreed to teach for a pro rata division of the student fees, which amounted to $\$ 50-\$ 60$ for the entire eight-week term for many, or to put it another way, a dollar to a dollar and a half a day. This arrangement, likewise used in the other colleges, continued until long after it was necessary. (In 1946 a long-suffering faculty finally demanded and received full pay for their summer work.)

The federal relief program was no minor factor in the University's adjustment to the depression. In its first biennial report of 1940 the State Board of Higher Education estimated that the Works Progress Administration had added over $\$ 700,000$ to the value of the physical equipment of the state colleges and that the Public Works Administration and the National Youth Administration had added another $\$ 800,000$. Between 1933 and 1938 federal expenditures on the University campus, exclusive of NYA allotments, came to $\$ 709,000$, supplemented by $\$ 158,000$ in matching funds from the University. Something more than a third $(\$ 338,000)$ went into new construction and repair and renovation. The largest building erected with federal funds specifically for University use was a $\$ 43,000$ winter sports building-the postwar development of hockey as the major intercollegiate sport was a direct result. Other campus additions were a small radio transmitter building and a tower, a chemical engineering and fuels laboratory addition to Babcock Hall, and a laboratory addition to the mechanical engineering building-renamed Chandler Hall in 1935. A frame dormitory $(\$ 54,000)$ was completed in 1941 to house eighty trainees of a National Youth Administration trade school. ${ }^{9}$ Later turned over to the University, it was the first unit of campus housing acquired since Budge Hall was opened in 1899. A similar dormitory for NYA girls was planned and a University dormitory had been approved by the WPA when the relief program came to an end during the war. Other physical improvement projects included 'It was named after the faculty director of the training program, Louis G. Harrington, dean of the College of Engineering. The name was changed to East Hall in 1952 much general repair work, a complete renovation of the hydraulics laboratory, the construction of new sewers and heat tunnels, such landscaping work as a dam across the coulee, extensive planting of evergreens, and the improvement of the little campus golf course.

The engineering and radio improvements, joined by a wide variety of federally financed relief-research projects, were the most significant for the University in the long run. Although the operation of the radio station continued under the informal lease arrangement with Dalton LeMasurier until 1940 when KFJM was leased to him outright for ten years, with the University reserving its call letters and the afternoon hours from three to five on weekdays during the regular academic term, the new equipment and an increase of power from a hundred to a thousand watts gave the station a far wider coverage than it had before the improvements were made. ${ }^{10}$ The accreditation of the College of Engineering was directly related to the improvement of facilities and even more to the expansion in research activities under federal sponsorship. ${ }^{11}$ The engineering departments were among the chief beneficiaries of such grants as $\$ 138,000$ for a mineral resources survey and another for the systematization of the records of the Geological Survey. The federal programs revived interest at Bismarck-Governor Langer was a strong advocate of resources development researchand from the low point of $\$ 100$ per month allotted for lignite research by the Board in 1933 state appropriations rose to a steady $\$ 10,000-\$ 15,000$ per year after 1935 . The combined federal aid and state support were more by a wide margin than had ever been devoted to such purposes before. The period saw the development of new approaches to preparing lignite for industrial use-by drying and carbon activation-and renewed work with ceramic clays. Further assistance, and recognition as well, came in 1944 when the United States Bureau of Mines established a gasification pilot plant on the campus as part of a national fuel research program.

${ }^{10}$ According to the 1940 contract LeMasurier paid $\$ 250$ per month to the University to operate a commercial station, KILO, on the University wave-length. This agreement was renewed for three years in 1950, and for three more years in 1953 with the Grand Forks Herald, LeMasurier's successor as owner of KILO.

${ }^{11}$ When the department of chemical engineering was accredited in 1939, there was much local pride in its being among the first six of its kind to be approved west
of the Mississippi. 
Nearly every department in the University benefited in one way or another from the federal research or survey projects; some thirty-odd were approved between 1935 and 1938 alone, for such varied activities as a systematization of the records of the weather bureau, a sociological survey of the state, the mapping of votes on important issues in the United States House of Representatives, and analyses of the scores of North Dakota students on English placement tests. In the same period over $\$ 50,000$ was allotted for the support of a correspondence course program for Civilian Conservation Corps camps all over the country. In addition to their major purposes, these projects offered opportunities for a number of the faculty to supplement their meager salaries. Professors were also called in for temporary or part-time jobs in government agencies. Irvin Lavine of the chemical engineering department was consultant for the state planning board. Spencer Larsen, professor of marketing and merchandising, served as chief consultant to the state tax survey commission. Simpson's years of investigation of ground water resources were recognized in his appointment as principal water geologist for the Mississippi Valley Committee of the PWA and for the National Resources Board. He supervised the preparation of several studies of the Mississippi Valley area and one general review of the entire ground water resources of the United States. It may be added that the great expansion of the federal bureaucracy at Washington offered employment opportunities which cost the University several of its ablest men, one of them being Jacob Perlman of the sociology department.

Federal relief programs also provided a large part of the assistance available on the campus for needy students. The Federal Emergency Relief Administration employed more than one hundred students in the winter of 1933-1934. In addition, an emergency Civil Works Administration allotment shortly before Christmas gave ten days employment to three hundred more to enable them to earn their second semester fees. The launching of the National Youth Administration in 1935 provided employment, at $\$ 15$ per month, for about 10 to 12 per cent of the student body until the eve of the war. The NYA trade school program opened in 1940 added another forty students-later increased to 120 - to the campus.

Even so, the NYA fell far short of providing jobs for everyone who wanted one. In 1938 West reported to the Board that nearly 40 per cent of the men students, that is, not quite a third of the total enrollment, were totally self-supporting, and that 85 per cent of the men earned part of their expenses. West took a deep personal interest in the problem of making it possible for the student without funds to attend the University. The University employment service, begun a short time before he took office, was considerably expanded and its service extended to include an active yearly canvass for jobs in Grand Forks. Such gestures as accepting farm produce for fees or setting up trailer camp facilities on the coulee bank near Chandler Hall attracted some attention but affected only a small number, chiefly summer students, and teachers with families, for example. The most ingenious measure, and one that received wide publicity, was Camp Depression, a quadrangle of ten discarded Great Northern cabooses set up in 1933 directly east of the power house. Supplied with heat, light, and water from University mains, these accommodated about forty boys who cooked their own meals and earned their rent by working a few hours a week around the University. The plan worked so well that it was extended to Macnie Hall. Considerable local interest was aroused, and townspeople often brought out Sunday dinner for the Camp Depression boys, along with milk and other staples for the week following. One young man, Horace Carson, revived memories of the sod-house frontier when he "homesteaded" near the campus in his own tarpaper shanty.

Student loans or scholarships were a minor element in the total picture of student aids until relatively late in the depression. University funds available for loans never came to more than $\$ 40,000$. The only scholarship fund of any size-it was also the largest gift in nearly two decades-was the $\$ 20,000$ given in 1936 and 1939 by a successful engineering graduate, Charles Boise (E.M., 1908), then living in London. In 1937, on the initiative of Governor Langer, the Board of Administration borrowed $\$ 150,000$ from the Bank of North Dakota and distributed it among the colleges to be 
lent to students in amounts no larger than $\$ 300$ with interest at one per cent. Loans were to be repaid at the rate of $\$ 10$ a month after maturity, January 1, 1939, unless the borrower was still a student, when they would be extended for one year. The University quota was $\$ 35,100$, and 189 students received aid. All but a tiny fraction of these unsecured loans were eventually repaid.

From the standpoint of the ordinary citizen, the University seemed to come through the depression with little damage, and perhaps even with some added prestige, as for example when West was elected president of the National Association of State Universities in 1944. He was the first president of North Dakota to hold the office while at the University. Not only were there no wholesale dismissals of faculty, but the rate of faculty turnover was actually less in the 1930's than it had been in the preceding decade when jobs were comparatively easy for the young Ph.D. to find. All of the deans and most of the department heads inherited from the Kane administration remained through the depression and well into the war years. The period was marked by several significant academic achievements, not the least of which was the approval given to the College of Engineering by the Engineers' Council for Professional Development. Members of the history faculty produced three books: The Red River Valley, 1811-1849: A Regional Study, by John Perry Pritchett; The Foreign Policy of Czechoslovakia, 1918-1935, by Felix J. Vondracek, and an ancient history textbook by Clarence Perkins. With Pritchett serving as Libby's assistant editor, the quarterly publication of the state historical society achieved the highest level of professional quality in its history just before it was forced to suspend publication in 1933 Gottfried Hult, now a half-forgotten relic of the days of McVey and Merrifield, worked steadily at his Ibsen translations and his poetry. His translation of Peer Gynt received considerable attention in literary circles when it appeared in 1933. In 1940 he published his second book of poetry, Inverted Torches. (It will be recalled that he had been on the list of those to be eliminated from the University in 1932.) Henry Haxo, head of the department of Romance languages, published two French language textbooks which were widely used and an edition of The Man in the Iron
Mask. Irvin Lavine produced two chemical engineering textbooks and a steady stream of articles. A. V. Overn, who joined the School of Education faculty in 1930, published several works in his field. In the biology department, George Wheeler won professional notice for his studies of the ants of North Dakota, and Neal Weber for his work on the ants of Central America and Africa. The publications of Richard Beck included an edition of Icelandic poems and stories and contributions to a history of Scandinavian literature. In 1939 he was honored for his work by the governments of Norway and Iceland with knighthood in the Order of St. Olav and the Order of the Falcon. The appearance on the campus of the two most distinguished visitors in University history was related, in part at least, to the achievements of the University and its alumni. "Jefty" O'Connor arranged the visit on October 4, 1937, of President Franklin D. Roosevelt. Two years later Crown Prince Olav of Norway, on a tour of the United States, acknowledged the strong Norwegian element in the University as well as in the state by giving the commencement address and accepting the honorary LL.D. degree.

Another sign of well-being, or so it seemed, was the revived enrollment; from 1937 until the war the record set in $1929(1,826)$ was passed every year, although by no great margin; the prewar peak was 1,960 in 1939-1940. For the most part student behavior patterns were not greatly different from those of the 1920's. Although the flirting with communism and "fellow-traveling" that appeared on some campuses was absent at North Dakota, there were, to be sure, some notes of the dissatisfaction and cynicism of the times. Antimilitarism found its expression in sporadic agitation against the annual military ball and "Scabby Blade" and in the brief appearance of the "Sons of Future Wars." When in 1937 the state legislature, reflecting the neutralism aroused by the munitions investigations of North Dakota's Senator Gerald P. Nye, abolished compulsory ROTC at the University and the Agricultural College, enrollment in the program fell off by half or more. Yet in 1932, when times could hardly have been worse and campus interest in a national election was the highest in many years, Hoover won handily over Roosevelt $(380-256)$ in a straw vote contest. Norman 
Thomas got a mere 67, and no one else on the political left received any support at all.

Social and extracurricular activities, which had been cut back in the first shock of the depression, were revived vigorously in the middle 1930's. The fact that an important aspect of the student constitution of 1942 was an elaborate point system aimed at controlling overparticipation in activities speaks for itself. In 1937 the Dacotah returned to the annual schedule abandoned in 1933, and the books brought out on the eve of the war were the most elaborate that have ever been published. The Flickertail Follies came back in 1935 after a three year absence. (This long break was caused less by hard times than by faculty dissatisfaction with the way the show was conducted.) Thanks to the fact that both West and Letich stayed on, although their salaries were reduced as sharply as those of the academic faculty, the University enjoyed continued success in athletics. In 1939 West won his eighth conference football title in thirteen years; his teams of 1937 and 1938 were among the best in University history. Letich's basketball teams won four consecutive conference titles, 1933-1936. In 1936 the University's first Negro athletic star, Fritz Pollard of Chicago, became the first University athlete to win a place on the United States Olympic team. He placed third in his event, the high hurdles, at Berlin.

All the signs of normal operation and recovery notwithstand ing, the University suffered severely from the prolonged financial starvation that resulted from the abnormally slow economic recovery of North Dakota. As late as 1939 the total state appropriation for its nine colleges and schools was $\$ 2,321,000$, only a little more than half that for 1929. The figures of 1929 and 1931 were not equaled until 1945. The consequences could not help but be severe. West observed in a memorandum to the faculty in 1944

Our problem for the past ten years has been to preserve a staff for the University. In other words, it has been defensive rather than offensive. During that time no buildings of any consequence have been built, no During that tis he few adjustments to the changing needs of the state have been made.

Reducing the extension division to a bureau to administer cor- respondence courses serving mostly CCC camps outside the state, or to book high school commencement speeches for the faculty, meant in the larger sense a retreat from the gains that had been made since the days of McVey in developing a broad conception of the University as a vital factor in the life of the state. The elimination of funds for travel to professional meetings, combined with low salaries and the president's preoccupation with local recognition, produced an unhealthy academic isolationism over the years. The abandonment of the Quarterly Journal and the Law Review in 1933 in order to save a few hundred dollars a year removed major incentives for faculty publication. The loss of the Quarterly also eliminated "the backbone of exchange relations" for the library. The damage resulting from drastic economies in this department were irreparable. Book purchases fell from 1,671 volumes in 19301931, an acquisition rate that was even then only a little more than half that recommended by the North Central Association of Schools and Colleges, to a low point of 437 in 1934-1935. ${ }^{13}$ The 19301931 figure was not equaled until 1947-1948, when 1,697 books were purchased. The reduction in periodical subscriptions was comparable, and even more difficult to replace when funds were again available. The University's capacity to offer graduate work on any level was brought into serious question as a direct result. In 1944, for example, West reported to the Deans' Advisory Council:

we have taken a hammering from the North Central Association in the matter of our library. We are presumed to be in the lowest $10 \%$ of the universies doing grath the Board of Review is that they will decree that on graduate work must pause and be discontinued until our Library meets the standards. They have
threatened to do that on other occasions.

One of the most serious consequences of economy was the steady although slow and half-concealed attrition of the faculty, largely because of the extremely low salary scale. Already falling behind in the 1920's, North Dakota salaries were among the lowest

${ }^{13}$ In his report of 1930, William H. Carlson, head librarian, pointed out that the University book purchase fund had not been increased since 1922. (The Graduate Division had been created and doctoral level work begun in the meantime.) Carlson commented that the fund for books was "entirely inadequate to meet the rapidly growing needs of the University. Our book fund is, proportionally, far below that 
in the nation for state universities from 1933 until after World War II. In 1938, when the average salary of a full professor at North Dakota stood between $\$ 2,000$ and $\$ 2,500$ per year, the average scale in "large state universities" was $\$ 4,163$ for professors, $\$ 3,189$ for associate professors, and $\$ 2,592$ for assistant professors. West repeatedly urged salary increases, and the University chapter of the AAUP prepared several elaborate reports on the salary problem, almost its sole concern for nearly a dozen years. In his second inaugural address of 1937 Governor Langer recommended immediate increases in order to save the standards of North Dakota colleges, and three years later the new State Board of Higher Education declared in its first biennial report:

The most serious problem .... is the trying one of securing qualified members for the faculties. Young and inexperienced instructors can be found willing to serve for a year or two to gain the experience which will qualify them for better positions in other states. North Dakota thus bequalify them for better positions in other states. North Dakota thus be-
comes a springboard or a proving ground from which other states constantly recruit .... No reme fo. can immediately

Unable to hold permanently enough ambitious young scholars to replenish its normal losses by retirement and death, ${ }^{14}$ the University was forced to rely more than it should upon aging veterans past their prime and, when they inevitably passed on, to an increasing degree upon graduate assistants elevated to faculty rank. There were some permanent additions from the outside, men who would become faculty leaders, among them Wilson Laird (geology), Walter Kaloupek (political science), John Penn (speech), Elwyn B. Robinson (history), and Erich Selke and Conrad Kjerstad (education). The latter two, trained at Minnesota and Chicago respectively, came to the University from teachers colleges in the state; Kjerstad had been president of the college at Dickinson. But these men were not enough to offset the general trend, with the result that over the years the faculty developed a strong local character, a note of provincialism which had been almost nonexistent in the first half century of the University's history. (In

${ }^{14}$ Raymond Hitchcock and Joseph Kennedy died in 1937, Howard Simpson in 1938 and H. Foster Jones, a veteran of some twenty years in the English department, in 1940. Charles Christian Schmidt retired and Elwyn Chandler relinquished the chair- some quarters at least the development was not viewed unfavorably; on one occasion the AAUP chapter took note of the talk going around about employing only "state citizens" in state institutions.) Moreover the University failed to keep pace with other institutions in academic training and scholarly production of its faculty. In 1936-1937 when 49 per cent of the faculties of the public universities in the North Central Association held earned doctorates, only 30 per cent at North Dakota had them. Moreover, the rate of faculty publication was considerably lower at North Dakota than the average for members of the association. ${ }^{15}$

It was inevitable that questions about accreditation should arise. The School of Medicine, inadequately supported even before the depression, was in the most serious danger in its history after 1933. Following inspection by a committee of the Council on Medical Education and Hospitals of the American Medical Association, Dean French was informed in 1936 that his school "would no longer be recognized as an acceptable medical school, but without prejudice to the students then enrolled." Almost immediately after the publication of the report the Association of American Medical Colleges dropped North Dakota from membership. The 1937 legislature thereupon increased the appropriation for the school to about $\$ 30,000$ a year, or a little more than double the amount appropriated in 1935. It was enough to expand the faculty slightly and to purchase some essential equipment, but not enough to provide the additional space or new building that the inspectors demanded. The Council on Medical Education accepted the improvements, plus the elevation of the admissions standard to three years of college (it was temporarily reduced to two during World War II), as an earnest of good intent and gave the school probationary approval for one year; this was renewed on a year-to-year basis until 1951 when the school was finally returned to good standing. But it was abundantly clear at the end of the 1930's that the School of Medicine would be closed if it were not thoroughly reformed; the coming of the war provided a few years more of grace, but no escape from the final consequences. It may fairly be said that what ${ }^{15}$ Sixty-five percent of the faculty members in public institutions in the association published books or monographs between 1931 and 1936 . 
stood between the school and extinction between 1933 and the end of the war was the reputation that French, Saiki, and Talbert had built for good teaching. They could point with more than justifiable pride to the fact that, despite the deficiencies of their school, all of their graduates were accepted elsewhere for their last two years of training, that none failed to finish, and that a fair share graduated with honors. There has been no better demonstration of the validity of the Mark Hopkins and his log aphorism at North $\mathrm{Da}$ kota than the achievement of the School of Medicine, operating for years under the threat of being closed, with a biennial budget that fell as low as $\$ 21,000$ in 1933 and never exceeded $\$ 66,000$ until 1945.

In a number of other instances the University received notes of warning about its continued good standing. The department of chemical engineering lost its recently won approval in 1942. The School of Commerce was warned about inadequate faculty and library. The Association of American Universities expressed concern about the University's ability to hold up standards on a number of occasions. The most serious threat of all was the investigation of the University in 1938 by a committee of the North Centra Association of Schools and Colleges, its major accrediting agency, as a sequel to an earlier probe at the Agricultural College, which had resulted in that college's loss of the accredited rating it had held since 1916. The difficulties of the Agricultural College that preceded its loss of approved standing pointed up the constant hazard for all the North Dakota colleges in the highly charged political atmosphere of the 1930's, particularly under the control of the politically selected Board of Administration, and in the context of a steady agitation for consolidation of offerings. Indeed, several of the colleges felt these pressures before the Agricultural College. The president of the State Teachers College at Dickinson, Conrad Kjerstad, was forced to resign in 1936, and in 1937 the Ellendale Normal and Industrial School was extensively reorganized by the Board of Administration and five veteran faculty members dismissed. That same year, in July, the president of the Agricultural College, John H. Shepperd, was dismissed because of alleged mismanagement. On the same day that his resignation was announced, West was appointed acting president of the college, meantime continuing in the same capacity at the University.

One Board member at least, according to the Nonpartisan Leader, frankly declared that the purpose of the move was to bring about the long delayed consolidation of departments, ordered by the legislature in 1933, and the creation of the Greater University of North Dakota. But, whatever the merit of its intentions, the Board made the situation an almost impossible one for West by its simultaneous and arbitrary demotion or dismissal of seven ranking members of the Agricultural College faculty. Having no desire to become involved in a prolonged and possibly personally disastrous fight over the organization and control of the Agricultural College, West quickly announced that he looked upon his appointment as an interim arrangement, pending the selection of a new president, when the expected political controversy erupted over the Agricultural College affair.

Early in 1938 the Board of Review of the North Central Association of Colleges and Secondary Schools opened an investigation of the college, and when the association held its annual meeting at Chicago in April, its Commission on Institutions of Higher Education voted to remove the Agricultural College from its accredited list. The grounds given for the action were that the Board of Administration had interfered unduly in the internal administration of the college, that faculty morale had deteriorated at the expense of the quality of instruction, and that the legal structure and organization of the Board of Administration provided no assurance of stable or constructive leadership or of sufficient institutional autonomy. ${ }^{16}$ The latter point applied equally to all of the colleges, of course, including the University.

A companion investigation of the University was ordered at the same meeting of the association. A three-man committee ${ }^{17}$ spent three days in Grand Forks and Bismarck in May. Its decision was not announced until July; when it came, however, the Univer${ }^{10}$ The American Association of University Professors censured the Board of Adminis-
tration and sharply criticized Governor Langer, and, by implication, President West. ${ }^{17}$ Charles $\mathrm{H}$. Friley, president of Iowa State College, chairman; Thomas N. Berrows, president of Lawrence College; and $\mathrm{C} . \mathrm{H}$. Oldfather, dean of the liberal arts college, University of Nebraska. 
sity received a clean bill of health. The only criticism was of the "potential threat" from the Board of Administration. As an official opinion from a major accrediting association on the state of the University and the conduct of the West administration in a particularly trying time, the report is worth quoting at some length:

1. There is no evidence of undue interference by control agencies with the internal administration of the University ... . [The Constitution] has been highly regarded since its adoption, and is considered a definite safeguard against improper interference with internal academic procedure.

In several instances a vigorous stand and concerted action by the Faculty have successfully resisted attempts at improper administrative interference.

2. The morale of the faculty appears to be high.

There is definite stability in the staff-especially among deans and department heads.

There is fine cooperation between departments and colleges.

There is a strong sense of unity among members of the staff.

There is high respect and regard for the president of the University, and good cooperation throughout the institution.

3. Although ... . there has been no undue interference at the University, the set-up [in the governing board] in the opinion of your committee remains a potential threat to its stability and normal progress.

The trouble at the Agricultural College and the investigations were surrounded by a swirl of public controversy, made no less acrimonious when Governor Langer sought-unsuccessfully-to secure a federal court injunction to restrain the association from its disaccreditation action. Charges from the Board and the governor that the college had been mismanaged, perhaps even corruptly it was hinted, that it was the instrument of conservative Fargo businessmen, and that the disaccreditation had been arranged as a political maneuver to embarrass the Nonpartisan League, were countered by accusations that the governor and his "henchmen" had interfered in the college for partisan purposes and that their real intention was to get control of its extension division in order to use farm and home demonstration agents for political purposes.

It was in such terms, at least in part, that the voters were asked to approve in the June primary a constitutional amendment removing the colleges from the control of the Board of Administra- tion entirely and placing them under a separate Board of Higher Education and a commissioner. The change had been originally proposed in 1936, it will be recalled, in the report of the tax survey commission. The measure passed by a comfortable margin $(93,000$ to 71,000$)$. It provided for a board of seven members to serve terms of seven years each, one to expire each year. They were to be appointed by the governor, subject to approval by the senate, from a list of three names submitted for each position by the president of the North Dakota Education Association, the chief justice of the state supreme court, and the superintendent of public instruction. It will be noted that representatives of the public schools were to have the major role in choosing the Board members and that the colleges would have no representation at all. The members could be removed only by impeachment, and the constitutional status of the new Board guaranteed its independence from direct control or alteration by the elective branches of the state government; that is to say, the Board was "removed from politics."

In the meantime West- "our agile administrator" he was called in the Agricultural College Bison of 1938-initiated a revision in the Agricultural College constitution whereby the faculty gained a larger voice in college government, and in July he recommended that a president be chosen. Late in the month the Board of Administration announced the appointment of Frank Eversull, president of Huron College. Eversull applied for reaccreditation of the Agricultural College in December, but his plea was not granted until August, 1939, after the newly installed Board of Higher Education had complied with the condition that dismissed faculty members be reinstated. ${ }^{18}$

By this time the University had undergone and successfully passed yet another test. In the spring of 1939 the Phi Beta Kappa honorary society sent Dr. Raymond Walters, president of the University of Cincinnati, to investigate reports that "political interference and financial mismanagement" had produced serious deterioration of academic standards at the University. A major item was the Phi Beta Kappa suspicion that West was a political ${ }^{18}$ That same year, however, the four teachers colleges lost their standing in the 
appointee. No small measure of the credit for the favorable report which the University eventually received was due to the heroic efforts of Dean Bek. He marshaled hundreds of typewritten pages of evidence to demonstrate continued high academic standards of both faculty and students, and he explained at length that not Governor Langer nor the NPL but he himself, Gillette, Libby, Simpson, and Wheeler had been responsible for West's election in 1933. Bek also received strong support from Frank McVey, who had played a major role in installing the North Dakota chapter a quarter century before.

The establishment of the new Board marked the opening of a new era in the North Dakota colleges' relation to the state government, a relationship that has not been fully explored at this writing. The kind of internal difficulties that had plagued the University in the fifteen years before 1933 came to an end. Some of them had of course been traceable to the partisan nature of the governing board, which invited pressures from both faculty and president; it is only fair to add, however, that political interference had been more of an exception than a pattern, considerably less than was charged by the supporters of the change. The fact that the old Board was politically constituted made it an open target for the charge of "politics" from anyone who objected to its policies. Although separation of the colleges from politics was the point that was emphasized in the campaign of 1938, the really significant aspect of the amendment was the broad grant of power over the colleges that was conferred upon the new Board in the strongest possible language: $\ldots$ full authority $\ldots$ with the right $\ldots$ to prescribe, limit or modify
the courses offered at the several institutions. In furtherance of its powers, the State Board of Higher Education shall have the power to delegate to its employees details of the administrations of the porto delegate to control. The said State Board of Higher Education shall have full under its to organize or re-organize within constitutional shd have full authority to organize or re-organize within constitutional and statutory limitations, the work of each institution under its control, and do each and everything necessary and proper for the efficient and economic administration of said educational institutions.

The Board was also given full control over the college budgets and the expenditure of all of their funds, both those collected by the institution and those appropriated for it by the legislature.

Yet despite the great powers conferred, two significant limitations upon the Board effectively prevented its molding the higher educational system into a single unit: one was the restriction that curricular changes must be kept "within constitutional and statutory limitations," and the other was the requirement that funds collected or appropriated for one college must not be transferred to another. In short, the legislature retained the power to appropriate specifically for each college, which meant that the college system would remain in the area of local politics, still subject to intersectional and interinstitutional logrolling at every session of the legislature.

Nevertheless, the Board was vested with large powers to prevent duplication and to influence the development of the institutions under its control, a responsibility that was to be discharged under the expert guidance of a professionally trained commissioner of higher education. In the language of the amendment this official, to be chosen by the Board for a term of three years, "shall be a graduate of some reputable college or university, and who by training and experience is familiar with the problems peculiar to higher education." Owing to the continued need for economy, the search for a commissioner was postponed when the Board was formed in 1939. The work therefore fell upon the shoulders of the permanent secretary, Robert Murphy, and in 1941 he was given the official title. A graduate of the University, Murphy had been a public school superintendent in North Dakota and had served through the 1920's as a salaried member and president of the Board of Administration. In 1942, following a paralytic stroke, he was replaced by Albert F. Arnason, president of the State School of Forestry at Bottineau. Formerly head of the department of social science at the school, Arnason held both the B.A. and M.A. degrees from the University. ${ }^{19}$

The new Board, which held its first meeting in July, 1939, set out conscientiously to study the situation that confronted it. All the ${ }^{10}$ Arnason resigned in 1957 to accept the position of assistant to the dean of the
School of Medicine. 
colleges were visited and yet another inquiry into the matter of "duplication" was launched-it was not completed, however, because of the coming of the war. One of the Board's most significant decisions, made during the first year, was to turn away from the provincial emphasis, especially marked in the 1930's when the Nonpartisan League was in the ascendancy, upon educational training and research that would be immediately useful in the development of the state. For the first time a governing board recognized, publicly at least, that the colleges must train students for leaving the state to take advantage of opportunities elsewhere as well as for staying in it. The new approach was of particular importance to the University and its cluster of professional schools after the war.

Meanwhile, one of the first reforms effected-it was required by the amendment-was the adoption of a uniform accounting system in the colleges. Robin Dee Koppenhaver, of the University accounting department, was employed to make the installations. Other immediate problems to which the Board addressed itself were the securing of more financial support from the legislature, improvement in salaries and fringe benefits for the faculties, and the outline of a long-range building program; there had been almost no major construction at any of the colleges since the depression began. The change in temper was unfortunately not reflected in the legislature. In no instance were the new proposals accepted immediately, and some were rejected outright. Appropriations were raised only very gradually until after the war. An effort to increase student fees was contested in the courts. Although the Board won its case, the resistance itself was a warning to proceed with caution. The building plans were indefinitely postponed when the legislature refused even to permit the institutions to accumulate reserve building funds. It also rejected the Board's recommendation that the colleges enter the Teachers' Insurance and Annuity Association retirement program for their faculties. The Board itself postponed - permanently, it turned out-the implementation of the excellent sabbatical leave system that it adopted.

World War II was, of course, the chief reason that so many of the Board's efforts were thwarted or reduced to the realm of planning for an indefinite future. The University felt the first noticeable effects of the war in Europe in the term of 1940-1941 when, because of the 1940 conscription law, enrollment fell by about two hundred from the record figure of the year before. Until Pearl Harbor the drop was gradual, hardly noticeable, in fact, but thereafter the men students melted away. Only 775 regular students, most of them women, enrolled in 1943-1944 and 866 in 1944-1945.

Long before this point was reached, however, the defense and war training programs had transformed the University into a military camp. An engineering defense training program under the auspices of the United States Office of Education opened on the campus in January, 1941, with the arrival of the first contingent of 159 trainees. Continuing in one form or another until July, 1943, this school enrolled a total of 971 students before it was discontinued. The war training programs began in 1942. Between June and November the University provided classroom facilities, ground school instruction, and housing and board for a total of nine hundred Army Air Corps glider pilots. From July, 1942, to August, 1943, training facilities and housing were provided for a series of small contingents (about twenty in each class) in a civilian pilot training ground school under the Civil Aeronautics Administration. A Signal Corps prescience course in radio also began in July; 680 young men passed through this course before it closed in July, 1943. The University provided mess facilities but no housing for this group.

Early in 1943 the Army Air Corps moved in with the establishment of the 304th College Training Detachment with a complement of 750. The first trainees arrived in March and were housed in Wesley College and fraternity houses. By June, 1944, when this program closed, 2,500 students had passed through it. An Army specialized training program in engineering, also begun in 1943, and a preprofessional training program trained another 550 servicemen. There were in addition a small Army and Navy medical training group enrolling about forty each year after June, 1943, and a branch of the United States Student Cadet Nurse Corps enrolling about eighty.

This was no small direct contribution to the war effort. Nearly all of the faculty who remained on the campus became involved 
in one way or another in war training. The mathematicians, engineers, and scientists were most in demand, of course, but professors of literature, history, and even music retooled themselves or recalled half-forgotten courses from their undergraduate days in order to take over elementary classes in physics and mathematics. Professors served on the numerous boards and agencies that came with the war, and they and their wives contributed their share to the aluminum drives, the Red Cross, and so on; some, including the president, maintained active correspondence with students and alumni stationed all over the world who were eager for a word from their alma mater, a symbol of the happier days of peace and of their interrupted careers. Many of the younger faculty men were called away to military service or took jobs in defense industries and government service. The dislocations occasioned by military service were somewhat mitigated for those professors who held commissions in the Army or Navy reserves by the considerable differential in pay between, for example, the salary of a major and an associate professor. A number of the University faculty, among them the head of the English department, seized the opportunity to leave North Dakota or the profession of teaching entirely. Although state regulations required that servicemen be reinstated in their old positions, neither the Board nor the University administration developed a policy of absentee promotion and salary increases to enable professors in service to keep pace with those who remained at home. The Board in fact exerted some pressure upon the colleges to dismiss surplus faculty members when enrollments dropped, a policy which would have had more serious consequences than it did at the University had not West generally disregarded it.

The University's greatest contribution to the war effort was the training it had given in years past to the thousands of former students and alumni who served in their country's armed forces. One hundred seventy-two of them lost their lives.

On the other hand, the war was not an entirely ill wind for the University. It postponed the final decision on such serious problems as the disposition of the School of Medicine. The service training programs, combined with the loss of regular students, brought a financial respite; in the biennium of 1942-1944, when the pro- grams were at their peak, the state's expenditures for educational maintenance came to less than half of what had been appropriated. At the end of the fiscal year in June, 1944, the University had a surplus of $\$ 200,000$. Air Corps funds paid for a large permanent addition to the University Commons. In 1944 the United States Bureau of Mines allotted $\$ 300,000$ to the University for the study of gasification of lignite; $\$ 90,000$ more was added in 1946. The pilot gasification plant that was built on the campus with these funds was the forerunner of a large Bureau of Mines lignite laboratory erected adjacent to the campus after the war.

Perhaps the most significant effect of the war was that it provided the diversion which helped to break through the long conditioning in resignation brought on by the depression. The University's second experience with a war was marred by no such local tragedy as the flu epidemic or by the internal frictions that soured the taste of victory after 1918. A new and freer spirit found expression after 1945-an atmosphere of good feeling and deep pride in a great achievement and a revival of optimism that had not been experienced for a generation. 
PART THREE

THE NEW UNIVERSITY 1945-1958 


\title{
XI
}

\section{A New Day}

\begin{abstract}
$\mathrm{T}$
1 HE OPENING OF THE fall term of 1946 was perhaps the most memorable occasion of its kind since that September day in 1884 when the University welcomed its first students. War veterans alone numbered 1,550, a figure within a few hundred of the previous enrollment record of 1,960 set in 1939. The total enrollment exceeded that earlier mark by nearly a thousand, and in 1947-1948 the figure soared to 3,077, a record that stood until 19551956. Only partially prepared for the sudden flood of the beneficiaries of the GI Bill (Public Law 346), the University administration, the faculty, and facilities in general were very nearly swamped.

Ample warning of what was in store appeared in the accelerating enrollment of veterans in the term of $1945-1946^{1}$-enough to cause the Board of Higher Education and the college administrations to take steps to obtain temporary buildings and trailers, chiefly for student housing, from CCC camps and war plant areas. There was even some talk of moving grain bins to the campus. The 1945 legislature provided little help. It ignored the warnings and the pleas of the Board to increase appropriations for the emergency. The biennial provision for the University was only $\$ 1,135,000-\$ 31,000$ ${ }^{1}$ One hundred and sixty-five veterans enrolled in the first semester and 750 in the second semester.
\end{abstract}


less than had been appropriated in 1931. In view of the differential in operational and living costs and allowing also for the fact that $\$ 250,000$ of the money allotted was for a new medical building, the 1945 appropriation was little better than the disaster figure of 1933. Moreover, in 1945, the University was years behind in facilities of every kind, considerably more so than it had been in 1933 .

In the matter of student housing, the old stand-by, the Grand Forks householder who rented out one or two rooms, was no longer adequate or even available as the town struggled with its own bulging population and a twenty-year backlog of housing needs. The fact that about one fourth of the veterans were married, some with small children, made the usual University housing problem even more difficult. The need was met after a fashion by crowding students into every room available on the campus, by the hurried erection of CCC barracks, three large blocks of corrugated iron "hutments," and a trailer camp. The hutments were not complete and ready for occupancy, however, until the fall of 1947. Meanwhile, basement rooms and attics all over Grand Forks brought premium rentals. One professor, newly appointed, lived alone for months in a remodeled coal bin, while his wife and child remained with his in-laws. Another, with his family, occupied the warming rooms of the Winter Sports Building until the skating season opened, when he had to move to makeshift quarters in the basement of Macnie Hall. To many a veteran the crowded living of postwar collegiate life, the interminable lines at the overflowing Commons or the totally inadequate snack-bar in the Budge Hall basement, the only recreational facility on the campus, were all too reminiscent of the barrenness and discomfort of the military life he had just left.

The University also found itself in difficulties in the search for new faculty. West had contrived, more or less in spite of the Board, which had hoped to divest itself of unneeded personnel during the war years, to hold some men who might otherwise have left. Even so, the science departments suffered heavy losses, and the College of Engineering required practically an entire faculty. The end of the war and the years immediately following were marked also by the death or retirement of an unusually high per- centage of the men who had been among the mainstays of the University for many years, some since the days of Merrifield. (A new rule by the Board made retirement mandatory at the age of seventy.) Within a half dozen years after the war ended every college except law had a new dean, and a great many of the departments had new chairmen. ${ }^{2}$

Moreover, the flood of students, a large proportion of whom were freshmen, required the addition of new faculty as well as replacements-the faculty roll increased from 135 in 1941 to about 175 in 1947. Sixty-five of those listed in the fall of 1946 had been on the campus less than a year. Appointments were being made with almost desperate haste up to the day classes began in September, and salary schedules and ranks suffered considerably in the process. Latecomers with inferior or incomplete training often were appointed at ranks and salaries equal to or above those of men with advanced degrees and years of experience. In fact, the University would be a decade or more in correcting the consequences of the disruption of orderly personnel procedures and the inevitable errors that accompanied the hasty enlargement of the faculty.

However serious and almost insoluble the problems of those early postwar years, the sense of urgency brought to the campus a feeling of optimism and well-being that had been missing for nearly a generation. The new atmosphere was emphasized rather than diminished by such vexatious circumstances as the lack of housing, the shortage of textbooks, and the extended class and laboratory schedules beginning at seven thirty in the darkness of biting winter mornings and continuing through the noon hour and often into the night. The symbol of the change was the ex-GI, noticeably older than his nonveteran classmates and easily identifiable by the articles of military clothing that pieced out his wardrobe. Looked upon at the time as a temporary phenomenon, the veteran remained an important element in the campus population for more than a decade. There were never fewer than a thousand

'William E. Budge, professor of ceramic engineering and associated with the University since 1911, resigned in 1943 because of ill health. Libby retired in 1945, and C. A. West and Roy Wilson, registrar since 1928, resigned. Abbott, Schonberger, and Towne retired in 1948, and Margaret Cable (ceramics) in 1949. Chandler and in 1948, Harrington in 1949, and Breitwieser in 1950 . 
enrolled until 1950-1951, and the last beneficiary of the World War II GI Bill was on the rolls in 1957-1958. The Korean veterans, benefiting from their own bill (Public Law 550), made their appearance in 1952-1953, and in 1956, the peak year for this group, there were 888 enrolled.

The veterans were a major factor in the changing character of the student body. The fact that many were married, or married while at the University, broke down the long-standing and semiofficial prohibition, and prejudice as well, against the married student. Increasing numbers of the nonveterans, albeit still a relatively small number, came to the University with wives or husbands or, more likely, married before they graduated. In 1957, 24 per cent of the men, 16 per cent of the women, and 46 per cent of the veterans were married. The University tacitly recognized the permanence of the phenomenon in 1956 when it shifted the hutments from the temporary Park Village site to its own land across the coulee, West Green, and began erecting permanent apartments in the area.

Equally noteworthy and likewise related to the presence of the veteran was the change in student behavior. The enthusiasms, the competitiveness, and the faddishness that were so much a part of the 1920's and even the 1930's disappeared or were considerably toned down. Many of the traditional collegiate activities, such as queen and popularity elections, continued in the postwar era, but more likely than not with a tongue-in-cheek note and at times in full burlesque. The "ugly" and "dream" man contests are examples. Forensics was popular only with the few who participated. The one major student activity dating from the 1920's that continued unabated was the annual Flickertail Follies. The show reached new heights in elaborateness (1957 box office receipts came to more than $\$ 8,000)$. Frequent criticisms from the faculty produced several efforts to curb the months-long preparations for the show, but it was not until 1957, following a thorough study of Follies' practices and finances, that anything concrete was accomplished. The Ad ministrative Committee approved a strict new code of rules including the reestablishment of the Follies managers' accountability to the University business office for the funds collected. The half- expected student protest failed to materialize; indeed, by 1957 the mainstays of the show, the Greek letter societies, were themselves objecting to the excessive time devoted to the annual performance. One new campus event made its appearance, the King Kold Karnival celebrated in conjunction with the Minnesota-North Dakota hockey series in February and featured by competitions in ice sculpture and the election of a queen.

The hazing that had been so enthusiastically practiced by the veterans of 1919 did not interest those of 1946, partly because of the blurring of distinctions among the undergraduate classifications that accompanied the mid-year or summer enrollment of undergraduate veterans, and the University's own arrival at maturity. One of the University's oldest traditions, the Carney Sing, came to an end in 1953, shortly before the death of Carney himself, because its competitive basis, interclass rivalry, no longer existed. Class organizations disappeared entirely, except for the seniors' election of officers to head their alumni group. The change, already more or less recognized by the University in the shift of representation on the Student Council from the basis of classes to residence halls, was formally confirmed in a new student constitution approved in 1957.

A related phenomenon was the changed relationship of the fraternities to the general student body. The frankly expressed class consciousness of Greek versus barbarian disappeared, or at least any such conviction was concealed in the atmosphere of the 1950's. The Greek letter societies enjoyed a considerable revival of prestige following the passing of the mature veterans of World War II, many of whom had little interest in the societies' activities or pretensions. The future of the fraternities was by no means certain, however, because of the altering relationships of the University itself to the student body in the mid-1950's. Four new dormitories and a new student union complete with bowling alley, coffee bar, and lounges provided living accommodations and recreational and social facilities far superior to what the crowded and no longer new chapter houses could offer.

School spirit likewise showed signs of undergoing change in the postwar years. The drum majorette, dating from the 1930's, 
still carried on, but the cheer leaders and pep organizations that had been so conspicuous in the era following the First World War declined in importance, at least temporarily, in the era of the GI. Varsity athletes were far less conspicuous than formerly, a change symbolized by the more subdued tones of the varsity sweater or jacket and its declining popularity for general campus wear. The University student of the 1950's appeared to have become somewhat more objective than his father had been about the teams that bore University colors and more likely to regard intercollegiate contests as spectacles and entertainment rather than the real stuff of University life. Whether this was a manifestation of a new intellectualism, the indifference of the veteran with a family and career to worry about, or a reflection of the ennui and cynicism, the conformity and complacency of a "beat generation," was not clear.

The capacity for crusading appeared also to have gone the way of the trivial-or youthful-enthusiasms of an earlier day. The revival of compulsory ROTC and the addition of an Air Force ROTC unit aroused not a single murmur in a student body drawn almost entirely from a region allegedly isolationist and pacifistic. The orthodoxy in politics and religion that had always marked the North Dakota campus, although not always the state, was even more marked after the war than before. It might perhaps be better to say that these students of the 1940's and 1950's were conformist rather than orthodox. More unanimously than ever they professed the correct attitudes and memberships, yet somehow were actually less involved and more aloof. The disappearance of the YMCA and the decline of the YW, both of them student-run, were signs of the time. The concern of the University as well as of various church organizations was manifested in the support given to the annual Religion and Life Week and in the growing importance of denominational religious foundations. ${ }^{3}$ Two of them completed expensive new buildings after the war.

Yet there were signs that the changed student behavior of the 1940's and 1950's might be only an interlude. The University's success in its new postwar sport, intercollegiate hockey, induced an enthusiasm reminiscent of the days of Letich and West. A new ${ }^{8}$ Episcopal, Lutheran, Newman, Wesley, and the Student Christian Fellowship. pep organization, Golden Feather, formed in 1956-1957, met with some favor, particularly among the freshmen. Migration days for athletic contests with the Agricultural College were still a strong tradition, and with the development of hockey the custom was extended to the annual games with the University of Minnesota at Minneapolis. In many respects the North Dakota students of the 1950's still had much in common with those of a half century before. Although one might carp at the complacency and lack of intellectual curiosity that were indicated in their slow response to the opportunities provided by the Fulbright scholarships and their reluctance to buy any books except the required texts and laboratory manuals, potentially better student material would have been hard to find. Above average size, blooming good health, and a Nordic handsomeness revealed the Scandinavian ancestry of so many of them. Even in the days of mass communications, the automobile, and the opportunities for extensive travel afforded by general military service, the North Dakota students still retained some of the simplicity and straightforwardness of their rural and small-town upbringing that had endeared their predecessors to Merrifield a half century before. Such virtues could not be lightly dismissed, even if they did perhaps exist at the expense of some of the intellectual ferment so vital to an institution devoted to study and inquiry.

These postwar students were better off financially than those of earlier years. A great many had automobiles, often new ones, and the informally well-dressed student was the rule (even the student without much money rarely showed his lack in his appearance). This was a reflection of the return of good times and the flourishing condition of North Dakota agriculture. At the same time working students were still very much in evidence, in a greater proportion than in most institutions. In $1953-1954$ only $71 / 2$ per cent of the men and 15 per cent of the women paid none of their expenses, and nearly 30 per cent of the men and 15 per cent of the women earned everything they spent. Often they worked because their parents believed it was the thing to do or because they themselves refused to sacrifice any comfort or pleasure in order to have time for reflection or study. 
A significant aspect of the postwar campus atmosphere was the decline of University fortunes in the two major sports, football and basketball. In the dozen years after the war the University rarely rose above mediocrity in either. The death of Letich and West's resignation in 1945 truly marked the end of an era in University sports history. The University failed to finish first in football a single time after West departed. Coach Louis Bogan, a former University basketball star who joined the athletic staff in 1950, did manage to win one basketball championship and to maintain respectable standings most of the time. A huge new fieldhouse, the University's first really adequate gymnasium, erected at a cost of more than a million dollars, served less to attract star players than to emphasize all too sharply the shortage of spectators. Part of the trouble was the increasing difficulty of attracting experienced high school players without some regular program of financial aid, that is, the athletic scholarship. In 1956 a new phase in North Dakota intercollegiate athletics was begun with the announcement that the Alumni Association and the Grand Forks Chamber of Commerce would each contribute to athletic scholarships for football, basketball, and hockey. A new football staff, headed by Marvin Helling, formerly a successful high school coach in Minneapolis, was appointed in 1957; Helling was the fourth football coach since the war.

Waning student enthusiasm for the old favorites of a half century was, of course, also a product of the spectacular success of intercollegiate hockey, which appeared for the first time after the war. A varsity team, coached by John Jamieson, a student, was formed in 1946-1947, but it was not until the following year, when Don Norman, a graduate student in physical education, took over the coaching, that intercollegiate play actually began. That year the University more than held its own with a 6-4 record against such powers as the University of Minnesota, University of Michigan, Michigan Technical College, and Colorado College. Although the unheated and drafty Winter Sports Building could be exceedingly uncomfortable for spectators, the enthusiasm aroused was far beyond the expectations of even the promoters, among them Red Jarrett, appointed director of athletics after the war. Norman coached two years. He was succeeded by Clifford "Fido" Purpur, a native of Grand Forks and a former National Hockey League star. Although Purpur's teams won no championships in the newly formed Western Intercollegiate Hockey League, ${ }^{4}$ which the University joined in 1947, the sport was firmly established as the major one at North Dakota and the University as a major hockey power in the seven years he coached. Most of the varsity players were recruited from Canada, the pattern throughout the league, but the rank and file of the student body took up the game in the form of overshoe hockey played at odd hours on the coulee or the flooded front yards of fraternity houses. The selection of a new coach in 1956, following the resignation of Purpur, attracted considerably more attention on the campus and in the local papers than the appointment of a dean a year later. The University schedule of 1957-1958 included twenty-nine games, a number of them extraleague contests with Harvard, the United States National team, and several independent teams from Winnipeg. Long before the season opened the University confidently looked forward to attracting $40,000-50,000$ spectators to its home contests; early in the season 1,800 turned out to witness an intersquad scrimmage. The discovery of a sport in which North Dakota could hold its own in the big time was a morale factor not to be lightly discounted, and the hockey teams were in their way symbolic of the rising optimism and self-confidence that characterized the University as a whole after 1946.

Equally important as a sign of the better times was the renewed vigor of the Alumni Association. During the depression alumni support had been limited mainly to sentiment, and at times not much of that, for example when the memorial corporation pressed for payment of overdue stadium pledges. During the war the alumni magazine suspended publication, and Frank Webb, director of alumni relations since 1930, resigned in 1945. His successor, appointed later the same year upon his return from war service, was J. Lloyd Stone, a former school superintendent and NYA director for North Dakota. Stone shifted the concept of the association from a dues-paying organization charging a subscription ${ }^{4}$ The University of Michigan, Michigan State University, Michigan Technical Col-
lege, University of Minnesota, Colorado College, University of Denver, and North Dakota. This conference broke up in 1.958 
fee for its monthly magazine to one of automatic membership for all graduates, with a free subscription to the Alumni Review, news sheet issued ten times yearly. A University Development Fund was incorporated in 1946.

A significant aspect of the postwar Alumni Association was the somewhat broader approach in its relation to the University than had been characteristic in the 1920's, when it had previously been most active. Then it had been concerned almost exclusively with the development of athletic teams and the facilities to accommodate them. To be sure, the association continued to encourage athletics after the war through such means as the athletic scholarships and the contribution of $\$ 20,000$ in 1953 toward the $\$ 75,000$ necessary to install an artificial ice plant in the Winter Sports Building and several thousand dollars in 1954 toward the cost $(\$ 83,000)$ of completing a swimming pool in the new fieldhouse. A major project undertaken by the association was its fund drive for a student union as a World War II memorial. Grants from the Development Fund and other gifts supplied the $\$ 150,000$ required as the initial pledge for the $\$ 350,000$ in bonds authorized by the legislature in 1947, under the provisions of an act passed that same session permitting the construction of buildings by self-liquidating building corporations. Alumni both inside and outside the legislature gave invaluable support to the bonding measure. The Memorial Student Union was completed in 1951. A major contribution to the Development Fund was John Hancock's gift in 1952 of $\$ 50,000$, which was to be spent over a period of five years in whatever way seemed best for the general improvement of the faculty. The first such benefaction in the history of the University, it was a gesture of gratitude toward those men Hancock revered as the great teachers of his University days-Merrifield, Macnie, Brannon, Squires, and Thomas.

Alumni also played an important role in the successful postwar campaign of the Board of Higher Education and the state college presidents to secure substantial appropriations for buildings and for operations. The need was obvious and great; even in 1945 when the legislature turned a deaf ear to the pleas of the Board and Governor Fred Aandahl (B.A., 1921) for large increases, it acknowledged the threat hanging over the School of Medicine by appropriating $\$ 250,000$ for a new science building and passing an act to create a state medical center as an administrative arm of the University. The center, supervised by an advisory council of nine, three of whom were to be appointed by the governor and six to be selected by the various agencies and organizations in the state concerned with health and welfare, was charged with the tasks of forming plans for the improvement and maintenance of health in North Dakota and particularly of studying ways and means to provide an adequate and permanent supply of doctors and nurses for the state.

The medical center act had its origin at the spring meeting of the Alumni Association in 1944. Presided over by a newly elected president, John Page, a professor of education at the University, the executive board of the association decided to make the improvement-in fact the salvation-of the medical school its project for the year. The committee ${ }^{5}$ appointed to prepare a concrete proposal recommended the creation of a state medical center, a somewhat vague administrative concept, but one which had the merit of drawing support for the medical school from a wide variety of sources. Harold Shaft, a Grand Forks lawyer and alumnus, drew up a bill, which was substantially the one approved by the 1945 legislature.

Work on the medical science building approved in 1945 was not begun immediately, owing first to the shortage of labor and materials and then to the higher priority of providing temporary housing and a teaching force to serve the flood of veterans. Before the legislature of 1947 met it was obvious that more money was necessary to provide an adequate building. In the meantime, under the stimulus of the extraordinary postwar prosperity and continued good crops, public temper shifted from habitual caution to an expansiveness not present since the First World War. With respect to the state colleges, the change of mood was reinforced by the spectacle of their obvious need for plant expansion and the repeated urgings from the Board of Higher Education; the Board had, in fact, campaigned for a construction program from almost the first ${ }^{5}$ Dr. C. R. Tompkins, Grafton, was chairman. Other members were Dr. Richard
Leigh, Dr. E. L. Grinnell, Dr. W. C. Daily, J. Earl McFadden, Armin F. Rohde,
Harold Shaft, and Loyde C. Thompson, all of Grand Forks. Harold Shaft, and Loyde C. Thompson, all of Grand Forks. 
year it was formed. As a result, the 1947 legislature ushered in a "new day in North Dakota" for higher education. The total ap propriation for the colleges came to nearly $\$ 9,000,000$. The University's share for operational expenses alone was $\$ 2,400,000$; an addi tional $\$ 420,000$ was appropriated for the medical building and its equipment, $\$ 600,000$ for a gymnasium and fieldhouse, and $\$ 61,000$ for additional veterans' housing. The session also enacted legisla tion, largely sponsored by University supporters and alumni, to permit the colleges, on specific permission from the legislature in each case, to form corporations empowered to bond themselves against the pledge of anticipated revenues to construct such income producing buildings as dormitories. ${ }^{6}$ The University student union, for which $\$ 350,000$ in bonds were voted at this session, came under the self-liquidating provisions because the proceeds of a $\$ 5.00$ per semester fee collected from each student would be used to retire the debt. The students had voted to accept the assessment in 1946.

The legislature also submitted to the voters a proposal to levy a four mill special tax to provide a building fund for the colleges and another one mill tax for the medical center, proposed by the newly formed Medical Center Advisory Council. In the fall campaign of 1948 the construction levy failed of approval, but the center's levy carried by a majority of 23,000 votes, thanks to the fact that hardly a month before the election some of the friends of the University came forward with a few thousand dollars to finance an educational campaign, which was presented by pamphlet, press, and radio as "Vote Yes for More Doctors." The Alumni Association played an important role in the drive, and in the years that followed no branch of the University enjoyed half so much attention in the Alumni Review as the revived School of Medicine. Underlining the widespread concern aroused by the shortage of physicians in rural areas was the fact that the two leading supporters of the medical school in the state senate were E. C. Stucke, a physician from Garrison and an avowed socialist, and Joseph B. Bridston, a conservative businessman from Grand Forks.

The 1949 legislature also appropriated heavily for college build-

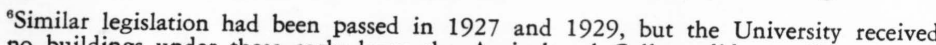
no buildings under these early laws; the Agricultural College did actually construct ings. The $\$ 3,270,000$ approved for the University included $\$ 325,000$ to complete and equip the gymnasium, $\$ 400,000$ for an engineering building, $\$ 75,000$ to pave and reroute the campus drive, and $\$ 92,000$ for a steam line to a new United States Bureau of Mines lignite laboratory. An appropriation of $\$ 3,675,000$ two years later included $\$ 480,000$ for an education building to replace Woodworth Hall, which had burned in $1949, \$ 400,000$ for a power plant, and $\$ 40,000$ for engineering equipment. The new medical building was more than doubled in size in 1953 with the completion of a wing paid for out of the proceeds of the medical center mill levy. The legislatures of 1953, 1955, and 1957 made no major appropriations for University buildings except for $\$ 37,500$ for the radio station and television equipment and $\$ 47,500$ for a new president's residence.

After the 1947 law had been defined more sharply by additional legislation in 1949, the self-liquidating measures permitted, in addition to the issuance of the $\$ 350,000$ in bonds for the student union, bond issues totalling $\$ 1,600,000$ for three men's dormitories, the first of a planned quadrangle of four buildings on a tract north of University Avenue that had been bought from Wesley College in $1946 ;^{7} \$ 850,000$ for two women's dormitories, the first of a planned group of three set just west of the old president's mansion in the area where the first athletic field had been; and $\$ 297,000$ for forty-one permanent brick apartments for married students and faculty. These, together with the hutments moved from the vacated Park Village site, formed the new West Green area and shared with the president's residence, completed in 1956, the distinction of being the first permanent University structures on the lands west of the coulee. In 1957 supervised housing available at the University included accommodations for 592 men, 311 women, 193 married students, and 37 faculty in University apartments and dormitories; 110 students in Wesley College; 332 in eleven fraternities; and 178 in seven sororities. New accommodations also included two cafeterias, one in the union and the other in a new men's dormitory. The old Carnegie Library-Commons was remodeled a third time to accommodate the department of home economics, which had ${ }^{7}$ The University received another valuable addition to its campus area that same
year, a 160-acre tract lying north of Wesley College, bequeathed in the will of Judge Harrison Bronson, the University's first M.A. (1895) 
been housed for years in the Davis Hall basement. The construction of student housing was an entirely new phase of University building which had considerable effect on students' relations to the University by making them increasingly dependent upon University facilities and hence more subject to University controls. Results of this development were the steadily expanding functions of the dean of women, the revival of the office of dean of men, and the creation of two new offices, director of University housing and director of the student union.

Other major new structures in the University area occupying a semi-official relation to the University were the $\$ 750,000$ Charles E. Robertson lignite laboratory of the United States Bureau of Mines, completed in 1951 on a site donated by the stadium corporation, and the buildings of the Newman and Lutheran student foundations. One new fraternity house was erected, by Theta Chi, and the old house was converted into an Episcopal student center. A large Catholic hospital, St. Michael's, was erected in the University area, a choice of site influenced by the anticipated expansion of the medical school to a four-year program.

The total effect was revolutionary. The amount of space available was more than doubled in the postwar decade, and the total valuation of the University property, estimated at about $\$ 2,000,000$ in $1939-1940$, was $\$ 17,000,000$ by 1957 . The shabby, threadbare University of 1946 had been transformed, almost overnight it seemed, into a shining new one. Most of the temporary or under-construction look of the early postwar years had also disappeared by 1958, although there still remained, half-hidden between the quadrangle and the fieldhouse, the corrugated iron hutment area of Tennis Village, the barrackslike veterans' apartments, and the three temporary wooden structures occupied by the University Press, the Geological Survey and department of geology, and the industrial arts department. The strict adherence in the new construction to the Tudor-Gothic stone-trimmed red brick style introduced by $\mathrm{McVey}$ drew some criticism from those who favored a more functional and contemporary architecture, but the campus had at least achieved the completed quadrangle and the harmony that McVey had envisioned forty years before.
The extensive building program, along with the rise in enrollment, the new winds of educational doctrine, the substantially enlarged faculty - up to nearly 250 by 1958 - and the greatly expanded financial support, all combined to produce a companion expansion in the curriculum and some marked changes in its content and emphasis, particularly in the areas of science, technology, and vocational or professional training. Other fields were affected too, however. On a single occasion the Council was asked to approve 123 new courses or course changes, nearly all in the departments of psychology and sociology, both of which had come under new leadership. West observed in a memorandum to the Administrative Committee in 1948 that the catalog was "getting out of hand both as to size and as to cost" and recommended a number of revisions and deletions. On several occasions the Board and Commissioner attempted to curb what they considered an unnecessary expansion of offering.

The most spectacular changes occurred in the School of Medicine, supported by an annual income of more than a half million dollars following the approval of the mill levy in 1948. The first phase of the school's transition was accomplished under the guidance of Dr. Wilbur F. Potter, appointed dean in $1948 ;{ }^{8}$ French had retired from administrative duties because of his age. In 1953, after five years of teaching combined with extremely arduous executive work, Potter resigned the deanship to devote his full time to teaching, his first love, and the headship of the growing department of physiology and pharmacology; he had been head of the department of physiology at the University of Mississippi for fifteen years before coming to North Dakota. Potter's successor as dean was Dr. Theodore $\mathrm{H}$. Harwood, formerly associate professor of internal medicine and assistant dean of the University of Vermont medical school

When Potter came in 1948 he found a faculty of only four, including himself, laboratories and classrooms limited to two floors of the old Science Building, and a library of 2,400 books, 3,000 bound journals, and 85 subscriptions hidden away in an upstairs balcony in the main library and accessible only by obtaining a key ${ }^{9}$ Alfred Lawton, who succeeded French when he retired in 1947 following an un interrupted tenure of thirty-six years, remained only one year. 
from the head librarian. By 1957 the school occupied the most expensively appointed and the second largest building on the campus. It contained a virtually new library of 7,200 books and 300 periodical subscriptions requiring the services of two full-time librarians and two part-time assistants. The full-time faculty had grown to twenty-three, with numerous graduate assistants, clerks, and secretaries. A graduate program, the first in the history of the school, was begun in 1948 in all the major departments: anatomy, bacteriology, biochemistry, pathology, and physiology. Anatomy and biochemistry each conferred its first Ph.D. in 1955; the first in physiology-pharmacology was conferred the following year. The department of pathology established a residency program and attracted its first resident in 1955. A division of nursing was established in 1947 and a department of medical technology in 1949. A chapter of the Phi Beta Pi honorary medical fraternity was installed in 1948. In accord with the intent of the medical center act, such established public services as the Public Health Laboratory and the state blood bank, the latter dating from the war, were expanded and several new ones added, among them a tissue diagnostic service. In 1956 the Medical Center provided funds for an out-patient treatment and diagnostic rehabilitation center adjacent to the medical building; a matching grant, bringing the total funds available for construction and equipment to $\$ 350,000$, was obtained from the United States Department of Health, Education, and Welfare. The building was completed in 1957. Another development looking forward to the expansion of Medical Center services was the action of the 1957 legislature authorizing the use of $\$ 600,000$ of Medical Center funds for a state tuberculosis hospital at the University provided that matching federal funds could be obtained under the terms of the Hill-Burton Hospital Construction Act.

The University could point to considerable progress toward discharging the promise of "Vote Yes for More Doctors." The number of practitioners in the state rose from 335 in 1946 to 430 in 1956. The four-year school, which according to legislation enacted in 1953 was to be in full operation by 1956, had not materialized by 1958 , however, and it was not known when, if ever, it would. Increasing numbers of the general public, as well as the physicians, realized that in addition to the prodigious cost of a four-year school, a major obstacle was the absence of adequate supporting clinical and hospital facilities in Grand Forks, or anywhere else in North Dakota for that matter.

The College of Engineering came under new leadership in 1949, following the death of Harrington. His successor, Elder Lium, was an alumnus who had joined the department of civil engineering in the 1930's after a dozen years of private practice in his profession. Benefiting from the general prosperity with its attendant high demand for engineers, the college grew rapidly. By 1957 engineering had become one of the most conspicuous branches of the University in terms of the space it occupied-Babcock and Chandler halls dating from prewar days, the pilot gasification plant installed during the war, the new Harrington Hall completed in 1952, and the Robertson lignite laboratory of the United States Bureau of Mines. For the first time in the history of the college, all of the departments were well equipped, largely because of the opportunities to acquire war surplus items. About $\$ 100,000$ worth of such materials was added in 1945-1946 alone, and in 1948 the college report noted with satisfaction the "most liberal" state appropriation and the "almost limitless" war surplus and other training facilities available. It was a development that Calvin Crouch would never have believed possible. Five departments were accredited, the department of chemical engineering having recovered its standing in 1951. Enrollments shot up from 281 enrolled and 34 degrees granted in 1939-1940 to 819 enrolled and 88 degrees in 1956-1957. As a result of the discovery of large oil resources in the state, a petroleum engineering program was begun in the department of mining engineering in 1954. The first doctoral program, a cooperative offering in fuel technology arranged between various departments of the college and the Robertson laboratory staff, was announced in 1949; the first Ph.D. was conferred in 1951. Graduate work in engineering, however, was not yet fully developed by 1957; only seven master's degrees and no doctorates were conferred that year.

Rapid turnover in faculty, a product of the demand for engineers in industry, presented many problems, but it also eased the numerous revisions of program called for by the rapid developments 
of modern technology. By 1957 the curricula of most of the departments had been extensively revised. The steady pressure to add more technical courses to the program and the increasingly sharp insistence from the Engineers' Council for Professional Development that up to one fourth of the program for a degree be made up of courses in the humanities, social sciences, and the like were pushing the college toward a five-year course, a step that would be easier to take if the competing departments at the Agricultural College could be persuaded to take it at the same time.

The most marked change of all in the engineering college occurred in the department of geology, separated from geography and transferred back to engineering from the liberal arts college in 1942, the same year that Wilson Laird became department head. In 1948 the geology department and the Survey were moved from the basement of Merrifield Hall to a temporary wooden building on the east side of the campus. The program was enlarged the next year to offer a professional B.S. in geology degree, and in 1957 a B.S. in geological engineering was added. Enrollment meanwhile climbed from three students majoring in geology in 1940, to thirty in 1948, and 105 in 1957. A major factor in the rapid growth of this department was the attention drawn to it by the discovery of oil at Tioga in 1951 and the subsequent developments which revealed that the entire western half of the state possessed untold riches in oil.

The Geological Survey was affected even more, for it was catapulted immediately to a position of major importance to the state at large. It received considerable public attention in its role as the technical advisory body of the State Industrial Commission for the regulation of the new oil and gas industry. In 1957 the legislature appropriated $\$ 330,500$ for the Survey, by then grown into an agency of twenty full-time and nine part-time employees, operating a fleet of nine cars and trucks. An additional appropriation of $\$ 37,500$ was made for the ground water investigations work, which had been transferred to a separate State Water Commission in 1945. The role of the Survey in 1957, when it had become one of the University's most conspicuous instruments of public service, was in considerable contrast to its position in the days when Leonard was forced to get along on $\$ 1,000$ per year, or even so recently as only a decade before when the biennial appropriation was only $\$ 18,900$.

An immeasurable and indeed an only half-realized aspect of the oil discovery was its contribution to the return of optimism in North Dakota and in the University. Although the proportion of total annual income in the state that came from oil $(\$ 30,000,000)$ was small compared to that derived from agriculture $(\$ 600,000,000)$, the announcement that there was oil in North Dakota and the continued discovery of new fields revived the romance and glamor of the days of the Dakota boom and the bonanza farms. The state seemed to have found at last that mineral resource for economic diversification that had been sought so long and with such disappointing results in lignite.

There were changes in the other colleges also, although less spectacular than in medicine and engineering. With the exception of the revival of the department of industrial arts under a new head, Marvin Poyzer, a University graduate, changes in the School of Education were few until the 1950's. They resulted then, in part at least, from two major accidents-one was the loss of Woodworth Hall by fire in the spring of 1949 and the other the death of Breitwieser in a plane crash at Minneapolis a year later. For nearly six years after the Woodworth fire, the classrooms and offices of the School of Education were scattered in various buildings over the campus. When the new Education Building was completed in 1955, it contained several features, including a small auditorium, which made it one of the most attractive structures of the University.

A considerable part of the credit for the merits of the new building, as well as some of the blame for several conspicuous faults, belongs to Garold Holstine, appointed as Breitwieser's successor in 1951. Formerly director of student teaching at the University of Oklahoma and ambitious to make a reputation in his first effort as a dean, Holstine was an aggressive innovator, and a not always tactful one, who on several occasions managed to cause considerable stir on the campus. Revision and reorganization of the School of Education offerings began soon after his arrival. New library courses for public school teachers were added, along with a 
program of audio-visual education. His efforts to revive the elementary curriculum, relinquished years before to the teachers colleges, were not immediately successful. (The Board approved its reestablishment in 1958.) In 1952, on the urging of Holstine and West, and despite considerable opposition from the College of Science, Literature, and the Arts, the school was designated as the College of Education by the Board. Although the move was defended on the ground that such was the intent of the founders as stated in the organic act of the University (which of course it was not), its real purpose was to control the advisement of freshmen and sophomores planning to take a degree in education.

Most of the expansion in the education offering was on the graduate level. Fourteen M.S. in Education degrees and one Ed.D. degree were awarded in 1946-1947. Ten years later there were nine of the former (requiring a thesis), six doctorates, and fifty M.Ed. degrees (requiring no thesis), the latter begun in 1951. Members of the faculty undertook such public services as surveys of public school systems, and several graduate teaching centers served by members of the faculty on weekends were established around the state, a revival of a type of extension work that McVey had planned to develop. (Until West's retirement University extension work in general continued on the limited depression scale of offering courses by correspondence and booking high school commencement addresses for professors.) Holstine also brought to the campus the annual summer Institute of Linguistics of Glendale, California, for an eleven-week session of advanced courses. This program affected the regular summer students very little, but its faculty and students, many of them missionaries drawn from all over the world, added a welcome note of cosmopolitanism to North Dakota.

An event of broad significance for the University that was related directly to the College of Education was the decision of Wesley College in 1953 to give up its music department. The Wesley faculty of three was transferred to the University music department, thereby ending a long-standing dispute between the University and its neighbor across the street. For Wesley the action marked another step in its drift from the status of affiliated college to an institution that differed little except in name from the newer religious foundations around the campus. For the University, the change presented at long last the opportunity and responsibility to develop a full-scale and coordinated fine arts program under central leadership, one of the most conspicuous needs of the University as it celebrated its seventy-fifth birthday.

The retirement of Dean Towne in 1948 provided the opportunity to revise the program of the School of Commerce, particularly in public administration and business. Towne's successor, following a year of an interim deanship, was Thomas J. Clifford, an alumnus who had joined the faculty as an instructor in accounting upon his return from military service in 1945. Twenty-nine years old when appointed, Clifford had the distinction of being the youngest dean in University history. A department of management and a secretarial training course were set up in 1951, and the department of accounting and business law was expanded to the position of ranking second only to education in the number of master's degrees conferred each year; eleven were conferred in 1957. The name of the school was changed to the College of Business and Public Administration in 1955, and the note of increased specialization was emphasized by the expansion of the program from two years to three.

The departments of economics and political science continued to be points of strength in the college and leaveners of its businesslike atmosphere, and both played increasingly prominent roles in public affairs and public service. The political scientists sponsored an annual municipal officers conference. Ross Talbot and Henry Tomasek, both products of the graduate school of the University of Chicago, were active in Nonpartisan League and Democratic party politics and acted as unofficial liaison between the University and the powerful North Dakota Farmers' Union. The department of economics, headed by William E. Koenker from 1952 , was the mainspring of the Bureau of Business and Economic Research established by the college in 1953 . The bureau began as a self-supporting project which received only small sums from the parent college from time to time-enough to finance a small quarterly bulletin, North Dakota Business. It had considerable success, however, in securing contracts for research projects from various 
agencies of the state government. One, for example, was a study of highway taxation for the Legislative Research Committee in 1956, preliminary to the consideration of the problem in the coming session of the legislature. By 1957 when the Bureau received its first annual budget $(\$ 1,200)$ from the College of Business, it had published the results of a half dozen such investigations, and it had established itself as a reliable and expert agency to which officials of the state government could turn. This was a considerable advance from the day not too long past when they had routinely gone elsewhere, as far afield as the University of Washington or commercial firms in Chicago, to obtain the information they needed.

Among the professional schools of the University, perhaps the least affected by the postwar expansion, except in some rise in enrollment and a modest enlargement of the faculty, was the School of Law. Yet here too several significant changes occurred. The market for law graduates in the postwar world was not comparable to that for business and technical graduates, and the legal profession, operating through its powerful professional societies, deliberately sought to limit the supply of lawyers and to improve their qualifications. A new course in legal writing and research was added shortly after the war, and in 1950 the entrance requirement was increased to three years of collegiate preparation, with a baccalaureate degree encouraged. Increasing the regular faculty to six, with an accompanying reduction of dependence upon special lecturers, was also a step toward a higher standard. At the same time the school tried to give the study of law a broader application than preparation for legal practice by relating it to current trends with the addition of an engineering-law curriculum (1948). A commerce-law program had been a popular offering for years.

The only other University division that displayed comparable stability was the College of Science, Literature, and the Arts. Between 1946 and 1954 this college experienced few changes that were immediately apparent in the catalog. That is to say, in its announced purposes, basic requirements, and general offering, the college differed little in 1954 from what it had been in 1924. The stability was more apparent than real, however. The death of Dean Bek in 1948 and the appointment of Robert B. Witmer, an alumnus and dean of the junior division of the college, meant a shift, more in sentiment and orientation than in any specific change of policy, toward the science side of the curriculum. While Thomas (Latin), Squires (English), and Bek (German), the guides of the college since its founding, had been trained and steeped in the humanities, Witmer had been trained as an electrical engineer and physicist. $\mathrm{He}$ had joined the faculty as a young instructor in the physics department in 1924. The currents of the time and the rivalries with the colleges of education, engineering, and business, all of which declared their independence of the liberal arts college, also inexorbly pushed it from its former position of "the heart of the University" to the dependent one of providing "service" for the professional colleges or to the competitive position of setting up its own practical or technical offerings, in the form either of new departments or revisions of older ones. Whether this trend would continue had not yet become clear in 1957; it was even then only half recognized. Not once since the war had this special problem of the liberal arts (a common one in most universities) been thoroughly and generally studied at North Dakota.

The liberal arts college added only one entirely new department, occupational therapy (1954). Two other departments, geography and men's physical education, were virtually new after the war. Although established as a separate department in 1942, geography received its full independence only with the appointment of Bernt L. Wills as head in 1946. Melvin Kazeck, appointed in 1947, developed the first courses in meteorology. By 1957 the department had a three-man faculty and offered a full program up to the master's degree.

The department of men's physical education was thoroughly reorganized and greatly expanded following the appointment of Leonard Marti in 1946 to head its academic program. The new curriculum, which included the first offerings leading to the master's degree, was actually almost entirely new from top to bottom, for until C. A. West retired as athletic director nearly all of the formal courses in physical education, for men as well as for women, had been taught in the women's department. The physical education program was much stimulated by the completion in the 
early 1950's of the gymnasium, fieldhouse, and swimming pool, the University's first complete athletic plant. The faculty in this department grew from four in 1946 to nine in 1956, and enrollment increased to 120 undergraduate majors and 30 graduate majors. A subsidiary development was the expansion of intramural sports.

Another relative newcomer, the department of public speaking, advanced rapidly after the war. A change in title to department of speech in 1948 when John Penn became head was indicative of the broadening of its functions and offering. From the traditional courses in public speaking, plus a few in dramatics, the curriculum, activities, and services of the department were expanded to include an extensive theater program-no small achievement in the absence of a suitable theater at the University, or even in Grand Forkscourses in speech and hearing correction, and an allied clinic which provided services for clients from all over the state.

A highly significant development, following the shift of responsibility for the radio station (KFJM) from the department of electrical engineering to speech in 1946, was a curriculum in radio broadcasting and, later, in television. Under the new management the operation of the University station underwent a series of reforms which one by one paved the way to independence and full-time operation by 1957 . The wave length sharing arrangement with KILO, a Grand Forks commercial station, became increasingly unsatisfactory to both parties after the war. Owing to the University's acquiescence to considerable pressure from KILO to relinquish part of its two hours of time, KFJM came dangerously close to losing its educational license entirely, and the status of the station was not completely clear until 1948 when the University firmly undertook to fill its entire allotted time with its own noncommercial programs. Andrew Kochman, appointed to the faculty in 1947, was the first of a series of trained managers who steadily improved the station's offerings. Kochman had considerable training in radio, and he had had two year's experience in commercial work before coming to the University. In 1957, on the expiration of its channel and time sharing contract with KILO, now owned by the Grand Forks Herald, the University station went over to full daytime broadcasting on its own wave length. Moreover, the University re- served an educational TV channel in 1953, and three years later successfully defended it against the application of a commercial firm. But the use of the channel by the University still lay in the indefinite future. In the course of these developments the radio station, for the first time, came to be recognized as the major asset that it was, useful not only for training University students as radio engineers or announcers and as an instrument for advertising the University, but also as an agency which raised the cultural and intellectual level of the area within its reach.

Among the long-established arts and science disciplines, the only one which experienced significant changes was chemistry, largely as a result of frequent changes in leadership. In 1948 Abbott retired from the headship of the department, which he had organized in 1910. In the next nine years three comparatively young men occupied the position; all came from other universities and all were active in research. Each contributed his bit to the revision of the chemistry offering and the elevation of its standing. A curriculum leading to the professional degree in chemistry was developed, and in 1951 the department was placed on the approved list of the American Chemical Society. At the same time, the graduate offering was more than doubled and faculty research actively encouraged, a policy supported by the great increase in funds available for such purposes, particularly in grants from the United States government. In the summer of 1957 the significance of Lawrence Summers' studies on organometallic compounds. was acknowledged by an invitation to submit a paper to the International Union of Chemistry meeting in Paris.

In one way or another the other liberal arts departments, stable and unchanging though the offerings of some of them appeared to be, were also affected after the war by the shifting intellectual climate, both outside the University and within it. In the department of sociology, following the retirement of Gillette, emphasis turned sharply to social work training, a trend that had begun in the welfare-conscious 1930's. A full undergraduate program offered in this field attracted a majority of the potential sociology students. Between 1951 and 1957, when the department was headed by Peter A. Munch, a Norwegian-trained scholar possessing a more than 
local reputation as a sociological theorist, only two students completed work for the master of arts degree in sociology. Although the humanities and history, and even the pure sciences, could take no path quite comparable to social work, they too reflected the trend, either in the relative or even absolute decline of their major and graduate students or in the expansion of the service side of their offerings at the expense of well-rounded programs. Almost no students took advanced degrees in the foreign languages, perhaps one or two a year in English, a few more in biology and physics, and two or three in history, about as many as had taken advanced degrees in the 1920's. The distribution of all University degrees also reveals the impact of the changing patterns in higher education upon the College of Science, Literature, and the Arts. In 1956-1957 the University conferred no fewer than thirty different graduate and undergraduate degrees, most of them associated with some specific vocational or professional training. The eighty-four B.A. and B.S. degrees conferred by the College of Science, Literature, and the Arts that year were six fewer than there had been in 1931-1932, when the total University enrollment was 1,732, half the 1956-1957 figure.

At the same time that vocational training and specialization were reaching increasingly into the undergraduate school, the graduate offering was being expanded; in some instances, for example in the departments of geology and speech, the movement was in both directions at the same time. Although the expansion of the graduate offering was a general phenomenon of the postwar University and advanced degrees were offered in more fields than ever before, the only marked increase in the number of graduate degrees conferred was in the College of Education. ${ }^{9}$ Of forty-six advanced degrees given in 1931-1932 two were Ph.D., twenty-one M.A., ten M.S., twelve M.S. in Education, and one M.S. in Mining Engineering. One hundred eleven advanced degrees were conferred in 1956-1957: three Ph.D., three Ed.D., twenty-three M.A., eight M.S., two M.S. in Chemistry, four M.S. in Chemical Engineering, "There was also a marked rise in the number of honorary degrees conferred after the war. Thirty-two honorary doctorates, nearly all of them to alumni or faculty
members who were retiring (seven of the latter, although for some reason Libby was passed over), were conferred between 1946 and 1954. Only fourteen honorary degrees had been awarded in the first half century of the University's history. Eighteen
were conferred between 1933 and 1945 . one M.S. in Geology, one M.S. in Mining Engineering, twenty-two M.S. in Education and forty-four Master of Education. A significant proportion of the increase in the number of advanced education degrees was accounted for by the summer session. All of which is to say that the University was actually faced with a relative shortage of graduate students in nearly every field but one. Prospective advanced students, even from among the University's own undergraduates and from the state teachers colleges, were being drained away by the larger and more famous graduate schools because of the lure of attractive fellowships and because in the era of general prosperity and GI legislation many could afford to go outside the state for advanced training.

In the meantime, the University was better prepared to offer advanced work than ever before. In 1951, following the death of Breitwieser, the graduate division was advanced from the status of a part-time responsibility of the dean of the School of Education to the status of a school with its own dean. The first to occupy the office was Daryle Keefer, formerly director of admissions at the University of New Mexico, who had joined the faculty in 1949 as dean of the junior division of the College of Science, Literature, and the Arts. Although the change in organization was made with little previous discussion in the University Council, it aroused no such protest as had a similar effort by Kane a quarter century before, largely because in 1951 the move was in keeping with the times and the development of the University. Keefer reorganized the graduate catalog and with the cooperation of a faculty committee managed to tighten a number of the procedures for advanced study. Definite requirements were laid down for course work and for oral and written examinations; most of the latter had been conducted with increasing informality, not to say laxity, in the preceding twenty years. The new dean also began the yearly publication of a bulletin of abstracts of all theses and dissertations completed.

Even more important as preparation for offering advanced training was the development of large research programs, one of the most marked features of the postwar University. Here the center of activity was shifting to the scientific and technological branches, some of which had previously engaged in almost no research at 
all. One reason for the new development and its pattern was the inclination of a number of young and vigorous faculty members new to the campus after the war, but the chief stimulus was financial support in significant amounts. Formerly dependent almost entirely upon the state legislature, which, when it did assign funds for research purposes, limited them almost exclusively to such projects as might directly develop the state's resources, the University now had available increasing sums of money from outside the state, nearly all for scientific or technological research. The most important sources were agencies of the United States government, civil as well as military. In short, one more link was being forged, at North Dakota as elsewhere, in the chain of "federal aid to education"-others had been depression relief, income from the GI Bill, and surplus war property - while many people still debated the pros and cons of federal aid as though it were a possibility for the distant future.

The star performer as a center of research was the reformed School of Medicine, which sponsored almost no research at all as late as 1948. Between 1950 and 1957 medical departments and individual members of the faculty received no less than $\$ 650,000$ in research grants, ${ }^{10} \$ 240,000$ of which went for the purchase of permanent equipment. Between 1948 and 1957 faculty and graduate students published 170 articles and papers in professional journals. The department of biochemistry, headed by William E. Cornatzer, alone published more than forty. Cornatzer was honored by invitations to lecture on liver diseases, his specialty, before the New York Academy of Science and a symposium at Johns Hopkins and to participate in the Gordon Research Conference of the AAAS at Bretton Woods in 1955. It was partly in recognition of the accomplishments of the department of anatomy that Christopher J. Hamre, the department head, was appointed acting dean of the Graduate School when Keefer received a leave of absence in 1957.

Not all of the support for medical research came from outside sources. Funds were available from the mill levy income of the Medical Center, and Cornatzer's work attracted significant ${ }^{10} \mathrm{Funds}$ available in the United States for the support of medical research grew from local philanthropy in the form of gifts totaling $\$ 85,000$ from Mrs. Guy L. Ireland in 1953 and 1957 for the construction and equipment of a cancer research laboratory. A matching grant of $\$ 74,000$ was obtained in 1957 from the United States Department of Health, Education, and Welfare, and in 1958 the American Cancer Society awarded a grant of $\$ 22,000$ to support a full-time research professor for two years.

Another important research program centered around lignite, in the College of Engineering and the Robertson Laboratory of the United States Bureau of Mines; an annual operating fund of $\$ 250,000$ was provided for the latter when it opened. The departments of chemical and mining engineering, headed by Albert $\mathrm{M}$. Cooley and Arthur Koth, continued a program of experiments with low-rank fuels, and Cooley conducted a series of investigations on potato dehydration financed by grants from the United States government. Other departments in the College of Engineering also undertook research programs, some of them for the first time. In 1952-1953 the college had a total of $\$ 65,000$ available for research, $\$ 23,700$ of which came from the federal government; the figure was $\$ 22,000$ the next year, of which $\$ 10,000$ was from federal sources, and in 1957-1958 the figures were $\$ 10,500$ and $\$ 4,500$ respectively. Until 1957 , when it was dropped, a special fund of $\$ 5,000$ was regularly appropriated for the School of Mines by the state legislature. The funds available specifically for research in the College of Engineering were somewhat less than astonishing, to be sure, in comparison with the huge amounts received by other institutions, but when those for the Robertson Laboratory are taken into account, they were by no means unrespectable, and by comparison with what had been available in the past, they were revolutionary.

Additional funds received for scientific research were $\$ 74,000$ in various grants, chiefly from federal agencies, to the faculty of the department of chemistry between 1951 and 1957; $\$ 9,000$ from private foundations to George Wheeler, head of the department of biology, to support the completion of his definitive study of the ants of North Dakota; and \$5,300 for a nuclear emulsion scanning project conducted by Edwin Whalin of the department of physics. 
Wheeler also received funds from the University to purchase a 160-acre tract near Inkster for a biology study area.

Although as a general rule the humanities, history, and social sciences, as well as the other nonscience disciplines, fared poorly by comparison, many of them in one way or another experienced a revival of scholarship. The appointment of Foster Y. St. Clair as head of the English department in 1947 brought to that position its most thoroughly trained scholar. Robert A. Caldwell, the department's first philologist, appointed in 1949, was well advanced by 1957 upon an edition of Geoffrey of Monmouth's Historia Regum Britanniae. Demetrius J. Georgacas, who joined the faculty in 1953 as assistant professor of classical languages, published regularly in domestic and foreign journals and stimulated a classics revival at North Dakota. His Classics Club, drawing support from faculty and students in every school on the campus, was reminiscent of James Boyle's Civics Club of a half century earlier. Georgacas won a Guggenheim fellowship in 1957, the first for any North Dakota professor in the thirty years these grants had been available, to enable him to complete an etymological dictionary of Greek.

In the social studies a significant development, although it eventually resulted in failure, was the creation of a Social Science Research Institute in 1953. Initiated by Peter A. Munch, it was the first organized effort in the University's history to draw the faculties of the social sciences and history into a cooperative body for the activation of research and the attraction of funds to support it. The institute wilted on the vine after a few hopeful years, however. A number of factors contributed to its failure. The almost simultaneous establishment of the Bureau of Business and Economic Research absorbed the interest of the vigorous department of economics. The law faculty was overlooked entirely, partly because its energies were absorbed by the newly revived North Dakota Law Review and by various codification and consultative commitments to state agencies. Paul C. Matthews, who joined the faculty in 1951, was deeply involved in casebook and textbook writing. Other members of the social studies departments who were essential to the success of any cooperative effort were also unable or unwilling to support it fully because of projects under way or because of their own highly individualized interests. Munch himself was a lone worker who contributed regularly to his professional journals. Melvin E. Kazeck of the department of geography was well along in his study of North Dakota geography, a pioneer effort, which was published in 1956. Elwyn B. Robinson of the history department was writing a history of North Dakota, projected as the first thoroughly analytical approach to the subject. Several of his colleagues were concerned with their own project, the development of the Orin G. Libby Historical Manuscripts Collection established in $1951{ }^{11}$ At any rate, the institute represented a serious attempt to develop interdisciplinary study and research, for which there was far too little encouragement at North Dakota. Moreover, it was able to point to one important achievement before it expired, a study of the impact of the oil rush upon the town of Williston, North Dakota, which was financed by a $\$ 20,000$ grant from the Hill Foundation of St. Paul. ${ }^{12}$

As further evidence of its qualifications for offering advanced training the University could point to a number of faculty honors and achievements. Between 1947 and 1958, years when conditions were unsettled and teaching loads heavy, University professors published a number of books and monographs on a wide variety of subjects. ${ }^{13}$ Two professors won Fulbright lectureships, two won fellowships with the Fund for the Advancement of Education, one a Carnegie fellowship, one a Sloan Executive Management fellowship, one a National Science Foundation fellowship for research and advanced study, and one a Guggenheim fellowship. Wilson Laird was president of the Association of American State Geolo${ }^{11}$ Its most important holdings are the original manuscripts of nearly all of Maxwell Anderson's published plays and the correspondence of William Lemke, John Moses, (1)

${ }^{13}$ Richard Beck, History of Icelandic Poets, 1800-1940 and Jon Porlaksson, Icelandic Translator of Pope and Milton; Louis G. Geiger, Joseph W. Folk of Missouri; Melvin E. Kazeck, North Dakota, A Human and Economic Geography; George F. Lemmer Britton and Bauer's Cases and Materials on Business Law, and a revision and expansion of Winslow's Forms of Pleading and Practice, two volumes; Peter A. Munch A Study of Cultural Changes; Rural-Urban Conflict in Norway; Arthur W. Munk (Wesley College), History and God; Clues to His Purpose; Philip Potter, Steam Power Plants. The Bureau of Business and Economic Research issued three monographs each in its Studies in Public Administration and North Dakota Economic 
gists. Martelle Cushman, Holstine's successor (1954) as dean of the College of Education, was national president of Phi Delta Kappa, the honorary education fraternity. John Rowe, who joined the faculty in 1955 as head of the department of business education, was president of the National Association of Business Teacher Education. The University of Iceland honored Richard Beck on his sixtieth birthday by publishing a collection of his writings. President West received an honorary degree from the University of San Marcos in Peru. Daryle Keefer spent a year as an adviser on public education in Peru, and in 1957 he was appointed chief adviser to the rector of the University of Saigon by the International Cooperation Administration. Alvin Austin, head of the department of journalism, received a leave of absence in 1957 to conduct a study sponsored by the Wall Street Journal on vocational opportunities and recruitment problems in journalism.

But much still remained to be done a decade after the warin the addition of more buildings and equipment, in improvement in personnel, and particularly in creating an intellectual spirit. Even allowing for the marked advances that the University had made, it had yet to recapture in the mid-1950's the vitality that had distinguished it under McVey. In the midst of all the expensive construction and the grants for research the library was seriously slighted, if not neglected outright. It was not until 1948 that, on the initiative of the faculty, a faculty library committee was formed. As late as 1952-1953 the total expenditure for books for the year was only $\$ 14,800$. The total collection of 160,000 cataloged volumes (1958) was a small one by the standards of the major universities of the country and needed to be enlarged considerably and immediately if the advanced programs were to prosper. Until 1954 little real effort was made to fill the gaps in the periodical collections dating from the poverty-stricken 1930's, and the University lacked subscriptions to many important current journals. Moreover, the library building itself, never intended for the purpose for which it had been used since 1928, was inadequate to house the collection essential for graduate training of high order or even to accommodate the oncoming wave of undergraduates.

The abnormally high rate of faculty turnover was a serious obstacle to the development of departmental traditions and reputation. In part, of course, the problem of holding personnel was insoluble, being the result of general restlessness and higher salaries and other inducements available in the nonacademic world of business, industry, and government. But there were also other local reasons. The Board did not implement the admirable sabbatical leave program it had approved during the war, largely because what money was available had to be applied to salaries. (There were a few exceptions in the form of relatively small grants to assist some members of the faculty to complete work for advanced degrees.) Despite urgings from West, the AAUP, and the Board, the legislature hesitated to make the improvements that were called for in the inadequate retirement system adopted years before (a small pension of about $\$ 150$ per month after twenty-five years of service, the same as that provided for all teachers in the public schools). The confusions and pressures of the postwar scramble for faculty had played havoc with the University salary scale, although from time to time efforts were made to adjust it. What was chiefly lacking was any policy of relating salary and rank to some agreedupon standards. The result was that the low scale, more or less uniform throughout the University, that had continued until the end of the war, gave way to several scales. At the top was the medical school and at the bottom the College of Science, Literature, and the Arts, with the other professional schools somewhere between. The problem-it would be better to say the necessity-of paying considerably above the established levels for professors or administrators in order to retain or attract the distinguished scholar received little if any consideration. In 1953 and again in 1954 the Board vigorously asserted its determination to base salaries and promotions on merit, instead of continuing to accept the acrossthe-board cost-of-living formula advocated by the faculty and the AAUP, but a clear definition of merit was not worked out, or at least not made public. All of this is not to say that salary increases were not considerable after the war. By 1953 the over-all average for the University was not irretrievably behind the average for comparable institutions. ${ }^{14}$ As had been the case in the 1920 's, how"s 4 alary averages in "large state universities" in 1953: professors, $\$ 7,000$; associate
professors, $\$ 5,600$; assistant professors, $\$ 4,600$; instructors, $\$ 3,700$. 
ever, the University was competing in a rapidly rising market, with which it was finding it increasingly difficult to keep pace.

The apparent difficulty in establishing firm personnel policies was related to the fact that in many respects the University was "just growing," that many of the significant changes that occurred were opportunistic and unrelated to any clearly conceived educational policy. The University of North Dakota after the war presented the paradox of an institution experiencing rapid change, yet somehow hoping not to be changed at all, reluctant even to indulge in self-examination. In an era when the institutional selfstudy project, often well financed by the great foundations, was so common as to be almost a fad, neither North Dakota's faculty nor administration seemed to find the time or the inclination to give any prolonged and thorough consideration to the kind of education the University proposed to give. Such innovations as general education (no longer new in the 1950's), which had produced significant changes in educational orientation elsewhere, particularly in the East, were given no thorough consideration at North Dakota. Little was done, except among some of the professional schools, toward the development of interdisciplinary programs. Even within the colleges themselves compartmentalization was the rule, with departmental majors regarded as sacred from intrusions by related disciplines. The postwar position of the United States as the leader of the Western coalition, with military and civilian representatives stationed all over the world, produced no appreciable responses or adjustments by the modern language departments nor even much effort to develop wider student interest in language study. Until 1956 when Roland Gibson, an economist specializing in Russian problems, joined the faculty, a single three-credit course in Russian history added in 1948 represented the University's major curriculum adjustment to the emergence of Russia as the second great world power.

To be sure, both administration and faculty, particularly the local chapter of the AAUP, undertook various investigations and studies of such matters as the possible reorganization of the administrative structure of the University, a reliable method for computing faculty teaching loads, and a standard of value for services rendered and their relation to promotions and salaries. None of these produced concrete results, however. A University Policies Committee was created in 1953 on the initiative of the Council, but it lasted only a year owing to confusion about its jurisdiction and to the imminent change of administration (West had resigned the September before it was formed). The one achievement of the committee before it expired was a recommendation to revive the annual exchange of lectures with the University of Manitoba. In 1946 a reform of possible significance for the future was the increase of faculty membership on the Administrative Committee to eight. Ten years later the constitution was further amended to admit all ranks of the faculty to voting membership in the Council after one year of service.

The Board of Higher Education was likewise increasingly concerned about the need for planning; from the first years of its existence it had spent much time in attempting to hammer out longterm future policies. The very nature of the Board, despite the large powers conferred upon it, prevented it, however, from dealing effectively with the problem; it was not possible for the Board to conduct the detailed studies that were necessary or to solve what were in many cases internal matters. Even such long-term plans as it made for a balanced and coordinated state college system had given way to the urgencies arising from the flood of students in 1946. One of the Board's first steps after the war was to foster the duplication that it had earlier sought to halt by permitting teachers colleges to offer "unencumbered" undergraduate degrees. It also permitted the Agricultural College to offer undergraduate majors in a number of new fields once limited to the University, and even graduate programs in such subjects as education and history. In 1957 the college launched a public campaign to be designated a second state university - to serve a state with a population of only $600,000 !^{15}$

By the middle 1950's the settlement of questions of broad policy, that is, some decision as to the direction which should be given to ${ }^{15}$ The Agricultural College, once secure in the advantage of serving directly the majority of North Dakota's population-farmers and their families-and training confronted with reduced needs for agricultural personnel. Farm population in this

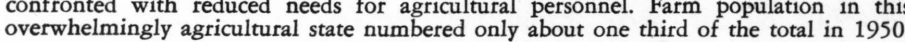


the growth of the University, was becoming imperative. How could the University, and indeed North Dakota higher education, best respond to the multiple problems of the atomic age, the increasing urbanization of an agricultural state, the stabilization of the farm economy, and the rising self-confidence and optimism that were developing in the 1950's as North Dakota completed its adjustment at last to the deflation of the overoptimistic expectations of the two Dakota booms? These issues and how to deal with them were to be a major concern of a new president, George W. Starcher, who assumed office in 1954.

On September 9, 1953, the Board accepted West's resignation, effective June 30, 1954, twenty-one years after he had assumed office in the depths of the depression. Still two years from retirement age and enjoying excellent relations with the Board and faculty, West 'was in frail health. He had been stricken with pneumonia several times in his last years in office, and he very much wanted a rest. West's had been the longest administration in University history, and perhaps the one most trying to the incumbent; it spanned the depression, the Second World War, and the era of the GI. The retiring president could and did take much satisfaction in having served longer than any of his predecessors, in being the oldest state university president in the country in point of service, and above all in being North Dakota's foremost "brick and mortar" president, the one who had supervised the realization of the long-projected quadrangle and McVey's dream of a University built in a single style. West could look back also to the successful guidance of the institution, with no irreparable setbacks in prestige or accreditation, through the moneyless and politically hazardous 1930's. No other state institution came through the depression or the political storms of the 1930's as well as the University, and none recovered more quickly after the war. Shortly after he gave up the reins of office, West could mark up one final credit to the effectiveness of his "tranquilizing" (his own term) personnel policies at the University in the contrast between the atmosphere of harmony that prevailed on his own campus and the open quarreling that de- veloped between elements of the faculty and President Frederick Hultz at the Agricultural College. ${ }^{16}$

West's valedictory address, "Famous Last Words," was delivered on the occasion of a community testimonial dinner for him, October 8, 1953, in the new Memorial Student Union. The retiring president warmed his audience with the sallies and homely stories of which he was so fond. He concluded with his analysis of the future of the Universtiy, its probable development, and the factors that would affect it:

The discovery of petroleum has turned over a new leaf in the state of North Dakota and in the University. The profound changes that will come can now only be imagined. It is obvious, however, that sharing an agriculcan now onles tural economy with a petroleum econ our thinking. The University must problems heretofore beyond the realm of this new field with its traditional caurage and persistency...

In the last decade "brick and mortar" has been emphasized to the extent In the last decade "briversity may have become over-shadowed. The ensuing decade will still emphasize construction, but academic attainments will become more evident. Traditionally, the University has been a ments will becomcational institution; now research in all fields has been teaching or educational been a notable response in the fields of physics, stimulated and there has been a notable respons will continue .... The chemistry, medicine, and engineld be reactivated into an Extension Division Division of Correspong in the state's economy . . .

in view of the past several years. The first unit of an engineering quadrangle is complete. Three se trestle board. We rejoice over the splendid new other units ares, but more are needed. The law school building, from the outside, is beautiful, but it houses the School of Law, the Law Library, the School of Commerce and the Art Department. Crowded conditions and the use of corridors for offices emphasize an anticipated need. The library the use of corridors for offices emphasize an is not fireproof. Many of the contains a quarter million volumes are irreplacable. There is no place on books and documents house in which even a considerthe campus except the gys able part of the student body may assemble. An auditorium is indicated the needs may be appalling.

${ }^{16}$ The difficulty at the Agricultural College was not resolved until November, 1957, when a state supreme court decision upheld the Board's dismissal of four prominen professors who had led the opposition to the president. This decision confirmed the extensive powers conferred upon the Board by the constitution academic circles a 1938. The Agricultural College quarrellege administration was formally censured by well as in North Dakota, and the College admings
the American Association of University Professors. 
In the ensuing months before he surrendered his office, West performed one of his most important services for the University by using his influence to win a voice for the faculty in the selection of his successor. The happy circumstances attending his going meant not only that his wishes had considerable weight but also that the half-conspiratorial method of faculty participation in his own election would not have to be repeated.

West's resignation, which had been more or less expected for the year preceding its announcement, excited more than the usual amount of speculation owing to numerous rumors about several local candidates, some of them said to be supported by political pressure. Moreover, the Board of Higher Education indicated no intention of consulting the faculty in its search for a president. It had never established the practice in similar situations at the other state colleges, despite the precedents for such action set by earlier Boards when choosing Kane and West. Fortunately the local chapter of the AAUP was a vigorous body, and it came forward to provide the leadership that the faculty needed in order to get itself heard. It was fortunate too that there were at the time two examples of joint faculty-board selection committees in operation, at Oregon and Illinois.

The first public move for faculty recognition was made at the regular AAUP meeting, open to all members of the faculty, on October 20, 1953. John Penn, ex-president of the chapter, introduced two motions that had been prepared by the executive committee: one, that the AAUP request the Board to adopt the procedure in use at Oregon and Illinois; the other, that a committee of five be appointed by the president of the chapter "to formulate a code of criteria which the Chapter believes should serve as a basis for the selection of a new president," this code to be submitted to the Board. After considerable discussion, during which several members of the faculty expressed grave concern about the possible consequences of what they viewed as a bold, not to say presumptuous move, both motions were carried. ${ }^{17}$

${ }^{17}$ The committee that was chosen included Christopher Hamre (anatomy), chairman, Alton J. Bjork (education), William E. Koenker (economics), Wilson E. Laird (geology), and George "C. Wheeler (biology). Wheeler, it will be recalled West in 1933 .
Following an unsuccessful effort by Penn to get a hearing before the Board when it met at Minot not long afterwards, Penn and Ernest Wenner, president of the AAUP chapter, consulted with Donald Westbee, a Board member living in Grand Forks. He advised them to address a request for a hearing to Commissioner Albert F. Arnason and gave them his informal assurance that their representative would be heard at the Board's December meeting The following Monday, November 16, Arnason arrived in Grand Forks and called the faculty into special session. He explained that he intended to bring the papers of all the "applicants" to the campus to be examined by representatives of the faculty if they chose, but it was apparent from the nature of his remarks that he, and presumably the Board, had no expectation of consulting with the faculty formally and that they might positively refuse to consult with the AAUP on the ground that it was not a truly representative body.

It was at this point that West came to the rescue. He called a special meeting of the Council for November 19, a day after the AAUP chapter was also called into special session to consider the progress of its efforts for a hearing and to discuss the significance of Arnason's remarks. When the Council met, West reviewed the history of faculty-board relations in the selection of other presidents, including himself, and he concluded by requesting that a faculty committee be appointed or elected to work with the Board of Higher Education. On December 2, regular meetings of the AAUP and the Council were scheduled on the same day, the Council meeting for eight thirty in the evening, an unusual hour, in the Memorial Student Union. At the AAUP meeting, which came earlier, the "code of criteria"18 was circulated and approved. The petition which had been approved some weeks before for AAUP representation on a joint faculty-board selection committee was changed to a request for faculty representation. At the Council meeting, a committee (Munch, Bjork, and Koenker) was elected to nominate candidates for a committee to work with the Board. Two days later they submitted eight names to the Council; eight more were nominated from the floor. The five elected were Ray-

${ }^{18}$ See appendix. 
mond Staley (mathematics) chairman, Ernest Coon (chemistry), Hamre, Koenker, and Laird. The code, leaked to the press immediately after its adoption, was received with general approval. The Board agreed to accept it and a faculty advisory committee.

As matters turned out, the arrangement between the faculty committee and Board proved to be a harmonious one. It should be noted that the Board's hesitation in dealing with the faculty had been largely a result of inexperience, most of the members being relatively new to their jobs. The Board's complete files of applications and nominations were turned over to the faculty committee for investigation, screening, and additions. The committee requested further nominations, largely from the faculty; more than 130 people were given some consideration and about forty were thoroughly investigated. Koenker later wrote: "The strategy was to canvass the faculty to find people who had at one time taught at the particular school at which the candidate was currently or had previously been located, and then for this person not only to present his opinion . . . but to write to people whose opinions he trusted in order to get their evaluation. Concerning most of the top 20 or 30 people, we had generally three to five confidential letters."

On February 26, 1954, the advisory committee and the Board met in joint session for a general discussion of the list of nominees. At the conclusion of the meeting, Commissioner Arnason was instructed to write to the five nominees heading the list of eligiblesthe Board had accepted the faculty evaluations without any major change-to inform them that they were under consideration for the presidency. They were Dr. Melvin W. Hyde, Assistant to the President, Drake University; Dr. William C. Jones, Dean of Administration, University of Oregon; Dr. Claude E. Puffer, Treasurer and Comptroller, University of Buffalo; Dr. George W. Starcher, Dean of the College of Arts and Science, University of Ohio; Dr. Lloyd Woodburne, Dean of the College of Arts and Science, University of Washington. Late in April the five nominees along with their wives were brought to the University campus for extensive interviews with the faculty committee, the deans, and the Board. Individual candidates were entertained informally on a round robin basis at lunches and dinners. After the faculty committee and the deans had submitted their recommendations, the Board invited members of each group to appear before it to present their views on the qualifications of the candidates in relation to the University's needs. On April 30, the election of Starcher was announced. He was to take office on July 1 . His salary was to be $\$ 13,000, \$ 500$ more than West had received in his last year. The Board also agreed to erect a new residence. On May 20, 1954, Professor Staley, chairman of the faculty committee, submitted his final report to the University Council, and his committee was discharged.

Forty-eight years old when he was elected, George William Starcher was born in West Virginia and reared on a farm in southeastern Ohio. In 1926 he graduated from Ohio University at Athens, and in 1930 he received a doctorate in mathematics at the University of Illinois, where he had been a graduate assistant for two years. He was married in 1928 to Margaret Shaver, whom he had known as a student at Ohio. Their only child, a son, was born in 1933. From 1930 to 1945 Starcher climbed the academic ladder at Ohio University from instructor to professor of mathematics, moving into administration in the early 1940's. He was successively acting dean of the College of Arts and Science and of the Graduate School (1943-1945), dean of the University College, the freshman division of the University (1946-1951), and dean of the College of Arts and Science (1951-1954). In 1945-1946 he was a Fellow in Human Relations at Harvard. Starcher's educational philosophy and administrative methods had been shaped not only by experience but also by intimate association with one of Ohio's ablest presidents, John Calhoun Baker, whom Starcher had helped to select in 1945.

Starcher's inauguration, held on April 20, 1955, was the first full-scale celebration of its kind since McVey's installation in 1910 . A number of distinguished visitors from the state and from colleges and universities were present. The importance given to the event emphasized the general expectation that a new and larger phase of the University's history had begun. In his address, "The Responsibilities of the University," Starcher expressed the views which had already become more or less well known on the campus in the ten months since he had assumed office. "The mission of the University," he said, 
is to prepare men and women for life in a changing dynamic society. We would fail if we should concern ourselves solely with turning out men and women prepared to fit neatly into the grooves of an established society. ... The principal source of our strength in the future is not alone our technology, our natural resources, our concepts of justice and equality, or the unity of spirit underlying our diversity in religious beliefs. It is our concept of the free society in which all of these can be brought to bear our of the lives of people through an approprate educaton person, prepared to act responsibly, is more than a polished and well-stored mind, or a sound and well-coordinated body, or a sensitive soul aroused to intense purposes. He is a person having what is, for him, an effective conceptual scheme, or way of thinking, that enables him to think and act in response to complex wholes, freed from limitations imposed either by indolence or from ignorance. Responsibility in its broadest sense means judgment and action based upon simultaneous awareness of complicated fact, high purpose and complex morality.

On the subject of University administration he observed:

Leadership is something that is required at all levels-not the dramatic heroic leadership demanded in a crisis, but the civilized leadership of many people working together as equals in peaceful collaboration for a common purpose. There will always be disagreement, compromise, negotiation, and adjustments at the level of legitimate differences in the University, as in every human group. But a spirit of teamwork and balance that seeks decisions from a university-wide point of view, without ignoring the importance of personal and individual motives, assures a solidarity built not upon servility, but upon common loyalties. Then, once a decision is made, and a course of action determined, we can avoid,

The Starcher administration is only fairly begun at this writing and its history will be recorded in detail at some later date. But it seems proper to note here some of the trends and points of emphasis that have appeared since July, 1954. The outgoing president had offered the keynote for his successor when he observed that "the ensuing decade will still emphasize construction, but academic attainments will become more evident." Indeed, the construction of the post-war period has begun to abate, at least temporarily, although since Starcher's arrival two major dormitories (Bek and Fulton Halls) have been completed, permissive legislation for bonds to construct another and an extension of the already inadequate student union has been passed, a state rehabilitation center building has been added to the new Medical Center, and a new housing area opened west of the coulee. In 1958 the Board was planning a long-term college building program which would cost an estimated long-term Council of State College Presidents was supporting an initiated measure to provide a one mill levy for the creation of a permanent college building fund

The chief emphasis, however, of the Starcher administration has been upon personnel and academic matters. The appropriations figures of 1955 and 1957 indicate the new direction-as well as the expansion of the University functions and the rising costs of higher expansion of the University functions and the rising $\$ 3,451,500$ included educationent, $\$ 47,500$ of this for the presidential residence. The 1957 figure was $\$ 4,557,000$, of which only $\$ 104,000$ was for plant improvement. Starcher's first major step as president, approved by the University Council in the spring of 1955, was the establishment of a one-year University College to 1955, was the establishment of all University provide a common core of general education for allized or professional students before inauguration of training. This innovation was accompanice that McVey had tried briefly a faculty-advisement system, a defore. Advisement and student perand to with the ad a dean of men in 1955. Both he and the dean of women, new since 1954, held doctorates in psychology. Student participation in the management of their own affairs was extended by a new constitution and by the practice of appointing students to faculty committees. By 1958 they participated in the deliberations of no less than eight. ${ }^{19}$ Preliminary participated in the deliberation facilities for the student health service. This remained one of the most conspicuous needs among the services to students; all that was available spicuous needs among the seventy-fifth anniversary was outas the University celebrated its seventy-fifth anniversary was out patient treatment.

The problem of elevating students' academic standards also received much attention in the form of recognition of excellence, financial assistance for the needy, and tighter academic regulations. A major deficiency in the University, as Starcher saw it, was the ${ }^{10}$ The number of standing faculty committees was expanded from twenty to thirty bership of these committees. 
almost complete absence of any significant number of scholarships or student aids, or any systematic program of graduate assistantships. In 1954 the Board of Higher Education approved his proposal that state undergraduate scholarships, amounting to the remission of all fees, be made available to 2 per cent of the enrollment of each institution of higher education in the state. Eleven graduate assistantships were established in 1955-1956, with $\$ 13,200$ set aside for their support. By 1958-1959 the number had grown to fifty-four and the funds available to $\$ 82,050$. The realm of state assistance was broadened in 1957 when the legislature organized the administration of a system of low-interest (1 per cent per year) state loans, provided in an initiated measure passed in the preceding election. At this same session $\$ 75,000$ was set aside annually from the Medical Center income for loans to finance medical students' last two years of training outside the state. Not to exceed $\$ 5,000$ at 6 per cent for each borrower, these loans were to be forgiven if the recipient returned to North Dakota and engaged in practice for five years in a town of 3,000 or smaller. Scholarship assistance from philanthropic sources, particularly from alumni or local friends, became of considerable importance for the first time. A major gift was the endowment by Chester Fritz of five annual undergraduate awards of $\$ 800$ each and one of $\$ 1,000$. In 1957 Dr. John Arneberg of Grand Forks gave $\$ 25,000$ to provide scholarships and awards for students or faculty "who have shown exceptional interest and proficiency in languages." The Alumni Association also undertook its first scholarship program in the form of twenty-five annual awards of $\$ 100$ each.

Reading for honors was revived, and in 1956 the University Council adopted new regulations to suspend from the University such students as were manifestly unable or unwilling to maintain a reasonable progress toward the " $\mathrm{C}$ " average required for graduation. The following year the Council approved a proposal by the English department that all students be required to pass an English proficiency examination at the beginning of the junior year. A North Dakota History, Government, and Citizenship Contest was begun in 1954. Even though the prizes offered were not large, the number of schools participating increased with each year. One hundred and twenty-two semifinalists came to the campus in January, 1958, for the final contests and to be entertained by a rousing hockey game. A Fine Arts Week, begun in 1956, and the extension he distinguished men to the campus for visits and lectures contributed to the elevation of academic standards and the culturai tone of the University.

Improvement of the faculty was also a major concern of the new administration. Both in public statements and before the Board the president repeatedly emphasized the immediate need to inthe president repeatedly emphosian to hold or to attract personnel crease salaries substantially in order to hold or to attract person of high quality in the increasingly sharp (Although the enrollment comparable institutions in the nation. (Alhough the crisi bulge in the late 1950's at North Dakota did not reach the crisis proportions of those universities in more populous areas, the student body increased by 40 per cent, from 2,635 to 3,700, between 1951 列 a possibility.) Fringe benefits for faculty were also enlarged significantly. In 1956 the faculties of the North Dakota colleges and the University became eligible for social security; this provision was in addition to the state retirement for teachers already in effect. A addition to the state retirement for also being developed by 1958 .

Faculty research and publication were actively encouraged. By Faculty research and publicatiderable progress toward persuad1958 the president had made considerable progress toward pesearch ing the Board and the legislature to set aside funds for research and to re-establish and extend the sabbatical leave program abandoned in the early 1930 's. A faculty lecture series intual rapport on recognition to professors and to encourage intellectual rapport on the campus was begun in 1954 . The University quarterly, dead since 1933, was revived in 1955 in a new format and under a new title, North Dakota Quarterly. Although it had not yet achieved the stature of a conventional "university press" organization, the University Press, managed by Joe W. Hughes since 1945, had about versity Press, managed by joe W. Hughes since 1945 , had about doubled the volume of its output between 1954 and 1958. The exchange lectures with the University of Manitoba were also revived. change lectures with the new atmosphere with its own contriThe AAUP responded to the new atmos general subject of the 
University's role in intellectual leadership and the dynamic role of research and creativity in higher education.

Philanthropy also played a part in stimulating the faculty. The Robert D. Campbell Foundation, established in 1955 with a gift of $\$ 165,000$ from its namesake, a pioneer Grand Forks physician, provided funds for important University projects for which no legislative appropriations were available. The Ireland gifts for cancer research, already mentioned, were another important contribution. Funds from the Hancock gift for faculty improvement provided small grants for research, study, and travel and two annual awards of $\$ 500$ for outstanding teaching; the first two of the latter, announced on Founders' Day, 1958, were presented to Erich Selke and William E. Koenker. There was also in the offing the possibility of a $\$ 250,000$ gift from the estate of J. F .T. O'Connor, who had died in 1949, provided the University or its friends could raise an equal amount to match it

One of the most significant developments in the effort to raise general standards was the improvement in the library that accompanied the change of administration and the appointment of a new head librarian, Jon R. Ashton, formerly a member of the faculty of the University of Wisconsin library school. Operations were reorganized, an open-stack system installed, and expenditures for books and periodicals raised from $\$ 16,000$ annually in 1953-1954 to $\$ 31,675$ in 1956-1957. A fitting event to emphasize the overdue attention to this most vital part of the University was the announcement, made on February 15, 1958, that the University had received a gift of a million dollars from Chester Fritz to be used for the construction of a new library. The donor of this gift, the largest ever received by any North Dakota institution, is (1958) an investment banker and businessman residing in Rome. He attended high school at Lidgerwood and spent two years at the University, 19081910. After graduation from the University of Washington, he lived for many years in China where he engaged in the banking and export business. His aunt, Katherine Belanger Tiffany, graduated in the class of 1902 at North Dakota. Her first husband, Neil C. MacDonald-he died in the early 1920's-was an old Merrifield "boy" who held both the B.A. and M.A. degrees from the University. A prominent figure in North Dakota public school circles in the years before the First World War, he was the first alumnus to be elected (1916) to the office of state superintendent of public instruction.

Public services also received renewed attention. Some, those of the medical school, the lignite laboratories, and the Geological Survey, were continuations of policies already well launched. A significant step was the revival of the Extension Division. The first full-time off-campus extension center in the University's history was opened in 1957 at Williston, and more such centers were planned. A timely move to provide leadership in improving the public schools was the Summer Institute for Teachers of Science and Mathematics in 1957 and 1958. Endowed by annual grants of $\$ 60,000$ from the National Science Foundation, the institutes were largely the result of the initiative of their director, J. Donald Henderson, associate professor of physics. The Bureau of Business and Economic Research was encouraged to broaden its services. The president also spoke often on the service aspect of the University's professional and graduate programs and the necessity of expanding them in order to supply the needs of a state which, however dependent upon agriculture, was becoming increasingly urbanized. The significance of the University's role in manning the state's public offices, as well as a large share of its professional positions, was emphasized in the 1956 elections when both gubernatorial candidates, John Davis and Wallace Warner, and the winning candidates for attorney general and lieutenant governor, Leslie Burgum and Clyde Duffy, were University alumni. Other University graduates holding high offices in 1958 were Gudmunder Grimson, the chief justice of the state supreme court, and William Langer, the senior United States Senator. An alumnus has sat in the Senate since Frazier was first elected in 1922, and there has been one in the governor's chair three fourths of the time since 1916.

Moreover, although it no longer held the commanding lead in enrollment which it once had over the Agricultural College, whose student body numbered about 3,000 in 1957, the University had recovered its position as the acknowledged apex of the state educational system. Significant of the revived prestige was the fact that in the fall of 1957 certain of the state's teachers colleges and 
two junior colleges made overtures for admission to the University as regional branches. This was the first such step in the history of North Dakota, and it offered what might be the solution to the problem of duplication and decentralization that the legislatures and boards of the 1930's had wrestled with many times but never solved, and which had been the subject of the Craighead Survey of forty years before.

Shortly after his arrival at North Dakota the new president began planning the celebration of the University's seventy-fifth anniversary in 1958. Following months of preparation by a number of faculty committees, a year of observances was opened on Founders' Day, 1958, in the University fieldhouse with the premiere performance of The Towering Vision, a cantata composed for the occasion by Professors Foster Y. St. Clair and Philip Cory. The main address was given by Eric Sevareid, a famous radio and television news commentator and a native of North Dakota. As on all anniversaries the celebrants surveyed the past as they looked forward to the future. This history, begun in 1955, was the first to be written since the final chapter of the Squires history, complete to 1917, had appeared in 1933. In November, 1957, as the first earth satellite sailed across the heavens, the Administrative Committee completed the organization of twelve committees composed of some eighty members of the faculty to make a thorough study of the University with a view to preparing it to meet the needs of the future.

Many serious problems loom ahead, but that future seems bright indeed as University, press, and public hail the birthday gift of Chester Fritz, the boy from Lidgerwood who has never forgotten his two years on the campus a half century ago. The Chester Fritz Library, which will be the first really adequate one ever to be built on the campus, is an appropriate symbol of the University's arrival at maturity and of the new era of its expanding intellectual leadership and service. 


\section{Bibliographical Note}

Most of the research materials upon which this volume is based are in the possession of the University. Unfortunately the records at North Dakota have been very poorly kept, a situation which apparently prevails at many institutions, judging from the laments that their historians often record. Minutes of the University faculty are nearly complete, save for record. Min 1906. Twe 1906. The University also possesse complete fles of the Student Work Committee and its successor, the Administrative Committee. These and the faculty and Council minutes record major policy decisions, but they have grown increasingly skeletal with the years, no longer reporting any debate and being accompanied by only an incomplete file of documents. Othe records available at the University are the reports of presidents, dean registrars, librarians, and departments. These were once included in the official published reports, but all are now filed separately and no longe published. Beginning in 1952, the Board of Higher Education has limited its report to a financial statement only, but in 1956 the University presiden began the practice of publishing his own biennial report and giving it general distribution. The records of the early governing boards of the University complete to 1899 , are preserved in University files of the Univerts 1915 are availe in the offices of the Board of Higher Edorbeen lost or destroyed.

The University's files of its own publications are nearly complete: catalogs and announcements dating from 1884, departmental and University bulletins from 1904, the Dakota Student from 1888, the Dacotab from 1903, the School of Education Record from 1915, the North Dakota Law Review (1927-1932, 1949-), the North Dakota Engineer from 1925, and the various alumni publications-the Alumni Register (1910-1912, complete), the Alumni Magazine (1925-1941, incomplete), and the Alumn Review from 1946. The Ouarterly Journal (1910-1933, 1955-) is of parReview for 1946. ticular value. The University also has an incomplete file of its weekly or biweekly newsletters and a number of clipping books. Many old photoin any systematic fashion. They are now being gathered in the library for

in any systematic

There are also a number of miscellaneous records in and about the 
University, but their condition is generally deplorable owing largely to the absence of any archival policy. Almost none of the correspondence of early boards has been preserved, and not much of that of any of the presidents, except for one file box of Webster Merrifield's letters and a somewhat large collection of John C. West's. Save for a few scattered letters and reports, the entire correspondence of every other president has been lost and in some cases deliberately destroyed. The state of the papers of colleges and scheos, of deans and professors and departments, including colleges and history, is litle if any better. Only one departs history, is little if any petter. Only one department, geology, has compile its history, atter adequate, that of Law being complete to only 1924, and Education's being largely a compilation of information drawn from catalogs. As for faculty and deans' correspondence, what has been preserved has been only by chance or by virtue of the good will of their relatives or friends. The family of Orin G. Libby has made available a few letters, most of them relating to the troubles of 1920-1922. A few of William G. Bek's and Earle J. Babcock's have survived in University files, and a somewhat larger collection of Joseph Kennedy's has been saved. There are also a few others, but they are not easily available. The one really significant professorial file is that of John M Gillette, the eminent sociologist who spent over forty years at North Dakota. This includes, in addition to many letters, class and research notes, and the like an unfinished autobiography "Eighty Years a Plainsm" "which the lates in lates in develpment, the trounge in University administration in 1933. Three important semiofficial sources of information are the minutes of the University chapters of Phi Bet Kappa and the American Association of University Professors, the latter complete only from 1930, and the records of the town and gown Fortnightly Club.

The University has had one earlier history. Written by Dean Vernon P. Squires and his son, Duane, it was published serially in the Quarterly Journal in the late 1920's and early 1930's. Owing to the elder Squires's long association with the University (1897-1930) and his intimate quaintance with the people who launched it, most of whom were still living in or near Grand Forks when he arrived, this work has mure still both as an organized collection of information on he or the personal memoir of a man who exerted a significant influence upon the University over an extended period of time. Unfortunately, the Squires history ends with the resignation of McVey. One other history was projected in the early 1940's. A semiofficial committee was actually formed to get it started, and Elwyn Chandler, another veteran of many years on the campus, spent his last years in bringing together a considerable body of information on such subjects as the University's site, the individual buildings, and athletics and athletic organizations - all of which were subjects which Chandler as a civil engineer and as a sports enthusiast of many years standing knew intimately. Chandler's most important contribution, at least as far as this writer is concerned, is his exhaustive roster of faculty,
Boards, and University employees, complete from 1884 to 1944 . In addition to the work of the University historians there is also available a history of the Agricultural College, still in manuscript, by Dr. William C Hunter. The only complete history of any of the North Dakota state colleges, this is a thorough study which deserves publication.

Other important sources include the journals and laws of the territoria and state legislatures, the biennial messages of the governors, the state "blu books," blue books, reporsioner of University and School Lands, and the reports them the Commission surver of higher eduction in of several special com North Dakota, all of files of the Grand Forks now and American-have been thoroughly searched and indexed. Newspapers examined over selected periods, all of them in the files of the State Historical Society at Bismarck, include the St. Paul Pioneer-Press, the Yankto Press and Dakotian, the Bismarck Tribune, the Fargo Forum, the Fargo Courier-News, the Nonpartisan Leader, the Red Flame, and a few shortlived local magazines. Several collections of papers and correspondence have also been useful: those of Congressman William Lemke, Governo John Burke, Governor John Moses, Judge J. F. T. O'Connor, and Samuel Torgerson, all in the University library; the papers of $\mathrm{H}$. L. Bolley and a Torgerson, al in the typed copy of early governors, Aricultural College; and the Allin and Eli C. D. Shortridge, in the library particularly those of Roger Allin and Elick.

A number of publications have proved useful for general orientation. These include college and university histories, among them William $\mathrm{H}$. Powers' Hise college and Powers History of South Dakota State College (State College, 1931), and such works as Earl D. Ross's Democracy's College: the Land Grant Richard Hofstadter's The Development and Scope of Higher Education in the United States (Columbia, 1952). Ernest Earnest's Academic Procession, An In formal History of the American College (Bobbs-Merrill, 1953) is entertaining as well as informative on such subjects as student life and manners, taining as waloms, college athletics, and intellectual and educational trends. The publich The published reports of various en and special commissions have proper context in the world of higher education, among these are the quarterly publications of the North Central Assocition Secondary Schools, the Association of American Universities, the Association of Land Grant Colleges, the American Association of University Professors, and the American Society for Engineering Education. Of particular value have been such reports as that of the Committee on Graduate Instruction of the American Council on Education (1934), Abraham Flexner's Medical Education in the United States (Carnegie Foundation for the Advancemen of Teaching, 1910), William Haggerty and George Works's "Faculties of Colleges and Universities Accredited by the North Central Association 
of Colleges and Secondary Schools during 1936-1937" (North Central Association Quarterly, January, 1939); and Beardsley Ruml and Sidney Education's Teaching Salaries Then and Now (Fund for the Advancement of

For orientation on the local scene I have of course made use of the
eneral histories of general histories of territory and state and such books as Thorstina of the Modern Sagas, the quarterly publications of the North Dakotina Walters' kota, and Minnesota state historical societies, bulletins of thota, South DaAgricultural College, and the M.A. and Ph.D. thesis file in North Dakota library. The latter includes the histories of two of the teachers collerity Ellendale and Valley City, and numerous studies of the teachers colleges, tion. On all questions about North Dakota history upon the advice and the extensive bibling heavily league, Professor Elwyn B. Robina of my colof the state.

\section{AN ACT Establishing a Territorial University at Grand Forks, Dakota.}

Be it Enacted by the Legislative Assembly of the Territory of Dakota:

\& 1. Where Established.] That there be, and is, hereby established in this Territory at the city of Grand Forks, in the county of Grand Forks, an institution of learning by the name and style of the "University of North Dakota."

$\S$ 2. BOARD OF REgENTS.] The government of the University shall vest in a board of regents, to consist of five (5) members, to be appointed by the Governor, by and with the consent of the council, and the Governor shall, during the term of his office, be a member of said board. The term of office of said regents shall be two for two years, and three for four years for the first term, and for four years thereafter, from and after their appointment, unless sooner removed by the Governor for cause; but appointment to fill vacancies, before the expiration of a term, shall be for the residue to fill vacancies,
of the term only.

$\S 3$. POWERS AND DUTIES OF BOARD.] The board of regents and their
(t) the the successors in office shall constitute a body corporate, by the name of "The Regents of the University of North Dakota," and shall possess all the powers necessary or convenient to accomplish the objects and perform the duties prescribed by law, and shall have the custody of the books, records, buildings and all other property of said University. The board shall elect resident and a secretary, who shall perform such duties as may be prescribed president and a secretary, who shall perform such duties as may be prescribed by the by-laws of the bord The secretary shall keep a faithful record of The thansactions of the board, and of the executive committee thereof. The Territorial Treasurer shall be the treasurer of the board and perform all the duties of such office, subject to such regulations as the board may adopt, not inconsistent with his official duties, and he and his sureties shall be liable on his official bond as Territorial Treasurer for the faithfu discharge of such duties.

§ 4. Regular and Special Meetings.] The time for the election of the president and secretary of said board, and the duration of their respective terms of office, and the time for holding the regular annual meeting, and such other meetings as may be required, and the manner of notifying the same, shall be determined by the board, shall constitute a 
quorum for the transaction of business, but a less number may adjourn from time to time.

§ 5. LAWS, REGULATIONS AND INSTRUCTION.] The board of regents shall enact laws for the government of the University in all its branches; elect a president and the requisite number of professors, instructors, officers and employees, and fix the salaries and the term of office of each, and determine the moral and educational qualifications of applicants for admission to the various courses of instruction; but no instruction, either sectarian in religion or partisan in politics, shall ever be allowed in any department of the University, and no sectarian or partisan test shall ever be allowed or exercised in the appointment of regents, or in the election of professors, teachers, or other officers of the University, or in the admission of students thereto, or for any purpose whatever. The board of regents shall have power to remove the president or any professor, instructor, or officer of the University, when in their judgment the interests of the University require it The board may prescribe rules and regulations for the management of the The bos vibraries, cabint, museum, laboratien versity, and of its several departments, and for the care and preservation thereof with penalties and forfeitures, by way of tion, which may be sued for and collected in the name of the board, before any court having jurisdiction of such actions.

§ 6. MAY EXPEND FUNDS.] The board of regents are authorized to expend such portion of the income of the University fund as they may deem expedient for the erection of suitable buildings and the purchase of apparatus, a library, cabinets, and additions thereto; and if they deem it expedient, may receive in connection with the University, any college in this Territory, upon application of its board of trustees; and such college this receiver so received shall become a branch of the University, and be subject to the visitation of the regents.

§ 7. REPORT.] At the close of each fiscal year the regents, through their president, shall make a report in detail to the Governor, exhibiting the progress, condition and wants of each of the colleges embraced in the University, the course of study in each, the number of professors and students, the amount of receipts and disbursements, together with the nature, costs, and results of all important investigations and experiments, and such other information as they may deem important, one copy of which shall be transmitted free by the Governor of the Territory, to all colleges endowed under the provisions of the act of Congress, entitled "An act donating land to the several States and Territories, which provide "An act for the benefit of a for the benc as provided in

§ 8. Powers of President.] The president of the University shall be president of the several faculties, and the executive head of the instructional force in all its departments; as such, he shall have authority, subject to the board of regents, to give general direction to the instruction and scientific investigations of the several colleges, and so long as the interests of the institution require it, he shall be charged with the duties of one of of the institutioneral colleges shall the professorships. The immediate government the regents shall have the be intrusted to their respective facultiuction and prescribe the books or power to regulate the course of instruction, and prescribe the buch degrees works to be used in the several courses, Universities, or as they shall deem appropriate, and to confer upon the faculty by by-laws the power to suspend appropriate, and to confer upon or other causes prescribed in such by-laws. r expel students for misconduct of The object of the University of North Deans of acquiring a thorough knowledg Dakota shall be the pcientific, industrial and of the various branches of learning corion and training of persons in the professional pursuits, in the instruction in the fundamental laws theory and art of teaching, and also instre in what regards the rights and of the United States, and of this Territory, in what following colleges duties of citizens, and to this end it shall consist of the following colleges or departments, to-wit:

1. The college or department of arts.

2. The college or department of letters.

3. The normal college or department.

4. Such professional or other colleges or departments as now are, or may, from time to time, be added therewith.

\& 10. SAME] The college or department of arts shall embrace courses ind their of instruction in mathers, engineering, application to the industrial arts such as agitecture, and commerce, in [and] mining and metallurgy, manufactures, archers branches included in the college of letters, as shall be nes for their chosen fitness of the pupils in the scientific and practical courses for the proper inpursuits and in military tactics; in the normal department the proper instruction and learning in the theory and art of teaching, and in all the various branches and subjects needful to qualify for teaching in the common schools; and as soon as the income of the University will allow, in such order as the wants of the public shall seem to require, the said courses in the sciences and their application to the practical arts shall be expanded the sciestith own faculty and apinto distinct colle college propriate title. of arts, and courses, or parts of courses, in the ture and philosophy, the University shall prescribe.

college of arts, as the regents of the University shall prits be open to $\S 11$. Pupils, Instruction, ETC.] The University shall be open to female as well as to male students, under such regulations and restrictions as the board of regents may deem proper; and all able-bodied male students of the University, in whatever college, may receive instruction and discipline in military tactics, the requisite arms for which shall be furnished by the Territory. After any person has graduated at the University, and after such Territory. After any pesfully taught a public school in this Territory for graperintent of Public Instruction shall have 
authority to countersign the diploma of such teacher after such examination as to moral character, learning and ability to teach, as to said superintenden may seem proper and reasonable. Any person holding a diploma granted my the by the board of fying that the peron holding the samerity, shall, after his diploma has been countersigned by the Territorial Superintendent of Public Instruction as aforesaid, be deemed qualified to teach any of the public schools of this Territory, and such dippoma shall be a certificate of such qualifications until annulled by the Superintendent of Public Instruction.

$\S 12$. TUITION FeE.] No student who shall have been a resident of the Territory for one year next preceding his admission, shall be required to pay any fees for tuition in the University, except in the law department and for extra studies. The regents may prescribe rates of tuition for any aforesaid, and for teaching extra studies.

$\S 13$. Appropriation.]. For the support and endowment of the University there is annually and perpetually appropriated:

1. The University fund income and all other sums of money appropriated by any law to the University fund income of North Dakota.

2. The agricultural college fund income of North Dakota.

3. All such contributions as may be derived from public or private bounty.

The entire income of all said funds shall be placed at the disposal of the board of regents by transfer to the treasurer of said board, thenceforth to be distinct and independent of the accounts of the Territory, and for the support of the aforesaid colleges or departments of arts, of letters, normal, and such other colleges or departments as shall be established in the said University, or connected therewith; but all means derived from other public or private bounty shall be exclusively devoted to the specific objects for which they shall have been designated by the grantor.

$\S 14$. TAx.] They [there] shall be levied and collected annually a territorial tax of one-tenth of one mill for each dollar of the assessed valuation of the taxable property of the Territory, which amount, when so levied and collected, is appropriated to said University fund income, to be used annually as a part thereof.

\$ 15. SPECIAL APPROPRIATION FOR ASTRONOMICAL APPARATUS.] The sum of two thousand dollars shall be set apart annually forever, from the receipts of the tax mentioned in the preceding section, so soon as a complete and well equipped astronomical observatory shall be given to the University on its own grounds, without cost to the Territory, to be expended by the regents in astronomical work and instruction;

Provided, Such observatory be completed by the 4th day of July, A.D.
\& 16. COMPENSATION OF REGENTS.] The regents each shall receive the 16. COMPENSATION OF REGENTS.] and from and in attendance upon actual amount of expenses in traveling in the performance of any duty in all meetings of the board, or incurred in the performance of any duty in pursuance of any direction of the board; accounts for such expense, duly authenticated, shall be audited by the board and be paid on their order by the treasurer out of the University fund income. No regent shall receive any pay, mileage, or per diem, except as above described.

\& 17. REgENTS to MAKe Rules, ETC.] The said board of regents (1). Rood government shall make such repartment thereof; to and management of the University, and of exisson of students; but every prescribe rules and regulations for the admissination to be prescribed by applicant for admission shall undergo an examination to be prescribed by the board, and shall be rejected if it shall appear that he be is not of good moral character; to require any applicant for admission in the normal department, other than such as shall, prior to admission, sign and file with said board a declaration of intention to follow the business of teaching common schools in this Territory for at least one year, to pay or to cause to be paid such fees for tuition as the board may deem proper and reasonable.

s 18. This act shall take effect and be in force from and after its passage and approval.

Approved, February 27, 1883. 


\section{The Constitution of the State of North Dakota \\ (Approved in convention, August 17, 1889)}

\section{ARTICLE VIII - EDUCATION}

SEC. 147. A high degree of intelligence, patriotism, integrity and morality on the part of every voter in a government by the people being necessary in order to insure the continuance of that government and the prosperity and happiness of the people, the legislative assembly shall make provision for the ent make provision schools which shall be open to all children of the state of North Dakota and free from sectarian control. This legislative requirement shall be irrevocable without the consent of the United States and the people of North Dakota.

SEC. 148. The legislative assembiy shall provide at their first session after the adoption of this constitution, for a uniform system of free public schools throughout the state, beginning with the primary and extending through all grades up to and including the normal and collegiate course.

SEC. 149. In all schools instruction shall be given as far as practicable in those branches of knowledge that tend to impress upon the mind the vital importance of truthfulness, temperance, purity, public spirit, and respect for honest labor of every kind . . .

SEC. 152. All colleges, universities, and other educational institutions, for the support of which lands have been granted to this state, or which are supported by a public tax, shall remain under the absolute and exclusive control of the state. No money raised for the support of the public schools of the state shall be appropriated to or used for the support of any sectarian school.

\section{Constitutional Amendment Establishing A State Board of Higher Education. \\ (Submitted by Initiative Petition:)}

\& 1. A board of higher education, to be officially known as the State Board of Higher Education, is hereby created for the control and administration of the following state educational institutions, to-wit:

(1) The State University and School of Mines, at Grand Forks, with their substations.

2) The State Agricultural College and Experiment Station, at Fargo, with their substations.

(3) The School of Science, at Wahpeton

(4) The State Normal Schools and Teachers Colleges, at Valley City, Mayville, Minot and Dickinson.

(5) The Normal and Industrial School, at Ellendale.

(6) The School of Forestry, at Bottineau.

(7) And such other State institutions of higher education as may hereafter be established.

\& 2. (a) The State Board of Higher Education shall consist of seven (7) 2. (a) (7) members, all than five (5) State, and who appointed by the years immediately preceding their appointe Governor, by and with the consent of the Senate, from a list of names selected as hereinafter provided. There shall not be on said board more than one (1) alumnus or former student of any one of the institutions under the jurisdiction of said State Board of Higher Education at any one time. No person employed by any institution under the control of the board shall serve as a member of said board, nor shall any employee of any such institution be eligible for membership on the State Board of Higher Education for a period of two (2) years following the termination of his employment.

On or before the 1st day of February, 1939, the Governor shall nominesition, selected by the unanimous netion of the President of the North Dakota Educational Association, the 
Chief Justice of the Supreme Court, and the Superintendent of Public Instruction, and, with the consent of a majority of the members-elect of the Senate, shall appoint from such list as such State Board of Higher Education seven (7) members, whose terms shall commence on the 1st day of July, 1939 , one of which terms shall expire on the 30th day of June, 1940, and one on the 30th day of June in each of the years 1941, 1942, 1943, 1944 1945, and 1946 . The 1945, and 1946. The term of offce of members appointed to fill vacancies at the expiration of said terms shall be for seven (7) years, and in the the balance of the term of the members whose places are to be filled.

(b) In the event any nomination made by the Governor is not consented to and confirmed by the Senate as hereinbefore provided, the Governor shall again nominate a candidate for such office, selected from a new list, prepared in the manner hereinbefore provided, which nomination shall be submitted to the Senate for confirmation, and said proceedings shall be continued until such appointments have been confirmed by the Senate, or the session of the legislature shall have adjourned.

(c) When any term expires or a vacancy occurs when the legislature is not in session, the Governor may appoint from a list selected as herein before provided, a member who shall serve until the opening of the next session of the legislature, at which time his appointment shall be certified to the Senate for confirmation, as above provided; and if the appointment be not confirmed by the thirtieth legislative day of such session, his office shall be deemed vacant and the Governor shall nominate from a list selected as hereinbefore provided, another candidate for such office and the same in $\operatorname{six}(6)$ month prior to the date of the expiration of the term of any member, the Governor shall nominate his successor from a list selected as above set forth, within the first thirty (30) days of such session, and upon confirmation by the Senate such successor shall take office at the expiration of the term of the incumbent. No person who has been nominated and whose nomination the Senate has failed to confirm, shall be eligible for an interim appointment

$\S 3$. The members of the State Board of Higher Education may only be removed by impeachment for the offenses and in the manner and according to the procedure provided for the removal of the Governor by impeachment proceedings.

$\S 4$. The appointive members of the State Board of Higher Education shall receive seven dollars $(\$ 7.00)$ per day and their necessary expenses for travel while attending meetings, or in the performances of such special duties as the board may direct; provided, however, no member shall receive a total compensation, exclusive of expenses, to exceed five hundred dollars $(\$ 500.00)$ in any calendar year; and no member shall receive total expense che five hundred dollars $(\$ 500.00)$ in any calendar year.

$\S 5$. The legislature shall provide adequate funds for the proper carrying out of the functions and duties of the State Board of Higher Education
\& 6. (a) The State Board of Higher Education shall hold its first m 6. (a) Bard of Administration at Bismarck, on meeting ath shall organize and elect one of its members the 6th day of one year. It shall also at said meetas president of such board for a ter ing, or as soon thereafter as a as secretary, who shall teside during his marck, North Dakota. Said secretary shall hold office at the will of the board. As soon as said board is established and organized, it shall assume all the powers and perform all the duties now conferred by law upon the Board of Administration in connection with the several institutions hereinbefore mentioned, and the said Board of Administration shall immediately upon the organization of said State Board of Higher Education, surrende and transfer to said State Board of Higher Education all duties, rights, an powers granted to it under the existing laws of this State concerning the powers granted to to all property, deeds, records, reports, and appurtenances of every kind belonging or appertaining to said institutions.

(b) The said State Board of Higher Education shall have full authority over the institutions under its control with the right, among it other powers, to prescribe, limit, or modify the courses offered at the severa institutions. In furtherance of its powers, the State Board of Higher Educainsticull have the power to delegate to its employees details of the adtion shall he institutions under its control. The said State Board of migher Education shall have full authority to organize or re-organize within Higher Education of each institution under constitution and its control, and do each and en said State educational institutions.

(c) Said board shall prescribe for all of said institutions standard ystems of accounts and records and shall biennially, and within six (6) months immediately preceding the regular session of the legislature, make months in detail the operations of the educational institutions under its control.

(d) It shall be the duty of the heads of the several State institutions hereinbefore mentioned, to submit the budget requests for the biennial appropriations for said institutions to said State Board of Higher Education; and said State Board of Higher Education shall consider said budgets and shall revise the same as in its judgment shall be for the best interests of the educational system of the State; and thereafter the State Board of Higher Education shall prepare and present to the State Budget Board and to the Education shall preparian budget covering the needs of all the institutions legislature a single unified budget covering the needs of all the by the Board under its control. "Said budget shall be prepared and presented by the Board of Administration until the State Board of Higher Edu ion organizes as provided in Section 6 (a)." The appropriations
tions shall be contained in one legislative measure.

(e) The said State Board of Higher Education shall have the control of the expenditure of the funds belonging to, and allocated to such institu- 
tions and also those appropriated by the legislature, for the institutions of higher education in this State; provided, however, that funds appropriated by the legislature and specifically designated for any one or more of such institutions, shall not be used for any other institution.

$\S 7$. (a) The State Board of Higher Education shall, as soon as Commissioner of Higher Education, whose State Capitol, in the City of Bismarck. Said Commissioner of Higher the cation shall be responsible to the State Board of cation shall be

(b) The State Commissioner of Higher Education shall be a graduate of some reputable college or university, and who by training and experience is familiar with the problems peculiar to higher education.

(c) Such Commissioner of Higher Education shall be the chief executive officer of said State Board of Higher Education, and shall perform such duties as shall be prescribed by the board.

$\S 8$. This constitutional provision shall be self-executing and shall become effective without the necessity of legislative action.

Approved June 28, 1938 . 93,156 to 71,448 .

\section{The AAUP "Code of Criteria" for Choosing a President of the University of North Dakota*}

1. Personal qualifications

a. Old enough to have mature judgment and yet young enough to formulate and execute a strong university program. Suggested age 30 to 55 years.

b. Sound character, integrity and courage.

c. Effective personality and skill in dealing with individuals and organized and unorganized groups of society and government.

2. Education

a. Earned doctorate degree in a basic discipline from a recognized institution.

b. Demonstrated continuing scholarship.

3. Experience

a. Teaching experience at the college or university level.

b. Administrative experience in a college or university at least at departmental level.

4. Other qualifications

a. Philosophy and outlook on education must be broad and for the University as a whole.

b. Staunch advocate of scholarship in teaching and research.

c. Understanding of educational problems and needs of midwest.

d. Faith in and wholehearted support of the principle of public education.

e. Significant and current portion of qualifying experience outside the state of North Dakota.

f. Wholehearted support of recognized principles of academic freedom and tenure.

*Adopted by the faculty, December 2, 1953, and accepted by the Board of Higher Education. 
$1895-1896$

A. Abrahamson, Grand Forks......\$50.00 Thomas Campbell, Grand Forks.. $\$ 200.00$ William Ackerman, Grand Forks 12.50 C. Adler, Lakota …................... 25.00 Mollie Aldrich, Grand Forks......... 19.00 Nellie Aldrich, Grand Forks......... 15.00 Jennie Allen, Grand Forks.......... 29.00 D. Allert, Langdon.. Robert Anderson, Grand Forks.... 100.00 Lizzie Angier, Grand Forks......... 25.00 A. Appel, Grand Forks............... 100.00 Genevieve Arnold, Grand Forks.. 12.00 $\begin{array}{ll}\text { T. F. Baird, Lakota ............................. } 12.50 & 25.00 \\ \text { T. }\end{array}$ C. F. Baker, Emerado.................... 10.00 W. C. Baker, Bismarck ............. 100.00

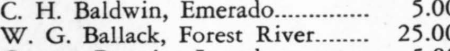
George Barcelo, Langdon............. 5.00 O. W. Barnes, Grand Forks...... William Baumeister,

$$
\text { Grand Forks .... }
$$

Thomas Beare, Grand Forks.......... 100.00 G. G. Beardsley, Grand Forks.... 50.00 J. W. Beek, Larimore D. H. Beecher, Grand Forks....... 100.00 V. E. Bemis, Inkster................... 50.00 E. A. Bickford, Kempton.............. 25.00 Olive J. Bird, Grand Forks.......... 12.00 John Birkholz, Larimore.............. 200.00 $\mathrm{H}$. O. Bjornarud, Langdo George F. Blackburn,

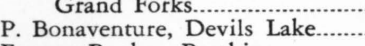
Eugene Booker, Pembina J. H. Bosard, Grand Forks W. B. Bosard, Emerado...

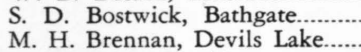

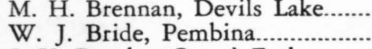
J. J. Bride, Pembina L. A. Brooks, Larimore. D. Brown, Grafton.... S. B. Brynjolfson, Hallson A. P. Buchanan, St. Thomas...... William Budge, Grand Forks A. S. Burrows, Grand Forks... A. K. Buttery, Emerado

S. Cairncross, Grafton John Carpenter, Forest River...... 10.00 Guy H. Corliss, Grand Forks....... 100.00 Bessie Cannell, Grand Forks........ $\quad 5.00$ R. M. Carothers, Grand Forks.... 25.00 George E. Carpenter,

John Carpenter, Forest River.... $\quad 5.00$ J. M. Carroll, Grand Forks........ 20.00 M. L. Cashel, Grafton................... 100.00 I. J. Chevalier, Bathgate............... 25.00 George Clark, Forest River........... 50.00 Geo. B. Clifford, Grand Forks.... 100.00 Cleve Clow, Lisbon Stephen Collins, Grand Forks....... 400.00 J. W. Considine, Minto................. 10.00 E. C. Cooper, Fargo............... 25.00
Burke Corbet, Grand Forks....... 100.00 J. M. Cravath, Grand Forks........ 100.00 Dora Creswell, Devils Lake..... $\quad 5.00$ J. Cummings, Grand Forks.......... 25.00 James Curtiss, St. Thomas............ $\quad 10.00$ T. Degnan, Langdon.... J. Deschenes Grardoch.. James Dinnie, Grand Forks Grand Forks.......... 100.00 H. E. Dorval, Langdon................... 5.00 J. A. Douglas, Grafton................. 100.00 W. Douglas, Pembina............. 10.00 Daniel Dow, Grand Forks... 25.00 D. S. Doyon, Grand Forks......... 12.50 Thomas Dugan, Langdon............ $\quad 5.00$ Mary Dunham, Grand Forks........ $\quad 2.00$ $\begin{array}{ll}\text { Charles Dunlap, Michigan City..... } & 50.00 \\ \text { John Dunlap, Michigan City....... } & 12.50\end{array}$ J. J. Dunlop, Grand Forks........... 12.50 Thomas Edison, Larimore........... 25.00 August Eggers, Grand Forks......... 25.00 F. Estabrook, Inkster................... 12.50 G. M. Esterly, Bathgate.............. 25.00 B. Eyford, Pembina....................... 10.00 E. J. Fox, Langdon................................. 10.00 W. A. Fox, Ardoch.................... 25.00 Frances Freeman, Grand Forks.... 10.00
N. N. Fuller, Larimore. F. R. Fulton, Grand Forks. J. T. Galbraith, Grand For William Gale, Emerado Peter Gannow, Graster... G. H. Garnett, St. Thomas. T. M. George Emerado Anna E. Gifford, Grand Forks... G. W. Glaspell, Grafton Mattie R. Glass, Grand Forks. L. C. Goplerud, Grandrok C. C. Gowran, Grand Forks. Ella Grant, Grand Forks. Martha Grant, Grand Forks. J. Greenwood, Grand Forks. A. J. Gronna, Lakota W. A. Gordon, Grand Fork Grant S. Hagar, St. Thomas. A. Hales, Moorhead, Minn... C. A. Hall, Lakota

H. Hancock, Emerado........... C. F. Harmon, Bathgate O. E Hasle, Park River. L. K. Hassell, Grand Forks H. I. Haussamen, Grafton F. Haverland, Emerado E. W. Hazelton, Grand Forks... W. H. Healy, Michigan City William Herriot, Grafton W. H. Higham, Grand Forks George Hill, Ardoch............... James J. Hill, St. Paul, Minn..... Annie E. Hinman, Grand Forks. E. K. Hogenson, Graft
Andrew Holmes,
Moorhead, Minn. M. Holmes, Grand Forks..... A. A. Hood, Emerado W. E. Hoover, Casselton John Hult, Grand Forks George Hyslop, Inkster

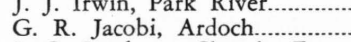
J. G. Jacobson, Churchs Ferry. B. James, Bathgate... William James, Bathgate.....
H. F. Johnson, Grand Forks. H. F. Johnson, Grand Forks..
M. N. Johnson, Petersburg O. H. Johnson, Inkster........ I. T. Johnsrud, Lakota Angus Johnston, Inkster.......... John H. Glass, Churchs Ferry...

$\$ 5.00$ 12.50 100.00 5.00 10.00 57.00 10.00 5.00 50.00 10.00
N. E. Jones, Fargo _...........\$15.00 J. Kavanaugh, Grand Forks.... 25.00 P. Kennedy, Grand Fork....... 25.00 Teorge B. Keenan, Grand Forks 12.50 Kelly, Devils Lake Kibbee, Drayton ................ 10.0 M. King, Pembina................ 12.50 John Kinnan, Grand Forks......... 13.50 I. Knold, Petersburg............. 25.00 J. Kohler, Grand Forks........... 12.50 W. A. Laidlaw, Langdon................ 5.00 T. J. Lamb, Michigan City........... 100.00 . . J . J. Lankin, Grand Forks................. 25.00 ames Lauer, Michigan City......... 10.00 . E. Lavayea, Larimore.............. 50.00 George D. Lay, Grand Forks........ 25.00 W. C. Leistokow, Grafton............. 100.00 W. Luke, Grand Forks.......... 25.00 G. Lundy, Inkster................ 25.00 H. Magoris, Larimore ............... 10.00 John Mahon, Langdon.................. 10.00 W. F. Manning, Devils Lake.......... 12.50 C.

C. Mather, Grand Forks........ 25.00 AcBride, St. Thomas.. 50.00 . McBride, Pembina .................. 25.25 George A. McCrae, Drayton......... 10.00 Alonso McDonald, Forest River.. 10.00 James McDonald, Forest River... 25.00 JcDonald, Forest River....... 10.00 Acx McKenzie, Bismarck............ 500.00 . McKiernan, Grand Forks......... 10.00 A. McKinney, Grand Forks......... 25.00 W. McLaughlin, Grand Forks 300.00 D. P. McLaurin, Grand Forks.... 100.00 M. McMahon, McCanna................... 12.00 Charles B. McMillan, Langdon.... 5.00 McPhail In, Grand Forks.... 25.00 George McQuinn, Pembina........ 5.00 R. L. Metcalf, Lakota 2.00 L. G. Mickelson, Emerado............. 10.00 
A. L. Miller, St. Thomas............ $\$ 100.00$ Fannie A. Miller, Grand Forks. H. R. Miller, Emerado. A. Moe, Churchs Ferry 1000 Grand Forks......... W. J. Mooney, Langdon D. C. Moore, Grafton D. E. Morden, Pembina. D. E. Morgan, Devils Lake... Robert Morrison, Pembin A. B. Muir, Johnstown............. F. P. Nash, Grand Forks O. E. Nash, Grand Forks W. K. Nash, Grand Forks.. C. E. Nelson, Park River T. W. Neville, Grand Forks A. W. Noltimier, Churchs Ferry H. H. Noltimier, Churchs Ferry E. M. Nixon, Pembina Jacob J. Nuessle, Emerado... A. H. Oakes, St. Thomas.............. William Oakman, Grand Forks. M. J. O'Connor, Grand Forks... John O'Leary, Grand Forks......... J. M. O'Neale, Grand Forks. C. Orton, Langdon W. M. Parker, Orr....................... B. O. Paulsness, Grand Forks....... O. H. Phillips, Garimore ks...... 100.00 George Platky, Grand Forks. 50.00 C. L. Prince, Grafton... 5.00 W. H. Pringle, Grand Forks......... 25.00 F. W. Reynolds, Bathgate........... 10.00 George Richards, Grand Forks.... 50.00 R. B. Richardson Mary Riley, Grand Forks......... 25.00 G. F. Robertson, Minto L. Robertson, Langdo Clara L. Robinson, Grand Fork Fannie Robinson, Walshville J. B. Robinson, Bathgate............ W. R. Rogers, Grand Fork Thomas Roycraft, Grand Forks.......... W. Rutledge, Grand Forks... 10.00 G. W. Ryan, Pembina................ 25.00 A. Schulke, Langdon..................... 5.00 Theo. P. Scotland, Rugby............ 12.50
W. A. Scouton, Inkster................\$12.50 T. R. Shaw, Pe Thomas Sheean, Langdon.............. 10.00 W. C. Short, Pembina.................. 12.50 J. S. Sinclair, Lakota................... 50.00 J. M. Smith, Emerado................... 10.00 J. Walker Smith, Grand Forks.... 100.00 W. G. Smith, Grand Forks........ 37.50 J. A. Sorley, Grand Forks............. 35.00 John J. Sprafka, Minto.................. 15.00 F. H. Sprague, Grafton................. 50.00 John J. Stampen, Grand Forks.... 10.00 S. St. John, Michigan City........... 10.00 W. L. Stockwell, Grafton.............. 25.00 A. Stonehouse, Larimore................ 50.00 S. Strandness, Larimore................. 12.50 T. L. Street, Gilby....................... 25.00 J. B. Streeter, Jr Lotta J. Stuart,

Grand Junction, Colo............ 12.50 M. L. Sullivan, Langdon............. 5.00 Josephine Swain, Grand Forks.... 2.00 A. G. Tanton, Devils Lake......... 12.50 C. F. Templeton Grand Forks..... 60.00 E. T. Thompson, St. Thomas 50.00 M. S. Titus, Minto....................... 100.00 S. S. Titus, Grand Forks …..... 200.00 Genevieve Towne, Grand Forks.. 2.00 J. D. Trenholme, Bathgate........ 15.00 J. K. Truax R. Tweadlie, Drayton................... 10.00 N. Upham, Grafton.................. 25.00 E. M. Upson, Grand Forks............ 100.00 John Vandersluis, Grand Forks.... 50.00 F. C. Warner, Pembina............. 5.00 L. A. Warnken, Emerado........... 5.00 B. F. Warren, Grand Forks........ 50.00 Bamuel Watt, Jr Jarimore....... 7.50 F. A. Welch, Grafton......... H. N. Wells, Grand Forks.......... 50.00 H. M. Wheeler, Grand Forks.... 100.00 C. A. Wilcox, Larimore-............ 200.00 W. L. Whithed, Grand Forks...... 50.00 George H. Wilder, Grand Forks 50.00 K. M. Wilkinson, Devils Lake.. 50.00 W. F. Winter, Langdon..... 10.00 J. F. Williams, Grand Forks...... 100.00 Anna Wilson, Grand Forks......... 2.00 J. B. Wineman, Grand Forks.... 25.00 Max Wittleshofer, Grand Forks.. 50.00
H. A. Woods, Grafton...

...\$25.00 . Orange Wright, Grand Forks....... 100.00 O. Young, Grand Forks.................. 100.00 N. C. Young, Bathgate. 25.00

BANKS AND BUSINESS FIRMS

Bank of Park River....................\$ $\$ 30.00$ Champion and Affelman,

Cochrane and Feetham, 10.00 Grand Forks

Einer and Amend, New York City... 100.00 Ephraim Brothers, Gr Farmers' State Bank, 100.00 St. Thomas... .. 25.00 100.00 Fist Nationa Bark Park River 50.00 Gansle and McIntosh, St. Thomas 50.00 Grand Forks Mercantile Co......... 300.00 Hall and Gallup, Grand Forks.... 50.00 The Herald, Grand Forks........... 100.00 W. Iddings Book and Stationery Company, Grand Forks........ 100.00 Johnson and Pierce, Larimore.... 20.00 Mallory Brothers, Emerado........... 5.00 Matt and March, Lisbon............... 3.00 McEwen and Dougherty,

E. W. and W. K. Nash, W. Grand W. Ko... 50.00 Grand Forks.
O'Connor and Grandy, Olson, Holt and Company, Pank, Lakota.....- 10.00 The Plaindealer, Grand Forks 100.00 5.00 Security Trust Company,

$$
\text { Grand Forks.................... } 150.00
$$
Smith and Wilder, Grand Forks 50.00 State Bank, Lisbon......

Wardwell and Thompson, 10.00 Pembina Thomp

\section{PUBLIC SCHOOLS}

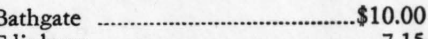

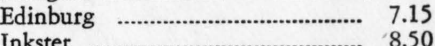
Larimore $\quad 1250$ Minto

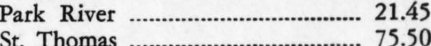

UNIVERSITY FACULTY

Webster Merrifield ……-...-....... $\$ 1,250.00$ E. J. Babcock ….......................... $1,000.00$ M. A. Brannon …........................ 1,000.00

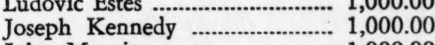
George S. Thomas …-............... 1, 1,000.00 George S. Thomas ................. 1,000.00 
INDEX 


\section{Index}

Aandahl, Fred, 246, 328, 416 Aandahl, Sam, 328

Abbott, George, 208, 215, 221, 304, 312, 380, 409n., 43

Abbott, N. C., 218

Academic freedom, 170, 275 ff., 300-302 Academic standards, 74, 359-61, 382, 449-51

ditation, 216-17, 359, 360, 393-94; chemistry, 431; engineering, 385, 423 216; investigation by North Central Assoc. of Schools and Colleges, 394-
96 ; investigation by Phi Beta Kappa,

Adelphi Society, 38, 56, 77, 123, 147 Administrative Committee, 185, 281

dministrative functions, 183-85; under Admissions policy. See Kntane, 343 ments.

Adult education. See Extension work. Affiliation with Wesley College, 163-65 Agricultural College, 42, 105, 338, 441 , 453; as rival for support and in cur$160,179-80,325,374,441 n$; and NPI, 232, 234; and extension work 219, 363; and accreditation problem 394-95. See also Athletics, football. Allen, Frances M., 8

Allen, Jennie, 55, 67

Allin, Roger, 104, 105

Alumni, 224-26, 326, 453

4lumi Association, 128, 181, 225, 321, 14. um, 326-27

Alumni Register, 200, 225
Alumni Magazine, 326, 327

Alpha Delta (Kappa Alpha Theta), 259

Alpha Kappa Z
Ambrose, F. Halsey, 305, 309, 313

American Association of University Pro-

ressors, 276, 303, 317, 393, 395n., salary reduction, 373, 383; and per-
sonnel policies after World War II, 439 440; and selection of Starcher,

American Federation of Teachers, 303

Anderson, Maxwell, 247, 249, 253, 254, 326n., $437 \mathrm{n}$. Anderson, W. J., 106

Appropriations: in 1880's, 19, 48, 57, 108, in $1890 \mathrm{~s}, 88,89,103-105$, 108; to 1920, 142-43, 218, 226-28, $39,366-67$; in 1930 's $373-74,390$; in 1940 's and 1950's, 407, 416, 418-19, 449

\section{Arbor Day, 82, 262}

Armory and gymnasium, 143, 182, 243,

Arnason, Albert F., 399, 445, 446

Arneberg, John G., 251, 45

And, Genieve, $81,103,104$

Artesian waters research, 219, 362,386,

424

Arvold, Alfred G., 252

Ashton, Jon. R., 452

Association of American Medical Schools, 159

Athletic Association (Athletic Board of Control), 238, 241, 242

Athletic field (University Field), 147,

Athletics, 76-77, 126, 174, 274, 288, (238-44; baseball, 77, 126; 369 , 390, 414; football, 124 ff., 239 $41,321-25,369,390,414$; hockey, 412-15. See also Physical education. Atkinson, Thomas, 350 
Babcock, Earle J., 71-72, 82, 95, 100, $119,185,199,215,287,345,352 \mathrm{n}$; and lignite research (q.v.), 117, 220; designated state geologist, 118; and School of Mines, 114, 115, 148, 152 53; appointed dean of engineering, 292; and attempt to oust Kane, 304, $310,311,317$

Banded Brothers of Bungaloo (Phi Tap pa Kegga), 259

Bangs, Philip, 326

Bangs, Tracy, 279 229, 230, 250, 329

Barr, Paul, 349

Baseball. See Athletics.

Basketball. See Athletics.

Bawden, William T., 232

Beadle, W. H. H., 4, 5
Bechdolt, Adolph, 98, 105, 106

Bechdolt, Adolph, $98,105,106$

Beck, Richard, 348, 389,437n, 438

Becker, Albert, 153, 281n., 299

Beede, Margaret, 349

Bek, William G., 198, 209, 216, 262,

286, 289, 352n., 409n.; on committee on discipline, 268, 295; appointed dean of College of Liberal Arts, 347 ; dean of College of Liberal Arts, 347; favors semicentralized organization, 374-75; and selection of West, 377 ; and $P$ i

32 , 234, 280; and academic freedom, 279; and construction, 281-82; and (1) created, 300; and attempt to oust Kane ( Colle 395. Board of Higher Educa tion formed, 383; activities, 397-400 417; and need for planning after dents, selection of.

Boarding department. See Students.

Bogan, Louis, 414 ,

Boise, Charles, 156, 387

Bolley, H. L., 180

Bond, Jesse, 350
Books published by faculty. See Publications. Bookstore, 196
Boyle, James, 168-69, 181, 198, 211, 55; and academic freedom, 277; publications, 167, 200 27,

Brannon, Melvin A., 97-98, 101, 114, $118,119,171,181,185,215$; first
impression of campus, 132-33; and reorganization of biology program, 157-59; and biological station, 220-21; promoted to dean of College of Liberal Arts, 206; leaves University, 199, 216, 228, 279-80; as possible Breitwieser, Joseph V., 348, 355-57, 371, Belsheim, Edmund, 328

Between-Us Day, 262

Biology. See Sciences.
Birdzell, Luther, 203, 222, 277, 284

Bisbee, Marcia, 15

Bismarck, 15, 20, 64, 86

Bjork, Alon J., 444n., 445

Black Maria, 145

Blackburn, William Maxwell: as president, $30-41$ passim; dismissal, 43-48; salary, 61

Blair, John E., 148, 149, 150

Board of Regents (see p. 21n. for other names for this body), 4, 59, 62, 75 $274,283,354,370,394,184,201$, and organization of University, 23.33 passim; and dismissal of Blackubrn, 44-47; and threat to close University,
105-106; and School of Mines, 114. 105-106; and School of Mines, 114 15; and loans for construction, 141-43;
State Board of Regents created, 231.

Brennan, George, 104, 123, 127

Bridston, Joseph B., 418

Bronson, Harrison, 120, 225, 284, 356, 419n.

Broughton, P. B., 26

Brown, W. H., 4 49-50,167,199, 202 Bruce, Andrew, 149-50, 167, 199, 202 Budge Hall, 182, 243 103, 145, 148, 183,184, 186; and location of University, 86; and site for University, 23-24, 29, 146, 238;
raises money in 1890's, 106-108; and
Board's borrowing for $141-42$

Budge, William E., 409n.

Buildings and grounds: landscaping and planning, 59, 82, 146-48; appropriations and construction after 1900, 143 ff., 152; in 1910's, 229-30; in 1920's,
$339-42$; in 1930's, 384; in 1940's, World War II, 441-42. See also Presi-

400 , 419-20; in 1950's, 425, 448-49.

Cable, Margaret, 201, 409n.

Carnegie Library. See Library facilities.

Celtic-American Society, 255 See also Campus.
Bull, Mrs. Elizabeth. See Mrs. Webste Merrifield.

Bulletin, 181, 225

Burdick, Usher L., 223

Bureau of Business and Economic Re-

Bureau of Educational Measurements, 205 Bureau of Educational Cooperation, 218 Burgum, Leslie, 453

Burke, Andrew, 8

Burke, John, 94, 143, 178, 181, 190 Burtness, Olger, 151,

Business and Public Administration, lege of. See Commerce, School of.

Cadet Band, 81, 124, 247

Caldwell, Robert A., 436

Campbell, Robert D. Foundation, 45 Campbell, Thomas, 155, 156, 326n

Campus: description of in early days, 24

$35,49,131-33$; additions to, 146 (3), grounds.

Cane Rush, 269

Capital. See North Dako

Carlson, William H., 350, 391

Carnegie Foundation for the Advancement of Teaching, 159, 198

Carney, E. Claude, 246, 269, 271, 272

Claxton, P. P., 232

Clay. See Lignite.

Clifford, Thomas J., 427

Cloetingh, Arthur, 252

Cochrane, John M., 11, 46, 150, 158

Cochrane, Mrs. John, 150

Code of Criteria, 444-46. See also Appendix

Coffman, Lotus D., 232, 289, 375

Collins, Stephen, 184, 186

Collins, William T., 11, 45, 46; and founding of University, 15-19; on firs Board of Regents, 21-25, 28

Commencement, 80-81, 127, 251,261 62, 274

Commerce, School of, 162, 348, 353, 394, 427; becomes College of Business and Public Administration, 427; firs commercial courses, 122, 204
Commons, 229, 258, 340-41, 419

Commons, 229, 258, 174

Concert Band, 327

Conte, Paolo, 292

Constitution, University, 281-82, 312 316, 441

Cooley, Albert M., 435

Cooley, Roger, 200, 203, 286, 346, 352n

Coon, Ernest, 349, 446

Cornatzer, William E, 434

Cornell University, 26, 70n., 15

Correspondence courses for CCC, 386,

Carney Sing, 262, 270, 287, 375, 411 Carpenter, Charles E., 279

Carson, Horace, 387
Casel, John W., 370

Catholic Association 256

Ceramics, 201.

Chandler, Elwyn, 153, 171, 215, 313, $323 n$., 371, 384, 392n.; 409n.; research, 157, 219; and civil engineering
course, 201, 208; dean of College of Engineering, 347

Chemistry. See Sciences.

Church, Governor, Louis Kossuth, 62, 75 Church affiliation. See Religion.

Civics Club, 168, 254-55

Clark, Sidney, 106
Classics Club, 436
Corwin Hall, 144

Cosmopolitan Club, 336

Cottage. See Macnie Hall.

Coulter, John Lee, 177, 325, 326n.

Council, University, 175, 180, 185, 197 $212,303,356,357$; and constitution, $281,433,441,445,450$

Courses at University. See Curriculum courses.

Cox, James, 351, 372

Craighead Report, 232-33, 282, 284, 374

Cawford, Lewis F., 232, 274, 283, 289

292

202, 299

Curriculum: first, 39; Merrifield-Montgomery, $41-44,47,55$; revised under
Sprague, $69 \mathrm{ff.;}$ major revision in
Craighead, Edwin, 232, 234 
$1894,119 \mathrm{ff}$; as of 1909,165 ; during World War I, 297; in 1920's, 353 ff. changes in 1930's, 383-84; changes Starcher administration, 449. See also names
schools.

schools.
Currie, Rolla, 125

Currie, Rolla, 125

Cushman, Martel
Cutts, Judge, 4

Dacotah, 181, 187, 247-48, 253, 316, $321,330,331,332,390$

Dakota Education Association, 32, 59

See also North Dakota Education As sociation.

Dakota Law Review, 352, 373, 391

Dakota Playmakers, 328-29, 381

Dakota Territory, 3, $7 \mathrm{ff}$.

Davies, George R., 211, 212, 347

Davis, Mrs. Hannah, 97, 100

Davis Hall, 182

Davis, John, 453

Davis, Paul, 322-23 185 . See names

Deans: first appointed,

Deans' Advisory Committee, 28

Debate: See Forensics.

Degrees, 41, 70, 119, 134, 176, 207 $274,358,382,424,432-33$; first graduate degree, 120; in education,
$204,354,356,357,426$; in engineering, 423; in law, 203; in medicine, honorary 432n. See also Curriculum. DeGroat, Clinton S., 81, 128

DeLong, Howard, 252

Delta Gamma, 260

Delta Sigma Rho, 254

deMores, Marquis, 12 es, 13, 51, 110

Denominational clleges, $13,51,110$

Depressions, 50, 102, 319-20, 366-78

passim

DeRemer, Joseph Bell, 340

Devine, Joseph M., 141

Diakoff, Alexis J.,

Dil, Cora F., 174

Doak, Henry, 351, 371-72

Dog Eagle, Franklin, 381

Dormitory buildings, 62-63, 419. Se also names of individual buildings. Douglas, J. Francis, 326n.

Dramatics, 171, 210, 248-53, 328-29
Duffy, Clyde, 255, 453

Dunlap, David, 166, 174, 241

Economics, 70, 168-69, 211, 222, 427 Education, School of, 148, 204, 348, 353, 354 Division of Education, 201, 204-206 separated from College of Libera Arts, 356; designated as college, 425-27; increases number of degrees,

Normal department, 22, 56, 74-75, 102, 114, 120; Normal College, $152,160-62$

Model School, 162, 204, 371

Teachers College, 161-62, 165, 204

See also Kennedy and Breitwiese

Eleectric lighting, 182

Elementary school system, 14

Elliott, Howard, 196

Ellis, Charles L., 342, 371

Employment service, 369n., 387

155, 353, College of, 148, 152-53,

cal training $153-54$; 388,394 ; practi-

201 ff. 228; research, 435. after World War II, 423-25; College of Mechanical and Electrical Engineering $152-55$ passim; Division of Engineer-
ing, 201-202. See also Mines, Schoo

Enrollment figures: to $1890,36,55,60$ $68-69,87$; in 1890 's, $109,117,137$; to $1920,271,286,321$; to 1930,338 ; in 1930's, 369, 389; in 1940 's, 401, Entrance requirements, 34, 41, 47, 55 Estes, Ludovic, 71, 95, 99, 100, 105 106, 114, 219

Evans, R. M., 21, 28, 376n.

Eversull, Frank, 397

Examinations, 39, 213, 359

Extension Division, 217-19, 224, 362-63

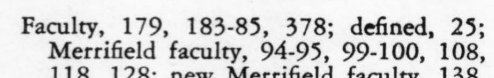
165, 128; new Merrifield faculty, 138, 200, 215-16; status in 1915, 280 ff.; and World War I, 299-300; and attempt to oust Kane, 309; faculty in ff.; turnover in 1930 's, 388 ff.; after World War II, 402, 408-409, 438-40, 440-42; honors between 1947-58, 437 38; under Starcher, 449, 451. See also Academic freedom; Publications; Salaries.

Fancher, F. B., 8

Farmers' Alliance, 50, 86, 87, 110

Farnsworth Charles S. 121, 125, 299

Federal relief. See Relief.

Fees, 37, 68, 114, 196, 272, 370

Finances, 48, 82, 137, 163, 183,400

403; problem of, in 1890 's, 103 ff.; in 1900 's, 140 ff.; legislative attempts to economize in 1909-17, 227 f.; during depression, 368, 370 ff., 382-83, 390

Gifts, 40, 150, 164, 251n., 452-53

Mill levy, 139-41, 187, 418

See also Appropriations.

Fine arts, 75, 182, 451

Flanagan, Joe, 126, 127, 239, 240, 288, 332

Flexner, Abraham, 159

Flexner Report, 159

lickertail Club, 323, 326

Flickertail Follies, 329-30, 369, 390, 410 Flickertails, 242, 325. See also Athletics. Folwell, William Watts, 25

44-46, 410. See also Public speaking.

Forthightly Club $181,371-72$

Founders' Day, 35, 177, 178, 262, 273 292, 340, 375, 376n., 45

Franklin Club, 181

Fraser, Gjems, 328 Fraternities, 254, 256 ff., $331,411-12$
Frazier, Lynn, 238, 244, 265, 271, 272,
367; as football hero, 126, 239, 240; as NPL governor, 222, 225, 233-34, $262,292,312$; and appointments to Board, 282-83; and attempt to oust Kane, 306; as outstanding alumnus, 284, 288, 326n.

French, Harley E., 198, 281, 289, 298, 304; and medical school, 206-207, 393, 394

Fritz, Chester L., 271, 450, 452, 454. See also Library facilities.
Fulton, Ella, 261, 265, 334

Fulton, F. R., 45, 52, 104, 106

Fussler, Karl, 313n., 350
Gansl, F. J., 245

Gasver, Francis, 313n

Gasification plant, 403

Geiger, George R., 350, 371

Geiger, Louis G., $437 \mathrm{n}$.

Geography, 429

Geological Survey, 154, 156-57, 179, 219 of.

Geology. See Sciences; Mines, School of. Georgacas, Demetrius, 436

German. See Languages.

GI Bill, 407, 410

Gibson, Roland, 440

Gill, Andrew, 242, 243, 299

Gillette, John M., 169-70, 181, 198, $347,398,409$ n., 431 ; and rural sociology, 211; and Sociology Club, 255; and committee on discipline, 268, 295; and study of state prisons and poor relief, 222,$278 ;$ as campus liberal,
$169-70,300,301 ;$ and opposition to Kane, 290, 296, 311, 316, 345; and attempt to oust Kane, 304, 306; elected president of Amer. Sociological Society, 316, to Phi Beta Kappa, 375; refuses presidency,

Gilman, Daniel Colt, 64, 65, 66

Glass, Mattie, 127

ersary of University, 375 Golden Feather, 413

Gordon, W. A., 104

Grades, $176,212-13,359$

Graduate training, 176, 195, 212; first programs, $72,120,211$; graduate di-

Grand Forks (and citizens of), 3, 5, 9 ff., $20,43,46,50,51,59,61,86$, 414,423

Grand Forks American, 306

Grand Forks Herald, 6, 9, 17, 43, 44 $88,91,278,283,302,303,305,430$ Grand Forks Plaindealer, 6, 9, 43

Grassick. James 298

Gray, John, 187

Greek. See Languages.

Greek letter social fraternities. See Fra-

Griffith, A. R., 78

Griffith, R. B., 104, 106 
Grimson, Gudmundur, 173, 177, 246, 272, 453

Gronna, Asle J 151, 173

Ground waters. See Artesian waters.

Grounds. See Buil

Gymnasium, 430. See also Armory.

Haagenson, Cushman, 338

Hagan, John, 306

Hamre, Christopher J., 434, 444n., 446 Hancock, John, 254, 271, 326, 342n., 376n., 416, 452

Hancock, Ruth, 336
Hanna, Louis B., 216, 226, 230-31, 255,

Hansbrough, Henry C., 50

Harpoon, 270

Harrington Hall, 423

Harrington, Louis, 378, 384n., 409n.

Harwood, Theodore H., 42

Haxo, Henry, 349, 388

Hazing, 270, 332-33, 411

Hazlett, Mr. and Mrs. Thomas, 164
Healy, E. A., 21, 25, 32, 45, 52

Heating plant, 34, 37, 48, 141, 340

Heising, Raymond, 208

Helling, Marvin, 414

Hempel, Walter, 239

Henderson, J. Donald, 453

Hetherington, C. H., 211

High schools. See Secondary schools.

Higher education: attitude toward in

Dakota Territory, 12-14; location of

colleges in Dakota, 86-87; legislative

attempts to rationalize system, 162-63,

222-23, 227, 230, 232-33; reorganiza-

eliminate duplication in, in 1930's

$368, \quad 374$ ff., 383 ; constitutiona amendment for, 396-97; problems of after World War
Hilborn, J. P., 164

Hill, James J., 9, 169, 196, 197

Hillyer, T. A., 292

History, 57, 70, 167, 211, 222, 349, 353. See also Libby.

History of the University, 30n., 375-76,

454
Hitchcock, Raymond, 208, 301, 304, 312, 335, 392

Hockey. See Athletics.
Holstine, Garold, 425-26

Homecoming Day, 226, 242, 262, 273 $288,322,326$

Homiletic Club, 176, 256

Honors system, 176, 360, 450

Hoodoo Day, 321

Howard, John, 328, 349, 355

Howe, Frederick, 290

Hult, Gottfried, 171-72, 199, 216, 235

375 ; addresses at University, 177, 196;

retirement, $347,371,372$; publica

tions, 352,388
Hultz, Frederick, 443

Humpstone, Henry, 349

Humpstone, Henry, 349

Huston, Howard, 326n

Hyde, Melvin W, 446

Hyma, Albert, 350

Icelandic Association, 172, 255

Iddings, B. W., 44

haugurations: for McVey, 196-97; for

Yoters Starcher, 447-48

$300,302,312,315$; and Kane, 288

$90,305-309$ passim
Indians, $9,13,50,381$

Indians, 9, 13, 50, 381
Industrial arts, 204, 425

Industrial arts, 204, 425

Ingwaldson, Ben F., $37,81,272$

Interfraternity Council, 260

Institute of Linguistics, 426

nstitute for Teachers of Science and Mathematics, 453

Investigations of University. See Accredi-

Ireland, Mrs. Guy L., 435, 452

Jackson, George P., 215

Jarrett, "Red Rabbit," 325, 414

Jenkins, David, 313n., 349, 364

Jewell, Thomas, 272

Johnson, Martin N., 151, 255
Johnson, Sveinbjorn, 225, 246, 372
Johnstone Hall, 144

ohnstone, M. Beatrice, 224, 262, 362,

Jones, H. Foster, $392 \mathrm{n}$.
Jones, William C., 446

Kaloupek, Walter, 392

Kaloupek, Walter, 392
Kane, Thomas F., 234; selection as presi- dent, 290-92; inauguration, 291 ff. tempt to oust in 1920, 302-18; administration, 319-27, 341-58, passim; attempt to remove in 1932, 372-73, resignation, $373,376-78$

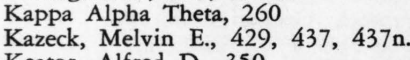

Keator, Alfred D., 350 434

Kees and Fisk, 24, 62

Kelsey, Vera, 253

Kennedy, Joseph, 96, 162, 187, 199 $205,216,286,392 \mathrm{n}$; and norma department, 102, 114; named dean of
Normal College, 152; awarded honorary LL.D., 294-95; opposed to Kane, publications, 167, 200, 206

Kiehle, David L., 4, 6

King, Cora Smith-Eaton. See SmithEaton.

King Kold Karnival, 411

Kjerstad, Conrad, 392, 394

Koch, Frederick, 171, 181, 216, 263 299; and regional drama, 210, 248-53

Koenker, William E., 427, 444n., 445, 446, 452

Koppenhaver, Robin Dee, 400

Koth, Arthur, 435

Laboratory work, introduction of, 71-73 304-17 passi

Ladd, Edwin F., 180, 282

Laird, Wilson, 392, 424, 437, 444n.,

LaMoure, Judson, 88, 142

nger, William, 151, 225, 246, 385, 67; as governor during depression, 453

Languages, 53, 95, 97, 116, 120, 121, 171 ff., 209-10, 286, 432; English language and literature, $70,99,171$, 210. (see also Squires), German, 209, $115-16,172$

Larimore Hall, 144

Larsen, Spencer, 368n., 386

Lavine, Irvin, 348, 386, 389

aw and Commerce Building, 339

$287,360,428$ 148-51, 202-204, 216
Lawton, Alfred, 421n.

Legislature, 142, 155, 157, 285, 400; sets educational pattern, $18-23,113$, 161-62; acts to curtail University activity, 186-87; out of sympathy with University in 1930's, $368 \mathrm{ff}$. See also
Hoducation Appropriations,

LeMasurier, Dalton, 364, 385

Lemke, William, 151; as student, 239 ,
LeMarier, $244,245,253,257,259,265,437$;
int in politics, 224, 367, 375

Lemmer, George F., 437n. and geological studies, 156-57, 219
and

362; publications, 167, 352n. ewinsohn, Joseph, 277-79

Libby, Orin G., 158, 169, 181, 198, 215 $222,250,280,289,296,345,347$ 375, 398, 409n.; and department of history, 167-68; and graduate seminar 211; and attempt to oust Kane, 298,
304-16 passim; publications, 200, 352, $352 n$ passim, publications, 200, 352 Libby, Orin G., Historial Manuscripts
Collection, 437

Liberal Arts, College of, 22, 148, 153 201, 204; designated college, 151; development in early 1900's, 165-74; in $1910 \mathrm{~s}, 207-11$; in $1920 \mathrm{~s}, 356 \mathrm{ff}$.; Jinior and senior divisions, 359; and the Arts adopted, 380; are, World War II 428-32

Library facilities, $40,49,57,70,117$ $150,174,195,203,228,340-41,358$ 143, 146, 182; 340-41; Chester Frit Library, 454

ibrary science, 210-11

ignite research, $71,143,155-57,219-20$ $285,361-62,345,348,385,420,435$ Lime Kiln Club, 80
Literary societies, 244,246

Lium, Elder, 423

Long, Annie, 182

Loomis, Harry, 23

Lottery, 87-88,

George, 338

ndation, $82 \mathrm{n}$., 336

ykken, Henry, 271

McCann, Edmund T., 332

CCCormack, M. L., 4, 23

McCumber, Porter J., 151, 277 
McDonald, Archie, 158, 206

288, 307 . 452, 224, 262, 271, 284 dent of public instruction, 225,283 . 453

273, 274, 286-87, 296-98, 302, 401

Miller, Ernest, 350

Mines, School of, 73, 103, 114-15, 146, $148,152-57,179,201,435-15,146$ Babcock; Geological Survey. Mines, School of, Building, 143, 146, 182,229

McLaughlin, S. W., 106

Maclean, James, 292

Macnie, John, 52, 53-55, 59, 95, 99, 119,

$153,166,186$; and students, 128-30,

264; adviser of Student, 78; publica-

Macnie, John S., 53, 125, 127

McVey, Charles, 287, 301

McVey, Frank LeRond, 99, 311, 398;

selected president, 187; as president, 190-236 passim; comparsion with Merrifield, 193; and students, 241, 243, 274: $253,256,258,261,268-70$, and politics, 283-85; and World War I, 285-86; resignation, 288 Main Building. See Merrifield Hall, old. Marclay, Walter, 36, 37

Mares, Irene, 81

Marti, Leonard, 429

Masonic Order of Grand Forks, 4, 5, 6 Mathematics. See Sciences.

May Fete, 262, 321, 329

Mechanic Arts Building, 152

Medical Science Building, 417-19

Medicine, School of, 58, 148, 150, 15760, 201, 206, 353, 360; accreditation, 23. research in 434-35. Medical Ceter, 417-19. See also Public Healt Laboratory.

Mellette, H. M., 81

Men's Union, 256, 261

Merrifield Hall, new, 340, 346

Merrifield Hall, old, $5,25,26,28-29$ storm, 59, 61: Merrifield, Webster, $11,31,32,52,63$.

$70,84,213,257-58,259,264$; and first days of University, $34,35,37,39$ 45; prepares first curriculum, 41-44 declines presidency, 47; selected presi-
dent, 89, 91; as president, 94-189 passim; educational views, 169-70; comparison with McVey, 193; buildin named for, 263

Merrifield, Mrs. Webster, 186, 187, 188 Metropolitan Theatre, 51, 127, 130, 133 , Military training, 22, 60, 75, 124, 244
Mining Engineering, College of. See

216 250 Valley Historical Association, Model School. See Education.

Montgomery, Henry, 31-32, 37, 45, 72

and museum, 40-41; and first curricu-

lum, 41-43, 47; as acting president,

$47,52,56-60$ passim
Montgomery, R. H., 253
Moran, Walter $H .349$

Morrell and Nichols, 339

Morrill Act, 13

Moses, John, 204, 246, 253, 367, 437n.

Mott, Mrs. E. S., 32, 33, 34, 39, 44-45, 376n.

Muir, Robert, 225, 282-83, 292; and
attempt to oust Kane, 303, 304, 306 Munch, Peter A., 431-32, 436-37, 437n., 445 Munk, Arthur W., 437n. Murphy, Lawrence W., 350

Murphy, M. F., 106, 259

Murphy, Robert, 323, 340, 39 $354-55,426-27$

National Association of State Universities, $138,165,388$

National Youth Administration, 384, 386-87.

Neston, David, 272

A., 151, 225, 246,

Netcher, Arthur, 249, 326

Newman Foundation, 165, 336

Nickeus, Johnston, 18
Nielson, Minnie, 225

Nielson, Minnie, 225
Nonpartisan League, 224-25, 232-34

273, 275, 315, 373, 378, 382-83; attempt to control Regents, $282-85$, 300 . and selection of Kane, 288-90; attempt to oust Kane, 305-309

Normal department and college. See Education. Mines, School of

84; first faculty member, 26, 34, 39;

Music, 74, 122, 124, 164, 247-48, 327

Nationality societies, 255-56
Normal Literary Society, 77

Normal schools, 14, 20, 86, 102, 160 Norman $, 374,414$

North Central Association of Colleges and Secondary Schools, 138, 215, 216, $394-96$

North Dakota: capital location, 15, 17 18, 20, 86; statehood, 14-15, 51, 62, 84; Constitutional provisions for edu-
cation, 84-85; history of, 139, 367. See also Dakota Territory. North Dakota Business, 427

North Dakota Educational Association, 67, 69, 112, 113, 224. See also Dakota Education Association.

ineer, 352

North Dakota Farmers' Union, 427

North Dakota Quarterly, 451. See also Quarterly Journal.

North Dakota Tax Survey Commission,

North Dakota Taxpayers' Association, 338-39, 373

Northrop, Cyrus, 64, 127, 180, 194

Norton, William W., 216, 218, 247-48,

, William $126,151,225,238$ 239, 272

Nye, Gerald P., 367, 389

Observatory, 23, 26, 29-30

O'Connor, J. F. T., 151, 225, 246, 253, $255,271,383 n$., 389, 452 Oil, 361, 424, 425, 443

Olav, Crown Prince of Norway, 389 Olson, Beatrice, 321
Olson, Hilda, 217

Olson, Hilda, 217 in

Order of the Coif 360

Ordway, Nehemiah $G, 25,81,111$

act establishing University, 311 ; and cornerstone laying, 4, 5, 7; and capital removal, $15,17,18,20$
Overn, A. V., 389

Page, John, 417

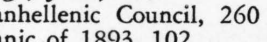

Patten, William, 72-73, 98, 118, 125

Patton and Miller, 14

Peik, W. E., 374
Penn, John, 392, 430, 444, 445
Per Gradus, 77, 123

Perkins, Clarence, 311, 349, 388, 409n Perlman, Jacob, 350

ohn. See St. John

Peterson, Samuel, 149, 150, 168

Pettijohn, John J., 218-19

Peiffer, Norma, 281n.

Phi Alpha Delta, 25

hi Beta Kappa, 177, 195, 217, 330,

Phi Delta Kappa, 360

Phi Delta Theta, 260, 296, 297

Physical education, 122, 211, 354, 429 30. See also Athletics.

Pierce, Gilbert A, 46, 60, 61, 63, 65,

Plank, Margaret, 217

Playmakers. See Dakota Playmakers.

Political and social science, $70,121,427$

Political clubs, 255

(183n, 277 282-85, 300; under West, 382; Board removed from, 397; student interes Pollard, Fritz, 390

Post office, 82

Potter, Philip, 437n.

Potter, William F., 247

Poupore, Anne, 217

ower, J. A., 232

Preparatory department, 41, 56, 68, 69, Preparatory department, 41,
$102,113,137,160,162$ 65, 91, 187, 288-91, 376-77, 442-47. See Blackburn; Sprague; Merrifield McVey; Kane; West; Starcher.
President's house, 67, 141, 258, 41 President's house, 67, 141,
Pritchett, John Perry, 388

Professional societies, 254-55, 360

Progressive Era, influence on University, 138-39

Public Health Laboratory, 158, 195, 206 220

Public relations, 67-68, 180-83, 224 nder Montgomery, 59; under West

Public services, 361-63, 453 speaking 328,430 See also Forensics.

Public support, 177, 179-80, 325

Publication by faculty, 109, 167, 200
201, 203, 352, 388, 393, 451 
Puffer, Claude E., 144

" 414-15

Ouarterly Journal, 195, 198, 200,321, $373,375,376,391$. See also Nortb Dakota Quarterly.
Quinn, Lawrence, 335

Radcliffe, S. J., 123, 125 Radio station, 209, 221, 363-65, 380-81, $385,430-31$

ecreational facilities, 256, 270, 408

Ciler Valley University. See Wesley Red scare, 300, 305, 315

Regents. See Board of Regents. Reinhardt, James M., 337, 352n.

Relief program, federal, $384-87$
Religion: church affiliation, $39,116,173$

256, 336; religious foundations an associations, $256,336,412,420$. Se also Wesley College.

Research programs, federal, 386; after
World War II, 433-36; by faculty, 99, 451-52

Reserve Officers Training Corps, 302, 332, 334, 337, 353, 389, 41

Reynolds, Emily K., 182
Rhodes scholarships, 176, 360

Rich, Lyle, 287

Rickaby, Franz, 328, 352n

Roach, William N., 45, 52, 62, 93, 101,

103
Roberts, S. G., 18

Robertson, Edward P., 163, 342n., 355 Robertson Hall, 342

Robertson Laboratory, 420, 423, 435

Robinson, Elwyn B

Rohde, Armin, 338

Rollefson, C. J., 116, 118

Roosevelt, Franklin D., 389

Roudiez, Leon, 76

Rovelstad, Adolph M., 349, 371

Rowe, John, 438

Rowland, Hywel, 327, 349, 355, 381

Ruediger, Gustave, 158-59, 166, 220, 279

Ruud, Martin G., 173, 246, 326

Rygh, George, 106, 116

Saiki, Arthur K., 349, 394

St. Clair, Foster Y., 436, 454
St. John Perrott, George, 95, 121, 217, 264

Salaries, faculty, 83-84, 88, 103, 105 $106,175,197-98,233,303,343-44$

Samuelson, Paul, 326-27

Sanford, Maude, 272

Sayre Hall, 144

Scandinavians, 8, 115-16, 173, 272, 336 Schlosser, Walter, 323, 326

Schmidt, Charles Christian, 162, 204, 205, 342, 352n., 371, 392n.

Scholarships, 176, 212, 213, 359, 387,

450; first, 82; athletic, 414
Schonberger, Emanuel D., 328-29, 349,

School of Education Record, 200

Schrier, William, 328

Science Building, 144, 152
Science, Literature, and Arts, College of. See Liberal Arts,

Sciences, 52, 56, 57, 71 ff., 103, 118, $121,171,208-10,361-62$; service to state, $72-73,221$; early equipment,
40, 117; biology, 72 (see also Bio40, 117; biology, 72 (see also Bio-
logical Station); chemistry, 208, 221, 353 , 431; geology, 361, 424; mathematics, 208; physics, 208-209

Scobey, J. O. B., 18

Scow, Emil, 232

Seal, 21, 263

Secondary schools, 69, 96, 182, 223-24; system developed by University, 14, $51,111-14$; control by University
broken, 160-63; University meets needs of, 204-205; State High School Council (Conference), 113 Selke, Erich, 392, 452

Serumgard, Olga, 272

Serumgard, Siver, 109

Sevareid, Eric, 454

Sewage. See Water and sewage system.
Shafer, George, 204, 246, 255, 262, 372

Shafer, George, 204, 246,

Shepperd, John H., 394

Sherman, Ben, 252

Shortridge, Eli C. D., 100, 102, 110

Sigma Chi, 259, 260
Sigma Delta Chi, 329

Sigma Tau, 360
Sigma Xi, 360

Simpson, Howard, 219, 304, 362, 392n.

Sioux. See Athletics, football.

Skulason, Bardi, 123, 124, 173, 178, 238

Skulason, Skuli, 173, 239

Smiley, Earl K., 335, 350, 371
Smith, "Bolshevik," 301

Smith, Fred E., 299

Smith-Eaton, Cora, 39, 76, 81, 122, 124,

Social Science Research Institute, 436-37 See also Gillette.

Sociology Club, 255

also Dakota Playmakers.

Sororities, 260. See also Fraternities.

South Dakota State College, 43

Spanish War, 134, 137

Spence, Bartholomew J., 209, 281n., 287 289, 295, 300

Sports. See Athletics. $77,00,125,127$

prague, Goldwin S., 77, 90, 125, 127

tion as president 63-65; 264; selec philosophy, 65-66; administration, 67 88 passim; resigns, $89-90$

Squires, Alden, 328

Squires, Duane, 328, 376

Squires, Vernon P., 98-99, 153, 181, $182,187,199,235,272,281 \mathrm{n} ., 286$ $346 ;$ and English department, 121,
210 ; description of campus, 132-33; receives honorary LL.D., 216; and history of University, 262, 263, 375 76; and attempt to oust Kane, 301 304, 313; publications, 167 Stadium, 323, 326-27, 339, 342
Staley, Raymond, $349,446,447$

Starcher, George W., 442; elected presiadministration, $448-54$ passim

State Board of Regents, of Administra

tion, of Higher Education. See Board

State School of Science, $153 \mathrm{n}$.

Stearns, Wallace, 215

Stefansson, Vilhjalmur, 246, 253, 271, Stephenson, Edward B., 209, 221, 299 Stenmo, Albert, 225

Stevens and Gavenjan, 27

Stewart, George Walter, 153, 167, 17

Stewart, Jack, 327

Stockwell, Walter L., 114, 255

Stolz, Karl, 235

Stolz, Karl, 235

Stout, George, 247,355

Strong, Frank, 178

Strong, George F., 174

Struble, Clara, 252

Stucke, E. C., 418
Student, $78,130,165,253,268,270$,
277, 286, 297, 330, 331, 332, 337, training Corps, 296, 297-

98
Student Union, 416, 418
Students: life during 1880 's, $36,38,60$, 79-80; during $1890^{\prime}$ 's, $111,123-24$,
tifents life during $180,38,60$, 128-31; from 1900-1917, 213-14, 23774 passim; in World War I, 287-88; during 1920 's, 320-21, 331-37; in 1930's, 389-91; after World War II, 410-14; assistance to, $213,369-70$, $386-88,450$; and attempt to ous Kane, 306-308; discipline, 25, $264 \mathrm{ff}$.; self-government, 335 , 381, 449; hous-

$117,144,331,341-42,384,407-408$,

419; married, 410; medical services for, 196, 335, 449; University relations to, 212-14, 420

Summer school and institutes, 114, 162, 205, 296, 357-59, 384, 426, 453 Summers, Lawrence, 431

Sweetland, John, 158, 174, 239, 244

Synergoi, 295

Talbert, George A., 349, 394

Taylor, Albert Hoyt, 171, 198, 199, 208 209, 221, 228, 299

Taylo, J., 157, 158, 232, 289

Taylor, John W., 310-11

Teacher training, 14, 56,113. See also Education; secondary schools.

Teachers College. See Education. Teachers College Building (Woodwort
Hall), 143, 196, 229, 419, 425 Teel, Charles, 44, 46

el, Charles E., 4, 11, 21, 23, 24,

Teel, Marie, 81
Telephone, 82, 229

Television course, 430

Telford, Charles W., 349

Theta Chi, 331, 420

Thomas, George S., 97, 99, 120, 121 166, 187, 212, 213; appointed dean president, 184: resigns, $199,206,209$ Thompson, Fred, 211, 242, 243, 299

Thormodsgard, Olaf, 349, 378

Thursby, E. H., 82, 127

Tiffany, Katherine Belanger, 452

Tingelstad, John, 172, 346 
Todd, J. W., 205, 216

Tomasek, Henry, 427

Totten, George: 283, 290; and attempt to oust 301-12 passim

Towne, Ezra T

yer, 304, 345, 348, 353, Townley, Arthur C., 224, 305

Transportation, 37, 56, 68, 144-45, 342 Travis, Joseph, 81

Traynor, Fred, 151, 259
Treichler, Herbert, 156

Tri-County Education Association, 114, 205

Trolley, 145

Trustees. See Board of Regents.

Twamley, Edna, 129

Twamley, James, 11, 52, 62, 89, 262, 264; at cornerstone laying, 4 ; and location of University, 15, 17; o first Board, 21, 24, 28; charges against, 46-47; family of, 213
Typhoid epidemic, 100

University Athletic Association. See Olympic Athletic Association. $60,145,230$

University Board of Regents, of Trustees. See Board of Regents.

University Bulletin, 167, 200
University College (D. J. Robertson, University College

453-54. See also Finances; History of

University of South Dakota at Vermillion, 6, 14, 19

University Settlement House, 255

Upson, Maxwell, 326n.

Van Hise, Charles R., 180, 194 Varsity Bachelor Club, 259, 260, 261 Vermilyea, C. E., 283, 298

World War II, 408-10ar I, 321; World War II, 408-10

Viets, Frank, 11

Vogel, Frank, 377

Vold, Lauriz, 20

Vondracek, Felix J., 349, 388

on Haller Medical Society, 17

Waldron, C. B., 147,180

Wallinger Casimir 180

Walsh, Edmund, 16

Walsh, George H., 7, 9, 15, 16, 18, 20, $21,48,88,103,178$

Walsh, Mrs. George, 376n.

Walsh, Thomas, 15, 16

Ward, Raymond, 397

, $151,182,188,224$ 239, 245, 259 , Warner, Wallace, 453

War training programs: in World War I, 296 ff.; in World War II, 401 ff. Water and sewage system, 38, 48, 83 , Wea-101, 144, 145

University Council. See Council.

University Field. See Athletic field.

establishin North Dakota: legislation for, 21-23; selection of site, 17-20 (see also North Dakota capital location); selection of land for, 23-24; announcement of opening, 32, 35; at$101,109-10$ 150-51; in 1880 's, 60 in 1890 's, $105 \mathrm{ff}$. reorganization 1901, 151 ff.; becomes real state versity, 138; rising standard for in 1900 s, 177; position among state institutions, 179; in 1909, 190-91; re organization under McVey, 195, 201 fr,; at end of World War 1,275 ; reintellectual life in 1920 's 360 . 61 ; optimism at in 1946, 409. long range policy, 441-43. branches of, 454; position in 1957 .

signal station, 73, 82, 219

Weber, Neal, 389

Wells, George, 203, 216, 299, 312

Weltzin, J. Frederick, 357

Wenner, Ernest, 445

Wesley College, 144, 256, 336; affilia tion with University, 163-65; and music department, 355, 426-27
West, C. A., 324-25, 390, 409n., 414,

West, John $C, 355,357,365 ;$ selecte president 377 ; administs; selected 442, passim; elected president. NASU, 388; appointed acting president of Agricultural College, 390 395-97; honorary degrees, 438; resigns,
442-44; and selection of Starcher, 445 West, Willis, 95n.

Westergaard, Waldemar; 173, 246, 253
Whalin, Edwin, 43

Whaling, Heiskell, 281n.

Wheeler, George, 348, 389, 398, 435

Wheeler, Henry, 58

Wheeler, W. E, 444n

White, Andrew D., 26, 64, 66

White, Frank, 139, 141, 142, 161, 163

232, 283

Wick, Willie, 82

Wilcox, Ernest, 354, 355

Wilker, Frank, 153, 156,171

Wills, Bernt L., 429

Winship, George, 9, 88

Winter Sports Building, 414

Witmer, Robert B., 428-29

Women's Christian Temperance Union,

Women's

261

Wood, Ethel (Mrs. Vernon P. Squires),

Wood, H. L., 156

Woodburne, Lloyd, 446

Woodworth Hall. See Teachers College Building.

Woodworth, Horace B., 52-53, 59, 74, 93,186 , and religious training, 53 , 119. retires, 166, 175; building named for, 263

World War I, 273-74, 285-88, 292, 296

World War II, 400-403; postwar effects,

Worst, John, 232, 234

Wright, Orange, 106

Yell, 127

Yoder, Albert H., 362, 364

Young, N. C., 184, 187, 278-79

Young, Robert T., 159, 171, 215, 221,

oung Men's Christian Association, 256, (27), 287, 292, 369n., 412 256,412 
This book was set

in Linotype Granjon,

12-point (on 13) 


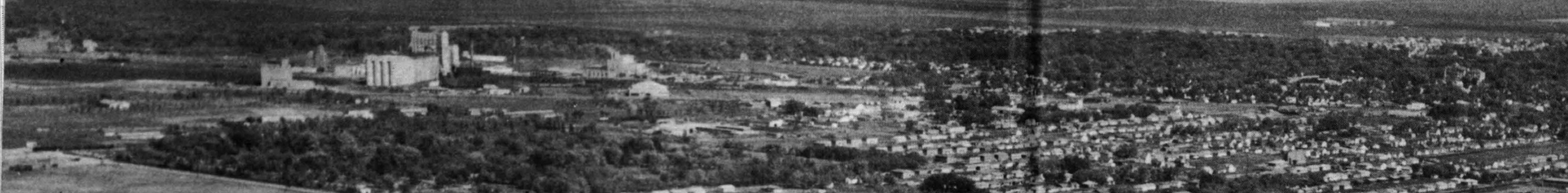

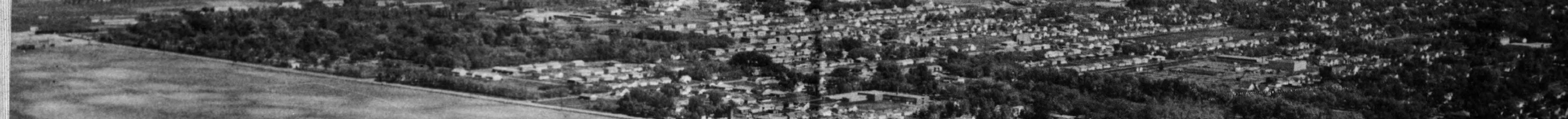

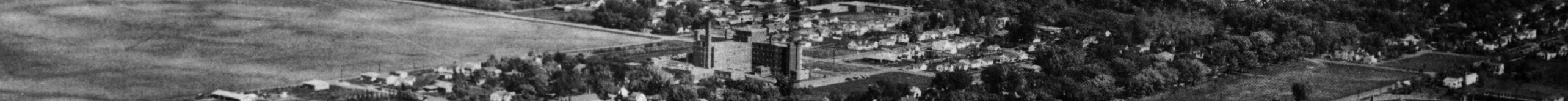

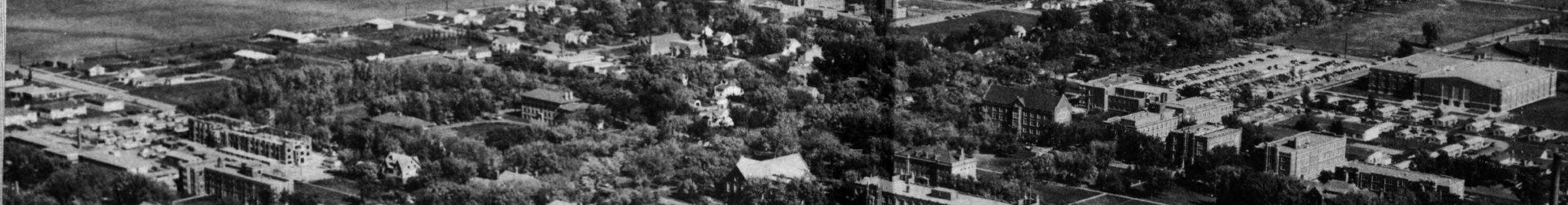

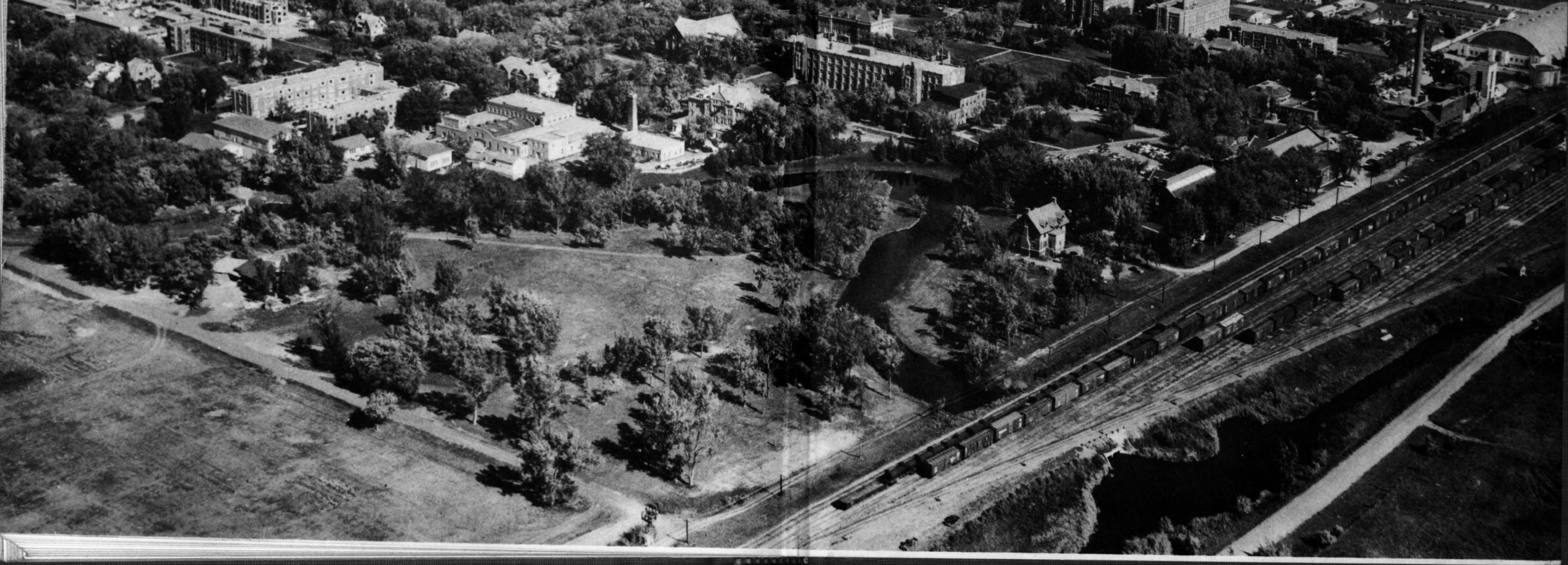

